\title{
ASPECTOS DA ESTRATIGRAFIA DAS SEQÜÊNCIAS PRÉ- CARBONÍFERAS DA BACIA DO PARANÁ NO BRASIL
}

\author{
Mario Luis Assine
}

Orientador: Prof. Dr. Setembrino Petri

TESE DE DOUTORAMENTO

COMISSÃO JULGADORA

nome

Presidente :

Examinadores:

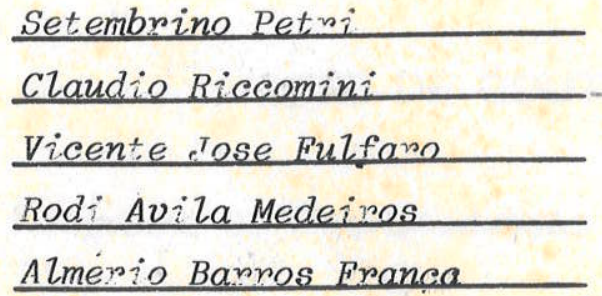

ass.
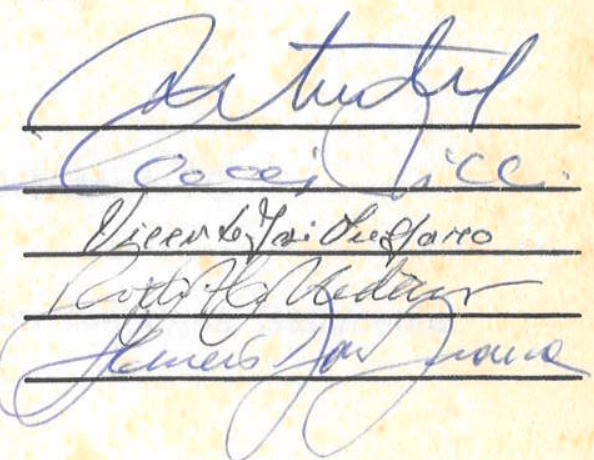


\section{UNIVERSIDADE DE SÃO PAULO INSTITUTO DE GEOCIENCIAS}

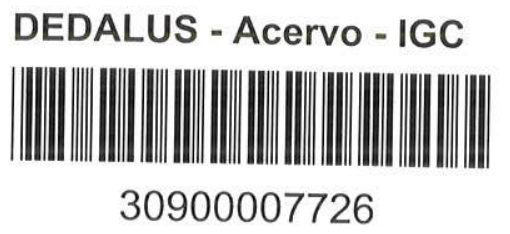

\section{ASPECTOS DA ESTRATIGRAFIA DAS SEQÜÊNCIAS PRÉ-CARBONÍFERAS DA BACIA DO PARANÁ NO BRASIL}

Mario Luis Assine

Orientador: Prof. Dr. Setembrino Petri

TESE DE DOUTORAMENTO

Programa de Pós-Graduação em Geologia Sedimentar

SÄO PAULO

1996 
Dedico este trabalho:

Aos meus pais, Cezarino e Anézia, sempre exemplos para mim.

À memória do geólogo José Geraldo Resende Rola, compartilhando com Marília e filhos a tristeza pela perda de um verdadeiro amigo. 


\section{AGRADECIMENTOS}

Externo meus mais sinceros agradecimentos: ao Prof. Dr. Setembrino Petri, pela disponibilidade, convívio amigável e, sobretudo, pela orientação equilibrada e segura, fundamental para o desenvolvimento da tese; ao Prof. Dr. Paulo C. Soares, com quem iniciei meus estudos sobre a Bacia do Paraná, pelas discussões estimulantes e apoio em diversas etapas deste trabalho; aos Profs. Dr. José Alexandre J. Perinotto e Dr. Carlos J. S. Alvarenga, pela insubstituível colaboração nos trabalhos de campo e na interpretação da geologia pré-carbonífera da porção norte da bacia; ao $\mathrm{Dr}$. Almério B. França, pelo incentivo, discussões enriquecedoras e auxílio em tantas coisas, como por exemplo na elaboração do abstract; aos Profs. Dr. Claudio Riccomini e Dr. Kenitiro Suguio, pela colaboração durante o programa de doutorado e pelas críticas e sugestōes apresentadas durante exame de qualificação; ao Prof. Dr. Paulo C. F. Giannini, pela leitura crítica do texto e sugestões apresentadas; aos Profs. Dr. Vicente J. Fulfaro, Dr. Dharani Sundaram, Dra Eleonora M. G. Vasconcellos, Gerson de Souza Saes, Sidnei P. Rostirolla, Olavo Soares, Robson T. Bolzon, e aos colegas Sérgio Baggio, Renata Moro, Andrea Hauch, Rodoilton Stevanatto, Paulo C. Artur, José Roberto de Góis, pela inestimável colaboração e discussão durante os trabalhos de campo; ao geólogo Édison J. Milani, pelos trabalhos desenvolvidos em conjunto, dos quais derivaram algumas das idéias apresentadas; aos Profs. Dr. Antonio R. Saad, Dr. José Manoel dos Reis Neto, Dra Marlene T. Barcellos-Popp e Elimar Trein, pelo estímulo e apoio; ao Dr. Rodi A. Medeiros, pelo entusiasmo e valiosos ensinamentos em alguns seminários de campo no âmbito da Petrobrás; aos geólogos Celso $\mathrm{H}$. Raffaelli e César A. Pereira, que sempre buscaram, na medida do possivel, atender minhas solicitações à Petrobrás. Ao geólogo Rob F. Daemon pelas análises paleontológicas. Aos geólogos Sven Wolff, Osmar Zanotto, Airton Marques, Antonio J. Catto e tantos outros, pela colaboração e acolhida sempre amistosa nas dependências da Petrobrás/Nexpar; aos desenhistas Otto L. Rosa e Sonia P. Radomski, pela paciência em tantos momentos e qualidade dos desenhos, que enriqueceram sobremaneira o texto; às bibliotecárias Eliane M. Stroparo (UFPR) e Elisabeth T. Kanda (Petrobrás/Nexpar) pelo auxílio na busca bibliográfica; aos geólogos Gerardo Verolavsky Barbé e Hector de Santa Ana, pela oportunidade que me proporcionaram de conhecer um pouco da geologia do Paleozóico do Uruguai; ao Departamento de Geologia da UFPR, pela liberação para realização do doutorado; ao Instituto de Geociências da USP, em particular aos professores do Departamento de Paleontologia e Estratigrafia, que me acolheram durante os últimos quatro anos; à Petrobrás, através do Núcleo de Exploração da Bacia do Paraná (Nexpar), pela autorização para consulta de relatórios internos e perfis de poços, e permissão para apresentar dados de sua propriedade; ao CNPq e a CAPES (PICD), pela concessão de bolsa de doutorado; à FAPESP (proc.1995/0770-0) e à FINEP/PADCT (proc.006591030300) pelo apoio financeiro e material ao desenvolvimento da tese; e a tantos amigos, enfim, que de uma forma ou outra, contribuíram para que este trabalho pudesse ser realizado.

CRÉDITOS: Carlos J. S. Alvarenga (seção colunar do ponto 14, p. 38); Robson T.Bolzon (figuras 57-F/G/H, 61-A); José Alexandre J. Perinotto (Fig. 71-E/F); José Roberto de Góis (figuras 51-B, 51-E e 51-F); Airton Marques (interpretação da seção sísmica da Fig. 34) e Antonio J. Catto (interpretação da seção sísmica da Fig. 36). 


\section{RESUMO}

O registro pré-Carbonifero da Bacia do Paraná é composto por duas seqüências estratigráficas limitadas por discordâncias regionais, que constituem dois ciclos de $2^{\mathrm{a}}$ ordem: Ordoviciano/Siluriano e Devoniano. No Ordoviciano Superior/Siluriano Inferior (Gr. Rio Ivaí) foram caracterizadas duas seqüências deposicionais: 1) a inferior, considerada de idade caradociana - ashgilliana, compreende arenitos de tratos de sistemas transgressivo e de mar alto da Fm. Alto Garças, que apresentam mergulho deposicional para oeste em direção às bacias do Chaco; 2) a seqüência neoashgilliana - llandoveriana inicia-se com as fácies subglaciais da Fm. lapó, correlacionadas com a glaciação gondwânica neo-ashgilliana. Folhelhos pós-glaciais da Fm. Vila Maria constitutem trato de sistemas transgressivo, com superfície de máxima inundação no Llandoveriano Inferior. A seção de topo da Fm. Vila Maria registra tendência regressiva, que culminou com a geração de discordância generalizada no Siluriano Superior. No Devoniano (Gr. Paraná) foram caracterizadas três seqüências deposicionais: 1) a seqüência basal, de presumida idade lochkoviana, resultou de rápida transgressão sobre embasamento peneplanizado, em onlap de oeste para leste, fenômeno que gerou espaço para acomodação de tratos psamíticos de sistemas transgressivo e de mar alto (partes inferior e média da Fm. Furnas). A existência de traços fósseis de trilobita corrobora a interpretação de ambientes marinhos para a Fm. Furnas; 2) fácies conglomeráticas de trato de sistemas de mar baixo (parte superior da Fm. Furnas) marcam o início da seqüência praguiana eifeliana. O empilhamento é transgressivo na transição entre as formações Furnas e Ponta Grossa, com superfície de máxima inundação no Emsiano Superior (Mb. Jaguariaíva). O Eifeliano é caracterizado por trato de mar alto com empilhamento regressivo progradacional (Mb. Tibagi). Tectonismo sinsedimentar foi responsável pela individualização de altos internos e marginais, resultando no levantamento inicial do Arco de Assunção e na compartimentação das sub-bacias de Apucarana e Alto Garças; 3) a base da seqüência givetiana-frasniana (Mb. São Domingos) é caracterizada por rápida inundação, com presença de lags transgressivos, à qual se associa 0 ingresso de águas quentes e o declíneo da fauna malvinocáfrica. A superfície de máxima inundação no Givetiano corresponde à máxima transgressão no Devoniano da Bacia do Paraná. Análise regional permitiu verificar a aplicabilidade da divisão tripartite da $\mathrm{Fm}$. Ponta Grossa em toda a bacia. Na faixa de afloramentos no Estado de Goiás o $\mathrm{Mb}$. Jaguariaíva não ocorre e o contato com a $\mathrm{Fm}$. Furnas é discordante, com presença de lags transgressivos. Na chapada dos Guimarães a parte superior da Fm. Furnas de autores prévios foi reclassificada como Fm. Ponta Grossa. A seqüência devoniana é desigualmente preservada e recoberta em discordância levemente angular por unidades westphalianas do $\mathrm{Gr}$. Itararé. As seqüências ordovício-siluriana e devoniana são aproximadamente cronocorrelatas às orogenias pré-andinas Oclóyica (Ordoviciano Superior/Siluriano Inferior) e Chanica (Devoniano Médio/Mississipiano Inferior), evidenciando correspondência entre eventos de subsidência na bacia e orogenias nas bordas da placa. 


\section{ABSTRACT}

STRATIGRAPHIC ASPECTS OF THE PRE-CARBONIFEROUS SEQUENCES IN THE PARANÁ BASIN, BRAZIL. The pre-Carboniferous record of the Paraná Basin is composed of two stratigraphic sequences bounded by regional unconformities: 1) Ordovician-Silurian sequence, and 2) Devonian sequence. The Ordovician-Silurian stratigraphic sequence (Rio Ivaí Group) is characterized by two depositional sequences. The oldest one (Caradocian/Ashgillian) is made up of sandstones (Alto Garças Formation), dipping westward to the Chaco basin, herein interpreted as transgressive and highstand systems tracts. The youngest sequence (Neoashgillian/ Llandoverian) begins with subglacial facies of the lapó Formation, a correlative of several Gondwana Neoashgillian glacial records. The shales of the Vila Maria Formation (Lower Llandoverian) are the post-glacial flooding record and comprise the maximum flooding surface of the transgressive systems tracts. The upper section of the Vila Maria Formation records the regressive facies and a widespread unconformity in the Late Silurian. The Devonian stratigraphic sequence (Paraná Group) is made up of three depositional sequences: 1) the lowermost one (Lochkovian?) records, from west to east, a coastal onlap over the basement comprising the transgressive and highstand systems tracts of the Furnas Formation (lower and middle sections). The presence of trilobite trace fossils in the Furnas Formation are important diagnosis for its marine environment. 2) The middle sequence (Praguian/Eifelian) is composed of conglomerates of lowstand system tract and transgressive facies toward the contact zone with Ponta Grossa Formation. The maximum flooding surface was in the Late Emsian during the deposition of the Jaguariaiva Member. The Eifelian (Tibagi Member) is characterized by a progradational regressive stacking, typical of highstand systems tracts. Sinsedimentary tectonics were responsible for creating internal and marginal highs, such as the Asuncion Arch, and sub-basins such as the Apucarana and Alto Garças. 3) The uppermost sequence (Givetian/Frasnian) is a transgressive sequence (São Domingos Member) associated with warm currents bringing about the decline of the Malvinokaffric fauna. The Givetian maximum flooding surface overlaps the maximum transgression of the Devonian in the Paraná basin. The Devonian sequence is separated from the Itararé Group (Westphalian) by a slightly angular unconformity. The regional analysis performed in this work has also aimed the practical application of the three-fold subdivision of the Ponta Grossa Formation. It has been observed that the Jaguariaiva Member does not occur in the outcrop area of Goiás State and that the contact with the Furnas Formation, in that area, is discordant with transgressive lags. In the Chapada dos Guimarães area, Mato Grosso State, the upper part of the Furnas Formation of previous authors was reclassified as Ponta Grossa Formation. The Ordovician-Silurian and Devonian sequences in the Paraná Basin are chronocorrelated to the Oclóyica (Late Ordovician/Early Silurian) and Chanica (Middle Devonian/Early Mississippian) pre-Andean orogenic phases, showing correspondence between intraplate subsidence and orogenies in the plate edges. 
SUMÁRIO

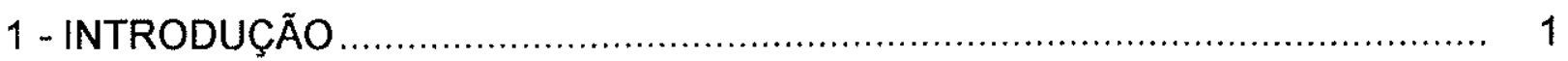

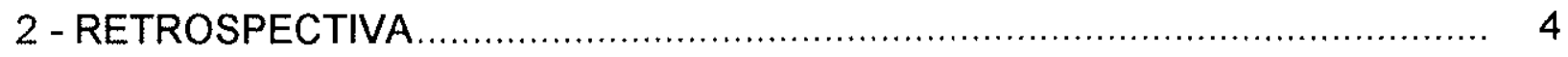

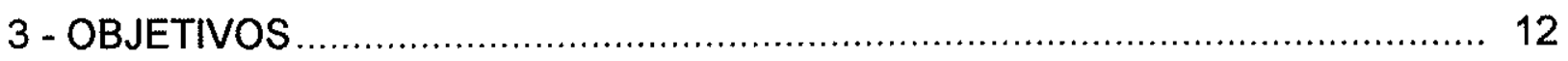

4 - MÉTODOS, MEIOS E TRABALHOS REALIZADOS ................................... 13

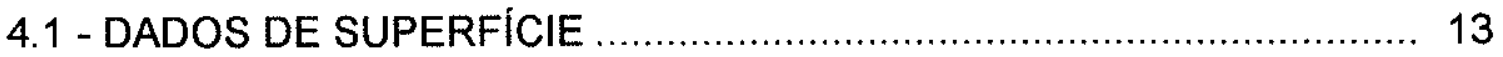

4.2 - DADOS DE SUBSUPERFÍCIE …............................................. 15

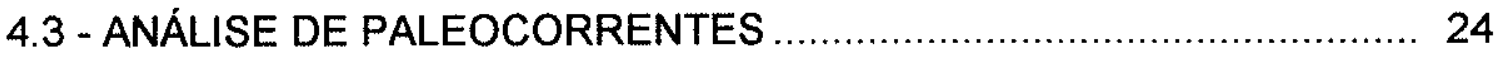

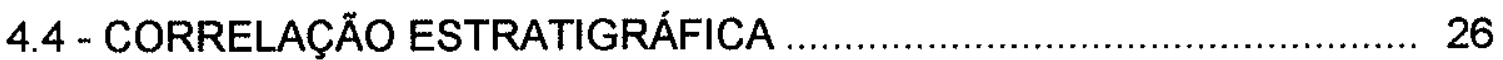

4.5 - ANÁLISE DE FÁCIES E INTERPRETAÇÃO

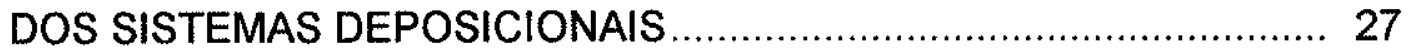

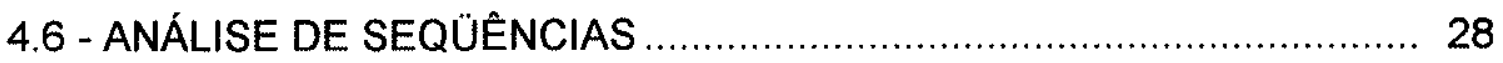

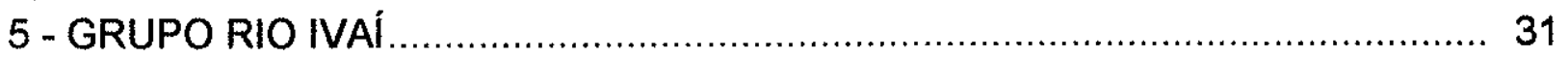

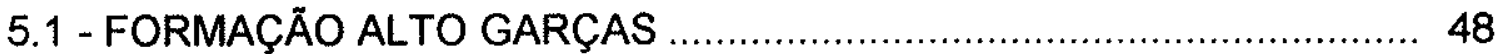

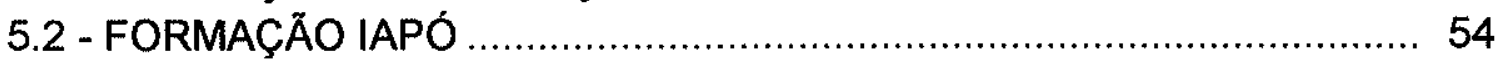

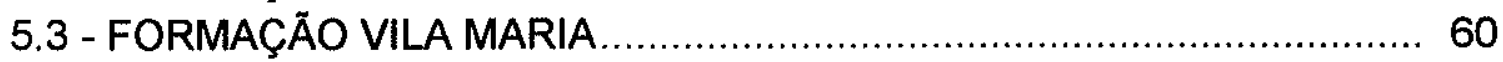

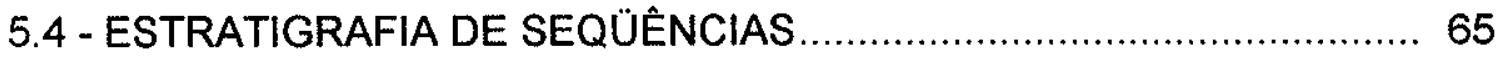

5.4.1 - Seqüência Caradociana - Ashgilliana .................................... 65

5.4.2 - Seqüência Neo-Ashgilliana - Llandoveriana........................... 67

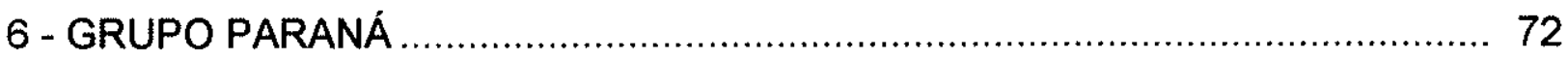

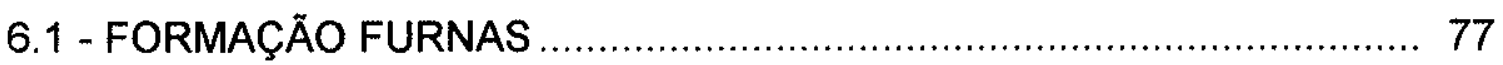

6.1.1 - Arranjo vertical de fácies ................................................. 77

6.1 .2 - Paleocorrentes................................................................ 92

6.1 .3 - Icnofósseis ..................................................................... 93

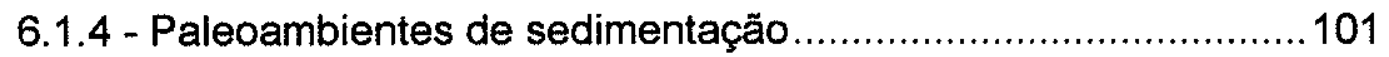

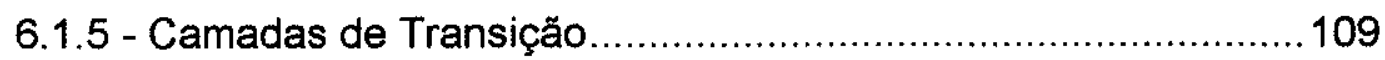

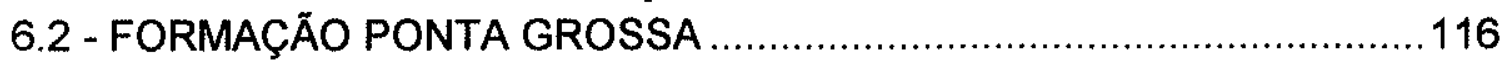

6.2.1 - Subdivisão Litoestratigráfica................................................116

6.2.2 - Arenitos do Membro Tibagi............................................... 119

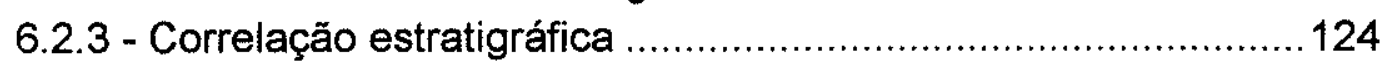

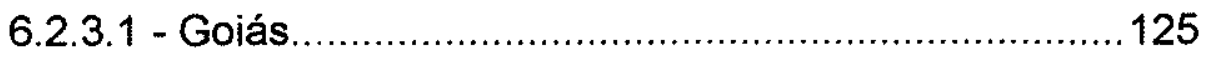

6.2.3.2 - Chapada dos Guimarães .................................... 130

6.2.3.3 - Uruguai ............................................................ 134

6.2.4 - Natureza do contato com a Formação Furnas..........................135 


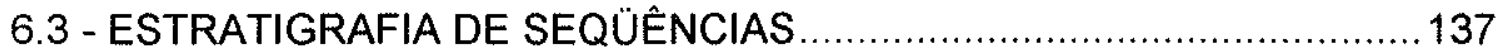

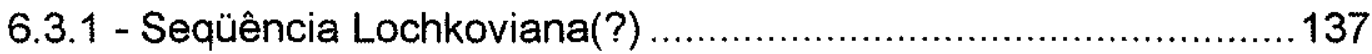

6.3.2 - Seqüência Praguiana-Eifeliana ..........................................142

6.3.3 - Seqüência Givetiana-Frasniana .......................................... 147

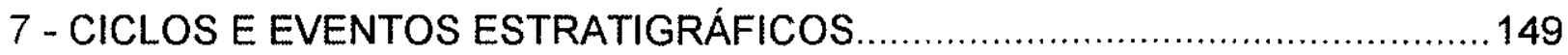

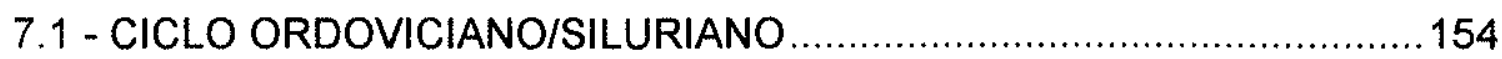

7.1.1 - Ordoviciano Superior: paleogeografia integrada às bacias do Chaco .............................................154

7.1.2 - Glaciação neo-ordoviciana: um evento gondwânico .................157

7.1.3 - Llandoveriano: transgressão generalizada............................. 161

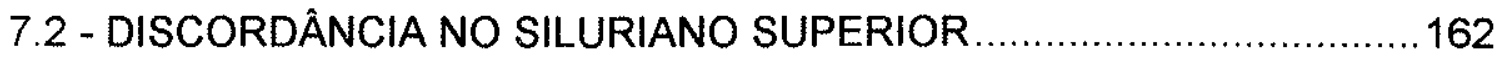

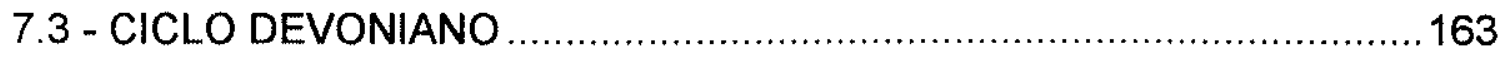

7.3.1 - Lochkoviano(?): transgressão sobre embasamento peneplanizado .......................................164

7.3.2 - Praguiano / Eifeliano: evidências de

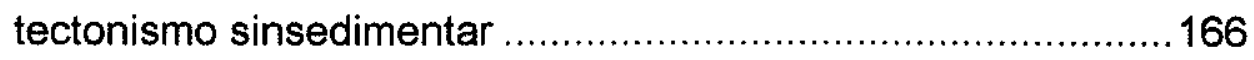

7.3.3 - Givetiano / Frasniano: máximo da transgressão marinha no Devoniano ...................................170

7.4 - DISCORDÂNCIA NO CARBONÍFERO INFERIOR ….........................171

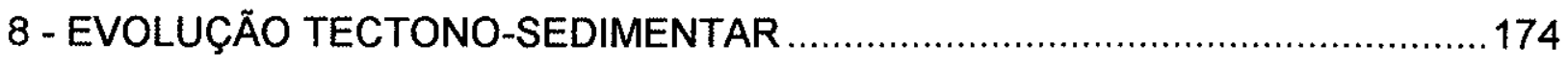

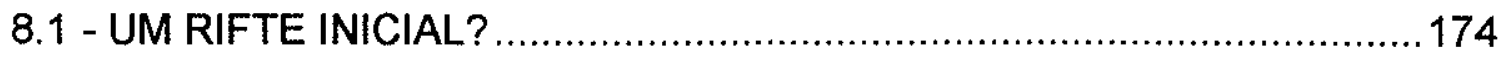

8.2 - O CICLO OROGÉNICO FAMATINIANO E A

EVOLUÇÃO PRÉ-CARBONÍFERA DA BACIA DO PARANÁ .................177

8.3 - CORRELAÇÃO ENTRE AS SEQÜÊNCIAS PRÉ-CARBONIFERAS DA BACIA DO PARANÁ E AS OROGENIAS PRÉ-ANDINAS ................186

9 - CONCLUSÕES 190

REFERÊNCIAS BIBLIOGRÁFICAS 194 


\section{FIGURAS}

Figura 1 - Mapa geológico simplificado da Bacia do Paraná

Figura 2 - Coluna estratigráfica das unidades pré-carboníferas

a Bacia do Paraná

Figura 3 - Diferentes correlações das unidades pré-carboníferas em subsuperfície

Figura 4 - Mapa de localização das faixas de afloramento e dos poços analisados

Figura 5 - Mapa geológico do flanco norte da bacia com indicação dos pontos descritos

Figura 6 - Mapa geológico do flanco noroeste da bacia com indicação dos pontos descritos

Figura 7 - Mapa geológico do flanco sudeste da bacia com indicação dos pontos descritos 18

Figura 8 - Padrões azimutais de dados de paleocorrente ................................ 25

Figura 9 - Mapa de isópacas do Gr. Rio Ivaí ............................................. 33

Figura 10 - Perfis de mergulho e de raios-gama, mostrando relações de contato do $\mathrm{Gr}$. Rio Ivaí 34

Figura 11 - Discordância entre os grupos Rio Ivaí e Paraná ............................. 35

Figura 12 - Seção estratigráfica A-A' 36

Figura 13 - Seções colunares do Gr. Rio Ivaí entre Amorinópolis e Bom Jardim de Goiás-GO

Figura 14 - Seçôes colunares do Gr. Rio Ivaí na bacia de drenagem do ribeirão das Perdizes, a sudeste de Baliza-GO 38

Figura 15 - Seção geológica e seções colunares do Gr. Rio Ivaí na região de Barra do Garças (MT) 40

Figura 16 - Seção estratigráfica mostrando o acunhamento da seqüência ordovício-siluriana para leste, porção norte da bacia 42

Figura 17 - Seção colunar do Gr. Rio Ivaí a oeste de Rio Verde do Mato Grosso

Figura 18 - Seções colunares do Gr. Rio Ivaí ao sul de São Lourenço de Fátima, Município de Rondonópolis (MT) 45

Figura 19 - Seção estratigráfica B-B' 46

Figura 20 - Seção estratigráfica C-C' 47

Figura 21 - Mapa de isópacas da Fm. Alto Garças ........................................ 49

Figura 22 - Fácies da Fm. Alto Garças ..................................................... 50

Figura 23 - Seção-tipo da Fm. lapó ............................................................. 55

Figura 24 - Ocorrências da Fm. lapó em afloramentos e poços .......................... 56

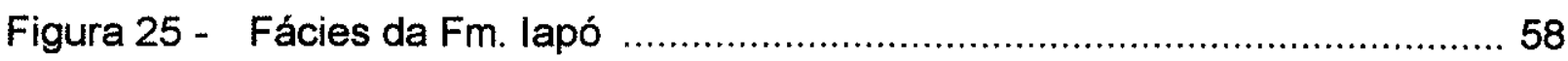


Figura 26 - Exemplos do Quaternário mostrando que as fácies subglaciais apresentam descontinuidade geográfica

Figura 27 - Fm. Vila Maria, conforme redefinida por Assine et al. (1994) ............ 62

Figura 28 - Fácies da Fm. Vila Maria ......................................................... 64

Figura 29 - Paleoambiente deposicional da Fm. Vila Maria ............................... 65

Figura 30 - Seqüências e tratos deposicionais no Ordoviciano-

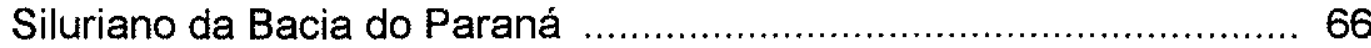

Figura 31 - Paleocorrentes nos Gr.s Rio Ivaí e Caacupé ................................... 68

Figura 32 - Interpretação esquemática da evolução geológica do Gr. Rio Ivaí ....................................................... 71

Figura 33 - Mapa de isópacas do Gr. Paraná ................................................ 73

Figura 34- Seção sísmica de reflexão mostrando a discordância angular entre a Fm. Furnas e estratos de uma bacia molássica ....... 74

Figura 35 - Discordâncias angulares entre a Fm. Furnas e unidades do embasamento pré-cambriano/eopaleozóico ............................... 75

Figura 36 - Seção sísmica de reflexão mostrando canais na base do Gr. Itararé, moldando a discordância no topo da Fm. Ponta Grossa .................... 75

Figura 37 - Seção geológica esquemática no flanco sul do

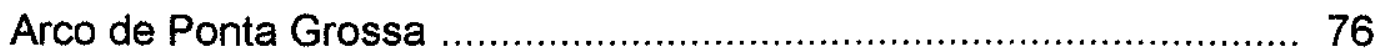

Figura 38 - Mapa de isópacas da Fm. Furnas ……........................................ 78

Figura 39 - Fácies da unidade I da Fm. Furnas ............................................... 81

Figura 40- Fácies da unidade II da Fm. Furnas ........................................... 82

Figura 41 - Fácies da unidade III da Fm. Furnas .............................................. 84

Figura 42 - Seção colunar da Fm. Furnas no canyon do do rio lapó no Guartelá, Tibagi (PR) ........................................... 87

Figura 43 - Correlação da seção estratigráfica da Fm. Furnas no canyon do rio lapó (Guartelá) com os perfis dos poços 2-MO-1-PR, 2-CS-1-PR e 2-RI-1-PR

Figura 44 - Seção colunar da Fm. Furnas no mirante do morro do Cristo Redentor, em Barra do Garças (MT)

Figura 45 - Fácies da Fm. Furnas nas faixas de afloramentos dos flancos norte e noroeste da bacia

Figura 46 - Paleocorrentes na unidade I da Fm. Furnas na faixa de afloramentos do flanco sudeste

Figura 47 - Paleocorrentes na unidade II da Fm. Furnas na faixa de afloramentos do flanco sudeste

Figura 48 - Paleocorrentes na unidade III da Fm. Furnas na faixa de afloramentos do flanco sudeste

Figura 49 - Paleocorrentes na Fm. Furnas na faixa de afloramentos do flanco noroeste 
Figura 50 - Paleocorrentes da Fm Furnas na faixa de afloramentos do flanco norte. 98

Figura 51 - Icnofósseis na Fm. Furnas.................................................... 99

Figura 52 - Traços fósseis de trilobita na Fm. Furnas....................................... 100

Figura 53 - Estruturas sedimentares geradas pela ação de ondas em substratos com diferentes granulometrias 103

Figura 54 - Exemplos da atuação de correntes de maré na Fm. Furnas. 106

Figura 55 - Mecanismo de Fm.de depósitos residuais de cascaiho (lags) em ambientes marinhos rasos

Figura 56 - Seções colunares da unidade III da Fm. Furnas em afloramentos onde foram constatados restos de vegetais vasculares

Figura 57 - Vegetais vasculares primitivos na parte superior da unidade III da Fm. Furnas.

Figura 58 - Camadas de Transição em Jaguariaíva (PR) ...............................113

Figura 59 - Fácies da Fm Furnas/Camadas de Transição ...................................114

Figura 60 - Mapa de isópacas da Fm. Ponta Grossa....................................... 117

Figura 61 - Litologias características da Fm. Ponta Grossa ...............................118

Figura 62 - Seção colunar da Fm. Ponta Grossa no bairro Santa Luzia, em Ponta Grossa (PR)

Figura 63 - Fácies do Mb Tibagi na seção do bairro Santa Luzia.

Figura 64 - Ondulações de onda em arenitos muito grossos do Mb. Tibagi 123

Figura 65 - Comparação entre os comprimentos de onda e as amplitudes das ondulações formadas por onda em sedimentos clásticos das formações Gates, Cardium e Wapiabi (Cretáceo do oeste canadense) e da Fm. Ponta Grossa

Figura 66 - Seçäo estratigráfica NS, mostrando falta de seção entre as formações Furnas e Ponta Grossa

Figura 67 - Características litológicas da Fm. Ponta Grossa na porção norte da bacia

Figura 68 - Correlação da seção colunar da Fm. Ponta Grossa ao sul de Amorinópolis (GO) e o perfil do poço 2-JA-1-GO 128

Figura 69 - O Gr. Paraná na chapada dos Guimarães.

Figura 70 - Esquemas estratigráficos propostos para o Devoniano da chapada dos Guimarães, Estado de Mato Grosso

Figura 71 - Depósitos residuais (lags) transgressivos na base da Fm. Ponta Grossa no Estado de Goiás

Figura 72 - Seqüências e tratos deposicionais no Devoniano da Bacia do Paraná

Figura 73 - Paleocorrentes nas fácies areno-conglomeráticas da unidade I da Fm. Furnas 
Figura 74 - Seção colunar levantada entre as cidades de Bonsucesso e Itapeva (SP).

Figura 75 - Seção estratigráfioca esquemática mostrando truncamento erosivo da Fm. Furnas pela Fm. Ponta Grossa na faixa de afloramentos no Estado de Goiás.

Figura 76 - Orientação dos eixos "a" de seixos assimétricos de depósitos residuais joeirados existentes na unidade III da Fm. Furnas

Figura 77 - Correlação entre as seqüências pré-carboniferas da Bacia do Paraná e os ciclos fanerozóicos

Figura 78 - Quadro de correlação estratigráfica

Figura 79 - Ciclos de $3^{a}$ ordem ou seqüências deposicionais no pré-Carbonífero da Bacia do Paraná

Figura 80 - Correlação estratigráfica das unidades pré-carboníferas das bacias do Paraná, Amazonas e Parnaíba

Figura 81 - Gondwana no Ordoviciano Superior ...............................................155

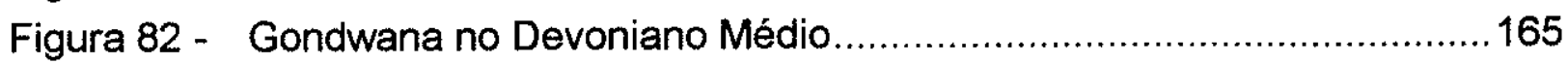

Figura 83 - Ciclos orogênicos e fases diastróficas no Paleozóico Inferiorl Médio da margem sudoeste do continente de Gondwana

Figura 84 - Evolução geológica da região centro-sul do continente sul-americano, no Paleozóico Inferior/Médio 179

Figura 85 - Mapa paleogeológico da região centro-sul do continente sul-americano no Ordoviciano Superior. 180

Figura 86 - Mapa paleogeológico da região centro-sul do continente sul-americano no Devoniano Médio 183

Figura 87 - Mapa de isópacas do Gr. Itararé 186

Figura 88 - Correlação entre orogenias e seqüências cratônicas norte-americanas

Figura 89 - Disposição geográfica das bacias intracratônicas norteamericanas de Michigan e Illinois, adjacente à bacia foreland e ao orógeno dos Apalaches 


\section{TABELAS}

Tabela 1 - Identificação dos poços indicados na figura 5 ................................. 15

Tabela 2 - Localização dos afloramentos descritos no flanco norte ..................... 19

Tabela 3 - Localização dos afloramentos descritos no flanco noroeste ............... 19

Tabela 4 - Localização dos afloramentos descritos no flanco sudeste................20

Tabela 5 - Código de fácies ................................................................. 22

Tabela 6 - Símbolos utilizados na confeção das figuras .................................23 


\section{1 - INTRODUÇÃO}

A Bacia do Paraná compreende uma área total de aproximadamente 1400000 $\mathrm{km}^{2}$, abrangendo terras do centro-sul do Brasil, do oeste do Uruguai, do leste do Paraguai e da mesopotâmia argentina (Fig. 1). Trata-se de uma bacia interior de natureza policíclica, marcada por eventos alternados de subsidência (seqüências) e soerguimento (discordâncias), desde sua implantação no Ordoviciano Superior até seu ocaso como entidade geotectônica subsidente no Cretáceo Superior.

Os eventos geológicos pré-carboníferos, que determinaram sua implantação e desenvolvimento inicial, após os eventos colisionais do Ciclo Orogênico Brasiliano, constituem aspectos dos menos conhecidos de sua geologia. Pouco compreendidas também são a natureza dos eventos de subsidência e a geração de discordâncias na bacia, pois poucos autores buscaram analisá-las em conjunto com outras bacias gondwânicas e com as orogenias pré-andinas.

Como produto das pesquisas desenvolvidas durante o programa de doutoramento, o autor publicou, com a colaboração dos colegas Paulo C. Soares e Édison J. Milani (Assine et al. 1994), uma reavaliação preliminar das seqüências tectono-sedimentares pré-carboniferas da Bacia do Paraná. As propostas apresentadas foram adotadas pela Petrobrás em sua mais recente versão da coluna estratigráfica da bacia (Milani et al. 1994). Ainda assim, a seqüência ordovíciosiluriana, referida litoestratigraficamente como Gr. Rio Ivaí (Fig. 2), carece de caracterização mais detalhada do seu arcabouço estratigráfico regional.

Com relação à seqüência devoniana (Gr. Paraná), têm persistido ao longo dos anos divergências quanto à idade, ambiente de sedimentação e natureza dos contatos inferior e superior de sua unidade basal, a $\mathrm{Fm}$. Furnas. De outra parte, ainda não foi realizada análise mais pormenorizada da seqüência em escala de bacia, com a integração dos dados de superfície e de subsuperfície.

Tendo em vista estas considerações, buscou-se, neste trabalho, delinear o arcabouço estratigráfico regional das sequêencias pré-carboníferas da bacia, com a finalidade de interpretar sua evolução geológica, do Ordoviciano Superior ao final do Devoniano. Para tanto, foi realizada detalhada reavaliação das informações disponiveis na literatura geológica e levantados novos dados de superfície e subsuperfície, a seguir integrados e correlacionados com os cicios estratigráficos e os eventos tectônicos reconhecidos por diferentes autores em outras bacias gondwânicas. 


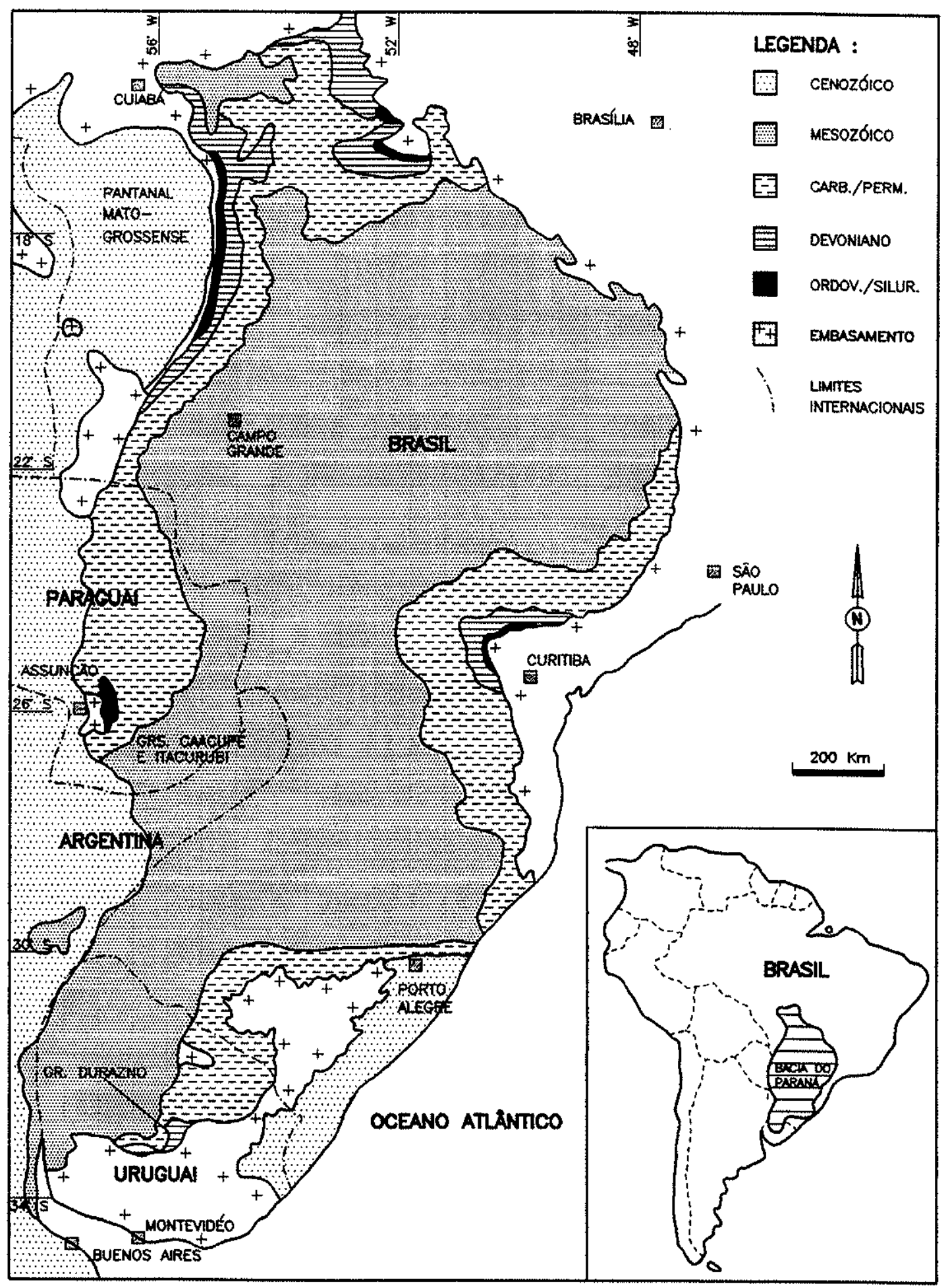

Figura 1 - Mapa geológico simplificado da Bacia do Paraná. 


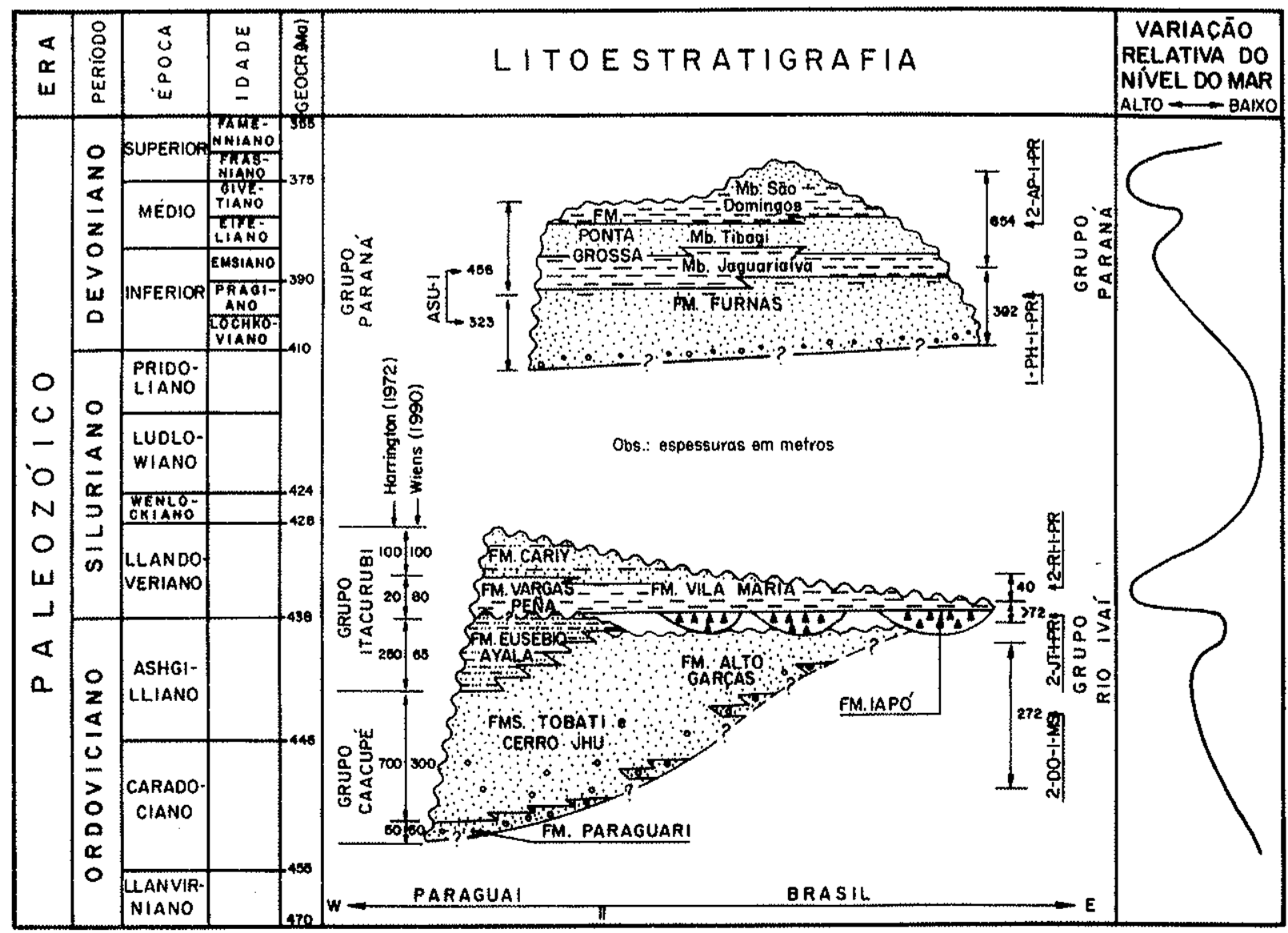

Figura 2 - Coluna estratigráfica das unidades pré-carboniferas da Bacia do Paraná (modif. de Assine et al. 1994). As espessuras máximas (em metros) e os poços ode as mesmas foram constatadas estão indicados na vertical. 


\section{2 - RETROSPECTIVA}

As bases da subdivisão litoestratigráfica das rochas pré-carboníferas da Bacia do Paraná remontam a Oliveira (1912), que dividiu a seção devoniana, da base para o topo, em três unidades litológicas: Arenito das Furnas, Folhelhos de Ponta Grossa e Arenito de Tibagi. Maack (1947) reconheceu uma quarta unidade devoniana no topo da seção, denominando-a Folhelhos São Domingos. Petri (1948), inspirado no Código Americano de Taxonomia Estratigráfica denominou a primeira de Fm. Furnas, englobando as três últimas sob a denominação de Fm. Ponta Grossa, Posteriormente, Lange \& Petri (1967) propuseram a formalização de uma divisão tripartite da Fm. Ponta Grossa, constituída, da base ao topo, pelos membros Jaguariaíva, Tibagi e São Domingos. Merece destaque, entretanto, 0 fato de que este procedimento não foi adotado por Diniz (1985) por considerar que a unidade tem comportamento heterogêneo em subsuperfície, e por Andrade \& Camarço (1980 e 1982) e Melo (1985 e 1988) que destacaram diferenças marcantes no empilhamento da unidade no flanco norte da bacia.

Para o conjunto das formações Furnas e Ponta Grossa foram empregadas as denominações Série Paraná (Moraes Rego 1931, Petri 1948, Sanford \& Lange 1960) e Série Campos Gerais (Maack 1947, Bigarella et al. 1966). Considerando o termo série inadequado e por considerar que a denominação Campos Gerais não tinha prioridade, Lange \& Petri (1967) propuseram que as unidades em questão fossem classificadas como Gr. Paraná. Com a adoção do termo Paraná como unidade litoestratigráfica na categoria de grupo, Gama Jr. et al. (1982) resgataram a denominação Série Campos Gerais para designar uma unidade cronoestratigráfica local.

Os folhelhos e arenitos da Fm. Ponta Grossa foram reconhecidos como devonianos no século passado (Derby 1878), por portarem uma ampla e variada fauna de fósseis marinhos (trilobitas, braquiópodes, tentaculites, bivalves, crinóides etc). As ocorrências foram descritas em detalhe por Clarke (1913), que permanece como a principal referência no estudo da paleontologia do Devoniano do Paraná.

As datações a partir dos macrofósseis sempre foram, entretanto, dificultadas pelo endemismo da fauna malvinocáfrica (Clarke 1913, Boucot 1971, Melo 1985 e 1988), de forma que o zoneamento cronoestratigráfico foi erigido com base em microfósseis. Segundo os trabalhos de Lange (1967) e de Daemon et al (1967), baseados respectivamente em quitinozoários e esporomorfos, as rochas devonianas da Bacia do Paraná foram depositadas no intervalo Emsiano/Frasniano, 
compreendendo, da base para o topo, cinco intervalos bioestratigráficos informais, aproximadamente correspondentes aos andares: $D_{1}$ (estéril), $D_{2}$ (Emsiano), $D_{3}$ (Eifeliano), $D_{4}$ (Givetiano) e $D_{5}$ (Frasniano). Lange \& Petri (1967) foram além, concluindo que há também uma correspondência entre as unidades lito e bioestratigráficas, a saber: $D_{1}$ (Fm. Furnas), $D_{2}$ (Mb. Jaguariaiva), $D_{3}\left(M b\right.$. Tibagi), $D_{4}$ e $D_{5}$ (Mb. São Domingos).

Estudando os testemunhos dos poços RSP-1, RVR-1 e RPL-1, perfurados pela Docegeo na serra da Petrovina (MT), Loboziak et al. (1988, apud Oliveira 1991) reconheceram apenas estratos dos andares Eifeliano Superior ao Frasniano Inferior, concluindo que o Emsiano não ocorre na área. À mesma conclusão chegou Oliveira (1991), analisando os acritarcas daqueles mesmos poços. Recentemente, a base da Fm. Ponta Grossa nos poços 1-PH-1-PR, 2-CN-1-PR e 2-AG-1-MT, posicionada no Emsiano por Lange (1967) e Daemon et al. (1967), foi reposicionada no Praguiano por Dino et al. (1995). Estes fatos evidenciam a necessidade de uma revisão e de um refinamento na cronoestratigrafia do Devoniano da bacia.

Poucos trabalhos utilizaram perfis geofísicos de poços com o objetivo de estabelecer a seqüencialidade dos eventos. Um trabaiho com esse objetivo foi o de Diniz (1985), que caracterizou um evento regressivo na parte intermediária da Fm. Ponta Grossa. À mesma conclusão chegaram Popp \& Barcellos-Popp (1986), que consideraram o Mb. Tibagi como a expressão sedimentar desta regressão.

Abaixo dos folhelhos emsianos marinhos da Fm. Ponta Grossa, ocorrem os psamitos/psefitos da Fm. Furnas. Esta unidade é constituida por espessa seção arenosa, pobremente fossilífera, onde foram encontrados apenas icnofósseis e restos de plantas primitivas, estes últimos em sua porção superior. Tais ocorrências apresentaram, até o momento, pouco valor cronoestratigráfico.

Idade eodevoniana para a Fm. Furnas foi admitida pela maioria dos pesquisadores que a estudaram (Oliveira 1912, Maack 1947,Petri 1948, Sanford \& Lange 1960, Lange \& Petri 1967, Petri \& Fúlfaro 1967, Northfleet et al. 1969, Schneider et al. 1974, Petri \& Fulfaro 1976, Soares et al. 1978, Popp \& Barcellos-Popp 1986, Melo 1988), basicamente a partir da concepção de um contato concordante com a Fm. Ponta Grossa.

Em termos paleoambientais, para a maioria dos pesquisadores a Fm. Furnas foi depositada em ambiente marinho-raso (Petri 1948, Sanford \& Lange 1960, Bigarella et al. 1966, Lange \& Petri 1967, Bigarella 1973, Petri \& Fúlfaro 1983, Borghi 1992). Outros autores postularam origem fluvial (Northfleet et al. 1969, Schneider et al. 1974, 
Andrade \& Camarço 1980, Melo 1987, Zalán et al. 1987a). Trabalhos mais recentes (Bergamaschi 1992, Assine et al. 1994) consideraram que a unidade é faciologicamente complexa, produto da associação de fácies deltaicas $e$ marinhas plataformais.

A natureza do contato entre as Formações Furnas e Ponta Grossa sempre foi um tema polêmico, pois se em alguns afloramentos é visivelmente gradacional, como na seção da estrada de ferro em Jaguariaíva onde Petri (1948) definiu as Camadas de Transição. Contatos litológicos abruptos foram descritos em Tibagi e considerados indicativos de discordancia por Bigarella (1973), que correlacionou a Fm. Furnas com - Gr. Caacupé, unidade basal da bacia no Paraguai, considerada na época de publicação daquele trabalho de idade siluriana (Harrington 1972). A correlação litoestratigráfica realizada por Bigarella (1973) não levou em conta, entretanto, a existência dos diamictitos da Fm. lapó, posicionados sob os arenitos conglomeráticos da base da Fm. Furnas no Estado do Paraná e correlacionados por Maack (1947) aos diamictitos glaciais de idade neo-ordoviciana/eo-siluriana da Fm. Pakhuis do Grupo Table Mountain da África do Sul. Sendo verdadeira esta correlação, a correspondência entre a Fm. Furnas e o Gr. Caacupé defendida por Bigarella (1973) não é factível.

O que se depreende da literatura é que, apesar da existência da Fm. lapó, a $\mathrm{Fm}$. Furnas continuou durante muitos anos sendo considerada a unidade litoestratigráfica basal da bacia em sua porção brasileira, mesmo que arenitos avermelhados sotopostos houvessem sido constatados em subsuperfície (Maino 1965), no intervalo 1702 a 1944 m do poço 2-AG-1-MT (Alto Garças).

O interesse pelas unidades pré-devonianas da bacia só foi despertado com a descoberta da Fm. Vila Maria no flanco norte da bacia (Faria \& Reis Neto 1978), considerada eo-siluriana por Burjack e Popp (1981) em função da presença do icnofóssil Arthrophycus alleghaniensis. Posteriormente, Gray et al. (1985), com base em palinomorfos, posicionaram os folhelhos da Fm. Vila Maria no Llandoveriano Inferior. Tal descoberta deu início a uma série de trabalhos que permitiram significativo avanço no conhecimento das unidades mesopaleozóicas da bacia. Andrade \& Camarço (1980) correlacionaram os sedimentos da Fm. Vila Maria com a seção psamítica situada abaixo da Fm. Furnas no poço 2-AG-1-MT. Posteriormente, os mesmos autores (1982) atribuíram idade siluriana para toda a Fm. Furnas, a partir da concepção de um contato concordante com a Fm. Vila Maria e discordante com a Fm. Ponta Grossa. 
Faria (1982) apresentou a seção-tipo da Fm. Vila Maria em superfície, estendendo também a denominação para os $242 \mathrm{~m}$ perfurados abaixo da $\mathrm{Fm}$. Furnas no poço 2-AG-1-MT. Considerou concordante o contato com a Fm. Furnas, deixando subentender assim uma idade siluriana para esta última, pelo menos em sua porção basal.

Zalán et al. (1987a), correlacionando perfis litológicos e petrofísicos de poços, rastrearam como Fm. Vila Maria seções de subsuperficie anteriormente consideradas pertencentes à Fm. Furnas, destacando uma seção arenosa basal formalizada como Fm. Rio Ivaí. Admitindo um contato discordante entre as formações Furnas e Ponta Grossa, e concordante entre as formações Furnas e Vila Maria, conceberam uma divisão tripartite do Siluriano da Bacia do Paraná, incluindo as formações Rio Ivaí, Vila Maria e Furnas (Fig. 3-A)

Assine \& Soares (1989), a partir da análise de formatos de perfis de raios-gama dos poços perfurados na bacia, apresentaram uma nova correlação estratigráfica (Fig. 3-B), onde a Fm. Vila Maria corresponde ao "marco síltico radioativo" de Zalán et al. (1987a). Adotando uma correspondência anteriormente aventada por Caputo \& Crowell (1985), estabeleceram a correlação entre os diamictitos da base da Fm. Vila Maria e os da Fm. lapó. Advogando um contato discordante entre as formações Vila Maria e Furnas, optaram pela não utilização da divisão tripartite do Siluriano da Bacia do Paraná nos moldes em que foi estabelecida por Zalán et al. (1987a). Contatos erosivos entre as formações Furnas e Vila Maria, na faixa aflorante em Goiás, foram relatados posteriormente por Pereira (1992).

Com base na nova correlação, Assine et al. (1994) demonstraram que as diferentes unidades apresentam assinaturas típicas em perfis de raios-gama dos poços perfurados na bacia. Destacaram a importância dos diamictitos da Fm. lapó como um marco estratigráfico, relacionado à glaciação no interregno Ordoviciano superior/Siluriano inferior. Com base na preservação irregular dos estratos silurianos e na pouca variação da espessura da Fm. Furnas, propuseram uma discordância regional entre as formações Vila Maria e Furnas.

Contato concordante entre as formações Furnas e Ponta Grossa foi demonstrado tanto pela inexistência de omissão de seção no topo da Fm. Furnas, quanto pela constatação em um grande número de poços de uma assinatura em perfis raios-gama característica de incremento gradativo de argilosidade, do topo da Fm. Furnas para a base da Fm. Ponta Grossa (Assine et al. 1994). O contato entre as formações Furnas e Ponta Grossa foi também considerado concordante por 


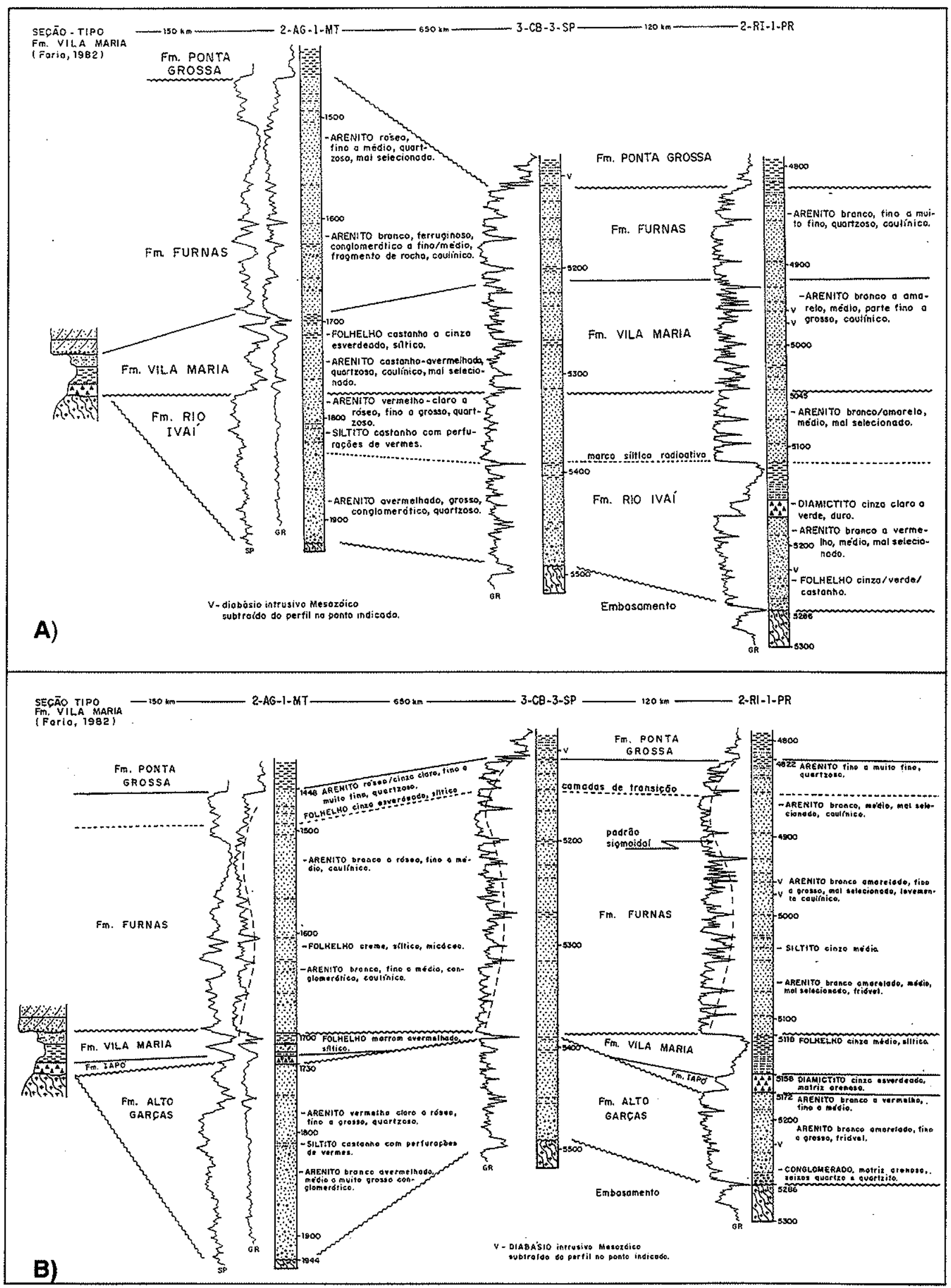

Figura 3 - Diferentes correlações em subsuperficie das unidades pré-carboníferas: A) Zalán et al. (1987a); e B) Assine \& Soares (1989). 
Bergamaschi (1992) e Borghi (1992). Corroborou tais interpretações a descoberta de palinomorfos na porção superior da Fm. Furnas, datados como praguianos por Dino e Rodrigues (1995).

Em decorrência das considerações acima, as unidades pré-carboníferas da bacia compõem duas seqüências tectono-sedimentares limitadas por discordâncias regionais. A seqüência inferior é de idade ordovício-siluriana e representada pelo $\mathrm{Gr}$. Rio Ivaí (Assine et al. 1994), que é constituído pelas formações Alto Garças, lapó e Vila Maria (Fig. 2). A seqüência superior, de idade devoniana e litoestratigraficamente correspondente ao Gr. Paraná (formações Furnas e Ponta Grossa), é limitada no topo por uma expressiva discordância, responsável pelas grandes variações de sua espessura.

Sobre a seqüência ordovício-siluriana, poucas são as informações disponíveis até o momento quanto a aspectos estruturais e paleogeográficos. Milani et al. (no prelo) realizaram a primeira tentativa de análise regional da seqüência, rastreando o Gr. Rio Ivaí em grande parte da bacia e constatando a existência de palinomorfos silurianos no que foi interpretado como Fm. Vila Maria em vários poços. Sugeriram que os depocentros estão controlados por falhas de direção NE, possivelmente reativações das estruturas do embasamento. Paleogeograficamente, relacionaram os sedimentos da Fm. Alto Garças às espessas seqüências clásticas que bordejavam a margem ocidental do continente de Gondwana no Ordoviciano Superior/Siluriano Inferior. Considerando a escala da análise realizada, os resultados são ainda preliminares, carecendo a seqüencia de estudos mais detalhados que possam definir mais claramente sua arquitetura deposicional e polaridade sedimentar.

A Fm. Furnas, unidade basal da seqüência devoniana, depositou-se, segundo Northfleet et al. (1969), numa depressão alongada na direção NNW-SSE, apresentando grande homogeneidade litológica e ausência de influência tectônica durante a sedimentação. Para os mesmos autores, a Fm. Ponta Grossa foi afetada pelo levantamento concomitante do Alto de Três Lagoas entre o Emsiano e o Givetiano, fato por eles deduzido a partir da não constatação dos andares Emsiano/Eifeliano no poço 2-TL-1-MS, onde, segundo Lange (1967) e Daemon et al. (1967), sedimentos de idade givetiana recobrem diretamente os arenitos da Fm. Furnas. Como indícios sedimentares desta movimentação tectônica, Northfleet et al. (1969) chamaram a atenção para a existência de arenitos lenticulares dentro dos folhelhos da Fm. Ponta Grossa em afloramentos no flanco sudeste da bacia (PR). 
Ramos (1970), com base no mapa de isópacas de Northfleet et al. (1969), que mostra dois depocentros, concluiu que houve notável controle tectônico durante a deposição da Fm. Ponta Grossa, que foi responsável pelo levantamento do Alto de Três Lagoas e compartimentação nas sub-bacias de Apucarana e Alto Garças. Para o mesmo autor, a maior espessura e a predominância de folhelhos na sub-bacia de Apucarana evidenciam maior subsidência em ambiente relativamente mais profundo. Condições mais rasas foram interpretadas para a sub-bacia de Alto Garças, tendo por base o fato de que a seção é mais arenosa.

Ferreira et al. (1981) atribuiram tal segmentação à tectônica responsável pelo Alinhamento de Guapiara, um alto que teria sido a feição regional mais importante à época da sedimentação, separando as duas sub-bacias. Com base em dados aeromagnetométricos, concluíram que a depressão de Apucarana foi controlada tectonicamente, sendo resultado do afundamento do bloco compreendido entre os alinhamentos de São Jerônimo-Curiúva e Rio Alonso.

Andrade \& Camarço (1982) também advogaram movimentações tectônicas durante a deposição dos sedimentos da Fm. Ponta Grossa. Para eles, após a deposição da Fm. Furnas, seguiu-se um suave levantamento do flanco norte (GO) da bacia, do que resultou a formação de um conglomerado basal na Formação Ponta Grossa. Novo levantamento entre o Emsiano e o Givetiano teria sido responsável pela reativação das áreas-fonte a leste e formação de uma cunha progradacional deltaica na porção média da Formação Ponta Grossa.

Para Fulfaro et al. (1982) a deposição da seqüência devoniana da Bacia do Paraná foi controlada por uma calha deposicional NW-SE, transversal à direção das estruturas brasilianas de seu embasamento cristalino, herança de aulacógenos tardios de direção preferencial NW-SE, desenvolvidos ao final da cratonização da faixa de dobramentos das região sul e sudeste da Plataforma Sul-Americana. Interpretaram tais estruturas NW como zonas de fraqueza, reativadas no final do Siluriano e início do Devoniano com o levantamento do Arco de Assunção. Nova reativação destes alinhamentos, a partir do Devoniano Superior, teria causado erosão nos blocos altos e gerado a discordância que separa os grupos Paraná (Devoniano) e ltararé (Carbonifero Superior/Permiano Inferior).

A concepção de que a origem da bacia foi controlada por aulacógenos, à semelhança das bacias norte-americanas, é matéria ainda em aberto. Zalán et al. (1987b), por exemplo, argumentaram que não há evidências que sustentem a interpretação de riftes ativos durante a deposição dos sedimentos silurianos. 
A extensão original da bacia devoniana era maior do que a atual área de ocorrência da seqüência devoniana. Lange \& Petri (1967) concluíram que as bacias do Paraná e do Parnaíba foram interligadas durante o máximo da transgressão devoniana (Givetiano/Frasniano) através da região hoje ocupada pelas bacias de drenagem dos rios Araguaia e Tocantins. Bigarella \& Salamuni (1967) argumentaram que as paleocorrentes da Formação Furnas nos flancos norte e noroeste indicam sentido de transporte para fora da atual borda da bacia, evidenciando maior extensão original para $\mathrm{N}$ e NW e uma possivel conexão com outras bacias, como as do Parnaíba e do Amazonas. Pouco se avançou desde então e o cenário paleogeográfico ainda é muito especulativo. Muitos dados e novas interpretações são necessários para que se possa estabelecer a fisiografia do Devoniano, integrando a Bacia do Paraná no contexto paleogeográfico regional, de forma que as reconstruções apresentadas por Weeks (1947), Lange \& Petri (1967), Melo (1988) e outros devem ser tomadas como ponto de partida. 


\section{3 - OBJETIVOS}

Para melhor caracterizar o arcabouço estratigráfico das seqüências précarboníferas da bacia e no sentido de buscar respostas a algumas das questões delineadas na retrospectiva apresentada, são objetivos deste trabalho: 1) levantamento, nas faixas de afioramento, de seções colunares representativas das diferentes unidades analisadas; 2) correlação das seções levantadas em superfície com o registro litológico e geofísico dos poços perfurados na bacia; 3) rastreamento das unidades em subsuperfície; 4) levantamento da distribuição geográfica $\theta$ caracterização faciológica da Fm. lapó; 5) definição do arranjo vertical e interpretação paleoambiental das associações faciológicas da Fm. Furnas; 6) caracterização sedimentológica (litologia, estruturas, padrões de variação textural na vertical etc) e interpretação paleoambiental dos arenitos da Fm. Ponta Grossa, de importância exploratória já que os folhelhos, aos quais os arenitos se encontram intercalados, são rochas potencialmente geradoras de gás; 7) reconhecimento de indicadores paleogeográficos, como por exemplo paleolinhas de costa; 8) definição da polaridade do preenchimento sedimentar nos grupos Rio Ivaí e Paraná; 9) interpretação das seqüências deposicionais (ciclos de $3^{a}$ ordem) e tratos de sistemas deposicionais; 10) definição da natureza das duas sub-bacias delineadas no mapa de isópacas da Fm. Ponta Grossa, se sindeposicional ou produto de tectônica modificadora ao final do ciclo; 11) correlação das seqüências identificadas com as de outras bacias gondwânicas; 12) verificação da existência de correlação das seqüências e/ou discordâncias existentes na bacia com as orogenias pré-andinas. 


\section{4- MÉTODOS, MEIOS E TRABALHOS REALIZADOS}

Os procedimentos para análise estratigráfica dependem da natureza da pesquisa que se pretende realizar. Uma análise regional de seqüências tectonosedimentares requer a integração de muitos e diferentes tipos de dados. Para atingir os objetivos propostos, além da análise crítica dos dados disponíveis na literatura geológica sobre o assunto, foram obtidos novos dados de campo nas faixas de afloramento das unidades pré-carboníferas nos flancos norte (GO/MT), noroeste (MT/MS) e sudeste (PR/SP) da bacia, a seguir integrados com informações de subsuperfície, principalmente de poços profundos perfurados nos programas de exploração petrolífera da Bacia do Paraná (Fig. 4; Tab. 1).

\section{1- DADOS DE SUPERFICIE}

A partir dos mapas geológicos das áreas de afloramento das unidades précarboniferas foram planejadas e realizadas diversas campanhas de campo. A metade de um total de cerca de 80 dias de trabalhos de campo foi concentrada no flanco sudeste ( $P R$ e SP), não só por facilidades de infraestrutura e acesso, mas também porque o conhecimento detalhado da faixa aflorante do Estado do Paraná é fator crítico para o entendimento da estratigrafia das unidades pré-carboníferas, já que aí a maioria delas foi definida e grande parte dos trabalhos desenvolvidos. Disto resultou um número muito grande de dados, que precisaram ser reavaliados e integrados na análise estratigráfica realizada. Além disto, no Estado do Paraná concentra-se a maior densidade de poços profundos perfurados na bacia, inclusive os mais recentes, com os quais os dados de superfície foram correlacionados.

Foram analisados e descritos 103 afloramentos, abrangendo as diferentes unidades litoestratigráficas aflorantes nos flancos norte (Fig. 5), noroeste (Fig. 6) e sudeste (Fig. 7) da bacia. Sua localização precisa está indicada nas tabelas 2,3 e 4.

$\mathrm{Na}$ descrição dos afloramentos, as fácies foram caracterizadas por critérios unicamente descritivos, buscando-se definir as litologias, as estruturas sedimentares e a geometria dos litossomas, dentro da filosofia exposta em Walker (1984). Para a descrição das fácies foi utilizado um código de fácies (Tab. 5), que foi baseado no esquema proposto por Miall (1978) e ampliado por Eyles et al. (1983). Em exposições lateralmente continuas, procurou-se descrever a geometria dos litossomas e o 


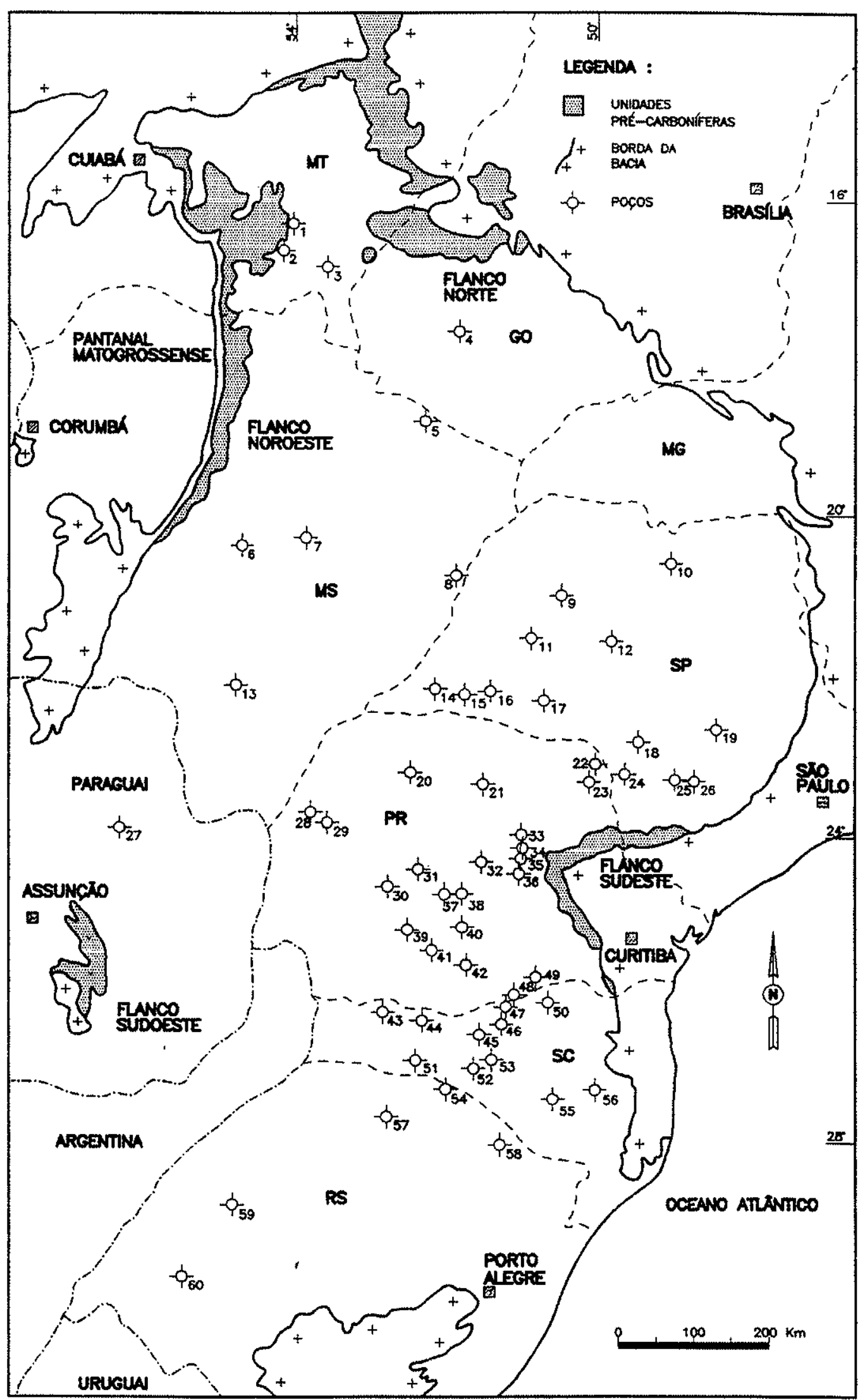

Figura 4- Mapa de localização das faixas de afloramento e dos poços analisados (para identificação dos poços consultar a Tab. 1). 
Tabela 1 - Identificação dos poços plotados na figura 4

\begin{tabular}{|l|l|l|l|l|}
\hline $1=\mathrm{RVR}-1$ & $2=\mathrm{RSP}-1$ & $3=2-\mathrm{AG}-1-\mathrm{MT}$ & $4=2-\mathrm{JA}-1-\mathrm{GO}$ & $5=2-\mathrm{RA}-1-\mathrm{MS}$ \\
\hline $6=2-\mathrm{CG}-1-\mathrm{MS}$ & $7=2-\mathrm{RP}-1-\mathrm{MS}$ & $8=2-\mathrm{TL}-1-\mathrm{MS}$ & $9=2-\mathrm{AR}-1-\mathrm{SP}$ & $10=2-\mathrm{OL}-1-\mathrm{SP}$ \\
\hline $11=2-\mathrm{LA}-1-\mathrm{SP}$ & $12=2-\mathrm{LI}-1-\mathrm{SP}$ & $13=2-\mathrm{DO}-1-\mathrm{MS}$ & $14=3-\mathrm{CB}-3-\mathrm{SP}$ & $15=1-\mathrm{TI}-1-\mathrm{SP}$ \\
\hline $16=1-\mathrm{TB}-1-\mathrm{SP}$ & $17=2-\mathrm{PP}-1-\mathrm{SP}$ & $18=1-\mathrm{MA}-1-\mathrm{SP}$ & $19=2-\mathrm{AB}-1-\mathrm{SP}$ & $20=2-\mathrm{RI}-1-\mathrm{PR}$ \\
\hline $21=2-\mathrm{AP}-1-\mathrm{PR}$ & $22=2-\mathrm{J}-1-\mathrm{PR}$ & $23=1-\mathrm{JT}-1-\mathrm{PR}$ & $24=1-\mathrm{SA}-1-\mathrm{SP}$ & $25=1-\mathrm{PN}-1-\mathrm{SP}$ \\
\hline $26=2-\mathrm{CP}-1-\mathrm{SP}$ & $27=\mathrm{ASU}-1$ & $28=2-\mathrm{AN}-1-\mathrm{PR}$ & $29=1-\mathrm{API}-1-\mathrm{PR}$ & $30=2-\mathrm{RP}-1-\mathrm{PR}$ \\
\hline $31=1-\mathrm{RO}-1-\mathrm{PR}$ & $32=2-\mathrm{CA}-1-\mathrm{PR}$ & $33=2-\mathrm{O}-1-\mathrm{PR}$ & $34=1-\mathrm{MO}-2-\mathrm{PR}$ & $35=2-\mathrm{MO}-1-\mathrm{PR}$ \\
\hline $36=2-\mathrm{R}-1-\mathrm{PR}$ & $37=2-\mathrm{CS}-1-\mathrm{PR}$ & $38=1-\mathrm{PT}-1-\mathrm{PR}$ & $39=2-\mathrm{LS}-1-\mathrm{PR}$ & $40=1-\mathrm{GP}-1-\mathrm{PR}$ \\
\hline $41=1-\mathrm{RS}-1-\mathrm{PR}$ & $42=1-\mathrm{PH}-1-\mathrm{PR}$ & $43=1-\mathrm{GO}-1-\mathrm{SC}$ & $44=2-\mathrm{AL}-1-\mathrm{SC}$ & $45=1-\mathrm{TP}-3-\mathrm{SC}$ \\
\hline $46=1-\mathrm{MC}-2-\mathrm{SC}$ & $47=2-\mathrm{PU}-1-\mathrm{SC}$ & $48=2-\mathrm{UV}-1-\mathrm{PR}$ & $49=1-\mathrm{RC}-1-\mathrm{PR}$ & $50=2-\mathrm{CN}-1-\mathrm{SC}$ \\
\hline $51=1-\mathrm{SE}-1-\mathrm{SC}$ & $52=1-\mathrm{HV}-1-\mathrm{SC}$ & $53=1-\mathrm{TG}-1-\mathrm{SC}$ & $54=1-\mathrm{MR}-1-\mathrm{RS}$ & $55=2-\mathrm{LA}-1-\mathrm{SC}$ \\
\hline $56=2-\mathrm{BN}-1-\mathrm{SC}$ & $57=2-\mathrm{RD}-1-\mathrm{RS}$ & $58=1-\mathrm{ES}-1-\mathrm{RS}$ & $59=2-\mathrm{IT}-1-\mathrm{RS}$ & $60=2-\mathrm{AL}-1-\mathrm{RS}$ \\
\hline
\end{tabular}

seu arranjo arquitetônico, ilustrados através de seções construídas a partir de fotomosaicos dos afloramentos, com o objetivo de definir associações de fácies e elementos arquiteturais, metodologia que foi desenvolvida para arenitos fluviais (Allen 1983; Miall 1985). Seções colunares foram levantadas sempre que possivel, visando estabelecer empilhamentos estratigráficos verticais representativos das diferentes unidades estratigráficas. Os símbolos utilizados na confecção destas seções estão apresentadas na tabela 6 .

\section{2- DADOS DE SUBSUPERFÍCIE}

A utilização de dados de subsuperfície é requisito fundamental para a análise estratigráfica das seqüências pré-carboníferas, em especial da ordovício-siluriana, porque as áreas de ocorrência em superfície são descontínuas e bastante restritas comparativamente à sua extensão em subsuperfície. Além do mais, os empilhamentos observados no centro das bacias podem ser bastante diferentes, em termos de espessura e natureza das fácies sedimentares, daqueles existentes nas bordas. Nestas, movimentações tectônicas e variações do nivel do mar alteram freqüentemente o nível de base da erosão, dando origem a variações faciológicas derivadas de flutuação no aporte sedimentar e a descontinuidades não observadas no centro. 
A análise baseou-se essencialmente no estudo dos perfis litológicos e geofísicos dos poços perfurados no programa de exploração petrolifera da bacia. Em casos especiais, como no estudo da Fm. lapó, da qual se conhecem poucos afloramentos, foram analisados também os testemunhos dos poços que a amostraram. A consulta a estes dados foi gentilmente permitida pela Petrobrás, através do Núcleo de Exploração da Bacia do Paraná (Nexpar).

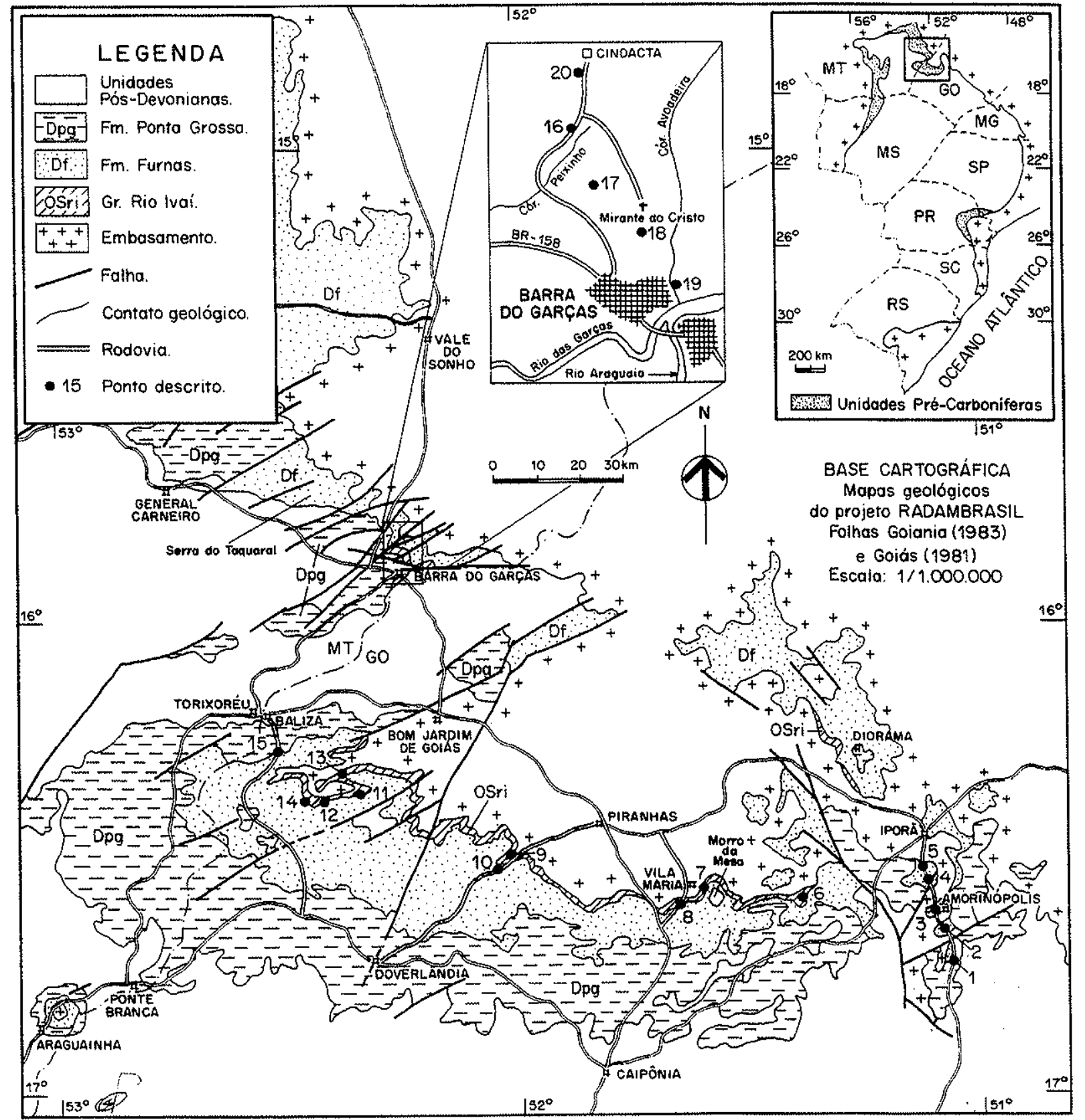

Figura 5 - Mapa geológico do flanco norte da bacia com indicação dos pontos descritos. 


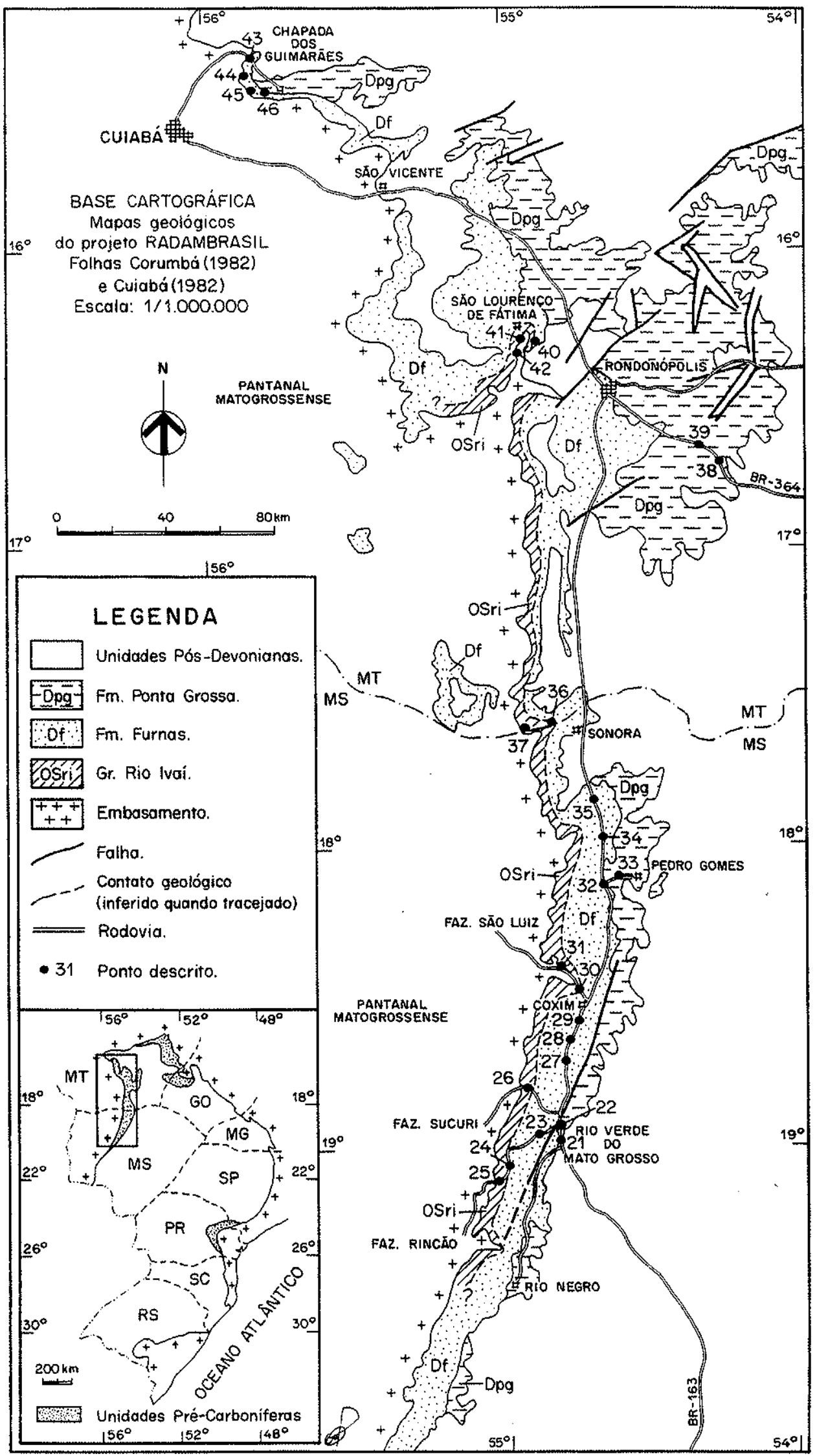

Figura 6 - Mapa geológico do flanco noroeste da bacia com indicação dos pontos descritos. 


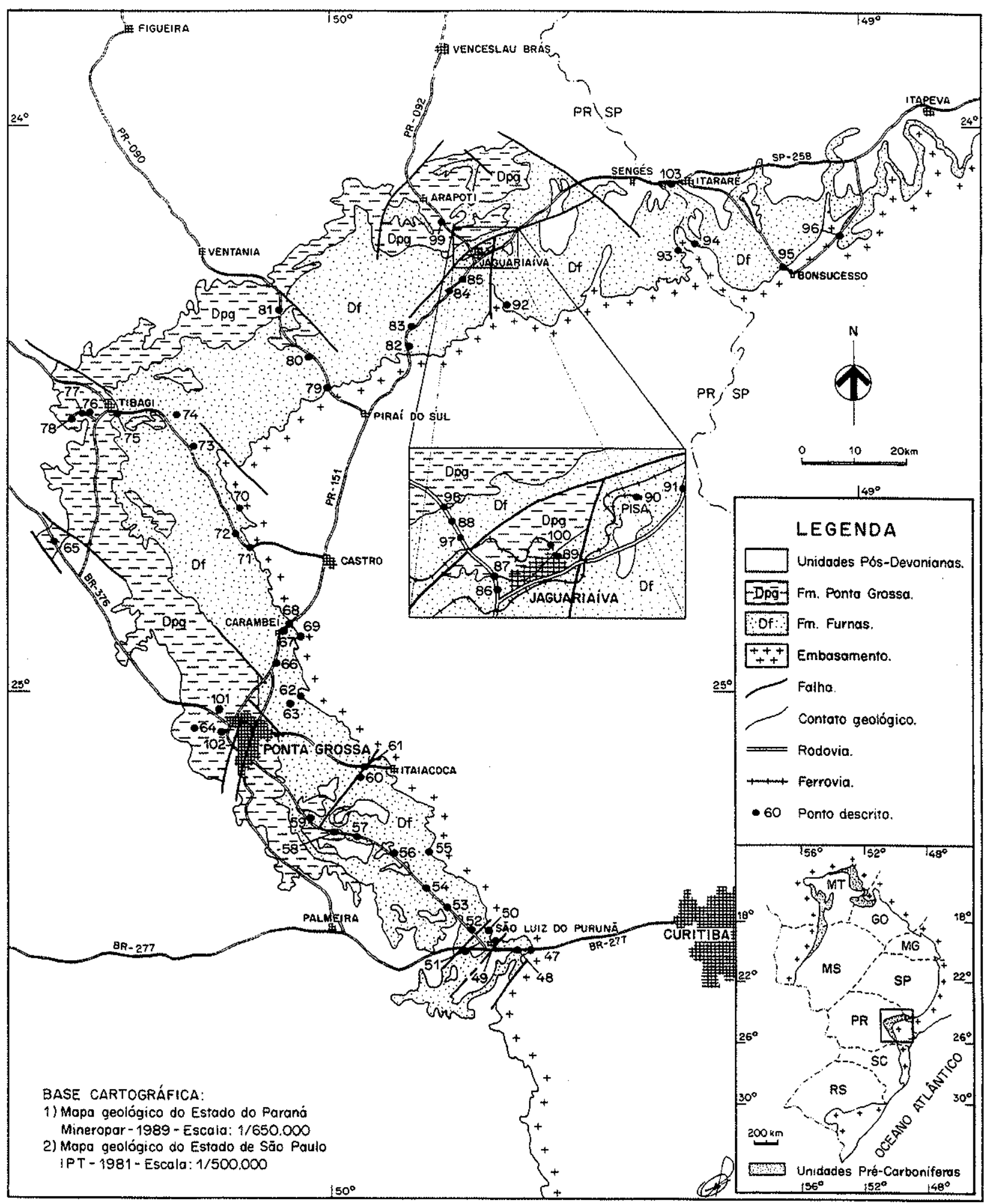

Figura 7 - Mapa geológico do flanco do sudeste da bacia com indicação dos pontos descritos. 
Tabela 2 - Localização dos afloramentos descritos no flanco norte (Fig. 5)

\begin{tabular}{|c|c|}
\hline PONTO & ENDEREÇO \\
\hline 1 & Estrada Iporá-Montevidiu: seção entre 16 e $18 \mathrm{~km}$ a sul do trevo de Amorinópolis \\
\hline 2 & Estrada Iporá-Montevidiu: $8,5 \mathrm{~km}$ ao sul do trevo de Amorinópolis \\
\hline 3 & Estrada Iporá-Montevidiu: $0,5 \mathrm{~km}$ ao norte do trevo de Amorinópolis \\
\hline 4 & Estrada Iporá-Montevidiu: $2,5 \mathrm{~km}$ ao norte do trevo de Amorinópolis \\
\hline 5 & Estrada Iporá-Montevidiu: $4,0 \mathrm{~km}$ ao norte do trevo de Amorinópolis \\
\hline 6 & $\begin{array}{l}\text { Faz. Pedra Alta, córrego Buriti Feio. Acesso pela estrada lporá-Caiapônia; a cerca } \\
\text { de } 52 \mathrm{~km} \text { de Iporá, entrar à direita ao lado do recinto de leilões Valdivino Raimundo } \\
\text { de Souza, percorrer } 11 \mathrm{~km} \text {, pegar bifurcação à direita e percorrer mais } 1,5 \mathrm{~km} \text {. }\end{array}$ \\
\hline 7 & Localidade de Vila Maria \\
\hline 8 & $\begin{array}{l}\text { Estrada que liga Vila Maria à Caiapônia, a cerca de } 4 \mathrm{~km} \text { a sul de Vila Maria, antes } \\
\text { do ribeirão Sucuri }\end{array}$ \\
\hline 9 & $\begin{array}{l}\text { Faz. de José Maria Vilela. Entrada à direita a cerca de } 25 \mathrm{~km} \text { da cidade de } \\
\text { Piranhas, na estrada para Doverlândia }\end{array}$ \\
\hline 10 & Estrada Piranhas-Doverlândia, a cerca de $27 \mathrm{~km}$ de Piranhas \\
\hline 11 & $\begin{array}{l}\text { Cachoeira das Perdizes. Acesso pela estrada Baliza-Doverlândia, com entrada a } \\
\text { cerca de } 26 \mathrm{~km} \text { de Baliza. Cachoeira dista } 12 \mathrm{~km} \text { da entrada. Coord.: S16 } 22^{\prime} 03^{\prime \prime} \text { e } \\
\text { W52 } 22^{\prime} 20^{\prime \prime}\end{array}$ \\
\hline 12 & $\begin{array}{l}\text { Estrada para a Faz. Bacuri. Acesso pela estrada Baliza-Doverlândia, com entrada } \\
\text { a cerca de } 28 \mathrm{~km} \text { de Baliza. Afloramento na estrada a cerca de } 3 \mathrm{~km} \text { da entrada. }\end{array}$ \\
\hline$\overline{13}$ & $\begin{array}{l}\text { Estrada para a Faz. Colorado. Acesso pela estrada Baliza-Doverlândia, com } \\
\text { entrada a cerca de } 24 \mathrm{~km} \text { de Baliza. Afloramento na estrada a cerca de } 9 \mathrm{~km} \text { da } \\
\text { entrada. Coord: } S 16^{\circ} 19^{\prime} 38^{\prime \prime} \text { e W } 52^{\circ} 23^{\prime} 11^{\prime \prime}\end{array}$ \\
\hline 14 & $\begin{array}{l}\text { Cabeceiras do córrego Lajeado, afluente do ribeirão das Perdizes. Acesso pela } \\
\text { estrada Baliza-Doverlândia, cerca de } 30 \mathrm{~km} \text { de Baliza. }\end{array}$ \\
\hline 15 & Estrada Baliza-Doverlândia; exposiçőes ao sul do ribeirão das Perdizes \\
\hline 16 & $\begin{array}{l}\text { Estrada do Rio Peixinho, que liga Barra do Garças à base do Cindacta II, } 0,5 \mathrm{~km} \\
\text { antes da bifurcação para o mirante do Cristo Redentor. }\end{array}$ \\
\hline 17 & ntinuação da rua D/Q21, em Barra do Garças. \\
\hline 18 & do Cristo Redentor, em Barra do Garças. \\
\hline 19 & s de Piscina/Loca/Lajedo, córrego Avoadeira, em Barra do Garças \\
\hline 20 & Barra do G \\
\hline
\end{tabular}

Tabela 3- Localização dos afloramentos descritos no flanco noroeste (Fig. 6)

\begin{tabular}{|c|l|}
\hline PONTO & \multicolumn{1}{|c|}{ ENDEREÇO } \\
\hline 21 & BR-163, km 672 \\
\hline 22 & BR-163, Rio Verde de Mato Grosso \\
\hline 23 & Localidade de Sete Quedas, 7km a oeste de Rio Verde de Mato Grosso \\
\hline 24 & $\begin{array}{l}\text { Estrada para o pantanal Mato-grossense (Faz. Rincão), cascata em ponte sobre o } \\
\text { ribeirão Anhumas, a 32km de Rio Verde de Mato Grosso }\end{array}$ \\
\hline 25 & $\begin{array}{l}\text { Estrada para o pantanal Mato-grossense (Faz. Rincão), a 37km de Rio Verde do } \\
\text { Mato Grosso }\end{array}$ \\
\hline 26 & $\begin{array}{l}\text { Estrada para o pantanal Mato-grossense (Faz. Sucuri). Acesso pela BR-163, km } \\
682 ; \text { após 16km, entrar à esquerda e percorrer 2km até o início da seção, que } \\
\text { estende-se por mais 2,5km }\end{array}$ \\
\hline 27 & BR-163, km 704 \\
\hline
\end{tabular}




\begin{tabular}{|c|c|}
\hline 28 & BR-163, km 707,5 \\
\hline 29 & BR-163, km 717,5 \\
\hline 30 & Estrada para o pantanal Mato-grossense, $3,5 \mathrm{~km}$ a oeste de Coxim \\
\hline 31 & $\begin{array}{l}\text { Estrada para a Faz. Monte Alegre. Acesso pela estrada para o pantanal Mato- } \\
\text { grossense; entrar a direita a } 18 \mathrm{~km} \text { a oeste de Coxim e percorrer } 1 \mathrm{~km} \text { (coord.: } \\
\mathrm{S} 18^{\circ} 24^{\prime} 00^{\prime \prime} \text { e W } 54^{\circ} 53^{\prime} 20^{\prime \prime} \text { ) }\end{array}$ \\
\hline 32 & MT-215, Km 1, entre a BR-163 e Pedro Gomes \\
\hline 33 & MT-215, Km 8,5, entre a BR-163 e Pedro Gomes \\
\hline 34 & BR-163, km 780,5 \\
\hline 35 & BR-163, km 794 \\
\hline 36 & Antiga BR-163, divisa MS/MT, sumidouro do rio Correntes \\
\hline 37 & $\begin{array}{l}\text { Estrada para a Faz. Piracema. Acesso pela antiga BR-163; entrar à esquerda após } \\
\text { o Sumidouro, no sentido de Cuiabá, e percorrer } 22 \mathrm{~km} \text { até a escarpa que bordeja o } \\
\text { pantanal Mato-grossense }\end{array}$ \\
\hline 38 & BR-364, km 150,5, entre Rondonópolis e a serra da Petrovina \\
\hline 39 & BR-364, km 163, entre Rondonópolis e a serra da Petrovina \\
\hline 40 & $\begin{array}{l}\text { Estrada de São Lourenço de Fátima para Rondonópolis, } 1 \mathrm{~km} \text { após a ponte sobre } \\
\text { o rio São Lourenço }\end{array}$ \\
\hline 41 & $\begin{array}{l}\text { Estrada de São Lourenço de Fátima para o pantanal Mato-grossense, } \\
\text { acompanhando o vale do rio São Lourenço, a } 1,5 \mathrm{~km} \text { de São Lourenço de Fátima }\end{array}$ \\
\hline 42 & $\begin{array}{l}\text { Cachoeira do Bispo. Acesso pela estrada de São Lourenço de Fátima para o } \\
\text { pantanal Mato-grossense, a } 2,5 \mathrm{~km} \text { de São Lourenço de Fátima }\end{array}$ \\
\hline 43 & Localidade de Salgadeira, na estrada de Cuiabá para chapada dos Guimarães \\
\hline 44 & Cachoeira dos Malucos na chapada dos Guimarães \\
\hline 45 & $\begin{array}{l}\left.\text { Estrada para o morro São Jerônimo (coord.: S15 } 26^{\prime} 28^{\prime \prime} \text { e W55 } 5^{\circ} 51^{\prime} 17^{\prime \prime}\right) \text {, Chapada } \\
\text { dos Guimarães }\end{array}$ \\
\hline 46 & 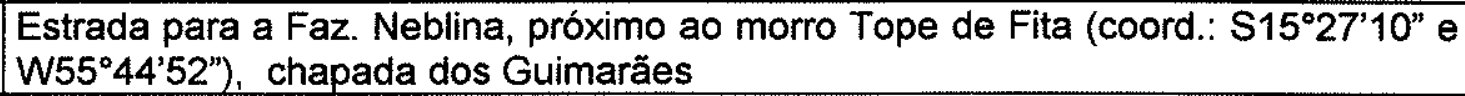 \\
\hline
\end{tabular}

Tabela 4- Localização dos afioramentos descritos no flanco sudeste (Fig. 7)

\begin{tabular}{|c|l|}
\hline PONTO & \multicolumn{1}{|c|}{ ENDEREÇO } \\
\hline 47 & $\begin{array}{l}\text { BR-277, sentido Curitiba para Ponta Grossa, escarpa do 2 }{ }^{\circ} \text { planalto, proximidades } \\
\text { de São Luiz do Purunã, 2km antes do posto da polícia rodoviária, }\end{array}$ \\
\hline 48 & $\begin{array}{l}\text { BR-277, sentido Curitiba para Ponta Grossa, proximidades de São Luiz do Purunã, } \\
500 m \text { antes do posto da polícia rodoviária }\end{array}$ \\
\hline 49 & Saibreira em São Luiz do Purunã \\
\hline 50 & Área de empréstimo em São Luiz do Purunã, 1km a norte da torre da Telepar \\
\hline 51 & BR-277, a 2km do encontro com a BR-376, recanto próximo ao rio dos Papagaios \\
\hline 52 & $\begin{array}{l}\text { BR-376, entre os km552 e km553, na confluências dos rios das Pombas e } \\
\text { Papagaios }\end{array}$ \\
\hline 53 & BR-376, km 544 \\
\hline 54 & BR-376, km 538,5 \\
\hline 55 & $\begin{array}{l}\text { Sítio Cercado. Acesso pela BR-376, km 533,5; percorrer 12km em estrada } \\
\text { secundária }\end{array}$ \\
\hline 56 & BR-376, km 530,8, nas proximidades da ponte sobre o rio Tibagi \\
\hline 57 & BR-376, $\mathrm{km} 519,5$ \\
\hline 58 & BR-376, km 519 \\
\hline 59 & BR-376, $\mathrm{km} 514$ \\
\hline
\end{tabular}




\begin{tabular}{|c|c|}
\hline 60 & Buraco do Padre, Município de Ponta Grossa \\
\hline 61 & Furnas Gêmeas na localidade de Passo do Pupo, Município de Ponta Grossa \\
\hline 62 & Escarpa da Fm. Furnas na estrada de Ponta Grossa para Alagados \\
\hline 63 & Canyon do rio São Jorge; acesso pela estrada de Ponta Grossa para Alagados \\
\hline 64 & Pedreira Moro em Ponta Grossa; acesso pela BR-376, km177,7 \\
\hline 65 & $\mathrm{BR}-376, \mathrm{Km} 424$ \\
\hline 66 & PR-151, km 123/125 \\
\hline 67 & PR-151, km 131,5 \\
\hline 68 & PR-151, km 137 \\
\hline 69 & Estrada Carambei-Catanduvas, a 6,5km do trevo com a PR-151 \\
\hline 70 & Entrada do canyon do rio lapó, afloramento na margem esquerda \\
\hline 71 & Rodovia Castro-Tibagi, $\mathrm{km} 16$ \\
\hline 72 & Rodovia Castro-Tibagi, km19,5 \\
\hline 73 & Canyon do Rio lapó; acesso pela rodovia Castro-Tibagi, $\mathrm{km} 35$ \\
\hline 74 & Canyon do Rio lapó no Guartelá; acesso pela rodovia Castro-Tibagi, km 42 \\
\hline 75 & Estrada Castro/Tibagi, na ponte sobre o rio Tibagi \\
\hline 76 & Arroio São Domingos, a cerca de $5 \mathrm{~km}$ a oeste de Tibagi \\
\hline 77 & Estrada para a cascata Santa Rosa, a 5,5km de Tibagi \\
\hline 78 & Estrada para a cascata Santa Rosa, a $12 \mathrm{~km}$ de Tibagi \\
\hline 79 & $\begin{array}{l}\text { PR-090, entre Piraí do Sul e Ventania; afloramento contínuo na escarpa do } 2^{\circ} \\
\text { planalto, com inicio a } 8,4 \mathrm{~km} \text { a oeste da ponte sobre o rio Piraí }\end{array}$ \\
\hline 80 & PR-090, entre Pirai do Sul e Ventania, a 20,3km a oeste da ponte sobre o rio Pirai \\
\hline 81 & $\begin{array}{l}\text { PR-090, entre Pirai do Sul e Ventania; afloramento nas proximidades do rio } \\
\text { Fortaleza }\end{array}$ \\
\hline 82 & PR-151, km203,5 \\
\hline 83 & PR-151, km206 \\
\hline 84 & PR-151, km217 \\
\hline 85 & PR-151, km219 \\
\hline 86 & PR-092, km 225,5 \\
\hline 87 & PR-092, km227,4 \\
\hline 88 & PR-092, $\mathrm{km} \mathrm{233,8}$ \\
\hline 89 & Rua Mal. Deodoro no bairro Lagoão, em Jaguariaíva \\
\hline 90 & Acesso ao terminal ferroviário da indústria PISA em Jaguariaiva \\
\hline 91 & PR-151, km237,5, a 500m da ponte sobre o rio das Mortes \\
\hline 92 & Gruta da Santa; acesso pela estrada de Jaguariaíva para o Distrito de Jangai \\
\hline 93 & Cachoeira do Corisco, vale do rio Itararé, Sengés-PR \\
\hline 94 & Escarpa do $2^{\circ}$ planalto, na estrada para a indústria Luber, a leste de Itararé (SP) \\
\hline 95 & Estrada Itararé-Bonsucesso, a $34 \mathrm{~km}$ do centro de saúde $\|$ em Itararé \\
\hline 96 & Estrada Itapeva-Bonsucesso, a $16,5 \mathrm{~km}$ do entroncamento com a SP-258 \\
\hline 97 & PR-092, km 232,4 \\
\hline 98 & PR-092, kn \\
\hline 99 & PR-092, km 237,7 \\
\hline 100 & $\begin{array}{l}\text { Estrada de ferro no cruzamento com a R. Mal. Deodoro, bairro Lagoão, em } \\
\text { Jaguariaíva }\end{array}$ \\
\hline 101 & $\begin{array}{l}\text { Corte em estrada de ferro no bairro Santa Luzia em Ponta Grossa; acesso pela } \\
\text { BR-376, km174,6 }\end{array}$ \\
\hline 102 & Final da Rua Paul Harris, bairro Jardim Sabará em Ponta Grossa \\
\hline 103 & Gruta da Barreira em Itararé (SP) \\
\hline
\end{tabular}


Tabela 5 - Código de fácies utilizado na descrição dos litotipos (baseado em Miall 1978 e Eyles et al. 1983)

\begin{tabular}{|l|l|}
\hline CÓDIGO & \multicolumn{1}{|c|}{ FÁCIES } \\
\hline $\mathrm{Dmm}$ & Diamictito maciço suportado pela matriz \\
\hline $\mathrm{Dms}$ & Diamictito estratificado suportado pela matriz \\
\hline $\mathrm{Dmg}$ & Diamictito gradado suportado pela matriz \\
\hline $\mathrm{Gm}$ & Conglomerado maciço ou incipientemente estratificado \\
\hline $\mathrm{Sp}$ & Arenito com estratificação cruzada planar \\
\hline $\mathrm{St}$ & Arenito com estratificação cruzada acanalada \\
\hline $\mathrm{Sr}$ & Arenito com ondulações assimétricas de corrente \\
\hline $\mathrm{Sh}$ & Arenito com estratificação plano paralela \\
\hline $\mathrm{Sm}$ & Arenito com estratificação ausente e/ou pouco evidente \\
\hline $\mathrm{Sg}$ & $\begin{array}{l}\text { Arenito com granodecrescência ascendente, com estratificação } \\
\text { ausente e/ou pouco evidente }\end{array}$ \\
\hline $\mathrm{Shc}$ & Arenito com estratificação cruzada hummocky \\
\hline Fld & Lamito com seixos caídos (dropstones) \\
\hline $\mathrm{Fl}$ & Folhelho e siltito laminado \\
\hline $\mathrm{H}$ & $\begin{array}{l}\text { Fácies heterolítica, caracterizada pela alternância camadas } \\
\text { centimétricas a decimétricas de siltitos laminados e arenitos com } \\
\text { estratificação cruzada hummocky }\end{array}$ \\
\hline
\end{tabular}

Dentre os perfis geofísicos utilizados, o de raios-gama revelou-se o mais útil. O perfil de raios-gama reflete muito bem as litologias e a granulometria dos arenitos, permitindo caracterizar padrões de variação textural e estabelecer assinaturas geofísicas típicas para as diferentes unidades. Paralelamente, foram utilizados os perfis de resistividade, sônico e densidade, tanto para definição de litologias quanto em correlações.

Perfis de mergulho ("dipmeter") foram utilizados como ferramenta adicional, auxiliando na distinção de litologias. Diamictitos, por exemplo, podem ser identificados em perfis de mergulho em função do típico aspecto caótico das atitudes, caracterizado por esparsos picos com magnitudes e azimutes variáveis (Serra 1985), conseqüência da heterogeneidade litológica que causa total ausência de correlação entre as microcurvas de resistividade. Perfis de mergulho são também úteis para a definição dos mergulhos estruturais das diferentes seqüencias, o que permite identificar discordâncias angulares.

Seções sísmicas de reflexão não foram utilizadas sistematicamente em razão de constituírem propriedade industrial. Buscou-se apenas a caracterização das discordâncias maiores em subsuperfície, tendo sido obtida a autorização para inclusão de duas seções ilustrativas. De qualquer forma, apesar dos progressos, os dados 
sísmicos ainda não têm a qualidade ideal para análises estratigráficas, conseqüência das dificuldades geradas pela extensa e espessa cobertura basáltica e presença de inúmeros corpos ígneos intrusivos em toda a seção sedimentar.

Tabela 6 - Símbolos utilizados nas seções colunares

\begin{tabular}{|c|c|}
\hline SÍMBOLO & DESCRIÇĀO \\
\hline$\therefore \Delta$ & Diomictito \\
\hline$-=-3$ & Folheino \\
\hline 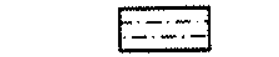 & Siltito \\
\hline & Arenito \\
\hline$\because \because$ & Conglomerado \\
\hline$+^{+}+$ & Embasomento pré-cambriano/eopaleozdico \\
\hline 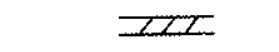 & Estratificaçōo cruzoda planar \\
\hline IZZ & Estratificaçðo cruzada sigmóide \\
\hline$\because$ & Estratificaçāo cruzada acanalada \\
\hline$\Leftrightarrow$ & Estratificaçzo cruzada hummocky \\
\hline$=$ & Estratificação plano-paralela \\
\hline$=0.0 .0 .00$ & Depósito residual de seixos e calhaus \\
\hline 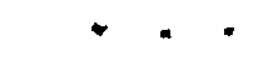 & Clasto de argila \\
\hline$\infty$ & Traco fóssil poralelo do acamamento \\
\hline 7 & Trą̧o fóssil vertical \\
\hline م & Contato discordante \\
\hline$\sim \sim$ & Contato diastemico \\
\hline & Contato normal \\
\hline 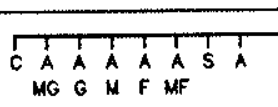 & $\begin{array}{l}\text { Gronulometria ( } A=\text { argila; } S=\text { silte; } A M F=\text { arenito muito fino; } \\
A F=\text { arenito fino; } A M=\text { arenito médio; } A G=\text { orenito grosso; } \\
A M G=\text { arenito muito grosso; } C=\text { cascalho) }\end{array}$ \\
\hline
\end{tabular}




\section{3 - ANÁLISE DE PALEOCORRENTES}

Segundo Miall (1990), a análise de paleocorrentes fornece informações que permitem a interpretação de quatro diferentes elementos em análise de bacias: 1) o mergulho deposicional, local ou regional, refletindo os padrões de subsidência da bacia; 2) o sentido do suprimento sedimentar; 3) a geometria e a orientação das unidades litológicas; e 4) o ambiente deposicional. Isto demonstra o potencial desta ferramenta, que deve ser utilizada concomitantemente com o estudo de outros atributos que integram a análise de fácies.

Com o objetivo de obter informações para a análise de paleocorrentes das unidades psamíticas pré-carboníferas, foi realizado extensivo levantamento de dados de paleocorrentes, utilizando-se como indicador de paleofluxo o sentido de mergulho das camadas frontais (foresets) das estratificações cruzadas. As formas de leito medidas enquadram-se nos ranks 4 e 5 de Miall (1974).

Os procedimentos de tratamento estatístico e representação dos dados foram os usuais, já consolidados na literatura sobre o assunto (Potter \& Pettijohn 1977, Selley 1982). Para cada estação, os dados foram distribuídos em classes de $10^{\circ}$, sendo as porcentagens lançadas em histogramas circulares de freqüência (rosetas), que dão idéia visual da dispersão dos valores. A partir dos azimutes medidos $(\alpha)$ e do número de medidas realizadas $(n)$ foram calculados para cada estação o vetor médio $(x)$ e o fator de consistência ( $f . c$.$) , através das seguintes equações:$

$$
x=\operatorname{arctg}\left(\sum \operatorname{sen} \alpha / \sum \cos \alpha\right) \quad f . c .=\sqrt{\left(\sum \operatorname{sen} \alpha\right)^{2}+\left(\sum \cos \alpha\right)^{2}} / n
$$

O vetor médio não foi calculado nas distribuições bimodais e polimodais (Fig. 8), pois as técnicas de tratamento estatístico são aplicáveis somente a distribuições unimodais de dados azimutais, não podendo ser usadas em distribuições bimodais ou polimodais, já que nestas a média não têm significado geológico (Selley 1982). Na falta de um critério objetivo e quantificável para definir quando a média tem significado geológico, optou-se pela utilização do fator de consistência, que é uma medida indireta da dispersão dos dados. Estabeleceu-se empiricamente o f.c. $=0,5$ como valor limite, abaixo do qual não foi efetuado o cálculo da média vetorial.

Embora sujeito a limitações de exposição e acesso, procurou-se obter ao menos 25 medidas em cada estação, o que é considerado número mínimo necessário para análises estatisticas significantes (Selley 1982). Contudo, como ressalta Miall (1990), 
a representação em mapa de estações com menos medidas é muito útil na análise de fácies e interpretação ambiental, mesmo que a média calculada não seja estatisticamente significante.
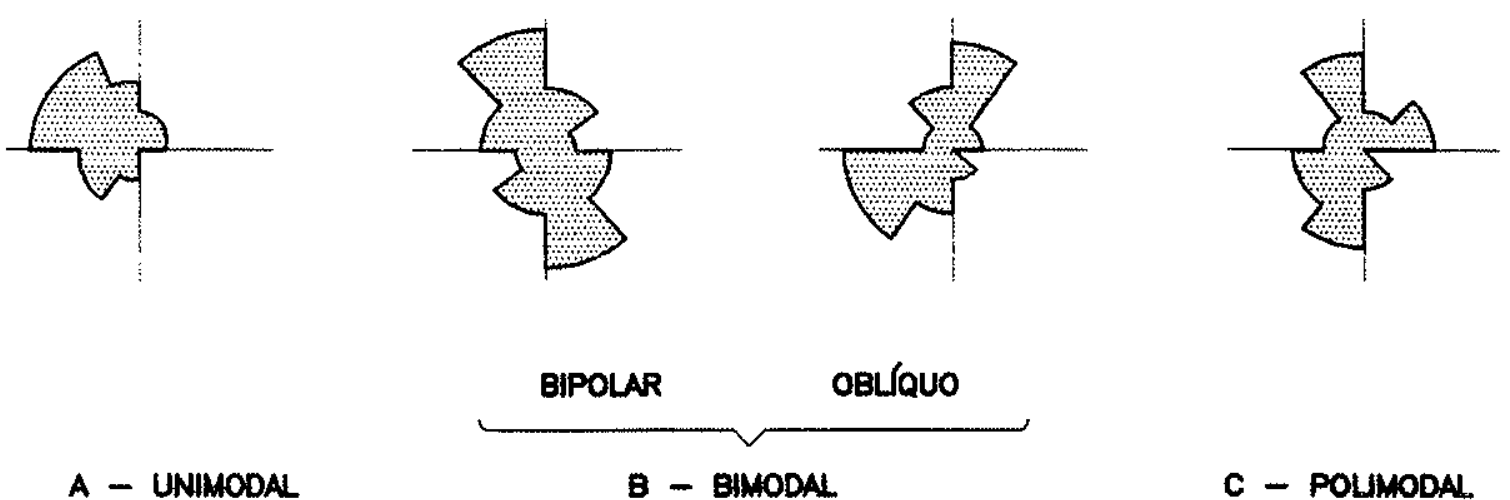

B - BMODAL

C - POLMODAL.

Figura 8 - Padrões azimutais de dados de paleocorrente (modif. de Selley 1968).

Com relação aos seixos, não foram observados padrões consistentes de imbricação nos intervalos psefíticos analisados, sendo freqüentemente não evidentes ou mesmo inexistentes. A exemplo do realizado por Bigarella et al. (1966), o procedimento adotado foi o de medir o elongamento "a" de seixos assimétricos, principalmente os de forma em bastão, buscando-se verificar alguma regularidade em sua orientação.

Paleocorrentes são deduzidas essencialmente através do estudo de afloramentos. Sob determinadas condições, entretanto, o perfil de mergulho (dipmeter) indica o mergulho das camadas frontais dos estratos cruzados e, conseqüentemente, o sentido do paleofluxo sedimentar. Tentativas foram realizadas, mas a qualidade dos dados na grande maioria dos poços não permitiu uma interpretação segura, não tendo sido por isso considerados na análise realizada.

\section{4- CORRELAÇÃO ESTRATIGRÁFICA}

A base para a realização de uma análise estratigráfica com dados de campo é a compilação cuidadosa de seções estratigráficas verticais ou seções-colunares (Miall 1990), onde possam ser observados os padrões verticais de variação de fácies, 
verificadas a natureza dos contatos e constatadas descontinuidades no registro sedimentar, visando estabelecer o empilhamento estratigráfico original.

As melhores seções são aquelas em que vários intervalos encontram-se presentes, prestando-se a correlações regionais. Mas, é raro encontrar seções contínuas, acessiveis e representativas das diferentes unidades, a não ser em áreas excepcionalmente expostas e de topografia favorável, o que no geral não é o caso das áreas de afloramento das unidades estudadas. Por isso, as seções levantadas revestem-se de especial importância na análise.

Através da correlação com tais seções, a posição estratigráfica de afloramentos isolados pode ser determinada, o que tornou possivel sua utilização na análise regional. Tais afloramentos forneceram informações preciosas em termos de fácies, elementos arquiteturais e paleocorrentes.

Se é raro encontrar seções completas em superfície, em função dos intervalos não expostos, os perfis geofísicos de poços constituem um registro contínuo na vertical, facilitando sobremaneira o estabelecimento dos padrões de variação textural. Mas, a descrição das fácies é limitada pela amostragem de calha, que não permite identificar estruturas sedimentares, geometria das fácies e macrofósseis. Através de testemunhos podem ser visualizadas as estruturas sedimentares e recuperados macrofósseis, mas a orientação das estruturas não pode ser determinada; além do mais, testemunhos em poços perfurados nos programas de exploração petrolífera normalmente são cortados em intervalos reduzidos, constituindo uma informação pontual.

A correlação entre as seções estratigráficas verticais levantadas em superfície e os perfis litológicos e geofísicos de poços foi muito útil pois propiciou a integração dos dados de superfície com os de subsuperfície, através do estabecimento de critérios para reconhecer as associações faciológicas em perfis petrofísicos e interpretar fácies em subsuperfície. Os dados complementaram-se, propiciando a correlação estratigráfica das faixas aflorantes entre si e com as ocorrências em subsuperfície, o que permitiu delinear o arcabouço estratigráfico e o arranjo vertical e lateral de fácies dentro das seqüências e/ou unidades litoestratigráficas.

\section{5- ANÁLISE DE FÁCIES E INTERPRETAÇÃO DOS SISTEMAS DEPOSICIONAIS}

A interpretação dos ambientes de sedimentação através da análise de fácies e do método dos sistemas deposicionais é um tema sobre o qual existe uma extensa 
bibliografia. Basicamente, consistiu na identificação e descrição dos atributos físicos, permitindo a caracterização de diferentes fácies, formadas por diferentes processos sedimentares. A seguir, as fácies foram agrupadas em associações geneticamente relacionadas, que foram comparadas com modelos de fácies existentes na literatura (Walker 1994), visando reconstituir os sistemas deposicionais em que a sedimentação se processou.

Em função da natureza regional da análise realizada e dos propósitos do trabalho, as formações Vila Maria e Ponta Grossa mereceram menos atenção, já que não existem dúvidas quanto ao fato de que foram depositadas em ambientes marinhos rasos. Atenção especial foi dada à interpretação do paleoambiente deposicional da Fm. Furnas, para a qual existem diferentes proposições na literatura (apresentadas no item 2). Diversidade de opiniões foi verificada também com relação a origem de seqüências psamíticas do Paleozóico Inferior/Médio de outras bacias, pois o assunto é ainda pouco compreendido (Cant \& Hein 1986), sobretudo devido a inexistência de modelos análogos atuais (Visser 1974). Buscou-se, assim, estabeler parâmetros que permitissem uma opção segura, a partir de critérios faciológicos distintivos. tais como: litologias, estruturas sedimentares, geometria dos litossomas, padrões de variação textural na vertical, paleocorrentes e icnofósseis.

Padrões de paleocorrentes foram usados interativamente com informações de lito e biofácies, pois fornecem informações importantes para a distinção entre fácies fluviais e marinhas. Distribuição unimodal de paleocorrentes é uma característica freqüentemente atribuída aos depósitos fluviais, já que são controlados pelo mergulho deposicional; mas é também muito comum em depósitos de submaré (Klein 1967), não servindo como critério diagnóstico. Paleocorrentes com distribuições bimodaisbipolares e polimodais são indicativas de ambientes marinhos, refletindo as freqüentes mudanças nos sentidos das correntes geradas por marés e ondas.

A interpretação de ambiente glacial para a deposição da Fm. lapó foi feita inicialmente por Maack (1947). Posteriormente, Trein \& Fuck (1967) e Bigarella (1973) interpretaram-na como depósitos de fluxos gravitacionais. Andrade \& Camarço (1980) também recorreram a fluxos gravitacionais para explicar a gênese dos diamictitos posicionados iniciaimente na parte inferior da Fm. Vila Maria. Várias seções foram levantadas e as fácies descritas, buscando-se suprir a falta de dados e substanciar a interpretação. Modelos de deposição glacial foram analisados com a finalidade de comparar as fácies geradas com aquelas presentes na Fm. lapó. 


\section{6- ANÁLISE DE SEQÜÊNCIAS}

A análise de seqüências tem por base o fatiamento do registro sedimentar em seqüências de menor ordem de grandeza (ciclos de $3^{a}$ e $4^{a}$ ordens), que são unidades de conotaçäo cronoestratigráfica. Isto pressupõe um refinamento cronoestratigráfico não proporcionado pelos dados bioestratigráficos disponíveis, devido aos seguintes fatores: 1) as formações Alto Garças e Furnas são essencialmente arenosas, não tendo sido constatados fósseis à exceção de icnofósseis sem valor cronoestratigráfico; na Fm. Furnas têm sido encontrados também restos vegetais, mas até o momento apenas nas proximidades do contato com a Formação Ponta Grossa; 2) os folhelhos da Fm. Vila Maria foram apenas datados, não havendo nenhum zoneamento bioestratigráfico; 3) a Fm. lapó tem-se revelado estéril em termos de macro e microfósseis; 4) na Fm. Ponta Grossa, zoneamentos bioestratigráficos com macrofósseis são dificultados pelo endemismo da fauna Malvinocáfrica (Boucot 1971, Melo 1985); e 5) após os trabalhos de Lange (1967) e Daemon et al. (1967), houve pouco avanço no refinamento cronoestratigráfico da Fm. Ponta Grossa. Dispõe-se do zoneamento baseado em acritarcas de três poços rasos perfurados em Goiás (Oliveira 1991), mas não foram publicados dados bioestratigráficos referentes aos poços perfurados na bacia nos programas de exploração petrolifera (Paulipetro, Petrobrás e BP).

Em função destes fatos, a análise seqüencial foi realizada com base na análise conjunta dos perfis de poços e de seções de superfície, balizada pelos dados bioestratigráficos existentes na literatura geológica, buscando-se definir as seqüências deposicionais (ciclos de $3^{a}$ ordem). Nas seções estratigráficas construídas foram verificadas superfícies de máxima inundação e descontinuidades no registro sedimentar, caracterizadas seqüências deposicionais, observadas variações laterais de fácies e interpretados os tratos de sistemas deposicionais.

Paralelamente, afloramentos e testemunhos da Fm. lapó foram amostrados para análise palinológica, já que não há nenhuma datação da unidade, sendo sua idade estabelecida apenas por relações estratigráficas e correlação geológica. Também foram amostrados alguns testemunhos da Fm. Ponta Grossa, nos casos em que o posicionamento cronoestratigráfico foi imprescindivel para 0 entendimento da estratigrafia das unidades estudadas. As análises foram realizadas por Roberto $\mathrm{F}$. Daemon da Petrobrás/Nexpar.

As reconstruções paleogeográficas do pré-Carbonífero da Bacia do Paraná são tentativas e preliminares em virtude da escassez de informações bioestratigráficas 
disponíveis, do pequeno número e da distribuição irregular dos poços. Os dados disponiveis não permitiram confeccionar mapas paleogeográficos segundo diferentes intervalos de tempo. Um esboço da evolução paleogeográfica foi erigido a partir da interpretação das seções colunares ou perfis estratigráficas verticais (Visher 1965), que propiciaram a identificaçăo de transgressões e regressões com base na lei de fácies de Walther. Mas, para a reconstituição paleogeográfica é fundamental a definição do sentido do preenchimento sedimentar (área-fonte) e da direção da paleolinha de costa.

Um método freqüentemente utilizado para a interpretação destes dois elementos paleogeográficos é a confecção de mapas de razão. Três situações, entretanto, podem induzir a erro na interpretação de áreas-fonte e paleolinhas de costa através deste procedimento: 1) quando nem todas as bordas da bacia estão preservadas, sendo bordas erosivas atuais modeladas em sedimentos das porções centrais da bacia, o que é o caso das formações Furnas e Ponta Grossa no Estado do Paraná; 2) se as variações faciológicas ocorrem paralelamente à linha de costa, fato verificado em várias plataformas atuais (Swift et al. 1991); e 3) no caso de sedimentos clásticos grossos serem levados para posições distais da plataforma, o que ocorre pelo afluxo de rios em nível de mar baixo, ou pela erosão das regiões costeiras durante tempestades e transporte para dentro da bacia por correntes de retorno dirigidas para costa-afora. Mapas de razão não foram assim considerados isoladamente, tendo sido analisados em conjunto com outros dados.

Informações úteis do ponto de vista paleogeográfico foram obtidas através da análise de paleocorrentes. Isto porque, em fácies controladas pelo paleotalude deposicional, o sentido de afluxo indica o mergulho deposicional da bacia e o sentido contrário as áreas-fonte. Indiretamente, também pode ser deduzida a paleolinha de costa, que é aproximadamente transversal à direção de transporte sedimentar.

Para a interpretação das relações entre sedimentação e tectônica, formadora e modificadora, foram analisados os arcabouços estratigráficos das seqüências $e$ avaliados os dados bioestratigráficos disponiveis, buscando-se verificar as variações laterais de fácies, a existência de descontinuidades no registro, evidências de mudanças nas áreas-fonte e elementos que evidenciassem a natureza dos altos e arcos. Mapas de isópacas foram construídos para as diferentes unidades através de interpolação linear manual, chamando-se atenção para o fato de que a distribuição dos poços é irregular, o que causou graus variáveis de incerteza no traçado das curvas, sobretudo nas porções norte e oeste da bacia. 
Caracterizados os episódios de subsidência e soerguimento na bacia, buscouse estabelecer sua relação com as orogêneses pré-andinas. Também foi testada a correlação com outras bacias, especialmente das gondwânicas, para verificar se as seqüências são produto de fenômenos locais ou reflexo de eventos ou ciclos de escala continental ou global. 


\section{5- GRUPO RIO IVAÍ}

Compreende, da base para o topo, as formações Alto Garças, lapó e Vila Maria. Das três, apenas a última foi até o momento datada, tendo sido posicionada no Llandoveriano inferior com base em tetradas de esporos de plantas terrestres e no fitoplâncton (Gray et al. 1985).

A atribuição de uma idade neo-ordoviciana para a Fm. Alto Garças deveu-se aos seguintes fatores: 1) idade eo-siluriana da Fm. Vila Maria, cronocorrelata à Fm. Vargas Peña, presente na porção paraguaia da bacia; 2) correlação dos diamictitos da Fm. lapó com o evento glacial no limite Ordoviciano/Siluriano; 3) correlação da Fm. Alto Garças com o $\mathrm{Gr}$. Caacupé, posicionado estratigraficamente abaixo dos folhelhos llandoverianos da Fm. Vargas Peña e considerado de idade neo-ordoviciana (Ciguel 1988 ); 4) idade ordoviciana inferior de algumas bacias molássicas do final do Ciclo Brasiliano, como por exemplo a Bacia de Castro. Nesta bacia, Moro et al. (1994) dataram radiometricamente riolitos em $488 \pm 8 \mathrm{Ma}$ (limite Tremadociano/Arenigiano).

Nos antigos perfis compostos dos poços, toda a seção abaixo da Fm. Ponta Grossa foi incluída na Fm. Furnas. A identificação do Gr. Rio Ivaí é fácil quando a Fm. Vila Maria está presente. Quando a mesma não ocorre, o reconhecimento do $\mathrm{Gr}$. Rio Ivaí baseia-se nas diferentes assinaturas geofísicas, uma vez que a Fm. Alto Garças apresenta um típico padrão de deflexão ascendente à esquerda e a Fm. Furnas caracteriza-se por padrão sigmóide. Constituem seções de referência as dos poços 2RI-1-PR e 2-AG-1-MT (Fig. 3B).

O Gr. Rio Ivaí ocorre em grande parte da bacia, delineando uma geometria assimétrica, com maiores espessuras a oeste (Fig. 9). Comparativamente aos dados apresentados por Milani et al. (no prelo), foram feitas poucas alterações em termos de espessura. A mais significativa refere-se ao poço 2-AR-1-SP (Araçatuba), onde o registro do $\mathrm{Gr}$. Rio Ivaí ficou restrito a apenas $40 \mathrm{~m}$. Dois motivos levaram a esta opção conservadora: 1) padrão atípico para as formações Furnas e Alto Garças no perfil de raios-gama; e 2) o intervalo amostrado palinologicamente em calha e considerado $\mathrm{Fm}$. Vila Maria é, na verdade, um diamictito com assinatura geofísica e características faciológicas diferentes, podendo pertencer ao $\mathrm{Gr}$. Itararé. A inexistência de testemunhos no referido poço e dificuldades de correlação dificultam melhor definição.

$\mathrm{Na}$ maioria das vezes, o $\mathrm{Gr}$. Rio Ivaí assenta-se diretamente em discordância litológica sobre rochas magmáticas e/ou metamórficas do embasamento cristalino précambriano/eopaleozóico. Quando recobre unidades sedimentares de bacias molássicas do fim do Ciclo Brasiliano, o faz freqüentemente em discordância angular. 
Esta relação pode ser observada no flanco sudeste (sobre o $\mathrm{Gr}$. Castro, a oeste das cidades de Castro e Piraí do Sul), no flanco norte (sobre a Fm. Piranhas, a sul da cidade de Bom Jardim de Goiás) e em subsuperfície (Fig. 10-A).

O contato superior com a Fm. Furnas é discordante. Contatos abruptos e erosivos foram constatados em vários pontos da bacia, a exemplo do observado por Pereira (1992) na faixa aflorante do flanco norte entre as cidades de Bom Jardim de Goiás e Amorinópolis. É notável o contraste entre as cores avermelhadas da Fm. Vila Maria e a cor branca da Fm. Furnas, constituindo um critério de campo muito útil para o reconhecimento de estratos silurianos na bacia (Fig. 11).

As cores avermelhadas da Fm. Vila Maria são cores de alteração, como já destacaram Gray et al. (1985). Como também ocorrem no registro dos poços e não afetam as camadas sobrepostas, são interpretadas como produto das condições ambientais e intemperismo anterior à deposição da Fm. Furnas, constituindo um argumento a mais na interpretação de uma discordância entre as duas unidades.

Um intervalo pelítico de cores avermelhadas também existe na parte intermediária da Fm. Cerrezzuelo, separando uma seqüência psamítica inferior de arenitos brancos acima (Fig. 11-E). Como a Fm. Cerrezzuelo é considerada a unidade basal do Devoniano uruguaio, merece ser investigada a possibilidade de que os pelítos vermelhos constituam estratos silurianos. Segundo Verolavski Barbé (1994), o intervalo tem expressão regional e em alguns pontos foram constatados diamictitos.

A ausência da Fm. Vila Maria em muitos poços no interior da bacia, como por exemplo nos poços 1-RS-1-PR e 1-API-1-PR (Fig. 12), é outra evidência de um contato discordante entre o Gr. Rio Ivaí e a Fm. Furnas (Fig. 12). Isto porque os folhelhos da Fm. Vila Maria representam uma superfície de máxima inundação (item 5.4), provavelmente tendo se depositado de forma contínua durante a transgressão eollandoveriana. Existem, mesmo, dados de campo e de poços que indicam contato discordante com ligeira angularidade (Fig. 10-B).

No flanco norte da bacia, na faixa aflorante entre as cidades de Amorinópolis e Bom Jardim de Goiás (GO), várias seções levantadas (Fig.13) atestaram a continuidade lateral do empilhamento estratigráfico estabelecido por Faria (1982) e detalhado por Pereira (1992). Mais a oeste, na bacia hidrográfica do ribeirão das Perdizes, a sudeste de Baliza, os arenitos inferiores da Fm. Alto Garças já se acham presentes, embora com espessura reduzida e ocorrência descontínua (Fig. 14). Nesta 


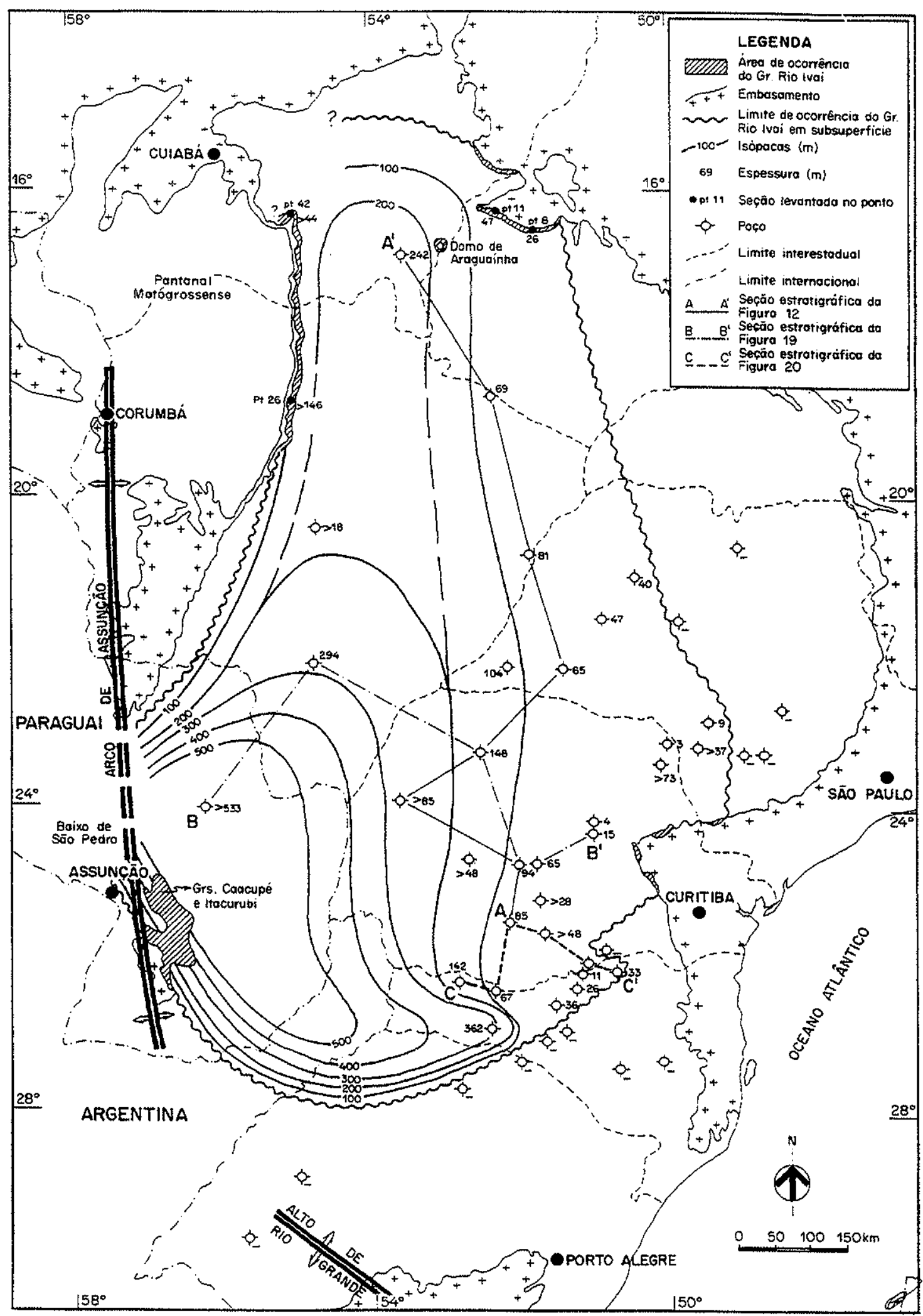

Figura 9 - Mapa de isópacas do Gr. Rio Ivaí. 
A

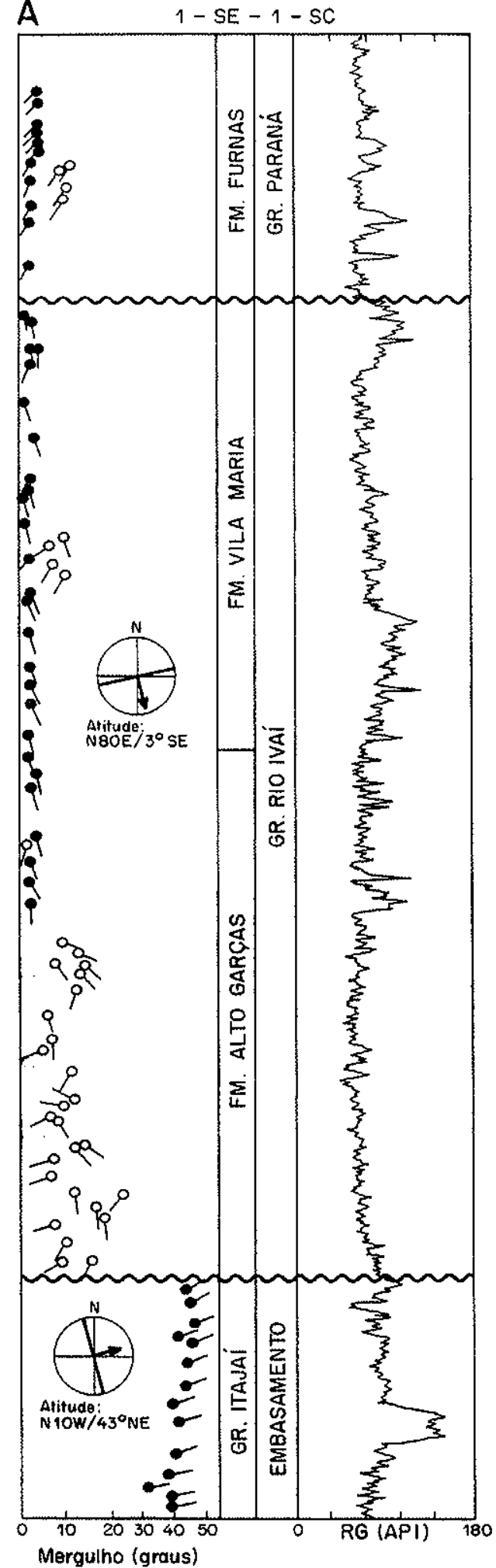

- Mergutho estrutural
B
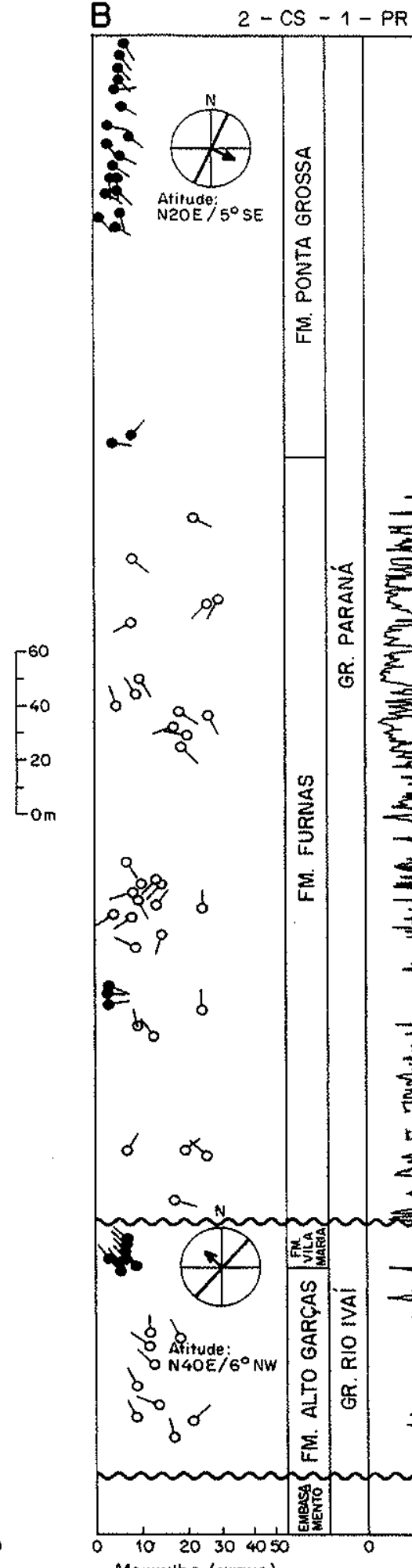

Mergulho (graus)

Poleocorrentes

Figura 10 - Perfis de mergulho (em graus) e de raios-gama (em API) mostrando relações de contato do $\mathrm{Gr}$. Rio Ivai: A) discordância angular na base com o $\mathrm{Gr}$. Itajaí (Pré-Cambriano Superior/Cambriano Inferior?) no poço 2-SE-1-SC (Seara); B) discordância ligeiramente angular no topo com o Gr. Paraná no poço 2-CS-1PR (Chapéu do Sol). 
$A=$

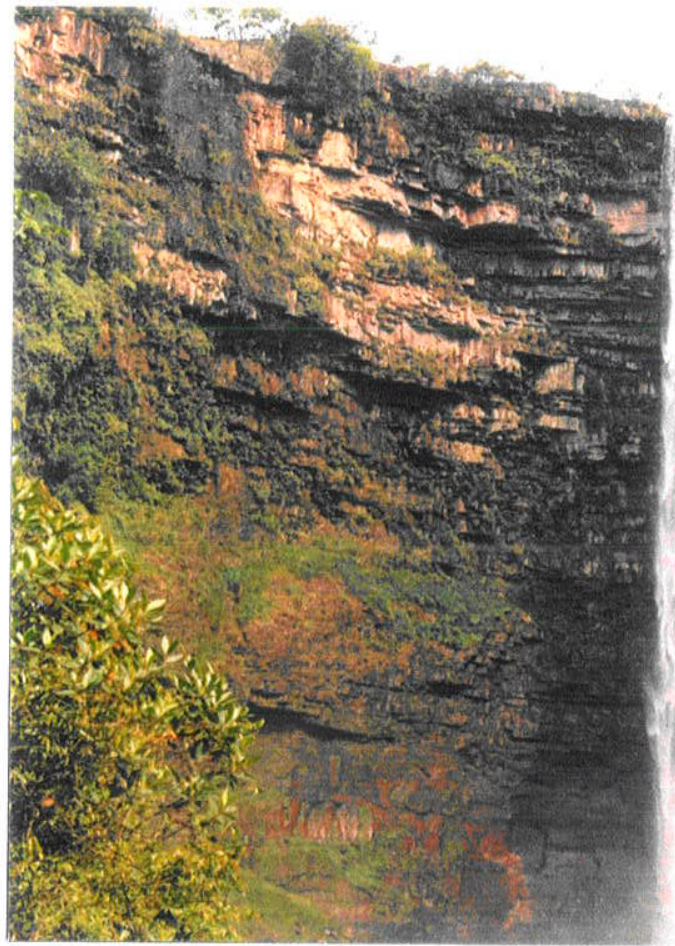

B -

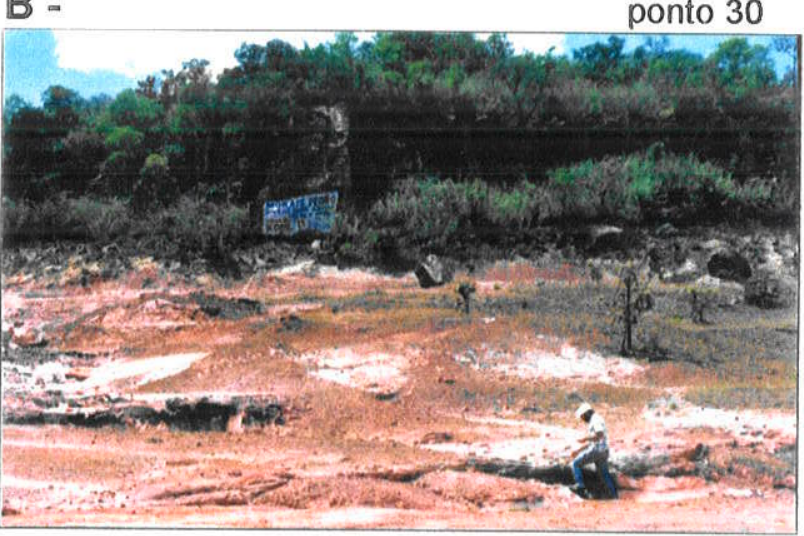

D -

Uruguai

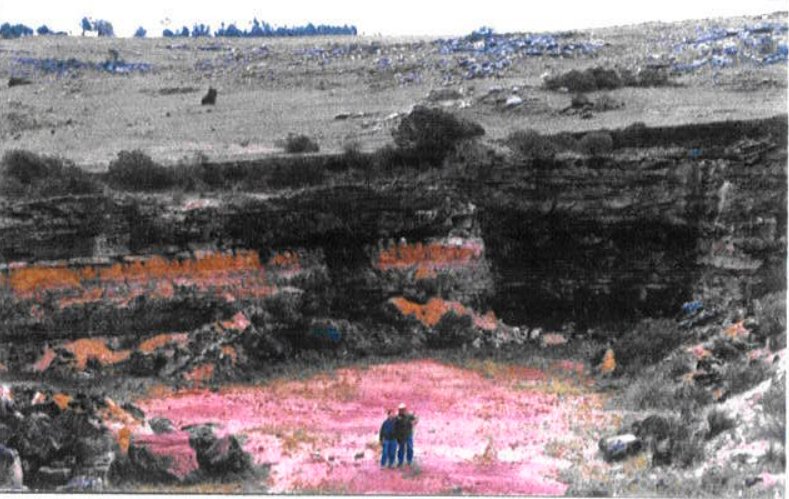

ponto 11

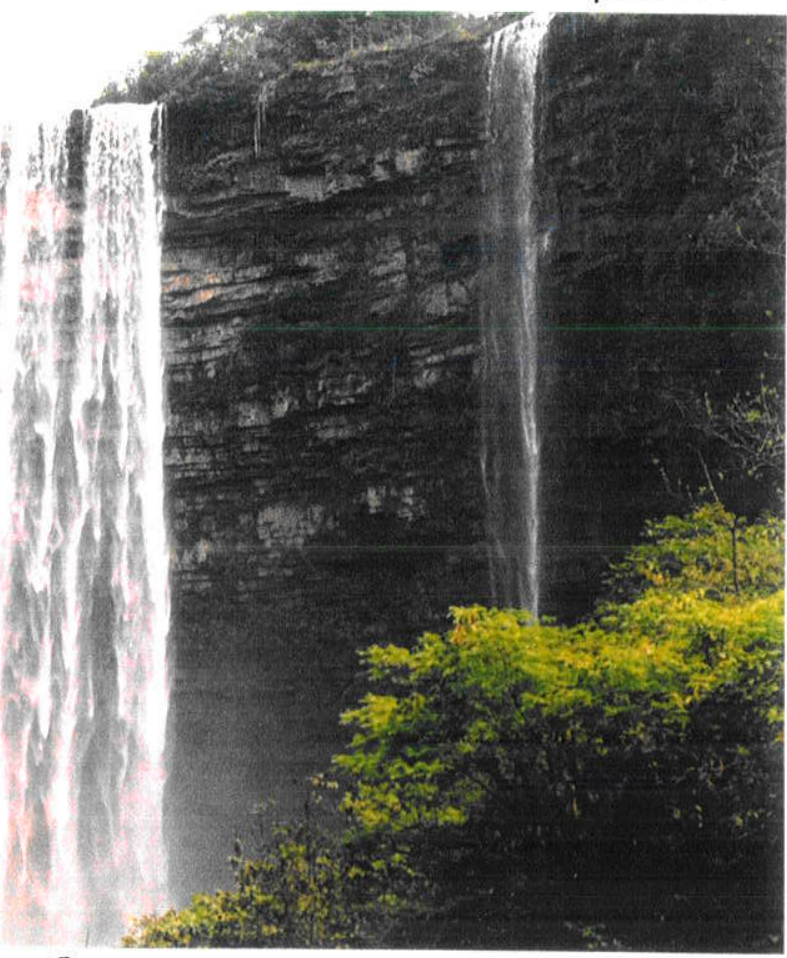

c.

ponto 7

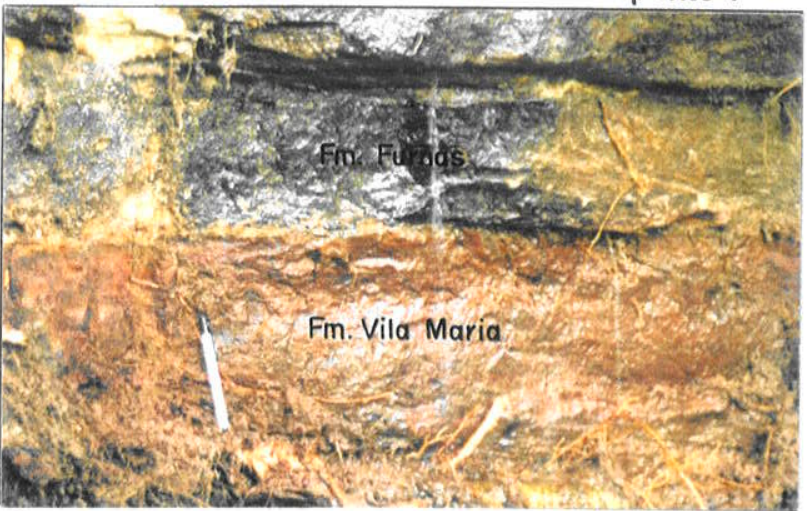

E -

ponto 71

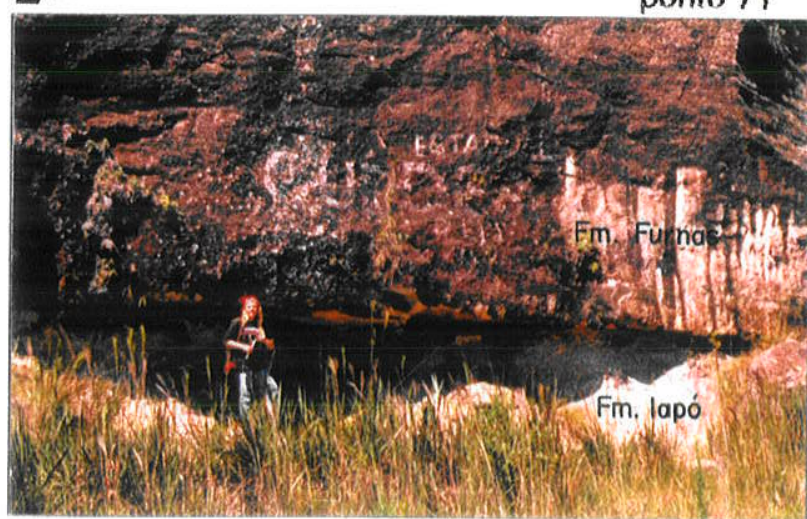

Figura 11 - Discordância entre os grupos Rio Ivaí e Paraná. As características faciológicas diferentes são realçadas pelo contraste de cores entre os pelitos avermelhados da Fm. Vila Maria e os arenitos brancos da Fm. Furnas, como na cachoeira do ribeirão das Perdizes (70m de altura), em Baliza-GO (A), e no vale do Taquari, em Coxim-MS (B). O contato é abrupto, como pode ser observado em Vila Maria-GO (C). Contraste semelhante de cores foi observado no meio da Fm. Cerrezzuelo no Uruguai (D), emergindo uma dúvida: poderia ser a parte inferior da $\mathrm{Fm}$. Cerrezzuelo siluriana? No Paraná, a Fm. Furnas assenta-se diretamente sobre diamictitos da Fm. lapó (E). 


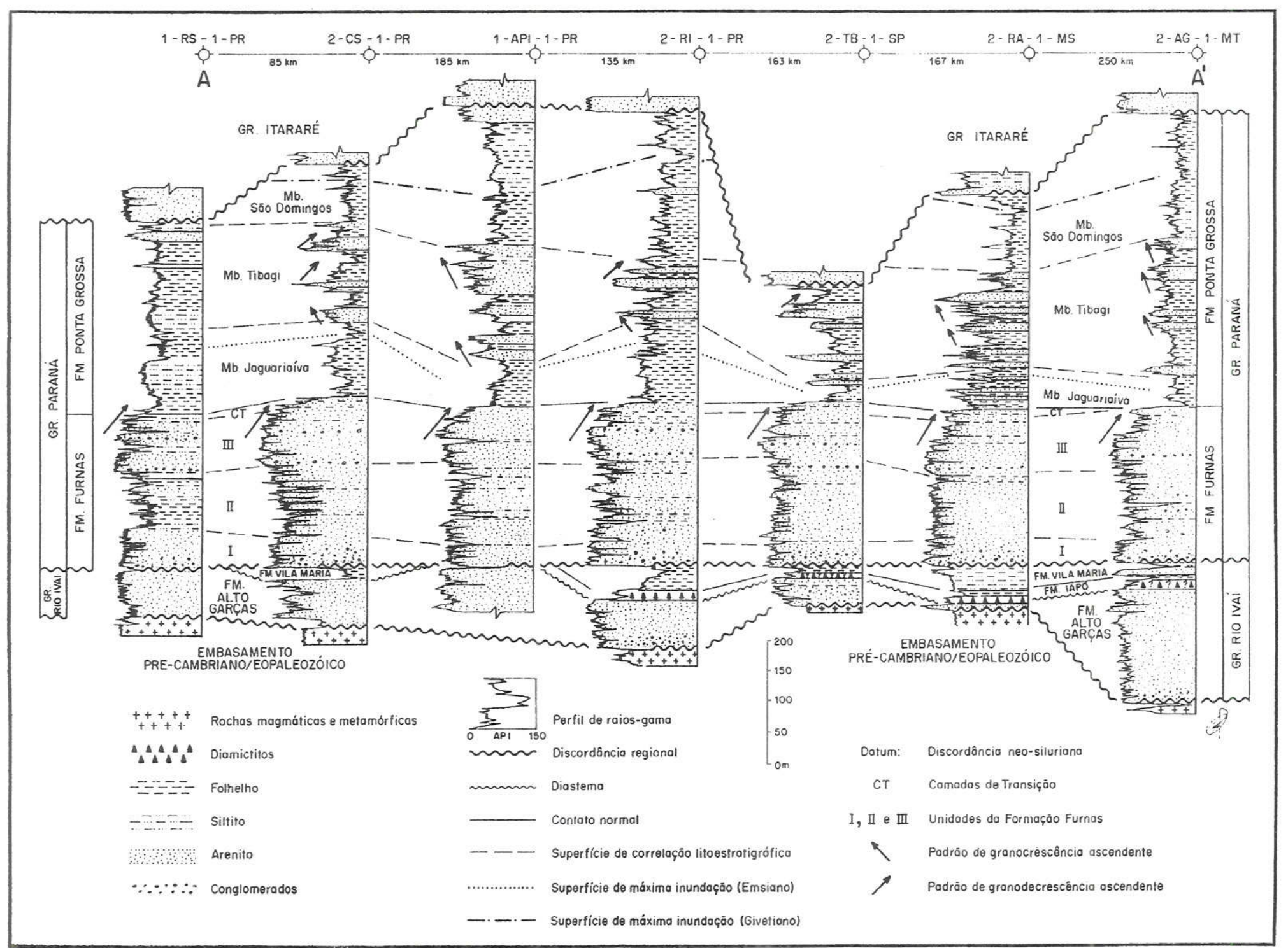

Figura 12 - Seção estratigráfica A-A' (localização na Fig. 9). 
área, os arenitos da Fm. Alto Garças localmente não ocorrem, como na seção da cachoeira (ponto 11), onde os diamictitos da Fm. lapó assentam diretamente sobre o embasamento pré-cambriano/eopaleozóico. O contato entre o $\mathrm{Gr}$. Rio Ivaí e a $\mathrm{Fm}$. Furnas é litologicamente nítido na área e marcado por uma mudança radical na coloração, da característica cor vermelha da Fm. Vila Maria para a invariável cor branca da Fm. Furnas (Fig. 11-A).

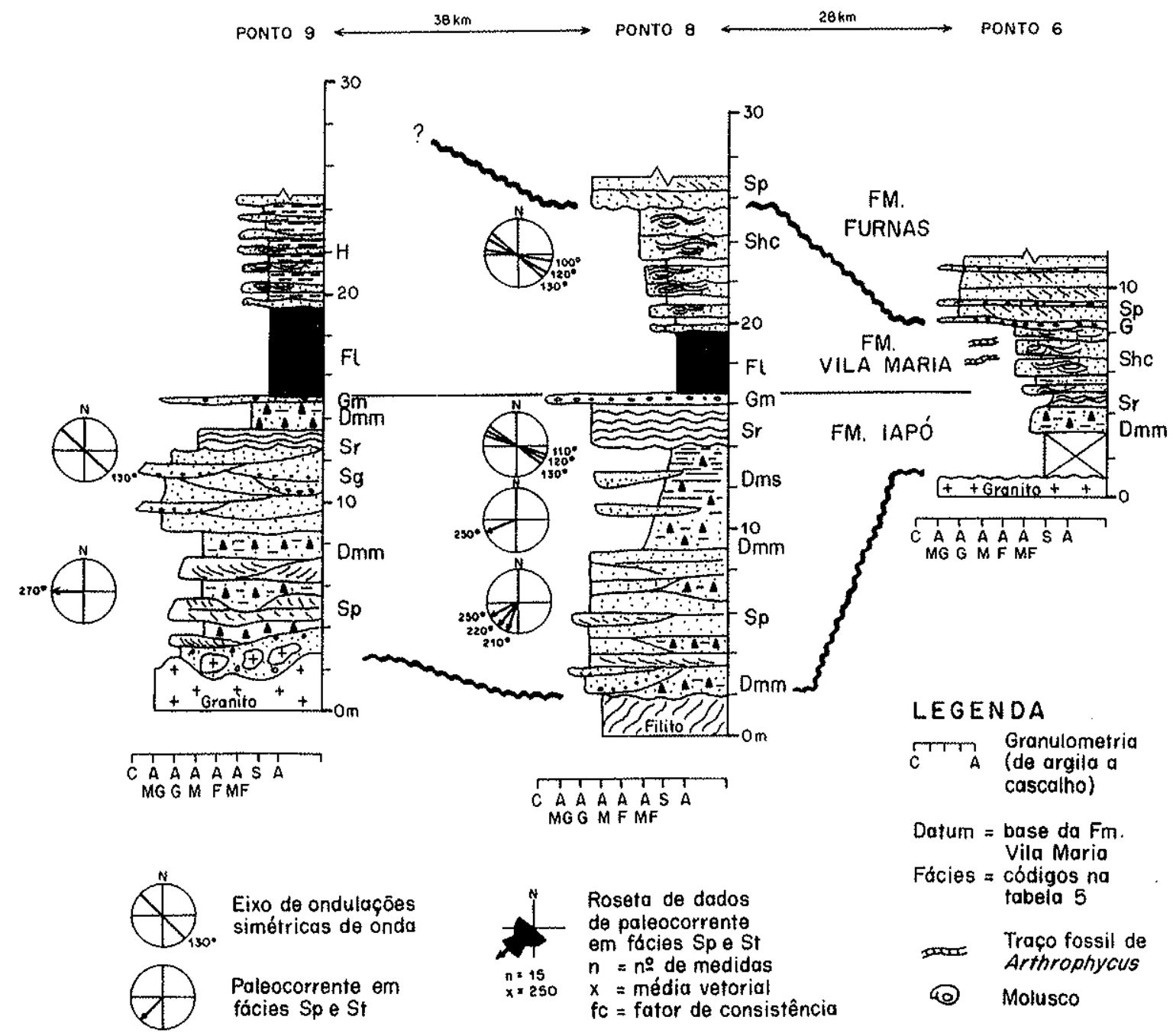

Figura 13 - Seções colunares entre Amorinópolis e Bom Jardim de Goiás (localização dos pontos: Fig. 5; código de fácies: Tab. 5; símbolos utilizados: Tab. 6). 


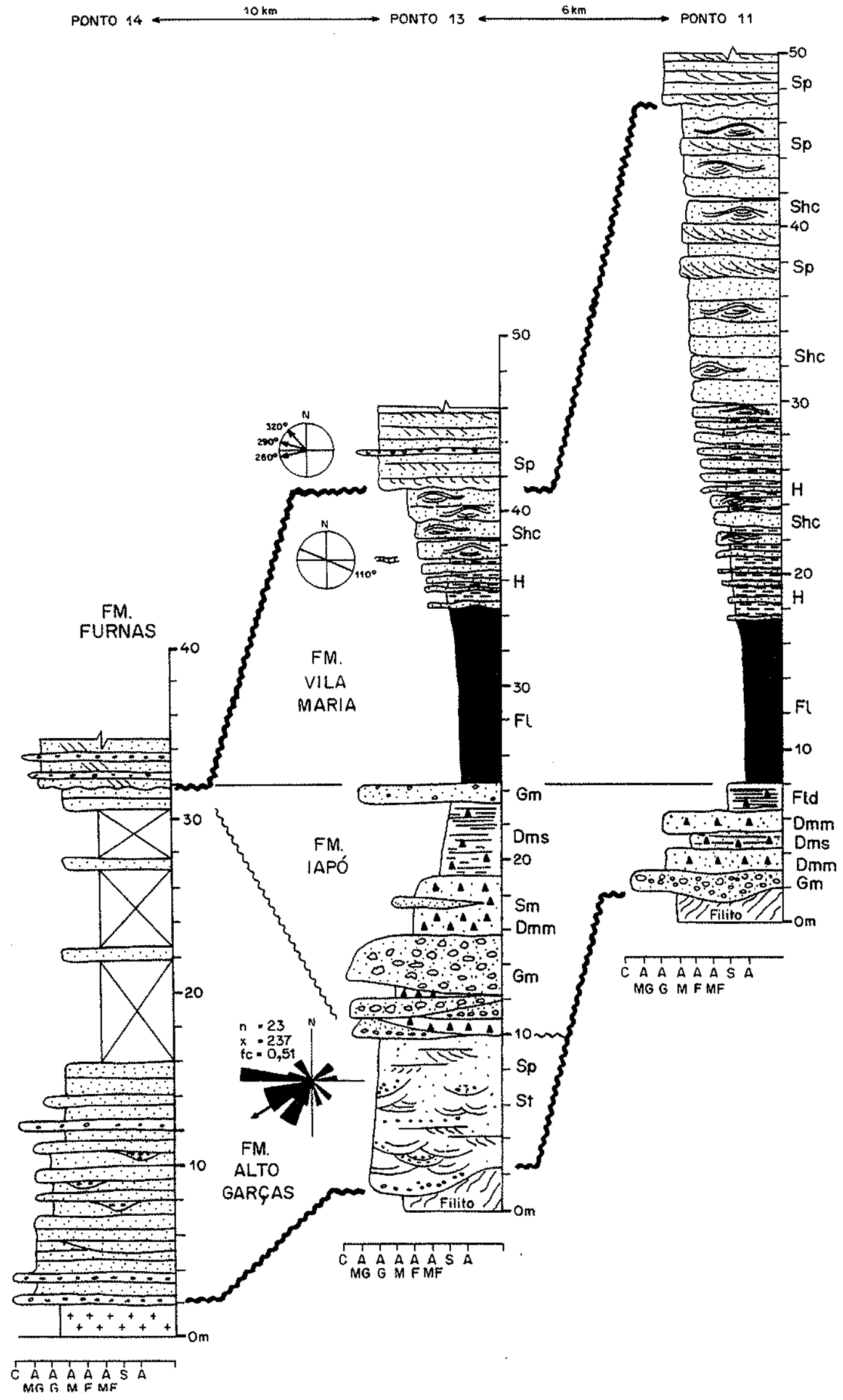

Figura 14 - Seções colunares do Gr. Rio Ivaí na bacia de drenagem do Ribeirão das Perdizes, a sudeste de Baliza-GO (localização dos pontos: Fig. 5; código de fácies: Tab. 5; símbolos utilizados: Fig. 13 e Tab. 6). 
Seções representativas do grupo ocorrem também a norte, na região de Barra do Garças, uma área muito afetada por intensa tectônica modificadora, responsável pela compartimentação em blocos limitados por falhas de direção predominante NE (N30-60E), cujos rejeitos podem ser superiores a 200m (Fig. 15). As três formações estão presentes e os arenitos da Fm. Alto Garças apresentam espessuras da ordem de duas dezenas de metros. Na figura 15 verifica-se que, ao contrário do que consideraram Milani et al. (no prelo), na seção do mirante do Cristo a Fm. Furnas aflora desde a base da escarpa. Para o topo, os arenitos brancos, grossos e com estratificação cruzada, dão lugar a arenitos avermelhados, finos e com estratificação truncada por ondas, pertencentes à Fm. Ponta Grossa. Além disso, os pelitos cinza esbranquiçados e fossiliferos (trilobitas e braquiópodes), que afloram na área do Cindacta II (ponto 20) e que Sundaram (1994) considerou como Fm. Vila Maria, pertencem, na verdade, à Fm. Ponta Grossa. Reavaliação das formas presentes confirmou uma idade devoniana para os mesmos (Sundaram com. pessoal).

É interessante registrar que Beurlen (1959) já havia notado a existência de uma seção clástica sotoposta à Fm. Furnas ao longo do rio das Garças, entre Barra do Garças e General Carneiro, que todavia não se encontra mapeada (ver Fig. 5 para localização). Caracterizou-a (Beurlen 1959., p. 38) como "uma seqüência basal de pequena espessura, constituída de siltitos vermelhos, bem estratificados, às vêzes argilosos, localmente, até mesmo argilas sílticas e siltitos de aspecto tilítico. Em nenhum lugar se podem observar os contatos estratigráficos dessa estranha seqüência. Mas ela ocorre sempre na serra, em baixo e sob os arenitos grosseiros, conglomeráticos". Na extremidade sudeste da serra do Taquaral (noroeste de Barra do Garças), na colonia Voadeira, situada no córrego homônimo, Beurlen (1959, p. 32) assim descreveu a seção sotoposta aos arenitos conglomeráticos brancos da base da Fm. Furnas: "O vale do córrego apresenta, nos arredores da colônia, na lapa, um arenito vermelho bem estratificado, com bancos da espessura de 20 a 40 centímetros, sem estratificação cruzada. A granulação é média ou fina, bastante monótona. Além dos grãos de quartzo, ocorre muita muscovita. $O$ limite inferior dêste arenito não pode ser observado, razão porque a espessura total é desconhecida. Segue-lhe na capa um metro de arenito conglomerático, com pequenos seixos: êste é encimado por um siltito argiloso, não estratificado, com seixos esparsos, pequenos, apresentanto, assim, aspecto semelhante ao de um tilito um pouco arenoso. A espessura dêsse siltito 'tilítico' é, aproximadamente, de 5 metros, realçando-lhe a côr rosada. É capeado de um arenito fino, bem estratificado, rico em moscovita". Embora tenha interpretado esta seção como parte da seqüência devoniana, considerou que "à primeira vista parece 

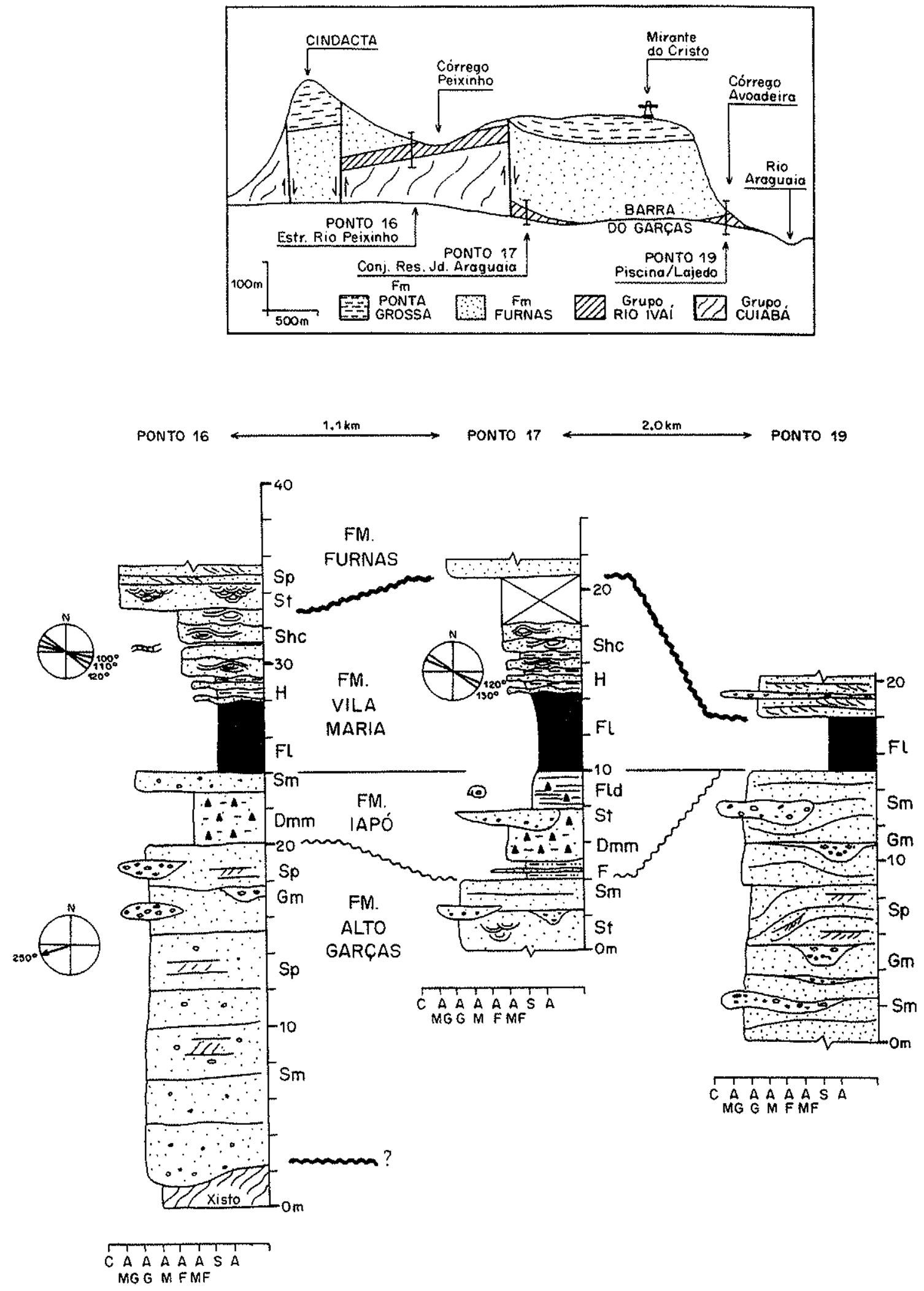

Figura 15 - Seção geológica e seções colunares do Gr. Rio Ivaí na região de Barra do Garças-MT (localização dos pontos: Fig. 5; código de fácies: Tab. 5; símbolos utilizados: Fig. 13 e Tab. 6). 
plausivel que as ditas ocorrências representem um equivalente da formação glacial lapó, descrita por Maack, na lapa do arenito Furnas, no Paraná" (Beurlen 1959, p. 42).

A relação de discordância entre o Grupo Rio Ivaí e a Fm. Furnas é evidente nas seções levantadas no ribeirão das Perdizes (Fig. 14) e em Barra do Garças (Fig. 15), onde, em pontos muito próximos, há uma preservação desigual da seção regressiva do topo da seqüência (fácies Shc e Sp) e, em alguns casos, ausência das formações Vila Maria e lapó.

Uma seção estratigráfica regional (Fig. 16), construída através da composição das seções das figuras 13, 14 e 15 e do perfil do poço 2-AG-1-MT, permitiu verificar que os arenitos da Fm. Alto Garças se acunham e desaparecem a leste da região do Ribeirão das Perdizes, o que se reflete numa redução progressiva da espessura da seqüência no rumo leste. Na altura da cidade de Amorinópolis (GO), o Gr. Rio Ivaí não mais ocorre e a Fm. Furnas assenta-se diretamente sobre o embasamento précambriano/eopaleozóico (Alvarenga \& Guimarães 1994).

Em contraposição, a seqüência adquire maior possança no rumo SW, sobretudo devido ao espessamento da Fm. Alto Garças, que alcança $214 \mathrm{~m}$ no poço 2-AG-1-MT (Alto Garças), situado a cerca de $170 \mathrm{~km}$ de Barra do Garças. Com base na figura 16, é de se esperar que o $\mathrm{Gr}$. Rio Ivaí aflore no Domo de Araguaínha, com espessura da ordem de aproximadamente $100 \mathrm{~m}$. Trabalhos de reconhecimento realizados permitiram verificar que arenitos mapeados como Fm. Furnas apresentam espessuras muito maiores do que as registradas na faixa de afloramentos da borda norte e em subsuperfície no poço 2-AG-1-MT, sugerindo a presença da Fm. Alto Garças. Rochas semelhantes aos diamictitos da Fm. lapó também foram observadas, mas o grau de deformação é muito acentuado, de forma que a comprovação da ocorrência de unidades ordovício-silurianas depende da realização de futuros estudos de detalhe.

Na porção noroeste da bacia ainda não se dispõe de mapas geológicos em que - Gr. Rio Ivaí tenha sido individualizado, mas a constatação de sua presença nas escarpas que bordejam o pantanal Mato-grossense, permitiu a inferência de uma faixa de ocorrência, não necessariamente contínua, desde Rio Negro (MS) até a região de Rondonópolis (MT) (Fig. 6). O empilhamento sedimentar é bastante semelhante ao do flanco norte, mas a espessura é bem maior, sobretudo devido à maior possança da $\mathrm{Fm}$. Alto Garças. Na região de Rio Verde do Mato Grosso foram medidos $146 \mathrm{~m}$ no ponto 26 (Fig. 17). Espessura similar foi verificada no ponto 25, inclusive com a presença de uma seção pelítica no topo, muito ferruginosa e com pelo menos $20 \mathrm{~m}$ de espessura, correspondente à Fm. Vila Maria. 


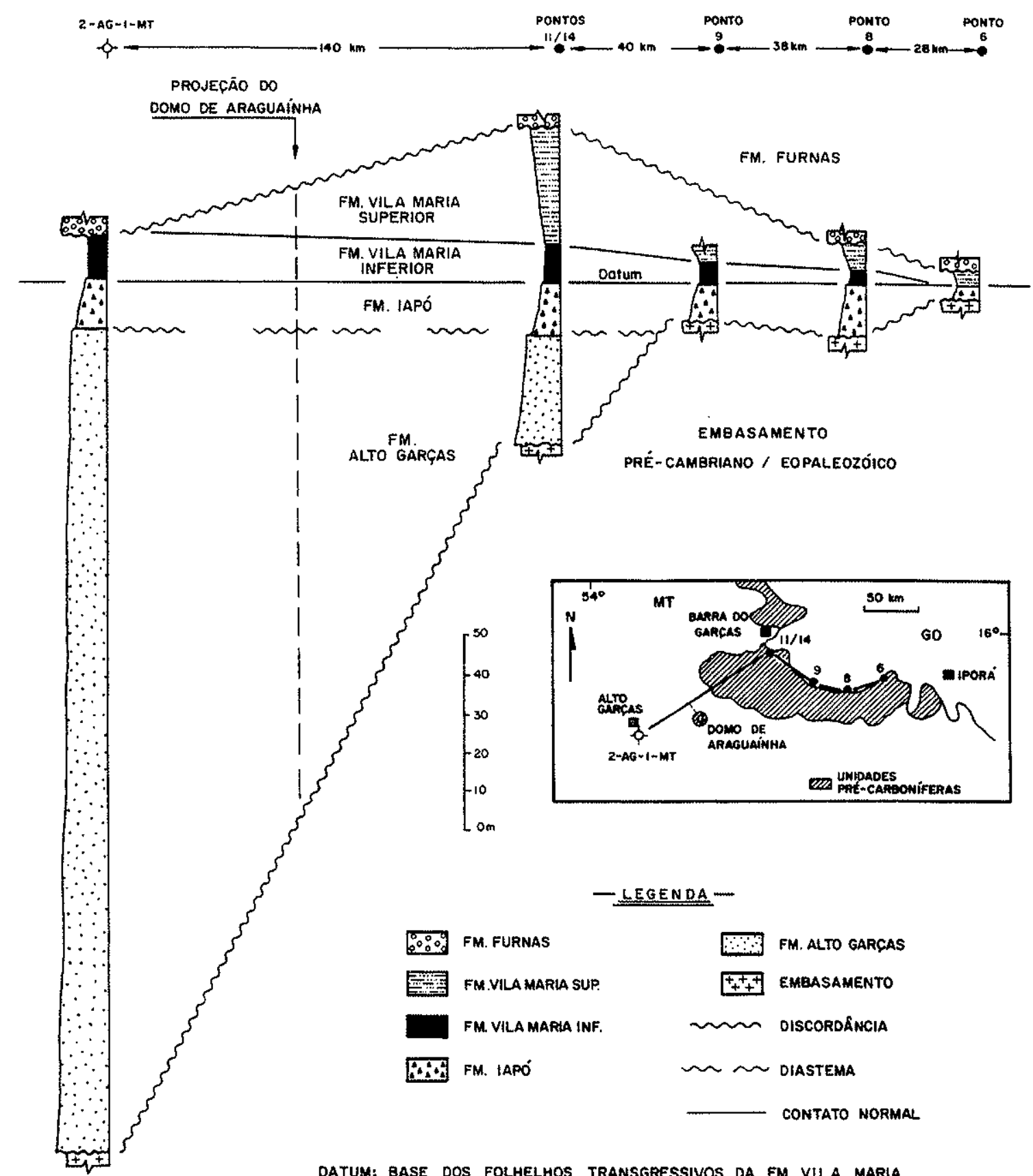

DATUM: BASE DOS FOLHELHOS TRANSGRESSIVOS DA FM. VILA MARIA.

Figura 16 - Seção estratigráfica mostrando o acunhamento da seqüência ordovicio-siluriana para leste, porção norte da bacia. 
$\mathrm{Na}$ localidade de São Lourenço de Fátima, a cerca de $30 \mathrm{~km}$ a noroeste de Rondonópolis (MT), foram recentemente descritos sedimentos da Fm. Vila Maria (Pereira et al. 1995), com ocorrência de niveis portadores de Arthrophycus. O empilhamento sedimentar na área é, entretanto, mais completo do que o relatado por aqueles autores, como pode ser observado na seção levantada na Cachoeira do Bispo (Fig. 18). A espessura da Fm. Alto Garças não foi determinada, sendo certamente maior que $60 \mathrm{~m}$, espessura mínima estimada em escarpas ao longo do vale do Rio São Lourenço.

É provável que a faixa de afloramentos do $\mathrm{Gr}$. Rio Ivaí se estenda mais para norte, mas não foram levantadas seções entre a localidade de São Lourenço de Fátima e a Chapada dos Guimarães. Uma evidência a favor desta suposição é o relato de Oliveira \& Mühlmann (1965, págs. 13-14): "Ao norte de S. Vicente, ocorre localmente uma seção sedimentar constituída de baixo para cima: 1- Arenitos marrons a vermelho arroxeados, médios a grossos, regularmente selecionados, pouco argilosos, pouco ferruginosos, friáveis, grãos subangulares/subarredondados, estratificação paralela espessa, intercalados por leitos de conglomerado, com matriz arenítica e seixos arredondados (até $10 \mathrm{~cm}$ ) de quartzo; 2- Arenito marrom arroxeado, fino a médio, argiloso, mal classificado, muito ferruginoso, micáceo, pouco friável, com estratificação paralela espessa. Esta seção está estratigraficamente abaixo dos arenitos brancos, finos, angulosos, regularmente classificados, limpos, friáveis, intercalados em camadas de conglomerados de seixos de quartzo bem rolados, que, nesta área, constituem a parte basal da Fm. Furnas, em sua expressão típica". Infelizmente os referidos autores não relataram a espessura desta seção sotoposta à Fm. Furnas.

A seqüência ordovício-siluriana acunha-se para leste também na porção sul da bacia. Esta geometria é facilmente observada em seções E-W (Fig. 19), onde se verifica que para leste os arenitos da Fm. Alto Garças não ocorrem, no que resulta uma espessura reduzida desta seqüência. Nos poços mais orientais, também a Fm. Vila Maria desaparece e a Fm. lapó assenta-se diretamente sobre o embasamento pré-cambriano/eopaleozóico. O mesmo se verifica na faixa de afloramentos do flanco sudeste, onde a Fm. lapó é recoberta em discordância diretamente pela Fm. Furnas (Fig. 11-E). Nesta área, a Fm. lapó apresenta-se de forma descontínua e com pequena espessura, por isso ainda não devidamente representada nos mapas geológicos. 


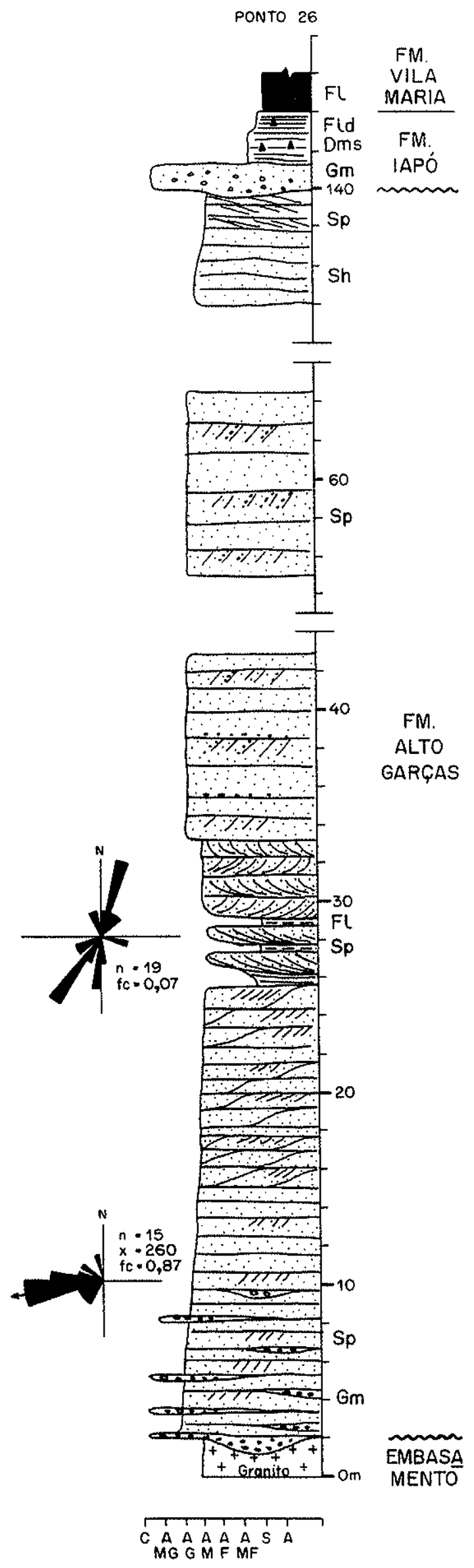




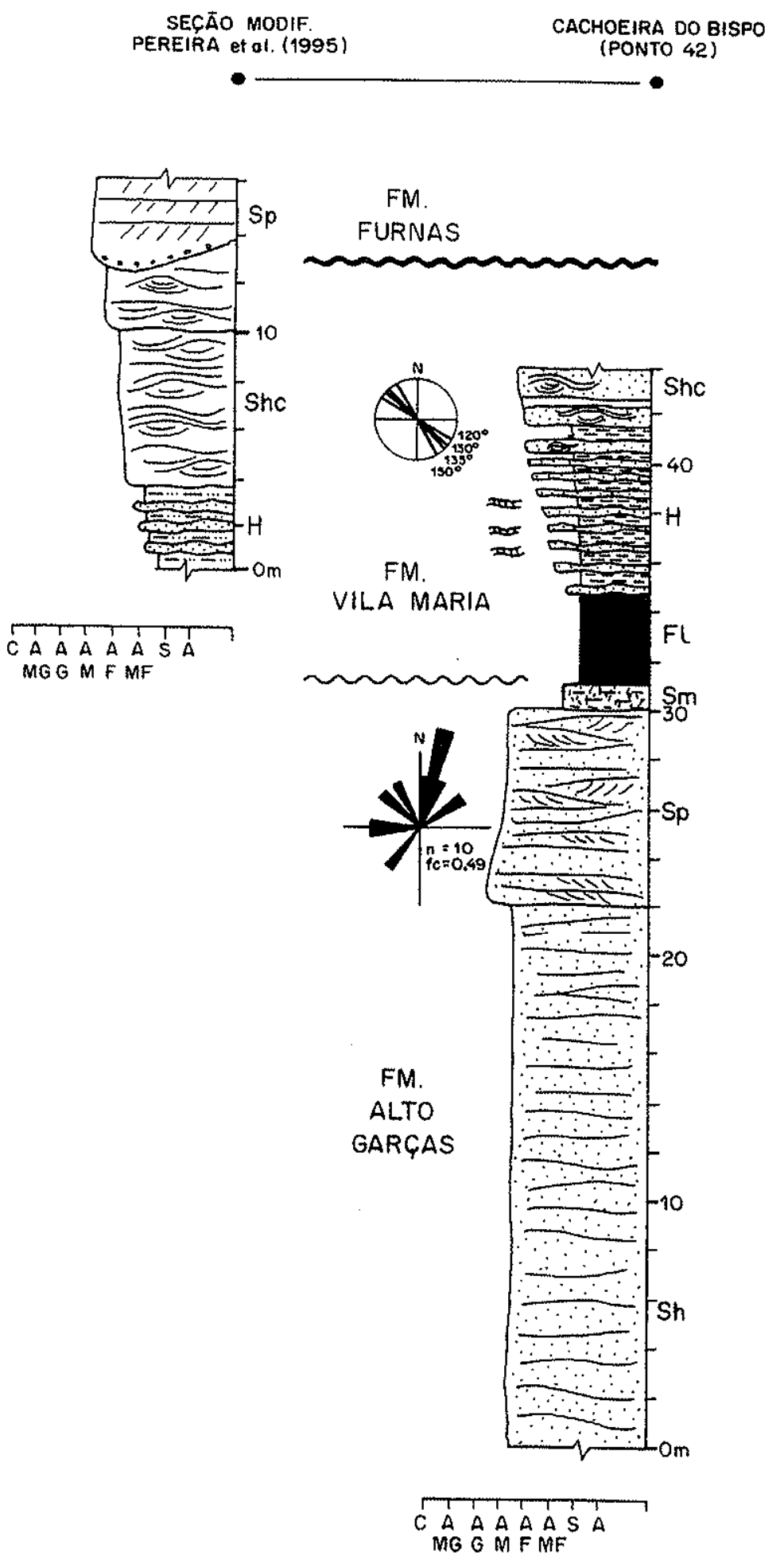

Figura 18 - Seções colunares do Gr. Rio Ivai ao sul de São Lourenço de Fátima, Município de Rondonópolis (localização: Fig. 6; código de fácies: Tab. 5; símbolos utilizados: Fig. 13 e Tab. 6 ). 


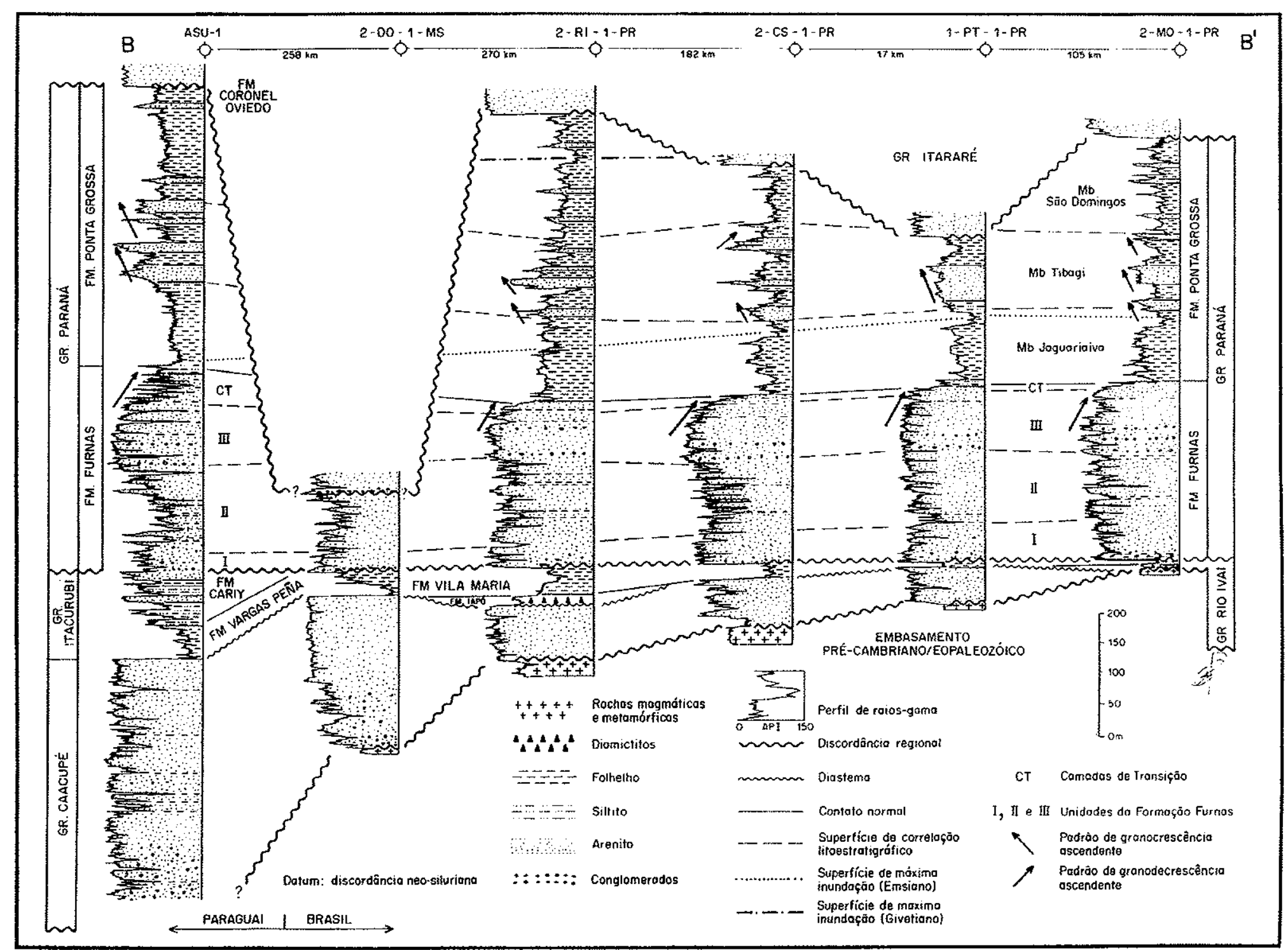

Figura 19 - Seção estratigráfica B-B' (localização: Fig. 9). 


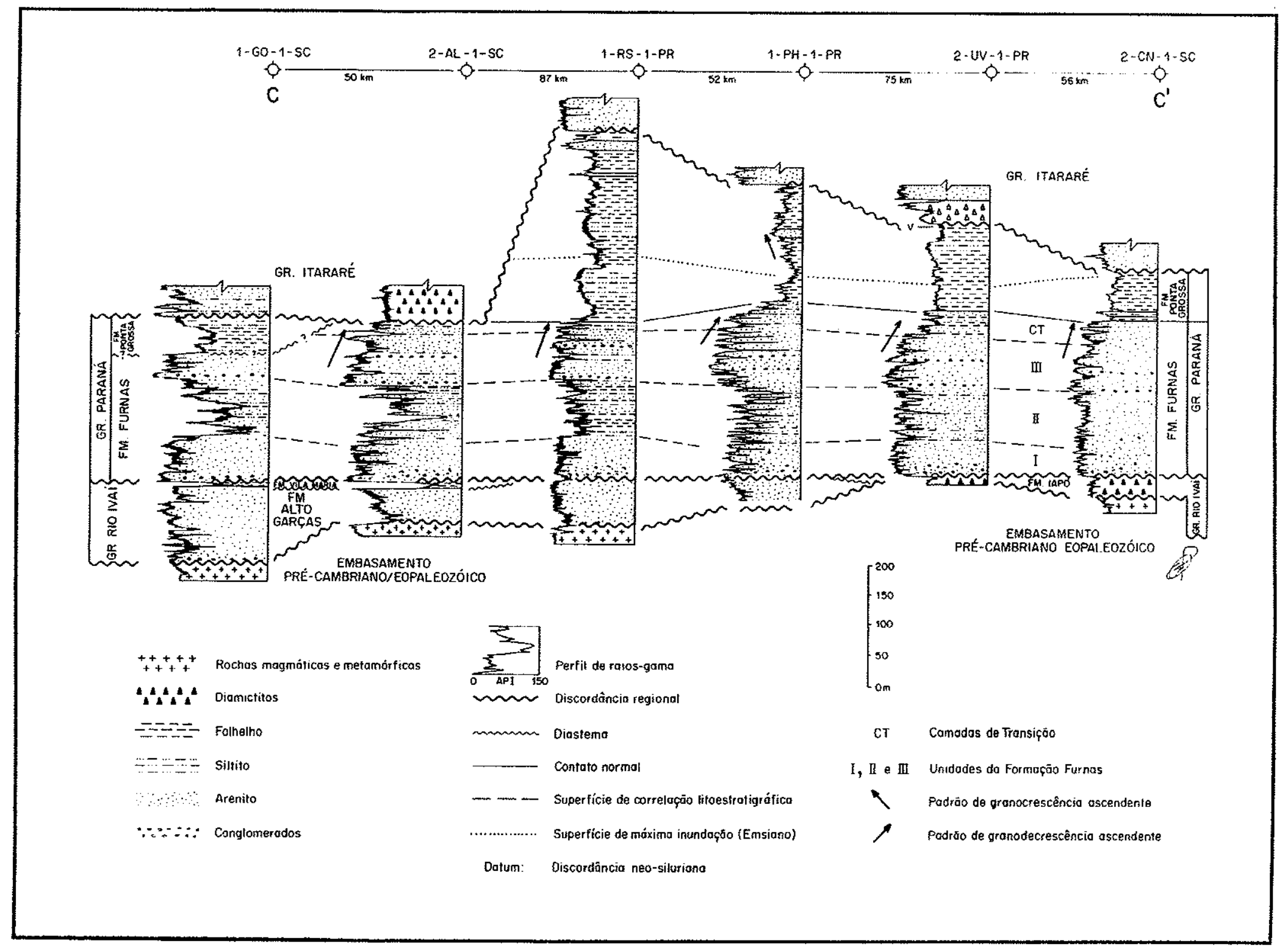

Figura 20 - Seção estratigráfica C-C' (localização: Fig. 9). 


\section{1- FORMAÇÃO ALTO GARÇAS}

Os arenitos da Fm. Alto Garças são facilmente confundidos com os da Fm. Furnas. A chave para a sua identificação é a constatação dos diamictitos da Fm. lapó e/ou dos folhelhos da Fm. Vila Maria, que, todavia, nem sempre ocorrem devido à erosão no topo do Gr. Rio Ivaí.

Nos poços o grau de dificuldade é menor porque o empilhamento estratigráfico é evidente na vertical, dispondo-se, além das amostras de calha e testemunhos, de perfis geofísicos que registram diferentes propriedades das rochas num espectro contínuo, o que permite estabelecer padrões ou assinaturas características, correlacionáveis de poço para poço. Em perfis de raios-gama, o padrão de deflexão à esquerda em direção ao seu topo permite reconhecer a unidade e diferenciá-la da Fm. Furnas (Figs. 12 e 19), mesmo quando as formações lapó e Vila Maria não se acham presentes, o que é o caso, por exemplo, dos poços 2-RP-1-PR, 1-API-1-PR e 3-CB-3SP. Assine et al. (1993) definiram como seções-tipo da Fm. Alto Garças os intervalos 1730 a $1944 \mathrm{~m}$ do poço 2-AG-1-MT (Alto Garças) e 5172 a $5286 \mathrm{~m}$ do poço 2-RI-1-PR (Rio Ivaí) (Fig. 3-B).

A Fm. Alto Garças correlaciona-se com o Gr. Caacupé, aflorante no flanco sudoeste da bacia (Paraguai). É muito provável a continuidade física entre as duas unidades em subsuperfície (Fig. 2). A Fm. Alto Garças foi reconhecida em subsuperfice em grande parte da bacia (Fig. 12 e 19), mas não está ainda mapeada em superfície, embora ocorra em extensa faixa no flanco noroeste da bacia formando as escarpas que bordejam o pantanal Mato-grossense (Fig. 6). Em vista disso, poucas são as informações disponíveis, insuficientes ainda para uma caracterização detalhada da unidade. As melhores exposições encontram-se a oeste de Rio Verde de Mato Grosso (Fig. 22-A), sendo a seção apresentada na figura 18 a mais representativa da unidade, embora incompleta em função de intervalos encobertos.

Em alguns afloramentos, onde se pode observar o contato com o embasamento, foi constatada a existência de um conglomerado basal com espessuras não maiores do que um metro. Apresenta matriz arenosa, clastos arredondados de até $20 \mathrm{~cm}$ (Fig.22-B), predominantemente de quartzo e quartzito, gradando lateralmente para arenitos conglomeráticos com estratificação cruzada (Fig. 22-C). As fácies são muito semelhantes às da Fm. Paraguari da base do Gr. Caacupé (Fig. 22-D). 


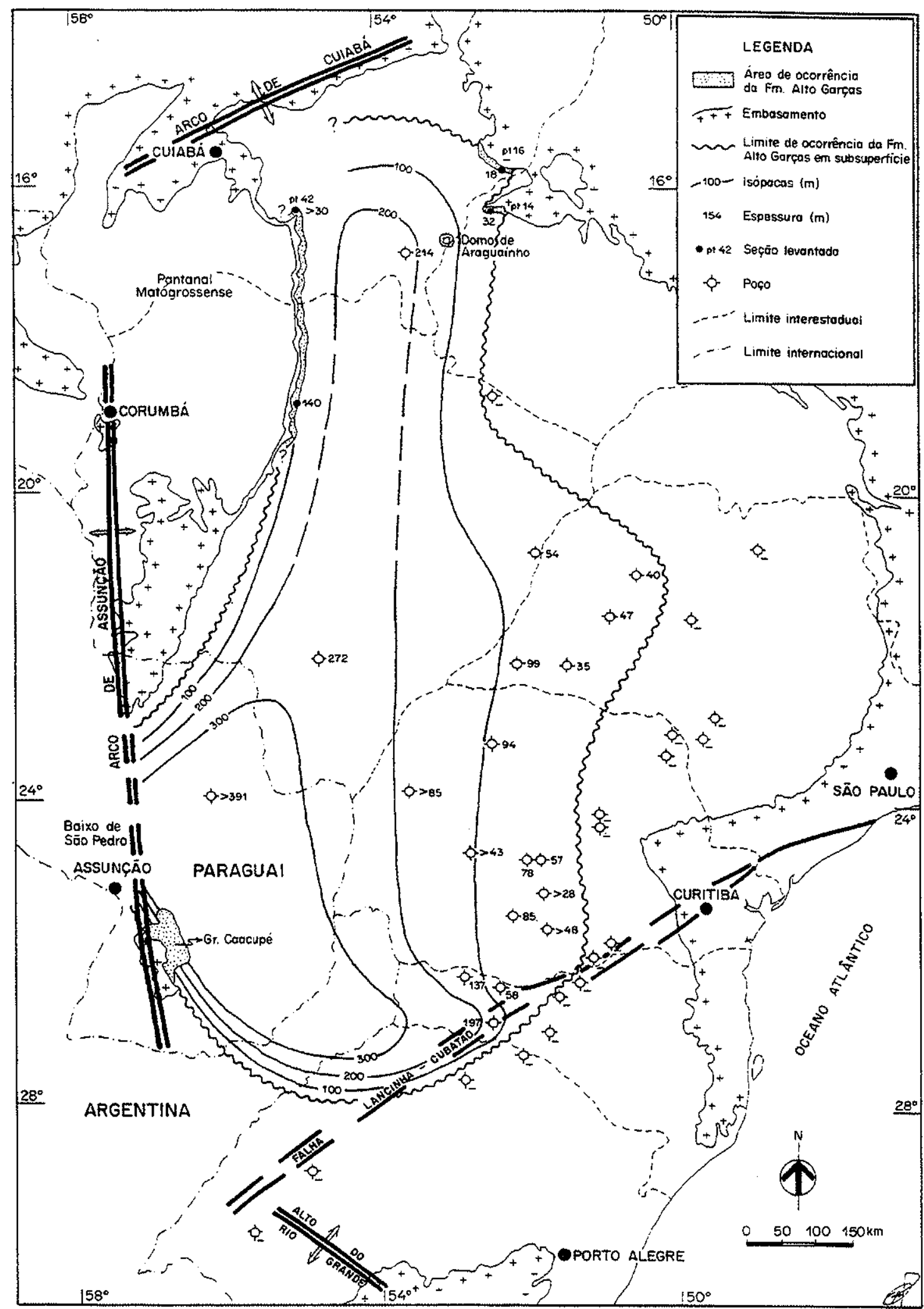

Figura 21 - Mapa de isópacas da Fm. Alto Garças. 
A -

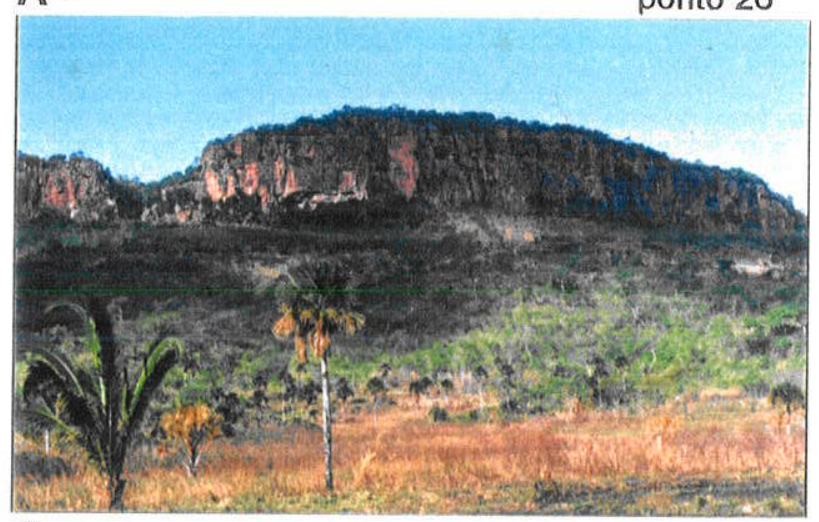

C -

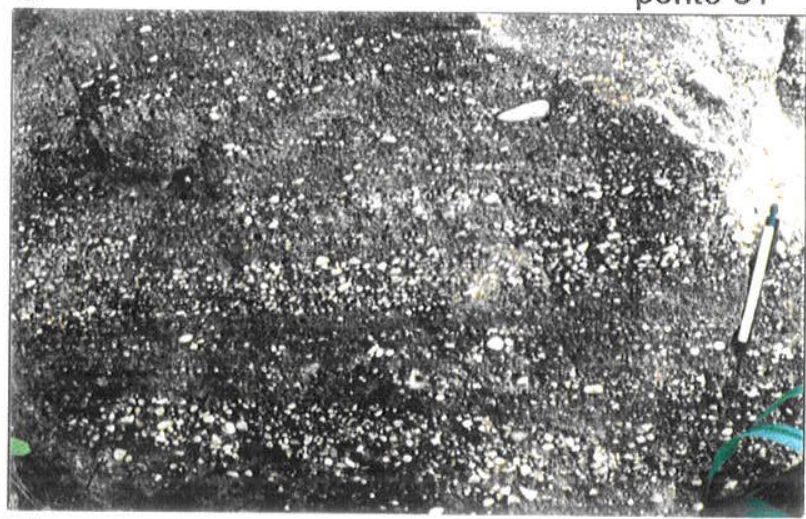

E -

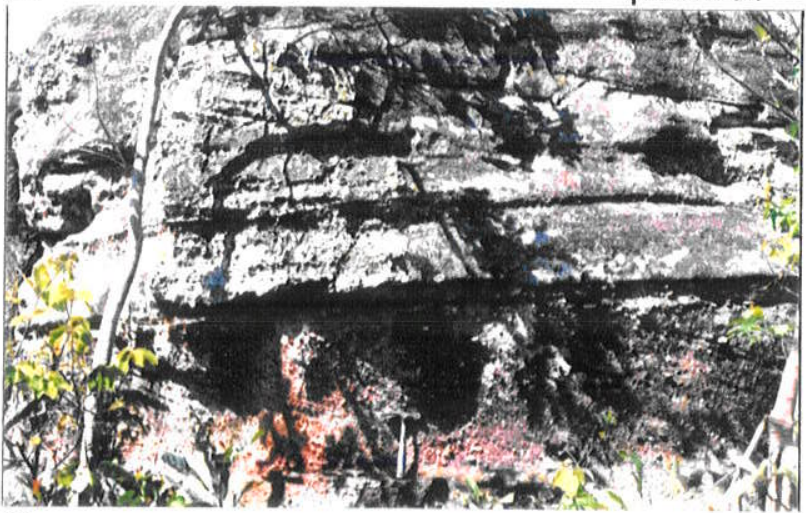

G -

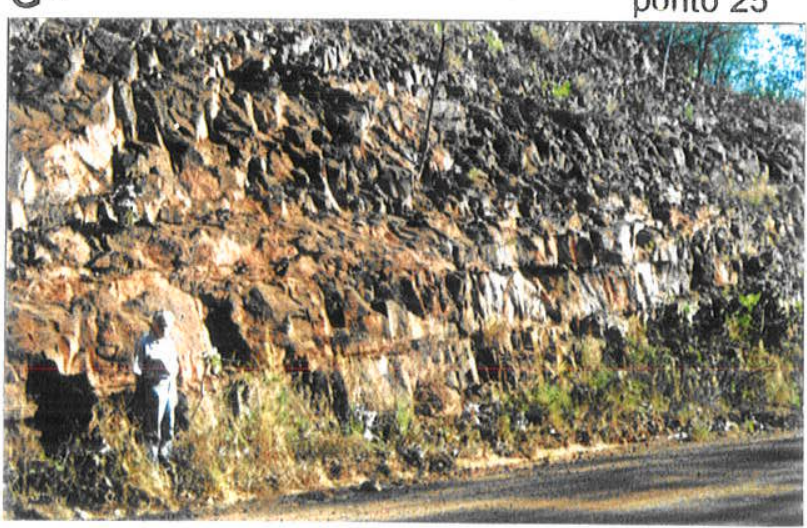

B -

ponto 25

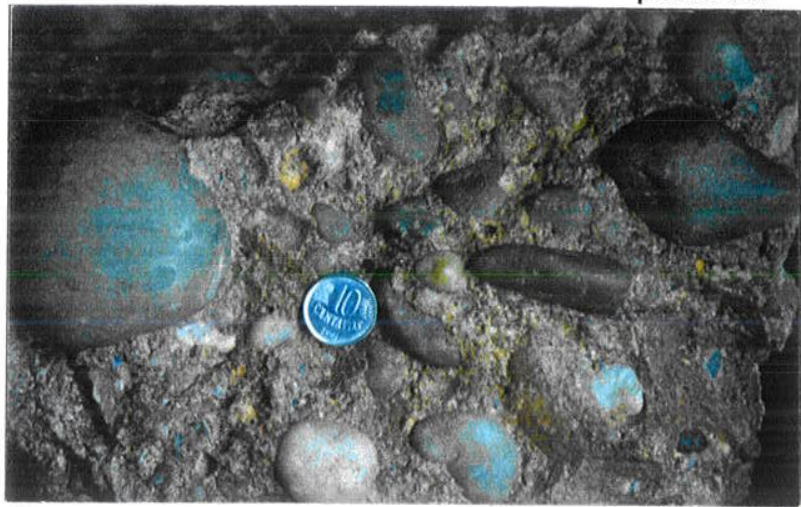

D -

Paraguai

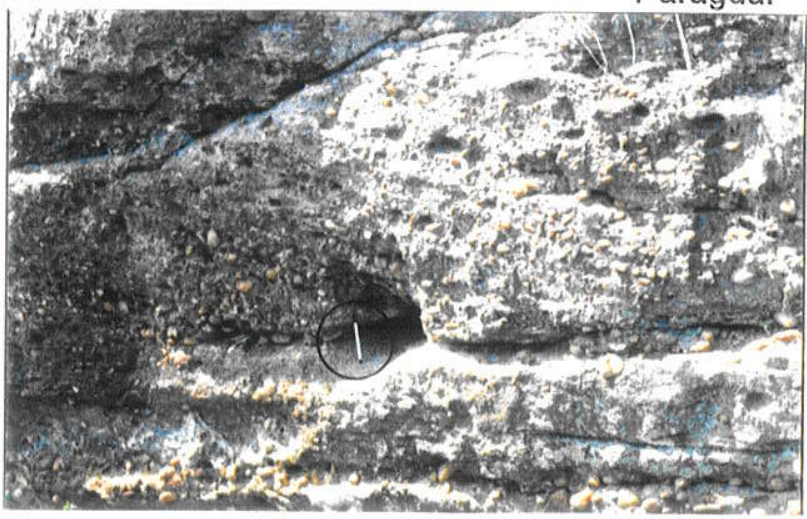

F -

ponto 26

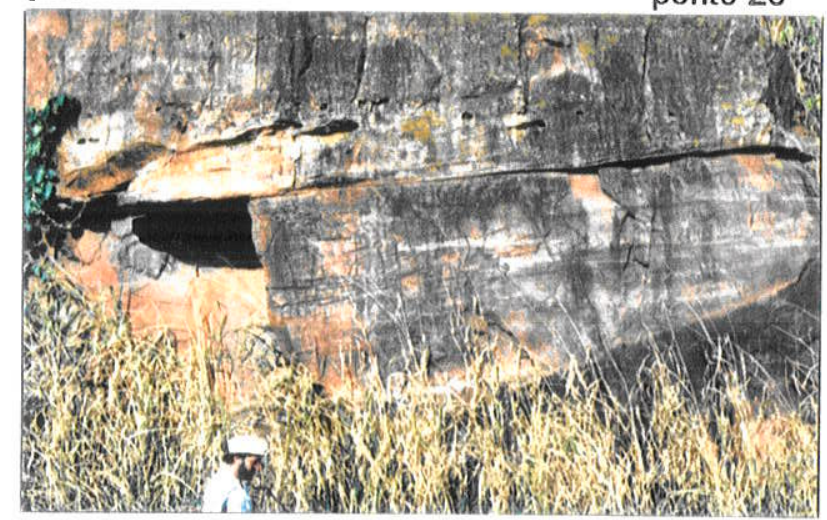

H.

Paraguai

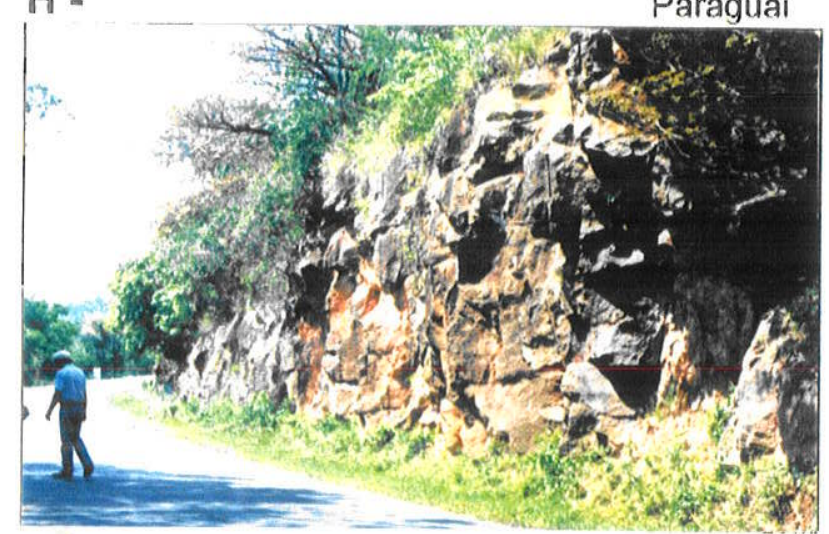

Figura 22 - Fácies da Fm. Alto Garças. Arenitos formando as escarpas da Bacia do Paraná voltadas para o pantanal matogrossense na região de Rio Verde do Mato Grosso-MS (A). Conglomerado basal (B) e arenitos conglomeráticos (C), semelhantes ao da Fm. Paraguari do Gr. Caacupé (D). Fácies $\mathrm{Sp}(\mathrm{E}) \mathrm{com}$ intercalações de níveis conglomeráticos $(F=$ níveis no topo). Arenitos em sets cuneiformes (G), similares aos do Gr. Caacupé do Paraguai (H). 
I-

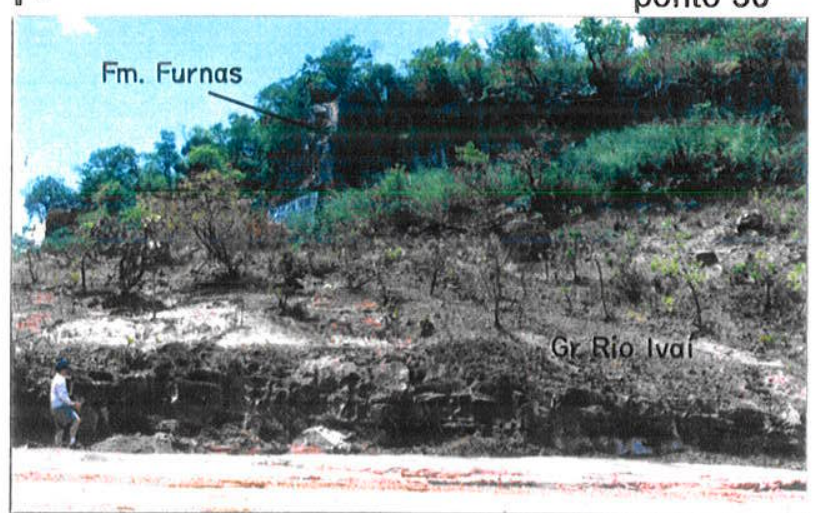

L -
J -

ponto 12

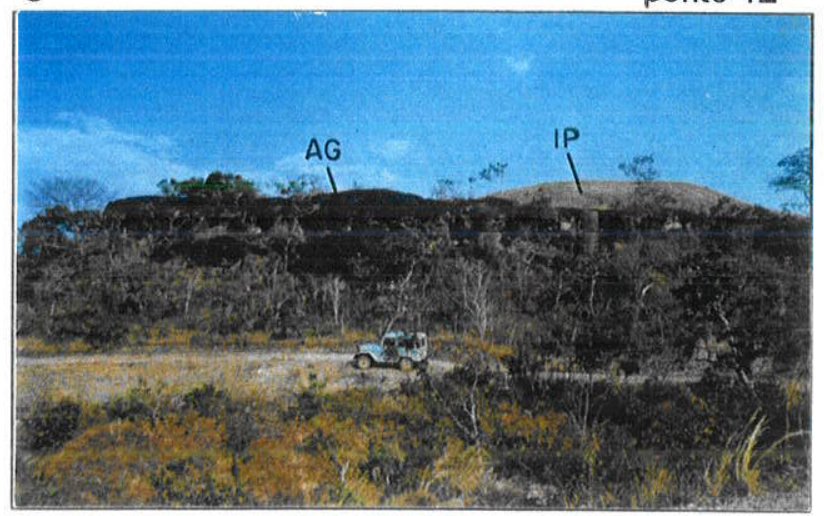

pontos $16 / 17$

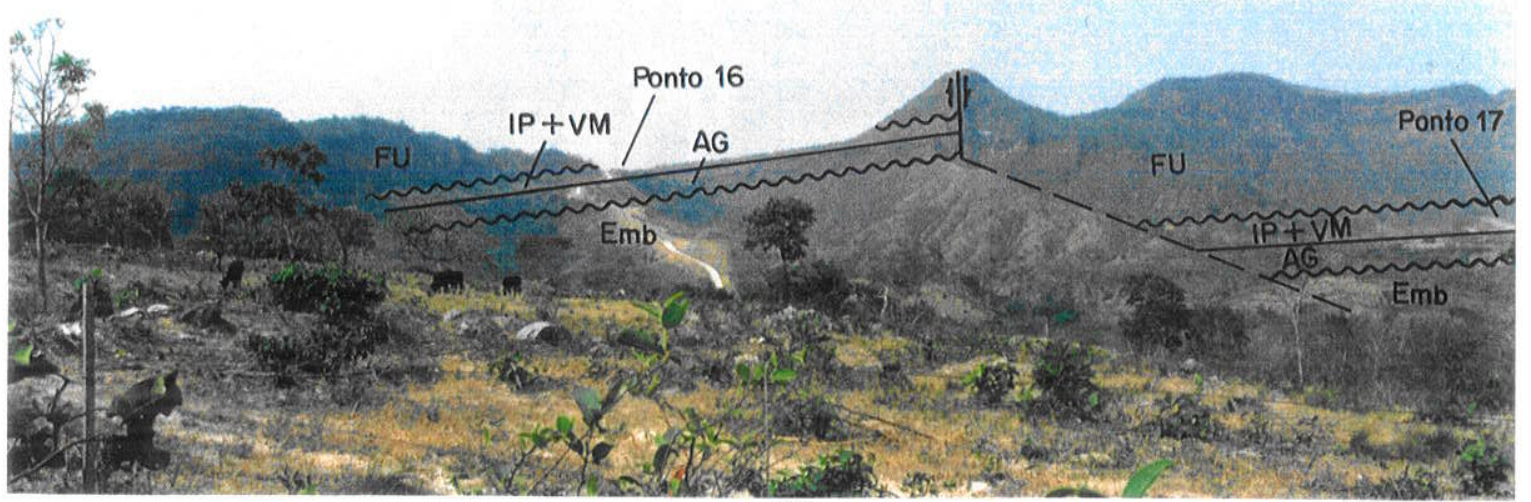

$M=$

ponto 13

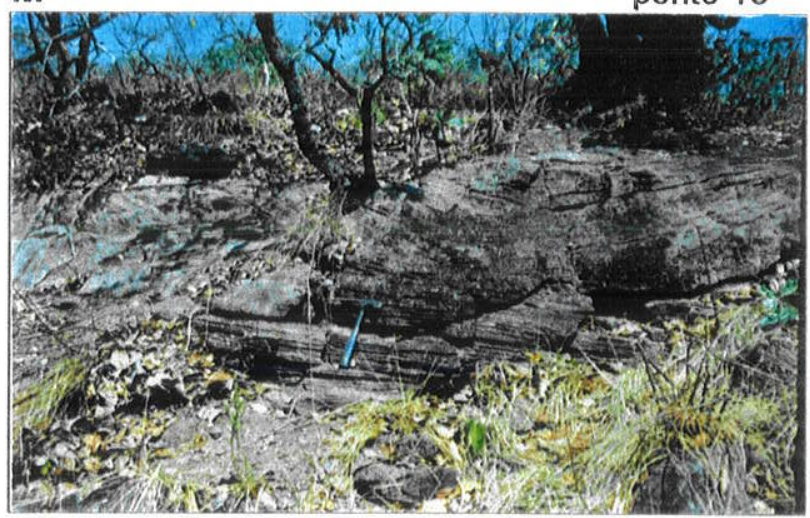

N -

ponto 19

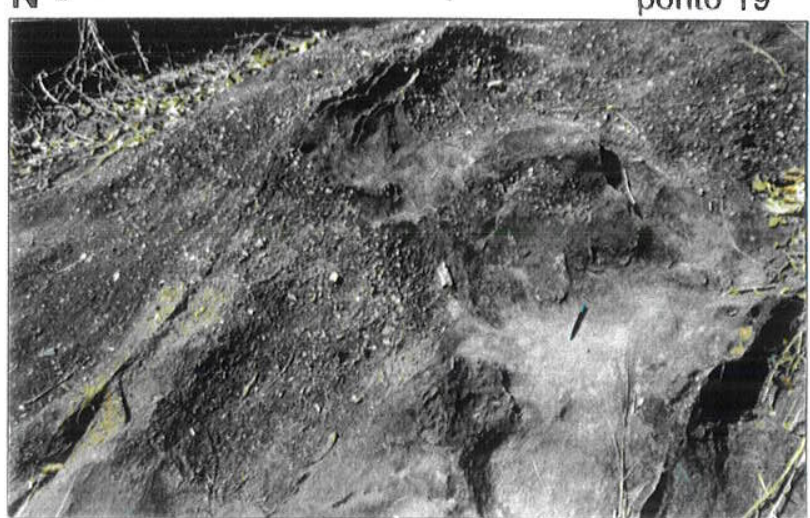

Figura 22 - Fácies da Fm. Alto Garças (continuação). Terminações de barras sigmóides com fluxo onshore para NE, indicativas da ação de marés (I). No flanco norte as espessuras são reduzidas, da ordem de duas dezenas de metros, como a leste de Baliza-GO (J) e em Barra do Garças-MT (L). No flanco norte, embora estejam presentes as fácies $\mathrm{Sh}$, Sp e St (M), ocorrem também fácies Sm com feições de deformação penecontemporânea e bolsões conglomeráticos de contornos irregulares $(\mathbf{N})$ $(E \mathrm{mb}=$ embasamento pré-cambriano; $A G=F m$. Alto Garças; $I P=F m$. lapó; $\quad V M=F m$. Vila Maria; $\mathrm{FU}=\mathrm{Fm}$. Furnas). 
Na porção inferior predominam arenitos brancos com tonalidades róseas, finos a grossos, pouco feldspáticos, com estratificação cruzada planar (Fig. 22-E), dispostos em sets de geometria cuneiforme a tabular (fácies Sp), aos quais se interestratificam delgados níveis (poucos centímetros a alguns decímetros) de conglomerados finos (fácies $\mathrm{Gm}$ ), constituídos de seixos subarredondados de quartzo (Fig. 22-F). São sucedidos por arenitos finos a médios, dispostos em sets cuneiformes ou de geometria sigmóide truncada no topo, com estratificação cruzada tangencial na base e terminações que gradam para níveis síltico-argilosos, predominam na parte superior da unidade (Fig. 22-G). Faciologicamente são semelhantes ao que tem sido referido como Fm. Cerro Jhu do Gr. Caacupé (Fig. 22-H), este caracterizado por arenitos de coloração branca com tonalidades róseas e castanhas, granulometria fina a média e estratificação cruzada predominantemente planar (Bigarella \& Comte 1969).

As paleocorrentes medidas na porção inferior apresentam, no geral, padrão unimodal e fluxo para oeste-sudoeste, mas, localmente, foram observados sets com sentidos de fluxo opostos (Fig. 22-1), com bipolaridade para SW e NW (Fig. 17).

Os arenitos da porção superior são finos a grossos, friáveis, semelhantes aos da porção inferior, mas se apresentam também com estratificação plano-paralela pouco distinta ou, ainda, com aspecto maciço. Ao longo do vale do rio São Lourenço, a oeste de Rondonópolis, formam relevos com aspecto ruiniforme. No ponto 30 apresentam-se em barras sigmóides com sentido de transporte para NE, contrário ao da base da unidade (Fig. 22-I).

De forma geral, os arenitos da Fm. Alto Garças na borda noroeste da bacia são mais maturos, melhor arredondados e menos feldspáticos que os da Fm. Furnas, sugerindo retrabalhamento policíclico.

Ainda não se dispõe de informações suficentes para uma interpretação mais detalhada dos paleoambientes de sedimentação. A reconstituição da história deposicional das espessas sucessões de arenitos quartzosos do Paleozóico Inferior/Médio, como os descritos, tem sido problemática por várias razões, sobretudo pela maturidade composicional e textural de muitos arenitos, pobreza ou mesmo ausência de fósseis, escassez de pelitos intercalados, grandes espessuras e ausência de ambientes sedimentares análogos no Recente aos quais possam ser comparados (Visser 1974). A maior parte das espessas seqüências de arenitos quartzosos ou quartzo-arenitos do Paleozóico Inferior teria sido originada em plataformas siliciclásticas marinhas, rasas e extensas (Chandler 1988).

A sucessão vertical de fácies denota empilhamento transgressivo para a unidade, permitindo caracterizá-la como predominantemente marinha. A maturidade 
composicional e mineralógica e a existência de icnofósseis, descritos no poço 2-AG-1MT (Maino 1965), reforçam esta interpretação. Os arenitos e conglomerados da base são considerados depósitos transicionais (braided deltas), sucedidos por arenitos marinhos plataformais com retrabalhamento por marés (padrão de paleocorrentes bipolar: Fig. 17). Os arenitos do Gr. Caacupé, que integram com a Fm. Alto Garças a mesma seqüência deposicional, também foram considerados marinhos (Bigarella \& Comte 1969, Harrington 1972).

Nos pontos 24 e 25 foram observados, próximo ao topo da unidade, conglomerados quartzosos intercalados nos arenitos. Os conglomerados formam níveis paralelos ao acamamento ou apresentam-se sob a forma de bolsões de geometria lenticular ou caótica, com espessura de até $20 \mathrm{~cm}$. A presença destes termos conglomeráticos na parte superior da Fm. Alto Garças foi interpretada como resultado do abaixamento do nivel de base, avanço de fácies costeiras para posições mais distais na plataforma e retrabalhamento por processos marinhos, denotando um caráter regressivo no topo da unidade. Conglomerados descritos no Mioceno do sudoeste do Estado de Oregon (EUA), com caracteristicas semelhantes, foram interpretados como produto de ambientes marinhos rasos dominados por onda (Leithold \& Bourgeois 1984). As características e gênese de depósitos de shoreface conglomeráticos foram recentemente analisadas por Hart \& Plint (1995).

A Fm. Alto Garças ocorre também na faixa de afloramentos do flanco norte da bacia, a oeste do meridiano $52^{\circ} \mathrm{W}$. Na região do vale do rio Araguaia (fronteira entre os estados de Goiás e Mato Grosso), sua espessura atinge um máximo constatado de $30 \mathrm{~m}$ (Fig. 14). Merecem referência as exposições na bacia de drenagem do ribeirão das Perdizes e do córrego Lajeado, a sudeste de Baliza no Estado de Goiás (Figs. 14 e 22-J), e nas serras Azul e do Taquaral em Barra do Garças no Estado de Mato Grosso (Figs. 15 e 22-L). Pelos relatos de Beurlen (1959), a faixa de ocorrência da unidade estende-se para oeste, pelo menos até a altura da cidade de General Carneiro (detalhes na p. 39).

Como na faixa de afloramentos da unidade no Estado do Mato Grosso do Sul (flanco noroeste), paleocorrentes medidas nos estados de Goiás e Mato Grosso indicam paleofluxo sedimentar para sudoeste. Este padrão similar de paleocorrentes sugere um mesmo contexto paleogeográfico, constituindo as ocorrências da região do vale do Araguaia as fácies proximais do trato de sistemas. A falta de continuidade e a distância entre as duas áreas de afloramento e a escassez de dados de subsuperfície dificultam, entretanto, as tentativas de correlação. 
Nos afioramentos do flanco norte, a unidade apresenta fácies compativeis com posição mais proximal. Os arenitos são de granulometria média a muito grossa, apresentando em muitos casos estratificações cruzadas planar ou acanalada (Fig. 21M). O que chama a atenção é a presença marcante de arenitos com aspecto maciço, dispostos em sets mal definidos e de contornos irregulares, aos quais se associam niveis de conglomerados irregulares e descontínuos, em contatos muitas vezes difusos e caóticos (Fig. 22-N). Em função destas características, são tentativamente correlacionados à seção superior da unidade na faixa de afloramentos no Estado do Mato Grosso do Sul, onde níveis conglomeráticos também foram constatados.

\section{2- FORMAÇÃO IAPÓ}

A Fm. lapó foi descrita e formalizada no Estado do Paraná (Maack 1947). Na seção-tipo, a oeste da cidade de Castro, ocorre logo abaixo dos arenitos conglomeráticos e conglomerados da base da Fm. Furnas (Figs. 10 e 23), onde é composta por duas fácies distintas. Diamictitos de coloração avermelhada e matriz arenosa ocorrem na parte basal, sendo sobrepostos por diamictitos de coloração cinza azulada e matriz siltico-arenosa. Ambos são caracterizados pela presença de clastos de composição variada (seixos a matacões) e composição diversa.

Afloramentos da unidade são, contudo, difícies de serem observados ao longo da faixa de afloramentos do flanco sudeste da bacia, porque a unidade é pouco espessa, de natureza descontínua e freqüentemente coberta por depósitos de tálus. Segundo Maack (1950-51), a Fm. lapó ocorre da Serra de São Joaquim até o norte de Piraí do Sul. Outros ocorrências foram cartografados no Estado do Paraná por Vieira \& Maingué (1971).

Durante os trabalhos de campo, afloramentos da unidade foram constatados também a leste de Carambeí (ponto 69) e no canyon do rio São Jorge (ponto 63). Possivelmente, também pertençam à Fm. lapó diamictitos existentes em São Luiz do Purunã (ponto 49), antes considerados pertencentes à Fm. Camarinha. Desta forma, a faixa aflorante da Fm. lapó pode ser estendida para sul até, no mínimo, a altura da cidade de Ponta Grossa. Para norte, a faixa aflorante da unidade pode ser estendida até o sul do Estado de São Paulo, pois na estrada que liga Bonsucesso a Itapeva, abaixo da Fm. Furnas, ocorrem diamictitos cinza arroxeados sustentados por matriz síltico-argilosa e constituídos por seixos de diversas composições, muito semelhantes aos descritos no Paraná. Diamictitos nesta região, abaixo da Fm. Furnas, foram há 
muitos anos relatados por Petri \& Fulfaro (1967), embora considerados précambrianos.

A ocorrência da Fm. lapó em um grande número de poços nos estados do Paraná, Santa Catarina, São Paulo e Mato Grosso do Sul (Fig. 24) sustenta sua correlação com os diamictitos presentes na faixa de afloramentos de Goiás (Figs. 13, 14 e 15), originalmente incluídos na base da Formação Vila Maria por Faria (1982). Como já referido anteriormente, esta correspondência foi sugerida pela primeira vez por Caputo \& Crowell (1985). Os diamictitos e fácies associadas formam um horizonte estratigráfico único, razão pela qual Assine et al. (1994) propuseram que sejam classificados como Fm. lapó.

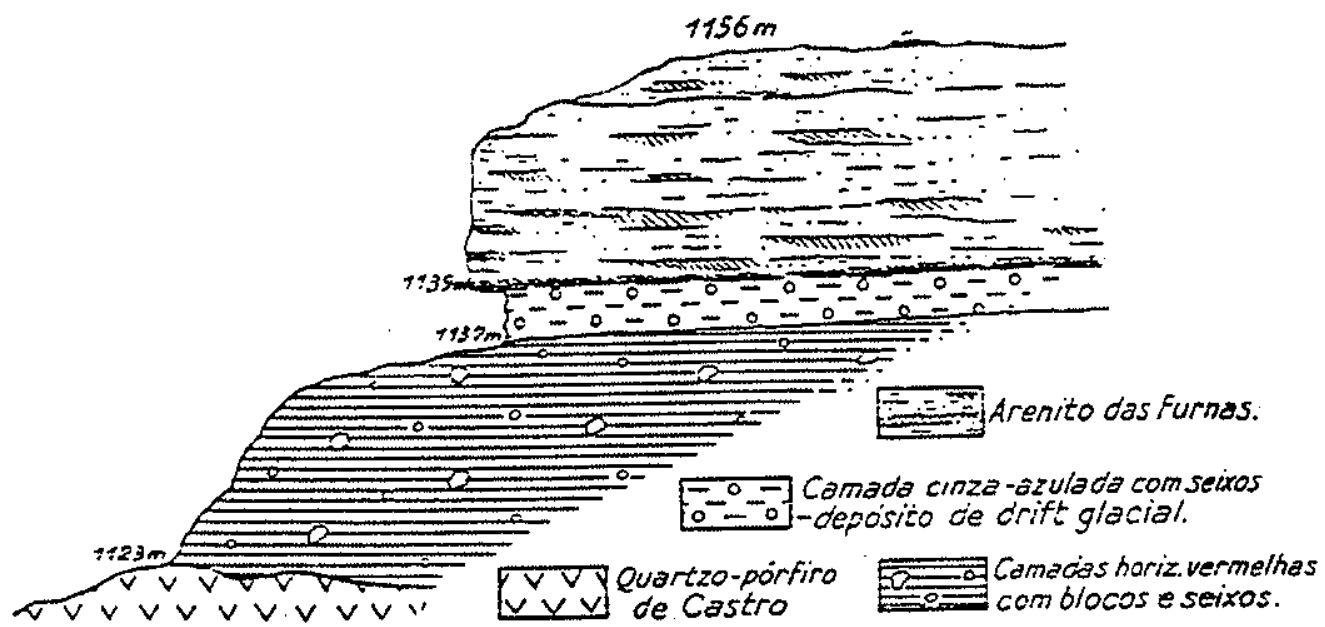

Figura 23 - Seção-tipo da Fm. lapó, conforme definida por Maack em 1947 (serra de São Joaquim; km16 da rodovia Castro-Tibagi; ponto 71; localização: Fig. 7).

A presença da unidade na faixa de afloramentos no Estado do Mato Grosso do Sul (Fig. 17) indica que sua distribuição geográfica é bastante extensa, abrangendo a maior parte da bacia. Possivelmente sua não constatação em muitos outros poços tenha sido conseqüência de: a) pouca atenção dada à unidade, já que não era prevista nos prospectos dos poços; b) identificação dos diamictitos em amostras de calha dificultada devido à sua pequena espessura e tipo de amostragem; c) diamictitos descritos nos intervalos correspondentes ao seu nivel estratigráfico foram 
considerados desabados das paredes, provindos da seção sedimentar do Gr. Itararé atravessada pelos poços.

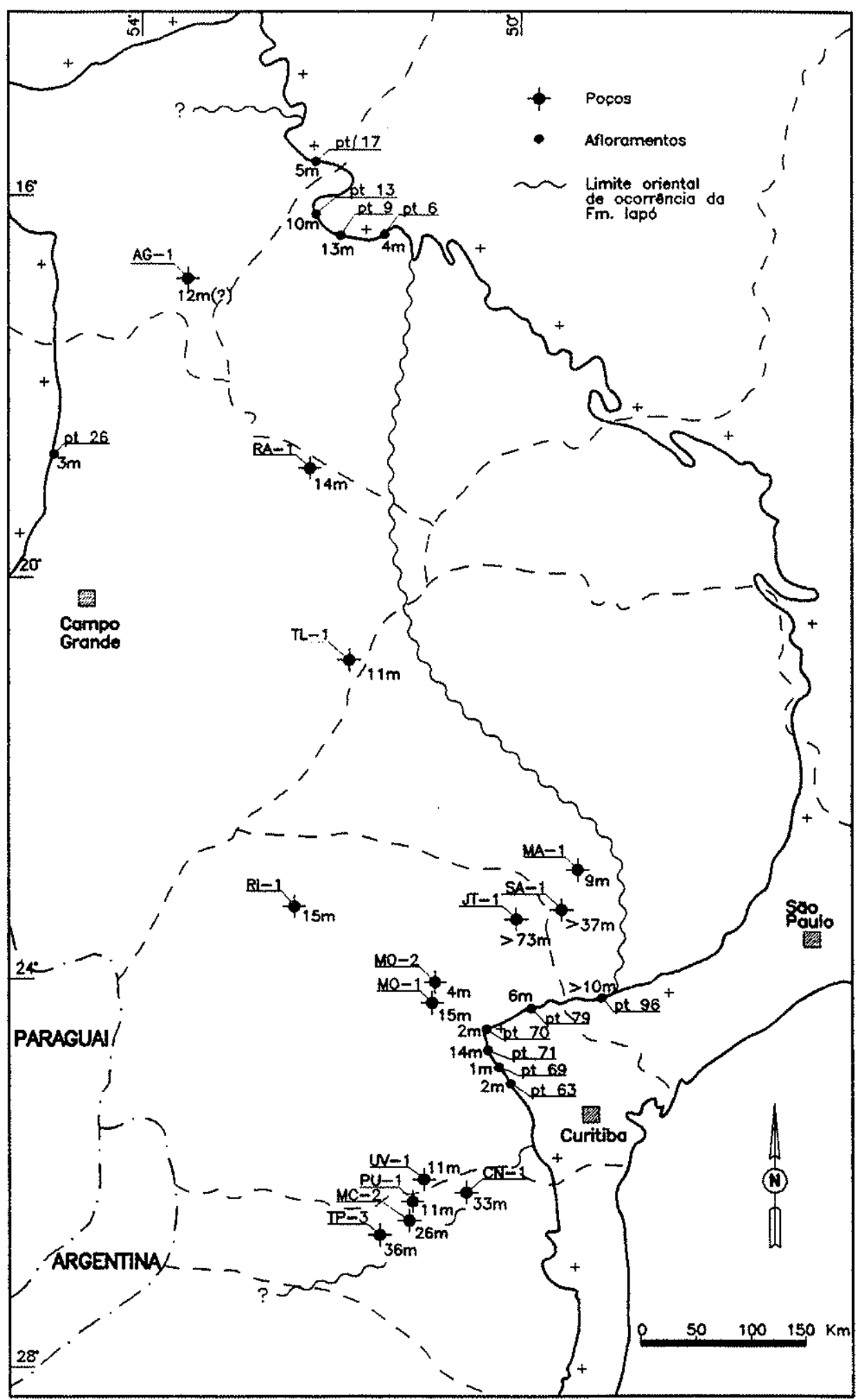

Figura 24 - Ocorrências da Fm. lapó em afloramentos e poços, com indicação das respectivas espessuras em metros. 
Um aspecto notável, já que a unidade tem ocorrência geográfica ampla, é sua pequena espessura, normalmente menor que 20m (Fig. 24). Uma espessura anômala foi verificada no poço 2-JT-1-PR (Joaquim Távora), que atravessou $73 \mathrm{~m}$ de diamictitos sem ter atingido a base da unidade.

Nos estados do Paraná e Goiás, a Fm. lapó freqüentemente assenta-se em discordância litológica sobre rochas do embasamento cristalino pré-cambriano/ eopaleozóico. Quando sobrepõe os arenitos da Fm. Alto Garças, contatos abruptos marcam uma descontinuidade faciológica. Em alguns afloramentos, como no ponto 26, é nítido o caráter erosivo dos diamictitos e conglomerados da Fm. lapó sobre os arenitos finos da Fm. Alto Garças.

Quando completo, o empilhamento estratigráfico é caracterizado por um conjunto de fácies (Fig. 25), que se apresenta numa seqüência vertical repetitiva na maior parte das seções descritas. $\mathrm{Na}$ base, justapostos lateralmente, ocorrem diamictitos maciços (fácies Dmm), que locamente mostram feições de cisalhamento, conglomerados (fácies $\mathrm{Gg}$ e $\mathrm{Gm}$ ) e, subordinadamente diamictitos gradados (Dmg). Arenitos grossos a conglomeráticos, maciços (fácies $\mathrm{Sm}$ ) ou com estratificações cruzadas planar (fácies Sp) e acanalada (fácies St), apresentam-se aleatoriamente sob a forma de canais irregulares, truncando erosivamente as fácies subjacentes. Em algumas seções verificou-se a presença de formas canalizadas na base da Fm. lapó, preenchidas por diamictitos e conglomerados (Fig. 25-G/H). Para o topo, comparecem diamictitos levemente estratificados (fácies Dms) e/ou arenitos com ondulações de corrente (fácies Sr). Quando a seção é completa, a sucessão vertical culmina com a presença de lamitos com seixos pingados (fácies Fld), alguns com evidências de ritmicidade.

Deposição subaquosa foi interpretada para as fácies $\mathrm{Dms}, \mathrm{Sr}$ e Fld. A presença de seixos pingados (fácies Fld) caracteriza a presença de material transportado por gelo flutuante (ice-rafts), indicando que se tratam de sedimentos glaciogênicos ou glacialmente influenciados. Deposição marinha é comprovada pela presença de macrofósseis (orbiculoideas e archeogastrópodes), observados na seção do Conjunto Residencial Araguaia em Barra do Garças (Figs. 15 e 22-L, ponto 17).

Os diamictitos maciços (fácies $\mathrm{Dmm}$ ) são cinza arroxeados a marrom avermelhados, apresentam matriz síltico-arenosa e base erosiva, sendo texturalmente heterogêneos (grânulos a matacões), litologicamente polimíticos. Os clastos apresentam evidências de abrasão glacial, sendo subangulosos a subarredondados, facetados, muitos com forma de bala (bullet-shaped clasts) e alguns estriados. Por estas características faciológicas, pela pequena espessura e ocorrência descontínua, 
A -

ponto 71

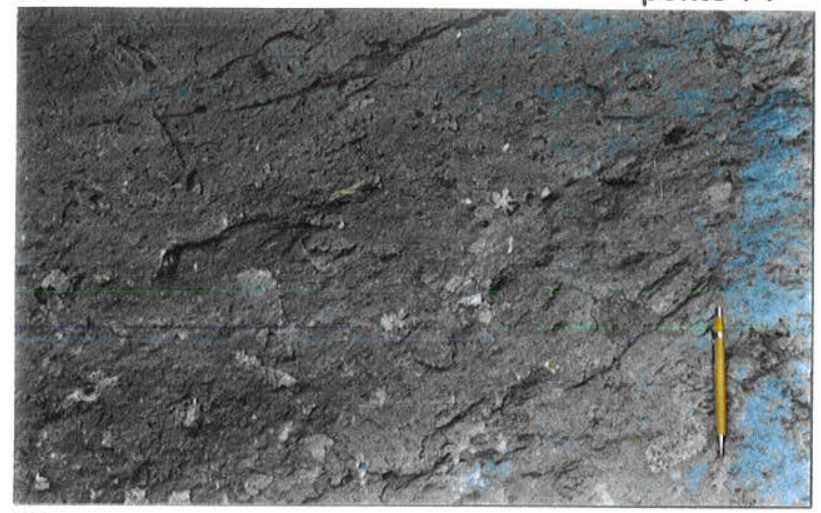

C.

ponto 6

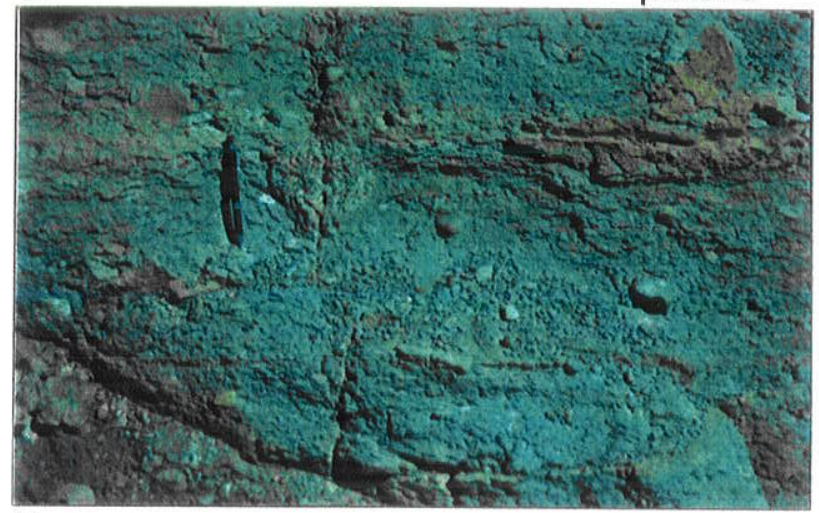

E -

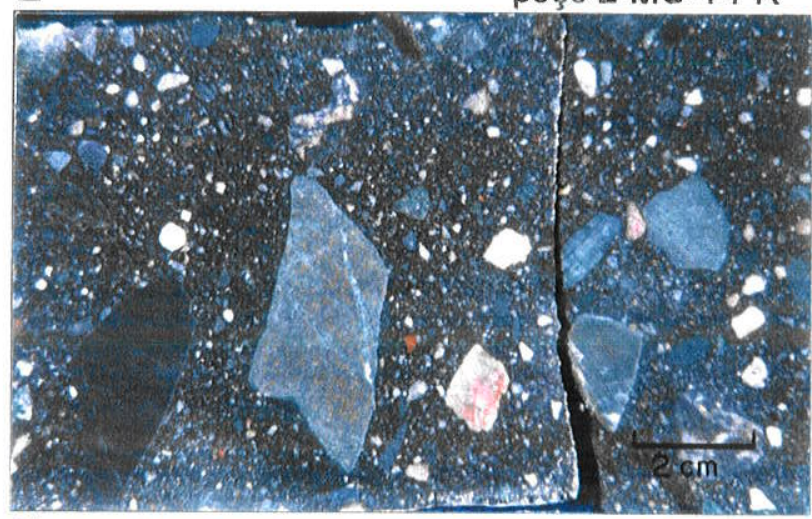

G -

ponto 17

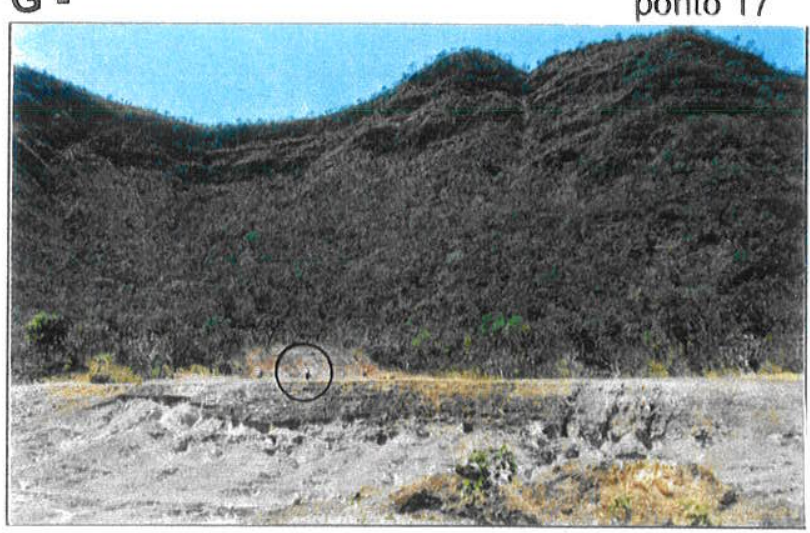

B -

ponto 96

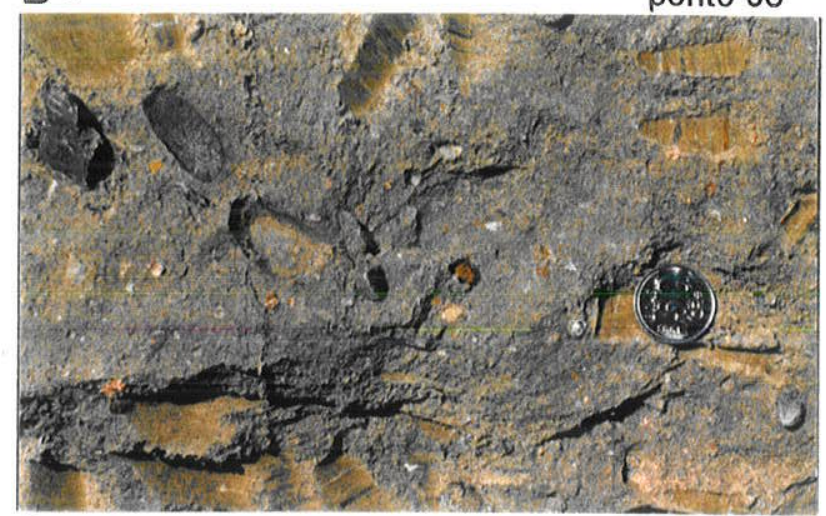

D -

ponto 13

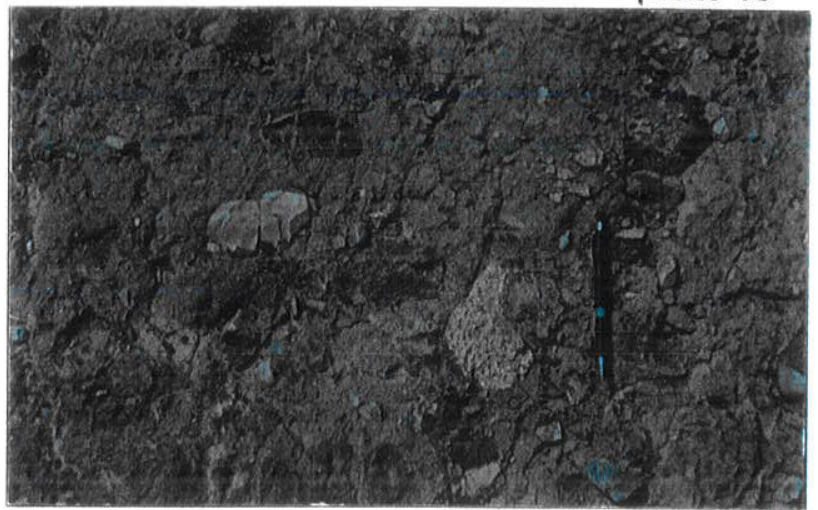

F .

poço 2-PU-1-PR

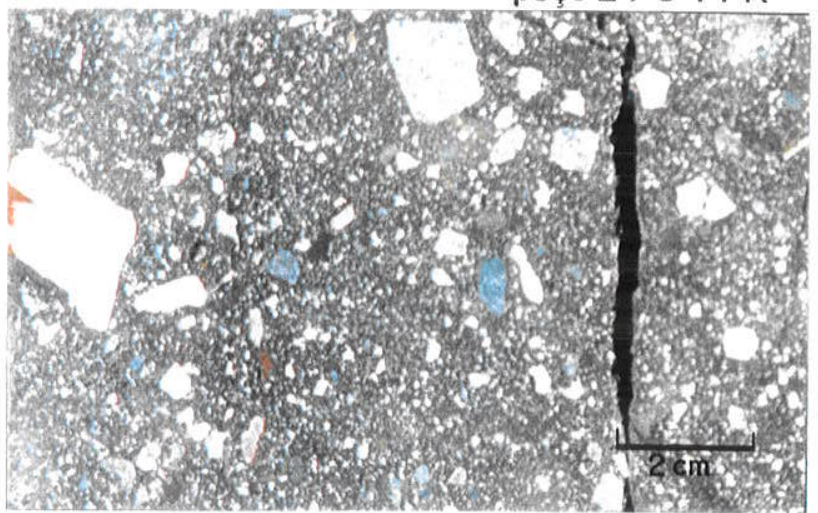

$\mathrm{H}$ -

ponto 8

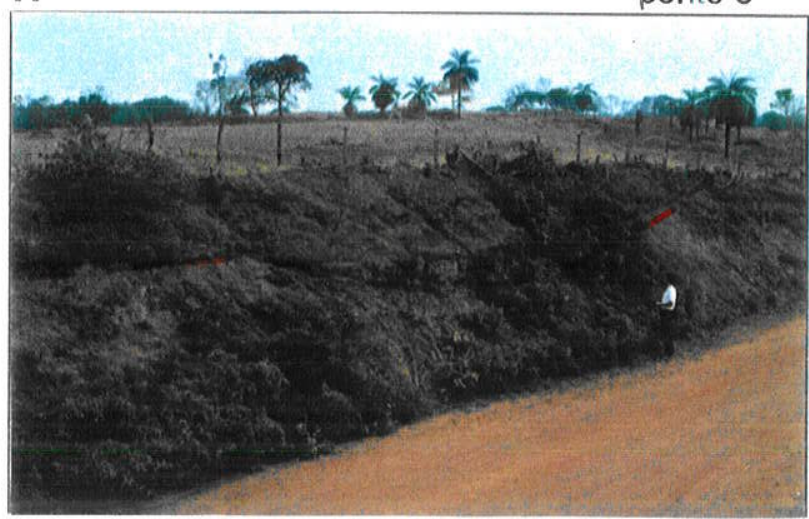

Figura 25 - Fácies da Fm. lapó. Diamictitos maciços (fácies Dmm), similares e na mesma posição estratigráfica, ocorrem nos flancos sudeste, norte e noroeste (A/B/C/D), e em vários poços no interior da bacia (E/F). Intercalados ocorrem conglomerados e arenitos com geometria lenticular e base erosiva ( $\mathbf{G}=$ arenitos com base em forma de canal em primeiro plano; Fm. Vila Maria ao fundo, tendo uma pessoa como escala; escarpa corresponde à Fm. Furnas). Feições erosivas canalizadas podem estar presentes na discordância com o embasamento pré-cambriano/eopaleozóico $(\mathbf{H})$. 

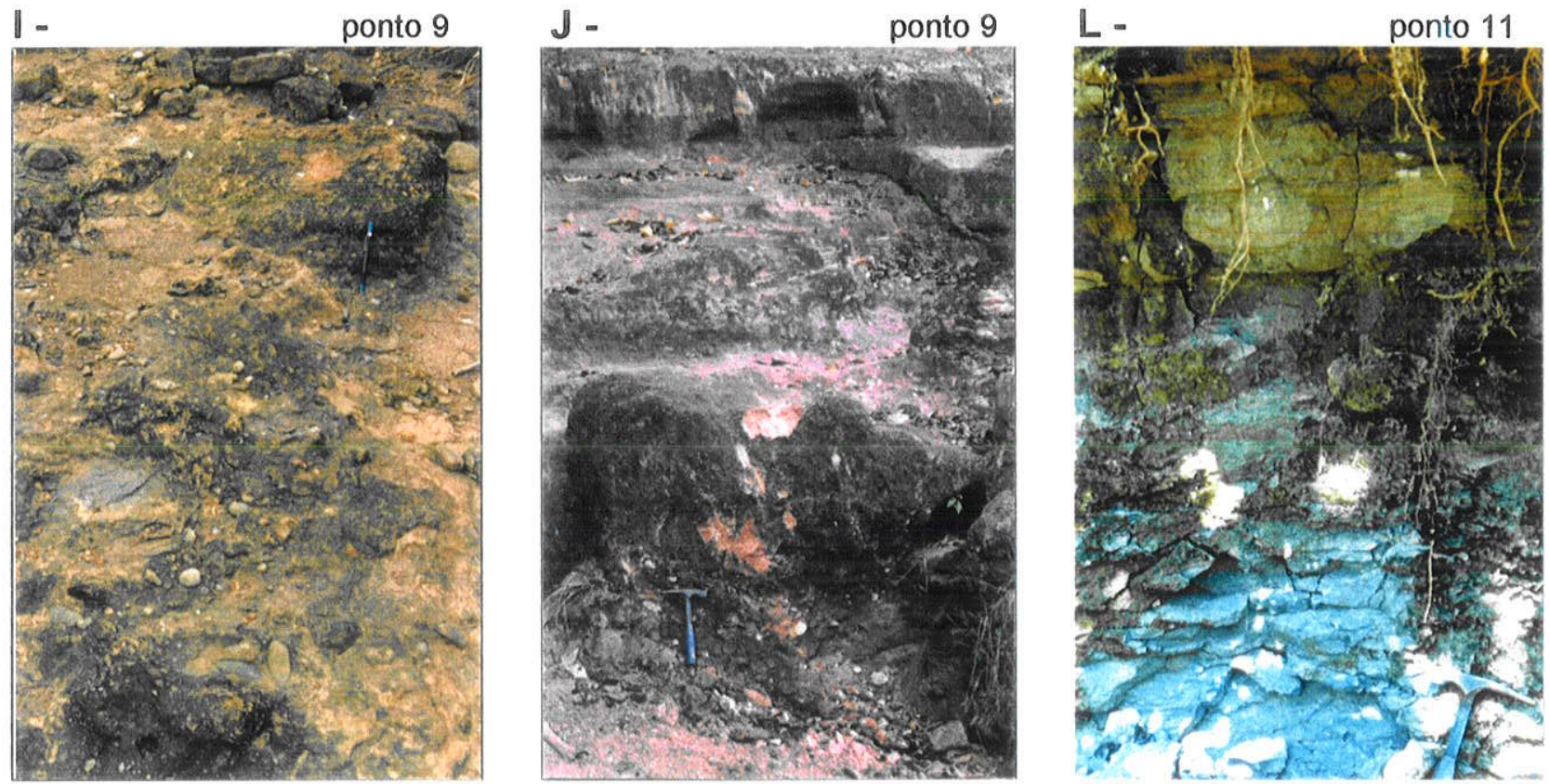

$\mathbf{M}=$

ponto 26

$\mathrm{N}$ -

ponto 6
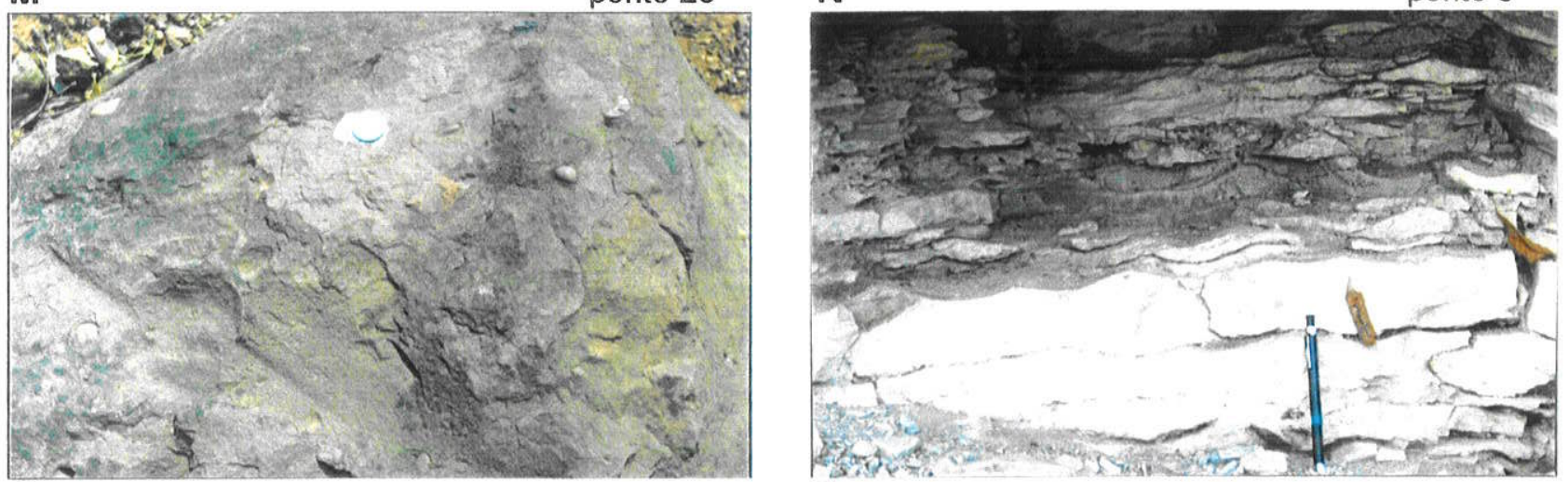

O -

ponto 26

$\mathrm{P}=$

ponto 11
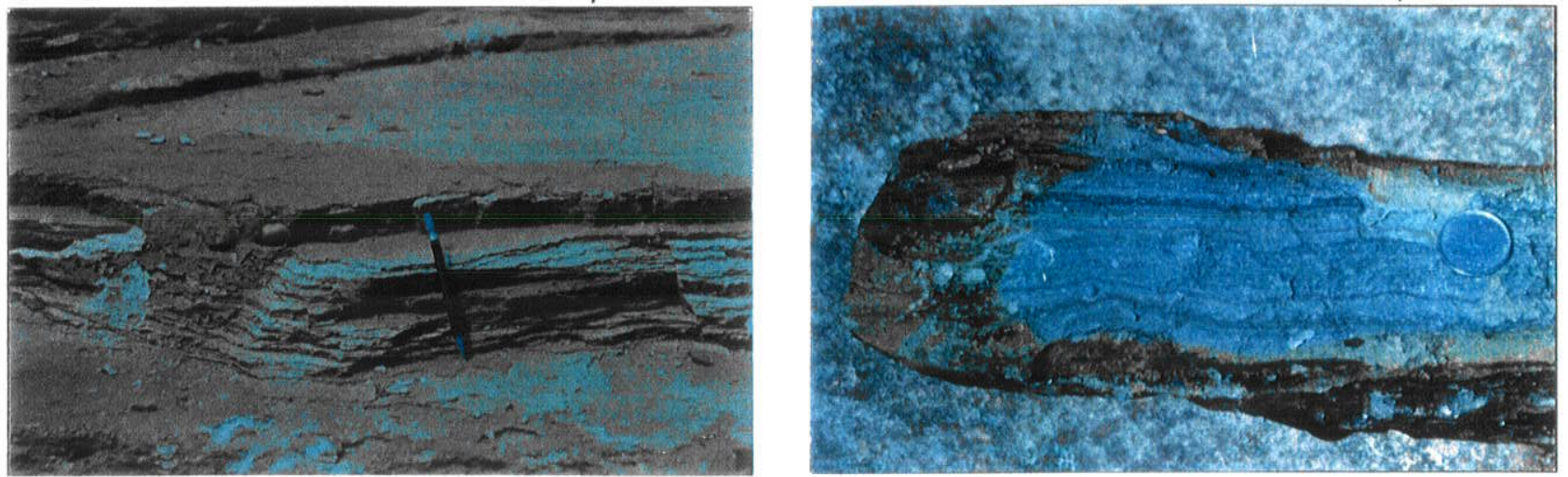

Figura 25 - Fácies da Fm. lapó (continuação). Matacões graníticos ocasionais foram observados nos diamictitos $(\mathbf{I} / \mathbf{J})$. A associação de diamictitos maciços de matriz síltico-arenosa, arenitos e conglomerados pode ser sobreposta por diamictitos estratificados da fácies Dms (L), diamictitos argilosos maciços $(\mathrm{M})$ e arenitos com ondulações de corrente da fácies $\mathrm{Sr}(\mathrm{N})$. Quando a seqüência está completa, no topo ocorrem fácies Fld (pelitos laminados com seixos pingados) (0), fácies estas que podem apresentar ritmicidade $(\mathbf{P})$. 
por assentarem-se diretamente sobre o embasamento e serem sobrepostos por fácies subaquosas glacialmente influenciadas, são interpretados como depósitos subglaciais, como já o fizeram anteriormente Pereira (1992) e Assine \& Soares (1993).

Ambientes subglaciais são pela sua própria natureza extremamente complexos, havendo diversidade muito grande de processos e fácies sedimentares. Por isso são ainda muito pouco compreendidos. Neste aspecto, a íntima associação dos diamictitos maciços (fácies $\mathrm{Dmm}$ ) com conglomerados (fácies $\mathrm{Gm}$ ), arenitos maciços (fácies $\mathrm{Sm}$ ) e arenitos com estruturas trativas indicativas de fluxo em meio aquoso (fácies $\mathrm{Sp}$ ), sugere geleiras de base úmida.

Segundo Maack (1950-51, p. 204), "a mistura heterogênea do material estranho ao país e impelido de longe (quartzitos coloridos, gnaisses e granitos) juntamente com rochas das vizinhanças (quartzo-pórfiros, filitos e itabiritos), o tipo de sedimentação e a composição da matriz, a forma oval, sub-angular dos blocos impelidos, facetados e estriados, e seu modo de distribuição na matriz, não admitem uma explicação dos depósitos como sendo talus".

A existência de afloramentos isolados e a não constatação da unidade em muitos poços não se devem apenas a problemas de exposição e/ou de identificação, mas também à natureza descontínua dos diamictitos. A descontinuidade das ocorrências é uma característica de depósitos subglaciais, como se depreende dos exemplos do Quaternário (Fig. 26).

Considerando a grande extensão areal da unidade, a espessura pequena (no geral menor que $20 \mathrm{~m}$ ), o empilhamento numa seqüência lógica e predizivel, a presença de clastos de variadas composições, inclusive de tipos litológicos não constatados no embasamento adjacente, interpreta-se, com base nos critérios de Visser (1989), uma glaciação continental ou de plataforma (shelf glaciation), em oposição à glaciação de altitude (mountain glaciation).

Os diamictitos da Fm. lapó são sobrepostos pelos folhelhos transgressivos da Fm. Vila Maria, cuja idade llandoveriana inferior foi determinada por Gray et al. (1985) a partir do estudo de esporos de plantas terrestres, acritarcas e prasinófitas. Este fato indica que a idade da Fm. lapó é, no máximo, eollandoveriana.

\section{3- FORMAÇÃO VILA MARIA}

Definida originalmente por Faria (1982) no Estado de Goiás, a Fm. Vila Maria englobava todo o conjunto sedimentar situado abaixo da Fm. Furnas e acima das rochas pré-cambrianas/ eopaleozóicas. O referido autor caracterizou três seqüências 
litológicas: a) basal (diamictitos polimíticos, com ocasionais intercalações delgadas de folhelhos e arenitos); b) intermediária (folhelhos fossiliferos); c) superior (arenitos com intercalações de siltitos).
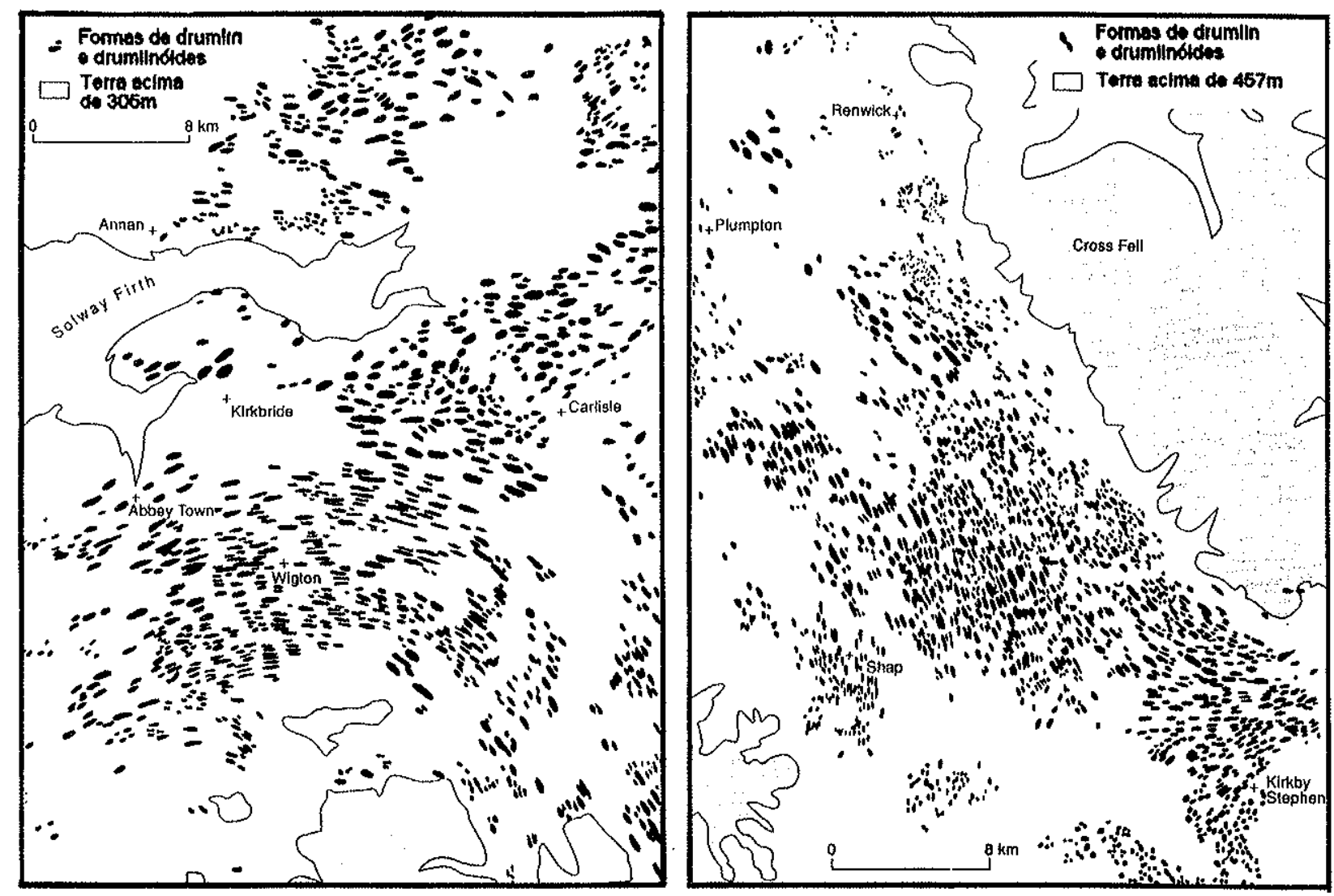

Figura 26 - Exemplos do Quaternário mostrando que as fácies subglaciais apresentam descontinuidade geográfica, pois formam elevações isoladas e paralelas ao movimento das geleiras (Smalley \& Warburton 1994)

Assine et al. (1994) propuseram a subtração da seção basal, constituída por diamictitos e fácies associadas, por considerarem-na a expressão da Fm. lapó no flanco norte da bacia (Fig. 27). A Fm. Vila Maria, assim redefinida, inicia-se com uma seção de folheihos (fácies $\mathrm{FI}$ ), que apresentam colorações geralmente vermelhas, com ocorrências locais de cor cinza escura (Fig. 28). Em direção ao topo, intercalações de arenitos muito finos dão origem à fácies heterolíticas (fácies $H$; Fig. 28-B/C), caracterizadas pela interestratificação de delgadas camadas de arenitos muito finos retrabalhos por ondas e de siltitos argilosos com abundantes marcas de onda simétricas. $\mathrm{Na}$ parte superior predominam arenitos muito finos a finos, com 
estratificação cruzada hummocky (fácies Shc; Fig. 28-D), ocorrendo subordinadamente arenitos com estratificação cruzada planar (fácies $\mathrm{Sp}$ ).

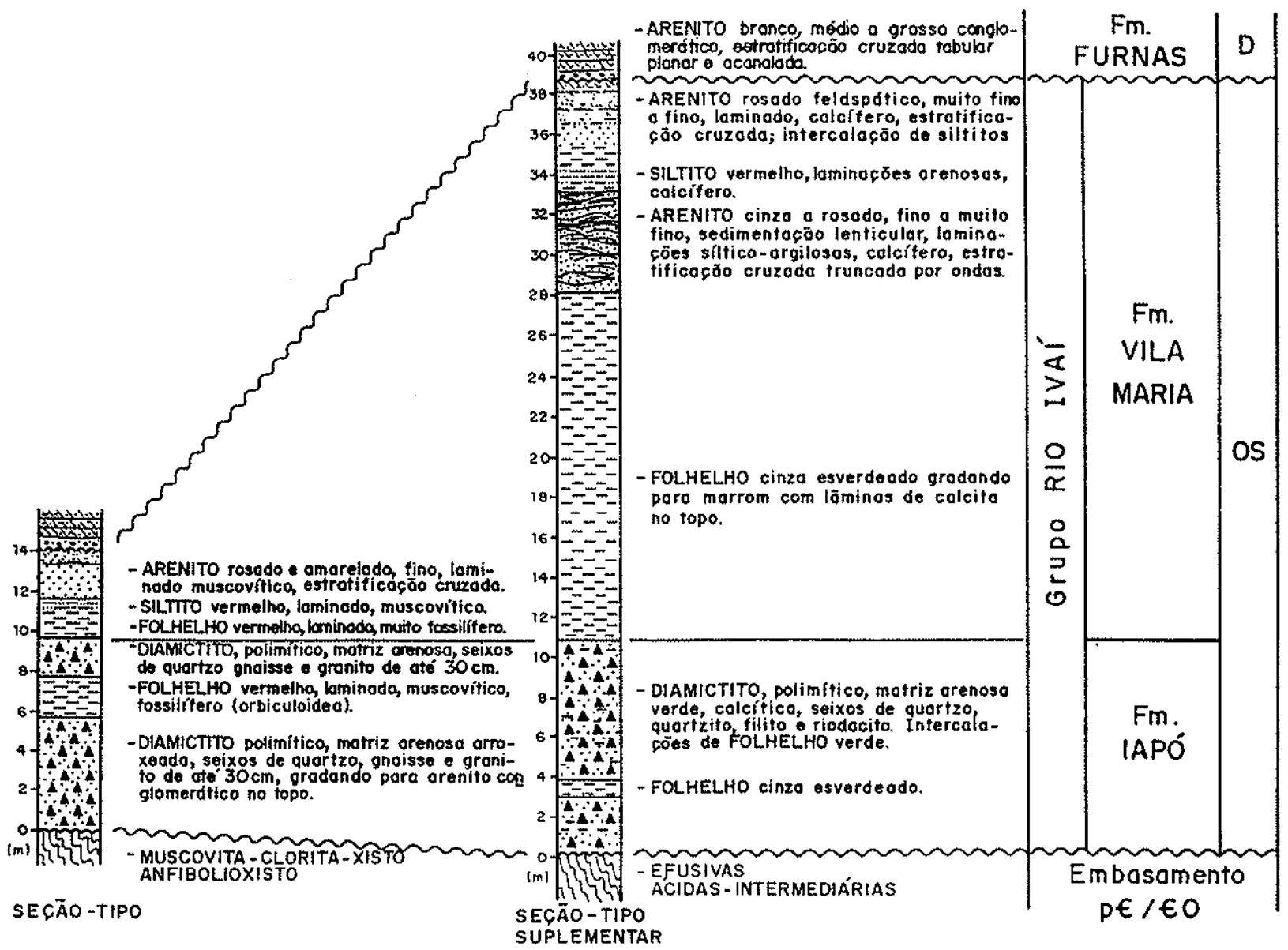

Figura 27 - Fm. Vila Maria, conforme redefinida por Assine et al. (1994), com base na seção-tipo (fazenda Três Barras) e seção-tipo suplementar (córrego da Aldeia), levantadas por Faria (1982) a sul de Bom Jardim de Goiás (GO). A seção basal de diamictitos foi considerada pertencente à $\mathrm{Fm}$. lapó, ficando a Fm. Vila Maria restrita aos folhelhos e arenitos do topo da seqüência.

Origem marinha para a Fm. Vila Maria é atestada pela presença de variados tipos de invertebrados (pelecípodos, gastrópodos e braquiópodos inarticulados), descritos por Popp et al. (1981), e acritarcas (Gray et al. 1985).

O empilhamento de fácies mostra progressiva diminuição da lâmina d'água no sentido do topo da unidade, de folhelhos de plataforma externa (costa-afora = offshore), depositados abaixo do nível das ondas de tempestade, até arenitos de 
plataforma interna rasa dominada por ondas (Fig. 29). Neste contexto, as fácies heterolíticas representam os depósitos da zona de transição para costa-afora, caracterizando-se pela alternância de lamitos decantados em periodos de bom tempo e arenitos depositados em eventos episódicos, relacionados a tempestades. A existência de arenitos com estratificação cruzada de alto ângulo, relativamente ao baixo ângulo da estratificação cruzada hummocky, indica retrabalhamento por processos marinhos rasos (correntes de deriva litorânea, correntes de maré, geostróficas) que operam continuamente nos periodos de bom tempo.

Durante os períodos de bom tempo, com taxa de sedimentação baixa em condições de submaré, diversos organismos transitaram pelo fundo lamoso, produzindo pistas horizontais de deslocamento e/ou alimentação da icnofácies Cruziana. Os niveis onde se encontram as pistas são planares e muito bem definidos, no contato do topo dos lamitos com a base dos arenitos. Dentre os icnogêneros presentes, predominam amplamente as pistas articuladas do icnogênero Arthrophycus, observadas em diversos afloramentos (Figs. 13, 14, 15 e 18). Constituem tanto formas em hiper-relevo côncavo sobre os siltitos laminados, como formas em hipo-relevo convexo, na base das barras arenosas retrabalhadas por ondas, situação em que é mais facilmente encontrada (Fig. 28-E/F/G/H). Segundo Burjack \& Pop (1981), apresentam diâmetros de 1,5 a $6,0 \mathrm{~cm}$ e padrão linear, levemente sinuoso.

Nas seções descritas foram constatados até três níveis principais com Arthrophycus, assim definidos dada a sua extensão lateral, boa preservação e alta densidade de pistas por metro quadrado. Representam paradas termporárias na sedimentação, quando o fundo foi palco de intenso trânsito de invertebrados de corpo mole. A boa preservação das pistas deve-se ao fato de que, na zona de transição para costa-afora, somente as grandes ondas de tempestade têm potencial para escavar o fundo. O papel das tempestades dá-se principalmente no transporte e deposição rápida de areias, carreadas das plataformas rasas por correntes de fundo dirigidas para costa-afora.

Faria (1982) descreveu gretas de contração na parte superior da Fm. Vila Maria, o que indicaria ambientes de intermaré, com exposição periódica. As fendas são descontínuas, não formando polígonos, e a elas estão associados traços do icnogênero Arthrophycus (Fig. 28-H), sugestivo de não-exposição. Alternativamente vêm sendo interpretadas como gretas de sinerese (Carlos Alvarenga, inform. pessoal), cuja formação não implica exposição periódica. 

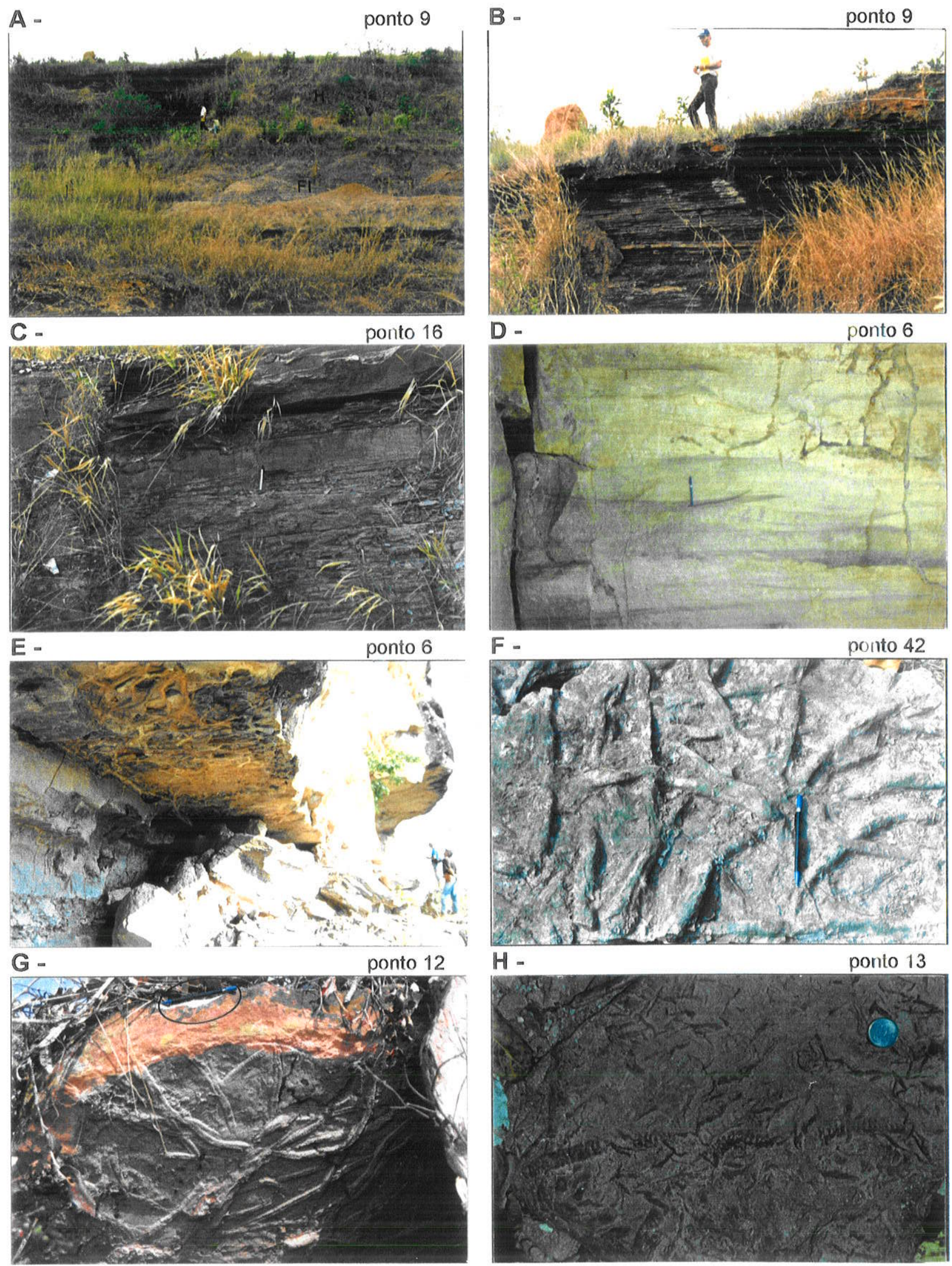

$\mathrm{H}$ -

ponto 13

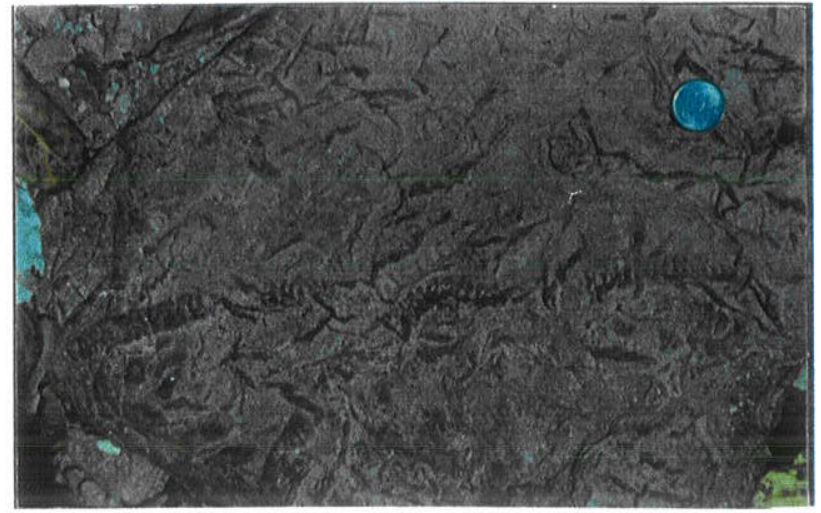

Figura 28 - Fácies da Fm. Vila Maria.

Seqüência vertical de fácies, que apresenta granocrescência e espessamento dos corpos arenosos em direção ao topo, de folhelhos $\mathrm{FI}$ avermelhados na base (A) para fácies heterolíticas $H$ (B). As fácies heterolíticas apresentam marcas onduladas simétricas e laminação com truncamentos de baixo ângulo, produzidos por ondas (C). No topo predominam arenitos com estratificação cruzada hummocky (D). Nas fácies heterolíticas ocorrem extensos níveis com traços fósseis, predominantemente do icnonogênero Arthrophycus (E/F/G/H). 


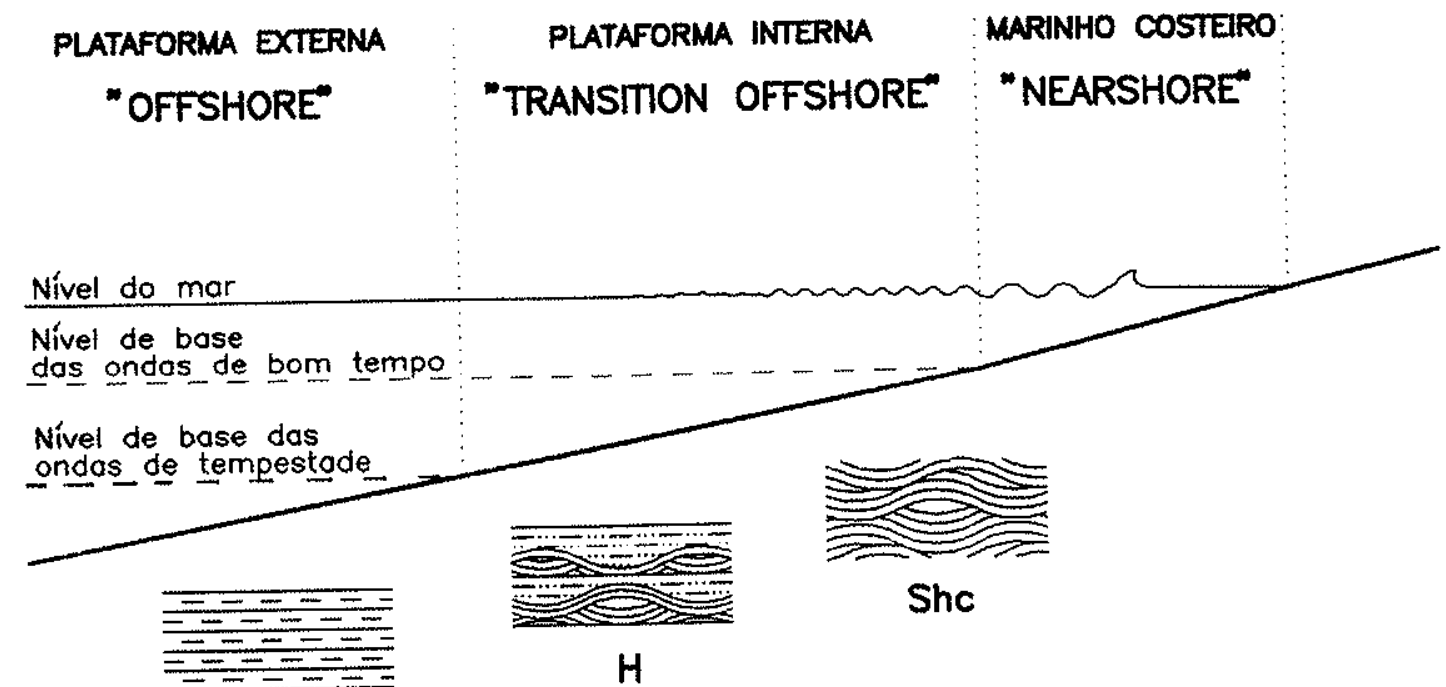

$\mathrm{FI}$

Figura 29 - Paleoambiente deposicional da Fm. Vila Maria

\section{4- ESTRATIGRAFIA DE SEQÜÊNCIAS}

$\mathrm{O}$ arranjo de fácies mostra que o $\mathrm{Gr}$. Rio Ivaí constitui um grande ciclo transgressivo-regressivo, correspondente a uma seqüência tectono-sedimentar (no conceito de Sloss 1963) ou ciclo de $2^{\mathrm{a}}$ ordem. Comporta duas seqüências deposicionais (Fig. 30), com duração da ordem de 10 a $15 \mathrm{Ma}$ (ciclos de $3^{\mathrm{a}}$ ordem).

\subsection{1- Seqüência Caradociana - Ashgilliana}

A sedimentação teve início no Ordoviciano Superior com a deposição da seção psamítica da $\mathrm{Fm}$. Alto Garças. As idades atribuídas à seqüência são aproximadas e determinadas pela posição estratigráfica, já que não há datações diretas.

Os dados disponiveis sobre a $\mathrm{Fm}$. Alto Garças indicam rápida transgressão na parte inferior, dando origem a um trato de sistemas transgressivo (transgressive systems tract). Segue-lhe um trato de mar alto (highstand systems tract), que se manifesta nos perfis de raios-gama pelo padrão de deflexão à esquerda que caracteriza a unidade. A superfície de máxima inundação foi posicionada com alto 
grau de inferência, uma vez que a unidade é essencialmente psamítica e os perfis não mostram picos de argilosidade correlacionáveis de poço para poço.

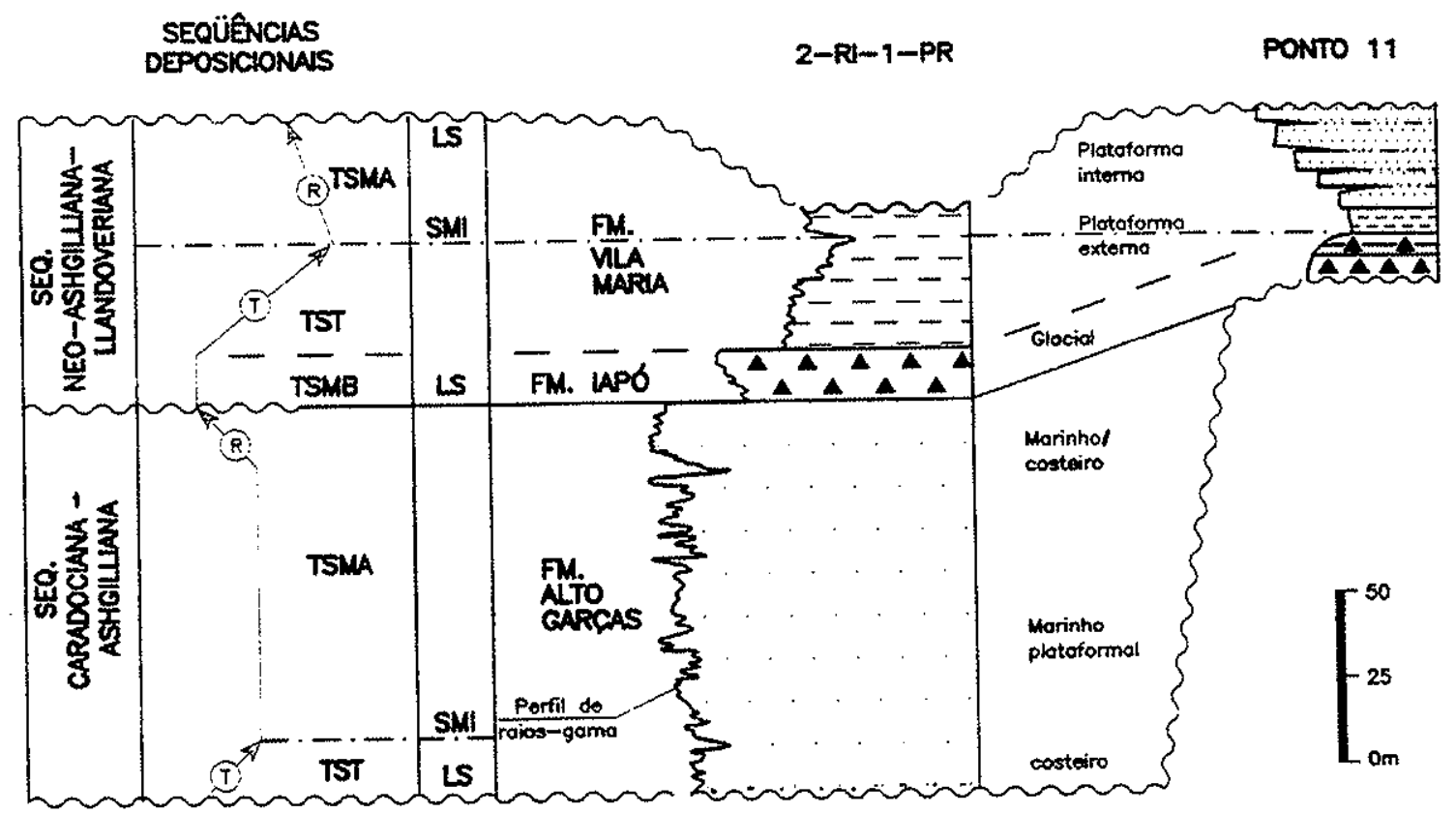

Figura 30 - Seqüências e tratos deposicionais no Ordoviciano Superior/Siluriano Inferior da Bacia do Paraná ( $T=$ transgressão; $R=$ regressão; $L S=$ limite de seqüência; $\quad \mathrm{SMI}=$ superfície de máxima inundação; $\mathrm{TST}=$ trato de sistemas transgressivo; TSMA = trato de sistemas de mar alto; TSMB = trato de sistemas de mar baixo; 2-RI-1-PR = poço Rio Ivaí; ponto 11 = cachoeira das Perdizes, sudeste de Baliza-GO).

O acunhamento para leste e o padrão de paleocorrentes da Fm. Alto Garças e do Gr. Caacupé, dirigido quase que invariavelmente para oeste (Fig. 31), refletem onlap costeiro de oeste para leste, em direção às bordas originais da bacia (Fig. 2). Decorre disso a conclusão de que o adelgaçamento delineado no mapa de isópacas (Fig. 9, p. 33) reflete a geometria original da seqüência, e que as seções estratigráficas das figuras 19 e 20 (p. 46 e 47) foram construídas na direção do mergulho deposicional.

O limite superior da seqüência foi posicionado no contato entre arenitos costeiros/plataformais da Fm. Alto Garças e diamictitos superpostos da Fm. lapó. A descontinuidade deposicional foi gerada pela queda do nível de base no advento da glaciação lapó. Embora haja mudança faciológica significativa, a descontinuidade não representa necessariamente grande lacuna no registro sedimentar, razão pela qual foi 
considerada de natureza diastêmica. O hiato de tempo pode ter sido de pequena duração ou, mesmo, geologicamente não significativo. Quando geleiras avançam por sobre plataformas continentais, a queda do nível do mar é compensada pelo rápido recobrimento dos sedimentos plataformais pelas geleiras e subsidência da área por glácio-isostasia. Como conseqüência, a passagem é marcada por contatos de diferentes naturezas, reflexo de posição paleogeográfica diversa. Contatos erosivos podem ter resultado de retrabalhamento marinho, erosão fluvial ou glacial.

$\mathrm{Em}$ alguns afloramentos no flanco norte da bacia, os arenitos da Fm. Alto Garças apresentam evidências de deformação penecontemporânea e fluidização. É possivel que tais feições tenham sido originadas pelo dinâmica das geleiras que se deslocaram sobre os arenitos marinhos ainda inconsolidados. Dúvidas ainda persistem quanto à associação genética entre arenitos com lentes conglomeráticas do topo da Fm. Alto Garças e diamictitos e conglomerados subglaciais da Fm. lapó. São necessários trabalhos mais detalhados para melhor esclarecer a questão.

\subsection{2 - Seqüiência Neo-Ashgilliana - Llandoveriana}

Como já referido anteriormente, a Fm. lapó assenta-se sobre unidades de diferentes idades, ora diretamente sobre o embasamento pré-cambriano/eopaleozóico, outras vezes em discordância angular sobre rochas do Ordoviciano Inferior, ou ainda sobre os arenitos neo-ordovicianos da Fm. Alto Garças. É recoberta por folhelhos eollandoverianos da Fm. Vila Maria. Estas relações permitem seu posicionamento no interregno Ordoviciano Superior/Siluriano Inferior.

Sua idade precisa, entretanto, não foi ainda estabelecida, em função da não constatação de macrofósseis diagnósticos e das amostras coletadas terem-se revelado palinologicamente estéreis. Em alguns afloramentos, existem depósitos residuais (lags) entre as formações lapó e Vila Maria, o que sugere retrabalhamento durante a transgressão e, possivelmente, um pequeno hiato entre as mesmas. A correlação com outras bacias gondwânicas (discutida no item 7.1.2) permite inferir uma

correspondência com a glaciação neo-ordoviciana, que teve seu máximo no Ashgilliano terminal (Hirnantiano).

Seu contato com as rochas subjacentes é marcado por uma descontinuidade associada à fase inicial da glaciação, quando houve uma queda eustática do nível do mar pelo acúmulo de gelo sobre o continente. Por isso, as fácies subglaciais, inicialmente formadas sobre o continente, podem ser consideradas o registro de um trato de sistemas de mar baixo (lowstand systems tract). 


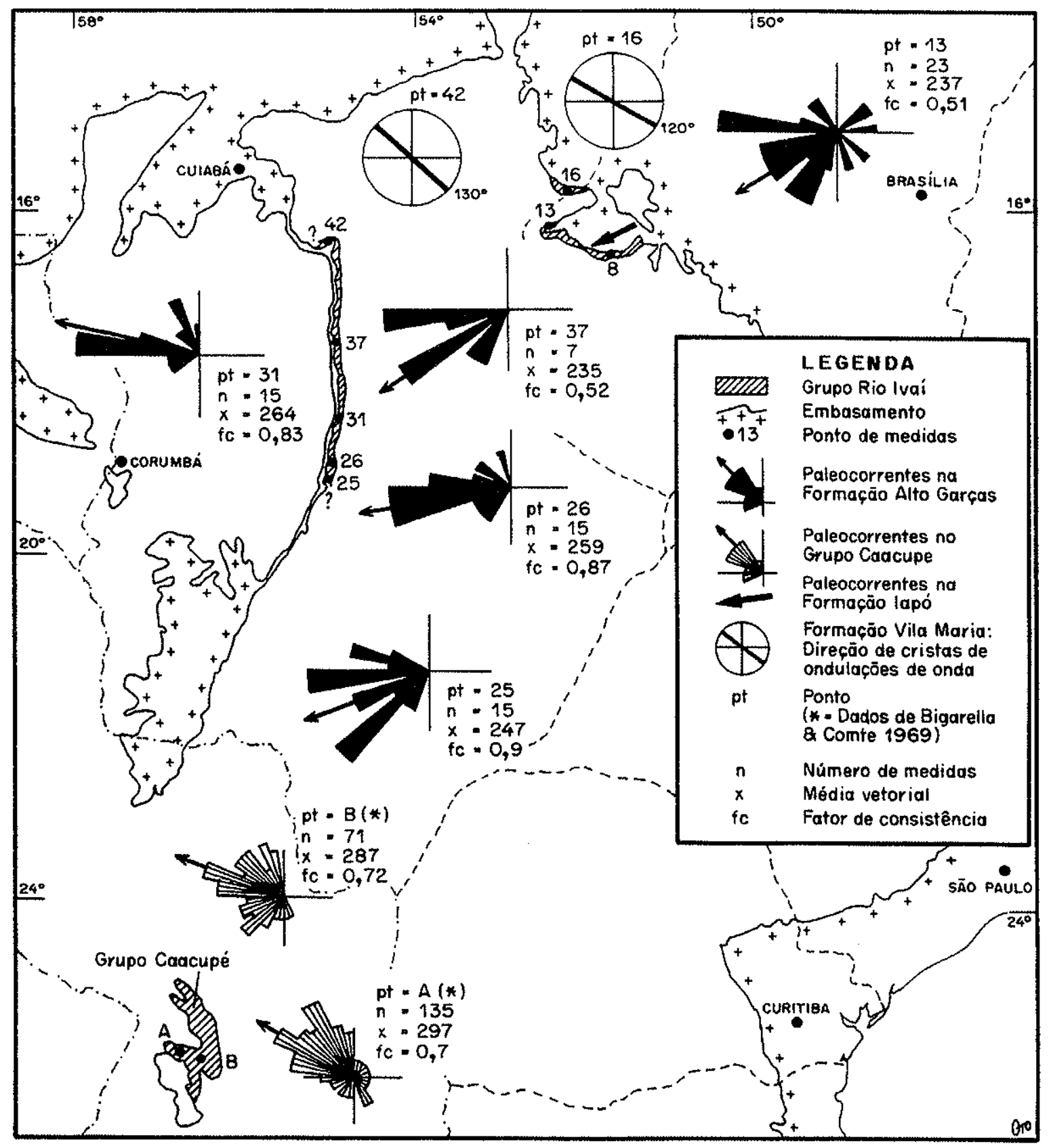

Figura 31 - Paleocorrentes nos grupos Rio Ivaí e Caacupé.

Segundo Eyles (1993), fácies subglaciais terrestres são pobremente preservadas no registro geológico e o principal papel das geleiras na história da Terra tem sido o suprimento de grandes volumes de sedimentos glaciclásticos para bacias sedimentares, onde são dispersos e ressedimentados por processos não-glaciais. Como, então, as fácies subglaciais teriam sido tão bem preservadas, já que sua 
espessura é pequena e o potencial de preservação de sedimentos glacio-terrestres é baixo, devido à erosão favorecida pelo soerguimento (rebound) após o recuo das geleiras?

O empilhamento estratigráfico e os modelos do Quaternário são a chave para a resposta. O recobrimento por fácies glácio-marinhas permite concluir que as geleiras avançaram por sobre sobre uma plataforma continental, onde anteriormente se processava a deposição dos arenitos também marinhos da Fm. Alto Garças. Fácies subglaciais formadas na base de geleiras que avançam sobre planícies costeiras e plataformas marinhas rasas são semelhantes às de geleiras sobre o continente (Boulton 1990), apresentando potencial muito maior de preservação, pois as chances de elevação acima do nível de base, pelo rebound glacio-isostático quando do recuo das geleiras, são menores. Além disso, a preservação é favorecida pela rápida transgressão eustática subseqüente.

A Fm. lapó apresenta pequena espessura, sem significativas recorrências de fácies. O registro estratigráfico aponta para um evento glacial singular e de grande magnitude. Os depósitos preservados representam sobretudo a fase final da glaciação, quando ocorreu o recuo das geleiras. Na escala do tempo geológico, podem ser considerados depósitos praticamente cronocorrelatos, constituindo um excelente marco estratigráfico. A utilização de depósitos glaciais como marcos estratigráficos não é nova. Alguns autores têm destacado o caráter time-transgressive dos depósitos subglaciais (Rust \& Romanelli, 1975; Barenjee \& McDonald 1985; Goldstein 1994).

A deglaciação deu ensejo a um delgado trato de sistemas transgressivo, cuja superfície de máxima inundação situa-se nos folhelhos pós-glaciais do Llandoveriano Inferior (Fm. Vila Maria). Evidências de retrabalhamento, dadas pela existência de delgadas camadas de conglomerados no contato com a Fm. lapó (ver Figs. 13 e 14), sugerem a formação de superfícies de ravinamento e lags transgressivos no início da transgressão.

Os folhelhos eollandoverianos da Fm. Vila Maria ocorrem numa grande extensão geográfica e são facilmente reconhecidos em perfis de poços. Constituem um marco estratigráfico de importância regional (marco síltico-radioativo de Zalán et al. 1987a), utilizado como datum em várias das seções estratigráficas apresentadas neste trabalho. Ao tempo da superfície de máxima inundação, os folhelhos marinhos llandoverianos da Fm. Vila Maria ultrapassaram os limites orientais da Formação Alto Garças, depositando-se diretamente sobre áreas pouco subsidentes. Isto é evidente quando se comparam o mapa de isópacas do $\mathrm{Gr}$. Rio Ivaí com o da Fm. Alto Garças (Figs. 9 e 21). 
O aumento da porcentagem de areia e o aparecimento de fácies costeiras em direção ao topo da Fm. Vila Maria indicam diminuição da lâmina d'água, o que caracteriza um empilhamento regressivo num trato de sistemas de mar alto (highstand tract system), conseqüência de uma taxa de aporte maior que o espaço para a acomodação dos sedimentos.

Medidas do eixo de ondulações simétricas produzidas por onda apontam para uma paleolinha de costa de direção WNW/ESE (Fig. 31), pelo menos na porção norte da bacia, o que grosso modo ajusta-se ao mergulho deposicional para WSW interpretado para a Fm. Alto Garças.

A sucessão dos eventos geológicos descritos pode ser explicada através da adaptação do modelo evolutivo de deposição glacial em plataformas continentais (Fig. 32) proposto por Bouton (1990). Dentre vários aspectos interessantes, destaca-se: 1) a regressão dá-se fundamentalmente no início do ciclo glacial; 2) durante o máximo glacial, quando o nível global do mar cai, nas plataformas periglaciais sujeitas ao avanço da calota polar o nível relativo do mar sobe; 3) a principal época de deposição dos tilitos é no final da glaciação com o recuo das geleiras; 4) o recuo das geleiras disponibiliza grande carga sedimentar, dando origem às fácies marinhas glacialmente influenciadas Dms e Fld; 5) a ausência de depósitos glaciais no Paraguai pode ser conseqüência de regressão por rebound glácio-isostático, que ocorre primeiro nas porções distais. 


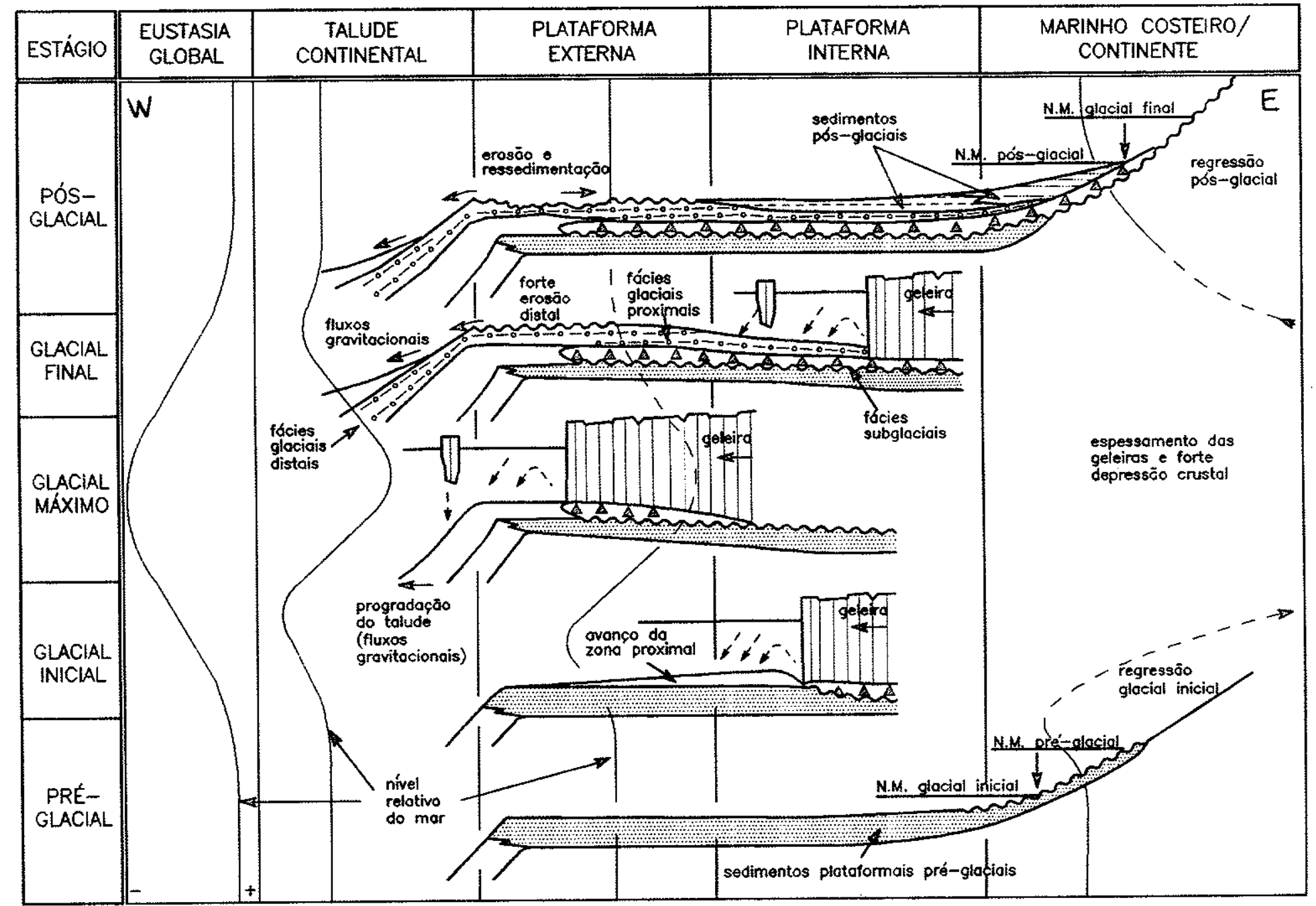

FÁCIES:

$\mathrm{Sp}, \mathrm{Sh}, \mathrm{Gm}$

बत्ब

Dmm, Gm, St, Sg Dms, Sr, Fld

FORMAÇĀO:

ALTO GARÇAS

IAPÓ

Fl, H Shc, Sp

Figura 32 - Interpretação esquemática da evolução geológica do Gr. Rio Ivaí

(figura adapatada do esquema de Boulton 1990; código de fácies = Tab. 5). 


\section{6- GRUPO PARANÁ}

Constituído, da base para o topo, pelas formações Furnas e Ponta Grossa, o Gr. Paraná atinge espessura máxima constatada de $818 \mathrm{~m}$ no poço 2-CA-1-PR (Cândido de Abreu), sem que o embasamento tivesse sido atingido (Fig. 33). No poço 2-AP-1PR (Apucarana) foi perfurado um total de $811 \mathrm{~m}$, estimando-se que faltaram ser perfurados cerca de $110 \mathrm{~m}$ da $\mathrm{Fm}$. Furnas, o que permite inferir uma espessura máxima de aproximadamente $920 \mathrm{~m}$.

Seu contato basal é discordante, sobre rochas de diferentes idades, de unidades pré-cambrianas/eopaleozóicas (Figs. 34 e 35) a ordovício-silurianas do Grupo Rio Ivaí (Fig. 12). A interface da discordância é uma notável superfície aplainada, já ressaltada por diversos autores, sendo rara a existência de paleossolos.

O topo é marcado por superfície de discordância erosiva com o Gr. Itararé. Contatos irregulares marcados por formas canalizadas têm sido mapeados em seções sísmicas por geofísicos da Petrobrás (Fig. 36). O contato discordante é sobremaneira evidente na faixa de afloramentos do flanco sudeste, em cujas extremidades o $\mathrm{Gr}$. Itararé assenta-se diretamente sobre a Fm. Furnas, sem a interveniência da Fm. Ponta Grossa. Seções geológicas evidenciam inclusive contato discordante com ligeira angularidade entre os grupos Paraná e Itararé (Fig. 37). A presença de palinomorfos de idade devoniana nos diamictitos e pelitos do Gr. Itararé (Pires et al. 1992) não deve causar espanto, pois é um fenômeno freqüente (França et al. 1994, Souza 1996). A existência de formas devonianas nos estratos basais do $\mathrm{Gr}$. Itararé deve-se à intensa erosão glacial de estratos devonianos, que foram rapidamente redepositados em ambientes glaciais, sem a destruição dos palinomorfos. Em alguns casos, blocos inteiros foram removidos e redepositados, do que resultou a preservação intacta de comunidades devonianas e formas sem evidências de retrabalhamento mecânico ou químico, fato que foi constatado em análise de amostra coletada no km 528,5 da BR376 (entre Curitiba e Ponta Grossa).

No flanco norte, em Goiás, a Fm. Ponta Grossa apresenta uma capa limonítica no seu topo, que é cortado erosivamente pela Fm. Aquidauana, inclusive com o desenvolvimento de conglomerado basal (DNPM 1975). Relações de contato discordantes são evidentes também no flanco noroeste, nas regiões da Serra da Petrovina e nas proximidades da cidade de Pedro Gomes, onde os estratos devonianos da Fm. Ponta Grossa, falhados e deformados por tectônica modificadora carbonífera, são sobrepostos por estratos suborizontais e menos deformados da Fm. Aquidauana (Gr. Itararé). 


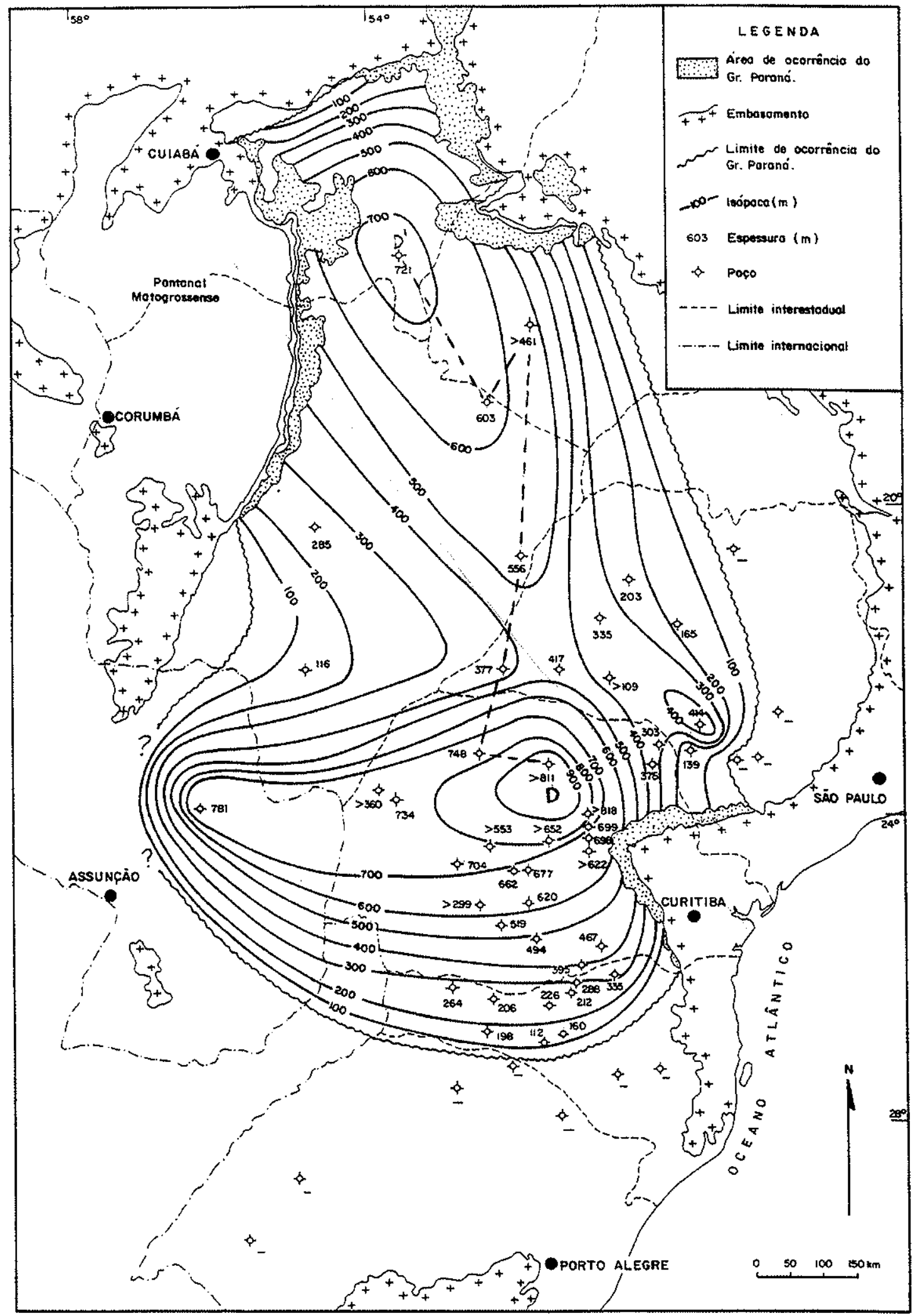

Figura 33 - Mapa de isópacas do Gr. Paraná. É nítida a compartimentação tectônica em duas sub-bacias: Alto-Garças (norte) e Apucarana (sul), separadas por um alto de direção aproximada $\mathrm{EW}$. O grau de inferência no limite sudoeste é alto, pois as unidades não afloram e as informações de subsuperficie são muito restritas. 

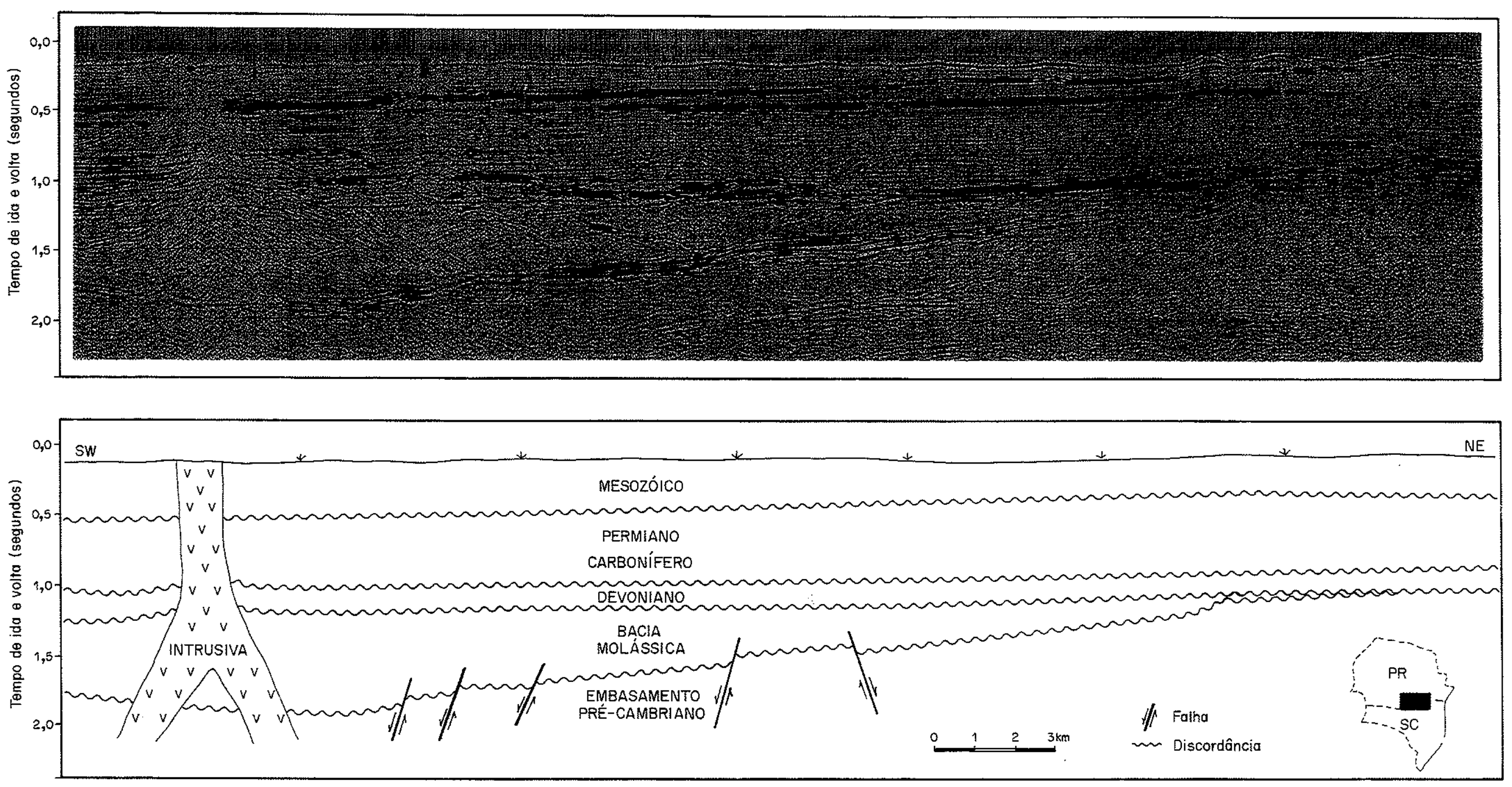

Figura 34 - Seção sismica de reflexão mostrando a discordância angular entre a Fm. Furnas e estratos de uma bacia molássica (eopaleozóica?). 
$\mathbb{A}=$

ponto 47

B ponto 93
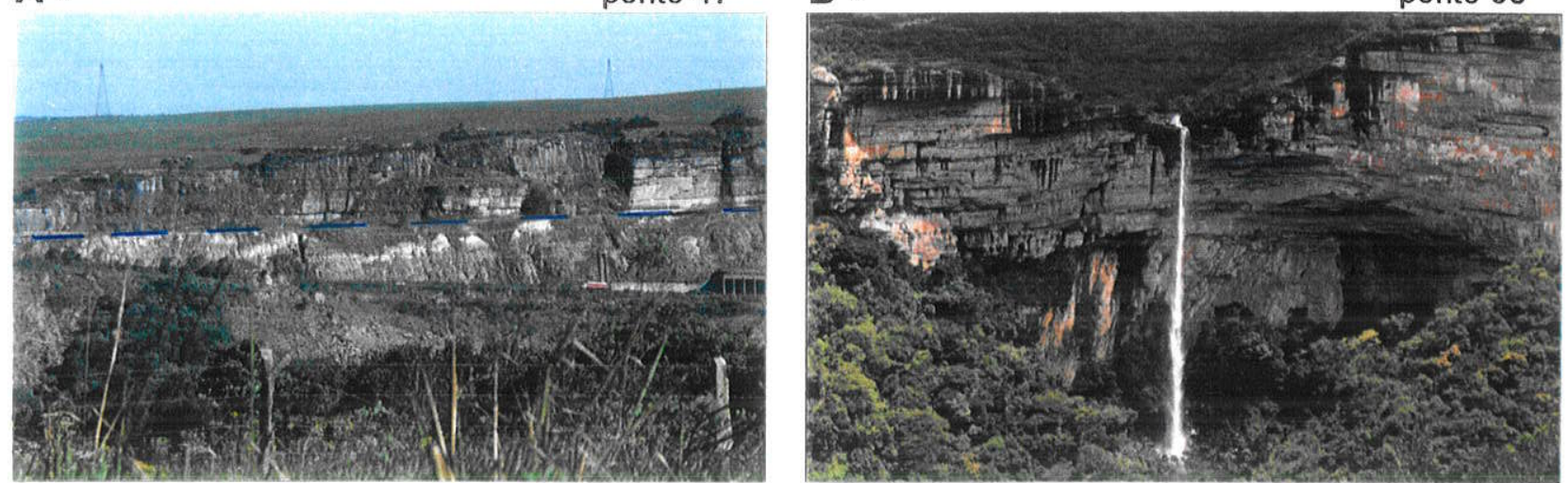

Figura 35 - Discordâncias angulares entre a Fm. Furnas e unidades do embasamento précambriano/eopaleozóico. Destaca-se a superfície aplainada que define o contato, tanto sobre rochas sedimentares eopaleozóicas da Fm. Camarinha, entre Curitiba e Ponta Grossa-PR (A), quanto sobre rochas metamórficas pré-cambrianas do Cinturão de Dobramentos Ribeira, na cachoeira do Corisco, em Sengés-PR (B).

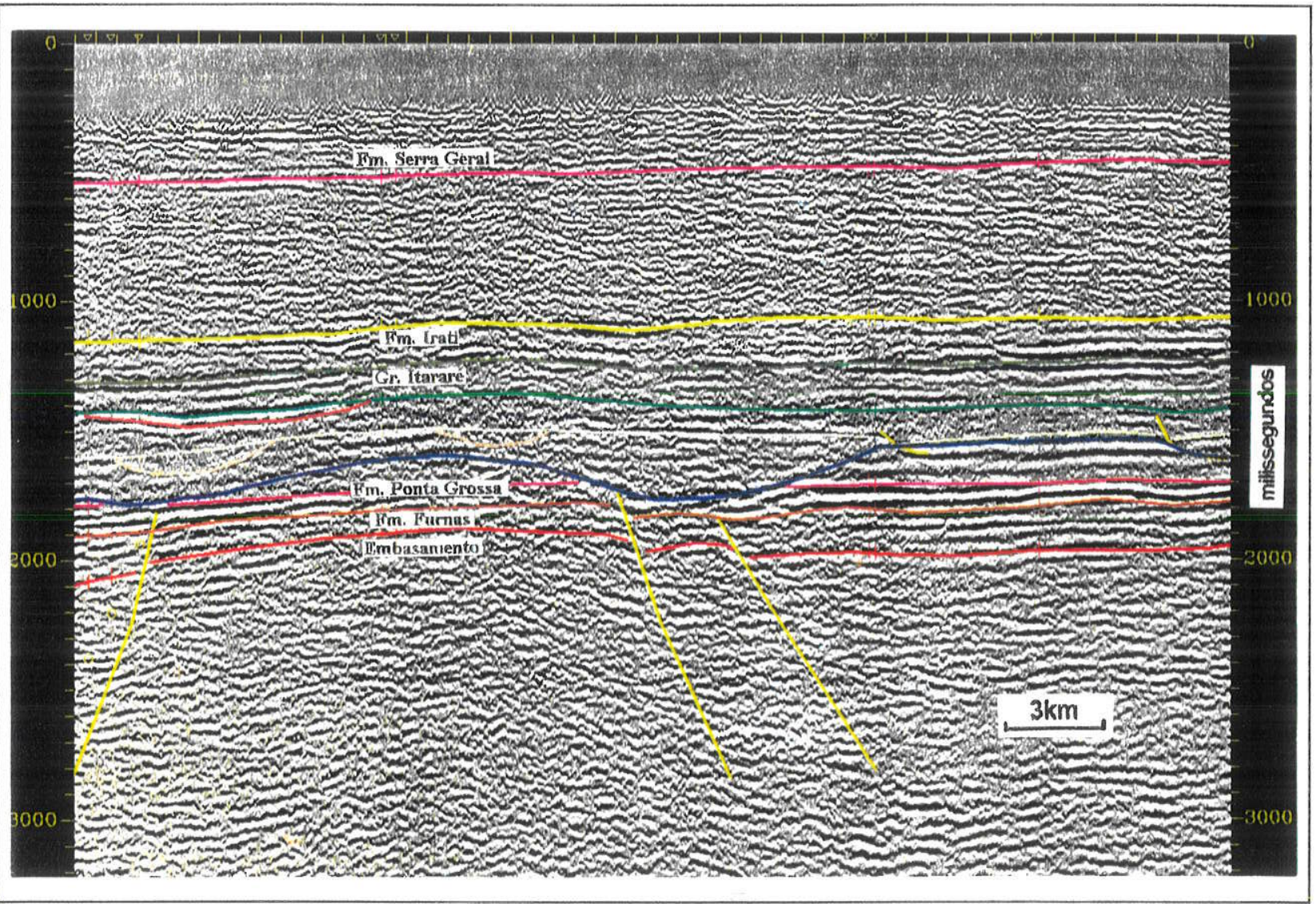

Figura 36 - Seção sísmica de reflexão mostrando canais na base do Gr. Itararé, moldando a discordância no topo da Fm. Ponta Grossa. A discordância é representada pela linha azul. O refletor rosa dentro da Fm. Ponta Grossa define o topo do Mb. Jaguariaíva. Este membro é freqüentemente sítio de alojamento de soleiras de diabásio, o que facilita sua identificação, pois as intrusivas apresentam grande contraste de impedância com as encaixantes. 


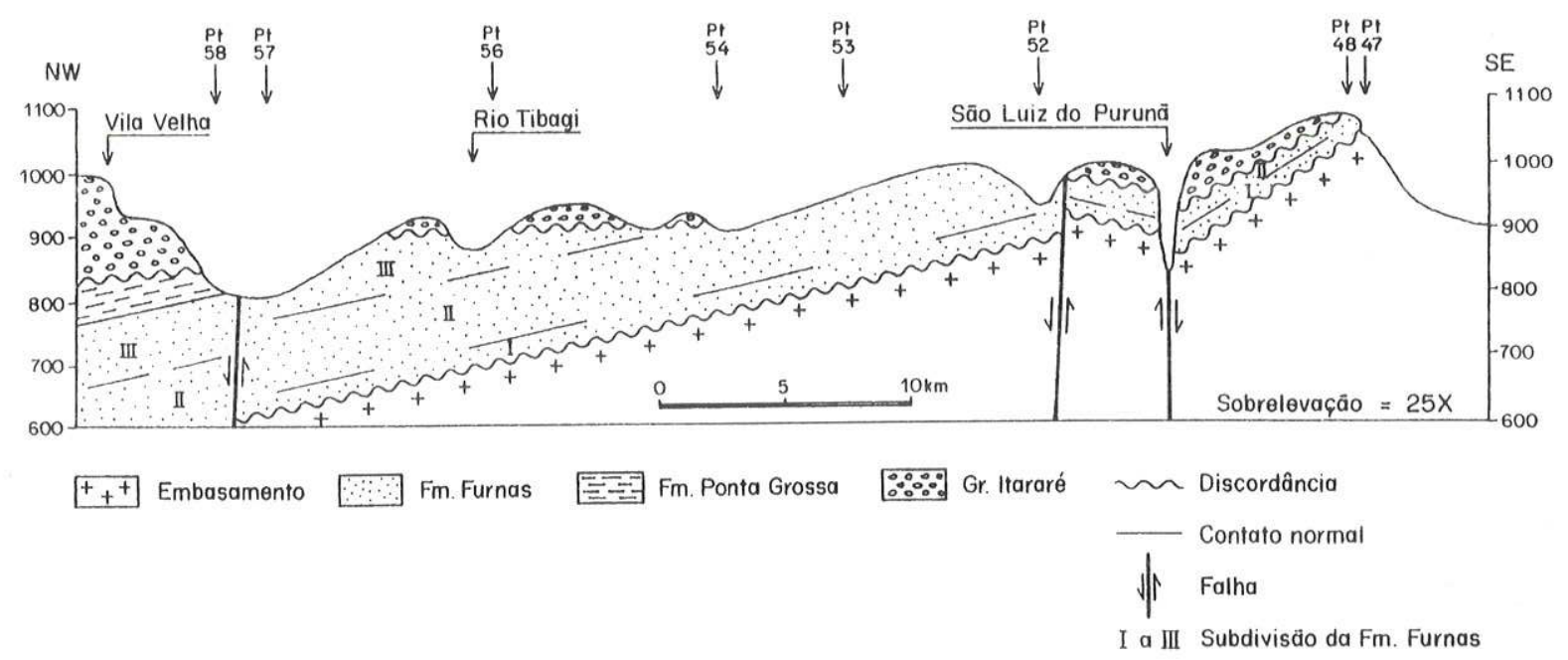

Figura 37 - Seção geológica esquemática no flanco sul do Arco de Ponta Grossa.

Não existem ainda dados que permitam estabelecer, com precisão, o início de sedimentação da Fm. Furnas, em função da pobreza em fósseis e da não-constatação de formas com valor cronoestratigráfico. A existência de macrofósseis vegetais do gênero Cooksonia (Bolzon et al. 1994, Mussa et al. 1996) não permite elucidar a questão, pois embora os registros mais antigos conhecidos sejam do Ludloviano (Taylor \& Taylor 1993), sua distribuição alcança o Emsiano. A unidade tem sido considerada essencialmente devoniana, mas é possível que a sedimentação tenha se iniciado no Pridoliano, como sugeriu Borghi (1992), já que pela curva eustática de Ross \& Ross (1988) significativa queda do nível do mar ocorreu no limite Ludloviano/Praguiano, sendo ascendente a partir do início do Praguiano.

Em função da passagem gradual para os estratos emsianos basais da Fm. Ponta Grossa, o topo da Fm. Furnas é considerado de idade eodevoniana. Corrobora esta interpretação a existência de um nível pelítico portador de palinomorfos na porção superior da Fm. Furnas, na área de Jaguariaíva-PR (ponto 90), cuja associação foi posicionada no Praguiano por Dino \& Rodrigues (1995).

Associação paleontológica semelhante, também considerada de idade praguiana, foi encontrada por Dino et al. (1995) na parte basal da Formação Ponta 
Grossa nos poços 2-CN-1-SC (Canoínhas; testemunhos $n^{\circ} 21$ e 22), 1-PH-1-PR (Pinhão; testemunho 7), 2-AG-1-MT (Alto Garças; testemunho 18), confirmando que as formações Furnas e Ponta Grossa constituem unidades geneticamente associadas e parcialmente contemporâneas, fazendo parte de uma mesma seqüência tectonosedimentar.

\section{1- FORMAÇÃO FURNAS}

A Fm. Furnas é uma unidade essencialmente psamítica, com geometria tabular e espessuras no geral entre 250 e $300 \mathrm{~m}$. Como pode ser visto no mapa de isópacas (Fig. 38), espessuras menores ocorrem apenas nas proximidades dos limites de ocorrência em subsuperfície. A concentração das curvas nas proximidades destes limites indica bordas erosivas, sendo nítido o caráter pós-deposicional do Arco de Ponta Grossa. Uma espessura máxima de $325 \mathrm{~m}$ foi verificada no poço ASU-1 (Assunção), onde a transição para a Fm. Ponta Grossa é bastante espessa. No Brasil, um máximo de $302 \mathrm{~m}$ foi constatado no poço 1-PH-1-PR. Isto se deve à reavaliação do poço 2-TL-1-MS, onde a parte superior da seção que vinha sendo considerada pertencente à Fm. Furnas foi reclassificada dentro da Fm. Ponta Grossa.

\subsection{1- Arranjo vertical de fácies}

A Formação Furnas é freqüentemente descrita como uma monótona seqüência de arenitos quartzosos brancos, de granulação média a grossa, feldspáticos e/ou caulínicos, mal classificados e portadores de estratificação cruzada, aos quais se interestratificam delgados niveis de conglomerados, sobretudo na porção basal.

Como conseqüência desta visão tem sido considerada indivisa. Mas, uma análise detalhada na faixa de afloramentos no Estado do Paraná (excluindo-se as camadas de transição, discutidas no item 6.1.5) permitiu a caracterização de três associações faciológicas distintas que se sucedem na vertical, referidas como unidades I, II e III. Por apresentarem posição estratigráfica definida e serem reconhecidas regionalmente, como se verá adiante, correspondem à hierarquia de membros na nomenclatura litoestratigráfica. 


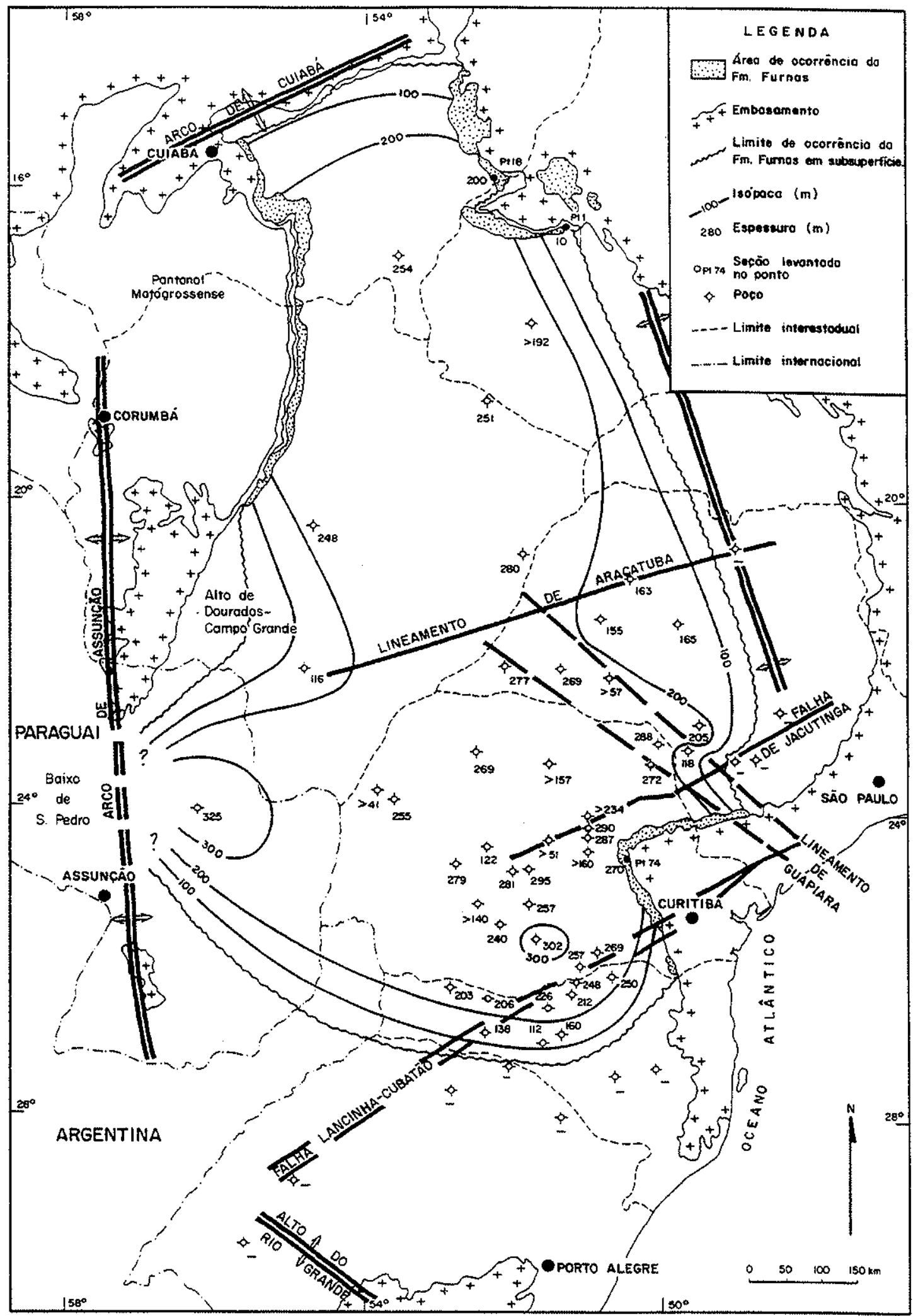

Figura 38 - Mapa de isópacas da Fm. Furnas. Verifica-se através deste mapa que a Fm. Furnas apresenta pouca variabilidade de espessura em toda a bacia, sendo a concentração de curvas nas bordas conseqüência de limites erosivos, atuais ou pretéritos. De outra parte, não existem informações sobre uma possivel continuidade física, através do Baixo de São Pedro (norte de Assunção), com estratos devonianos da Bacia do Chaco. 
UNIDADE I (INFERIOR) Unidade basal, disposta imediatamente acima da discordância com as unidades subjacentes, em contatos planos e bem definidos (Fig. 39-A). Faciologicamente é constituida, predominantemente, de arenitos médios a muito grossos, feldspáticos e/ou caulínicos, com grãos angulosos a subangulosos, dispostos em sets com geometrias tabular, lenticular e cuneiforme, espessuras entre 0,5 e 1,5m e estratificações cruzadas planar e tangencial na base (Fig. 39-B). Arenitos conglomeráticos e conglomerados quartzosos de granulação fina, com seixos (no geral menores que $2 \mathrm{~cm}$ ) e calhaus (diâmetro máximo constatado de $15 \mathrm{~cm}$ ) subangulosos a subarredondados, ocorrem intercalados nos arenitos. Os conglomerados apresentamse em camadas de pequena espessura (no máximo $1 \mathrm{~m}$ ), geometria lenticular a irregular (Fig. 39-C), padrão de granodecrescência ascendente, sendo texturalmente maciços ou com estratificação plano-paralela mal definida (Bigarella et al. 1966). As fácies acima ocorrem intimamente associadas, havendo transições laterais entre conglomerados e arenitos (Fig. 39-D/E). Na base há concentração de seixos e calhaus, ocorrendo por vezes conglomerados basais com espessuras em geral menores que $2 \mathrm{~m}$, matriz arenosa e clastos com diâmetro máximo constatado de $12 \mathrm{~cm}$ (Fig. 39-F). O conjunto é granodecrescente para o topo, com redução progressiva dos termos conglomeráticos, passando transicionalmente para a unidade II. As litologias da unidade $\mid$ apresentam maior resistência à erosão que os estratos sobrepostos, formando relevos escarpados ao longo das faixas de afloramento (Fig. 39-G).

UNIDADE II (MÉDIA) É constituida de arenitos finos a grossos, predominando a fração areia média. Os arenitos apresentam-se dispostos em sets tabulares e/ou cuneiformes com 0,5-2,0m de espessura. Os sets apresentam estratificações cruzadas planares a tangenciais na base $e$, secundariamente, acanaladas, com ângulos das camadas frontais menores que $25^{\circ}$ (Fig. 40-A/B). As terminações basais das camadas frontais muitas vezes gradam lateralmente para siltitos e/ou folhelhos brancos a verdes claros, frequentemente ricos em muscovita. Estes níveis pelíticos podem apresentar intercalações milimétricas de arenito muito fino/fino, resultando num acamamento ondulado (wavy bedding) (Fig. 40-C/D). Cruzadas bipolares do tipo espinha de peixe (herringbone cross-stratification) podem ser localmente observadas (Fig. 40-E). Em niveis ricos em intercalações pelíticas, os arenitos podem apresentar lâminas de argila entre as camadas frontais dos estratos cruzados, estruturas flaser e intraclastos sítico-argilosos (rip-up clasts), resultado do retrabalhamento dos níveis pelíticos subjacentes (Fig. 40-F/G/H). Evidências da atuação de ondas são muito restritas (Fig. 40-I). O topo dos sets é normalmente truncado por superfícies de reativação, mas, em 
alguns casos, as formas de leito estão preservadas, desenhando camadas com geometrias sigmóides de até $4 \mathrm{~m}$ de espessura (Fig. 40-J/L). Alguns cosets, com alguns metros de espessura, são internamente caracterizados por clinoformas constituídas de sets decimétricos com baixo ângulo de mergulho, internamente portadores de estratificação cruzada e separados por niveis siltico-argilosos de espessura centimétrica (Fig. 40-M). Entre os cosets de arenitos ocorrem intercalações de siltitos argilosos de cor verde clara, formando camadas de alguns centímetros até dois metros, sob as quais é comum a presença de traços fósseis paralelos ao acamamento. Esta intercalação de níveis finos entre os bancos arenosos se reflete na morfologia, dando origem a encostas com aspecto banqueado em degraus, característico da unidade II (Fig. 39-G).

UNIDADE III (SUPERIOR) Compõe-se de arenitos médios a muito grossos, dispostos em sets com estratificações cruzadas tabular e acanalada, com espessuras que variam de 0,5 (Fig. 41-A/B) a 5,0m (Fig. 41-C/D). Alguns sets apresentam lâminas de argila e defomação penecontemporânea nas camadas frontais (foresets), mesmo em arenitos com seixos dispersos (Fig. 41-E/F/G). Sentidos bipolares de fluxo foram observados em alguns afloramentos, caracterizando estratificações cruzadas tipo espinha de peixe (Fig. 41-H). A unidade caracteriza-se pela existência de depósitos residuais (lags) de seixos e calhaus, delgados e extensos (centenas a milhares de metros), que ocorrem em superfícies erosivas planares separando cosets. Os clastos são arredondados, assimétricos (muitos em forma de bastão) e compostos por quartzo de veio e quartzito, apresentando diâmetro máximo constatado de $15 \mathrm{~cm}$ (Fig. 41 I/J/L/M/N/O). Os níveis estendem-se muitas vezes por centenas de metros: no canyon do rio lapó, no Guartelá (ponto 74), um nível de conglomerado foi rastreado lateralmente por cerca de $1500 \mathrm{~m}$. Na maioria dos casos, representam superfícies com clastos dispersos sem contato físico entre si, mas, por vezes, formam camadas de conglomerados quatzosos clasto-suportados com até $0,5 \mathrm{~m}$ de espessura. Em alguns casos os pavimentos são recobertos por siltitos, evidenciando que são feições de topo e não lags basais. Os níveis síltico-argilosos são escassos e pouco espessos na unidade III, o que resulta numa morfologia de paredões mais íngremes que os da unidade II (Fig. 41-P/Q). Na parte superior da unidade III da Fm. Furnas ocorrem também arenitos muito finos com estratificação cruzada hummocky e camadas sílticoargilosas, muitas vezes portadoras de restos de vegetais vasculares primitivos. 

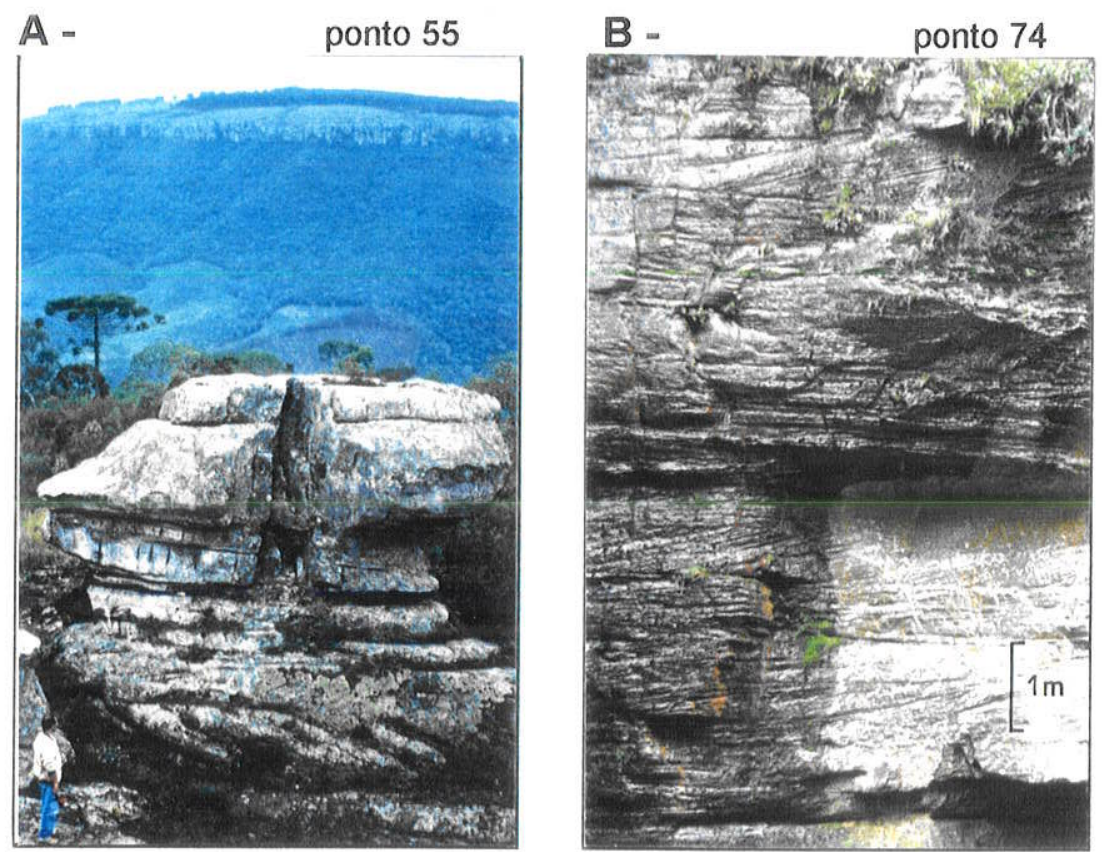

C -

ponto 63

D -

ponto 63
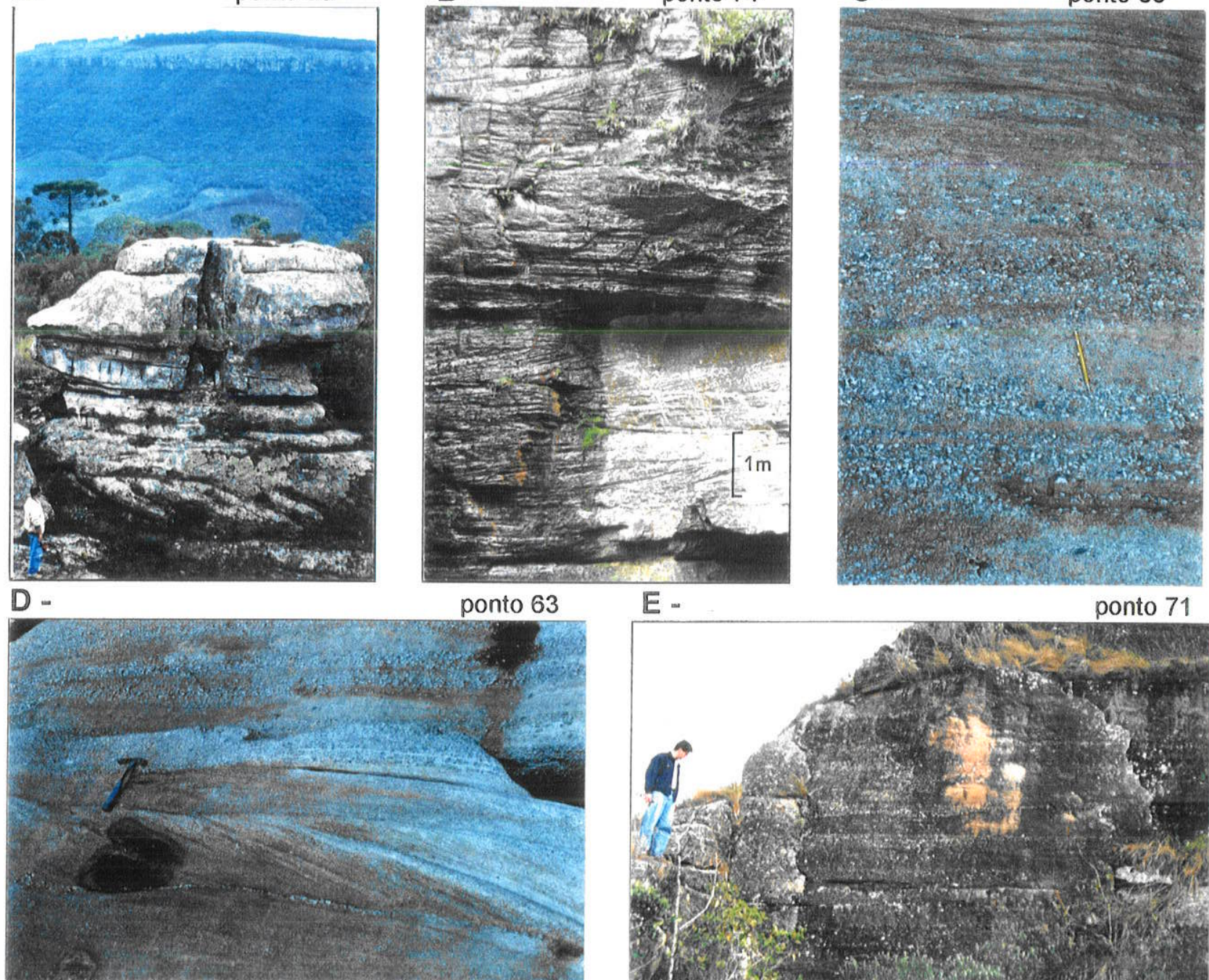

E -

ponto 71

F -

ponto 50
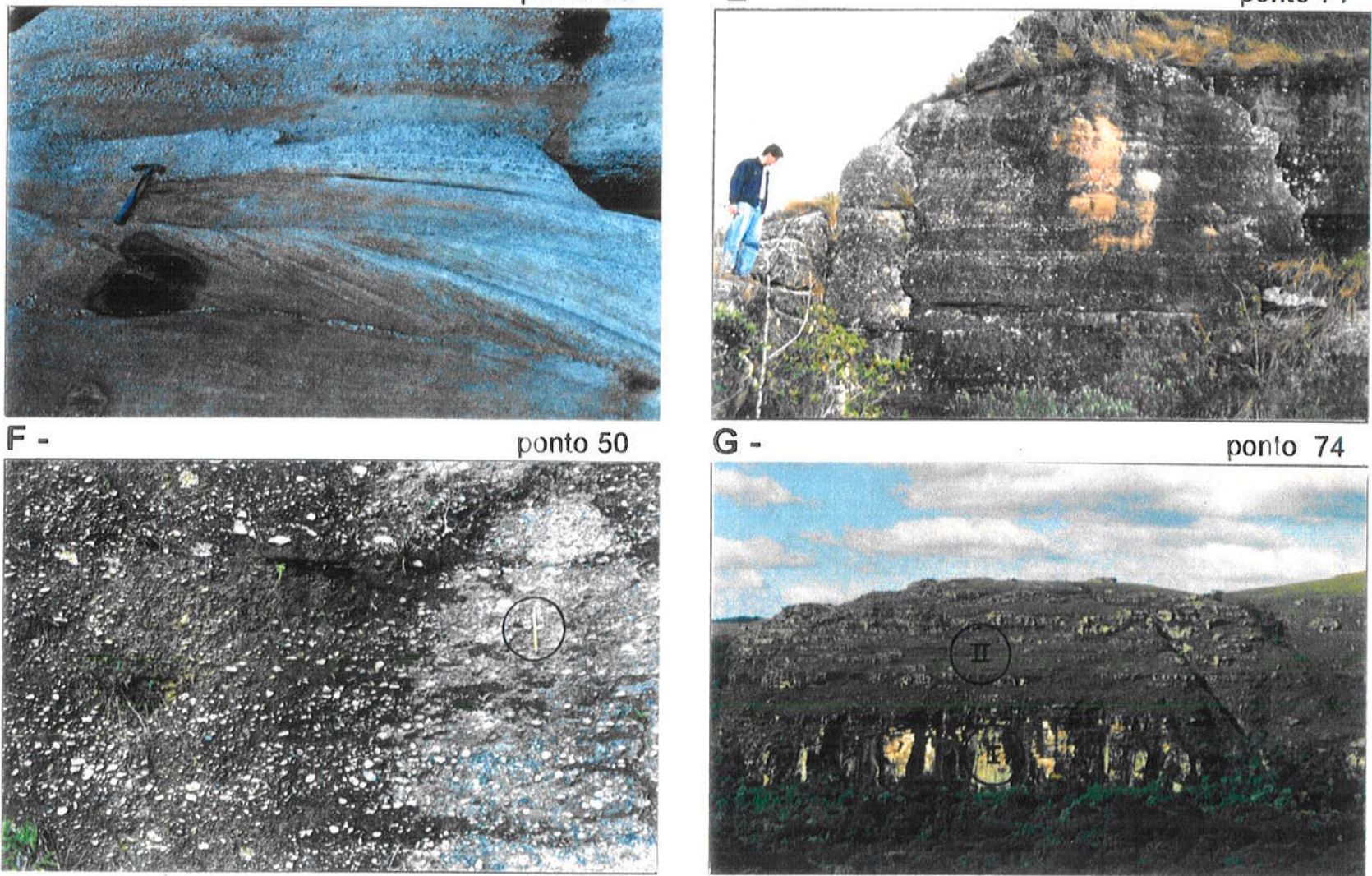

G -

ponto 74

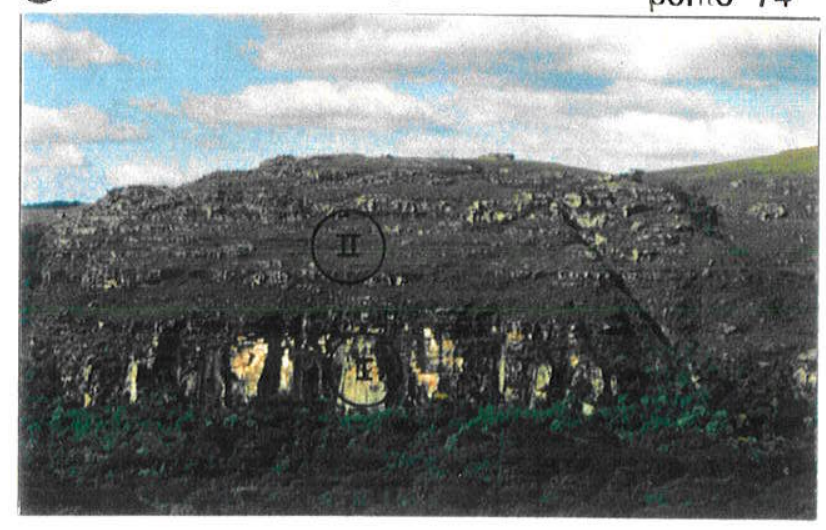

Figura 39 - Fácies da unidade I da Fm. Furnas A unidade é constituída predominantemente por arenitos grossos, dispostos em sets de 0,5 a $1,5 \mathrm{~m}$ com estratificação cruzada tabular, observando-se ao fundo seu contato plano com o embasamento pré-cambriano (A). As camadas frontais dos estratos cruzados apresentam tangencialidade na base e inclinações menores que $25^{\circ}$ (B). Interestratificados aos arenitos ocorrem delgados níveis conglomeráticos com estratificação plano-paralela mal desenvolvida (C/D) e natureza descontínua (E). Na base podem ocorrer conglomerados quartzosos (F). Esta faciologia é responsável pelo relevo escarpado que caracteriza a unidade I da Fm. Furnas (G). 
A -

ponto 74

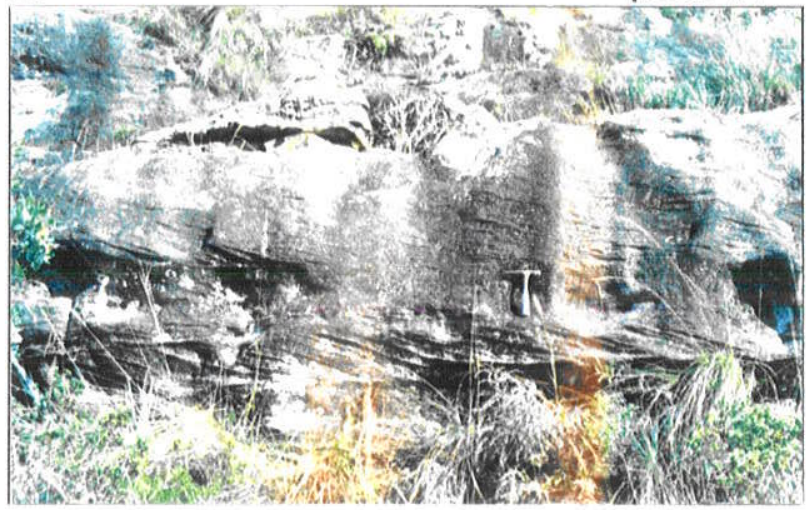

C.

ponto 74

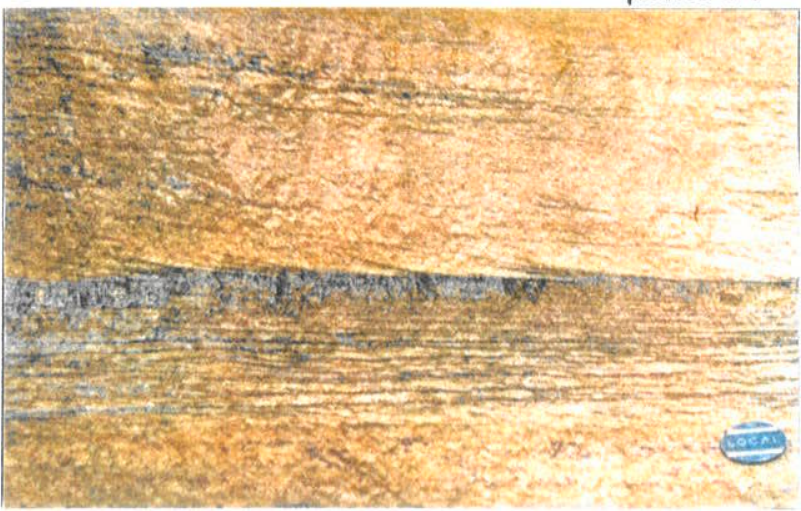

E -

ponto 73

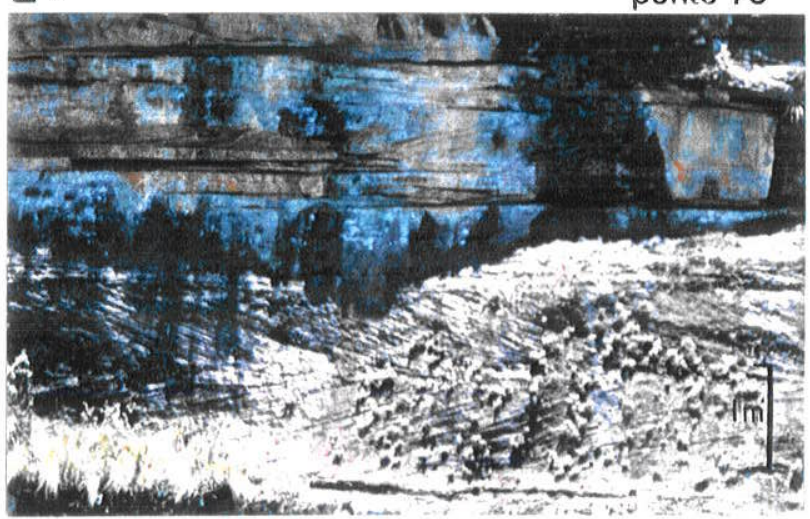

G -

ponto 52

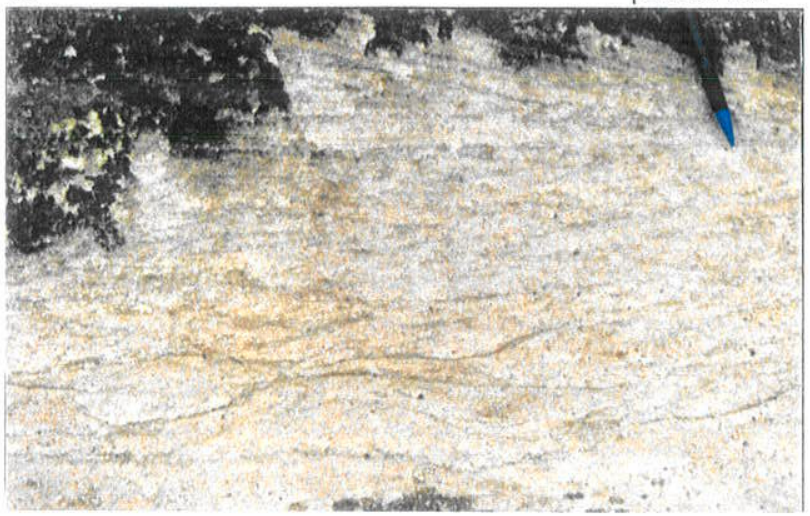

Bponto 74

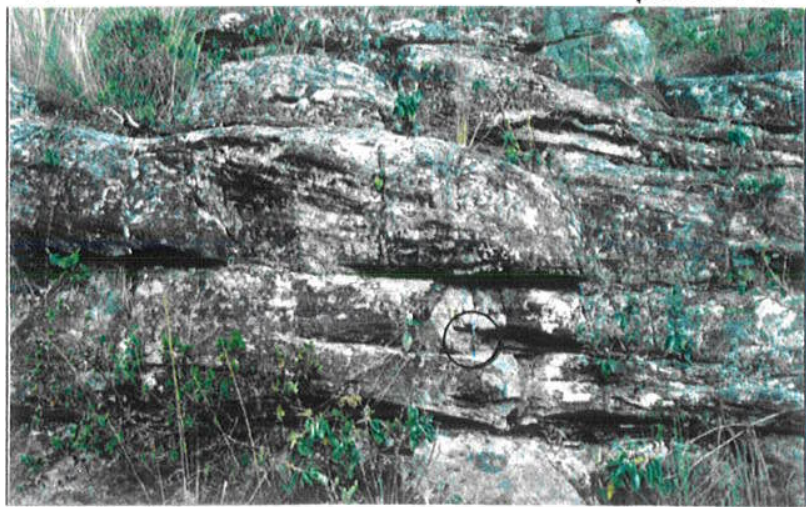

D -

ponto 74

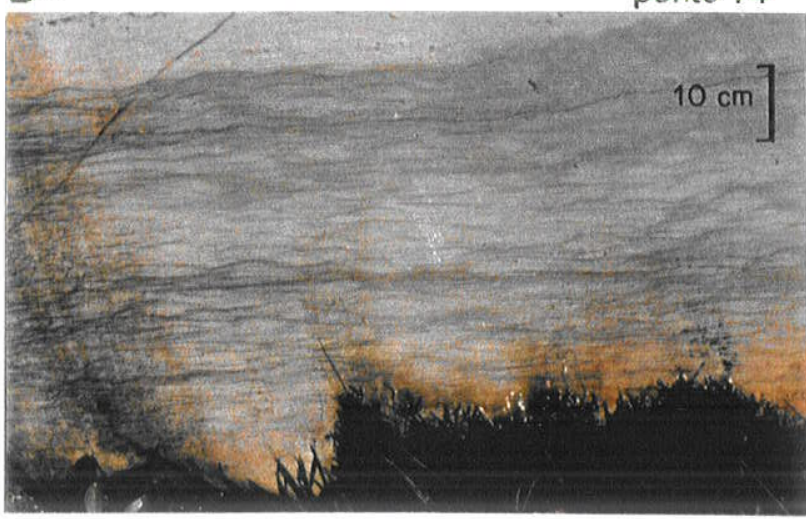

F -

ponto 52

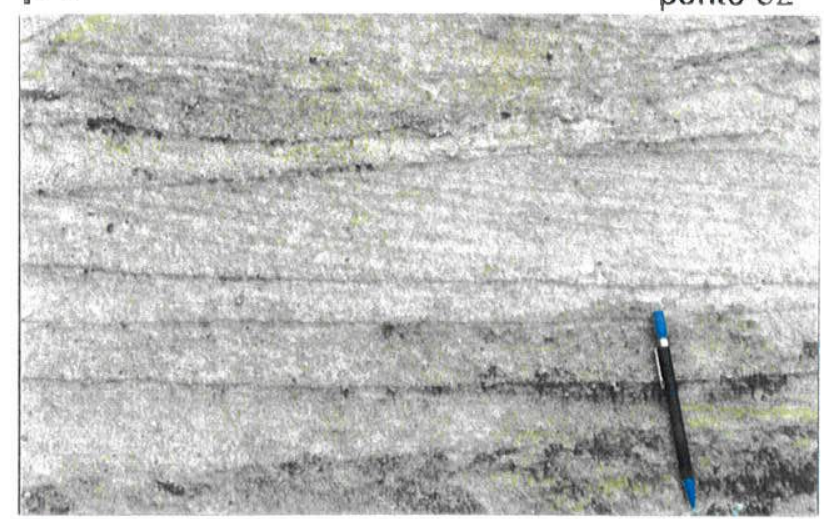

H -

ponto 52

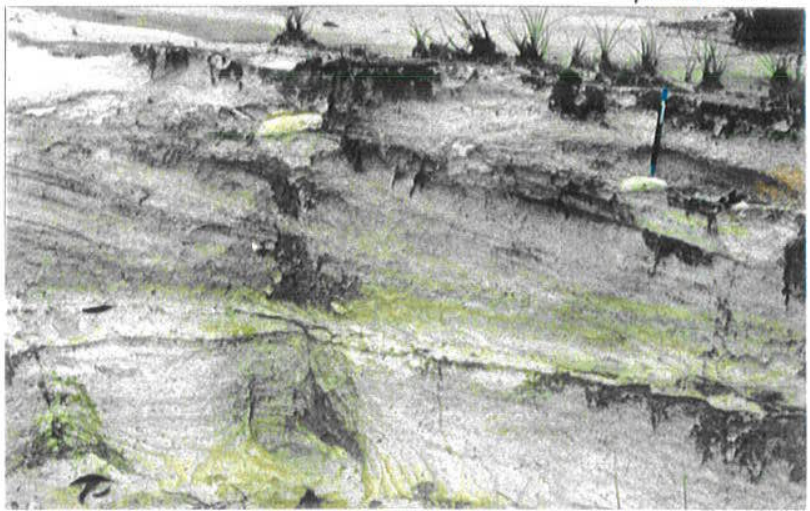

Figura 40 - Fácies da unidade II da Fm. Furnas. Arenitos com estratificação cruzada sigmóide e/ou tangencial na base, em sets com topo truncado por superfícies de reativação, sobre as quais podem ocorrer horizontes síltico-argilosos (A/B). As terminações dos foresets mostram gradação mergulho abaixo para arenitos finos e siltitos, podendo resultar em laminações wavy (C/D). Localmente, ocorrem sets com estratificação cruzada do tipo espinha de peixe (E), lâminas de argila nos foresets (F), laminação flaser (G) e intraclastos de argila (H). 
I-

ponto 53

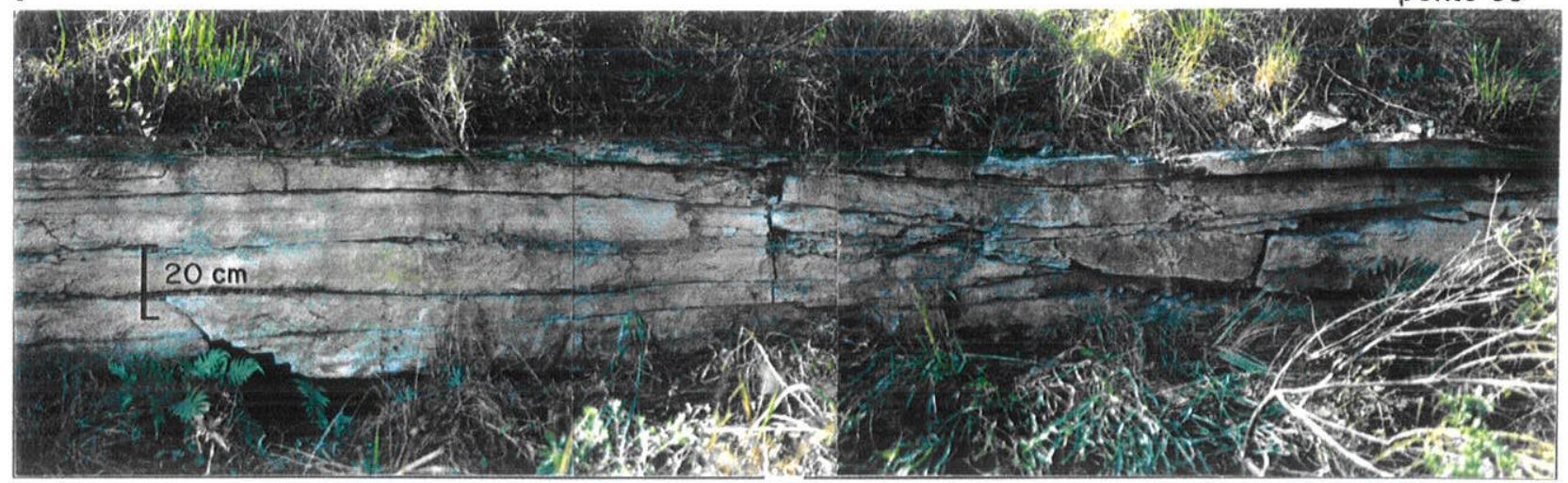

J -

ponto 74

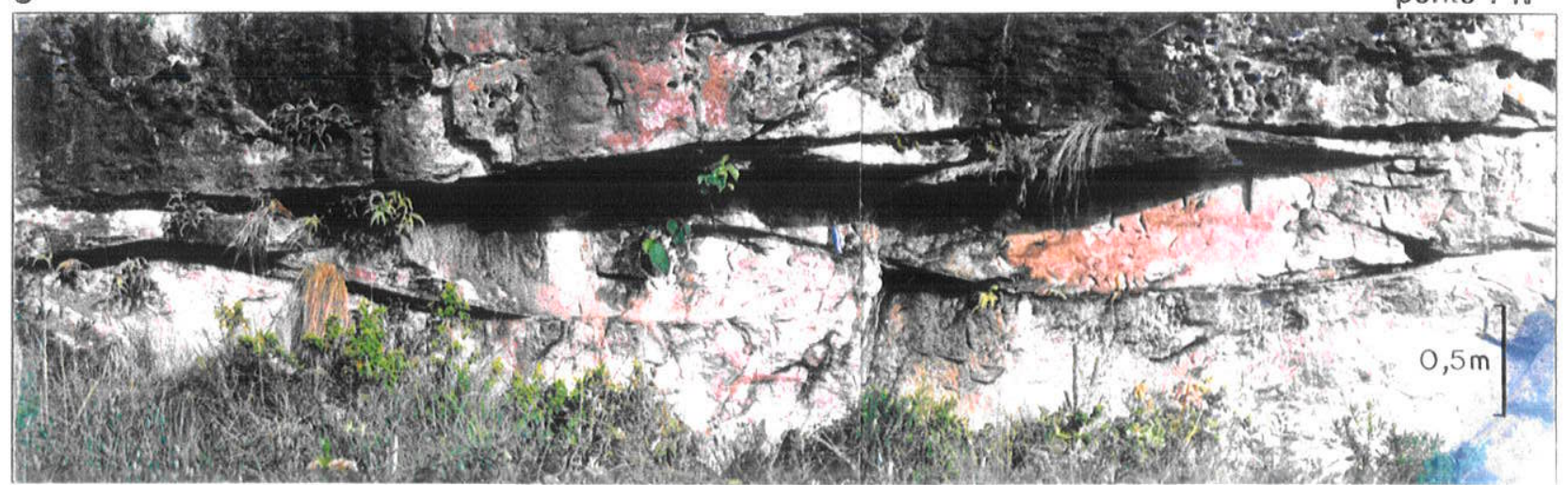

L =

ponto 61

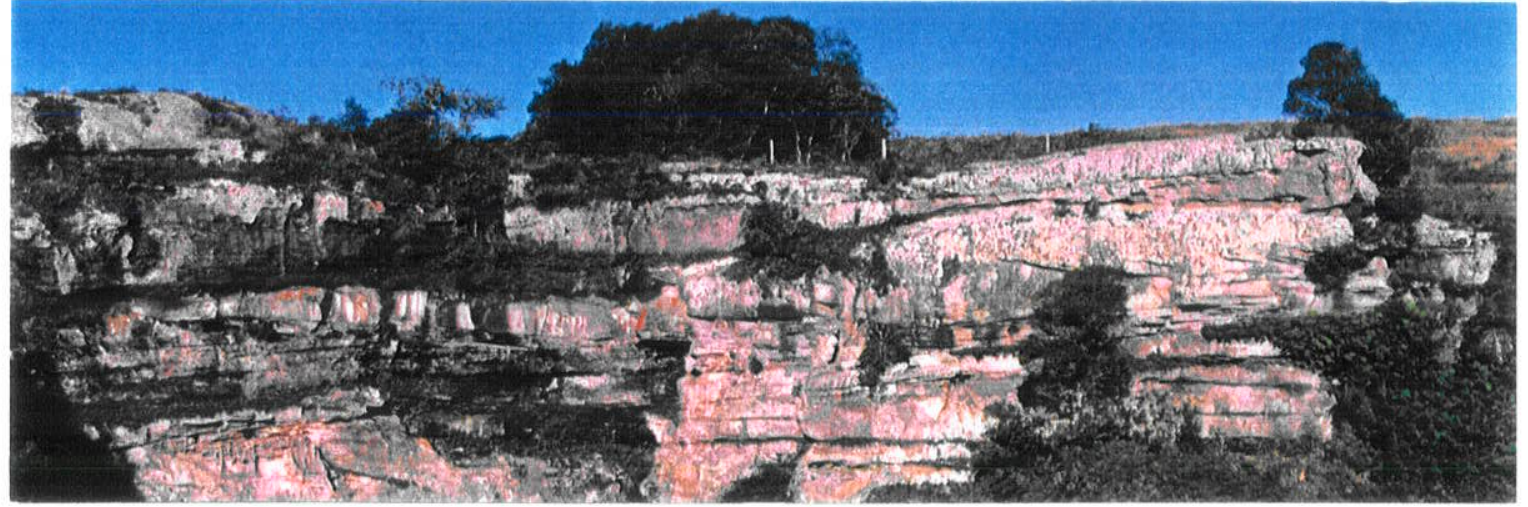

M-

ponto 79

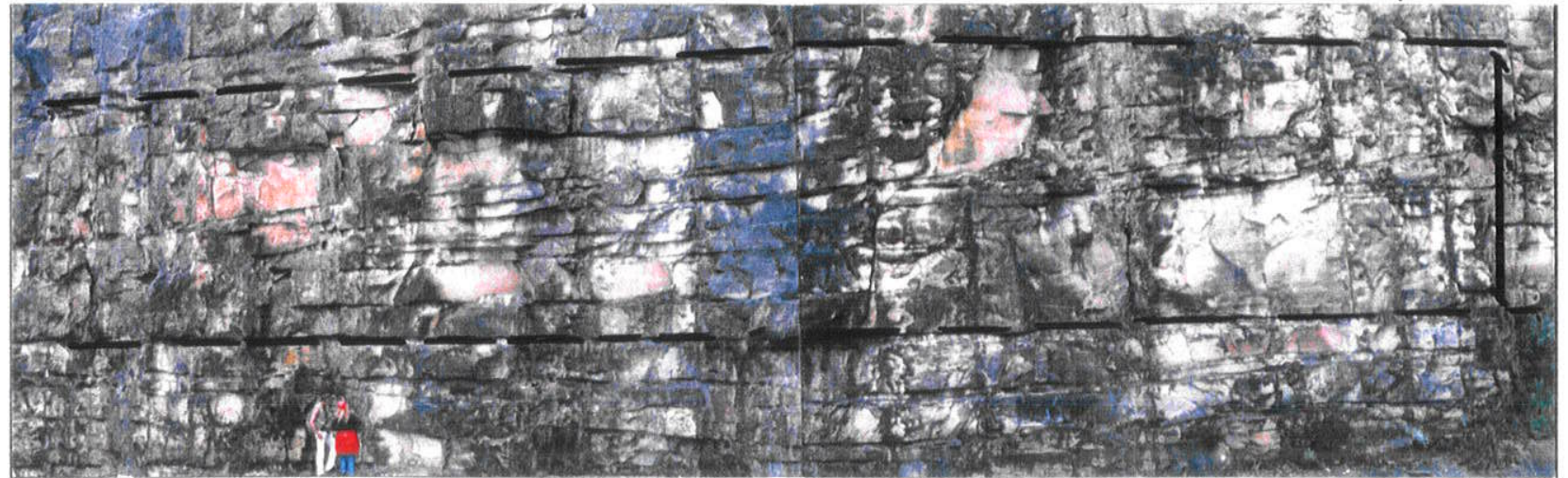

Figura 40 - Fácies da unidade II da Fm. Furnas (continuação). Feições sugestivas da ação de ondas foram muito restritamente observadas (I). Mais comum é a presença de geometrias sigmóides de tamanho variável $(\mathrm{J})$. Em alguns casos, as próprias formas de leito ficaram preservadas, delineando sets com padrão textural de granocrescência ascendente e estratificações cruzadas de médio a grande porte, tangenciais na base (L). Muitas vezes, sets de estratos cruzados de pequeno porte, separados por horizontes síltico-argilosos, fazem parte de formas de leito de menor ângulo e maior hierarquia (M). 


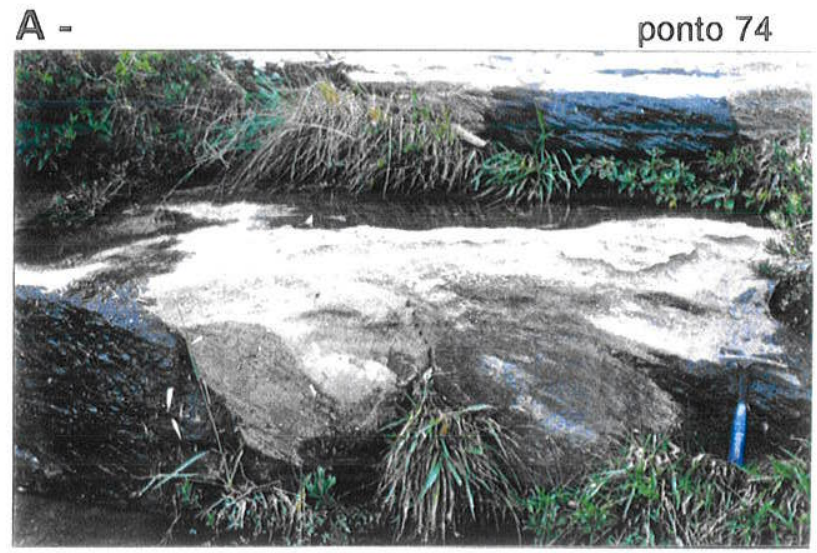

C.

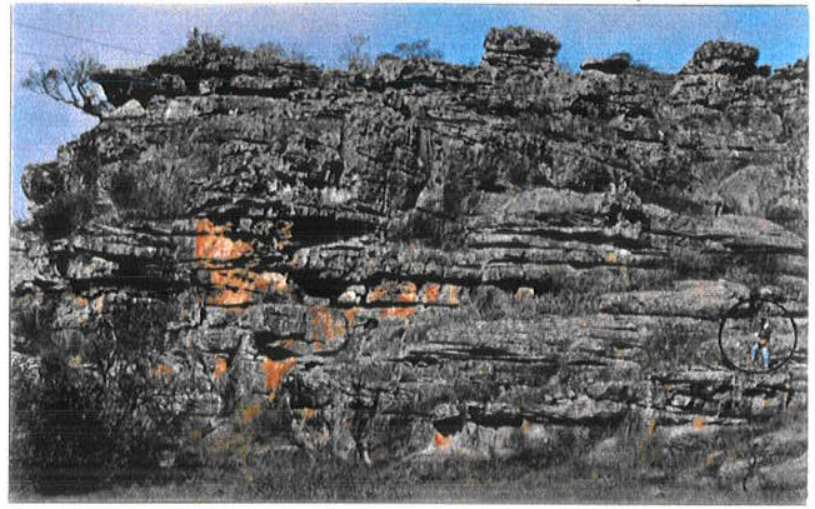

E -

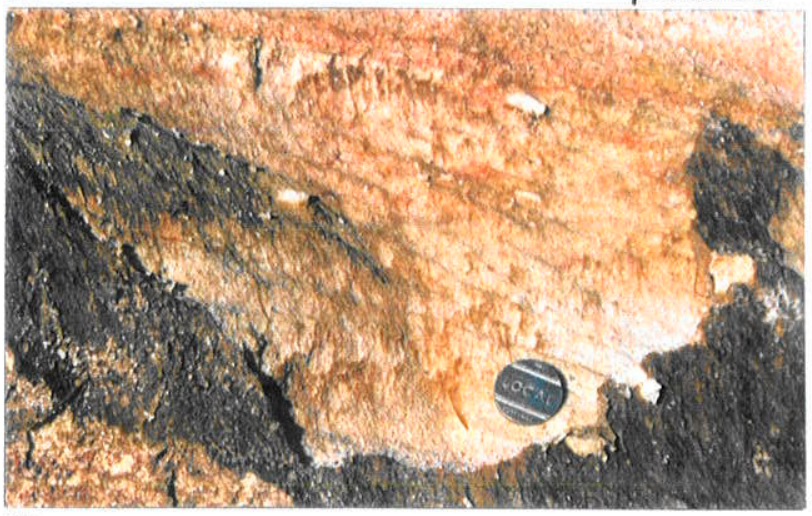

G -

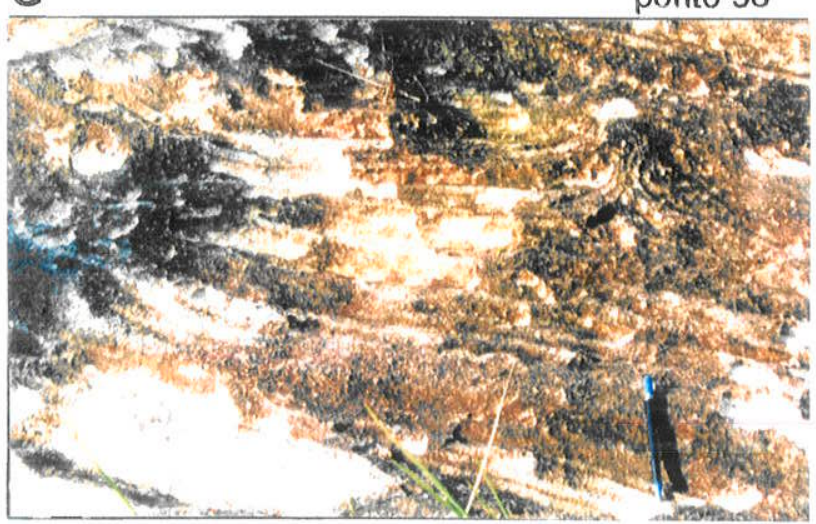

B -

ponto 74

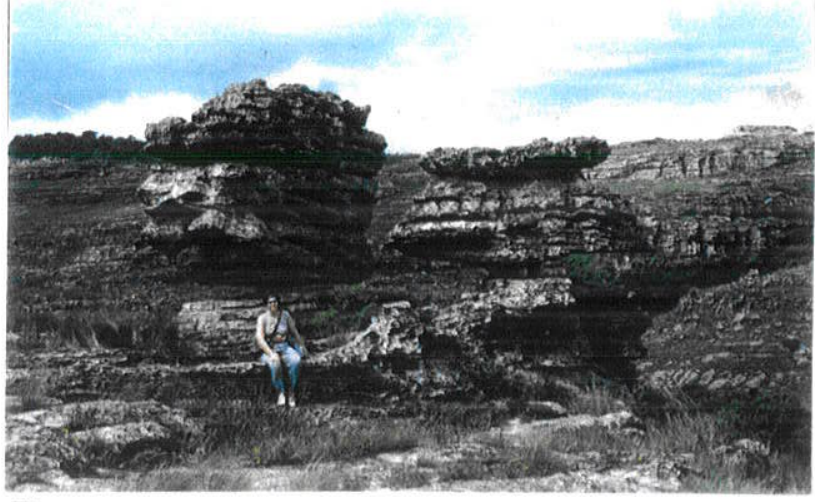

D.

ponto 74

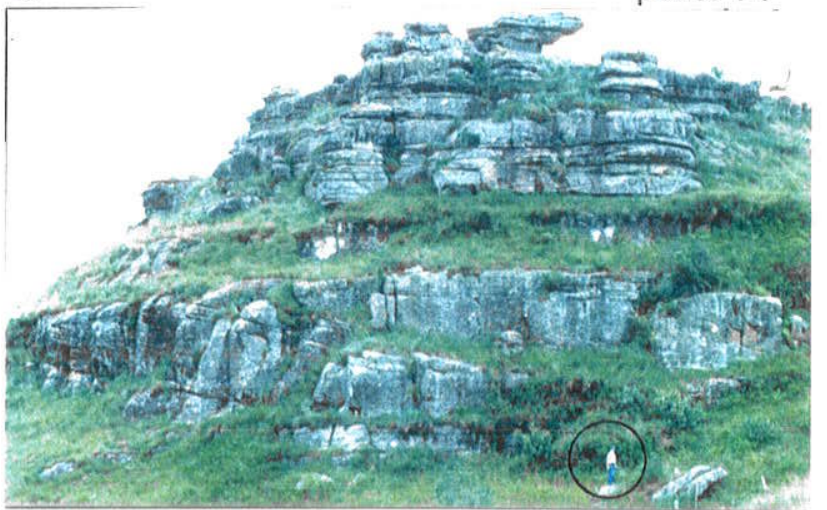

F -

ponto 56

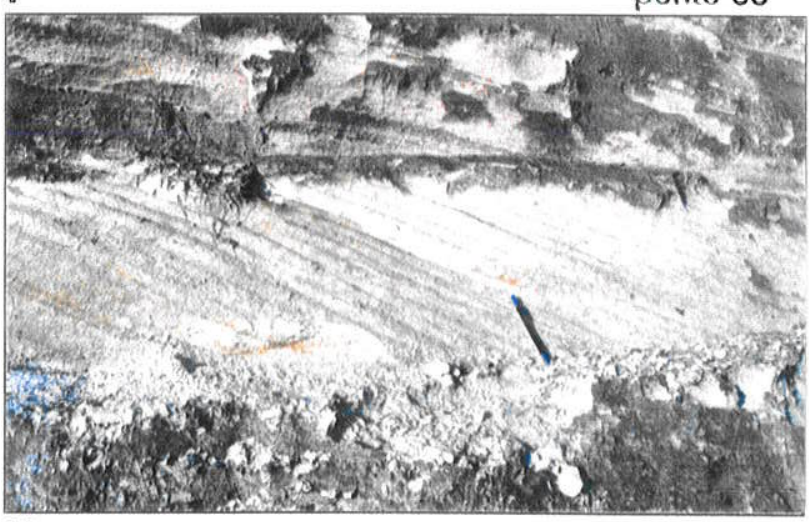

H -

ponto 74

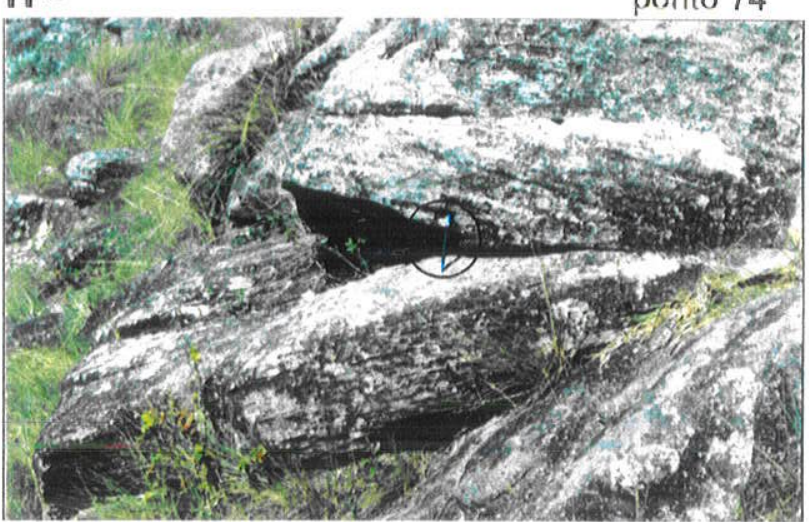

Figura 41 - Fácies da unidade III da Fm. Furnas

Arenitos médios a muito grossos, com estratificações cruzadas tabulares e acanaladas, em sets de 0,5 a $5 \mathrm{~m}$ de espessura (A/B/C/D). Localmente, os arenitos apresentam seixos dispersos (E), lâminas de argila nos foresets (F), deformações penecontemporâneas (G), ou ainda reversões de fluxo caracterizando estratificação cruzada tipo espinha de peixe $(\mathrm{H})$. 
I-

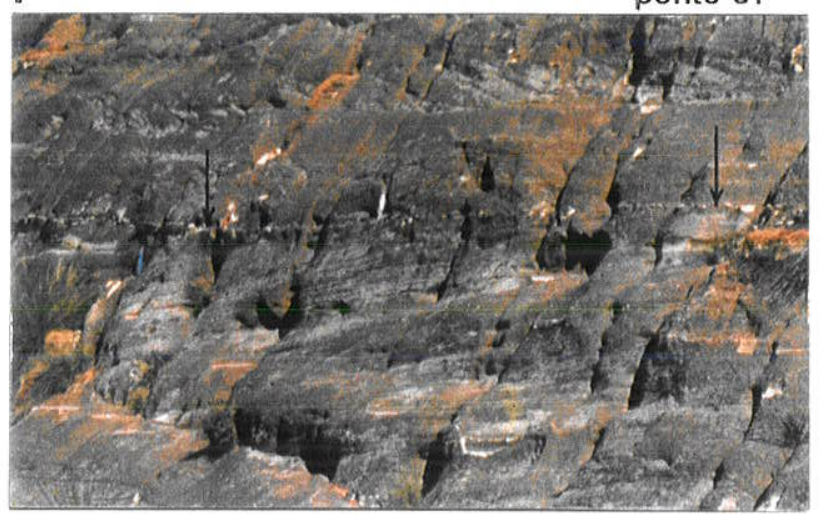

L -

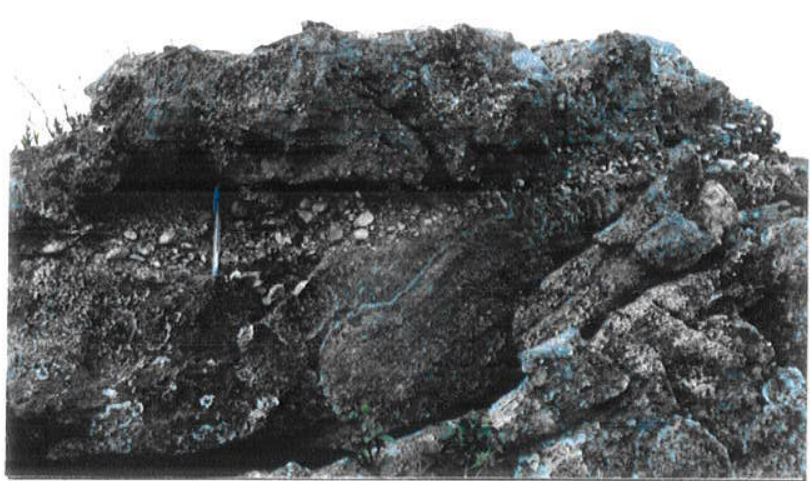

N -

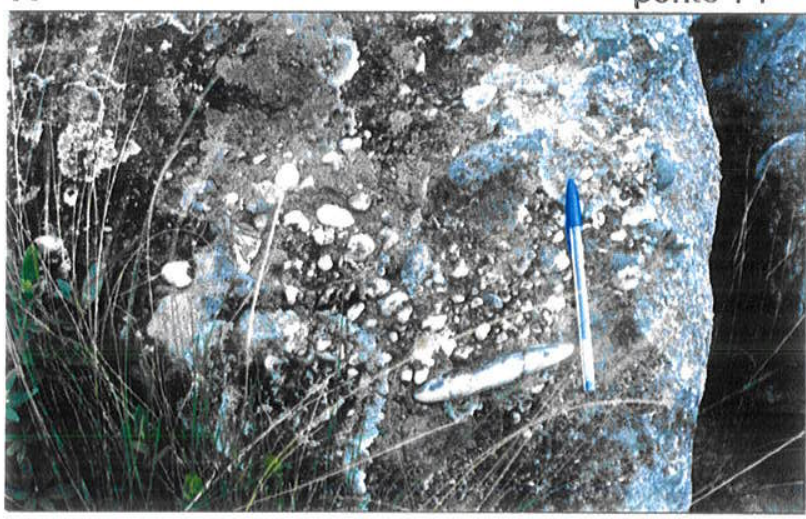

P .

ponto 74

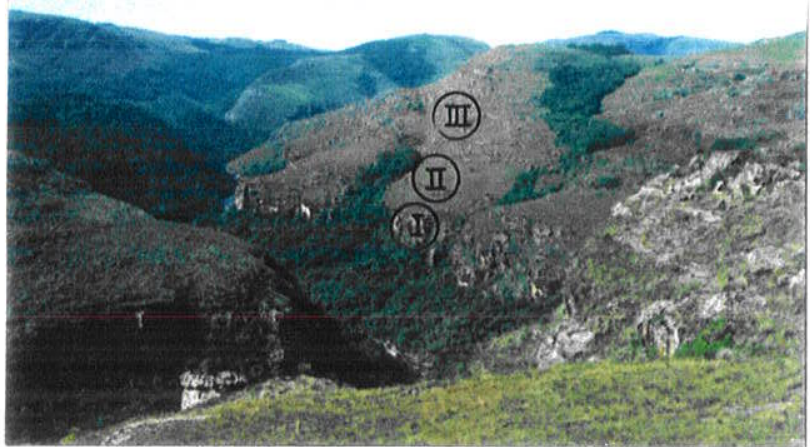

$J=$

ponto 57

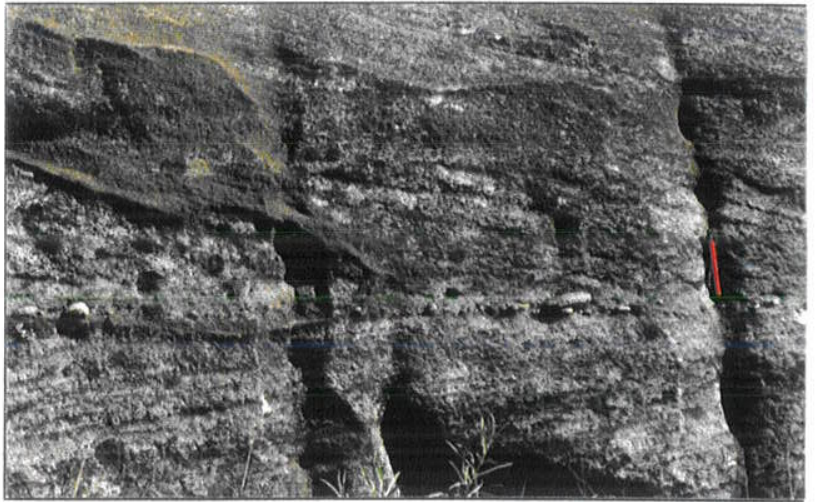

M -

ponto 74

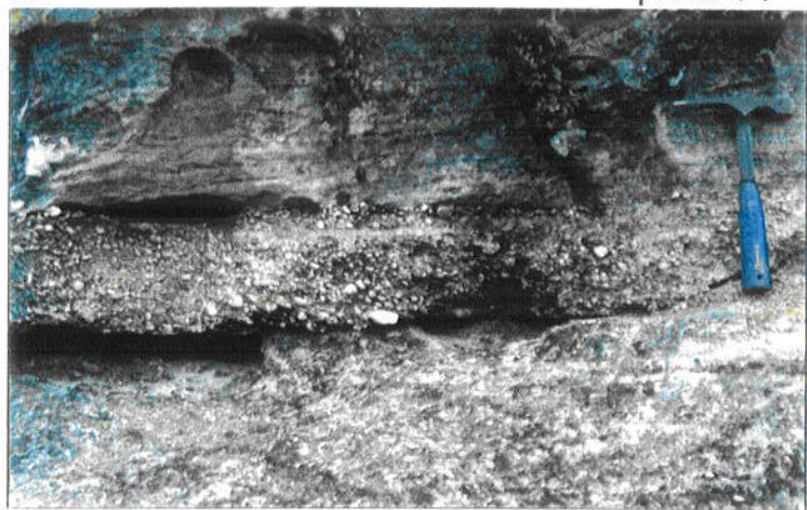

0 -

ponto 74

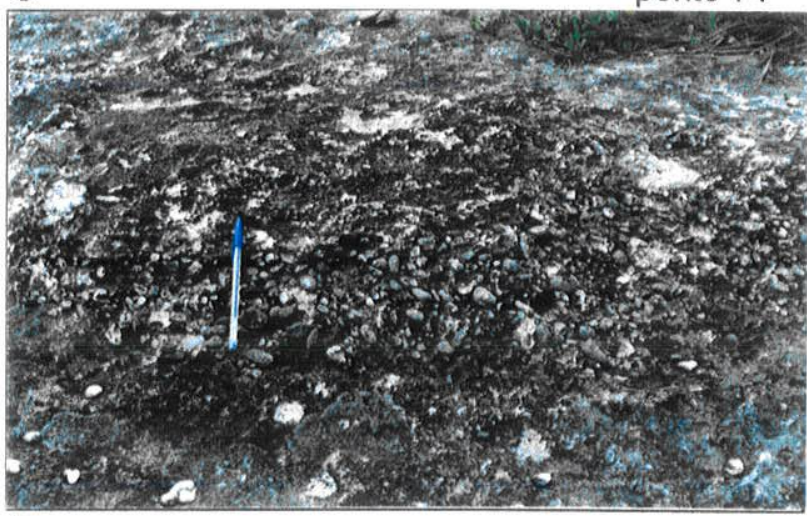

Q -

ponto 74

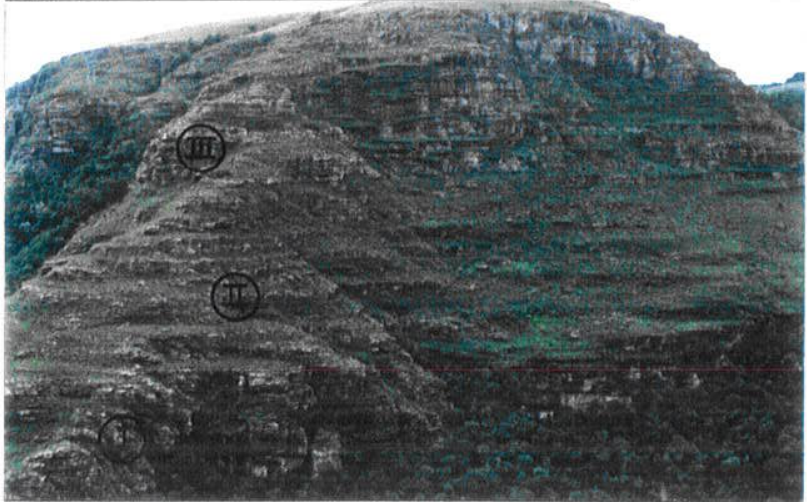

Figura 41 - Fácies da unidade III da Fm. Furnas (continuação). Pavimentos de seixos joeirados no topo de sets de arenitos com estratificação cruzada (I), caracterizados por clastos isolados $(J)$ ou por camadas de conglomerados de até $0,5 \mathrm{~m}$ de espessura ( $\mathrm{L} / \mathrm{M})$; nestes horizontes é comum a presença de calhaus arredondados $(\mathrm{N})$ e seixos orientados segundo o eixo "a" $(\mathrm{O})$. A presença de conglomerados e a pobreza em pelitos são responsáveis por uma morfologia mais íngreme, comparativamente à unidade ॥ (P/Q). 
Dentre as seções da Fm. Furnas levantadas na faixa de afloramentos no Estado do Paraná, a mais representativa é a do canyon do lapó no Guartelá (Fig. 42), que apresenta empilhamento vertical praticamente contínuo de $250 \mathrm{~m}$, desde o contato basal com rochas vulcânicas do $\mathrm{Gr}$. Castro até as Camadas de Transição no topo da Fm. Furnas.

A correspondência entre as três unidades caracterizadas em superfície e os registros de poços no Estado do Paraná é bastante boa, permitindo correlacionar as fácies descritas no campo com assinaturas características em perfis de raios-gama dos poços (Fig. 43). A análise comparativa permitiu verificar que a unidade I é caracterizada por valores baixos de radioatividade, compativel com fácies arenoconglomeráticas em que há pobreza em argila. A unidade II apresenta arenitos com valores mais altos de radioatividade, indicativos de arenitos mais finos e/ou com matriz pelítica, e um padrão serrilhado em perfis de raios-gama com inúmeros picos de maior radioatividade devido à presença de intercalações síltico-argilosas. A unidade III caracteriza-se por valores muito baixos de radiotividade e padrões em caixa nos perfis de raios-gama, representando um brusco deslocamento à esquerda em relação à unidade II, indicativo de aumento da granulometria e diminunição da argilosidade. Fácies conglomeráticas foram descritas nos poços 2-MO-1-PR e 1-MO-2-PR, sendo correlacionadas com os pavimentos de seixos descritos na unidade III da seção do Guartelá. Para o topo, a Fm. Furnas apresenta, paulatinamente, mais e mais intercalações pelíticas, delineando um padrão geral de granodecrescência, com deflexão à direita em direção aos folhelhos da Fm. Ponta Grossa.

Com base nos critérios acima, as três unidades foram reconhecidas não só nos poços no Estado do Paraná, mas também naqueles perfurados em outros estados (Figs. 12, 19 e 20), podendo-se afirmar que a subdivisão proposta pode ser aplicada em subsuperfície em praticamente toda a bacia.

Espessuras similares às registradas no flanco sudeste da bacia e nos poços perfurados foram também verificadas na faixa de afloramentos do flanco norte, confirmando as estimativas de Beurlen (1959), que relatou possanças de $200 \mathrm{~m}$ ou mais nas serras Azul e do Taquaral. Na Figura 44 pode-se verificar que a lógica do empilhamento estratigráfico é muito semelhante à da seção do canyon do lapó (Fig. 42), com fácies similares (Fig. 45) e o mesmo aumento brusco na granulometria quando da passagem da unidade II para a III. Icnofósseis também ocorrem comumente na unidade II, embora predominem formas verticais, conforme pôde ser verificado na seção levantada nas escadarias do morro do Cristo Redentor (Fig. 44) e na estrada de acesso à base do Cindacta II, entre os pontos 16 e 20. Devido a eventos tectônicos 
Ponto 74

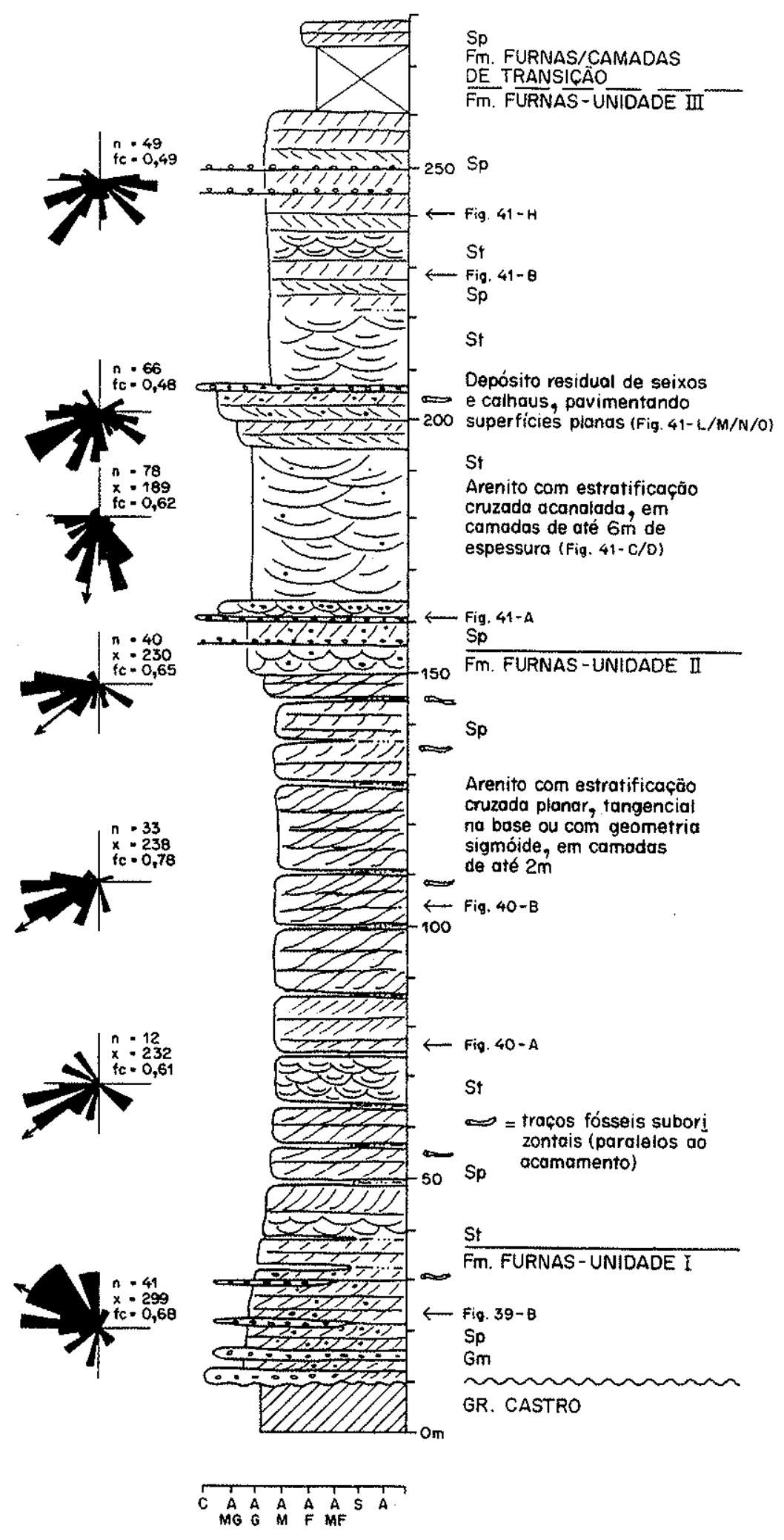

Figura 42 - Seção colunar da Fm. Furnas no canyon do rio lapó no Guartelá (ponto 74), em Tibagi-PR. (localização: ver Fig. 7; código de fácies: ver Tabela 5; simbologias utilizadas: ver Fig. 13 e Tabela 6 ). 


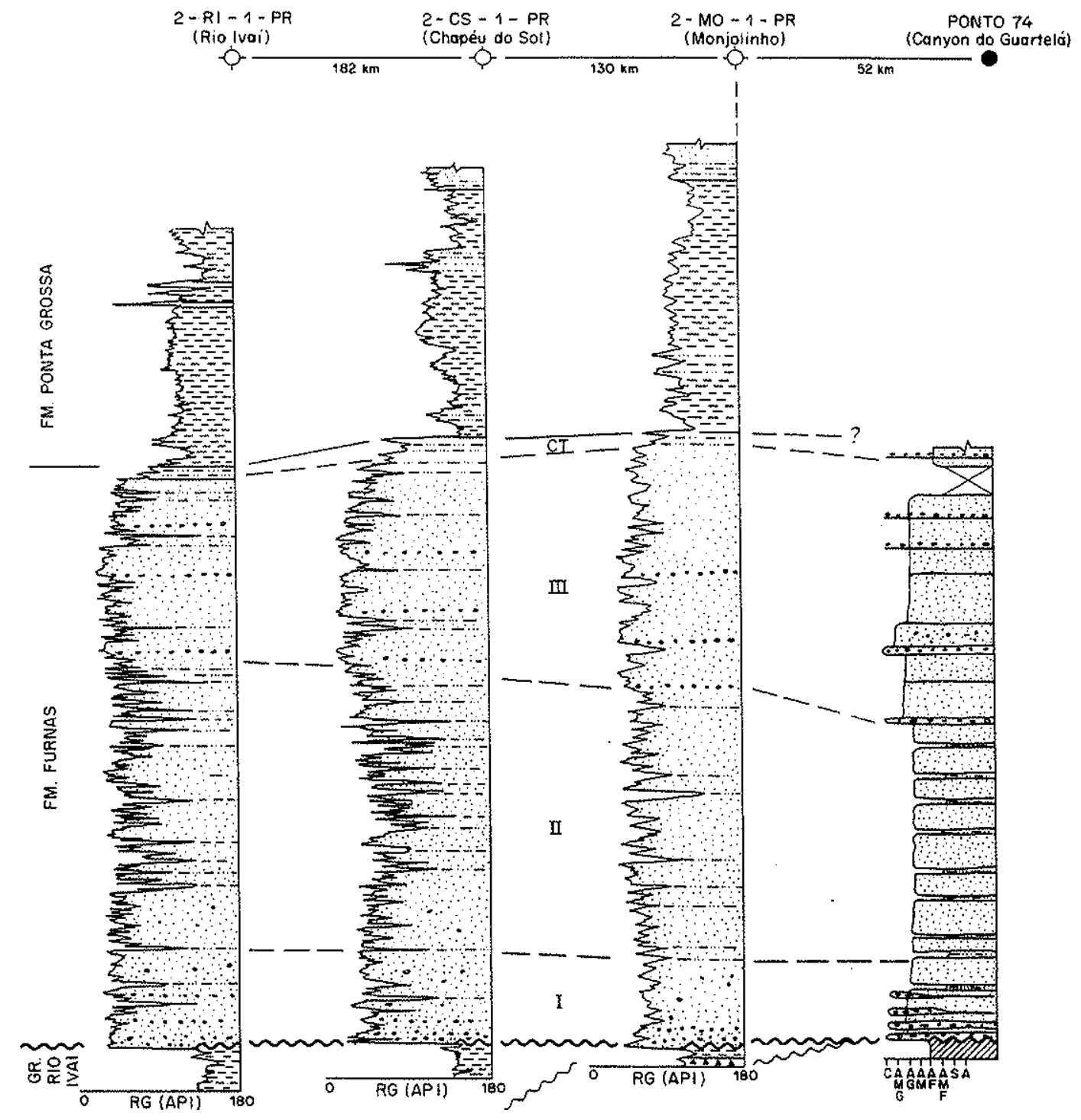

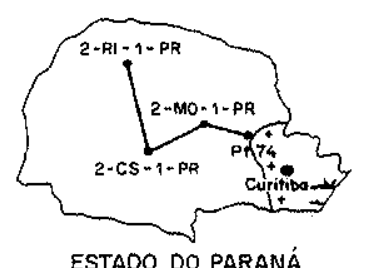

ESTADO DO PARANÁ

Obs.: Diabásios foram retirados dos perfis

Figura 43 - Correlação da seção estratigráfica da Fm. Furnas no canyon do rio lapó (Guartelá) com os perfis dos poços 2-MO-1-PR (Monjolinho), 2-CS-1-PR (Chapéu do Sol) e 2-RI-1-PR (Rio Ivaí). 


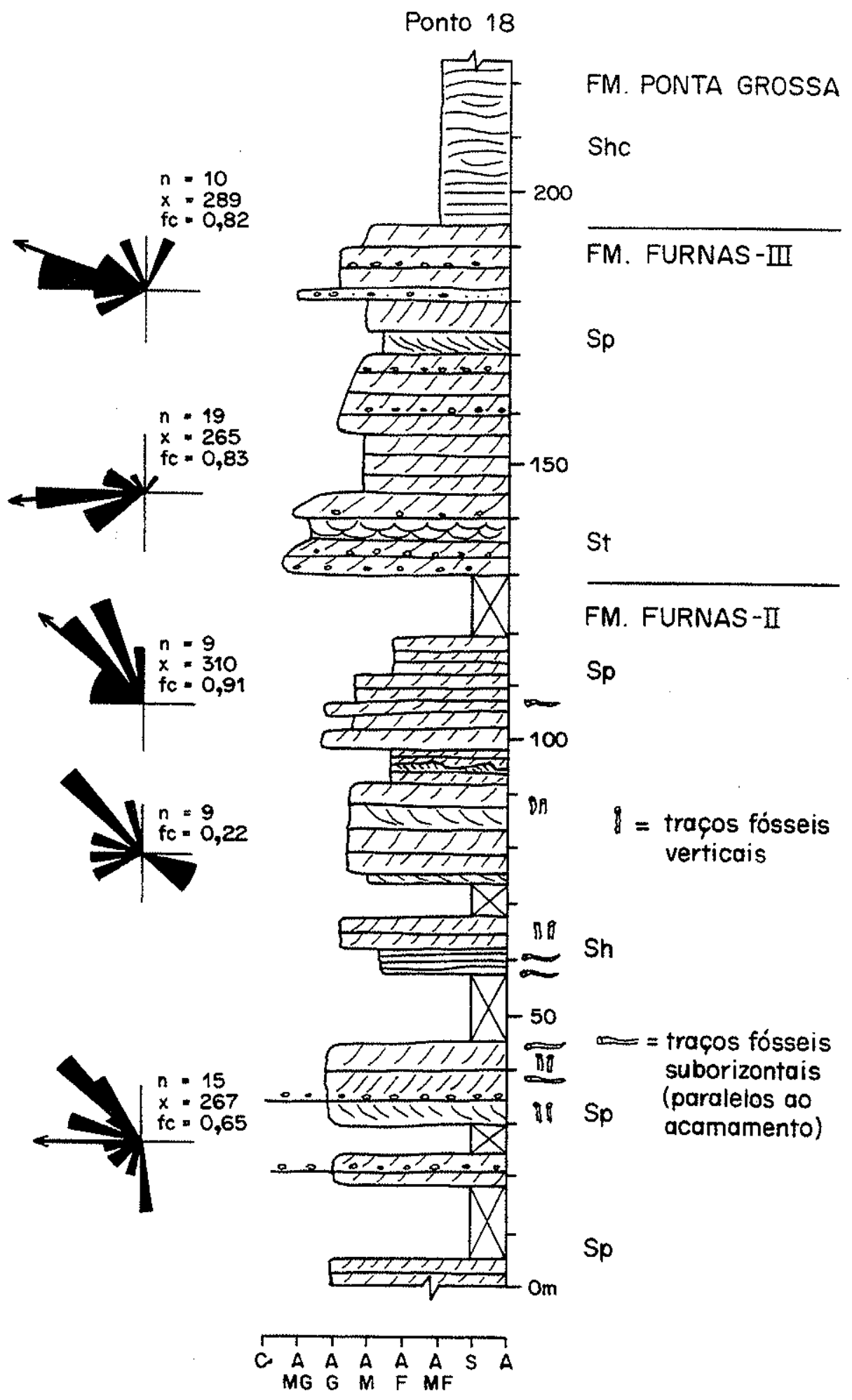

Figura 44 - Seção colunar da Fm. Furnas no mirante do morro do Cristo Redentor, em Barra do Garças-MT. 
A -

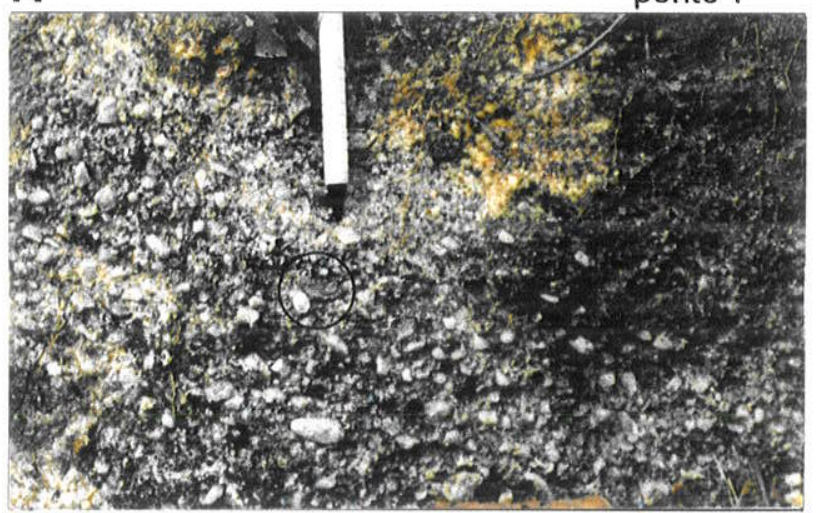

C -

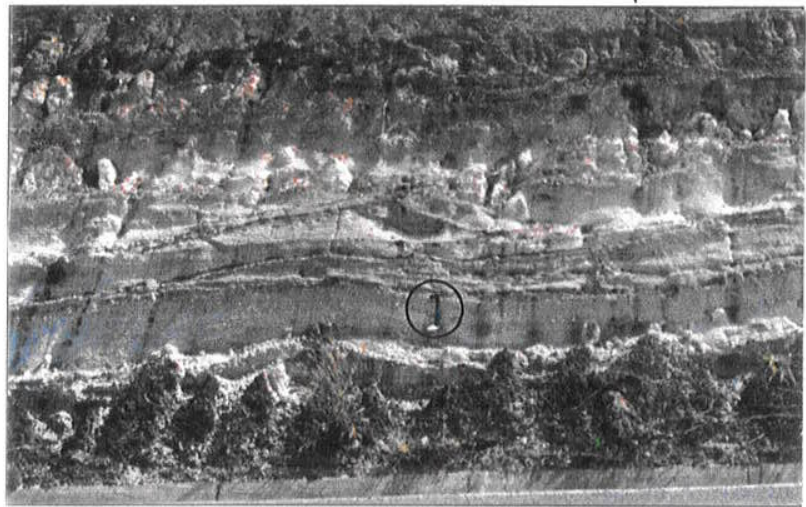

E -
B -

ponto 2

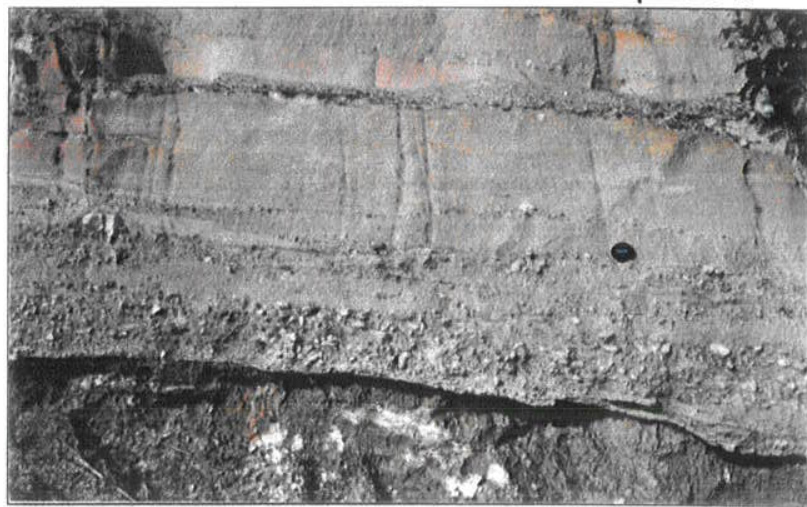

D -

ponto 2

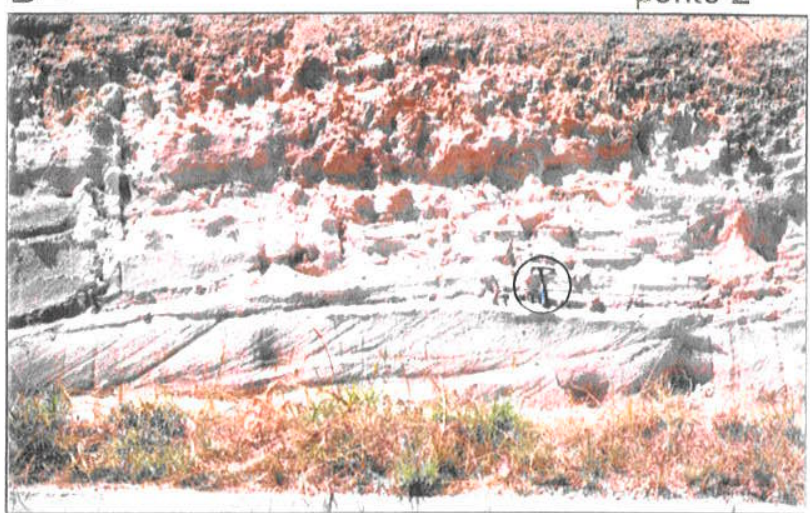

ponto 5

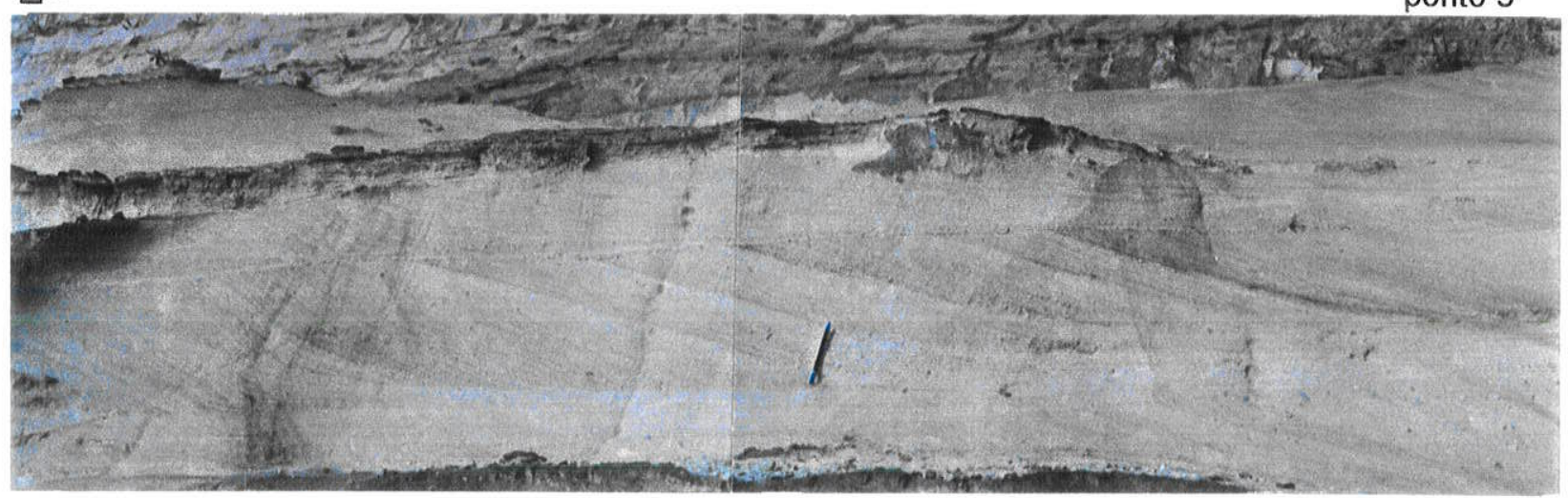

F ponto 5

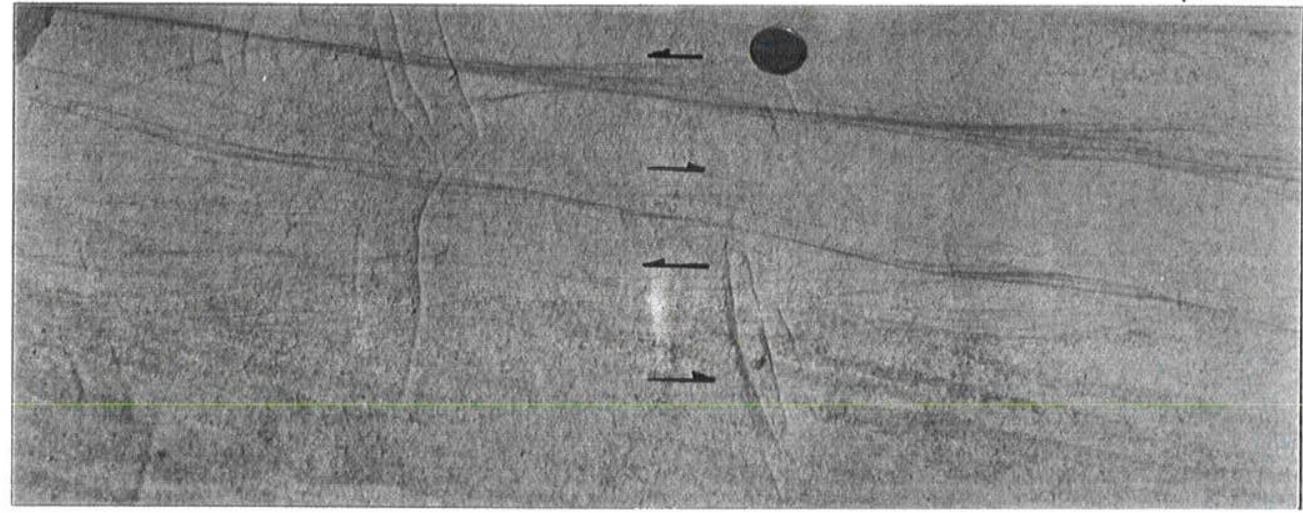

Figura 45 - Fácies da Fm. Furnas nas faixas de afloramento dos flancos norte e noroeste da bacia. Conglomerado basal com clastos (em destaque) do folhelho Vila Maria (A). Na região de Amorinópolis-GO, a Fm. Furnas inicia-se com um delgado conglomerado basal (B), que é sobreposto por sets de arenitos com estratificação cruzada, cujos topos são ondulados e pavimentados por seixos e calhaus (C/D). Arenitos finos a muito grossos com variação granulométrica cíclica nas camadas frontais (E) e laminação cruzada com sentido oposto ao fluxo principal, ressaltada por filmes de argila (F). 

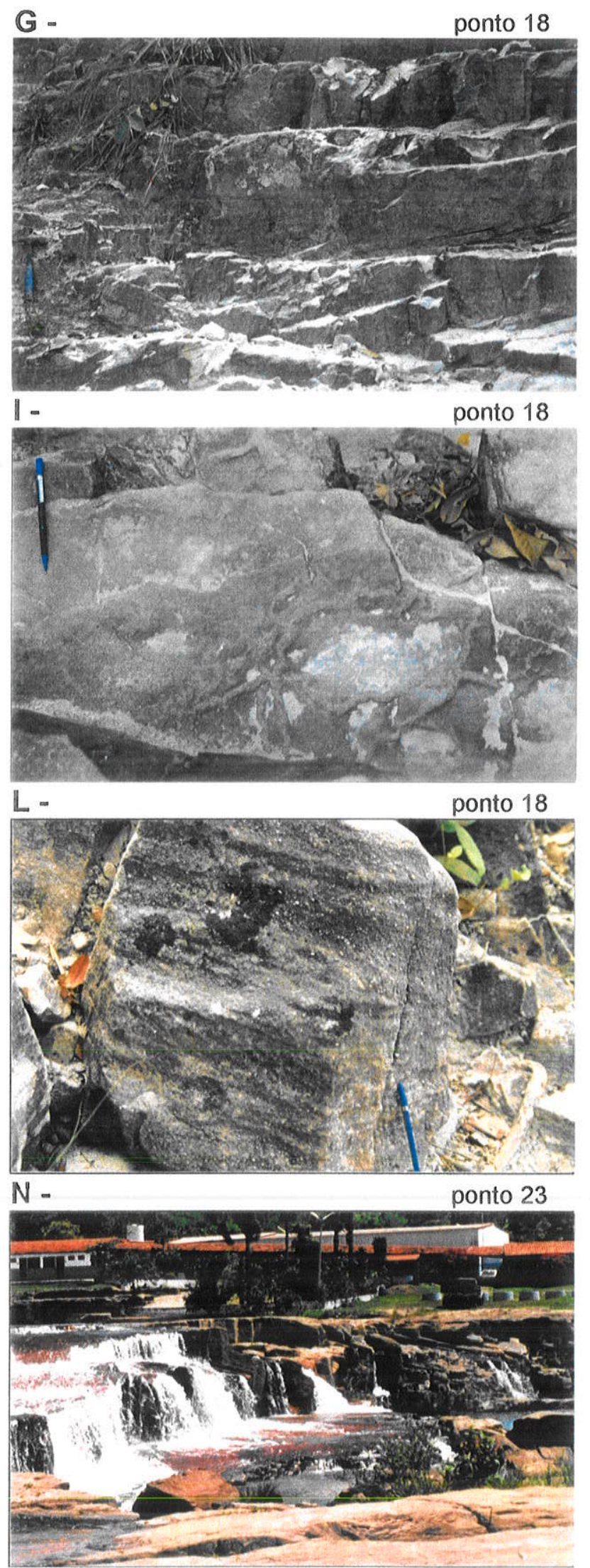

H-

ponto 18
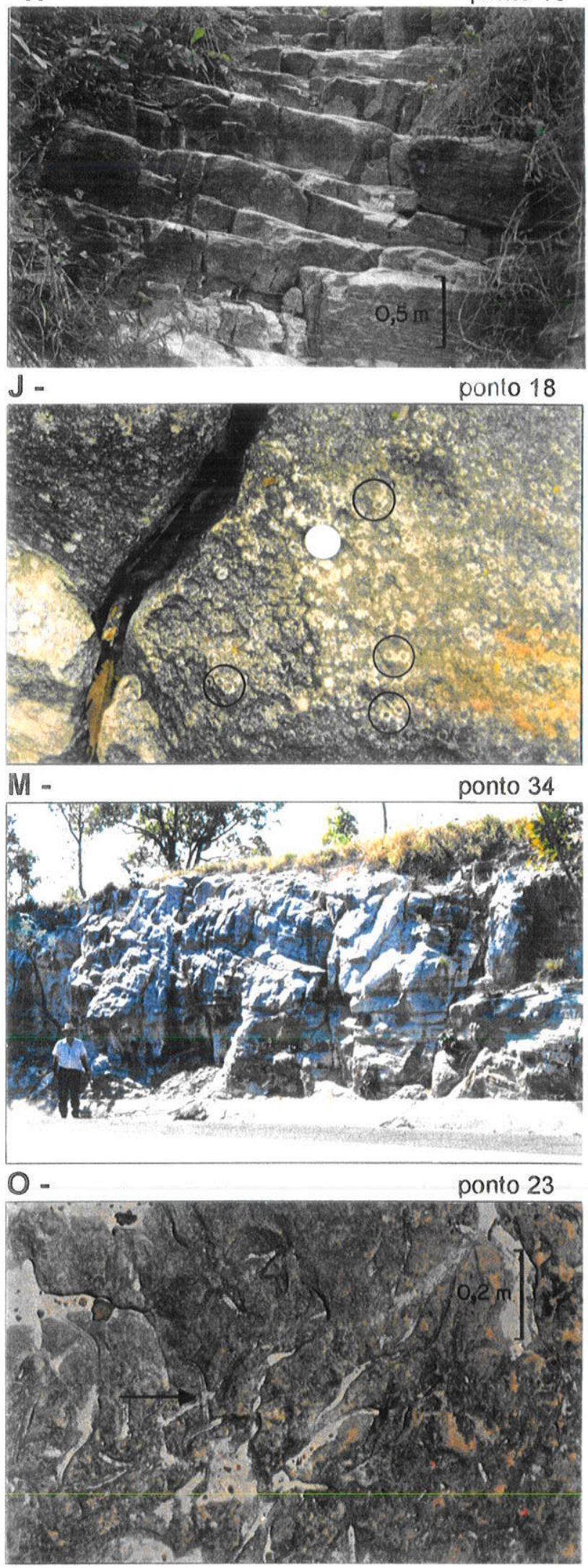

Figura 45 - Fácies da Fm. Furnas nas faixas de afloramento dos flancos norte e noroeste da bacia (continuação). Na seção do morro do Cristo, no topo de sets de arenitos com estratificação cruzadas da unidade II $(\mathbf{G} / \mathrm{H})$ ocorrem icnofósseis paralelos $(\mathrm{I})$ e perpendiculares ao acamamento $(\mathrm{J}=$ Arenicolites em destaque); a passagem para a unidade III é marcada por aumento brusco na granulometria (L). Sets de até $3 \mathrm{~m}$ de espessura, com estratificação cruzada tabular e/ou acanalada $(\mathrm{M} / \mathrm{N})$, por vezes com traços fósseis bilobados no topo (O), em afloramentos no flanco noroeste. 
locais, as espessuras diminuem progressivamente de oeste para leste na faixa de afloramentos no Estado de Goiás, desaparecendo na altura de Amorinópolis, conseqüência de erosão e truncamento no topo com a ativação do Arco Paranaíba no Emsiano (discussão nos itens 6.2.4 e 6.3.2).

No flanco noroeste não foi encontrado nenhum ponto em que pudesse ser levantada uma seção estratigráfica vertical representativa da unidade. Uma série de dados permite, entretanto, considerar factível a subdivisão reconhecida no restante da bacia. Arenitos muito grossos e níveis conglomeráticos típicos da unidade I ocorrem no ponto 30, logo acima do contato com o Gr. Rio Ivaí (Fig. 11-C). Níveis sílticos com icnofósseis horizontais associados ocorrem no ponto 29 , em fácies semelhantes às da unidade II. Depósitos residuais de cascalho formando pavimentos planares e extensos, similares aos da unidade III, foram observados nos pontos 28 e 34 . Além disso, as mesmas assinaturas em perfis de raios-gama podem ser observadas no perfil do poço 2-CG-1-MS (Campo Grande), o único, perfurado nas proximidades, em que se dispõe de perfis geofísicos. É importante registrar que no flanco noroeste a unidade apresenta algumas diferenças sutis, como porcentagens maiores de arenitos finos e a presença mais constante de estratificações cruzadas de baixo ângulo com truncamento por ondas (pontos 21, 29 e 35).

Do exposto conclui-se que a Fm. Furnas apresenta características litológicas similares e padrão de empilhamento estratigráfico vertical reconhecível em praticamente toda a bacia. Em apenas uma área, a da chapada dos Guimarães, foram observadas características faciológicas particulares e empilhamento destoante. A compreensão da estratigrafia desta área específica requer o tratamento integrado com a Fm. Ponta Grossa, o que será discutido no item 6.2.3.2.

\subsection{2- Paleocorrentes}

Com base na subdivisão efetuada, os diferentes afloramentos do flanco sudeste puderam ser posicionados estratigraficamente, o que permitiu a discriminação, em mapa, dos dados de paleocorrentes segundo as três unidades. Tal procedimento permitiu reavaliar os dados de Bigarella et al. (1966), que foram também discriminados segundo as unidades identificadas. Em estações de medida com claros padrões bimodais oblíquos ou bipolares, a média não foi considerada por não ter significado geológico, conforme discutido no item 4.3. 
A discriminação das paleocorrentes segundo as três unidades permitiu verificar que os padrões são distintos: a) a unidade I apresenta padrão predominantemente unimodal, com paleofluxo principal para oeste (Fig. 46); b) na unidade II, o padrão também é unimodal, mas com sentido de transporte nitidamente para sudoeste (Fig. $47)$; c) padrões bimodal/bipolar a polimodal de sentidos variáveis (cruzadas tabulares planares) e unimodal para sul (cruzadas acanaladas) caracterizam a unidade III (Fig. 48).

Os dados levantados na unidade I na faixa de afloramentos do flanco noroeste apresentam padrão unimodal para noroeste (Fig. 49), mas foram levantados poucos dados em apenas duas estações. Embora os dados não sejam estatisticamente significantes, os paleofluxos similares aos do flanco norte sugerem condições semelhantes para as duas áreas quando da deposição dos psamitos/psefitos da base da Fm. Furnas. As paleocorrentes nas unidades II e III, consideradas em conjunto, mostram grande variação azimutal de valores, definindo padrões diversos, desde unimodais para oeste até polimodais. Embora os dados mostrem grande dispersão de valores, um transporte principal para oeste é evidente.

Paleocorrentes levantadas na faixa de afloramentos do flanco norte (Fig. 50) indicam padrões predominantemente unimodais na unidade $\mathrm{I}$, com fluxo principal também para noroeste. $O$ mesmo padrão unimodal para noroeste foi verificado para as unidades II e III.

\subsection{3- Icnofósseis}

Embora ainda não tenham sido encontrados organismos ou moldes fósseis (body fossils) na Fm. Furnas, os icnofósseis são abundantes. Ciguel \& Aceñolaza (1986) relataram a ocorrência de uma grande diversidade de formas, ainda não detalhadamente estudadas. Predominam amplamente formas suborizontais paralelas ao acamamento, ao passo que as formas verticais têm ocorrência subordinada (Fig. 51).

Traços fósseis paralelos ao acamamento ocorrem principalmente na unidade II. Constituem formas em epi-relevo côncavo e/ou convexo, desenvolvidas nas superfícies de topo de cosets de arenitos com estratificação cruzada. A preservação é melhor quando tais superfícies são recobertas por lâminas ou camadas de siltitos.

Traços sinuosos e estreitos ( 1 a $2 \mathrm{~cm}$ de largura), dos icnogêneros Paleophycus e Planolites, são os mais comuns. São atribuídos a organismos vermiformes, que se 


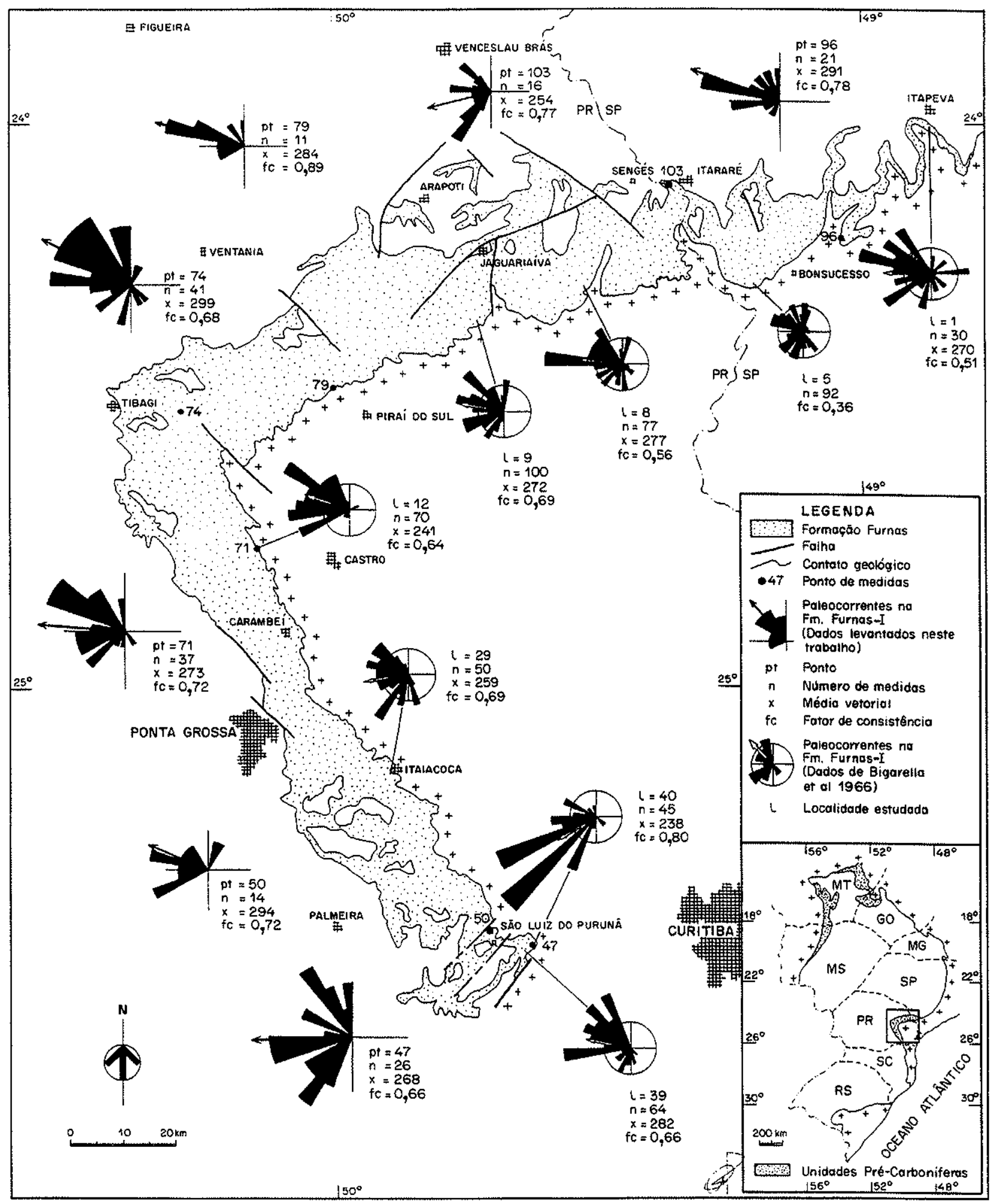

Figura 46 - Paleocorrentes na unidade I da Fm. Furnas na faixa de afloramentos do flanco sudeste. 


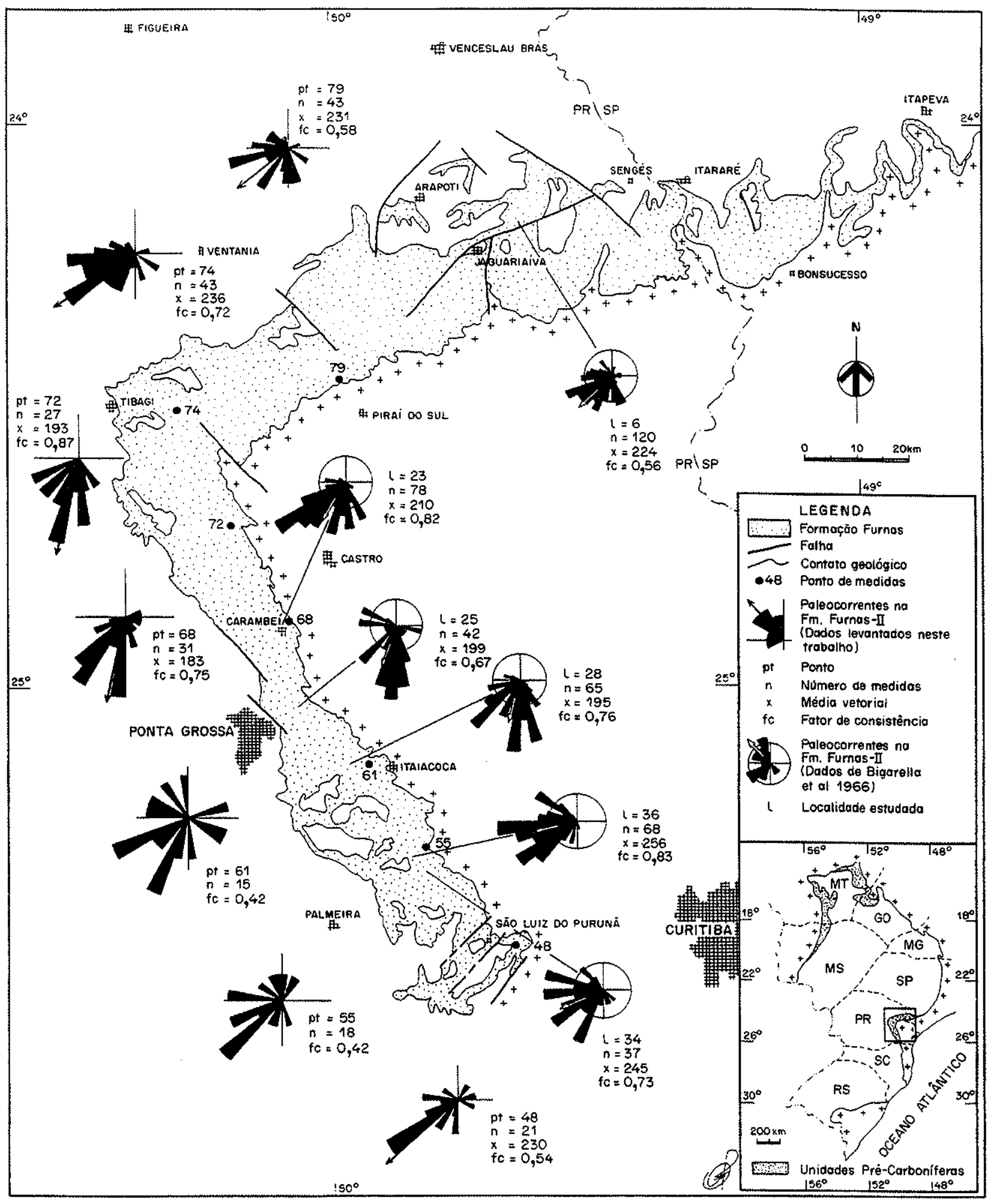

Figura 47 - Paleocorrentes na unidade II da Fm. Furnas na faixa de afloramentos do flanco sudeste. 


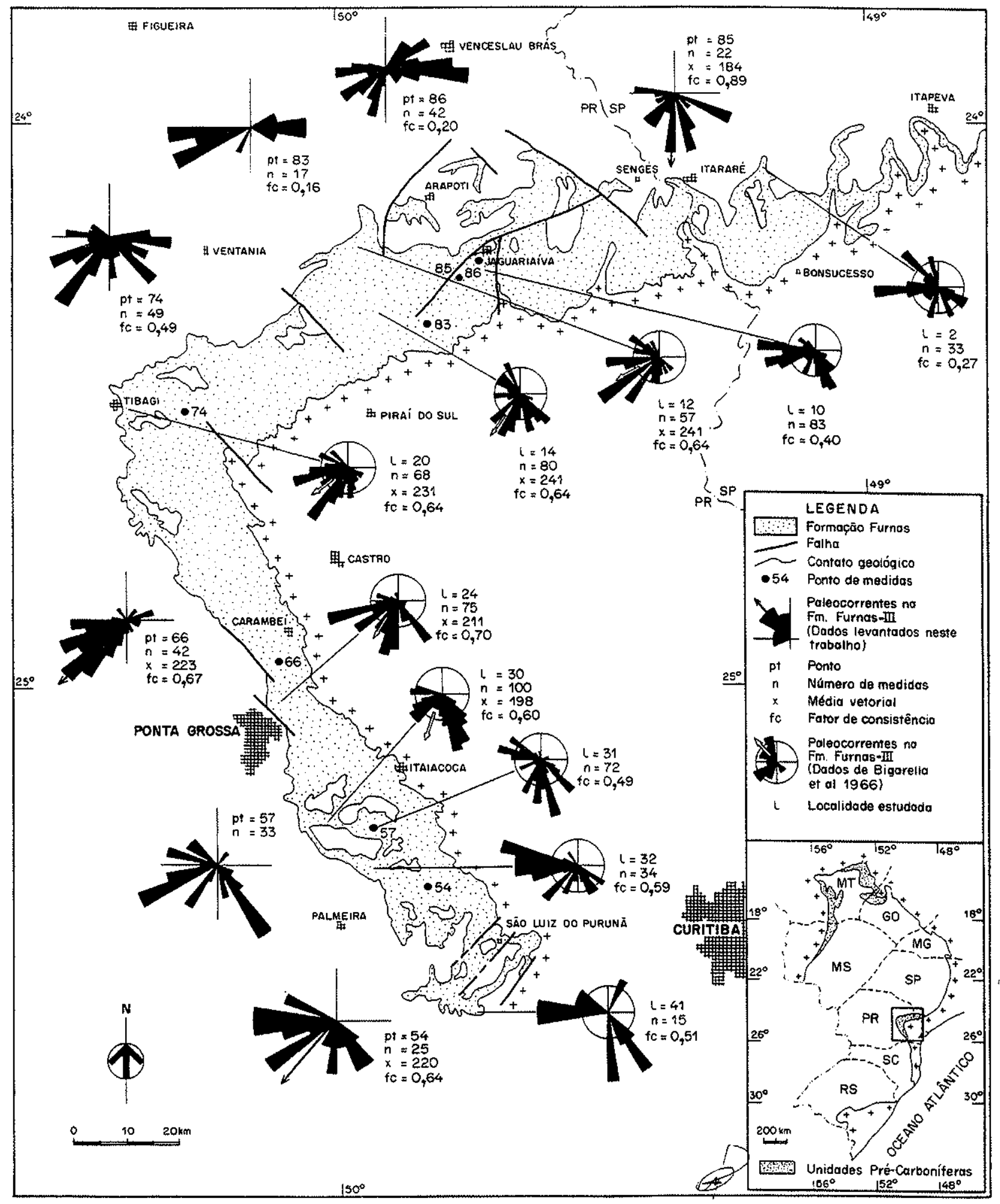

Figura 48 - Paleocorrentes na unidade III da Fm. Furnas na faixa de afloramentos do flanco sudeste. 


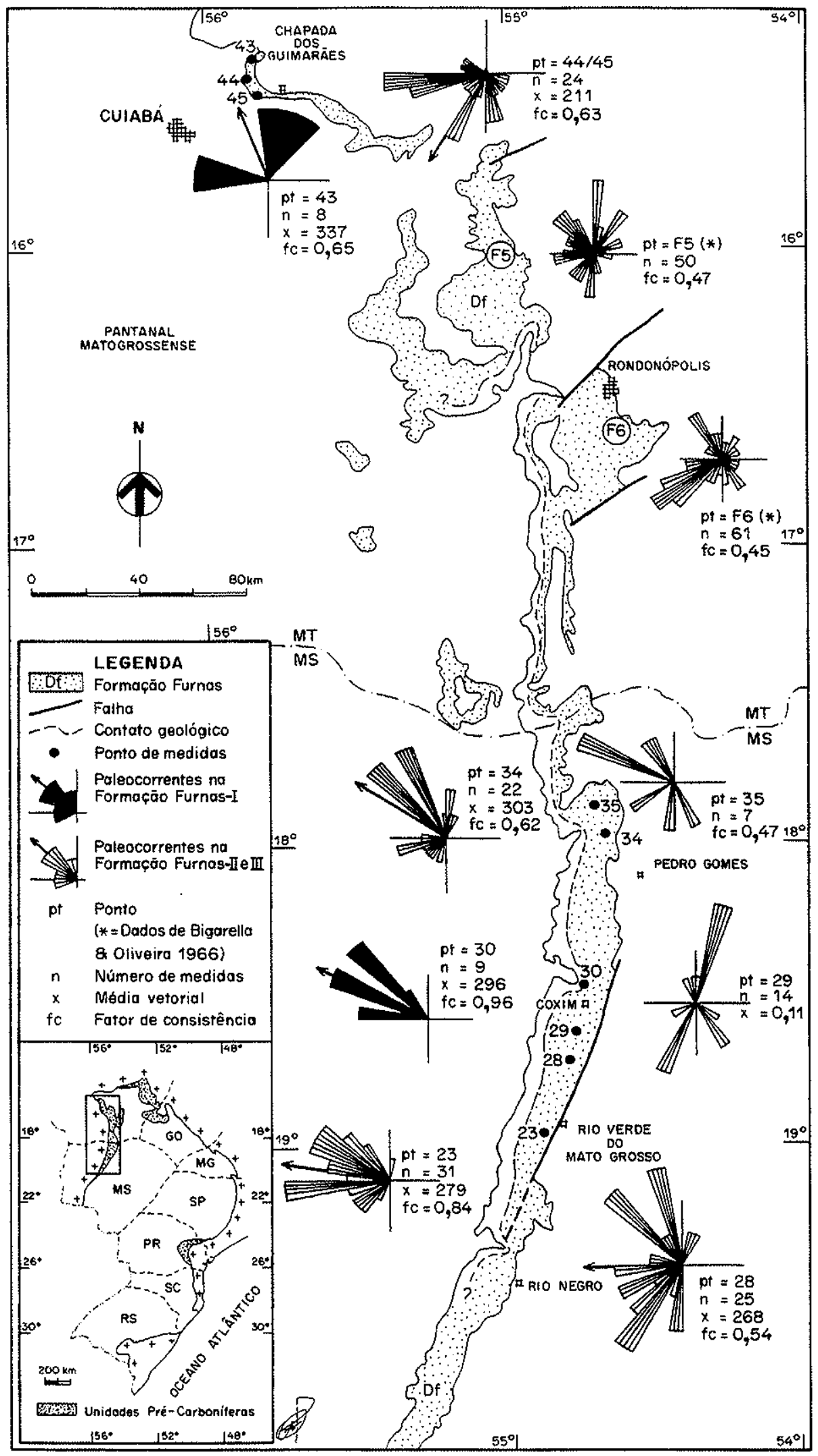

Figura 49 - Paleocorrentes na Fm. Furnas na faixa de afioramentos do flanco noroeste. 


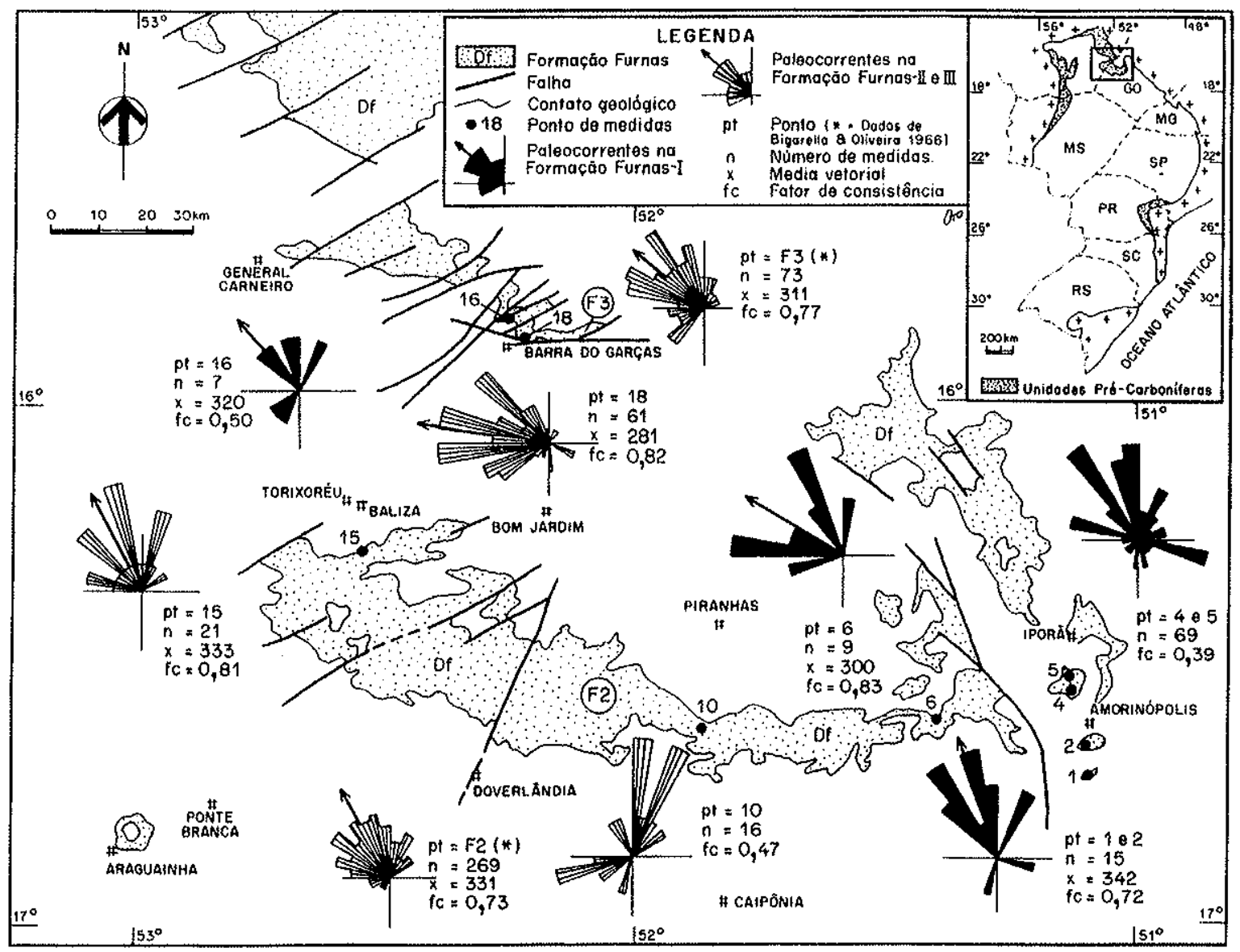

Figura 50 - Paleocorrentes na Fm. Furnas na faixa de afloramentos do flanco norte.

locomoviam através do fundo. Estes traços de deslocamento e/ou alimentação são muito abundantes em alguns níveis, encontrando-se presentes sobretudo no topo de cosets, mas foram observados também em algumas camadas frontais de estratos cruzados, indicando hábitos oportunistas.

Os icnofósseis encontram-se melhor preservados em litologias de granulometria fina, mas a natureza do substrato não é fator limitante, tendo sido observados traços fósseis horizontais até mesmo em níveis conglomeráticos (Fig. $51-\mathrm{G} / \mathrm{H}$ ).

Em vários afloramentos, além dos icnogêneros Paleophycus e Planolites, foram constatados traços bilobados (Fig. 52-A). Traços bilobados de formas grosseiramente elipsoidais e com largura de 0,5 a 2,0cm foram interpretados como Rusophycus (Fig. 52-B). Freqüentemente apresentam-se bilobados em apenas uma das extremidades, têm perfil vertical assimétrico, mais profundo do lado não bilobado, orientando-se, em 

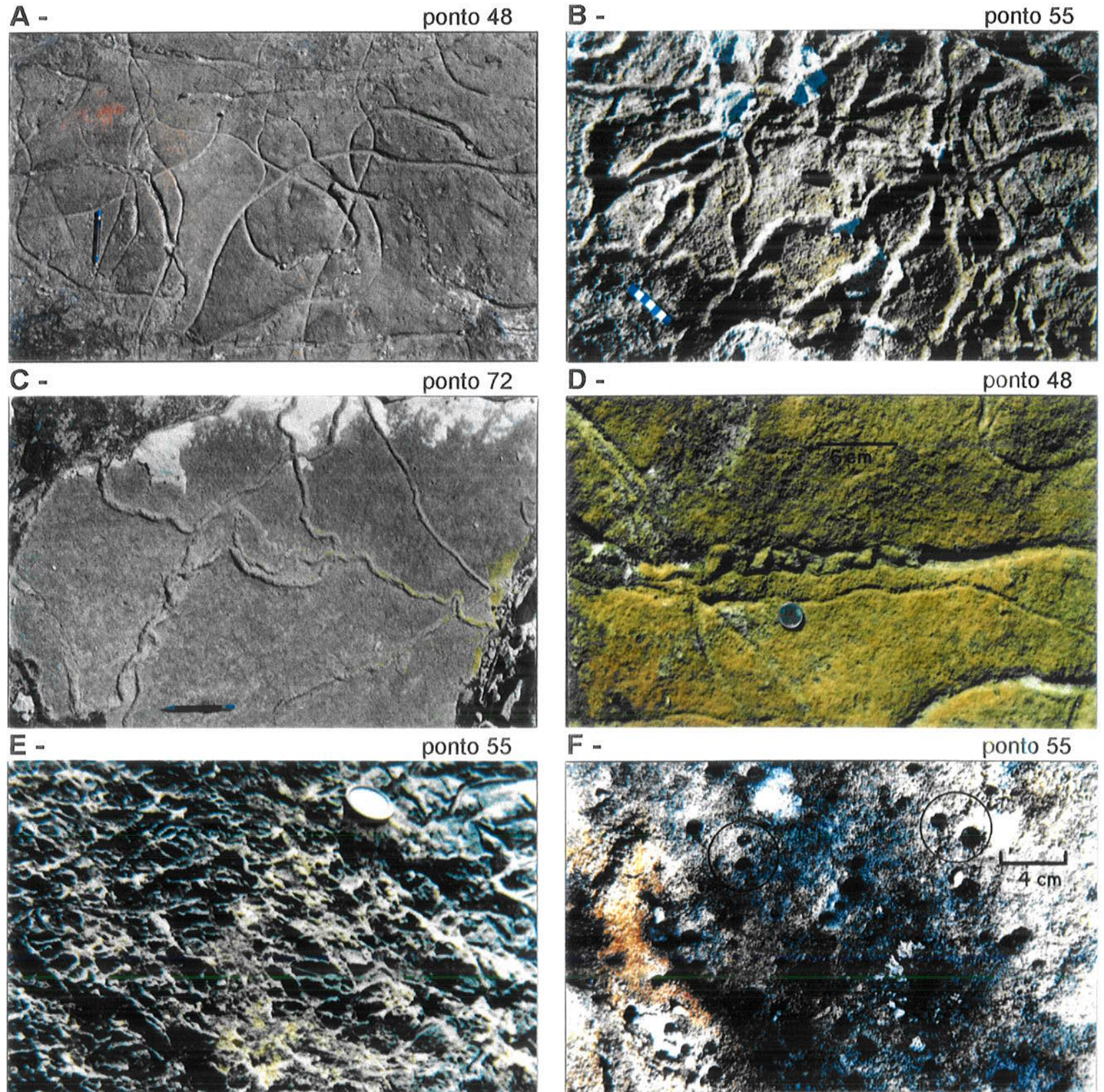

G -

ponto 23

$\mathrm{H}$ -

ponto 55
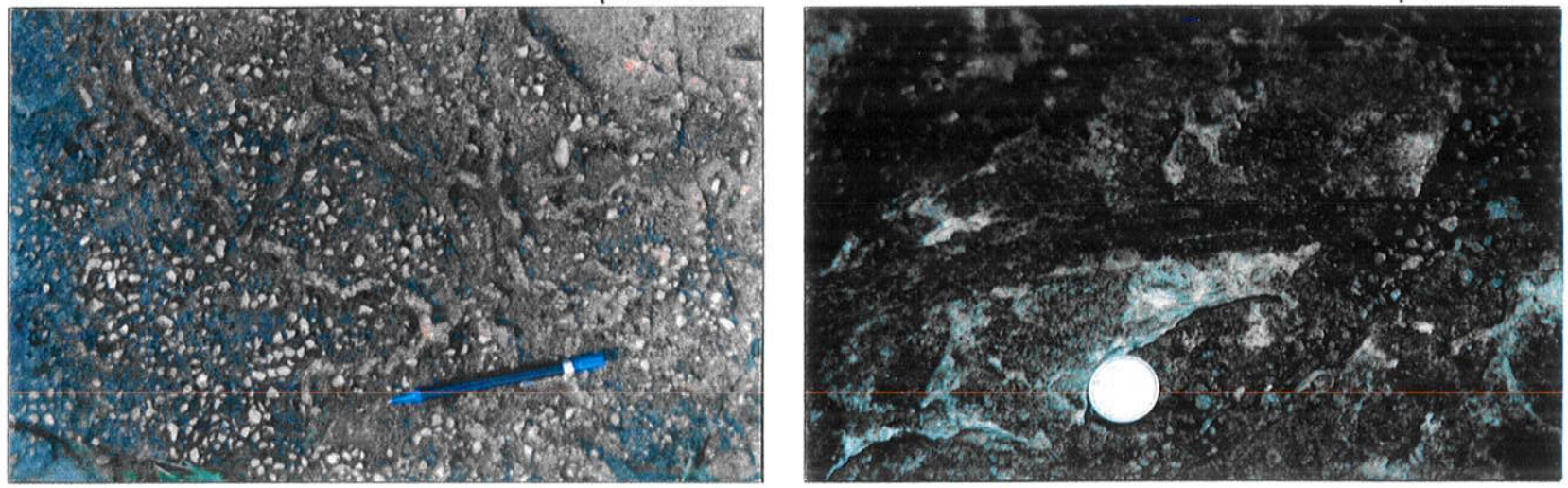

Figura 51 - Icnofósseis na Fm. Furnas. Pistas de deslocamento e/ou alimentação, paralelas ao acamamento (A), são as mais comuns na Fm. Furnas, incluindo os icnogêneros Paleophycus $(\mathbf{B}=$ escala em centímetros) e Planolites (C/D). Em alguns casos a bioturbação é tão intensa que forma trama biogênica complexa $(E=$ escala tem $6 \mathrm{~cm})$. Fomas verticais, como Arenicolites $(F=$ plano de acamamento), ocorrem subordinadamente. Os icnofósseis ocorrem até mesmo em niveis conglomeráticos $(\mathrm{G} / \mathrm{H})$. 

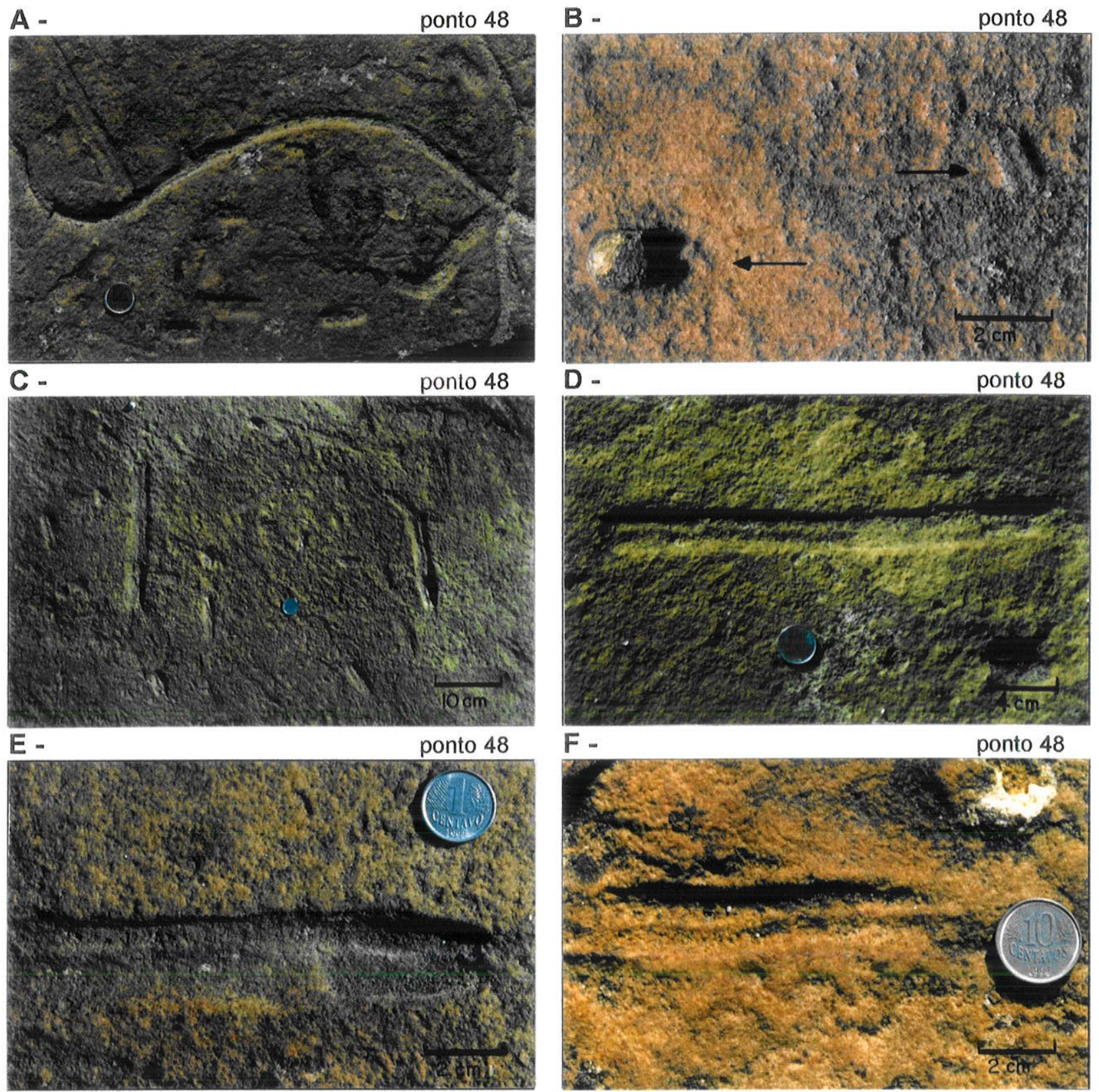

G -

ponto 29

$\mathrm{H}$

ponto 67
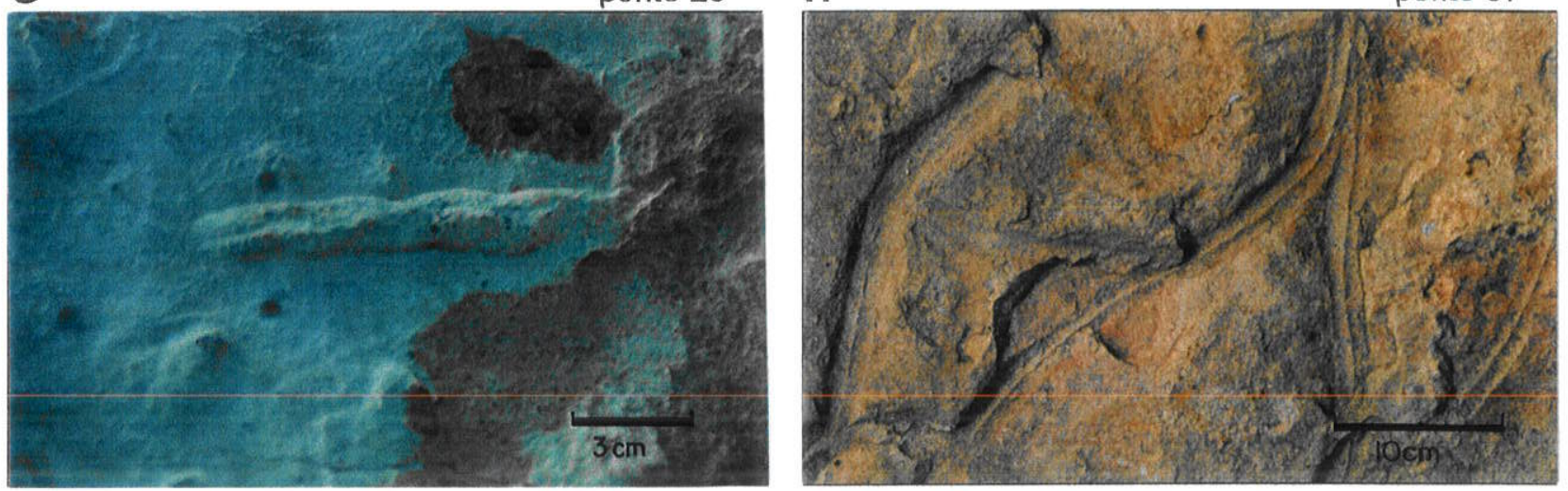

Figura 52 - Traços fósseis de trilobita na Fm. Furnas. A associação inclui traços bilobados (A). Detalhe de traços bilobados do icnogênero Rusophycus (B). Rusophycus conectados por traços bilobados lineares de deslocamento do icnogênero Cruziana (C/D/E). Cruziana em epi-relevo côncavo, desenvolvida sobre substrato de arenito grosso (F). Cruziana em hipo-relevo convexo, onde estão preservados detalhes como estrias transversais (G). Nos traços bilobados sinuosos, que vem sendo classificados como Didymaulichnus $(\mathrm{H})$, tênues estrias transversais foram observadas em alguns casos.

INSTITUTO DE GEOCIENCIAS - USP INSTIIUTU LE GLU........ - u 
alguns casos, paralelamente à corrente. A presença do icnogênero Rusophycus se reveste de grande importância paleoambiental, pois este traço fóssil é considerado uma marca de repouso de trilobitas.

Traços bilobados lineares retilíneos foram constatados em alguns afloramentos. Apresentam larguras similares às dos Rusophycus, estando em muitos casos a eles associados (Fig. 52-C). Há, mesmo, exemplos de traços curtos e mais profundos de Rusophycus conectados por traços bilobados lineares menos profundos (Fig. 52-D/E). Isto demonstra que ambos os traços foram construídos pelo mesmo organismo, permitindo considerar tais traços como pertencentes ao icnogênero Cruziana, embora não exibam a órnamentação nos lóbulos característica deste icnogênero. Pistas longitudinalmente convexas, típicas do icnogênero Cruziana também foram constatadas, porém normalmente sem apresentar estrias transversais, cuja preservação é difícil devido à natureza do substrato, muitas vezes arenoconglomerática (Fig. 52-F). Nos casos de pistas desenvolvidas sobre substrato síltico, situação em que os traços apresentam-se na base de camadas arenosas em hiporelevo convexo, o grau de preservação é maior, sendo visíveis as estrias de deslocamento produzidas pelos endopoditos (Fig. 52-G).

Mais comuns são traços bilobados lineares e sinuosos, sem ornamentação nos lóbulos. Foram descritos pela primeira vez na Fm. Furnas por Lange (1942), que os denominou Fraena furnai. Posteriormente, Lange \& Petri (1967) referiram-se a eles como Rouaultia furnai, não apresentando os motivos que os levaram à mudança na sistemática. Fernandes \& Guimarães Neto (1985) e Ciguel \& Aceñolaza (1991), em breves comunicações, reinterpretaram-nos como traços de deslocamento pertencentes ao icnogênero Didymaulichnus. Alguns apresentam tênues estrias transversais de deslocamento (Fig. 52-H), ficando a possibilidade de poderem ser classificados também como Cruziana. Estudos mais detalhados são necessários para elucidar a questão.

\subsection{4- Paleoambientes de sedimentação}

As litofácies de arenitos grossos a muito grossos, a onipresença de sets com estratificações cruzadas, a presença de níveis de conglomerados, a pobreza em fácies pelíticas, a não constatação de organismos fósseis e, mesmo, a ausência de glauconita (Zalán et al. 1987a), têm-se constituído em critérios e argumentos que muitos pesquisadores têm utilizado para a adoção de um modelo de fácies fluvial 
entrelaçado (braided) como paleoambiente deposicional da Fm. Furnas. Soma-se a isso a inexistência de ambientes de sedimentação modernos que possam servir de modelo deposicional para uma interpretação marinha.

Alguns atributos caracterizados na análise de fácies realizada, somados a uma série de argumentos, como a grande extensão geográfica e a uniformidade litológica destacadas por Petri \& Fúlfaro (1983), permitiram a interpretação de tratos deposicionais predominantemente marinhos para a maior parte da unidade. Em primeiro lugar, o paradigma de que arenitos grossos e cascalhos nas plataformas continentais são depósitos relictos demonstrou-se inconsistente com os novos dados de geologia marinha, que evidenciaram sedimentos em trânsito ao sabor das correntes, produzindo toda uma gama de formas de leito, como as grandes cadeias arenosas (sand ridges) na plataforma atlântica da América do Norte. Trabalhos, como os de Nemec \& Steel (1984) e de Phillips (1984), têm evidenciado origem marinha para fácies psamítico-psefíticas com estratificação cruzada, freqüentemente interpretadas como fluviais.

Arenitos grossos com estratificação cruzada e alguns niveis conglomeráticos são, da mesma forma que em ambientes fluviais entrelaçados, as litologias dominantes em seqüências marinhas transgressivas. Ao contrário dos sistemas marinhos regressivos, as plataformas marinhas transgressivas são freqüentemente pavimentadas com areia média a muito grossa, que podem se estender até a borda da plataforma (Swift et al. 1986). Neste material, correntes de maré, oceânicas ou geostróficas (derivadas de fluxos concomitantes com tempestades segundo Snedden \& Swift 1991) geram grandes barras arenosas (sand ridges) através da superposição de dunas e sandwaves, produto da atuação de correntes durante muitos séculos. Estas formas de leito formam relevos de fundo significativos, da ordem de dezenas de metros de altura, sendo derivadas de correntes de fundo orientadas paralelamente à costa ou ligeiramente obliquas no sentido costa-afora (offshore). Disto se conclui que a presença de conglomerados e arenitos grossos a muito grossos com estratificação cruzada não constitui critério que permita distinguir fácies fluviais de marinhas.

Ressalta-se ainda que a paleolatitude era alta ao tempo da deposição da Fm. Furnas, fato já destacado por Maack (1950-51), e que as plantas vasculares apenas iniciavam a colonização dos continentes. Estes dois fatos foram responsáveis pelo predomínio do intemperismo mecânico no continente, por altas taxas de denudação e por grande disponibilidade de clásticos grossos na plataforma continental, com a conseqüente pobreza em sedimentos finos. Plataformas continentais em altas latitudes 
são caracterizadas pelo predominio de areias e cascalhos mesmo nos dias atuais (Hayes 1967).

Ambientes oxidantes e com alto afluxo terrígeno, como os que se interpreta para a Fm. Furnas, são inibidores para a formação de glauconita autigênica (Van Houten \& Purucker 1984). Isto mostra que sua ausência não é argumento que corrobore a interpretação de uma origem fluvial. Ademais, o intervalo Siluriano superior/Devoniano inferior é mundialmente desfavorável à acumulação de glauconita (Odin 1982).

A pobreza em estratificações cruzadas hummocky, típicas de sistemas costeiros regressivos e marinhos plataformais dominados por ondas, não deve ser usada como argumento contrário a uma origem marinha. Tal afirmativa deve-se ao fato de que a própria natureza granulométrica dos arenitos e conglomerados da Fm. Furnas é um fator limitante à formação de tais estruturas, que têm sido mundialmente registradas somente em litologias de granulometria no máximo areia média inferior (Duke 1990, Swift et al. 1991). Em areias mais grossas e conglomerados, as ondas produzem estratificação cruzada ou camadas gradadas (Fig. 53).

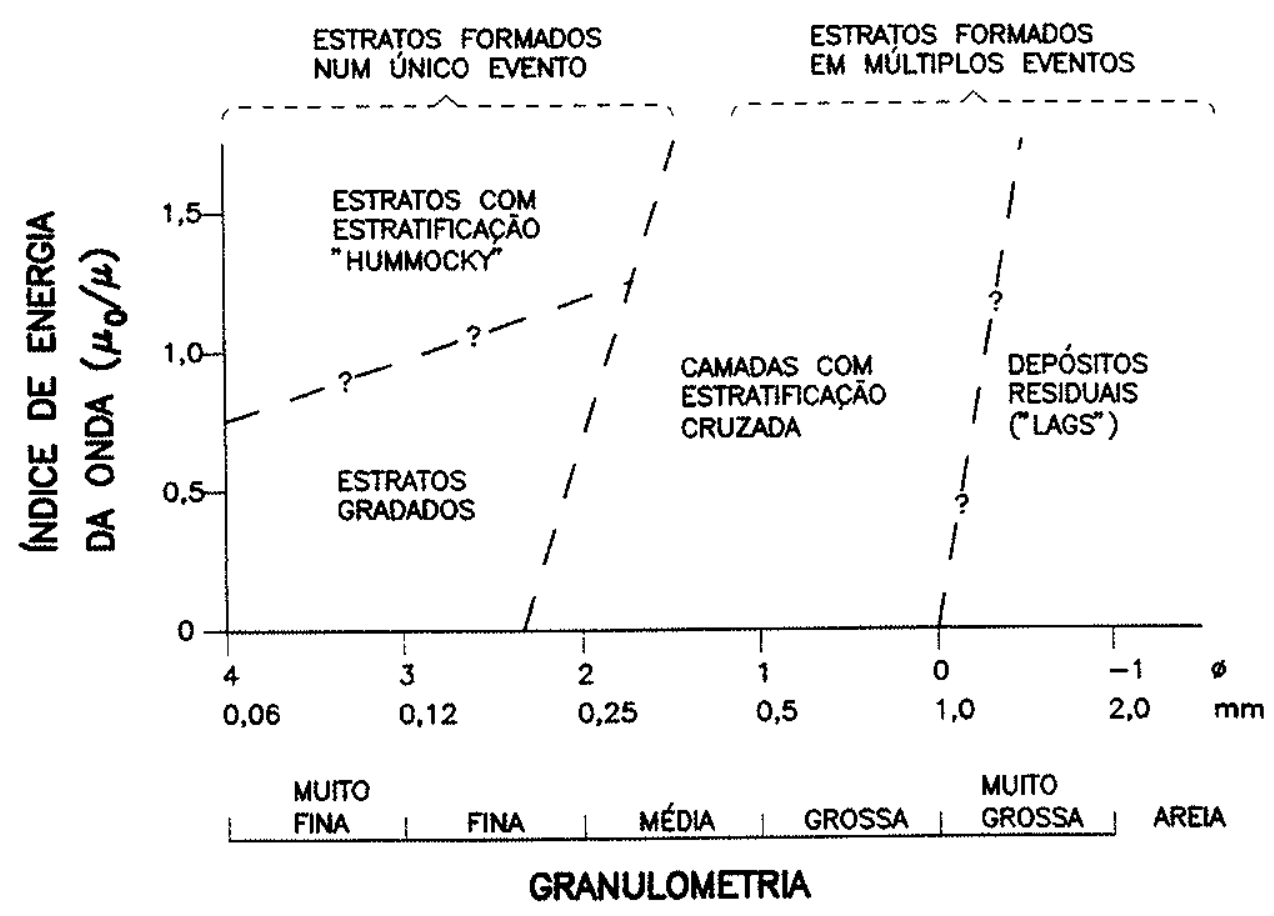

Figura 53 - Estruturas sedimentares geradas pela ação de ondas em substratos com diferentes granulometrias (Swift et al. 1991) ( $\mu_{0}=$ velocidade orbital máxima da onda; $\mu=$ velocidade média de propagação). 
Da análise dos elementos arquiteturais de fácies, verificou-se que a geometria dos litossomas é caracterizada pela tabularidade das camadas, sendo subordinada a existência de formas canalizadas e estruturas de corte e preenchimento. Com exceção daqueles da unidade $\mathrm{I}$, os conglomerados apresentam considerável continuidade lateral e geometria planar, numa relação extensão lateral /espessura muito alta, o que de acordo com Clifton (1973) é uma característica de sedimentos marinhos.

Análise mais detalhada dos padrões de paleocorrentes indicou que, no mínimo, existe contraste bem marcado nos padrões das três associações identificadas. Em alguns pontos na associação II, mas principalmente na associação III, são evidentes padrões bipolares, freqüentemente oblíquos, que indicam correntes com sentidos opostos de fluxo, sugerindo a atuação de marés.

Por fim, se ainda não foram constatados organismos fósseis, icnofósseis são comuns na maior parte da unidade. A presença dos icnogêneros Rusophycus e Cruziana, traços fósseis atribuídos a trilobitas, constitui um elemento decisivo na interpretaçäo paleoambiental, pois atesta uma origem marinha para os estratos onde ocorrem. A associação com outros traços horizontais é característica da icnofácies Cruziana, que batimetricamente tem sido considerada típica de ambiente marinho sublitoral, entre os niveis de base das ondas de bom tempo e de tempestade (Seilacher 1967; Frey \& Pemberton 1984).

UNIDADE 1 As camadas conglomeráticas da base da formação são interpretadas como depósitos de fluxo em lençol não confinado (sheet flood) em planícies aluviais costeiras, com deposição direta sobre um embasamento plano, sem evidências de vales incisos. Os conglomerados basais não ocorrem em todos os locais, como salientado anteriormente por Bigarella et al. (1966), evidenciando pontos principais de afluxo (braided deltas), lateralmente contíguos a outros ambientes costeiros onde interagem processos aluviais e marinhos litorâneos.

Em algumas rosetas podem ser observadas correntes para SE (Fig. 46), evidenciando influência marinha já na parte inferior da unidade, dado pelo retrabalhamento dos sedimentos das planícies aluviais costeiras. Isto é corroborado pela existência de icnofósseis a menos de $3 \mathrm{~m}$ do contato com o embasamento nos pontos 50,71 e 92, em meio a arenitos conglomeráticos e conglomerados.

As paleocorrentes nas fácies desta associação mostram sentido de fluxo principal para oeste na porção sul (Fig. 46) e NW na porção norte da bacia (Figs. 49 e $50)$, indicando continente a leste. 
UNIDADE \| É caracterizada pela icnofácies Cruziana, que indica condições marinhas sublitorais. O fluxo neste ambiente de plataforma foi de natureza intermitente, sendo responsável pelas superficies de reativação que limitam os sets e abundantes intraclastos síltico-argilosos em alguns níveis. Os traços fósseis, preservados nas superfícies de topo dos cosets arenosos, materializam períodos de menor energia, com diminuição acentuada ou mesmo paradas temporárias no transporte sedimentar, quando o substrato arenoso tornou-se mais estável e foi habitado por organismos que, deslocando-se por sobre a superfície de fundo, produziram abundantes pistas horizontais e extensos pavimentos bioturbados.

A cessação das correntes em muitos casos fica evidente uma vez que as superfícies mais representativas e extensas de icnofósseis são recobertas por camadas de siltitos e/ou folhelhos esbranquiçados e/ou esverdeados, que podem, em alguns casos, ter mais de 1,0m de espessura. A ausência de feições de exposição, tais como gretas de ressecação, corrobora a interpretação de condições sub-maré.

Os arenitos com estratificação cruzada formaram-se por transporte trativo de fundo, gerado por correntes marinhas. Paleocorrentes, conspicuamente dirigidas para SW no flanco sudeste da bacia, são interpretadas como produzidas por correntes paralelas à costa (alongshore currents), como já o fizeram Bigarella et al. (1966) e Bigarella \& Salamuni (1967). Há muitos exemplos de plataformas marinhas com correntes paralelas à costa, como o trato deposicional dos arenitos do Mb. Shannon do Campaniano do Meio-Oeste dos EUA, analisado em Parrish et al. (1984). Correntes marinhas paralelas à costa, em contextos oceanográficos diversos, são predominantes também em uma série de exemplos atuais, como no Mar do Norte, na Baía de Hudson no Canadá, na costa leste norte-americana e na costa sudeste da África do Sul (Johnson \& Baldwin 1986).

$\mathrm{Na}$ porção norte da bacia predominam correntes dirigidas para costa-afora, tendo portanto o mesmo sentido de transporte sedimentar dos sedimentos costeiros da unidade I. Situações similares foram constatadas em várias plataformas atuais e em unidades antigas (Leckie \& Kristinick 1989).

A natureza das correntes não pôde ser definitivamente estabelecida, mas alguns elementos indicam a atuação de correntes de maré (Fig. 54), que segundo Klein (1982) constituem os processos dominantes em extensas plataformas cratônicas invadidas por águas marinhas durante as transgressões. Correntes de maré têm capacidade de transportar areias muito grossas e até mesmo seixos, que podem se depositar nas camadas frontais (foresets) dos estratos cruzados ou formar depósitos residuais (lags) entre os sets (Banks 1973, Walker 1985). 

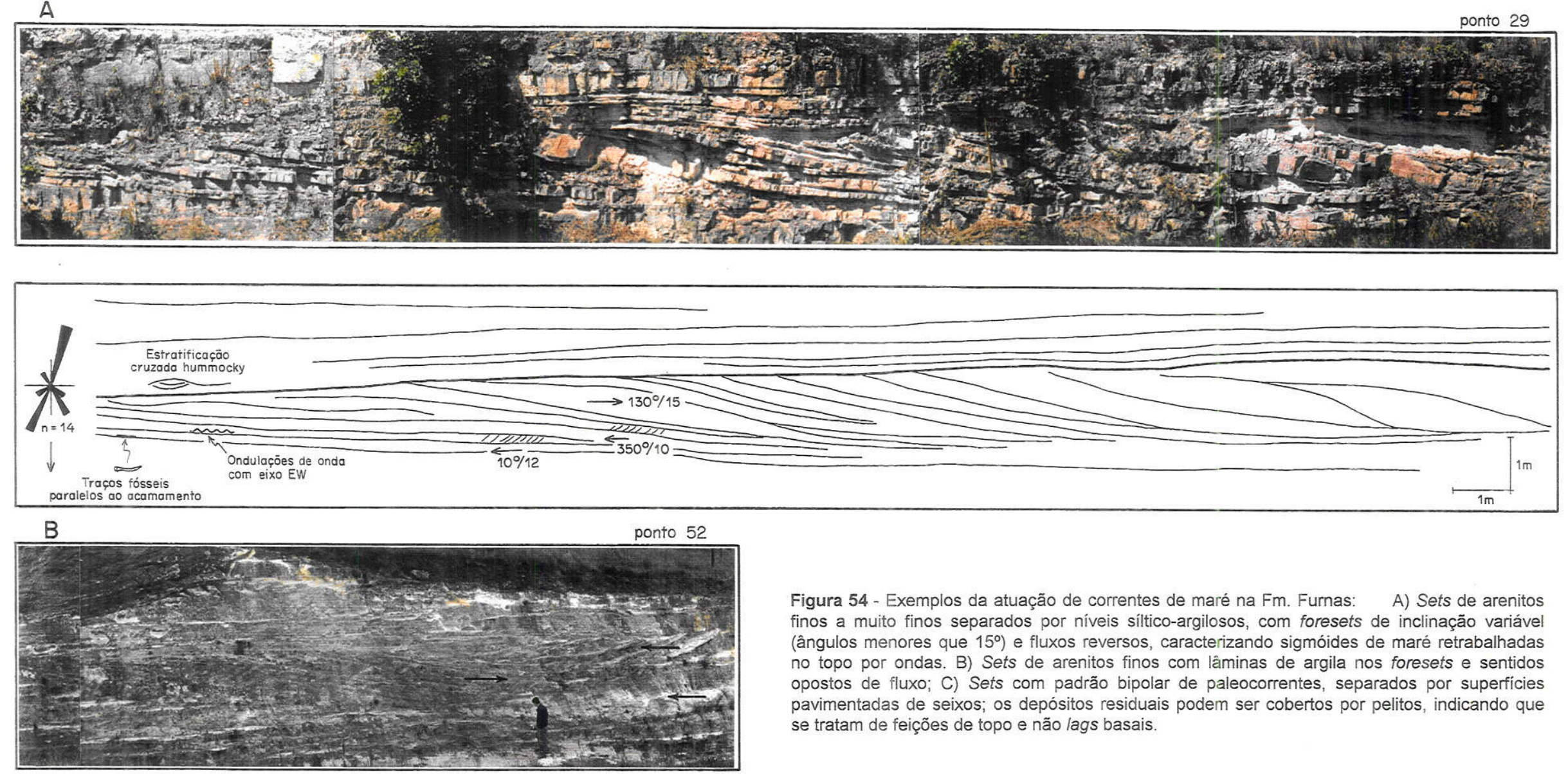

Figura 54 - Exemplos da atuação de correntes de maré na Fm. Furnas: A) Sets de arenitos finos a muito finos separados por níveis síltico-argilosos, com foresets de inclinação variável (ângulos menores que $15^{\circ}$ ) e fluxos reversos, caracterizando sigmóides de maré retrabalhadas no topo por ondas. B) Sets de arenitos finos com lâminas de argila nos foresets e sentidos opostos de fluxo: C) Sets com padrão bipolar de paleocorrentes, separados por superficies pavimentadas de seixos; os depósitos residuais podem ser cobertos por pelitos, indicando que se tratam de feições de topo e não lags basais.

C

ponto 86

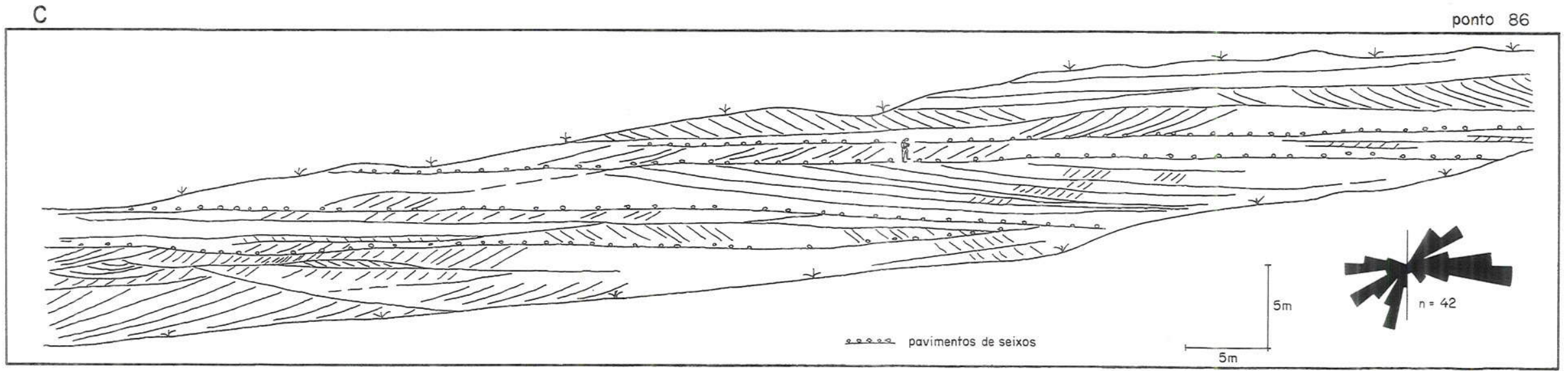


Um conjunto de características indica que correntes de maré constituíram um agente importante na deposição da unidade: a) sets sigmóides de dimensões decimétricas a métricas e separados por níveis síltico-argilosos, sob os quais ocorrem icnofósseis paralelos ao acamamento. No ponto 29 (Fig. 54-A) verificou-se atuação conjunta de marés e ondas; b) estratos cruzados com sentidos opostos de fluxo (Fig. 54-B/C; Fig. 40-E, p.82; Fig. 45-F, p.90); c) lâminas e intraclastos de argila nos foresets dos estratos cruzados (Fig. 40-F/H); d) estratificação ondulada e flaser (Fig. 40-D/G).

O predomínio de correntes unimodais não deve ser considerado um argumento contrário à atuação de marés, pois muitas plataformas marinhas atuais são caracterizadas por correntes de maré unidirecionais e muitos exemplos do passado apresentam padrão unimodal e poucas evidências de fluxo no sentido contrário. $O$ padrão unimodal é reflexo de assimetria no fluxo, situação em que as correntes reversas são insuficientemente fortes para transportar sedimentos. Correntes unimodais podem resultar também da separação das trajetórias das correntes de maré enchente e vazante, fenômeno observado no Mar do Norte.

UNIDADE III $\mathrm{O}$ ambiente foi mais enérgico que na unidade II, o que se reflete na maior granulometria, na pobreza em intercalações sílticas e na existência de pavimentos de seixos (depósitos residuais ou lags) nas superfícies planares limítrofes dos sets. Os lags apresentam valores muito altos de razão extensão lateral/espessura, sendo por isso considerados indicadores de processos marinhos rasos, conforme critérios estabelecidos por Clifton (1973). A geometria planar e a continuidade das superfícies de erosão no topo dos cosets, nas quais estão alojados os lags, são interpretadas como produto de processos marinhos erosivos, por fluxos em lençol, que foram suficientemente competentes para revolver o fundo e transportar areias, mas não frações mais grossas, que ficaram assim concentradas. Este processo de concentração de depósitos residuais pela ação de ondas é conhecido como joeiramento (winnowing).

As paleocorrentes apresentam, em muitos casos, distribuições bipolares obliquas ou polimodais (Figs. 48 e 49, p. 96 e 97), sugerindo a atuação de correntes de marés. Valores de variância acima de 4000 , indicativos de ambientes marinhos segundo Long \& Young (1978), foram calculados para as distribuições apresentadas nas figura 48 e 49 . 
Um modelo muito interessante para explicar a formação de superfícies planares pavimentadas por seixos foi apresentado por Anderton (1976), tendo sido já aplicado à Fm. Furnas por Bergamaschi (1992). O mesmo modelo foi adotado também por Richards (1986) em estudo sobre o Triássico Inferior dos Alpes, para explicar superfícies de erosão marinha com seixos e lateralmente persistentes por mais de $8 \mathrm{~km}$.

O modelo baseia- se na distribuição de diferentes formas de leito em seis zonas alinhadas no sentido das correntes de maré. As superfícies planares de abrasão marinha são produzidas pelo aumento da amplitude das ondas durante eventos episódicos relacionados a tempestades, que causam remobilização dos sedimentos de fundo, carreamento das partículas menores pelas correntes e queda dos clastos maiores após a passagem das ondas, num processo de joeiramento que resulta na pavimentação do fundo por seixos e calhaus (Fig. 55).

$\mathrm{Na}$ parte superior da Fm. Furnas, mas ainda dentro da unidade III, existem intercalações de arenitos muito finos e siltitos, portadores de vegetais vasculares primitivos, há muito tempo já relatados (Bigarella et al. 1966) e classificados como Horneophyton, Zosterophyllum e Cooksonia por Mussa et al. (1996).

No ramal ferroviário de acesso à indústria PISA (ponto 90), em Jaguariaiva $(P R)$, há uma ocorrência muito importante, pois, além dos vegetais, ocorrem também palinomorfos que permitiram a Dino \& Rodrigues (1995) posicionar o intervalo no Praguiano. O intervalo foi interpretado por Bergamaschi (1992) como fácies de turbiditos lagunares, estando sobrepostos a arenitos interpretados como flúviodeltaicos. Na mesma linha de raciocínio, Dino \& Rodrigues (1995) concluíram que a parte superior da Fm. Furnas foi depositada em ambientes continentais a transicionais, destacando a presença de abundante matéria orgânica lenhosa como sugestiva de transporte de material de origem continental. Mussa et al. (1996) utilizaram a mesma interpretação paleoambiental, considerando um transporte mínimo para os vegetais, que tinham por habitat ambientes costeiros emersos com alto teor de umidade ou, mesmo, submersos.

Uma interpretação diferente para o afloramento do ponto 90 é apresentada na figura 56-A. Nela, pode-se verificar que as fácies sotopostas, interpretadas como flúvio-deltaicas por Bergamaschi (1992), são as mesmas descritas para a unidade III e caracterizadas por extensas superfícies planas pavimentadas de depósitos residuais de seixos e calhaus joeirados pela ação de ondas e marés (Fig. 57-A). O intervalo heterolítico portador de microfósseis e de restos vegetais (Fig. 57-B), caracterizado pela alternância de pelitos e arenitos muito finos com laminações cruzadas 


ZONAS: $\quad 6 \quad 4 \quad 5 \quad 4 \quad 4$

I - CONDIÇÕES DE BOM TEMPO: correntes de marés normals

II - CONDICOEES OE TEMPESTADES MOOERADAS: correntes de maré de intensificadas por ondas
de tempestade

IE- RETORNO ÁS CONDIÇŌES DE BOM TEMPO: correntes de marés normais

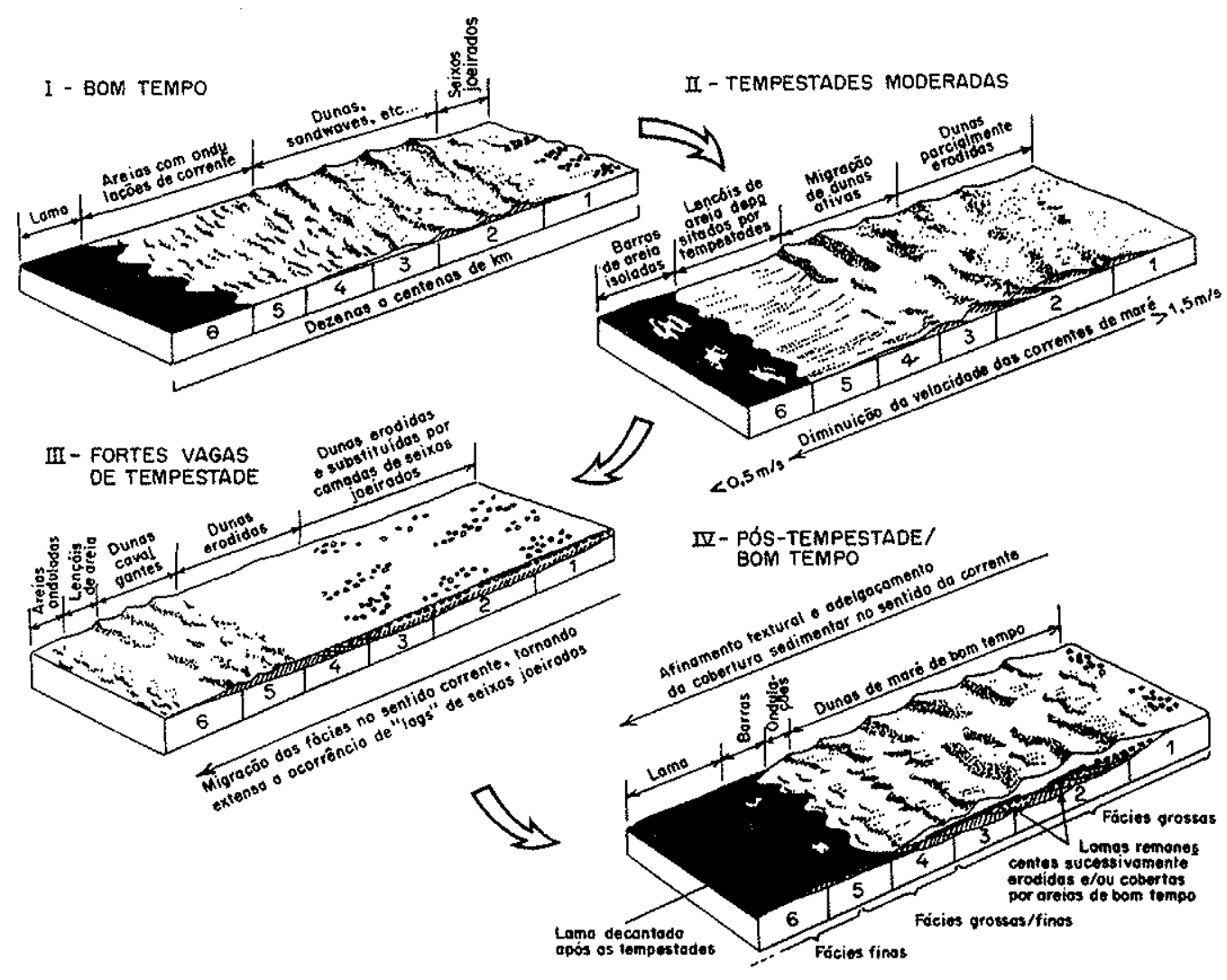

Figura 55 - Mecanismo de formação de depósitos residuais de cascalho (lags) em ambientes marinhos rasos (baseado em Anderton 1976, com modificações introduzidas por Johnson \& Baldwin 1986 e Richards 1986). São mostradas as formas de leito e estruturas sedimentares geradas numa plataforma arenosa rasa dominada por correntes de maré, episodicamente afetada por fortes ondas de tempestade que promovem retrabaihamento do fundo, com joeiramento (winnowing) dos sedimentos e formação de pavimentos de cascalho. 
A) PONTO 90

B) PONTO 66

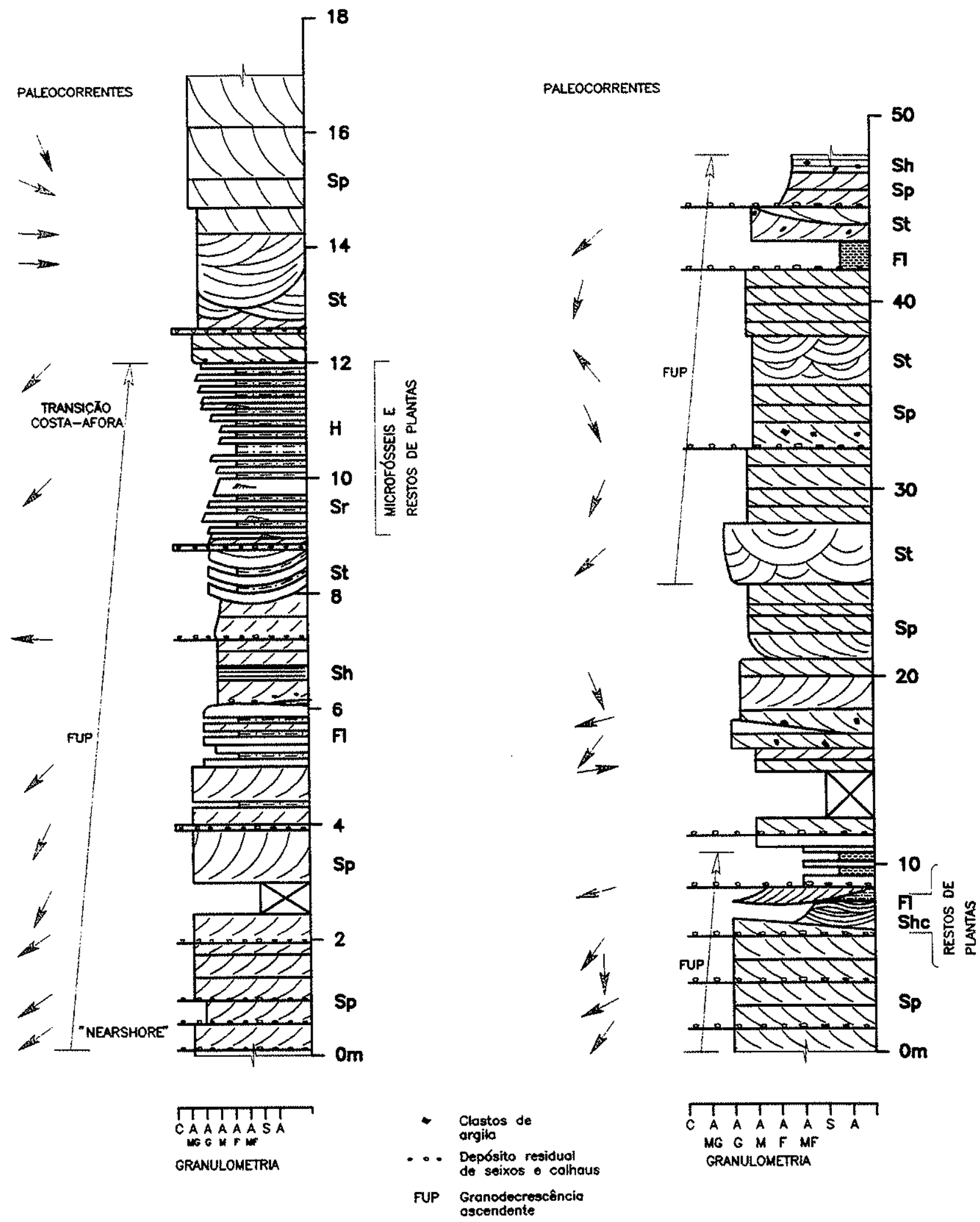

Figura 56 - Seções colunares da unidade III da Fm. Furnas, em afloramentos onde foram constatados restos de vegetais vasculares (pontos 66 e 90) 
A -

ponto 90
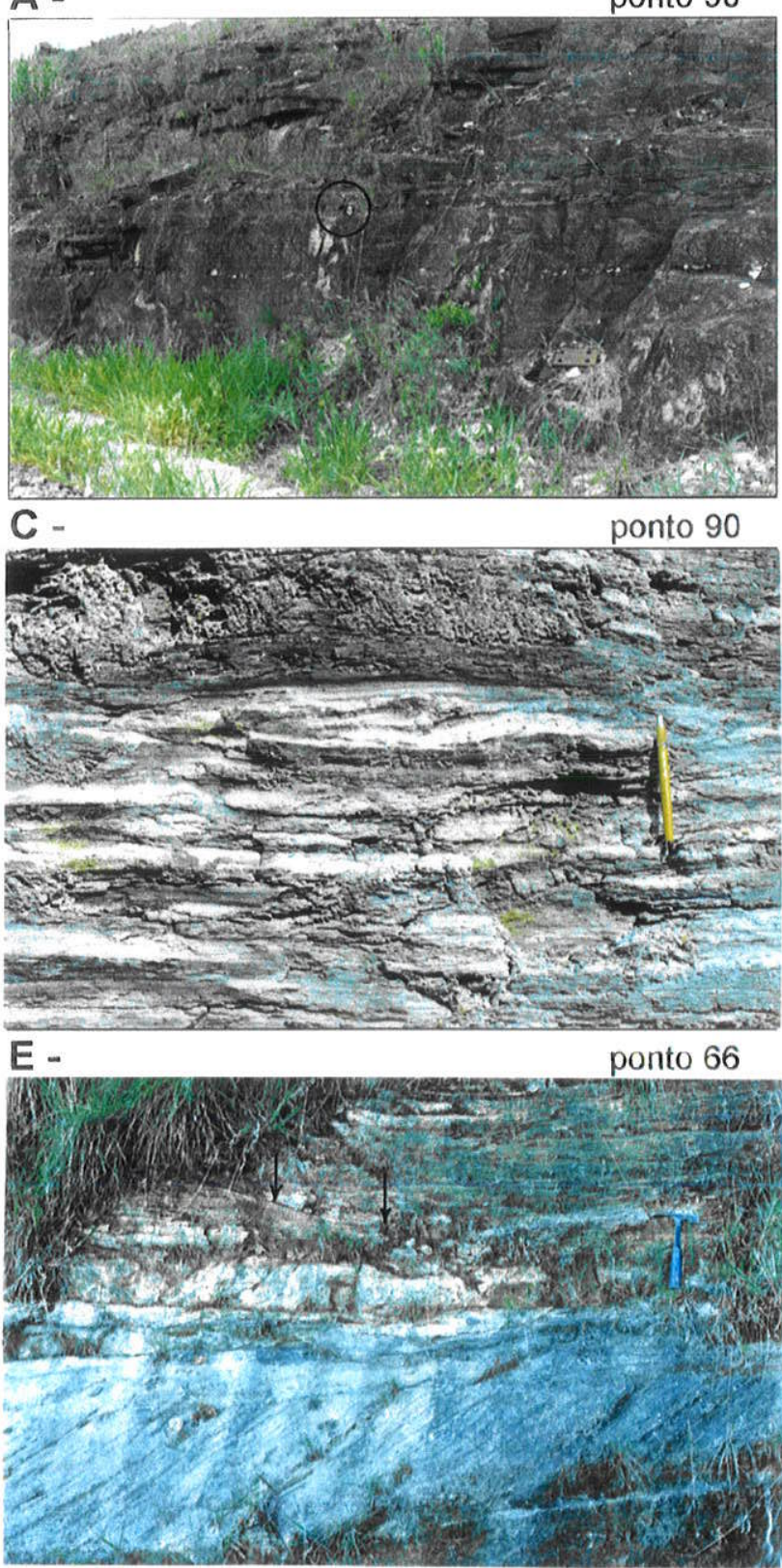

G -

ponto 66

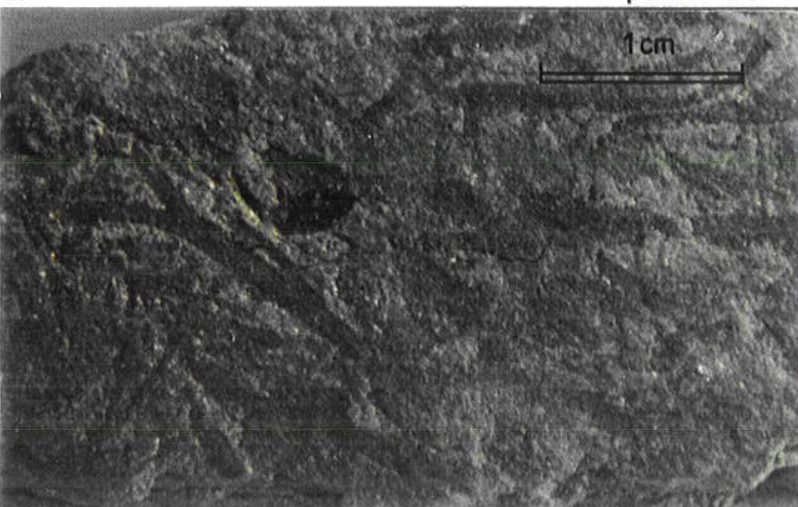

B -

ponto 90

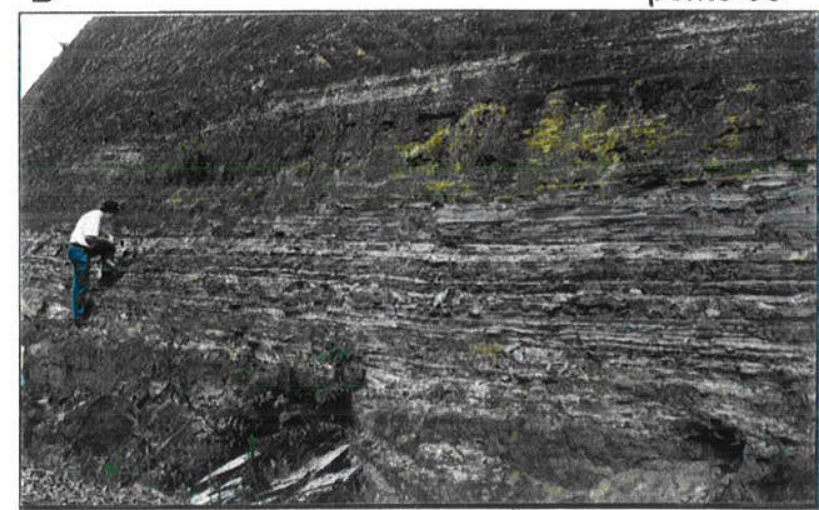

D -

ponto 90
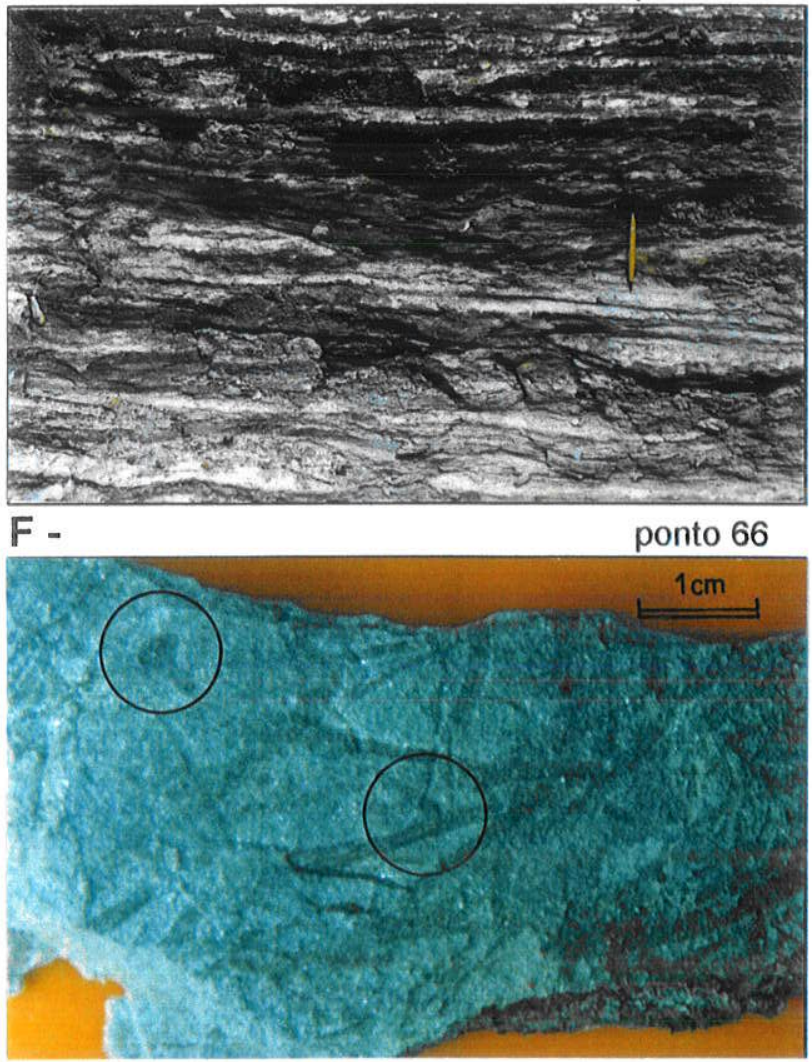

H -

ponto 66

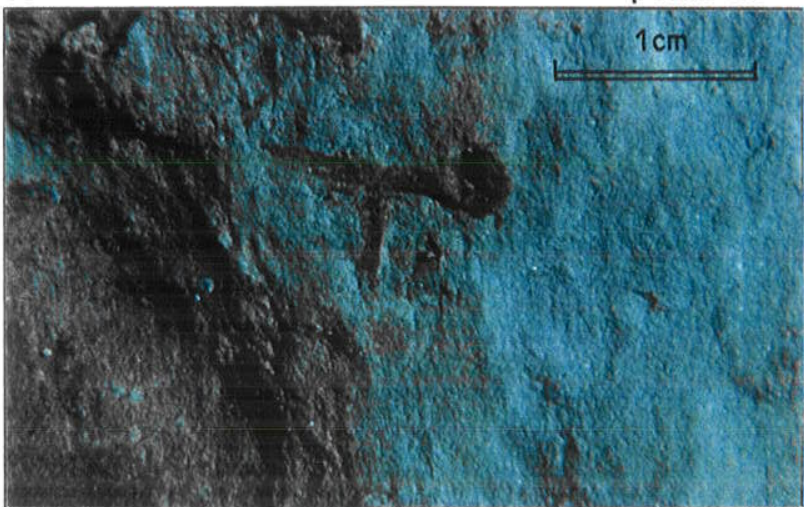

Figura 57 - Vegetais vasculares primitivos na parte superior da unidade III da Fm. Furnas. No afloramento do ramal ferroviário da indústria PISA (Fig. 56-A), sobre arenitos com pavimentos de seixos (A), ocorrem vegetais em fácies heterolíticas (B), caracterizadas por ripples assimétricos unidirecionais e discreto retrabalhamento por ondas (C/D). Entre Ponta Grossa e Carambeí (Fig. 56-B), em fácies de arenitos sílticos com estratificação cruzada hummocky ( $E$ = truncamento ressaltado por setas), ocorrem talos dicotômicos e esporângios de Cooksonia (F/G/H). 
cavalgantes unidirecionais para sudoeste e feições sugestivas de tênue atuação de ondas (Fig. 57-C/D), é interpretado como fácies mais distais de plataforma interna, representando um pulso inicial da transgressão que atingiria o máximo no Emsiano. Um argumento a favor é a existência de um lag transgressivo na base da seção heterolítica, possivelmente uma superfície de ravinamento marinha. Dentro desta perpectiva, é necessário considerar um rápido e considerável transporte, bacia adentro, de vegetais arrancados de seus habitats costeiros por grandes ondas de maré aumentadas por tempestade.

A descoberta, durante os trabalhos de campo, de vegetais vasculares classificados como Cooksonia por Bolzon et al. (1994), em fácies de arenitos muito finos e siltitos com estratificação cruzada hummocky (Figs. 56-B e 57-E/F/G/H), corroborou tal interpretação. À parte aspectos de sistemática, a ocorrência permite considerar tempestades como um agente tafonômico, responsável pela erosão dos vegetais na costa e transporte rápido por suspensão para partes mais profundas da bacia em questão de horas, antes da putrefação e dilaceração dos talos e esporângios. Nesse caso o retrabalhamento é mínimo, apesar do nível alto de energia do meio. Um outro aspecto importante é que a ocorrência dos vegetais situa-se, pelo menos, cerca de 40m abaixo do contato com a Fm. Ponta Grossa, com certeza abaixo das camadas de transição.

\subsection{5- Camadas de Transição}

Para Petri (1948), a ausência de hiato deposicional entre a Fm. Furnas, pelo menos em sua parte superior, e a Fm. Ponta Grossa é comprovada pela presença de um intervalo de arenitos com intercalação de siltitos portadores de fósseis marinhos, comumente encontrados na Fm. Ponta Grossa. O referido autor denominou de "Camadas de Transição" este intervalo no topo da Fm. Furnas, cuja espessura é pequena, quase sempre menor que $20 \mathrm{~m}$.

As Camadas de Transição foram identificadas por Petri (1948) em afloramentos na cidade de Jaguariaíva. Compõem uma seqüência de fácies granodecrescentes em direção ao topo, desde arenitos médios a grossos na base, típicos da Fm. Furnas, até folheihos da Fm. Ponta Grossa no topo, com no máximo $20 \mathrm{~m}$ de espessura (Fig. 58). Os arenitos finos a muito finos formam conjuntos de camadas centimétricas, que exibem laminação cruzada quando não destruída pela atividade de organismos 


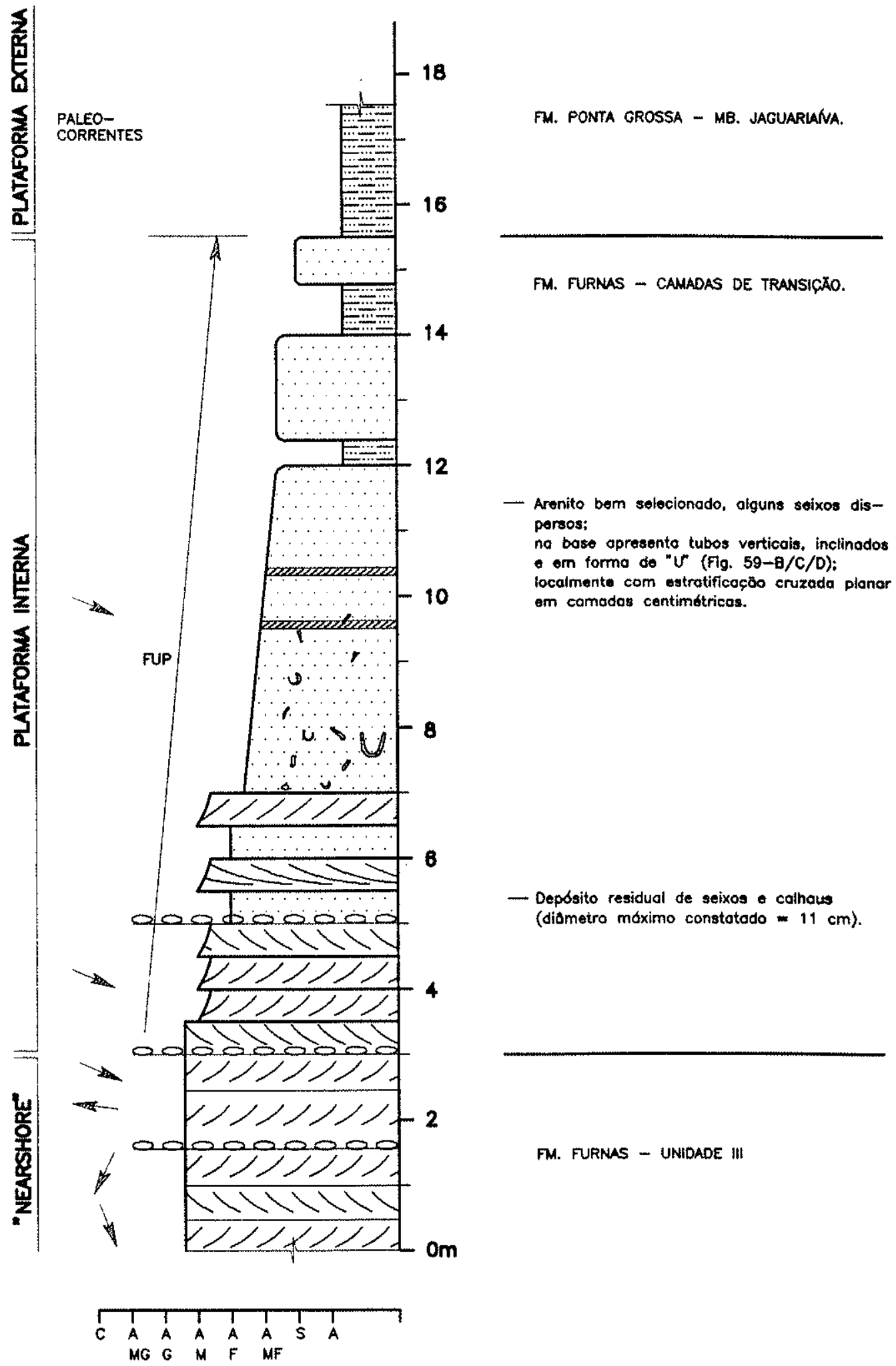

Figura 58 - Camadas de Transição em Jaguariaiva (ponto 89) 
A -
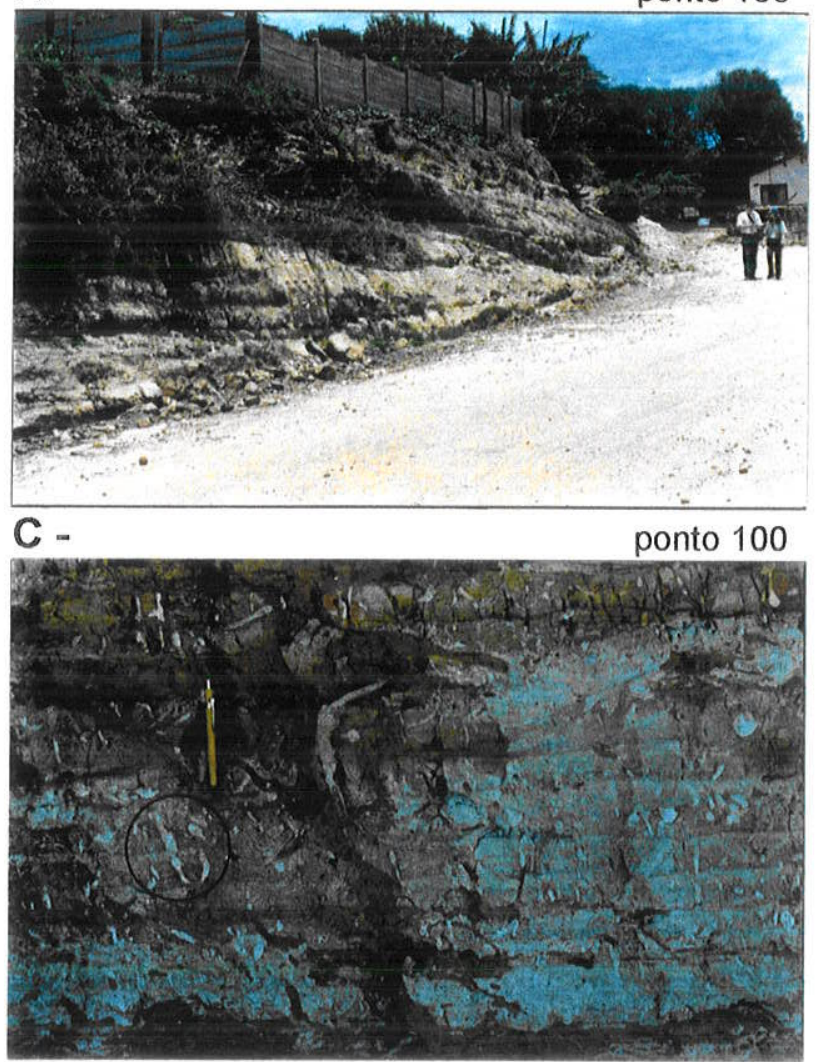

$E$ -

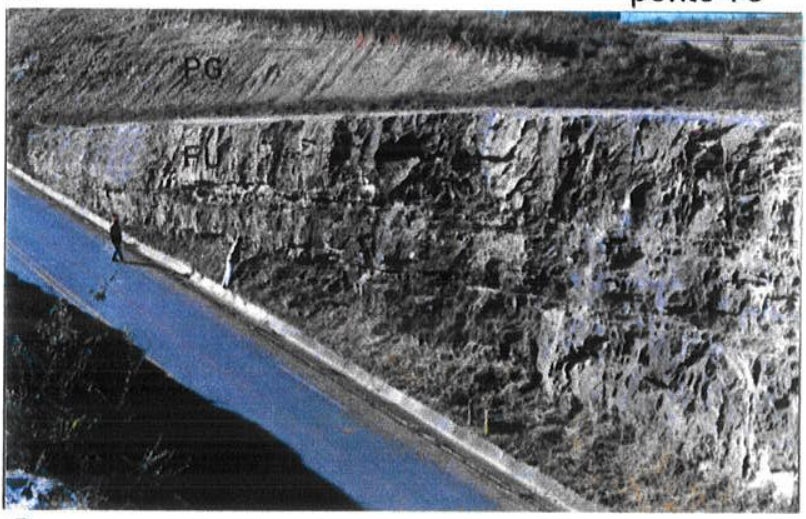

G -

ponto 97

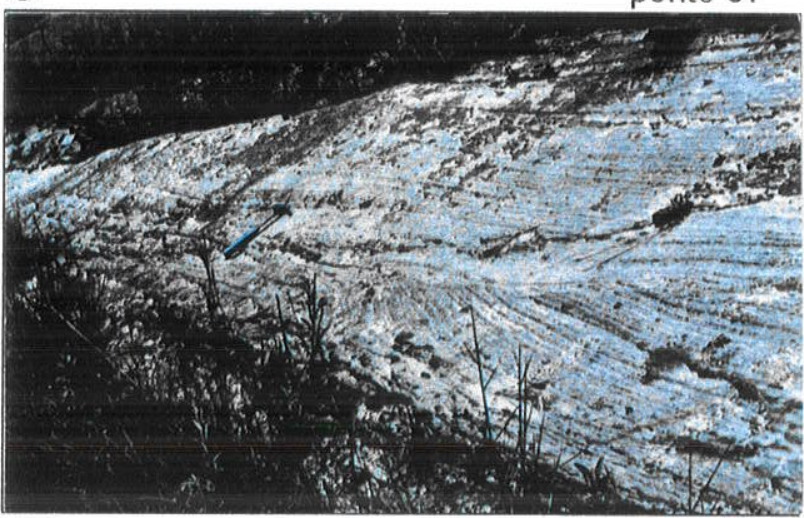

B -

ponto 100

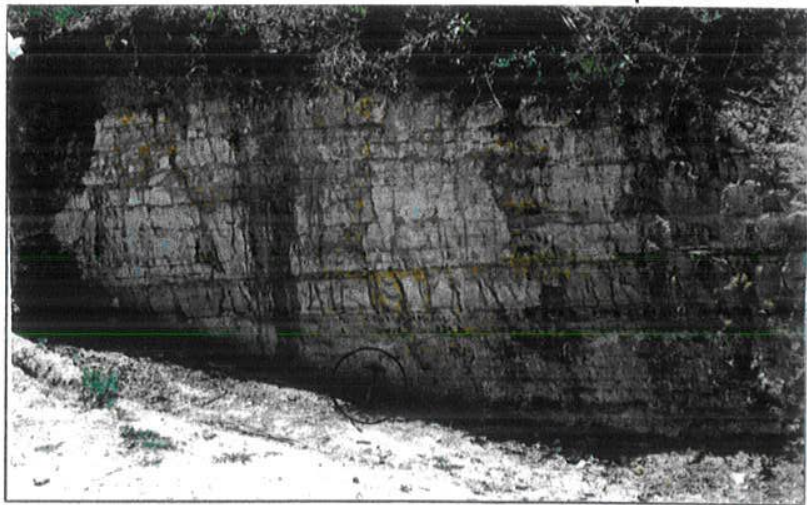

D -

ponto 100

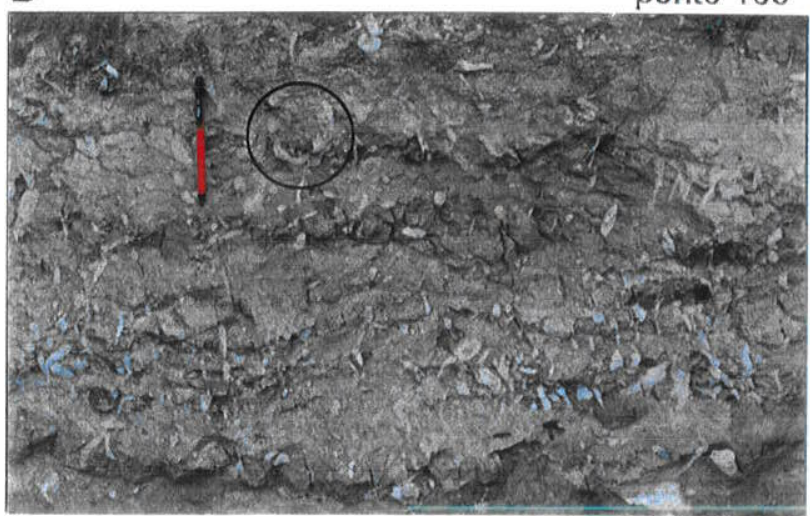

$\mathrm{F}$ -

ponto 75

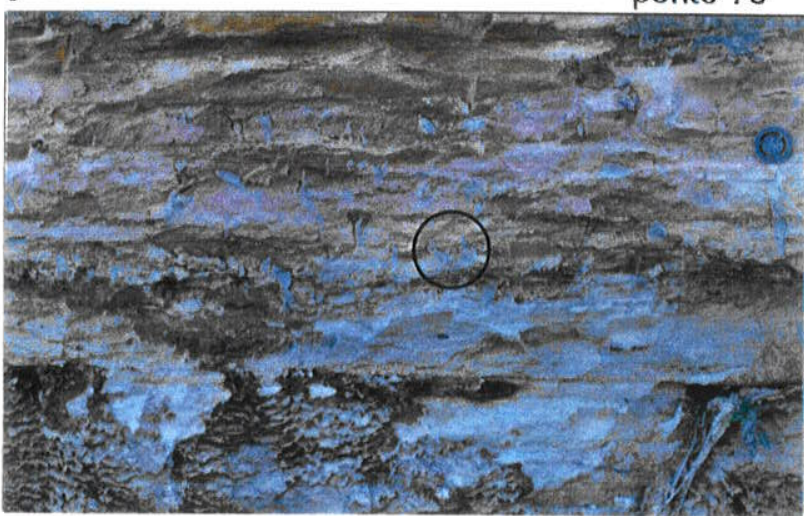

$\mathrm{H}$ -

ponto 32

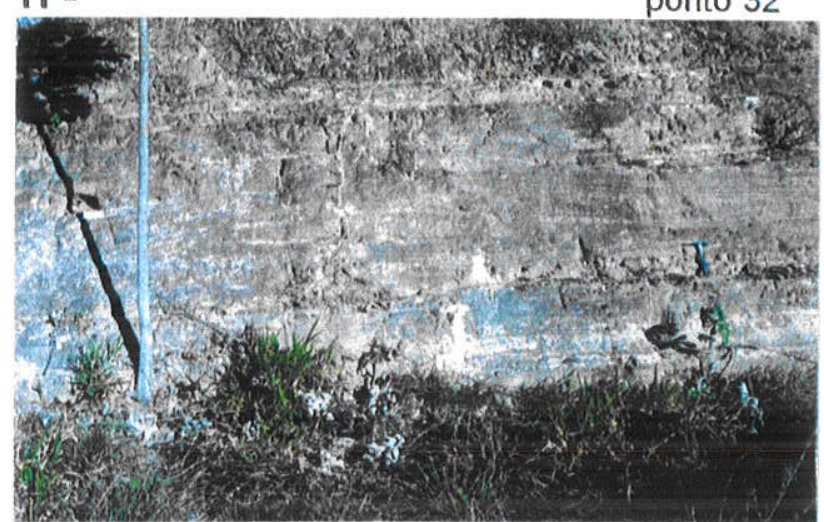

Figura 59 - Fácies da Fm. Furnas/Camadas de Transição. Afloramento em Jaguariaiva (A), onde arenitos finos a muito finos com estratificação plano-paralela (B), apresentam-se em alguns intervalos bastante bioturbados, com icnofósseis verticais, inclinados e vários tubos em forma de "U" (indicados em C/D). As Camadas de Transição em Tibagi (PR), no contato com a Fm. Ponta Grossa (E: $F U=F m$. Furnas; $P G=F m$. Ponta Grossa), apresentam as mesmas litofácies e icnofósseis $(F=$ tubo em "U" em destaque). Também ocorrem camadas com estratificação cruzada hummocky (G/H). 
perfuradores (Fig. 59-A/B/C/D). Camadas decimétricas de arenitos médios com estratificação cruzada planar ocorrem na parte inferior. Afinidade com a Fm. Furnas III é demonstrada pela existência de linhas de seixos separando conjuntos de sets e pela ocorrência de restos de vegetais vasculares.

Petri (1948) também identificou as Camadas de Transição no contato entre as formações Furnas e Ponta Grossa na entrada da cidade de Tibagi, onde podem ser observadas fácies semelhantes àquelas das camadas de transição em Jaguariaíva, inclusive com os mesmos icnofósseis (Fig. 59-E/F). Trata-se de um afloramento importante, pois serviu de base para que Bigarella (1973) e Zalán et al. (1987a,b) advogassem uma discordância entre ambas as unidades, calcados num contato que consideraram abrupto, incluindo indistintamente as camadas de transição dentro da Fm. Furnas.

Outros afloramentos das camadas de transição foram constatados nos trabalhos de campo. Em alguns casos apresentam laminação subparalela, em outros estratificação cruzada hummocky indicando ambientes marinhos de plataforma interna, sujeitos à ação de ondas de tempestade (Fig. 59-G-H).

A presença de arenitos com estratificação cruzada hummocky e a intercalação de siltitos com fósseis marinhos têm levado alguns autores (Diniz 1985, Bergamaschi 1992) a incluir as Camadas de Transição na base da Fm. Ponta Grossa. O procedimento aqui adotado, de posicioná-la no topo da Fm. Furnas, atende à definição original de Petri (1948) e aos critérios operacionais utilizados nos poços, onde a base da Fm. Ponta Grossa é marcada acima de um intervalo de aumento gradativo da argilosidade (Camadas de Transição), a partir do qual a seção se torna essencialmente pelítica. 


\section{2- FORMAÇÃO PONTA GRÒSSA}

A Fm. Ponta Grossa é uma unidade predominantemente pelítica, cujo paleoambiente marinho plataformal é atestado por ampla variedade de macro (trilobitas, braquiópodos, tentaculites etc) e microfósseis (acritarcas, quitinozoários etc). Como se depreende do mapa de isópacas (Fig. 60), sua espessura é bastante variável, delineando duas sub-bacias ou baixos estruturais. A maior espessura foi constatada no poço 2-AP-1-PR (Apucarana), onde foi perfurada uma seção de $654 \mathrm{~m}$ de rochas do Emsiano ao Frasniano.

\subsection{1- Subdivisão Litoestratigráfica}

No Estado do Paraná a unidade foi subdividida em três membros (Fig. 2). O Mb. Jaguariaiva, unidade basal de idade emsiana, consititui um pacote homogêneo de folhelhos sílticos de coloração cinza média/escura, muito fossiliferos e freqüentemente bioturbados (Fig. 61-A/B). Na metade superior ocorrem folhelhos pretos com teores relativamente altos de matéria orgânica, constituindo um intervalo potencialmente gerador de hidrocarbonetos na bacia. Sua espessura varia de 50 a 100m nas faixas de afloramento, valores que se repetem na maioria dos poços (Figs. 12 e 19, p. 36 e 46). Seção com cerca de $100 \mathrm{~m}$ de espessura foi levantada por Petri (1948) na estrada de ferro Jaguariaíva-Jacarezinho, na cidade de Jaguariaíva (ponto 100), no que pode ser considerada a seção-tipo da unidade.

O Mb. Tibagi foi definido na região de Tibagi (PR), como a unidade intermediária da Fm. Ponta Grossa, e datado como do Eifeliano (Lange 1967). É caracterizado pela presença de arenitos finos a muito finos, lenticulares e fossíliferos (tipicamente Australospirifer iheringi Kayser), entremeados em folhelhos silticos (Fig. 61-C/D). A seção clássica é a das cabeceiras do arroio São Domingos (ponto 76), onde ocorrem arenitos com $20 \mathrm{~m}$ de espessura (Oliveira 1927). Maack (1950-51) mediu espessuras de $35 \mathrm{~m}$ na área de Tibagi. Espessuras de até $150 \mathrm{~m}$ foram constatadas em subsuperfície (Figs. 12 e 19). Os arenitos são marinhos, apresentando estratificação cruzada hummocky (Fig. 61-E/F).

O Mb. São Domingos é a unidade de topo, constituindo uma seção de folhelhos laminados de cor cinza, às vezes betuminosos, entremeados aos quais se 


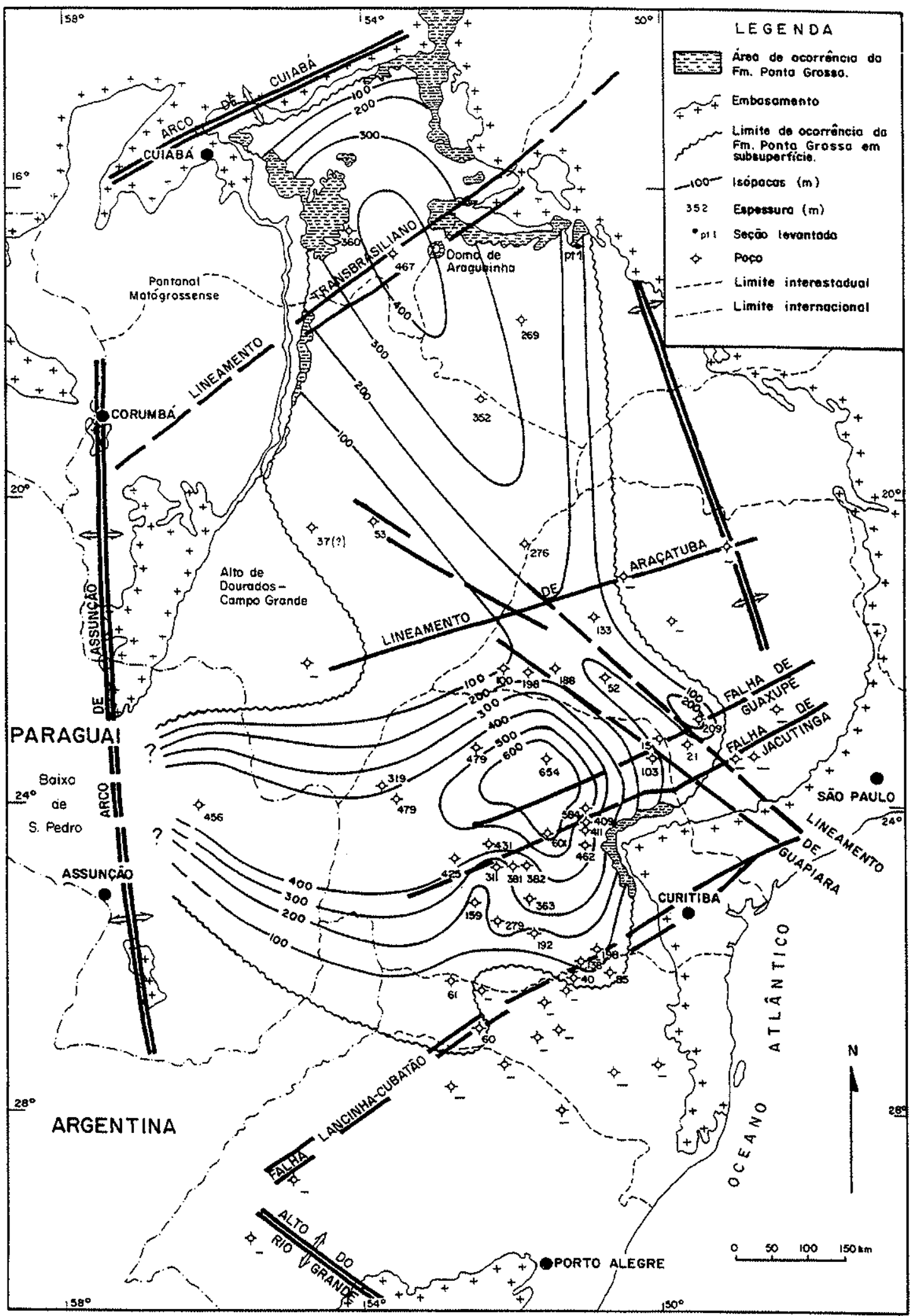

Figura 60 - Mapa de isópacas da Fm. Ponta Grossa. É nítida a compartimentação tectônica em duas sub-bacias: Alto-Garças (norte) e Apucarana (sul), separadas por um alto de direção aproximada EW. 
A -

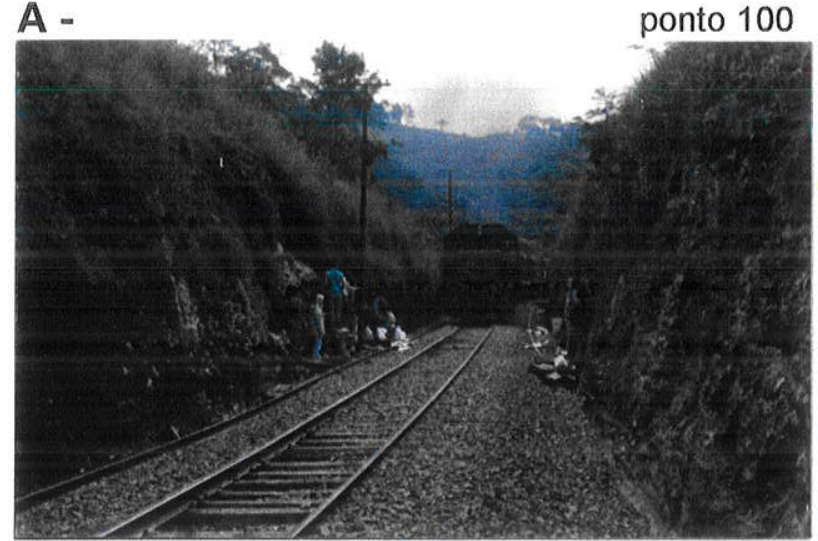

C -

ponto 76

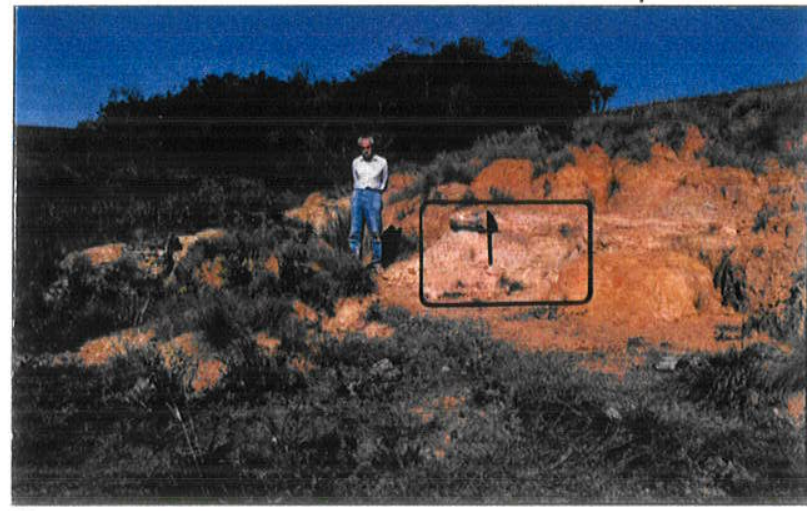

E -

ponto 99

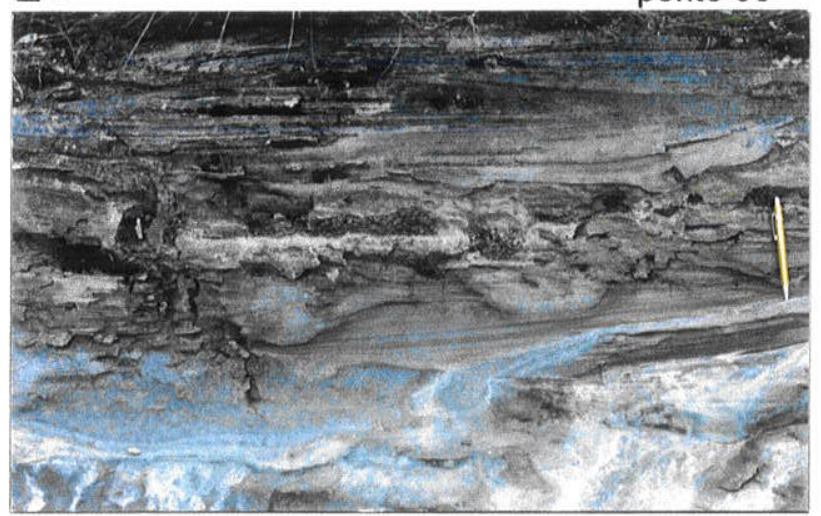

G -

ponto 65

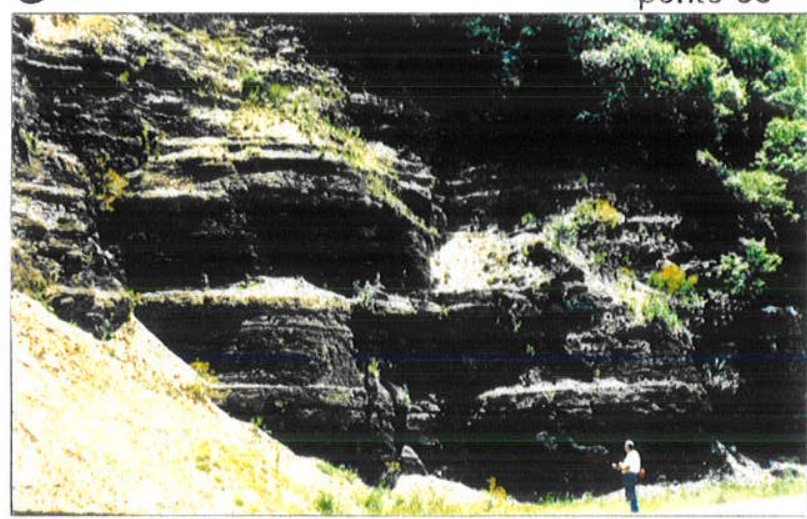

B -

ponto 100
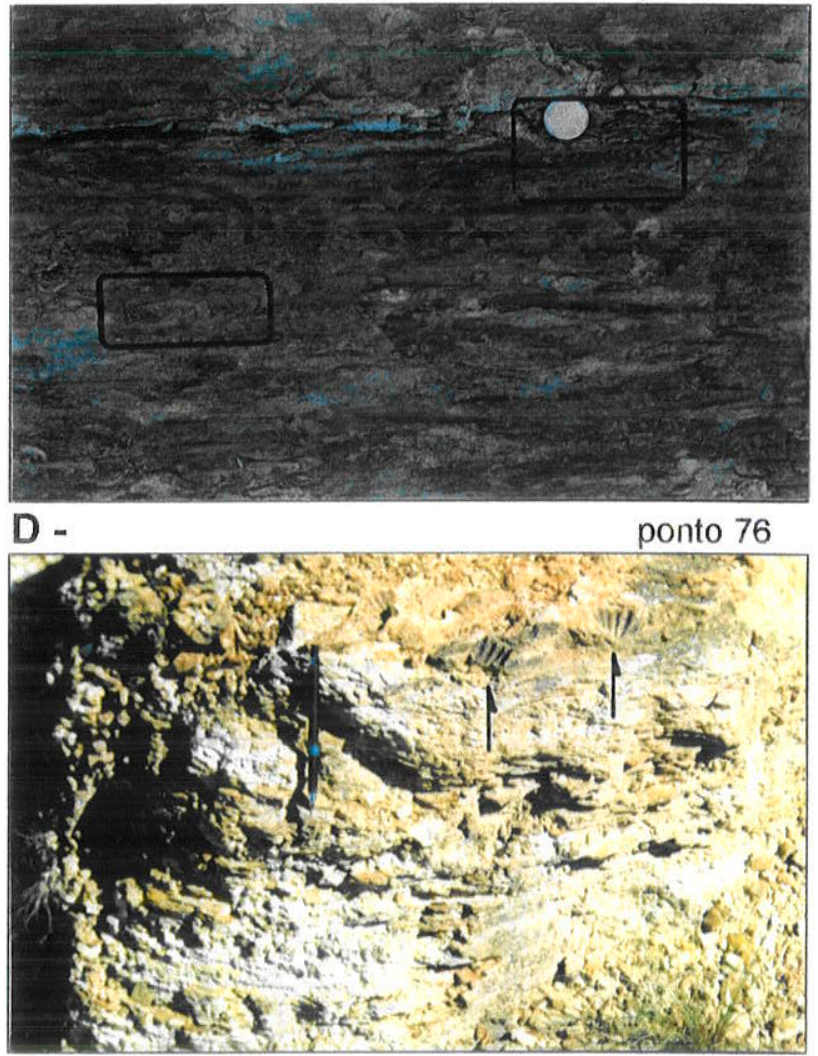

F -

ponto 99

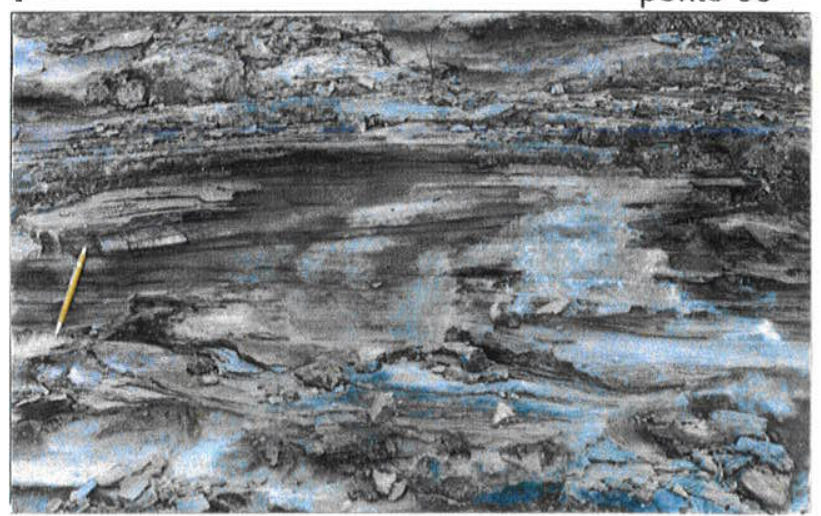

H ponto 65

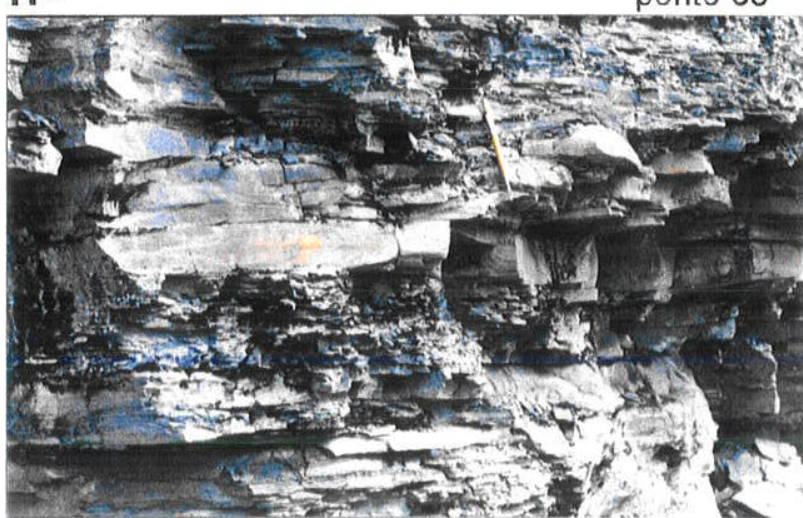
Figura 61 - Litologias típicas da Fm. Ponta Grossa. Mb. Jaguariaíva na seção-tipo (A),
caracterizado por folhelhos silticos muito bioturbados $(B=$ Zoophycus em destaque). Mb. Tibagi na localidade-tipo, com moldes de Australospirifer no topo de camadas de arenitos muito finos (C = vista geral; $\quad \mathrm{D}=$ detalhe). Arenitos com estratificação cruzada hummocky (E/F) evidenciam sistema de plataforma dominada por tempestades. Folhelhos laminados do Mb. São Domingos (G), com intercalações de tempestitos $(\mathbf{H})$. 
apresentam delgadas camadas de arenitos finos (Fig. 61-G/H). Sua idade é givetianal frasniana. A fauna é semelhante à do $\mathrm{Mb}$. Jaguariaíva, mas representada por um menor número de espécies, faltando formas tipicamente malvinocáfricas. Comparativamente ao $\mathrm{Mb}$. Jaguariaiva, os folhelhos do Mb. São Domingos são também muito menos fossilíferos. No Estado do Paraná aflora numa estreita faixa, desde Ventania até a altura de Palmeira (Lange \& Petri 1967). Na área-tipo, a oeste de Tibagi-PR, Maack (1950-51) mediu uma seção com 90m de espessura. Sua área de ocorrência e sua espessura nas faixas de afloramento nos flancos norte e noroeste é, por outro lado, muito mais ampla. Expressivas seções ocorrem em subsuperfície, atingindo valores da ordem de $350 \mathrm{~m}$ no poço 2-AP-1-PR (Apucarana), onde um intervalo regressivo frasniano foi preservado da erosão carbonífera que gerou a discordância no topo da unidade.

\subsection{2 - Arenitos do Membro Tibagi}

Os arenitos do $\mathrm{Mb}$. Tibagi são comumente finos a muito finos, sílticos, micáceos, apresentando estratificação plano-paralela, ondulada ou cruzada hummocky, quando não obliterada por bioturbação. Além de ocorrerem em meio a folhelhos fossiliferos marinhos, as estruturas sedimentares presentes e a presença de concentração de braquiópodos, em especial do gênero Australospirifer, indicam deposição em sistemas marinhos plataformais sob a ação de ondas. Os corpos arenosos apresentam freqüentemente padrão de engrossamento textural para o topo.

Como nas modernas plataformas dominadas por ondas, a sedimentação foi episódica, alcançando taxas máximas de deposição durante tempestades, com a edificação de barras arenosas retrabalhadas por ondas, e mínimas durante prolongados períodos de bom tempo, quando pelitos se formaram pela decantação de partículas finas. Disto resultou o que antigamente parecia paradoxal, a intima associação entre argilas marinhas plataformais e depósitos clásticos grossos, hoje reconhecidos como formados em eventos raros de alta energia (Blatt et al. 1991).

Existem poucas referências de afloramentos dos arenitos Tibagi na literatura geológica. Em Tibagi, além da ocorrência na área das cabeceiras do arroio São Domingos, citam-se outras duas ocorrências a norte de Tibagi relatadas por Maack (1950-51). Na região de Lambedor, Petri (1948) identificou sete camadas de arenitos do Mb. Tibagi, densamente fossiliferas (grandes espécimes de Australospirifer iheringi). 
Na região de Ponta Grossa, Lange \& Petri (1967) descreveram uma seção de arenitos finos em cujo topo se apresenta um delgado nivel de arenitos argilosos contendo seixos discóides dispersos ( $\mathrm{km} \mathrm{14,3} \mathrm{da} \mathrm{antiga} \mathrm{Estrada} \mathrm{de} \mathrm{Ferro} \mathrm{Central} \mathrm{do}$ Paraná). Sobre o nivel de seixos foram caracterizadas mais três camadas de arenitos com espessuras entre 0,5 e 1,5m, com padrão de afinamento textural em direção ao topo (ponto 101; Figs. 62 e 63). Tanto os arenitos quanto os folhelhos e siltitos intercados apresentam fragmentos vegetais de Spongiophyton. Por serem sobrepostos por folhelhos datados como givetianos (Lange 1967, Daemon et al. 1967), Lange \& Petri concluíram que o afloramento representa o contato entre os membros Tibagi e São Domingos. Duas outras ocorrências de arenitos do $\mathrm{Mb}$. Tibagi na região de Ponta Grossa foram constatadas nos pontos 64 e 102.

O Mb. Tibagi ocorre também na pedreira Moro, onde uma soleira de diabásio se interpôs entre uma camada de arenitos finos a muito finos, com cerca de $3 \mathrm{~m}$ de espessura, e folhelhos pretos sobrepostos (Fig. 64). Capeando os arenitos, que apresentam granocrescência ascendente (coarsening upward), ocorre uma camada, com cerca de $15 \mathrm{~cm}$ de espessura, de arenitos muito grossos, com pequenos seixos dispersos, e topo ondulado, definindo cristas subparalelas levemente sinuosas, magnificamente expostas pela lavra do diabásio. As ondulações são simétricas, com amplitudes entre 2 e $8 \mathrm{~cm}$ e comprimentos de onda entre 0,4 e 1,3m, e orientadas na direção NE/SW. Tais características permitem considerá-las ondulações formadas pela ação de ondas (wave coarse-grained ripples), uma feição observada nas plataformas marinhas atuais de todo o mundo, em profundidades de 5 a $110 \mathrm{~m}$, mas também reconhecida em seqüências marinhas plataformais de várias idades (Leckie \& Krystinik 1989), ocorrendo associadas, lateral e verticalmente com arenitos com estratificação cruzada hummocky. Uma análise comparativa de alguns parâmetros geométricos permite verificar a similaridade entre as ondulações existentes na pedreira Moro e alguns exemplos da literatura geológica (Fig. 65).

Um aspecto importante do ponto de vista paleogeográfico é que, nos casos conhecidos de ondulaçöes formadas por onda em areias grossas e cascalhos nas plataformas atuais, as cristas são paralelas à linha de costa. Tal orientação ocorre porque, embora as tempestades possam se dirigir à costa em diferentes direções, as ondas refratam quando o substrato torna-se mais raso, fazendo com que as cristas das wave ripples fiquem aproximadamente paralelas aos contornos batimétricos (Komar 1976, Swift et al. 1986). Ondulações similares são observadas em várias plataformas atuais, em profundidades entre 5 e $110 \mathrm{~m}$, e sempre orientadas paralelamente à linha de costa (Leckie 1988, Leckie \& Krystinik 1989). 

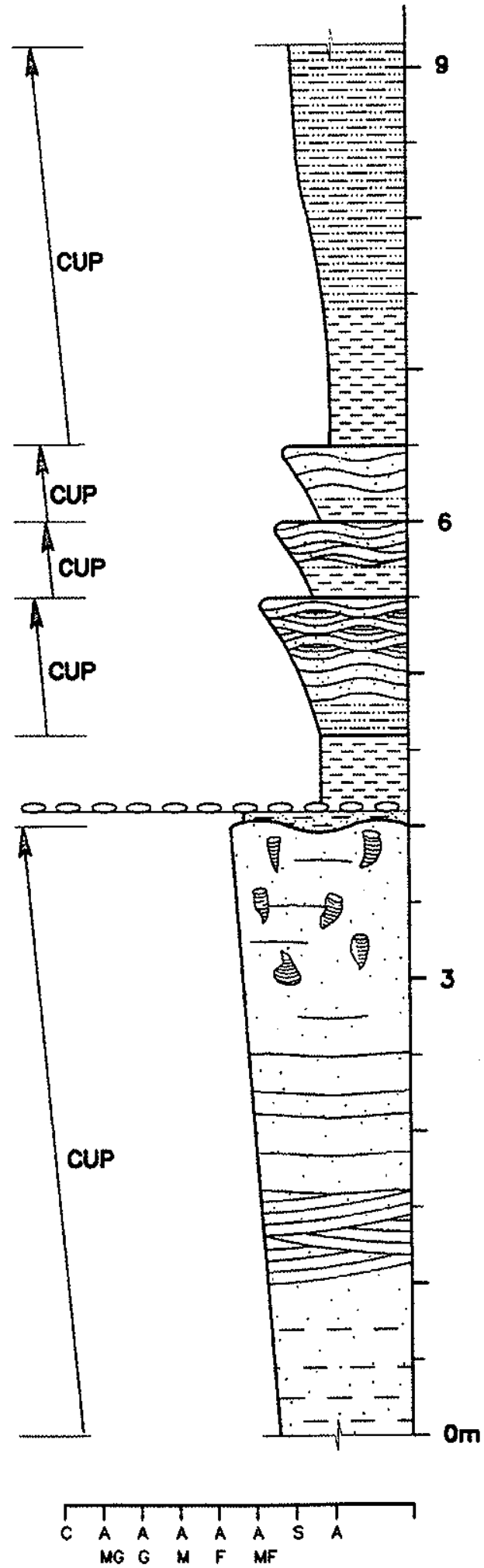

- SHTTO COM INTERCALACÕES OE ARENTO MUITO FINO.

- aRentTo mutto fino, slltico, COM laMINACÃO ONDULADA E SUTIS TRUNCAMENTOS (FIG. 63-E).

- ARENITO MUITO FINO, SLLTCO, COM LAMINAÇŌES CRUZADAS TIPO "HUMMOCKY".

- FOLHELHO CINZA ESCURO. MUITO RICO EM FRAGMENTOS DE SPONGIOPHYTON.

- arentTo argiloso. rico em SeIXos DISCÓIDES NO TOPO (FIG. 63-D)

- ARENITO MUTO FINO. BKTURBADO. COM LAMINACĀOO PLANO-PARALELA POUCO NÍTDA, LOCALMENTE COM TRUNCAMENTOS DE BAIXO ANGULO (5-10);

TUBOS VERTICAIS/INCLNADOS E FRAGMENTOS DE SPONGIOPHTTON NA PARTE. SUPERTOR (FG. 63-B):

TOPO ONDULADO COM COMPRIMENTO DE ONDA DE APROXIMADAMENTE $3 \mathrm{~m}$.

Figura 62 - Seção colunar da Fm. Ponta Grossa no bairro Santa Luzia, em Ponta Grossa-PR (ponto 101; antigo km 14,3 da Estrada de Ferro Central do Paraná, referido em Lange \& Petri 1967). As setas indicam padrões de granocrescência ascendente. 
A -

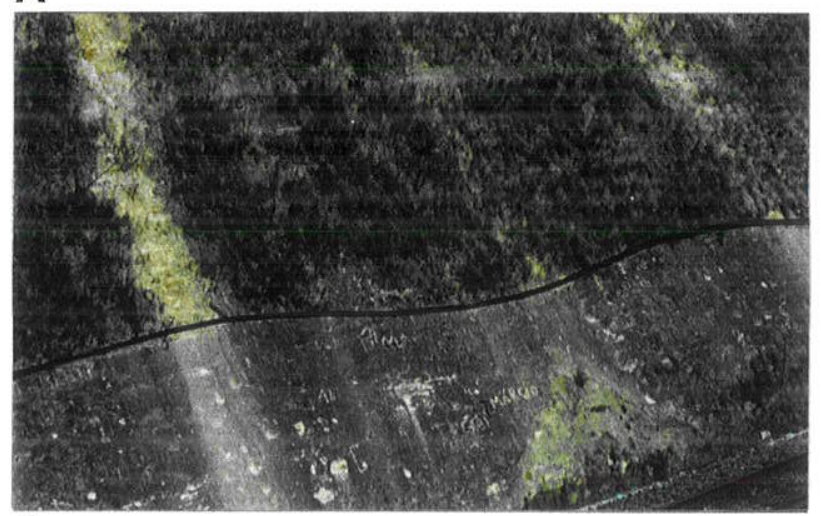

C -

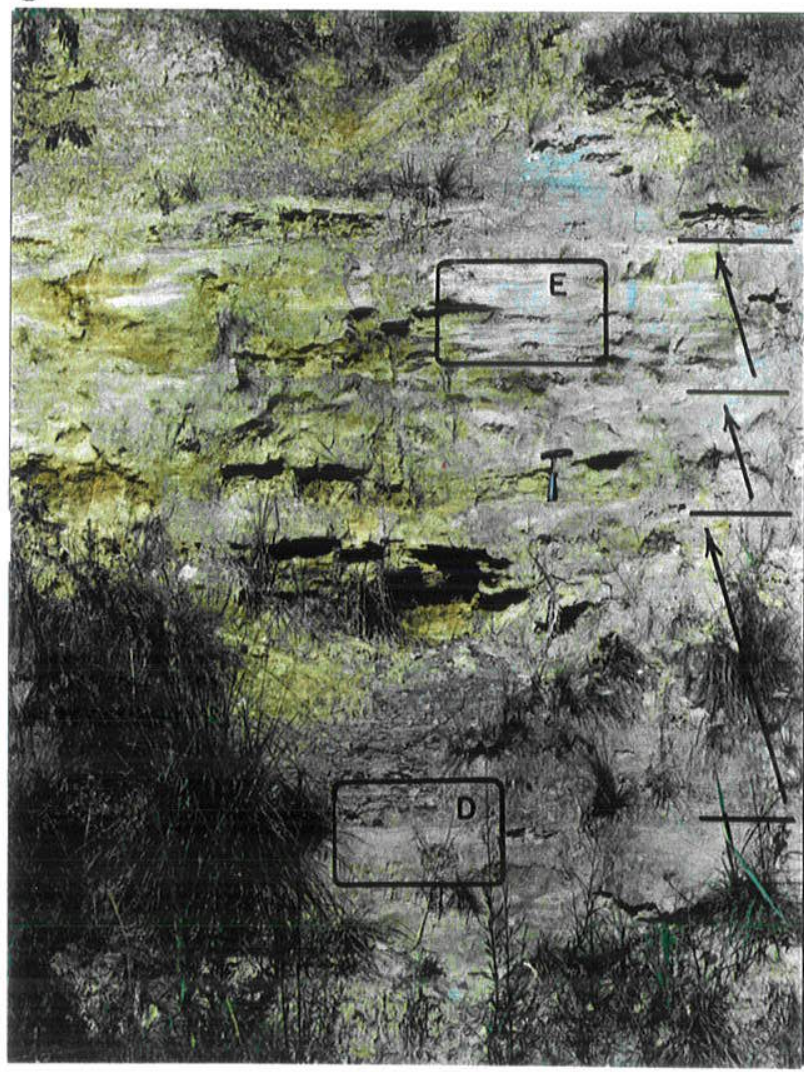

B -

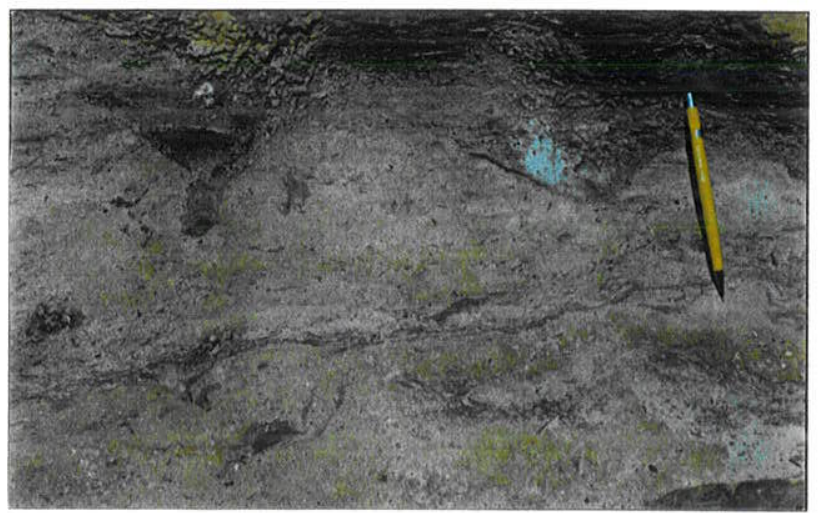

D -

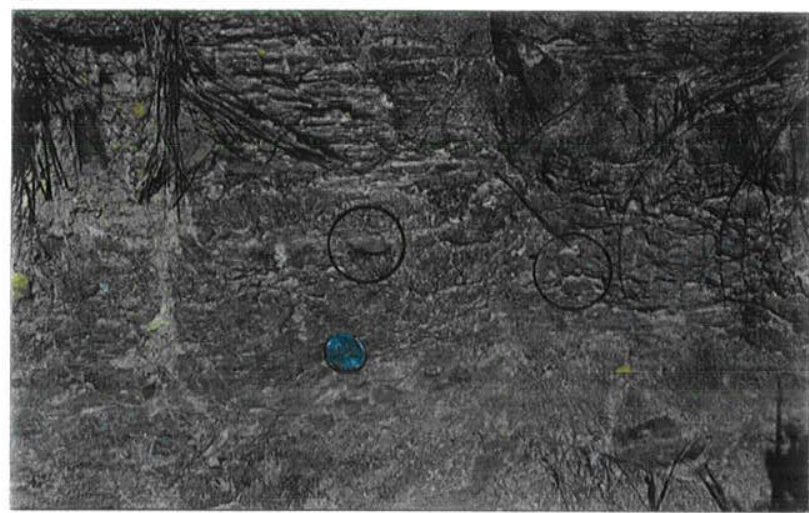

E -

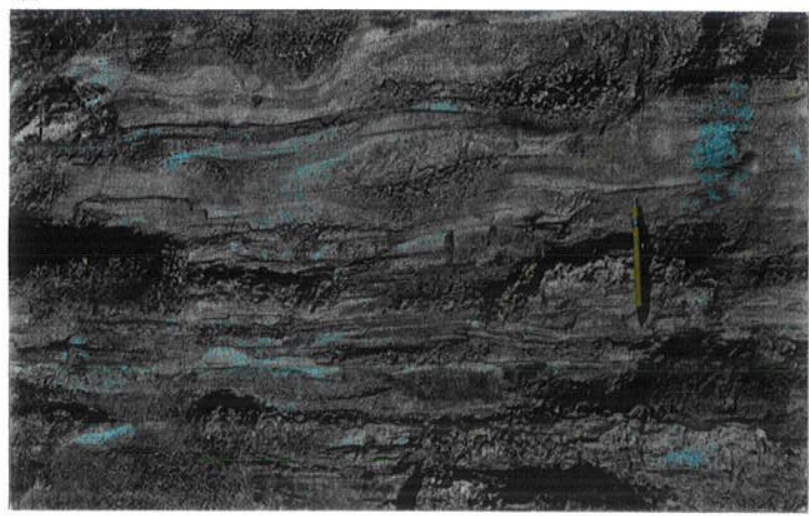

Figura 63 - Fácies do Mb. Tibagi na seção do bairro Santa Luzia (ponto 101; ver Fig. 62). $\mathrm{Na}$ base tem-se uma camada de arenito com cerca de $3 \mathrm{~m}$ de espessura e topo ondulado (A), muito bioturbada e com restos de Spongiophyton (B). Sobre a mesma sucedem-se seqüências de fácies com granocrescência ascendente $(C=$ setas indicam seqüências de fácies; retângulos indicam locais das fotos D e E). O contato com a camada de arenito da base é marcado por nível de seixos discóides (D), que constitue um lag transgressivo. Os arenitos apresentam ondulações de oscilação e laminações com sutis trucamentos por ondas (E). 
A -

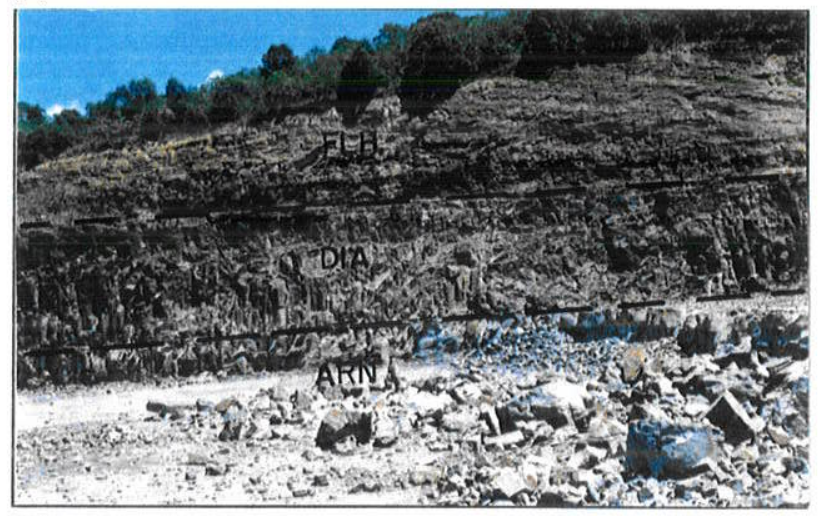

C -

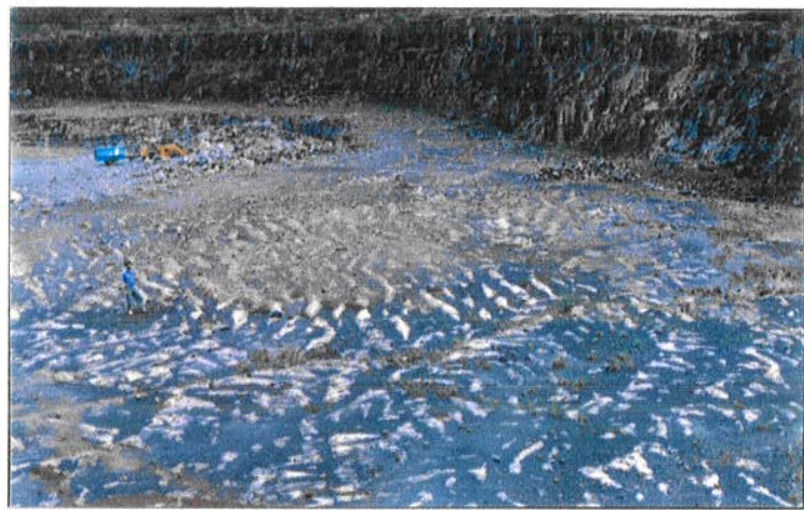

E -

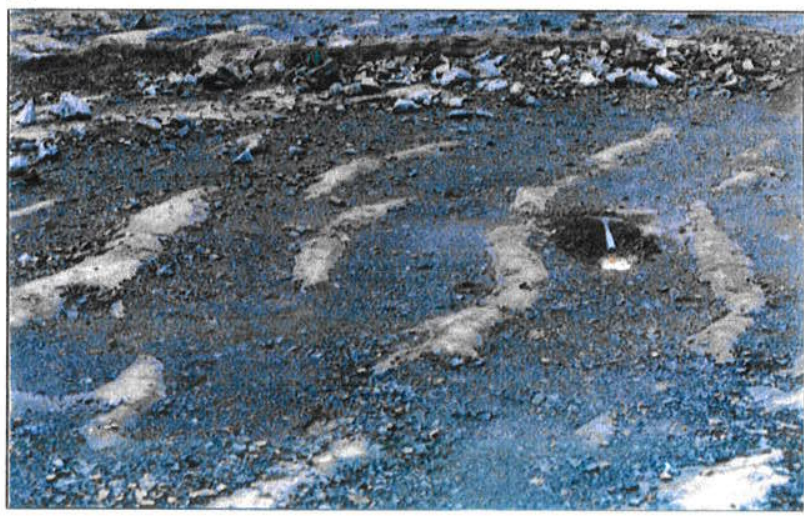

B -

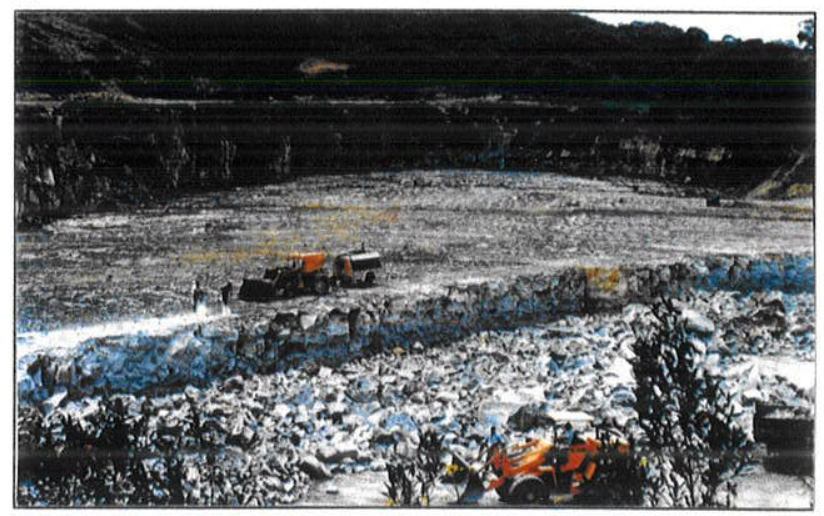

D -

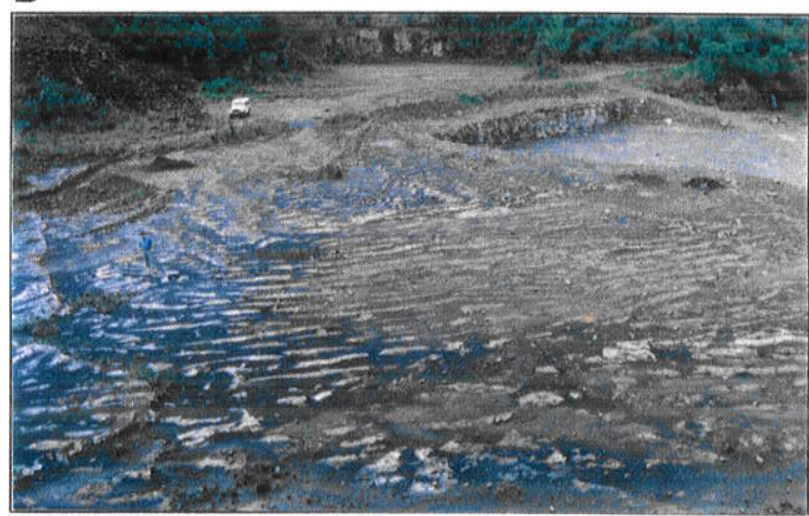

F -

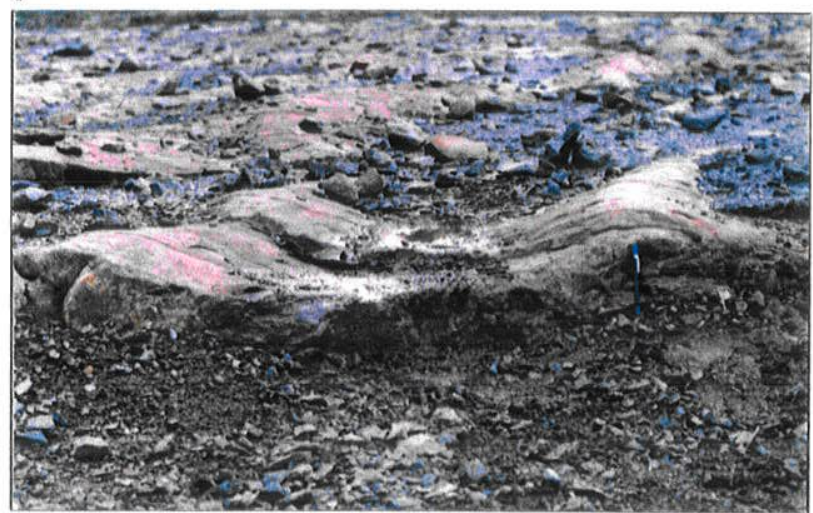

Figura 64 - Ondulações de onda em arenitos muito grossos (wave-formed coarse-grained nipples) do Mb. Tibagi. Na pedreira Moro (ABB), em Ponta Grossa (PR, ponto 64), uma soleira de diabásio (DIA) se interpôs entre arenitos (ARN) e folhelhos cinza escuros sobrepostos (FLH). Os arenitos são finos a muito finos, com aspecto mosqueado e granocrescência ascendente. No topo do arenito ocorre uma delgada camada de arenitos muito grossos, com pequenos seixos dispersos e cerca de $20 \mathrm{~cm}$ de espessura, que apresenta base plana e topo com ondulações subparalelas e levemente sinuosas (C/D). A simetria das cristas e a estrutura interna, caracterizada por ondulações concêntricas, indicam origem a partir da atuação de ondas sobre fundo arenoso (E/F). 


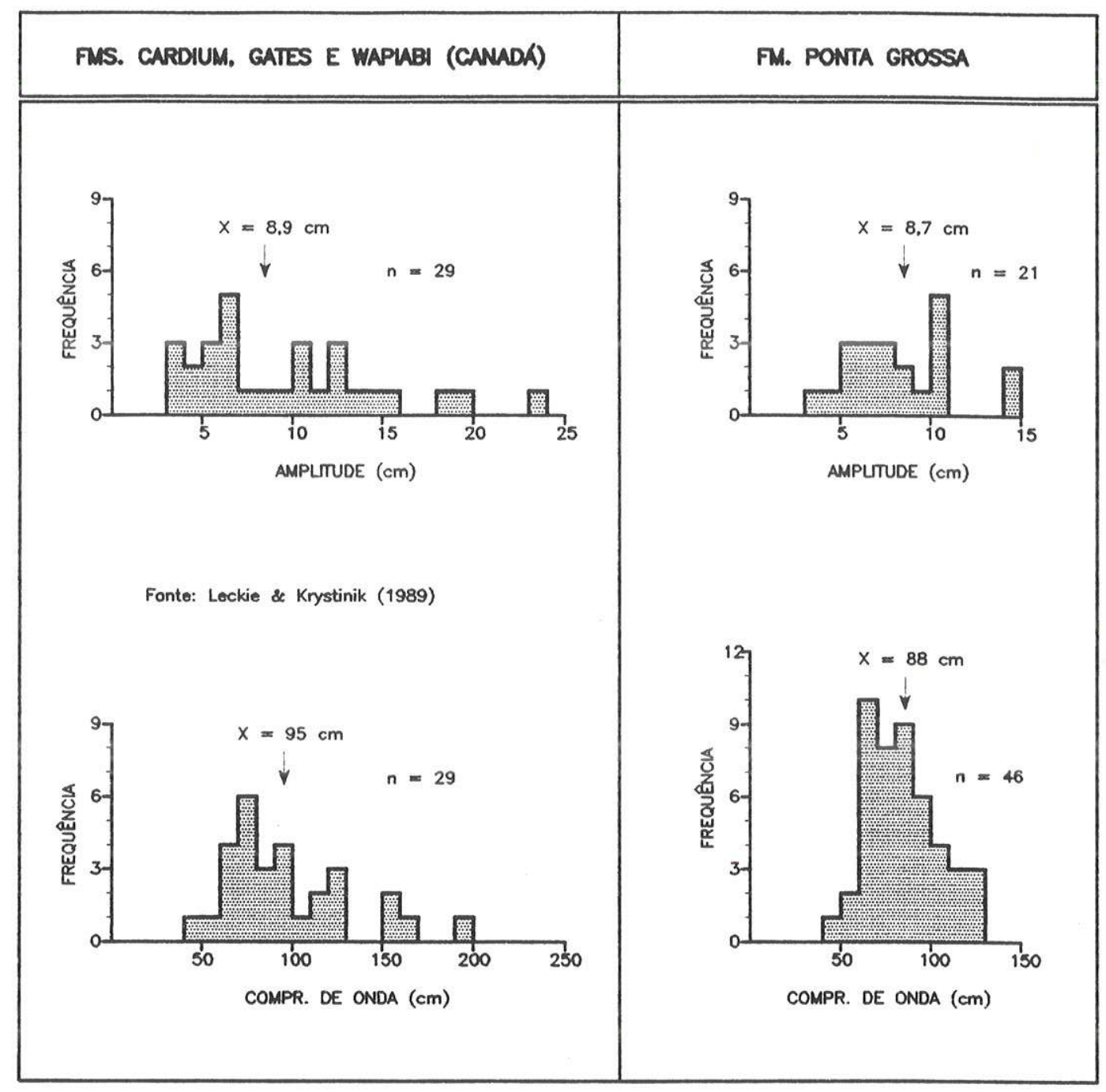

Figura 65 - Comparação entre os comprimentos de onda e as amplitudes de ondulações formadas por onda em sedimentos clásticos grossos das formações Gates, Cardium e Wapiabi (Cretáceo do oeste canadense) e da Fm. Ponta Grossa (pedreira Moro, ponto 64) ( $x=$ média aritmética e $n=$ número de medidas)

\subsection{3 - Correlação Estratigráfica}

A continuidade física da Fm. Ponta Grossa em subsuperfície é comprovada pelo registro dos poços, interligando as faixas aflorantes. As seções estratigráficas das figuras 12 e 19 (p. 36 e 46) mostram que a subdivisão litoestratigráfica em membros Jaguariaíva, Tibagi e São Domingos, estabelecida na faixa de afloramentos do flanco 
sudeste, tem expressão regional, sendo reconhecida em quase toda a bacia, tanto na sub-bacia de Apucarana quanto na de Alto Garças.

A utilização da terminologia proposta por Lange \& Petri (1967) em toda a bacia é bastante interessante, pois permite multiplicidade de denominações, simplificando a comunicação geológica e o entendimento da evolução tectono-sedimentar da bacia. A subdivisão tripartite (membros Jaguariaíva, Tibagi e São Domingos) só não é observada quando a seção está incompleta, seja por erosão no topo durante a gênese da discordância sub-Itararé, seja por erosão e/ou não-deposição dos membros inferiores em situação de borda de bacia ou em paleoaltos internos sindeposicionais, como o alto na área dos poços 2-TL-1-MS (Três Lagoas) e 2-RA-1-MS (Rio Aporé), que define as sub-bacias de Alto Garças e Apucarana (Fig. 66).

\subsubsection{1 - Estado de Goiás}

$\mathrm{Na}$ faixa de afloramentos do flanco norte da bacia, a parte inferior da Fm. Ponta Grossa constitui uma seção onde predominam arenitos. O contato com a Fm. Furnas é geomorfologicamente bastante nítido, definido por uma quebra topográfica entre arenitos brancos, grossos e mal selecionados da Fm. Furnas e arenitos brancoavermeihados, finos a muito finos, da Fm. Ponta Grossa. Este constraste é visível em Goiás sendo particularmente evidente no Morro da Mesa (Fig. 67-A), situado nas proximidades da localidade de Vila Maria (Fig. 5, p. 16). Pode ser observado também na região de Barra do Garças (Fig. 44, p. 89) e, mais a norte, na Serra do Roncador (DNPM 1975).

O padrão textural da seção sedimentar inferior da Fm. Ponta Grossa no Estado de Goiás é nitidamente de granocrescência ascendente. Na base predominam arenitos finos a muito finos, bem selecionados, micáceos, com estratificação cruzada hummocky quando não totalmente bioturbados (Fig. 67-B/C), enquanto que na parte superior se apresentam intercalações de arenitos com granulometria média a muito grossa, por vezes conglomerática (Fig. 67-D/E). Estes, retrabalhados por ondas, deram origem a depósitos residuais, que se intercalam aos arenitos (Fig. 67-F). Uma excelente seção da Fm. Ponta Grossa foi levantada a sul de Amorinópolis, cuja espessura é compativel com os $170 \mathrm{~m}$ estimados para a Fm. Ponta Grossa no Morro da Mesa (DNPM 1975). Na figura 68 está apresentada sua correlação com o perfil do 


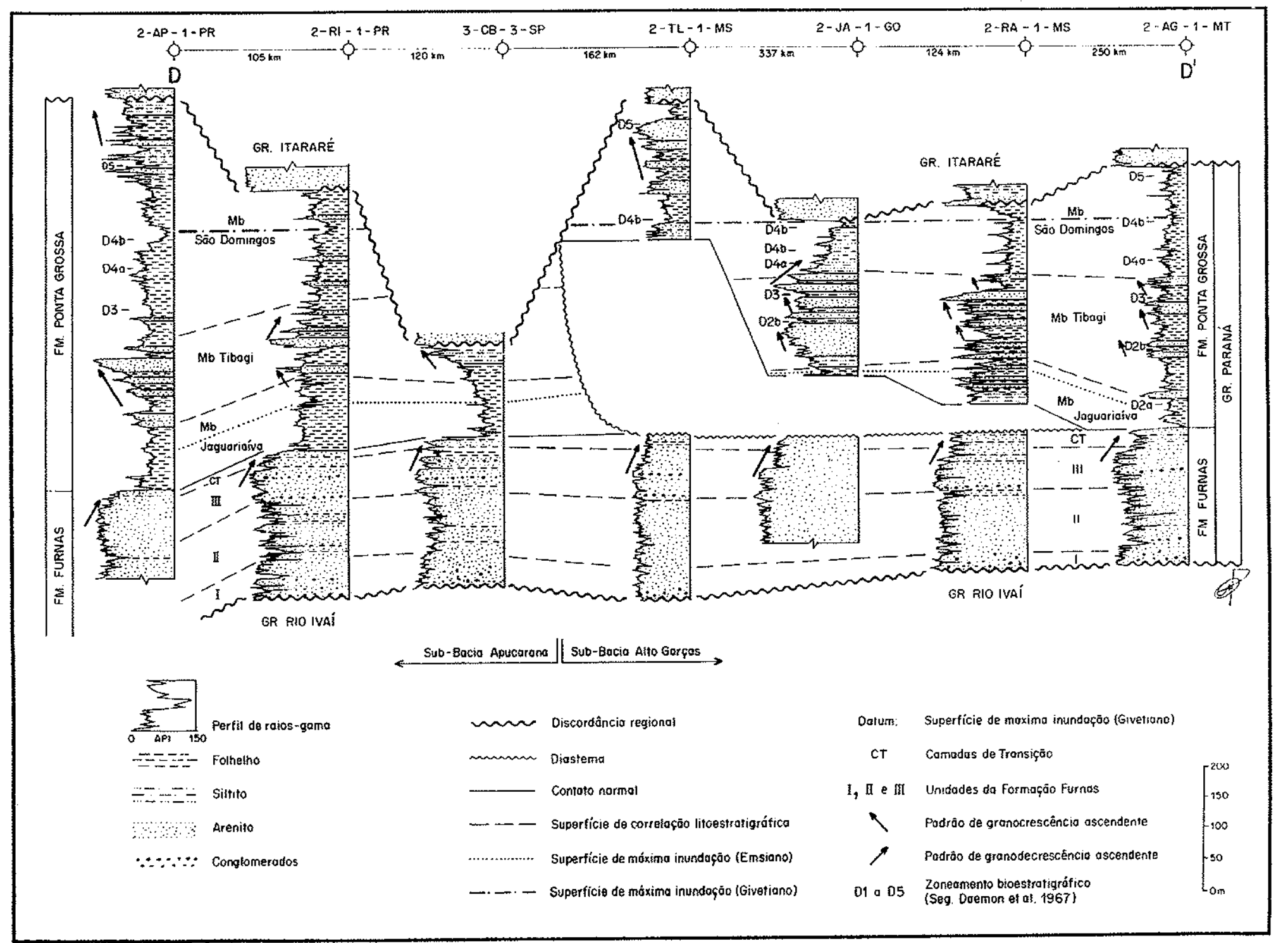

Figura 66 - Seção estratigráfica NS mostrando falta de seção entre as formações Furnas e Ponta Grossa (localização: Fig. 33) 
A -

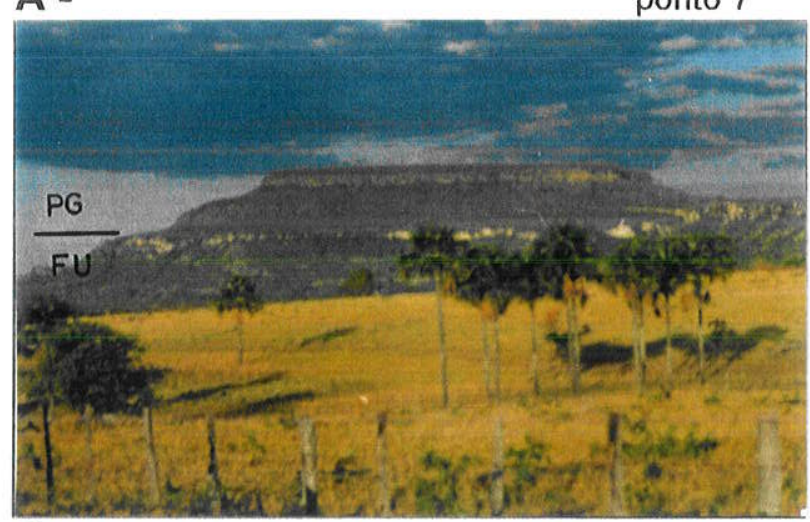

C -

ponto 1

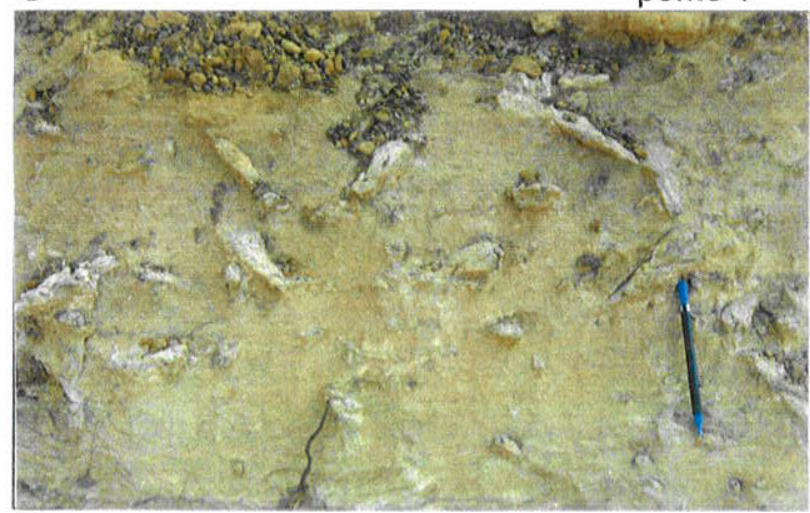

E -

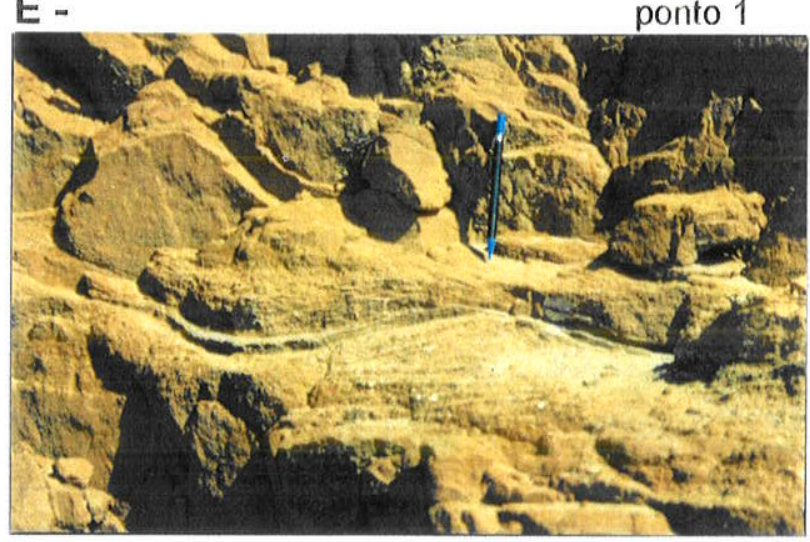

G -

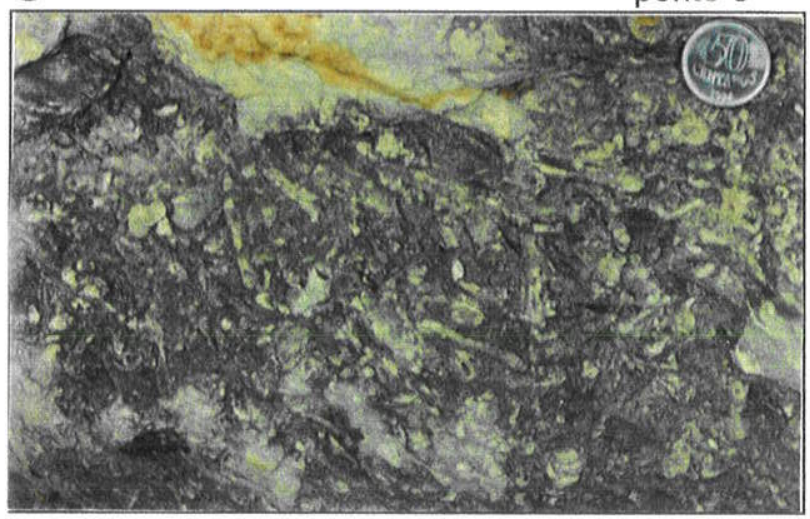

B -

ponto 1

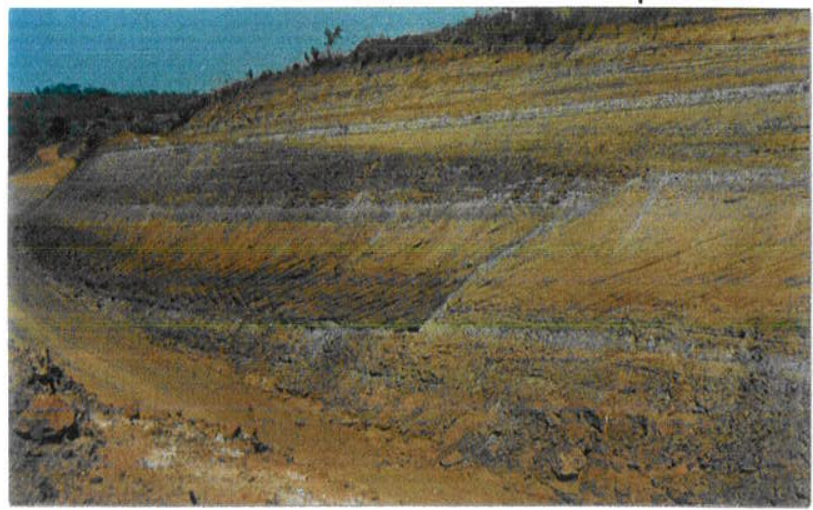

D - ponto 1
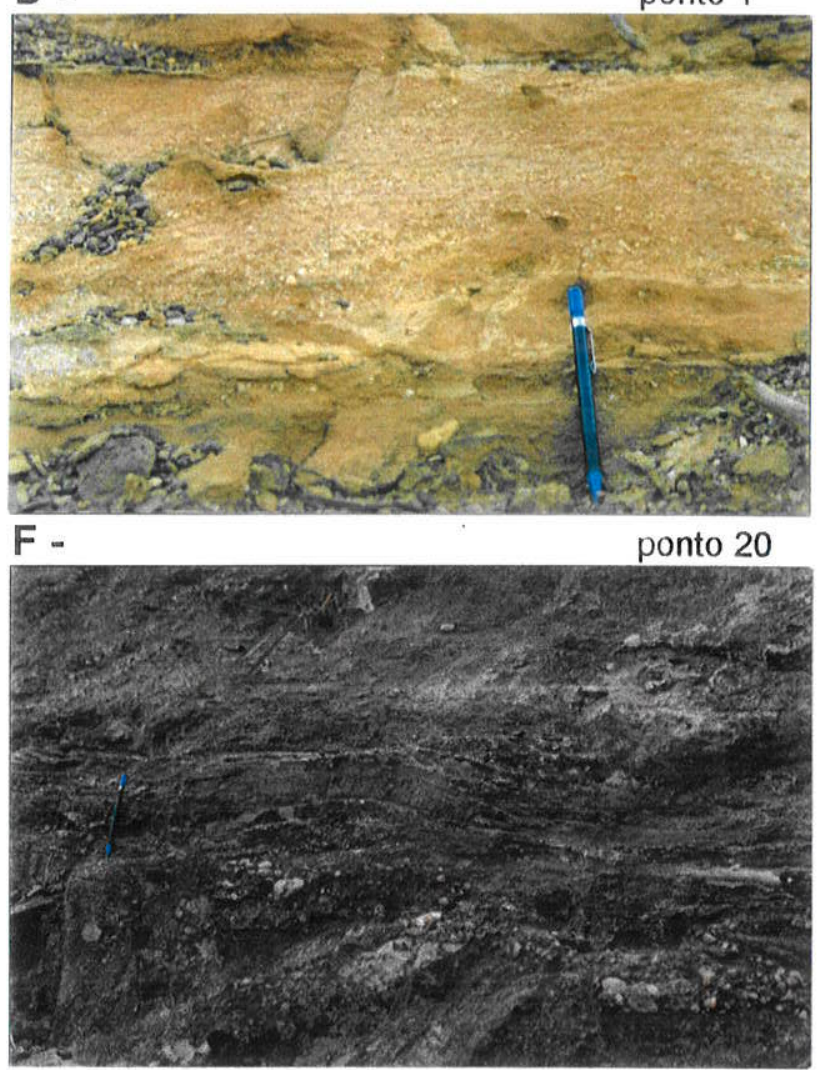

H -

ponto 38

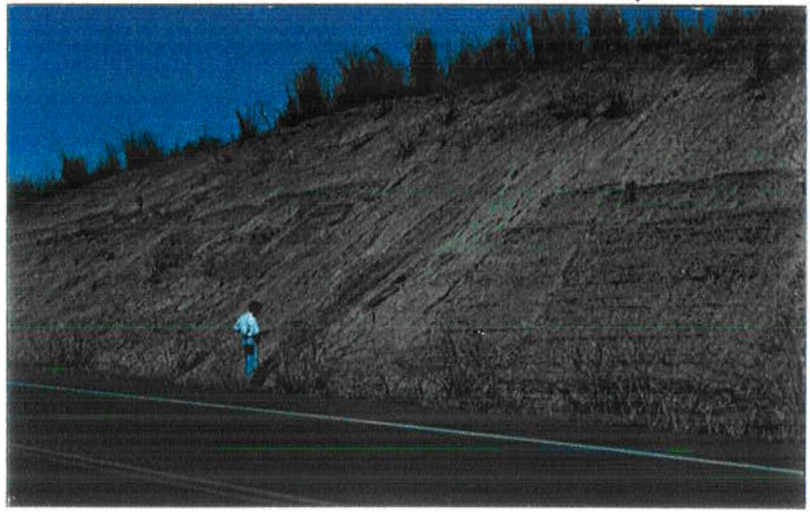

Figura 67 - Características litológicas da Fm. Ponta Grossa na porção norte da bacia. A parte inferior da Fm. Ponta Grossa é psamítica, formando relevos escarpados como o do morro da Mesa (A: $P G=F m$. Ponta Grossa; FU = Fm. Furnas). Predominam arenitos finos (B), que freqüentemente apresentam-se bioturbados (C). São sucedidos na vertical por arenitos grossos a conglomeráticos (D/E), cujo retrabalhamento por ondas pode formar lags de conglomerado (F). Siltitos emsianos bioturbados podem ocorrer na base (G). Na parte superior predominam folhelhos do Givetiano/Frasniano (H). 


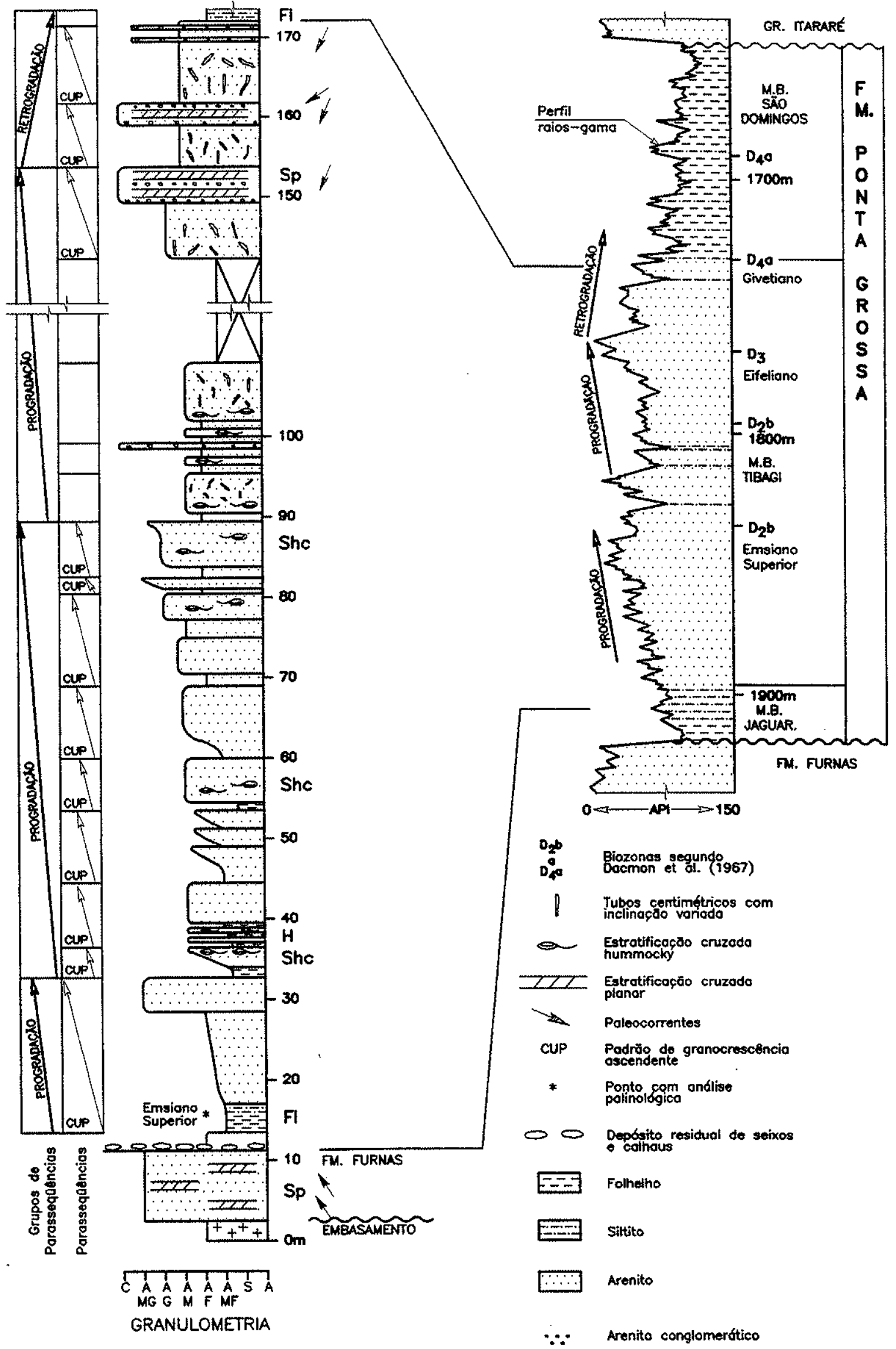

Figura 68 - Correlação da seção colunar da Fm. Ponta Grossa ao sul de Amorinópolis-GO com o perfil do poço 2-JA-1-GO (Jataí). 
poço 2-JA-1-GO (Jataí; cerca de $150 \mathrm{~km}$ ao sul), onde se verifica empilhamento sedimentar similar, mas com a existência de uma seção pelítica na base correlacionada com o Mb. Jaguariaíva.

A existência de siltitos intensamente bioturbados (Fig. 67-G), com apenas alguns metros de espessura mas palinologicamente férteis, logo acima do contato com a Fm. Furnas (pontos 1 e 3), permitiu o posicionamento da base da Fm. Ponta Grossa no Emsiano superior (análise palinológica realizada por R. F. Daemon). Esta idade é compativel com o topo do Mb. Jaguariaiva no Estado do Paraná, evidenciando que a seção pelítica inferior correspondente ao $\mathrm{Mb}$. Jaguariaiva é praticamente ausente na faixa de afloramentos no Estado de Goiás.

Disto se conclui que a Fm. Ponta Grossa se inicia com o Mb. Tibagi no flanco norte da bacia. Assim como no Estado do Paraná, os arenitos são fossilíferos, com a presença marcante de Australospirifer iheringi (Andrade \& Camarço 1980). O padrão de granocrescência ascendente dos corpos arenosos e do conjunto como um todo é exatamente o mesmo observado nos perfis dos poços. Nesta região, o Mb. Tibagi compreende os membros inferior e médio de Andrade \& Camarço (1980.), atingindo cerca de $200 \mathrm{~m}$ de espessura no Município de Caiapônia, em Goiás. A existência de níveis conglomeráticos, que se espessam para leste em detrimento dos arenitos da base, refletem proximidade da borda original da bacia.

Esta é uma diferença marcante quando se comparam as seções devonianas aflorantes nos flancos norte e sudeste. No Estado de Goiás o empilhamento reflete condições de borda, caracterizando-se pela presença de deltas retrabalhados por ondas com sentido de progradação de NE para SW, polaridade deduzida pela distribuição das fácies (Andrade \& Camarço 1980) e corroborada pelo padrão de paleocorrentes nas fácies de planície deltaica (parte superior da seção colunar ao sul de Amorinópolis apresentada na figura 68). No Estado do Paraná os arenitos do Mb. Tibagi originaram-se em barras de costa-afora construídas por ondas, indicando assim um contexto distal de plataforma externa dominada por tempestades.

Uma espessa seção pelítica, de idades givetiana e frasniana, constitui a parte superior da Fm. Ponta Grossa no flanco norte da bacia. Referida como membro superior por Andrade \& Camarço (1980, 1982), representa a exposição em superfície do Mb. São Domingos, presente nos poços 2-JA-1-GO, 2-RA-1-MS e 2-AG-1-MT. 


\subsubsection{2 - Chapada dos Guimarães}

As correlações apresentadas acima permitem algumas considerações sobre o Devoniano da chapada dos Guimarães (Fig. 69-A), onde, conforme argumentação apresentada a seguir, tem-se incluído na Fm. Furnas uma seção que seria mais apropriadamente classificada dentro da Fm. Ponta Grossa. Para iniciar a discussão, registra-se que Oliveira \& Muhlmann (1967) já haviam percebido que a Fm. Furnas, como tem sido considerada na área, compreende duas unidades arenosas distintas: a) uma inferior, constituída de arenitos brancos, médios a grossos, com estratificação cruzada, lentes conglomeráticas interestratificadas e conglomerados basais (referida como Fm. Chapada 1 por Melo 1985, 1988) ; b) outra superior, caracterizada por arenitos róseos, finos a muito finos, com estratificação predominantemente planoparalela (classificada como Fm. Chapada 2 nos trabalhos de Melo 1985 e 1988).

O contato entre ambas as unidades é nítido, materializado por uma superfície plana, visivel nos paredões de pontos turísticos da chapada, como por exemplo Véu da Noiva e, mais claramente, no Portão do Inferno (Figs.69-B/C). A existência desta descontinuidade faciológica, dentro do intervalo que tem sido considerado pertencente à Fm. Furnas na chapada dos Guimarães, também foi reconhecida por Schubert (1994), embora este autor não a tenha considerado uma discordância visto que a posicionou no meio da unidade II de sua divisão tripartite da Fm. Furnas. Entretanto, segundo Saes et al. (1993), o contato entre ambas é uma superfície de discordância regional, posição que é compartilhada pelo autor do presente trabalho.

Os arenitos brancos da porção inferior (Fig. 69-D) são de granulometria média a grossa, apresentando-se em sets de pequeno a médio porte, com estratificações cruzadas tabulares, acanaladas $e$, em alguns casos, espinha-de-peixe. Como já referido acima, apresentam intercalações de lentes delgadas de conglomerados, que adquirem maior proporção em direção à base. $\mathrm{Na}$ localidade de Salgadeira (ponto 43) e na trilha de acesso à cachoeira dos Malucos (ponto 44), em discordância angular por sobre filitos do $\mathrm{Gr}$. Cuiabá, ocorrem cerca de $10 \mathrm{~m}$ de conglomerados de granulação fina e seixos angulosos (em geral menores que $2 \mathrm{~cm}$ ), dispostos em camadas tabulares $e$ interestratificados com arenitos grossos. Estas características faciológicas são plenamente compativeis com as da Fm. Furnas em outras partes da bacia.

De outra parte, os arenitos finos posicionados acima da citada descontinuidade, de coloração rósea/avermelhada e com intercalações de siltitos também avermelhados, constituem fácies que não foram observadas na Fm. Furnas alhures. 
A -

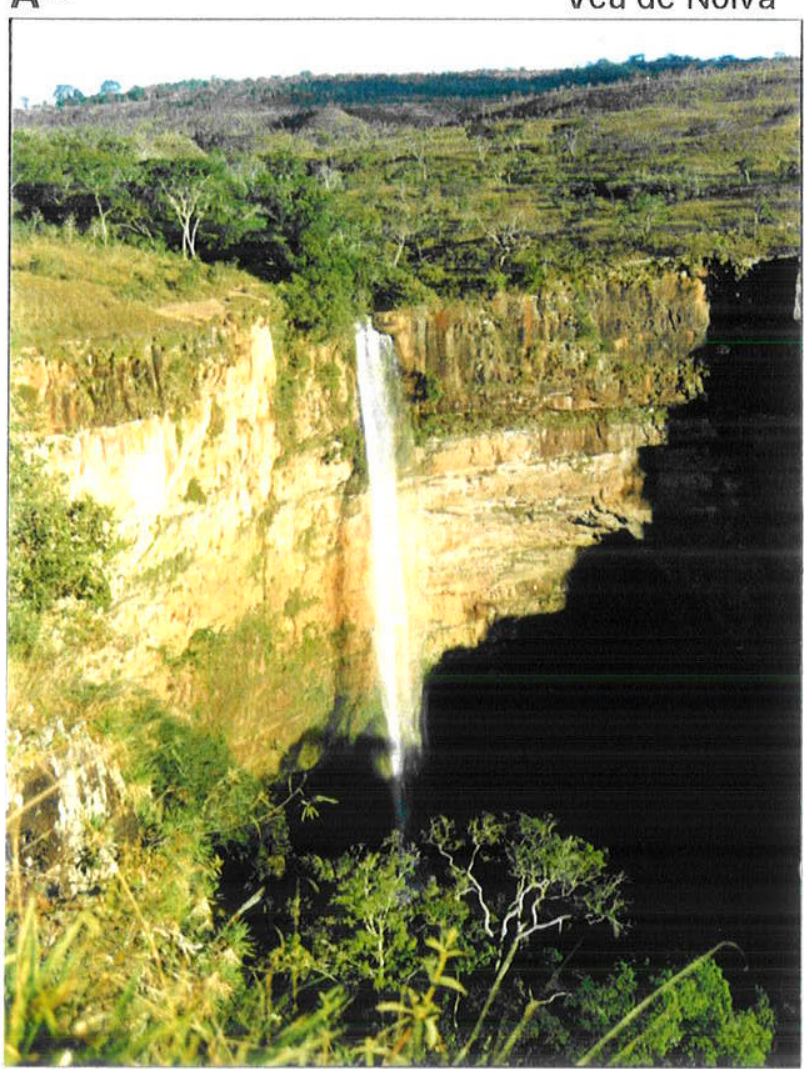

D -

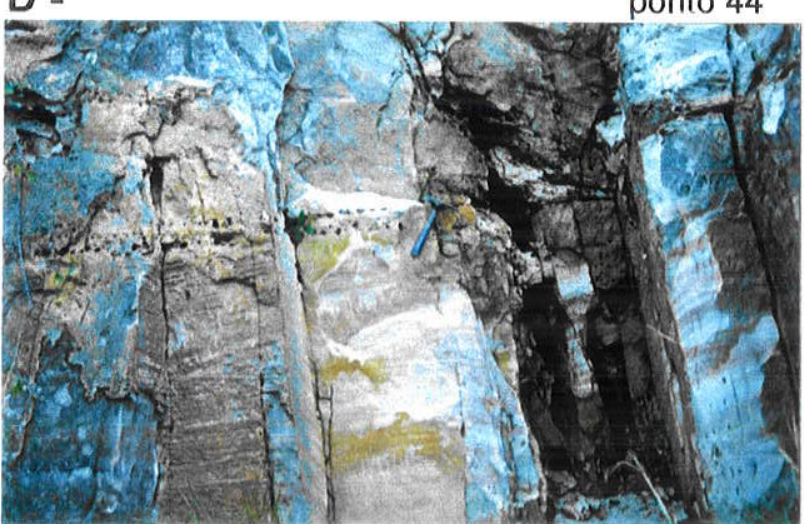

F -

ponto 46

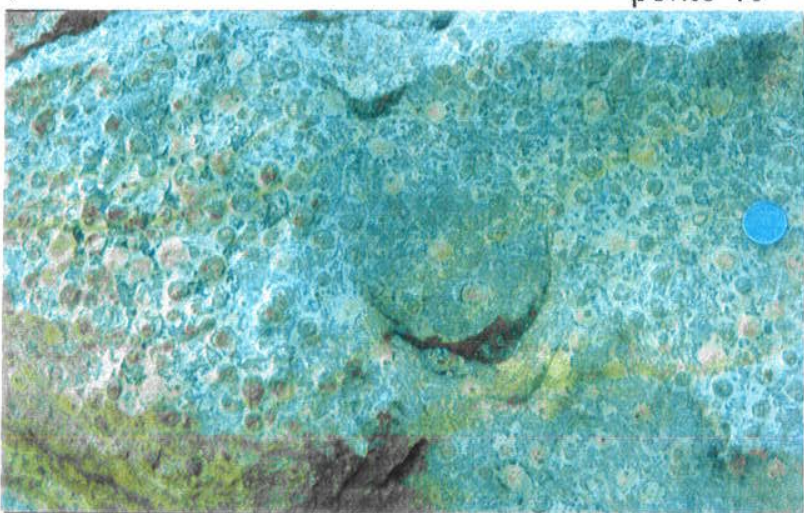

B -

Portão do Inferno

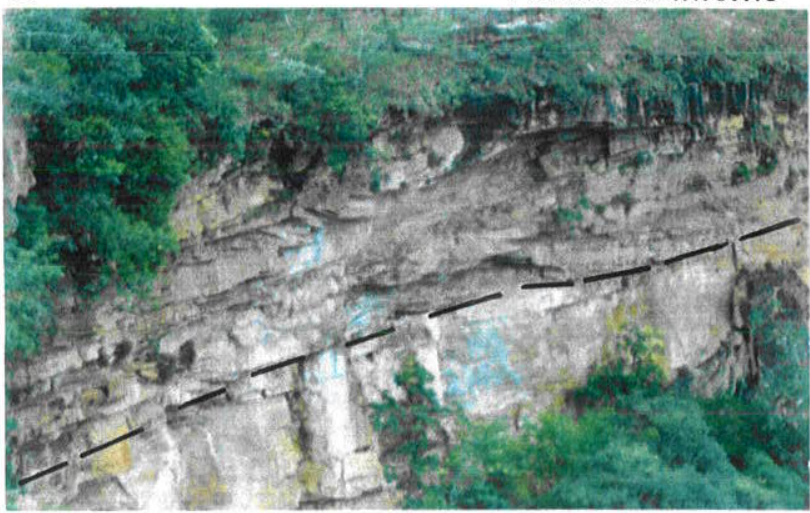

C -

Portão do Inferno

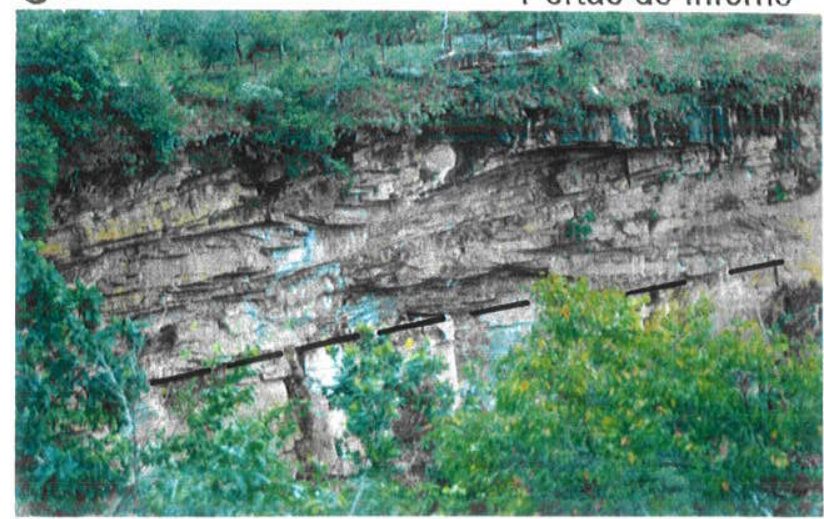

E -

ponto 45

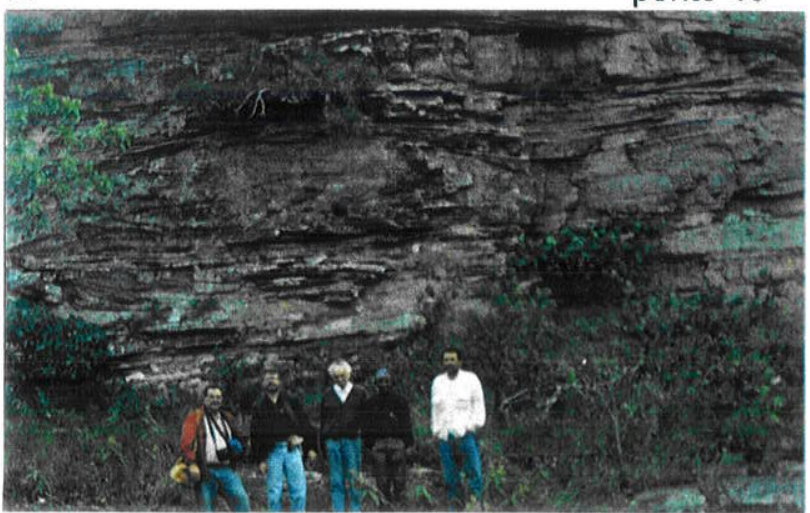

G -

ponto 46

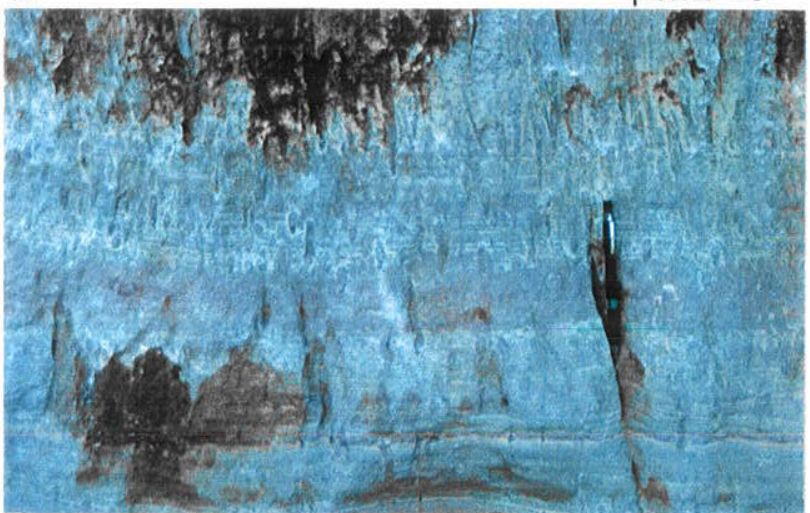

Figura 69 - O Gr. Paraná na chapada dos Guimarães. Toda a escarpa arenosa vem sendo considerada pertencente à $\mathrm{Fm}$. Furnas (A). No entanto, há visível descontinuidade na seção psamítica $(B / C)$, separando arenitos brancos com estratificação cruzada na parte inferior (D) de arenitos e siltitos avermelhados com retrabalhamento por ondas na parte superior (E). No topo do que é considerado Fm. Furnas em trabalhos anteriores, existem magníficos exemplos de skolithos em arenitos finos, mostrados em cortes transversal (F) e longitudinal (G). 
Estão muito bem expostas no Portão do Inferno (Fig. 69-E) e na estrada para o Morro São Jerônimo (ponto 45). São caracterizadas por estratos com estratificação planoparalela e/ou cruzada hummocky, intercalados com sets de geometria sigmóide. Como interpretaram Saes et al. (1993), constituem sandwaves de maré em plataforma marinha com retrabalhamento por ondas de tempestade. Estes arenitos são correlacionados neste trabalho com os arenitos da parte inferior da Fm. Ponta Grossa na faixa de afloramentos do Estado de Goiás (membro inferior de Andrade \& Camarço 1980), que também se assentam em discordância sobre a Fm. Furnas. É digno de nota que Melo $(1985,1988)$ já havia proposto esta correspondência. Além disso, ressalta-se também que no Estado de Goiás a seção inferior da Fm. Ponta Grossa, constituída de arenitos finos avermelhados, era incluída na Fm. Furnas até o trabalho de Andrade \& Camarço (1980). Utilizando-se do mesmo raciocínio exposto na discussão do Devoniano do Estado de Goiás (item 6.2.3.1), estes arenitos são considerados a expressão do Mb. Tibagi na chapada dos Guimarães.

No topo dos arenitos finos avermelhados ocorre uma seção de arenitos finos com laminação plano-paralela e/ou cruzada hummocky, freqüentemente bioturbados, com espessura de no máximo $30 \mathrm{~m}$. Destaca-se a presença conspícua de tubos verticais, com diametro de cerca de $1 \mathrm{~cm}$ e comprimento de vários decímetros, do icnogênero Skolithos (pipe rocks), o qual caracteriza icnofácies de ambientes marinhos rasos/litorâneos (Fig. 69-F/G). Schubert (1994) considerou a seção como sua unidade III (topo) da Fm. Furnas, relatando que na mesma foram encontrados restos de plantas vasculares primitivas, similares aos do topo da Fm. Furnas no Estado do Paraná. Este posicionamento não é aqui adotado, entretanto, em função da opção, discutida anteriormente, de classificar-se a seção de arenitos como pertencentes à Fm. Ponta Grossa.

O topo da seqüência devoniana na chapada dos Guimarães é constituído predominantemente por folhelhos cinza escuros/médios de idade givetiana (Lange 1967, Lange \& Petri 1967), onde não se acham presentes formas tipicamente malvinocáfricas. Constitui a único local até o momento onde foram constatados espécimes de braquiópodos do gênero Tropidoleptus (Derby 1890, Caster 1947a,b), um táxon de faunas boreais, cujo aparecimento na bacia foi interpretado como uma ingressão marinha de águas mais quentes vindas do Norte (Boucot et al. 1983, apud Melo 1985).

$\mathrm{Na}$ figura 70 está apresentada comparação entre interpretações de diferentes autores para o Devoniano da chapada dos Guimarães. Na proposta apresentada 
neste trabalho, os arenitos com Skolithos são colocados na parte superior do Mb. Tibagi. Na seção do morro Tope de Fita, no topo dos arenitos com skolithos, Quadros (1981) descreveu alta freqüência de espécimes de braquiópodos da fauna malvinocáfrica, entre os quais predominam amplamente os da espécie Australocoelia tourteloti.

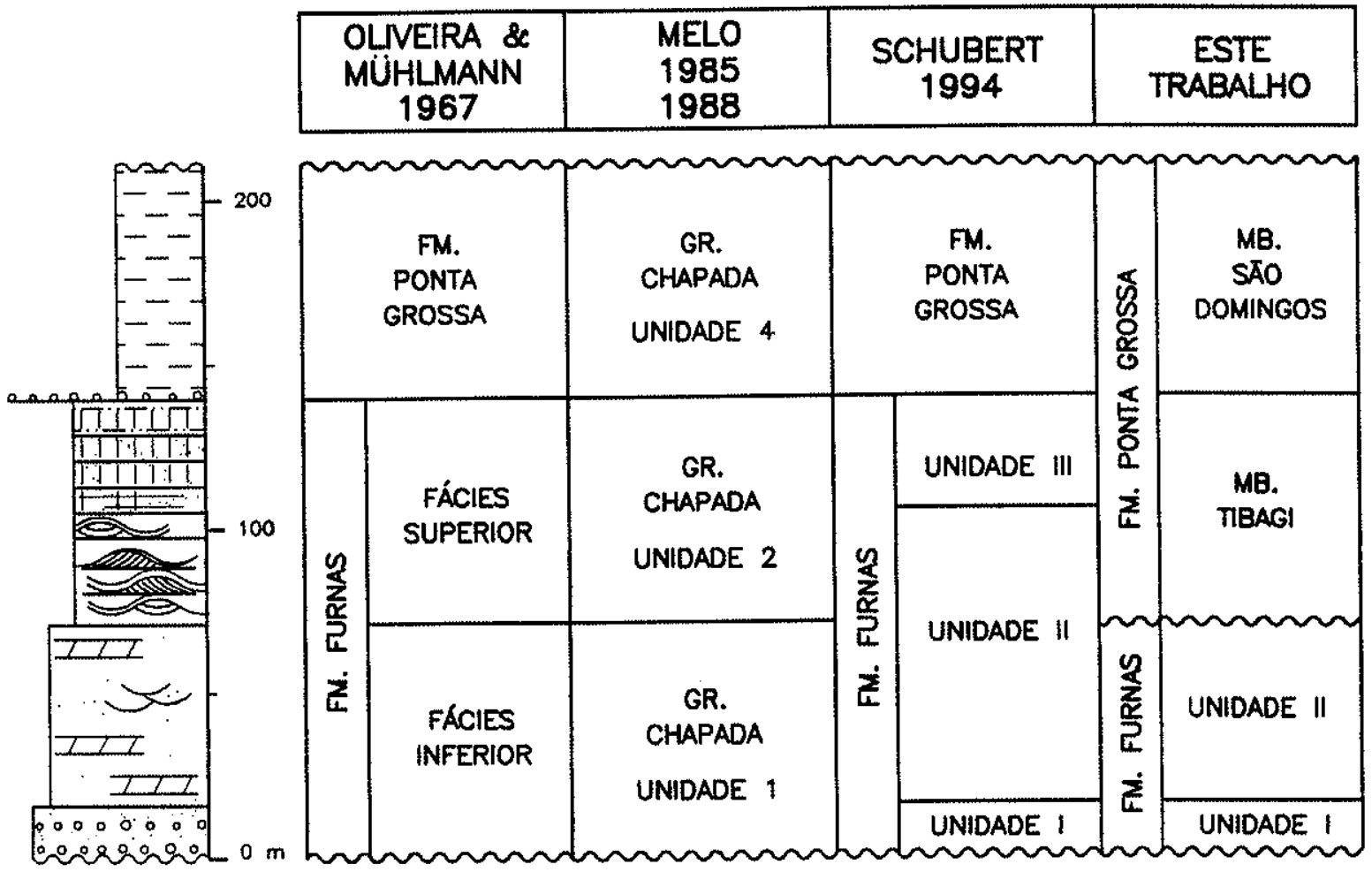

Figura 70 - Esquemas estratigráficos propostos para o Devoniano da chapada dos Guimarães, Estado do Mato Grosso.

Das palavras de Quadros (1981, p. 769), deduz-se que a ocorrência de braquiópodos no morro Tope de Fita representa o nivel mais alto da fauna malvinocáfrica na chapada dos Guimarães, logo abaixo dos folhelhos do Mb. São Domingos: "Os fósseis foram achados no interior de grandes concreções constituídas por material síltico-arenoso ou síltico argiloso... As concreções situavam-se logo abaixo de um folhelho cinza azulado, geralmente tendo uma areia fina-síltica como 
massa envolvente. Outras vezes esta massa era síltico-argilosa, porém sempre em nivel abaixo do folhelho".

Por último, merece destaque o fato de que, também na chapada dos Guimarães, entre os membros Tibagi e São Domingos ocorrem lags transgressivos. Oliveira \& MühImann (1965), que mapearam toda a região, relataram a presença, poucos metros abaixo dos folhelhos superiores, de um delgado, mas persistente, nível de arenito síltico com clastos angulosos de quartzo de até $20 \mathrm{~cm}$ de diâmetro. Feição similar, embora com clastos achatados e arredondados foi descrita por Lange \& Petri (1967) no topo do $\mathrm{Mb}$. Tibagi na região de Ponta Grossa, no Estado do Paraná (ponto 101, Fig. 63).

\subsubsection{3 - Uruguai}

Sobreposta à seção psamítica da Fm. Cerrezzuelo, litoestratigraficamente correlata à Fm. Furnas, existe uma seção pelítica com cerca de 100m de espessura, classificada como Fm. Cordobês. De há muito é posicionada no Devoniano Inferior, idade corroborada pelas análises micropaleontológicas de Da Silva (1990), que identificou acritarcas da espécie Triangulina alargada, considerada pelo referido autor fóssil-guia do Emsiano. Sob esta ótica, a Fm. Cordobês e a Fm. La Paloma, imediatamente sobreposta, correlacionar-se-iam, respectivamente, com os membros Jaguariaiva e Tibagi da Fm. Ponta Grossa.

Outra posição foi assumida, contudo, por Verosiavsky Barbé (1994). A partir de quitinozoários e de outras formas de acritarcas, posicionou a Fm. Cordobês no intervalo Eifeliano Superior/Frasniano, correlacionando-a com o Mb. São Domingos da Fm. Ponta Grossa. Desconsiderou o acritarca Triangulina alargada como fóssil-guia do Emsiano, adotando argumentação de Oliveira (1991). Admitindo-se as colocações de Verolavsky Barbé (1994), a seção regressiva do topo do Devoniano no Uruguai, classificada litoestratigraficamente como Fm. La Paloma, seria correlacionável com a seção psamitica regressiva frasniana existente no topo da Fm. Ponta Grossa nos poços 2-AP-1-PR (Apucarana) e 2-TL-1-MS (Três Lagoas) (Fig. 66, p. 126).

Qual das duas correlações é correta? O autor do presente trabalho considera que há a necessidade de novos estudos bioestratigráficos para uma definição segura. Outros dados precisam ser considerados, porque a Fm. Cordobês é portadora de extensa paleofauna caracterizada pela presença marcante de formas malvinocáfricas 
(Figueiras 1991, Sprechmann et al. 1993), cujo desaparecimento ocorreu no Eifeliano Superior (Melo 1985, Isaacson \& Sablock 1990).

\subsection{4 - Natureza do contato com a Formação Furnas}

As considerações acima indicam que o contato entre as formações Furnas e Ponta Grossa nem sempre é concordante. No Estado de Goiás, onde o Mb. Jaguariaíva não ocorre, a base da Fm. Ponta Grossa é marcada por uma concentração de cascalhos (diâmetro máximo constatado de $21 \mathrm{~cm}$ ), que pode variar desde uma superfície de cascalhos dispersos e isolados, até uma camada de conglomerado com alguns decímetros de espessura (Fig. 71), por isso referida como conglomerado basal por Andrade \& Camarço (1980). Trata-se de um extenso lag transgressivo, formado como conseqüência de rápida transgressão erosiva, com erosão marinha, retrabalhamento e joeiramento dos sedimentos de fundo, recoberto diretamente por siltitos e arenitos da Formação Ponta Grossa.

A julgar pelos dados paleontológicos disponíveis na literatura geológica (Lange 1967, Daemon et al. 1967), contatos discordantes entre as formações Furnas e Ponta Grossa ocorrem também quando não estão presentes os andares Emsiano e Eifeliano, sendo a Formação Furnas sobreposta diretamente por folhelhos givetianos e/ou frasnianos, como é o caso dos poços 2-TL-1-MS (Três Lagoas; Fig. 66), 2-RP-1-MS (Ribas do Rio Pardo) e 2-PP-1-SP (Paraguaçu Paulista). Situação similar, de pequena espessura da Fm. Ponta Grossa e contato abrupto com a Fm. Furnas, ocorre nos poços 2-CG-1-MS (Campo Grande), 1-MA-1-SP (Mandaçaia) e 1-SA-1-SP (Sarutaiá), embora não se disponha de dados bioestratigráficos que confirmem a ausência dos andares Emsiano/Eifeliano. Tais datações são de importância crucial para o entendimento da evolução tectono-sedimentar da bacia, sendo importantes a revisão e o refinamento cronoestratigráfico da Fm. Ponta Grossa, fato que ficou evidente a partir da reavaliação do poço 2-CN-1-SC (Canoinhas), apresentada por Dino et al. (1995).

De qualquer forma, na maioria dos perfis de raios-gama dos poços perfurados no programa de exploração petrolífera da bacia, a parte superior da Fm. Furnas apresenta um incremento contínuo de argilosidade em direção à Fm. Ponta Grossa, oque indica uma passagem gradual. Além disso, as seções estratigráficas (Figs. 12, 19 e 20) evidenciam que, na maioria dos casos, não há falta de seção no topo da Fm. Furnas, o que seria de se esperar no caso de uma discordância regional. 


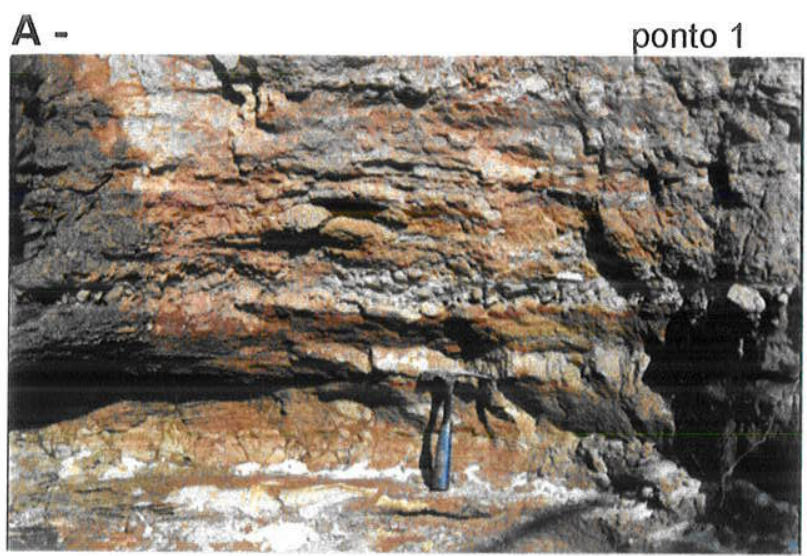

C -
B -

ponto 3

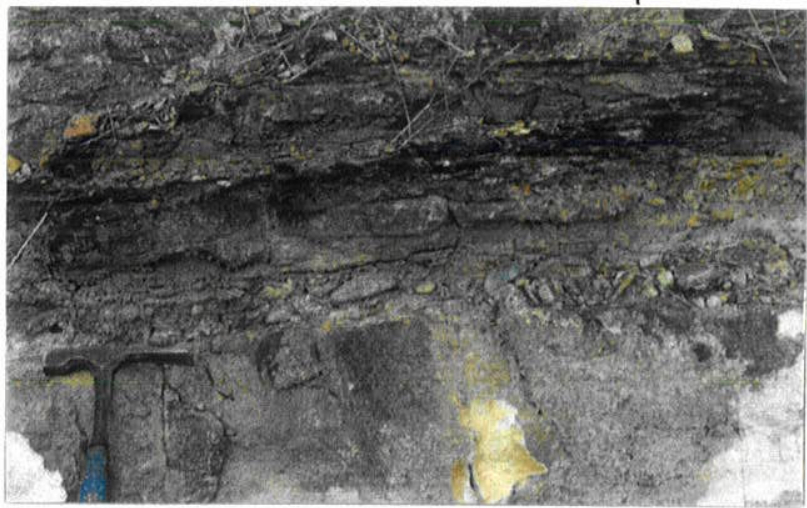

ponto 4

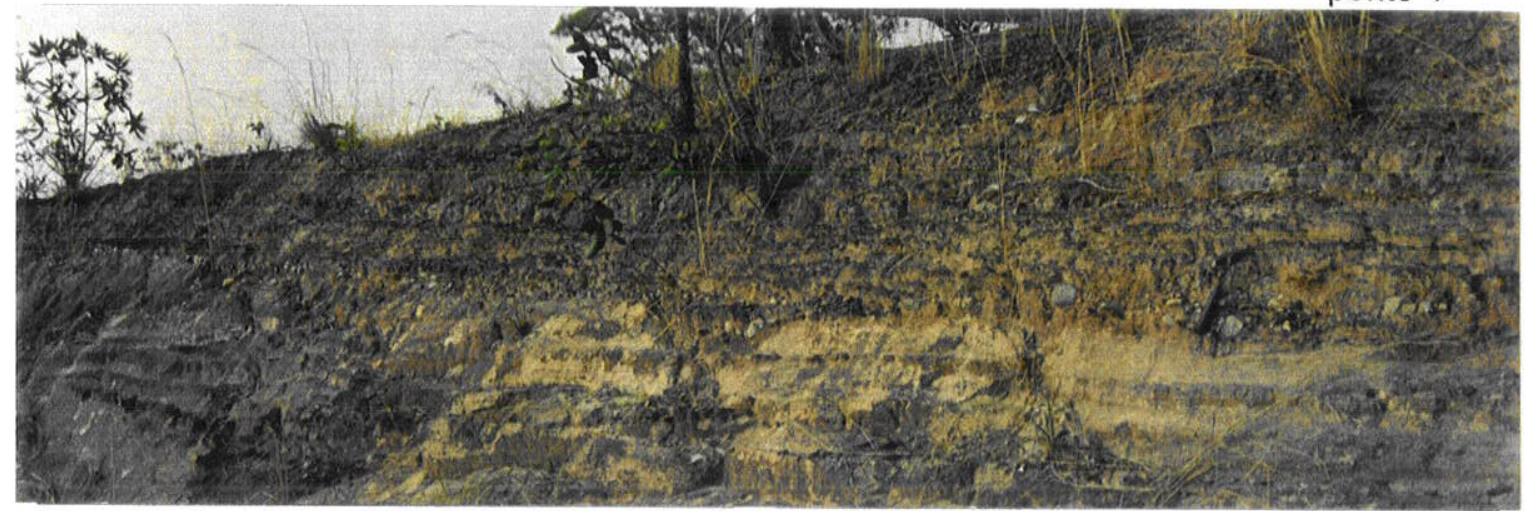

D -

ponto 5

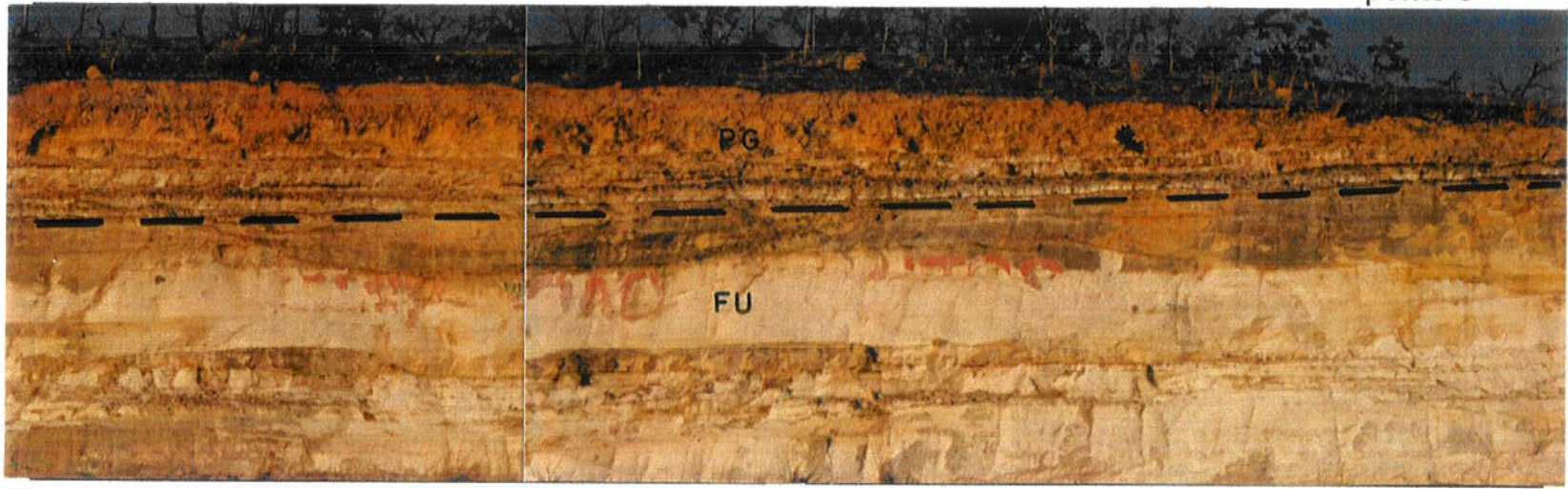

E -

ponto 4
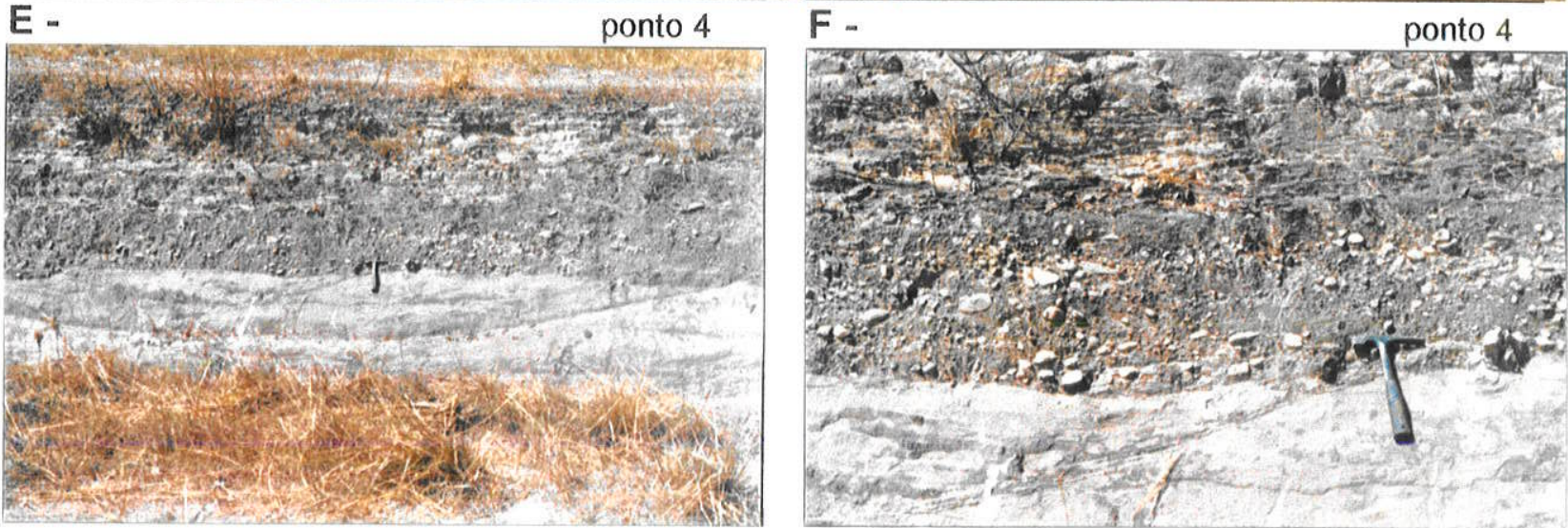

Figura 71 - Depósitos residuais (lags) transgressivos na base da Fm. Ponta Grossa no Estado de Goiás. $\quad \mathrm{Na}$ base da $\mathrm{Fm}$. Ponta Grossa há uma concentração de seixos e calhaus, arredondados e assimétricos (A/B). O contato com a Fm. Furnas é erosivo e plano (C/D: FU = Fm. Furnas; PG = Fm. Ponta Grossa). Em alguns casos a espessura do lag transgressivo chega a um metro, constituindo verdadeiros conglomerados basais (E/F). 
Um contato concordante entre as formações Furnas e Ponta Grossa foi demonstrado por Petri (1948) nas localidades de Jaguariaiva e Tibagi (PR), com a caracterização das Camadas de Transição, que materializam passagem gradual entre ambas unidades. Em Tibagi, onde o contato entre as duas formações é bem definido litologicamente (Fig. 59E), por isso utilizado como argumento em favor de um contato discordante por Bigarella (1973) e Zalán et al. (1987), Petri (1948) descreveu fósseis devonianos em pelitos intercalados nos arenitos grossos da Fm. Furnas, alguns metros abaixo do contato.

A ausência de hiato significativo entre a Fm. Furnas e os folhelhos emsianos da base da Fm. Ponta Grossa foi confirmada por datações de camadas pelíticas existentes na parte superior da Fm. Furnas, em Jaguariaiva (PR), que indicaram uma idade praguiana (Dino \& Rodrigues 1995).

\section{3- ESTRATIGRAFIA DE SEQÜÊNCIAS}

A quase inexistência de informações a respeito da cronologia da Formação Furnas e o pequeno número de dados cronoestratigráficos sobre a Formação Ponta Grossa dificultam o fatiamento cronoestratigráfico em seqüências de menor ordem de grandeza ( $3^{a}$ e $4^{a}$ ordens), a confecção de mapas de fácies em diferentes intervalos de tempo e o estabelecimento da contemporaneidade lateral das diferentes unidades litoestratigráficas, muito útil para o entendimento das migraçōes de fácies e reconstruções paleogeográficas.

Pela empilhamento estratigráfico são interpretadas três seqüências deposicionais, delineando três superfícies de máxima inundação (Fig. 72). Correspondem a três ciclos de $3^{a}$ ordem com duração de 10 a $15 \mathrm{Ma}$.

\subsection{1 - Seqüência Lochkoviana(?)}

A seqüência, que comprende as unidades I e II da Fm. Furnas, ainda não foi datada por nenhum método. Idade lochkoviana é indicada pelo fato de estar sotoposta aos estratos praguianos da unidade III da Fm. Furnas. A correlação com a 


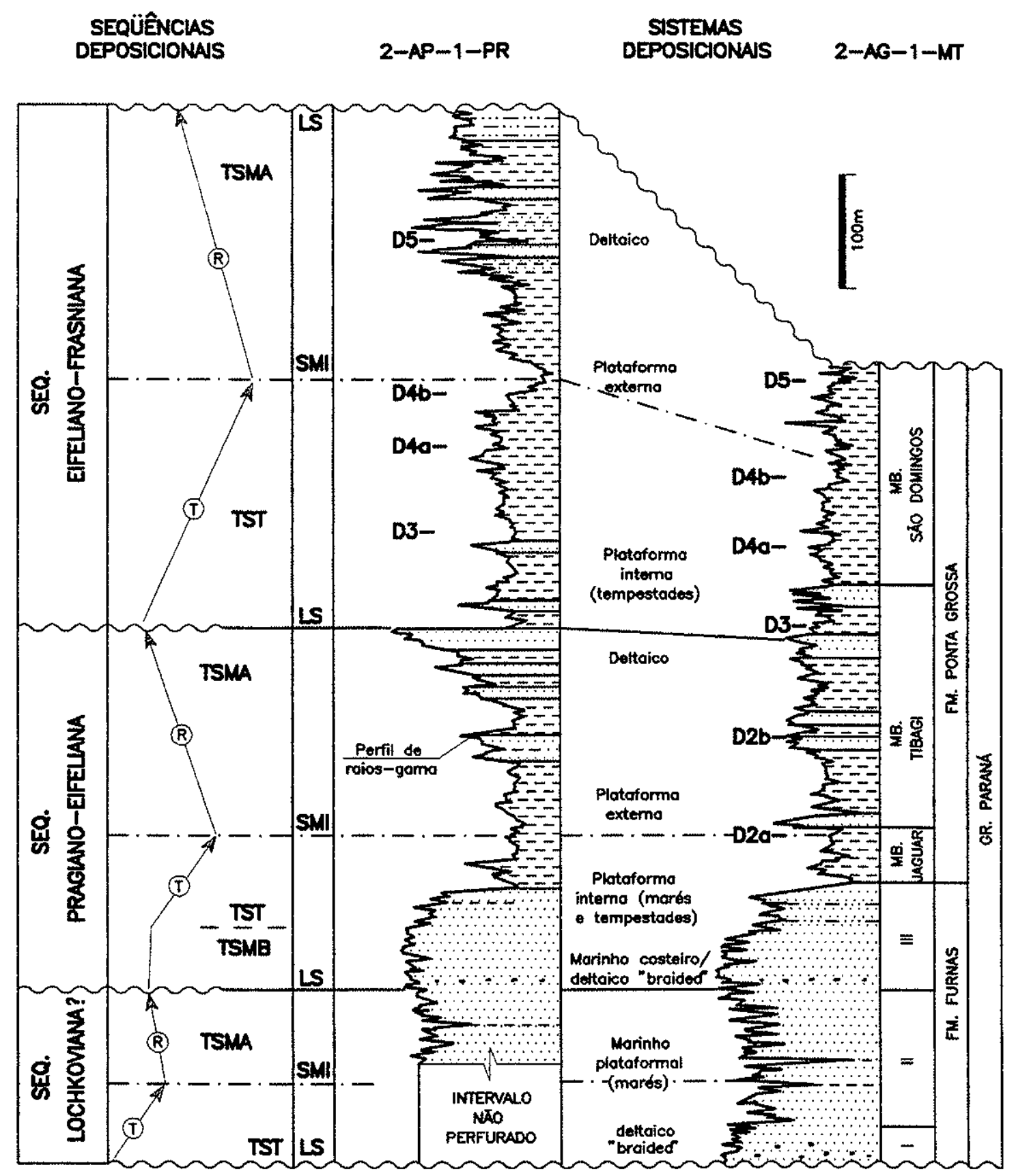

Figura 72 - Seqüências e tratos deposicionais no Devoniano da Bacia do Paraná $\quad(T=$ transgressão; $R=$ regressão; $L S=$ limite de seqüência; $S M I=$ superficie de máxima inundação; $T S T=$ trato de sistemas transgressivo; TSMA = trato de sistemas de mar alto; TSMB = trato de sistemas de mar baixo; 2-AG-1-MT = poço Alto Garças; 2-AP$1-P R=$ poço Apucarana; $D=$ intervalo bioestratigráfico, segundo Daemon et al. 1967). 
curva de variação relativa do nivel do mar de Ross \& Ross (1988) é sugestiva de que a superfície de discordância basal teria tido sua escultura final elaborada no limite Ludloviano/Pridoliano. É possivel, assim, que a sedimentação tenha se iniciado no Siluriano Superior, como sugerido por Borghi (1992), mas não existem elementos que permitam comprovar esta possibilidade, de forma que presumida idade lochkoviana foi admitida para a seqüência.

Inicia-se com um trato de sistemas transgressivo (transgressive system tract), desenvolvido sobre a superficie peneplanizada da discordância sobre o embasamento magmático-metamórfico pré-cambriano/eopaleozóico. As rochas do embasamento, logo abaixo da discordância, apresentam-se comumente frescas, sem a presença de paleossolos, o que pode ter sido conseqüência do clima subpolar reinante e da ausência de cobertura vegetal significativa no continente. A pequena espessura, o caráter retrogradante e a tabularidade das camadas nos depósitos costeiros da Fm. Furnas 1 indicam uma rápida transgressão, sem evidências de vales incisos (transgressive noincised valley fill).

A subida relativa do nivel do mar gerou espaço para a acomodação dos arenitos marinhos plataformais (shelf-sand bodies) da unidade II da Fm. Furnas, caracterizando um trato de sistemas de mar alto, identificado nos perfis de raios-gama por padrão de deflexão à esquerda (Fig. 72).

As superfícies bioturbadas no limite dos cosets, caracterizadas por traços fósseis da icnofácies Cruziana, evidenciam flutuações nas taxas de sedimentação, podendo estar associadas a hiatos deposicionais/hardgrounds e representar limites de parasseqüências.

Com base no padrão das paleocorrentes das fácies deltaicas arenoconglomeráticas da Fm. Furnas I (Fig. 73), interpreta-se um mergulho deposicional para WNW quando do início da sedimentação da seqüência. Disto deduz-se que a linha de costa tinha direção aproximada NNE-SSW, o que se coaduna com a orientação N25-35E dos eixos "a" dos seixos alongados ( 3 a $5 \mathrm{~cm}$ ) dos conglomerados basais (Maack 1946). As paleocorrentes dos arenitos plataformais da unidade $\|$ da Fm. Furnas são paralelas à costa no flanco sudeste (Fig. 47, p. 95) e dirigidas para costa-afora no flanco norte (Fig. 50, p. 98), resultado do retrabalhamento por correntes de maré e, possivelmente, correntes geostróficas.

Conseqüência do mergulho deposicional, a seqüência exibe um afinamento textural para oeste-noroeste, visivel nas seções das figuras 19 e 20 . Na porção sul da bacia, existem evidências de afinamento textural para sudoeste, acompanhando a 


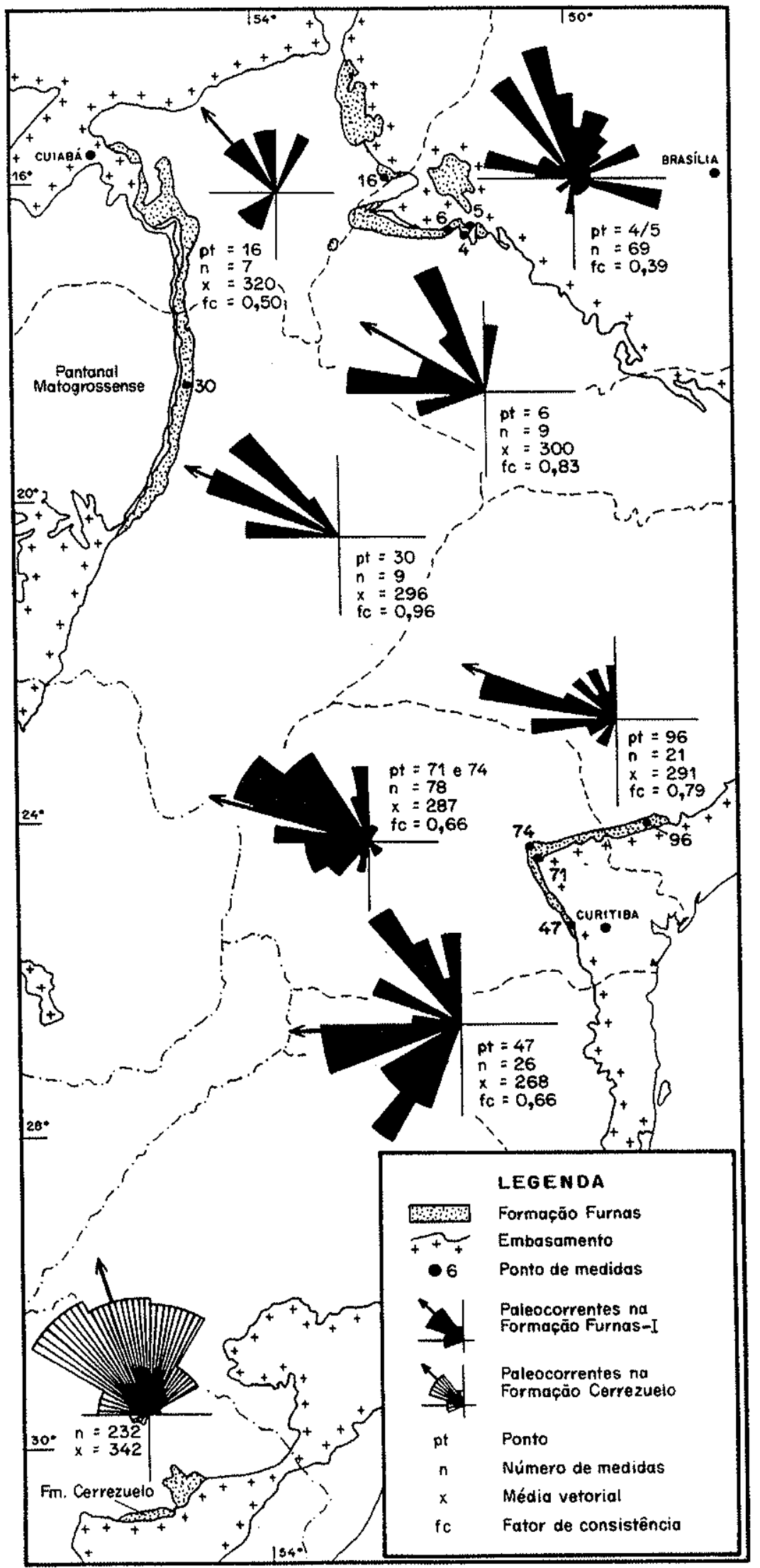

Figura 73 - Paleocorrentes nas fácies arenoconglomeráticas da unidade I da Fm. Furnas. 


\section{PONTO 96}

PALEOCORRENTES

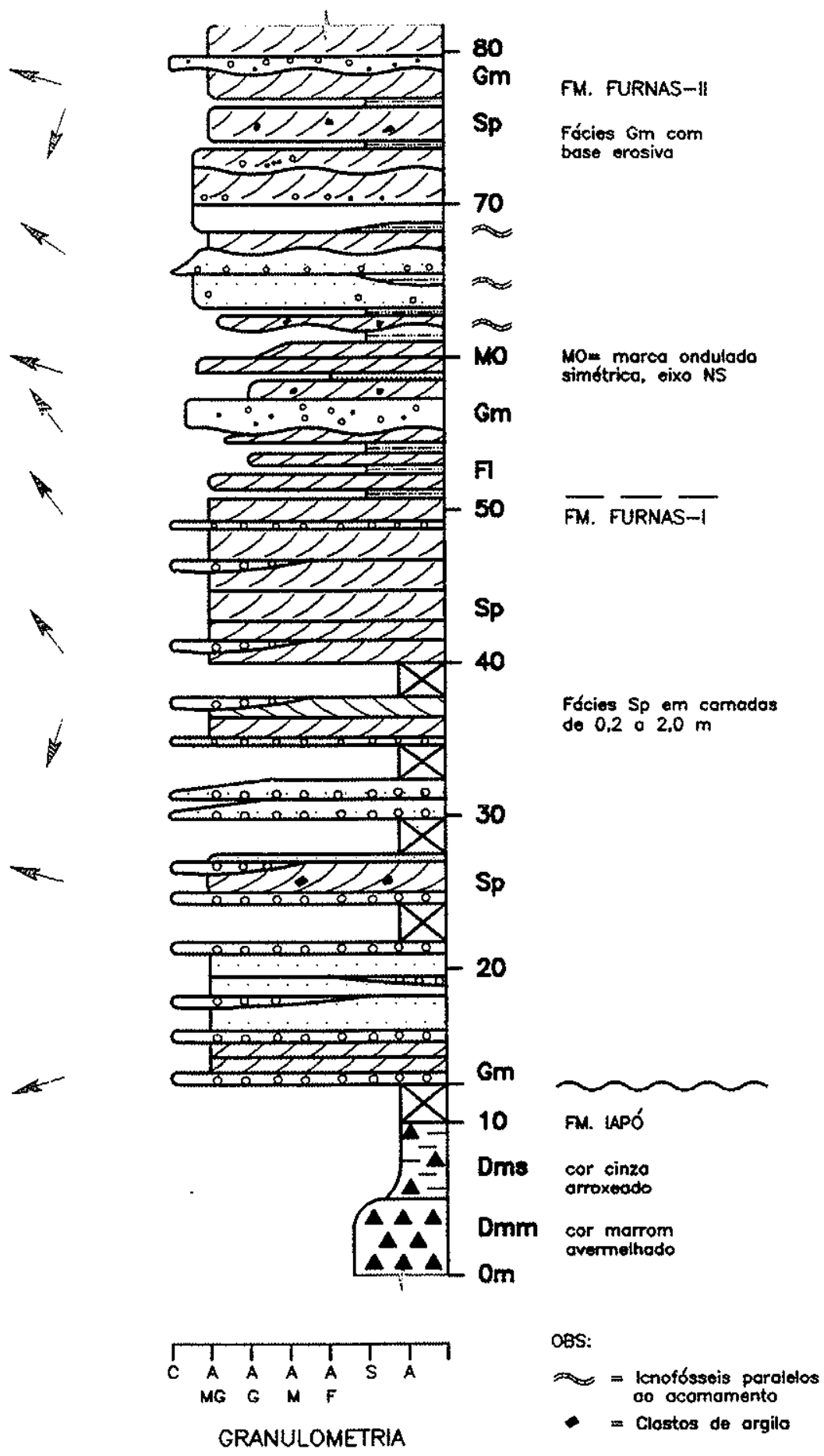

Figura 74 - Seção colunar entre as cidades de Bonsucesso e Itapeva (SP). 
paleolinha de costa, à semelhança do constatado por Swift et al. (1991) na costa atlântica norte-americana. Dentre as seções levantadas na faixa de afloramentos do flanco sudeste da bacia, condições mais proximais foram observadas na região entre Itapeva e Itararé, onde são comuns arenitos conglomeráticos e conglomerados também na unidade II (Fig. 74).

\subsection{2 - Seqüência Praguiana - Eifeliana}

A existência de seixos e calhaus sob a forma de depósitos residuais na unidade III da Fm. Furnas permite interpretar queda do nível de base, com introdução de clastos na plataforma pela progradação de sistemas deltaicos, caracterizando um trato de sistemas de mar baixo. O contraste faciológico com a unidade II da Fm. Furnas resulta de mudança no nível de energia do meio, de águas mais profundas para mais rasas.

Depósitos continentais são de ocorrência restrita já que foram alvo de retrabalhamento por ondas e marés, que promoveram joeiramento e concentração de cascalhos em diversas superfícies de abrasão marinha em ambientes rasos de shoreface. Descontinuidades deposicionais entre as unidades II e III da Fm. Furnas em porções marginais da bacia, como em Barra do Garças (Fig. 44, p. 89), caracterizam limite de seqüências deposicionais.

A unidade III da Fm. Furnas exibe progressivo incremento de argilosidade em direção ao topo, bem evidente nos perfis de raios-gama dos poços, compondo com as Camadas de Transição um empilhamento transgressivo que culmina com os folhelhos marinhos emsianos do Mb. Jaguariaíva da Fm. Ponta Grossa. A subida do mar foi rápida, de forma que praticamente não há interdigitação entre as formações Furnas e Ponta Grossa, embora o contato seja provavelmente diácrono, devendo as duas unidades ter coexistido lateralmente.

Os sedimentos que deram origem ao Mb. Jaguariaíva foram depositados em condições de baixa energia, com taxas de sedimentação muito baixas e intensa colonização bentônica do fundo, do que resultaram estratos intensamente bioturbados e muito fossilíferos, os horizontes paleontologicamente mais ricos da Fm. Ponta Grossa. Fósseis na posição de vida foram observados, tendo sido já anteriormente relatados por Lange \& Petri (1967) e Diniz (1985). 
Nos folhelhos do Mb. Jaguariaíva registra-se o clímax de uma tendência ascendente de aumento da radioatividade e/ou argilosidade, delineando um pico de radioatividade a partir do qual os valores voltam novamente a decrescer, por isso interpretado como a superfície de máxima inundação no Devoniano inferior. Durante o período de máxima inundação o aporte terrígeno foi mínimo, materializando uma zona de condensação, na qual são comuns folhelhos pretos ricos em matéria orgânica.

Seções marinhas condensadas têm espessura geralmente de poucos metros e tipicamente apresentam-se como picos de radioatividade nos perfis de raios-gama de poços. Em muitos poços é claramente delineável um intervalo de radioatividade mais alta, incrementada pela afinidade entre o urânio e a matéria orgânica presente nos folhelhos betuminosos. À semelhança dos folhelhos da Formação Irati, neles também se alojam soleiras de diabásio, o que torna fácil a identificação do $\mathrm{Mb}$. Jaguariaíva em seções sismicas de reflexão (Fig. 36, p. 75).

Este empilhamento é plenamente reconhecido na sub-bacia de Apucarana, tanto na faixa de afloramentos no Estado do Paraná como em quase todos os poços, caracterizando um trato de sistemas transgressivo. Na sub-bacia de Alto-Garças o mesmo empilhamento pode ser observado no poço 2-AG-1-MT.

Na faixa aflorante no Estado de Goiás, pelo menos entre Amorinópolis e a localidade de Vila Maria, a Fm. Ponta Grossa inicia-se com o Mb. Tibagi, em cuja base ocorre um intervalo com cerca de $10 \mathrm{~m}$ de espessura de siltitos muito bioturbados, cuja datação indicou posição cronoestratigráfica no Emsiano Superior. São interpretados como o registro continente adentro do pico de máxima inundação no Emsiano.

$\mathrm{Na}$ verdade, quase toda a seção superior da Fm. Furnas também não ocorre a leste da localidade de Vila Maria, já que o Mb. Tibagi trunca discordantemente e com pequena angularidade os estratos da Formação Furnas, cuja espessura se reduz progressivamente para leste, atingindo valores de cerca de $10 \mathrm{~m}$ a sul de Amorinópolis (Fig. 75).

Em Goiás a Fm. Ponta Grossa avançou para além dos limites orientais da Fm. Furnas, assentando-se diretamente sobre o embasamento pré-cambriano/ eopaleozóico a leste da cidade de Amorinópolis. Este recobrimento em onlap da Fm. Furnas pela Fm. Ponta Grossa, as espessuras e o caráter litológico do Mb. Tibagi indicam situação proximal, ou seja, a área estava próxima da borda original da bacia quando da deposição da seqüência praguiana-eifeliana.

A discordância entre as formações Furnas e Ponta Grossa, que desaparece progressivamente em direção às partes mais profundas da bacia (não existe nos poços 
2- JA-1-GO e 2-AG-1-MT) e caracteriza-se como descontinuidade de borda, é interpretada como produto de movimentação tectônica na borda nordeste da bacia a partir do Emsiano (item 7.3.2).

A existencia de lags transgressivos (linhas de seixos isolados até camadas de conglomerados com um metro de espessura), no contato entre as formações Furnas e Ponta Grossa no Estado de Goiás, evidencia transgressão erosiva. Disto resulta que, em Goiás, o limite da seqüencia deposicional coincide com uma superfície transgressiva.

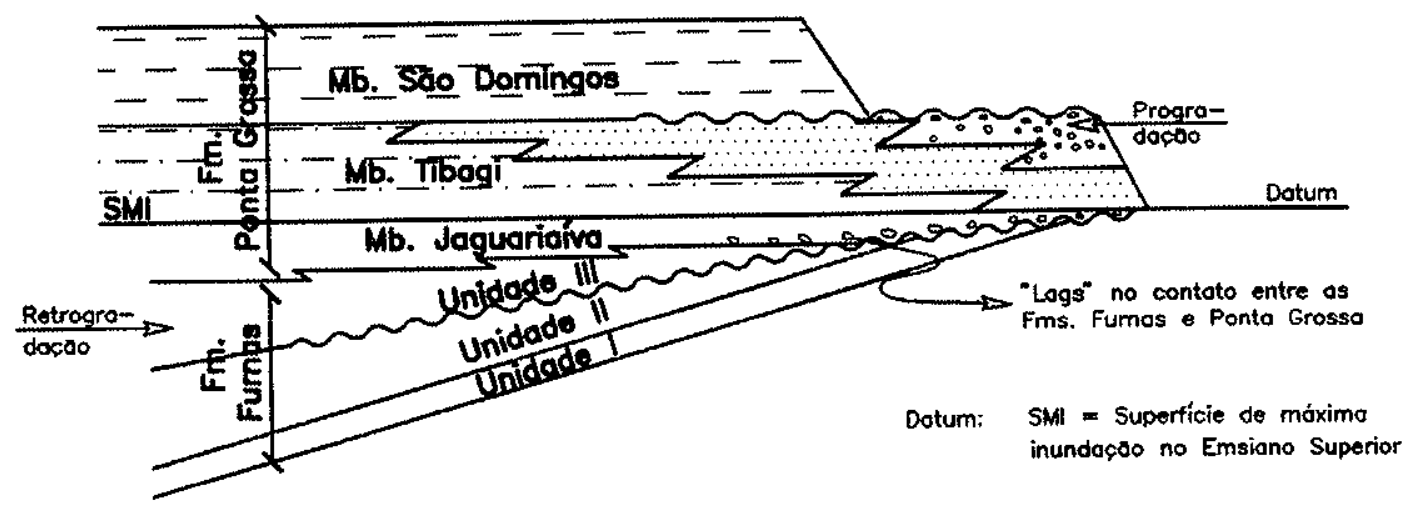

Figura 75 - Seção estratigráfica esquemática mostrando o truncamento erosivo da Fm. Furnas pela Fm. Ponta Grossa na faixa de afloramentos no Estado de Goiás.

Da superfície de máxima inundação até o topo do Mb. Tibagi tem-se um típico trato de sistemas de mar alto (highstand systems tract). Arenitos com padrões granocrescentes caracterizam o Membro Tibagi, sendo visiveis nos perfis de raiosgama de praticamente todos os poços em que a unidade ocorre (Fig. 12, p. 36; Fig. 19, p. 46; Fig. 66 , p. 126). Não só as seqüências de fácies apresentam padrão de granocrescência textural ascendente, mas também a seqüência como um todo, o que se reflete no aumento da porcentagem da fração areia em direção ao topo. Este padrão, observado na maioria dos poços, caracteriza um empilhamento regressivo, fato já destacado por Diniz (1985) e Popp \& Barcellos-Popp (1986). 
Seqüências de fácies com granocrescência ascendente são características de barras marinhas construídas por ondas, de arenitos litorâneos regressivos e de complexos de canais deltaicos distributários (Tillman 1985). O padrão textural na vertical é bastante semelhante nos três casos, de forma que sua distinção requer uma análise faciológica de detalhe, sendo difícil sua caracterização somente a partir de perfis de raios-gama.

Em porções mais proximais, como na faixa de afloramentos no Estado de Goiás, o empilhamento evidencia a presença de deltas retrabalhados por ondas, num padrão de granocrescência ascendente que culmina com o avanço de fácies de planície deltaica (correspondentes ao membro médio de Andrade \& Camarço, 1980). Na seção levantada na região de Amorinópolis-GO (Fig. 68, p. 128) podem ser visualizadas várias seqüências de fácies com granocrescência ascendente, desde arenitos de plataforma dominada por tempestades (shelf sand ridges) na base até arenitos conglomeráticos de canais deltaicos distributários na parte superior.

Em posições mais distais, como na faixa de afloramentos no Estado do Paraná, os arenitos do $\mathrm{Mb}$. Tibagi constituem fácies de plataforma, onde barras arenosas de costa-afora, construídas por tempestadas, ocorrem intercaladas em folhelhos plataformais.

Em tratos de sistemas de mar alto, ocorre regressão por progradação com nivel do mar estacionário. Quando sobreposto por outro trato transgressivo, sem a interposição de quedas significativas do nivel de base, praticamente não há erosão no topo. Isto explica porque os depósitos de planície deltaica do topo do $\mathrm{Mb}$. Tibagi em Goiás ficaram preservados, mesmo num contexto de borda de bacia.

Transgressão de oeste para leste foi interpretada há já 50 anos por Maack (1946) para o Devoniano do Estado do Paraná. Este cenário paleogeográfico de terras emersas a leste e oceano a oeste é compatível com a diminuição para oeste da porcentagem de caolinita e aumento do teor de boro no mesmo sentido (Rodrigues \& Quadros 1976). Os poucos dados de paleocorrentes de fácies deltaicas do Mb. Tibagi também se ajustam à esta interpretação (Fig. 68, p. 128).

Medidas realizadas em vários afloramentos mostram que os eixos "a" dos seixos dos depósitos residuais da unidade III da Fm. Furnas estão orientados segundo direção preferencial NE-SW (Fig. 76), embora com grande dispersão de valores. $\mathrm{Na}$ figura 76 pode-se verificar também que os eixos maiores dos seixos no lag basal transgressivo da Fm. Ponta Grossa em Goiás apresentam orientação semelhante. Mas, qual o significado desta orientação? 


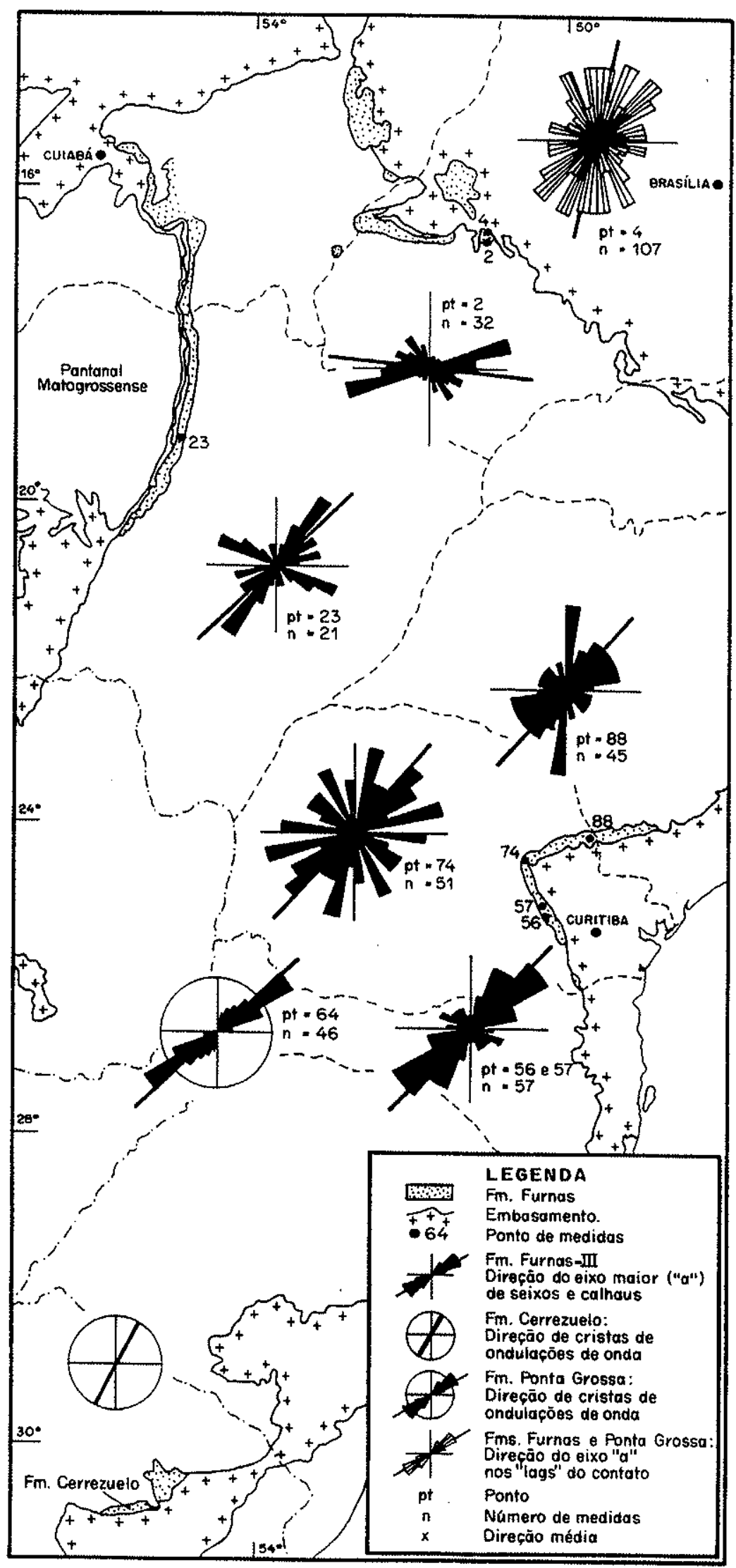

Figura 76 - Orientação dos eixos "a" de seixos assimétricos de depósitos residuais joeirados da unidade III da Fm. Furnas. 
Dados apresentados por Cheel (1991) evidenciaram que, em arenitos marinhos com estratificação tipo hummocky, os grãos de areia assimétricos têm seus eixos maiores ("a") orientados paralelamente à paleolinha de costa. Isto porque, embora as ondas de tempestade tenham direções aleatórias, elas se refratam quando atingem fundos mais rasos à medida que avançam em direção à costa, orientando-se em conseqüência aos contornos batimétricos, como no caso das ondulações de onda em arenitos grossos a muito grossos (item 6.2.2). Usando este mesmo raciocínio, postulase aqui que os eixos "a" dos seixos e calhaus dos depósitos residuais (lags) retrabalhados por ondas devam também orientar-se paralelamente aos contornos batimétricos, sendo assim um paleoindicador de linha de costa.

Com base no critério exposto acima, deduz-se que a direção da paleolinha de costa regional não se alterou significativamente com relação à seqüência sotoposta, permanecendo orientada no rumo aproximado NE/SW. Corrobora esta interpretação a direção também NE/SW de cristas de ondulações formadas por ondas em arenitos muito grossos com seixos (wave-formed coarse-grained ripples) existentes no topo de barras marinhas retrabalhadas por ondas existentes na pedreira Moro (item 6.2.2), em Ponta Grossa (PR).

Em uma costa de direção NE/SW, é bastante sugestiva a interpretação de que muitos dos padrões bipolares de fluxo deduzidos dos estratos cruzados na Fm. Furnas no flanco sudeste (Fig. 48, p. 96) representam correntes de maré perpendiculares à costa, embora com a interferência de correntes sudoeste paralelas à costa, evidentes na maioria das rosetas.

\subsection{3 - Seqüência Givetiana-Frasniana}

A seqüência constitui um ciclo transgressivo-regressivo com superfície de máxima inundação no Givetiano (intervalo bioestratigráfico $D 4 b$ ), reconhecida nos perfis de raios-gama pela existência de um máximo de argilosidade. A superfície constitui um marco estratigráfico, materializando o momento de maior profundidade e maior anoxia da lâmina d'água. Relativamente aos estratos emsiano-eifelianos, a diminuição da porcentagem de caolinita e aumento do teor de boro no Membro São Domingos indica condições mais oceânicas no Givetiano/Frasniano (Rodrigues \& Quadros 1976). 
Abaixo da superfície de máxima inundação tem-se um trato de sistemas transgressivo, cuja base é uma superfície transgressiva, com o desenvolvimento de delgados depósitos residuais, como os descritos por Lange \& Petri (1967) em Ponta Grossa (Fig. 62, p. 121). Os sedimentos marinhos pelíticos do trato transgressivo jazem diretamente sobre depósitos deltaicos ou marinhos plataformais do topo da seqüência praguiana-eifeliana, numa situação em que a superfície transgressiva coincide com o limite da seqüência.

Os folhelhos do Givetiano representam uma expansão do sítio deposicional, sendo o registro do pico máximo de transgressão no Devoniano da Bacia do Paraná. À transgressão associa-se mudança ecológica drástica, responsável pelo desaparecimento da fauna malvinocáfrica no início do Givetiano. Segundo Melo (1985, 1988), representantes da fauna malvinocáfrica são encontrados somente até a parte basal do $\mathrm{Mb}$. São Domingos, que o referido autor posicionou no topo do Eifeliano (intervalo D4a de Lange 1967 e Daemon et al. 1967). O ingresso de águas mais quentes, vindas do norte, teriam sido responsáveis pelo declínio das comunidades endêmicas malvinocáfricas, o que é sugerido pela presença, na chapada dos Guimarães, de braquiópodes (Tropidoleptus carinatus Conrad, Pustulatia pustulosa Hall e Paranaia margarida Derby), gastrópodes e do trilobita Phacopina brasiliensis Clarke (Petri \& Fulfaro 1983). O gênero Tropidoleptus, pertencente à fauna boreal, é comum no Devoniano Médio/Superior da Bacia do Parnaíba e da Bolivia. Este fato reforça a interpretação de que possivelmente houve interligação entre as bacias do Paraná e do Parnaíba no Givetiano, através da região hoje ocupada pelos vales dos rios Araguaia e Tocantins (Araguaia-Tocantins sea-way de Lange \& Petri 1967).

Os perfis de raios-gama dos poços mostram claramente o aumento de argilosidade no $\mathrm{Mb}$. São Domingos até uma posição intermediária, quando o padrão se inverte delineando a superfície de máxima inundação no Givetiano. Deste ponto até o topo da seqüência, há aumento paulatino na espessura e na granulometria dos arenitos, caracterizando trato de sistemas progradacionais de mar alto no Frasniano. Os sistemas deltaicos deste trato ainda não foram observados nas faixas de afloramento, tendo sido reconhecidos inicialmente no poço 2-AP-1-PR. Pela correlação apresentada na figura 67 (127), pertenceriam também a este trato a maior parte da Fm. Ponta Grossa no poço 2-TL-1-MS, em que não foram registrados os andares Emsiano e Eifeliano. A sua assinatura nos perfis de raios-gama é muito similar a do Mb. Tibagi, com eles podendo ser confundidos. 


\section{7 - CICLOS E EVENTOS ESTRATIGRÁFICOS}

Ciclos estratigráficos de $1^{\text {a }}$ ordem constituem os ciclos maiores na evolução fanerozóica do planeta, tendo duração de 200 a 400 Ma. Compõem um par alternado de nível do mar alto seguido de outro de mar baixo, que Fisher (1984) associou, respectivamente, com períodos de clima quente (greenhouse) e frio (icehouse) (Fig. 77).

É interessante observar que os limites dos ciclos de $1^{\mathrm{a}}$ ordem, definidos por Fisher (1984) nos picos de extinção em massa de organismos marinhos, não são exatamente coincidentes com os episódios de queda abrupta do nivel do mar. Por isso os limites dos ciclos de $1^{\mathrm{a}}$ ordem não coincidem exatamente com limites de ciclos de $2^{a}$ ordem ou superciclos de Vail et al. (1977). A defasagem observada resulta da utilização de critérios diferentes na definição dos limites dos ciclos. Resulta também do atraso da queda do nível global do mar em relação às colisões continentais e extinções em massa delas decorrentes, pois o encurtamento da crosta continental e conseqüente aumento da capacidade cúbica das bacias oceânicas ocorre após o início das colisões.

As seqüências pré-carboníferas da Bacia do Paraná integram um ciclo de $1^{\text {a }}$ ordem, correspondendo ao período inicial de greenhouse. Perfazem dois ciclos de $2^{a}$ ordem, materializados por duas sequências estratigráficas limitadas por discordâncias regionais: ordovício-siluriana e devoniana (Fig. 77). Tais discordâncias são reconhecidas também em outras bacias gondwânicas (Fig. 78 ), de forma que se pode considerá-las seqüências tectono-sedimentares cratônicas no sentido de Sloss (1963).

Os cicios de $2^{\mathrm{a}}$ ordem comportam ciclos menores de $3^{\mathrm{a}}$ ordem ou seqüências deposicionais, cujos limites correspondem a descontinuidades de menor amplitude temporal e que, por definição, gradam para concordâncias nas partes mais profundas da bacia. Na Bacia do Paraná foram caracterizados cinco ciclos de $3^{\mathrm{a}}$ ordem (itens 5.4 e 6.3), cujas seqüências e tratos de sistemas deposicionais estäo sintetizados na figura 79 .

Quando se compara o registro sedimentar pré-Carbonifero da Bacia do Paraná com o das outras duas bacias intracratônicas brasileiras (Amazonas e Parnaíba), é notável a semelhança dos empilhamentos estratigráficos e dos formatos dos perfis de raios-gama (Fig. 80). Os mesmos ciclos de $2^{\mathrm{a}}$ e $3^{\mathrm{a}}$ ordens, embora com diferentes espessuras, podem ser reconhecidos, evidenciando a existência de eventos comuns 


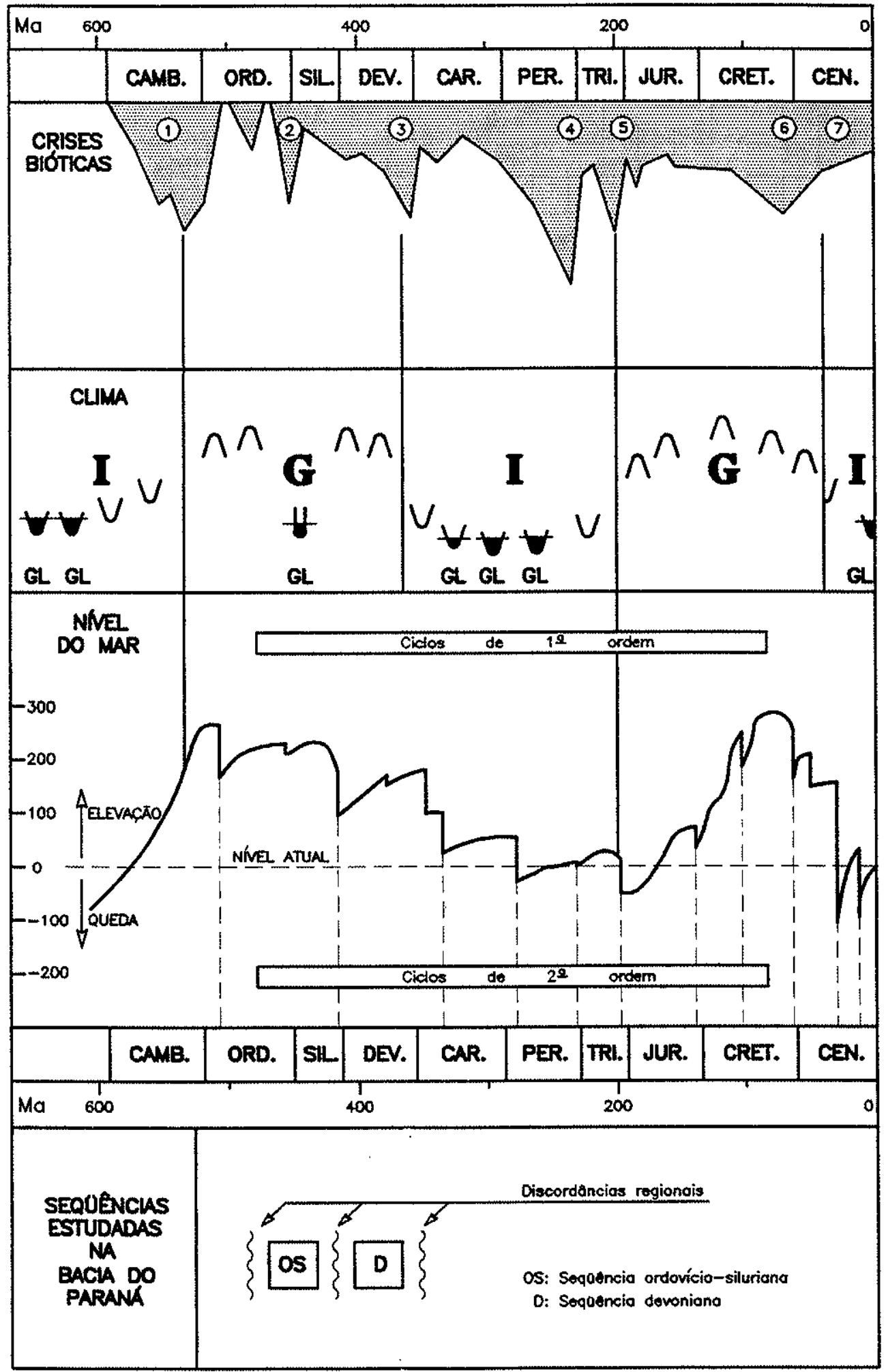

Figura 77 - Correlação entre as seqüências pré-carboniferas da Bacia do Paraná e os ciclos fanerozóicos (adaptado de Fisher 1984; curva de variação do nível do mar de Vail et al. $1977 ; \mathbf{I}=$ periodo icehouse; $\mathbf{G}=$ período greenhouse; $\mathrm{GL}=$ glaciação) 


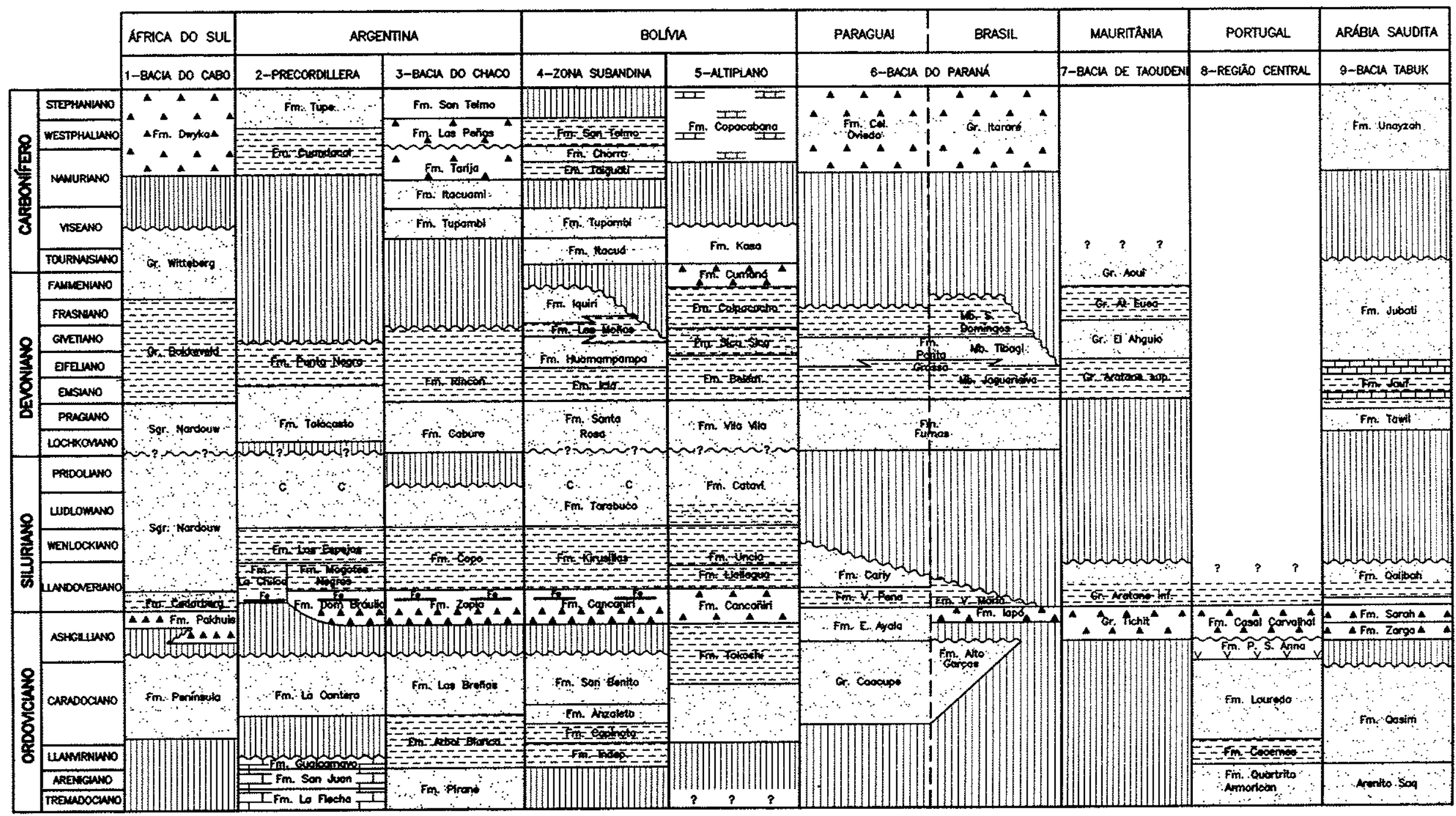

Figura 78 - Quadro de correlação estratigráfica (elaborado a partir de várias fontes: 1 = Broquet 1992, Gray et al. 1986; 2 = Sanchez et al. 1991a/b, Benedetto et al. 1992; 3 = Russo et al. 1979, Pezzi \& Mozetic 1989, Cingolani et al. 1992, França et al. 1995; 4 e 5 = Antelo 1978, Vistalli 1989, Benedetto et al. 1992. França et al. 1995, Isaacson \& Diáz Martinez 1995; 6 = Assine et al. 1994; 7 = Deynoux \& Trompette 1981; 8 $=$ Robardet et al. 1990; 9 = Vaslet 1990, Husseini 1991; $\mathrm{Fe}=$ Depósitos ferriferos; $\mathrm{C}=$ Clarkeia anthesiensis $)$. 


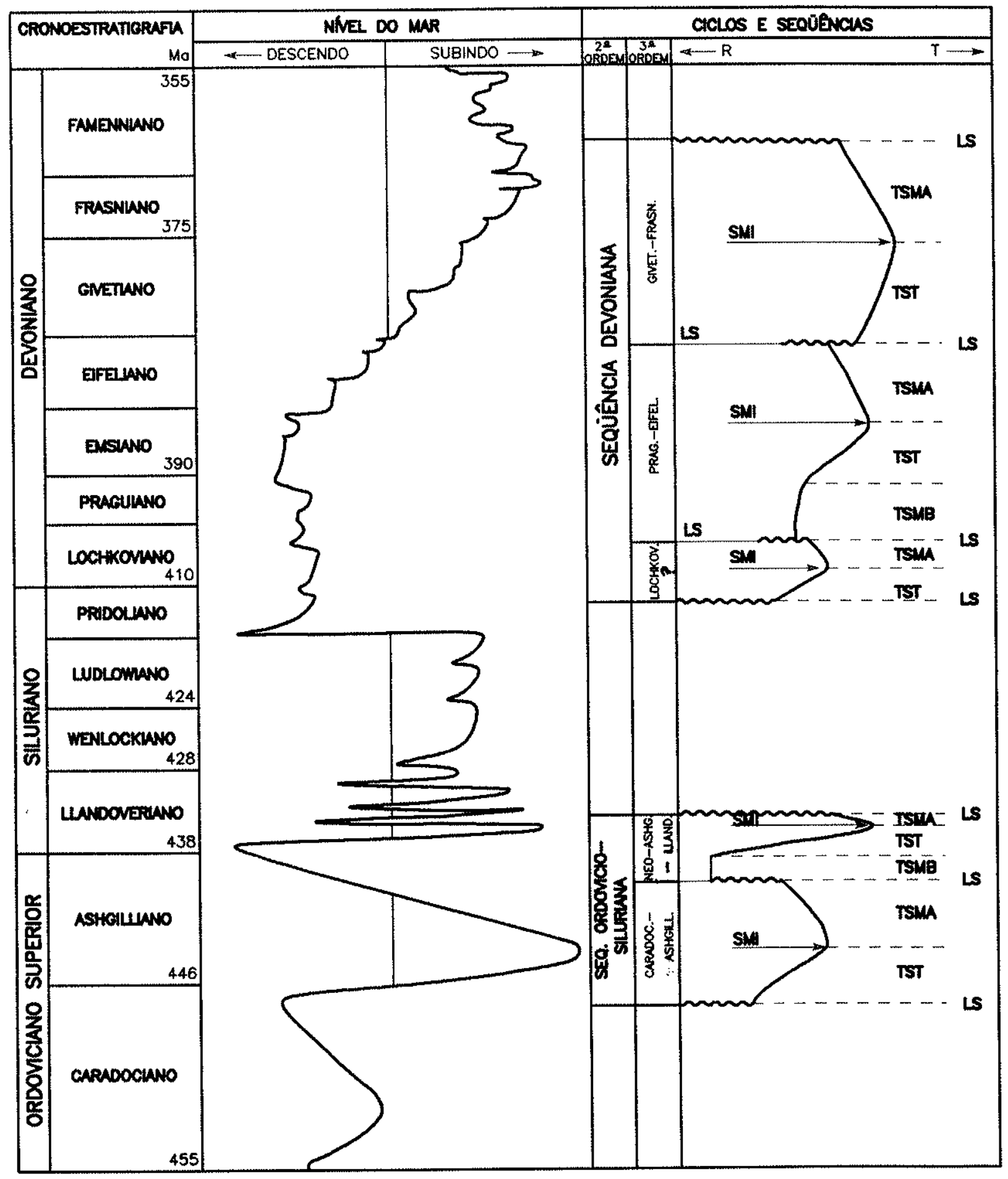

Figura 79 - Ciclos $3^{a}$ ordem ou seqüências deposicionais no préCarbonífero da Bacia do Paraná (curva de variação do nível do mar: Siluriano = Ross \& Ross 1988; Devoniano = Johnson et al. 1985; (LS = limite de seqüência; SMI = superficie de máxima inundação; TST = trato de sistemas transgressivo; TSMA = trato de sistemas de mar alto; $\mathrm{TSMB}=$ trato de sistemas de mar baixo). 


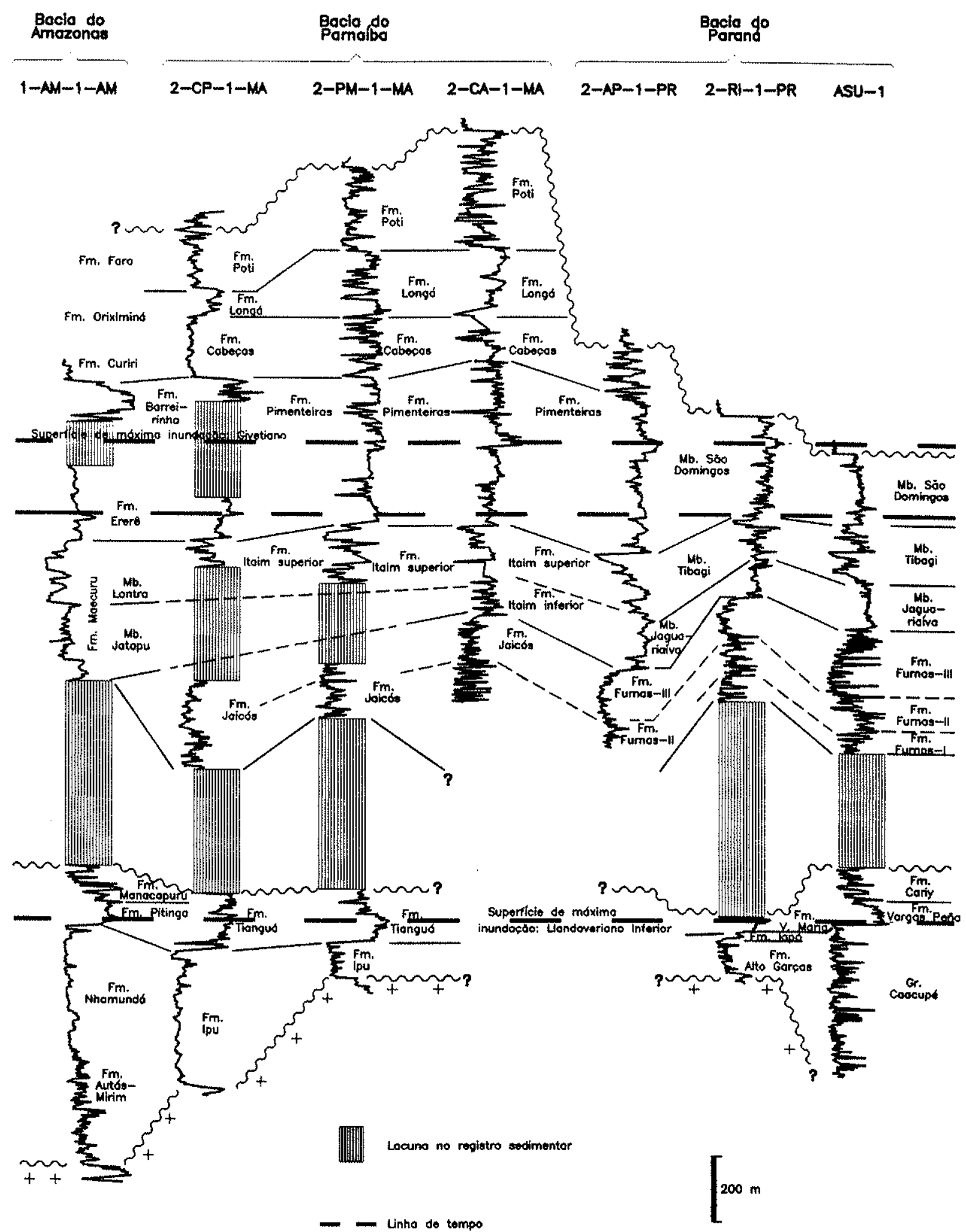

Figura 80 - Correlação estratigráfica das unidades pré-carboniferas das bacias do Paraná, Amazonas e Parnaíba (perfis de raios-gama reformatados a partir de: Assine et al. 1994; Góes \& Feijó 1994; Cunha et al. 1994; Della Fávera 1992). 
nas três bacias. Nem sempre, porém, todas as seqüências estão presentes, observando-se lacunas em vários poços. Faltas de seção podem ser conseqüência de fenômenos peculiares de erosão ou de não-deposição, resultado de posição paleogeográfica desfavorável à preservação ou interveniência de movimentos tectônicos localizados.

\section{1 - CICLO ORDOVICIANOISILURIANO}

O ciclo Ordoviciano/Siluriano ( $2^{\mathrm{a}}$ ordem) foi o primeiro ciclo intracratônico da Bacia do Paraná, com duração de aproximadamente 25Ma (do Caradociano ao Llandoveriano). Equivale à seqüência Beta das bacias intracratônicas brasileiras, correlacionada por Soares et al. (1978) à seqüência Tippecanoe (Sloss 1963) das bacias paleozóicas norte-americanas.

A sedimentação da seqüência ordovício-siluriana ocorreu em condições climáticas temperadas (50 a $60^{\circ}$ de latitude sul). Em quase todas as reconstruções paleogeográficas, baseadas em dados paleomagnéticos e sedimentológicos, o pólo sul estaria posicionado no centro-norte do atual continente africano (Fig. 81). Apesar disso, os registros glaciais concentram-se no interregno Ordoviciano Superior/Siluriano Inferior. Não fosse um período de greenhouse, a influência glacial no registro sedimentar seria muito mais expressiva.

\subsection{1 - Ordoviciano Superior: paleogeografia integrada às bacias do Chaco}

O empilhamento estratigráfico, o sentido geral das paleocorrentes (Fig. 31, p. 68) e o espessamento para oeste da seção psamitica que compõe o conjunto Fm. Alto Garças / Gr. Caacupé (visível nas seções estratigráficas das figuras 16 e 19, apresentadas, respectivamente, nas páginas 42 e 46), caracterizam um trato de sistemas transgressivo no Ordoviciano Superior, com onlap de oeste para leste. Os sentidos de fluxo das paleocorrentes para SW (Fm. Alto Garças) e NW (Gr. Caacupé) indicam linhas de costa com diferentes direções regionais, NWISE na porção norte e NE/SW na porção sul da bacia. Como tais direções coincidem com a direção dos orógenos brasilianos marginais (Canastra/Araxá na porção norte e Ribeira na porção sul), é razoável inferir que os orógenos brasilianos constituíam terras altas, tendo 
condicionado a orientação das linhas de costa e, conseqüentemente, os contornos orientais da bacia.

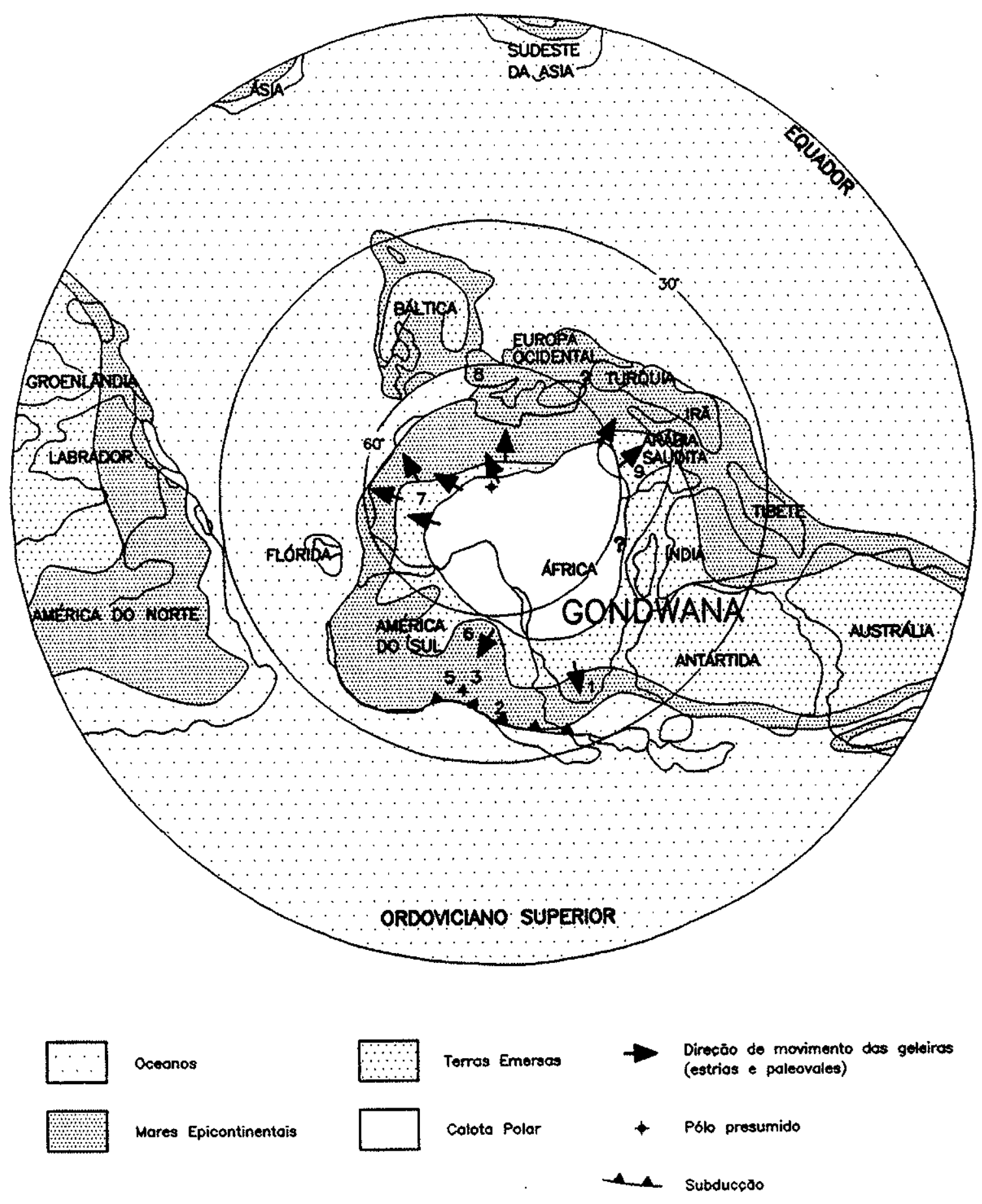

Figura 81 - Gondwana no Ordoviciano Superior (modif. de Vaslet 1990) 
O espessamento e as paleocorrentes dirigidas para oeste contra as bordas atuais evidenciam que os limites ocidentais da Bacia do Paraná são erosivos. Disto se conclue que a inclinação atual para leste dos estratos da $\mathrm{Fm}$. Alto Garças foi resultado de levantamento posterior do Arco de Assunção, conclusão a que haviam chegado anteriormente Bigarella \& Comte (1969) em estudo sobre o Gr. Caacupé. O Arco de Assunção é uma feição tectônica de eixo aproximado norte-sul na altura do atual meridiano $58^{\circ} \mathrm{W}$, coincidente com o limite ocidental da Bacia do Paraná.

Como o Arco de Assunção não existia, a Bacia do Paraná tinha continuidade física com as bacias do Chaco-Paraná e do Chaco-Boreal, o que é atestado pela existência em subsuperfície de estratos ordovicianos no norte da Argentina (Pezzi \& Mozetic 1989), leste do Paraguai (Wiens 1995) e, possivelmente, leste da Bolívia (base da Fm. El Carmen?).

As bacias do Chaco-Paraná (também denominada Chaco-Paranense e situada no oeste do Paraguai e norte da Argentina) e do Chaco-Boreal (também denominada Chaco-Tarija ou Chaqueña e situada no leste da Bolívia), apresentam-se hoje individualizadas pela interveniência do Alto de Michicola. Mas, possivelmente constituiam embaciamentos num mesmo contexto geotectônico, com tratos deposicionais contínuos, razão pela qual serão neste texto referidas, para efeito de simplificação, como bacias do Chaco.

Extensas bacias pericratônicas, caracterizadas por extensas plataformas marinhas rasas, constituíram uma característica do Paleozóico Inferior gondwânico. Gondwana era então um grande continente centrado no pólo sul, com uma calota polar reduzida em período de greenhouse. Este cenário foi interrompido apenas no final do Ordoviciano (Ashgilliano terminal), quando rápida e intensa glaciação foi responsável pelo avanço de geleiras por sobre as plataformas continentais onde ocorria a deposição de espessas seqüências psamíticas (Fig. 81).

Desta sucessão de eventos resultou empilhamento estratigráfico muito similar em varias bacias da margem do continente de Gondwana (Fig. 78, p. 151), em que arenitos marinhos costeiros e plataformais são recobertos, muitas vezes em discordância erosiva, por diamictitos subglaciais e/ou glaciogênicos (depósitos de origem glacial redepositados no talude por fluxos gravitacionais). O empilhamento sedimentar é muito bem exemplificado pelo Grupo Table Mountain da Bacia do Cabo (África do Sul), em que diamictitos da Fm. Pakhuis assentam-se erosivamente sobre arenitos da Fm. Península (Rust 1981). 
Na Bacia do Paraná os diamictitos da Fm. lapó assentam-se sobre arenitos da Fm. Alto Garças, ultrapassando sua área de ocorrência no sentido leste, para assentar-se diretamente sobre o embasamento cristalino pré-cambriano/eopaleozóico. A assinatura da Fm. Alto Garças em perfis de raios-gama é muito semelhante a do $\mathrm{Gr}$. Caacupé (Fig. 80). A mesma assinatura geofísica caracteriza a Fm. Ipu da Bacia do Parnaiba (Fig. 80), em cujo topo ocorrem diamictitos (Caputo \& Lima 1984). Também correlatas são as formações Austás Mirim e Nhamundá de Gr. Trombetas da Bacia do Amazonas. A Fm. Autás Mirim é de idade ashgilliana (Rawtheyano, segundo Grahn 1992a).

\subsection{2 - Glaciação neo-ordoviciana: um evento gondwânico}

Diamictitos posicionados abaixo de folhelhos llandoverianos foram descritos em várias bacias gondwânicas. Em nenhuma delas os diamictitos foram diretamente datados, por revelarem-se estéreis em termos de macro e microfósseis. Idades neoordovicianas foram atribuídas aos diamictitos do $\mathrm{Gr}$. Tichit da Bacia de Taoudeni do norte da África (Deynoux 1985) e aos das formações Sarah e Zarqa do Oriente Médio (Vaslet 1990), situados na margem norte do continente de Gondwana, pois os folhelhos sobrepostos aos diamictitos apresentam formas hirnantianas (Ashgilliano tardio). Diamictitos da Fm. Pakhuis, subjacentes aos folhelhos llandoverianos da Fm. Ceddarberg da Bacia do Cabo na África do Sul, foram recentemente considerados de idade ashgilliana (Visser 1992).

Diamictitos na mesma posição estratigráfica, abaixo de folhelhos eollandoverianos, ocorrem em várias bacias sul-americanas. Dada a falta de elementos que permitissem sua datação e considerando um contato concordante com os folhelhos llandoverianos, vários autores atribuíram uma idade eo-siluriana para estes diamictitos. Com base neste aparente não sincronismo dos depósitos glaciais da África e da América do Sul, Caputo \& Crowell (1985) interpretaram uma migração do pólo glacial da África do Norte para a América do Sul, do Ordoviciano para o Siluriano, o que seria conseqüência da migração do continente de Gondwana em relação ao pólo sul.

Alguns novos dados permitem, entretanto, reavaliar esta interpretação. $\mathrm{Na}$ Precordilhera Argentina foram encontrados trilobitas e braquiópodes ashgillianos em siltitos sobrepostos aos diamictitos da Fm. Dom Bráulio (Levy \& Nullo 1974, Baldis \& Blasco 1975, Benedetto 1990, Sánchez et al. 1991a). Os diamictitos apresentam 
clastos facetados e estriados, constituindo o registro da glaciaçäo neo-ordoviciana na Precordillera Argentina (Peralta \& Carter 1990).

No noroeste da Argentina, diamictitos eopaleozóicos constituem a Fm. Zapla, cuja natureza glacial foi inicialmente estabelecida por Schlagintweit (1943), que a eles se referiu como "horizonte glacial de Zapla". Nas serras subandinas e Cordillera Oriental, os diamictitos foram durante muito tempo considerados llandoverianos por estarem sotopostos aos folhelhos da Fm. Lipeón, esta considerada de idade wenlockiana. Entretanto, a descoberta de graptolitos do gênero Retiolites na parte basal da Fm. Lipeón permitiu posicionar o início de sua sedimentação no Llandoveriano (Cingolani et al. 1992), o que indica idade mais antiga para a Fm. Zapla.

Informações cronoestratigráficas mais precisas foram obtidas nas serras subandinas de Salta e Jujuy. Nesta área a Fm. Zapla jaz em discordância sobre estratos do Ordoviciano Médio, apresentando espessura máxima de $120 \mathrm{~m}$. É constituída por diamictitos na base e arenitos e siltitos na parte superior, onde Monaldi \& Boso (1987) encontraram restos de braquiópodos e trilobitas do gênero Dalmantina, o que permitiu o posicionamento da unidade no Ashgilliano.

Os diamictitos da Fm. Zapla constituem um importante horizonte guia, rastreável da Bacia do Chaco-Paraná até o Peru (Laubacher et al. 1982). Na Bolívia são referidos como Fm. Cancañiri, sendo sobrepostos pela Fm. Kirusillas, equivalente lateral da Fm. Lipeón. A idade dos diamictitos da Fm. Cancañiri tem sido matéria de divergências já que não há datações seguras. Muitos fósseis retrabalhados (trilobitas, braquiópodos, moluscos e briozoários) dificultam sua datação (Suárez-Soruco 1992). O achado de trilobita do gênero Dalmanitina (Toro et al. 1991, apud Benedetto et al. 1992) sugere idade ashgilliana superior, à semelhança das formações Dom Bráulio e Zapla. Ao que parece, Suárez-Soruco (1995) considerou os espécimes encontrados também retrabalhados, pois posicionou a unidade. no intervalo Llandoveriano/ Wenlockiano Inferior. Na zona subandina os diamictitos são recobertos por pelitos da Fm. Kirusillas, onde foram encontrados graptolitos do Llandoveriano Superior (Branisa et al. 1972), indicando idade não mais jovem que Llandoveriano Superior para a Fm. Cancañiri.

Os diamictitos da Fm. Cancañiri apresentam espessuras muito variáveis, de um metro até cerca de $1500 \mathrm{~m}$ no depocentro, apresentando espessamento de NE para SW. As fácies presentes registram processos de fluxos gravitacionais, motivo pelo qual muitos a consideraram, mesmo, de origem não-glacial. Os diamictitos não foram depositados em ambientes subglaciais, cujos depósitos raramente atingem $50 \mathrm{~m}$ de 
espessura (Eyles 1993). A presença de clastos facetados e estriados, inclusive de grandes matacões de rochas do embasamento, e a correlação com diamictitos glaciais presentes em várias bacias gondwânicas, permite interpretá-los como possiveis depósitos glaciogênicos, produto da ressedimentação de grandes massas de sedimentos trazidos à bacia por geleiras. Sob esta ótica e levando-se em conta a arquitetura deposicional da $\mathrm{Fm}$. Cancañiri, que mostra espessamento das unidades para oeste (Suárez-Soruco 1995), infere-se que as seções mais espessas de diamictitos constituem fácies distais ressedimentadas em condições de talude. Isto poderia ser a explicação para a existência de diamictitos neollandoverianos, idade considerada por Suárez-Soruco (1995).

Com relação à $\mathrm{Fm}$. lapó, idade precisa ainda está por ser estabelecida. Em seus diamictitos não foram constatados macrofósseis e as amostras processadas apresentaram-se estéreis em microfósseis. Nos lamitos seixosos (fácies Fld), foram constatados macrofósseis (orbiculoideas) no ponto 17 , que todavia não forneceram informações de vaior cronoestratigráfico. Considerando que os diamictitos estão sobrepostos por folhelhos eollandoverianos e que há boa correlação com outras bacias, Grahn \& Caputo (1992) e Assine \& Soares (1993) admitiram idade neoashgilliana para a glaciação lapó.

Os dados e argumentos apresentados acima evidenciam que os diamictitos glaciais, depositados nas bacias sul-americanas no interregno Ordoviciano Superior/ Siluriano Inferior, são principalmente de idade ashgilliana, ponto de vista anteriormente expresso por Peralta \& Baldis (1992) e Assine \& Soares (1993).

Além das ocorrências africanas e sul-americanas, diamictitos glaciais de idade ashgilliana também foram constatados nos terrenos gondwânicos da Península Ibérica, Normandia e República Tcheca (Brenchley et al. 1991) e Oriente Médio (Vaslet 1990), testemunhando a ocorrência de uma glaciação continental com máximo avanço da calota polar no Ashgilliano Superior. Os diamictitos e fácies geneticamente relacionadas têm ampla distribuição geográfica, formando depósitos cronocorrelatos, gerados com o avanço da calota polar em direção às latitudes mais baixas nas plataformas continentais que bordejavam o continente de Gondwana.

A pequena espessura e o registro de ciclos únicos, como os da $\mathrm{Fm}$. lapó, apontam para uma glaciação de curta duração. Uma característica marcante das unidades associadas à glaciação neo-ordoviciana é o fato de assentarem-se sobre discordâncias erosivas. Este fato é muito bem registrado na Bolívia, onde a Fm. 
Cancañiri se assenta discordantemente sobre rochas de diferentes idades (SuárezSoruco 1992).

A regularidade estratigráfica e a pequena variação lateral de espessura da $\mathrm{Fm}$. lapó sugerem uma deposição por glaciação de escala continental, em oposição a geleiras de montanha, conforme critérios discutidos em Visser (1989). As poucas paleocorrentes medidas em arenitos e conglomerados associados aos diamictitos da Fm. lapó indicam fluxo para oeste, compatível com a reconstrução paleogeográfica apresentada na figura 81 (p. 155).

Fora da calota polar, relevos montanhosos gerados durante a Orogenia Oclóyica no final do Ordoviciano, como o Arco da Puna, podem ter sido palco de geleiras de montanha (Gohrbandt 1992). Estas geleiras podem ter sido reponsáveis pelo afluxo sedimentar vindo de oeste para as bacias bolivianas e argentinas, em oposição ao deslocamento das geleiras polares na Bacia do Paraná.

De outra parte, hipótese a ser investigada é a possibilidade de outra glaciação no Llandoveriano Superior, um evento proposto por Grahn \& Caputo (1992) com base no registro das bacias do Amazonas, do Parnaíba, do Araripe e do Jatobá. Tillitos foram descritos na Fm. Nhamundá da Bacia do Amazonas (Carozzi et al. 1973) e na Fm. Ipu da Bacia do Parnaíba (Caputo \& Lima 1984), mas a existência de tilitos na Fm. Cariri da Bacia do Araripe é duvidosa (Assine 1992), assim como na Fm. Tacaratu da Bacia do Jatobá. Com relação à Bacia do Amazonas, não ficou claro no trabalho de Grahn \& Caputo (1992) se as datações apresentadas referem-se a estratos imediatamente sobrepostos aos diamictitos da Fm. Nhamundá, ou se representam idades obtidas da análise do conteúdo micropaleontológico de folhelhos da Fm. Pitinga, considerada por eles equivalente lateral da Fm. Nhamundá. A mesma observação pode ser feita com relação aos diamictitos da Fm. Ipu e folhelhos da Fm. Tianguá da Bacia do Parnaíba.

Ainda que as informações disponíveis sejam incompletas e que não tenha existido no Llandoveriano Superior um evento glacial de expressão global, as bacias do Amazonas e do Parnaíba situavam-se em latitudes mais altas relativamente às suas posições no final do Ordoviciano, conseqüência da migração do continente de Gondwana para norte, fator que pode ter dado origem a depósitos glaciais em regiões de altas latitudes, mesmo em um período de greenhouse. Desta forma, a existência de eventos glaciais no Llandoveriano Médio/Superior deve ser melhor investigada para que se possa meihor comprender os eventos no interregno Ordoviciano Superior/Siluriano Inferior. 
Considerando a ocorrência generalizada de depósitos glaciais ou glacialmente influenciados no Ashgilliano, deduz-se que os registros glaciais não são apenas conseqüencia da passagem da placa gondwânica pelo pólo sul, como propuseram Caputo \& Crowell (1985), do que resultariam unidades não-síncronas. Os diamictitos são produto de glaciação continental de grandes proporções no final do Ordoviciano, que pela sua magnitude modificou completamente a paleoclimatologia do globo, alterando paleoecossistemas e ocasionando a extinção de um grande número de espécies da fauna marinha (Fig. 77, p. 150).

\subsection{3 - Llandoveriano: transgressão generalizada}

Os folhelhos da Fm. Vila Maria materializam um evento transgressivo pósglacial no Llandoveriano Inferior. A Fm. Vila Maria apresenta pequenas espessuras, maiores que $100 \mathrm{~m}$ somente no poço 1-SE-1-SC (Seara), onde uma seção regressiva superior se acha também preservada.

A Fm. Vargas Peña, que representa a continuidade da Fm. Vila Maria em terras paraguaias, é do Llandoveriano Inferior/Médio (Grahn 1992b). É sobreposta pela seção regressiva da Fm. Cariy, cujo topo pode ser de idade wenlockiana.

O Llandoveriano foi um período de nível de mar alto com muitas oscilações (Ross \& Ross, 1988), o que pode ter ocasionado preservação desigual em diferentes bacias. Folhelhos llandoverianos ocorrem em grande parte das bacias paleozóicas sulamericanas.

Folhelhos eollandoverianos pós-glaciais da $\mathrm{Fm}$. Cedarberg ocorrem sobrepostos aos depósitos glacigênicos neo-ashgillianos da Fm. Pakhuis da Bacia do Cabo na África do Sul (Gray et al. 1986). O mesmo ocorre em bacias da margem norte do Continente de Gondwana, como por exemplo na Mauritania, em Portugal e na Arábia Saudita, testemunhando cenário de transgressão generalizada no Llandoveriano inferior, um fenômeno global registrado em quase todas as bacias gondwânicas (Fig. 78, p. 151). Nas bacias do Parnaíba e do Amazonas, o Llandoveriano é representado, respectivamente, pelas formações Tianguá e Pitinga, cujos estratos basais foram posicionados no Llandoveriano Médio por Grahn (1992b) com base em quitinozoários. A correlação apresentada na figura 80 sugere que a Fm. Tianguá da Bacia do Parnaíba, como a Fm. Vila Maria, apresenta na parte inferior um 
trato de sistemas transgressivo de idade eollandoveriana (deflexão à direita no perfil de raios-gama, até a superfície de máxima inundação).

$\mathrm{Na}$ base da Fm. Pitinga ocorrem camadas de hematita. A ocorrência de depósitos de ferro acima de diamictitos glaciais parece ser uma caracteristica do início da transgressão llandoveriana, já que ocorre em algumas bacias sul-americanas (Fig. 78 , p. 151), constituindo a base de tratos de sistemas transgressivos. Os depósitos da serra de Zapla (base da Fm. Lipeón) constituem uma jazida de minério de ferro (hematita), utilizada pela indústria siderúrgica argentina.

\section{2 - DISCORDÂNCIA NO SILURIANO SUPERIOR}

Gray et al. (1985) já haviam notado a ausência de estratos do Siluriano Médio/Superior em um grande número de bacias gondwânicas, do Oriente Médio à América do Sul, tendo a ela se referido como discordância pré-emsiana. Segundo Gorhbandt (1992), erosão removeu os depósitos silurianos na região andina da Bolívia e sul do Peru. Para Barret \& Isaacson (1988) a passagem Siluriano/Devoniano na América do Sul é caracterizada por uma discordância generalizada, recoberta por unidades francamente transgressivas.

Em algumas bacias, unidades llandoverianas são diretamente sobrepostas por unidades devonianas, caracterizando uma discordância de expressão regional (Fig. 78 , p. 151). Na Bacia do Paraná, por exemplo, o contato entre os grupos Rio Ivaí e Paraná envolve uma lacuna no registro sedimentar de aproximadamente $20 \mathrm{Ma}$, uma vez que não ocorrem estratos dos andares Wenlockiano ao Pridoliano.

Nas duas outras bacias intracratônicas brasileiras existem dados contrastantes com respeito à cronoestratigrafia das seções pós-llandoverianas e pré-emsianas. Grahn (1992b) considera que a parte superior da Fm. Pitinga e a Fm. Manacapuru representam registro incompleto, com vários hiatos, dos andares Wenlockiano ao Lochkoviano Inferior, havendo discordância com a Fm. Jatapu (Emsiano). Na falta de informações mais detalhadas, destaca-se apenas o padrão similar dos perfis de raiosgama das formações Vargas Peña/Cariy (Bacia do Paraná no Paraguai) e das formações Pitinga/ Manacapuru (Bacia do Amazonas) (Fig. 80, p. 153), sugerindo um mesmo evento estratigráfico.

Correlações preliminares, mostradas na figura 80 , sugerem que a discordância neo-siluriana na Bacia do Parnaíba situa-se entre a Fm. Tianguá (Llandoveriano) e a 
Fm. Jaicós, cuja parte basal, segundo Grahn (1992b), é do Siluriano Superior/ Lochkoviano. O contato entre as formações Jaicós e Itaim é considerado concordante pelo autor do presente trabalho, mas com discordâncias nas bordas ou em altos internos, situação semelhante à que ocorre na Bacia do Paraná.

Em algumas bacias persistem dúvidas quanto a passagem Siluriano/Devoniano, como se pode verificar na figura 78 (p. 151). Na Bacia do Cabo na África do Sul o Sgr. Nardouw, composto de três formações, tem sido considerado a transição entre os folhelhos Ilandoverianos da formação Cedarberg e os emsianos do Grupo Bokkeveld. A Fm. Rietvlei (topo) é a única datada por ser portadora de braquiópodos do Praguiano (Theron \& Loock 1988). Com base em estudo de estratigrafia de eventos, Cooper (1986) posicionou o limite Siluriano/Devoniano no contato entre as formações Rietvlei e Skurweberg, interpretação que ainda está por ser comprovada.

A discordância é nítida nas bacias intracratônicas por sua posição mais proximal, sendo menos nítida ou mesmo inexistente nas bacias pericratônicas. Isto fica evidente quando se compara o registro sedimentar da Bacia do Paraná, onde a discordância é bem marcada truncando estratos llandoverianos, com o das zonas subandinas da Bolivia e Argentina, onde a deposição foi praticamente contínua durante todo o Siluriano, possivelmente com hiato apenas na passagem Siluriano/Devoniano (Fig. 78). Da análise da figura 77 (p. 150), verifica-se que nenhuma crise biótica está associada à discordância.

Na Bacia do Paraná, a regressão a partir do Llandoveriano e a formação da discordância neo-siluriana foram conseqüência da atuação desigual de três fatores: 1) posição mais proximal da bacia em relação às bacias do Chaco; 2) queda acentuada do nível do mar no Siluriano superior (limite Ludloviano/Pridoliano), colocando grande extensão do interior do cráton acima do nivel de base de erosão; e 3) tendência de soerguimento da área devido ao reequilibrio glácio-isostático (rebound) com o recuo das geleiras.

\section{3 - CICLO DEVONIANO}

No Devoniano ocorreu o segundo ciclo de sedimentação na Bacia do Paraná, com duração de aproximadamente $45 \mathrm{Ma}$ (ciclo de $2^{\mathrm{a}}$ ordem). $\mathrm{O}$ ciclo equivale à seqüência Gama de Soares et al. (1978), que corresponde à seqüência Kaskaskia das bacias norte-americanas (Sloss 1963). 
A sedimentação da seqüência devoniana da Bacia do Paraná ocorreu em condições climáticas temperadas similares às da seqüência ordovício-siluriana. Isto se deveu ao fato de que, embora Gondwana tivesse migrado em direção ao Equador do Ordoviciano ao Devoniano Superior, as paleolatitudes foram semelhantes (entre 50 e $\left.60^{\circ} \mathrm{sul}\right)$. Segundo as reconstruçōes paleomagnéticas, o pólo sul no Devoniano Médio já estava posicionado na junção da Antártida com as atuais extremidades sul dos atuais continentes sul-americano e africano (Fig. 82).

\subsection{1 - Lochkoviano(?): transgressão sobre embasamento peneplanizado}

Numa paleogeografia similar à da seqüência ordovício-siluriana, a Bacia do Paraná era palco de um mar epicontinental no Devoniano inferior, conectado a oeste com o oceano (Sanford \& Lange 1960, Lange \& Petri 1967, Bigarella \& Salamuni 1967).

Paleocorrentes para oeste nos depósitos deltaicos da unidade I da Fm. Furnas indicam terras altas a leste (fato já destacado por Bigarella 1973) e mergulho deposicional da bacia para oeste em direção às bacias do Chaco-Paraná/Tarija. Diminuição da fração areia e aumento da argilosidade no sentido oeste podem ser observados nas seções das figuras 19 e 20. Destes dados deduz-se uma linha de costa regional de direção aproximada norte-sul durante a sedimentação da Fm. Furnas.

O empilhamento estratigráfico é retrogradacional, denotando rápida transgressão sobre uma superfície peneplanizada e a configuração de plataforma marinha arenosa, extensa e rasa, sujeita a atuação de correntes de marés, ora paralelas à costa, ora dirigidas para costa-afora. Segundo Klein (1982), em áreas estáveis e caracterizadas por movimentos epirogênicos amplos, extensas áreas de inundação marinha ocorrem, favorecendo regimes dominados por marés. Em mares epêiricos as paleocorrentes são complexas, como exemplificam os casos do mar do Norte e da baía de Hudson.

A transgressão na seqüência anterior foi rápida, aumentando na mesma proporção o espaço para a acomodação dos sedimentos (trato de sistemas transgressivo). Com o preenchimento, a taxa de sedimentação e a paleobatimetria foram progressivamente decaindo (trato de sistemas de mar alto). 

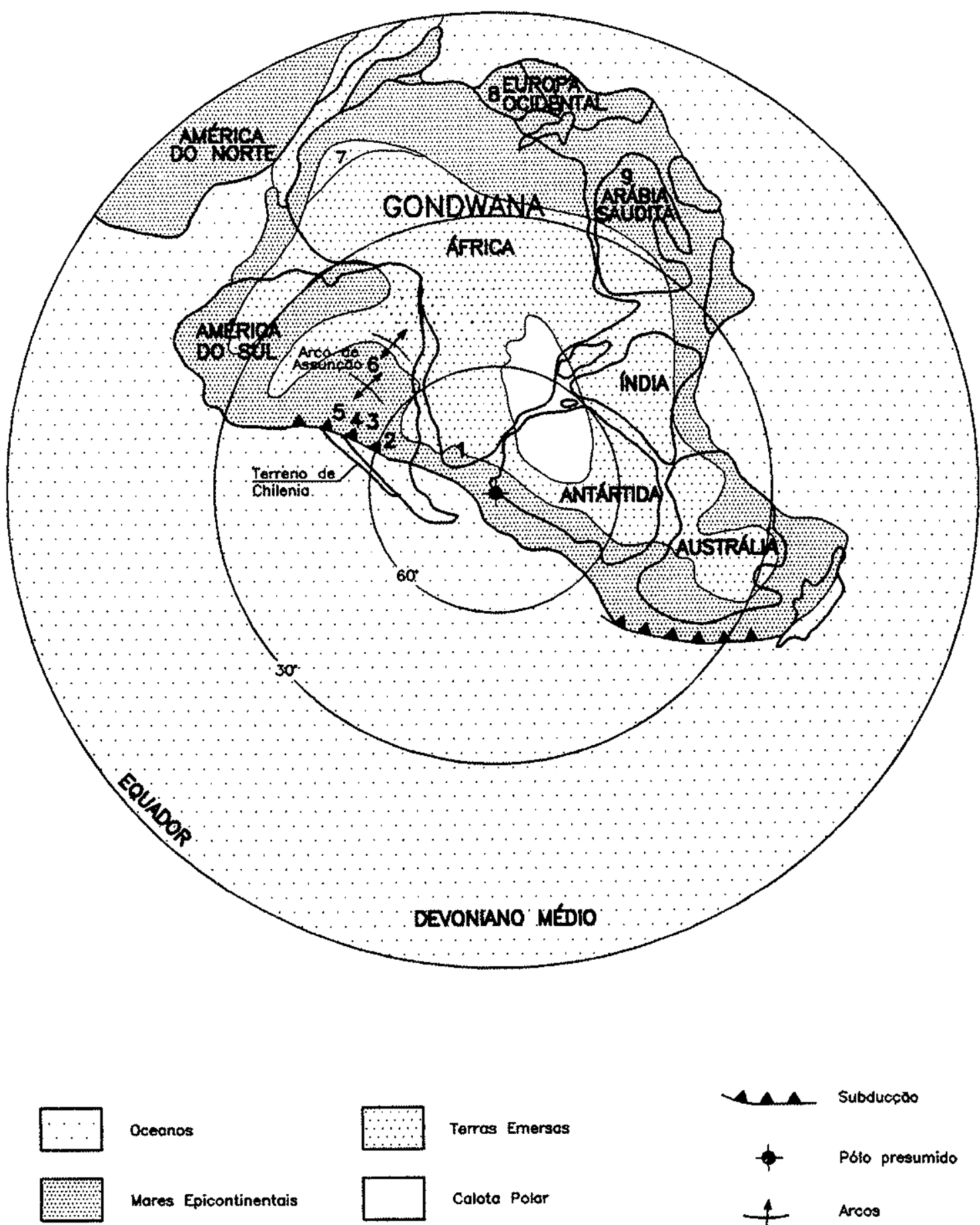

Oceanos

Mares Epicontinentais
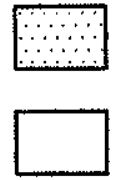

Terras Emersas

Calote Polar

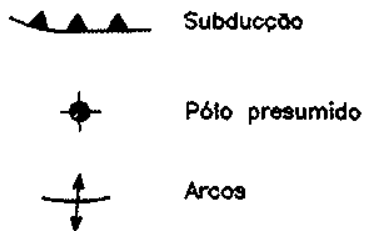

Figura 82 - Gondwana no Devoniano Médio (modif. de Williams 1995) 
Os registros dos poços perfurados e o mapa de isópacas da Fm. Furnas (Fig. 38, p. 78) mostram impressionante regularidade em termos de espessuras e de assinaturas em perfis de raios-gama, indicando taxas de sedimentação pouco variáveis. A concentração de curvas nas proximidades das bordas indica limites erosivos posteriores. Esta pouca variabilidade em termos de espessura indica período de quiescência tectônica, quando o espaço para acomodação dos sedimentos foi gerado mais pela elevação do nível de base com a transgressão no início do Devoniano do que por subsidência do substrato da bacia.

A espessura da Fm. Furnas no poço ASU-1 (Assunção), compatível com as espessuras médias na parte central da bacia, sugere que o Arco de Assunção ainda não era ativo no Devoniano Inferior e que a concentração de curvas no mapa de isópacas também é devida a soerguimento e erosão posteriores. Corrobora esta interpretação a existência de uma unidade correlata de idade eodevoniana na porção paraguaia da Bacia do Chaco-Paraná, com aproximadamente $300 \mathrm{~m}$ de espessura, composta de arenitos brancos com estratificação cruzada e litoestratigraficamente classificada como Gr. San Alfredo Inferior (Wiens 1995). Esta unidade corresponde à Fm. Caburé da porção argentina da Bacia do Chaco-Paraná.

A existência de plataformas marinhas arenosas foi uma característica do Devoniano Inferior em várias bacias gondwânicas. Na Bolívia a base do Devoniano (Lochkoviano) é também caracterizada pela presença de plataforma marinha terrígena, litoestratigraficamente classificada como Fm. Santa Rosa. Na Bacia do Cabo, a correlação é feita com o Sgr. Nardouw, cujo topo é do Praguiano (Fm. Rietvlei). Em uma área tão distante como a da atual Arábia Saudita, então na borda nordeste do continente de Gondwana, o Devoniano inicia-se com a Fm. Tawil, uma unidade faciologicamente similar (Fig. 78, p. 151).

\subsection{2 - Praguiano / Eifeliano: evidências de tectonismo sinsedimentar}

Foi interpretada uma queda do nível de base no topo da unidade II da Fm. Furnas, a partir da constatação de que a unidade III da Fm. Furnas registra nivel energético maior, com a entrada na bacia de sedimentos de maior granulometria. A mudança litológica em superfície é nítida e correlacionada a uma mudança abrupta nos perfís de raios-gama. Descontinuidade possivelmente cronocorrelata ocorre entre os estratos lochkovianos da Fm. Santa Rosa (Bolivia) e as camadas praguianoemsianas (Isaacson \& Díaz Martínez 1995). 
Esta queda no nivel de base pode ter sido conseqüência de uma variação eustática do nível do mar, já que pela curva da figura 79 (p. 152) verifica-se uma queda no Praguiano. Não se descarta, entretanto, a possibilidade de uma reativação tectônica inicial, prenunciando um tectonismo sinsedimentar que paulatinamente se torna mais evidente em direção ao topo.

A associação faciológica da unidade III da Fm. Furnas é marinha rasa a continental, indicando um trato de mar baixo. A atuação conjunta de ondas e marés promoveu contínuo retrabalhamento das fácies depositadas, propiciando a formação de inúmeras superfícies pavimentadas com depósitos residuais (lags) constituídos de seixos e calhaus.

Transgressão rápida e mudança faciológica radical ocorreu na passagem Praguiano/Emsiano, dos arenitos grossos da Fm. Furnas para os siltitos e folhelhos do $\mathrm{Mb}$. Jaguariaíva da $\mathrm{Fm}$. Ponta Grossa. O fenômeno é também registrado em várias bacias gondwânicas (Fig. 78, p. 151) com a deposição, entre outros, dos pelitos emsianos das formações Gydo (Gr. Bokkeveld da Bacia do Cabo), Icla (zona subandina da Bolívia) e Tawil (Arábia Saudita).

É interessante observar que nestas bacias a transgressão começou no início do Emsiano, quiçá no Praguiano como sugerem as interpretações de Dino et al. (1995) para a Bacia do Paraná, quando, pela curva de variação no nível do mar da figura 79 , construida por Johnson et al. (1985) com base no registro da América do Norte, Europa e Ásia, a transgressão iniciou-se efetivamente somente no fim do Emsiano. Surge logo a questão: por que ocorre esta discrepância? Duas causas podem ser aventadas: 1) a curva não é uma curva verdadeiramente eustática, incorporando um componente tectônico atuante nas bacias que serviram de base para sua construção; 2) a curva é eustática e a transgressão gondwânica foi resultado de subsidência tectônica. É possivel, mesmo, que ambas as causas sejam verdadeiras.

Na Bacia do Paraná, pelo menos uma evidência aponta no sentido de tectônica sinsedimentar atuando já a partir do Praguiano. No flanco norte da bacia, na altlura da cidade de Amorinópolis, o contato entre as formações Furnas e Ponta Grossa é uma discordância de borda, interpretada como limite entre duas seqüências deposicionais (item 6.3). Na seção da figura 75 (p.144) verifica-se que a Fm. Furnas se acunha de oeste para leste e que a Fm. Ponta Grossa a sobrepõe em diferentes níveis, configurando uma discordância ligeiramente angular. Faltam as seções correspondentes à parte superior da Fm. Furnas e à parte inferior da Fm. Ponta Grossa. Na base desta, sobre o lag transgressivo que a separa da Fm. Furnas, ocorre 
um intervalo de poucos metros de siltitos de idade emsiana superior, que representa o registro do pico de máxima inundação no Emsiano, que transgrediu continente adentro em onlap de oeste para leste. Em função destes fatos, foi interpretado o levantamento de um arco de direção aproximada N/S na borda nordeste da bacia, na região dos baixos cursos dos rios Grande e Paranaíba, já a partir do Emsiano (Fig. 60, p. 117).

A existência das cunhas clásticas do Mb. Tibagi é evidência sedimentar da continuidade do tectonismo e reativação das bordas da bacia durante o Eifeliano. A figura 67 (p. 127) ilustra o empilhamento estratigráfico do Devoniano na região de Amorinópolis, onde se observa um padrão nitidamente progradacional com área-fonte a leste. Segundo as conclusões de Diniz (1985), afluxo sedimentar vindo de leste também ocorreu na região do Pontal do Paranapanema em São Paulo.

No processo de reativação o Arco de Assunção individualizou-se como elemento geotectônico, passando a ter expressão geomorfológica. Esta afirmativa encontra suporte no registro sedimentar, que mostra aumento da fração areia no $\mathrm{Mb}$. Tibagi nos poços situados mais a oeste (2-AN-1-PR e 1-API-1-PR), um fato já constatado anteriormente por Diniz (1985). Na figura 19 pode-se verificar este aumento da porcentagem de areia, sobremaneira evidente no poço ASU-1 (Assunção), situado bem próximo do Arco.

A reativação tectônica não se restringiu às bordas da bacia. A figura 66 (p. 126) ilustra a existência de altos internos sindeposicionais ou sítios menos subsidentes nas áreas dos poços 2-JA-1-Go (Jataí) e 2-RA-1-MT (Rio Aporé). Situação possivelmente similar ocorre na região da chapada dos Guimarães (item 6.2.3.2).

A segmentação atual da Fm. Ponta Grossa em duas sub-bacias, evidente no mapa de isópacas (Fig. 60, p. 117), é interpretada como conseqüência desta reativação. Uma das causas para explicar a existência das sub-bacias poderia estar relacionada à erosão diferencial ao tempo da discordância eocarbonifera, o que caracterizaria as sub-bacias como simplesmente pós-deposicionais ou estruturais. Mas, a julgar pelos dados bioestratigráficos disponiveis (Lange 1967; Daemon et al. 1967), a espessura reduzida da unidade nos poços situados entre os dois depocentros (PP-1-SP = Paraguaçu Paulista; RP-1-MS = Ribas do Rio Pardo; e TL-1MS = Três Lagoas) é conseqüência de falta de seção correspondente aos andares Emsiano e Eifeliano, o que aponta para a existência de altos internos sindeposicionais no Emsiano/Eifeliano. Estes altos, onde a Fm. Furnas é recoberta diretamente por estratos givetianos do Mb. São Domingos, foram há muito reconhecidos por Northfleet 
et al. (1969), que caracterizaram os altos de Campo Grande e Três Lagoas nas áreas dos poços homônimos.

Embora os dados de subsuperfície sejam poucos para uma definição mais precisa, pode-se verificar no mapa de isópacas que o alto que define as duas subbacias está associado a um lineamento de direção WNW/ESE, aproximadamente coincidente com o Lineamento de Guapiara, um elemento geotectônico comprovadamente ativo durante o Mesozóico, quando alojou impressionante enxame de diques responsáveis por anomalias magnéticas e gravimétricas de grande magnitude, mas cuja atuação já a partir do Devoniano foi anteriormente sugerida por Ferreira et al. (1981). O lineamento, que aparentemente não obedece a nenhuma estrutura do embasamento pré-cambriano/eopaleozóico, pode representar uma estrutura associada ao Lineamento Chiquitano existente na Bolívia, hipótese que merece ser investigada.

Com a interposição parcial do Arco de Assunção, ainda não plenamente emerso, a Bacia do Paraná diferenciou-se da Bacia do Chaco. O mar devoniano passou a ter características de maior restrição na Bacia do Paraná, o que é atestado pela presença de uma fauna malvinocáfrica mais endêmica, com várias espécies não encontradas em outros sítios. A bacia continuava a ter intercomunicação com o da Bacia do Chaco através do Arco de Assunção, mas as vias de comunicação são especulativas. Continuidade através do Baixo de São Pedro, no Paraguai, é indicada pela existência de unidades devonianas em subsuperfície (Gohrbandt 1992, Wiens 1995). Na parte norte da bacia, as paleocorrentes para NW na Formação Furnas e o sentido oeste de progradação dos deltas eifelianos (Fig. 68, p. 128; Andrade \& Camarço 1980) sugerem comunicação através da região hoje compreendida pela Bacia do Pantanal.

Para sul, as unidades devonianas da Bacia do Paraná diminuem acentuadamente de espessura no Estado de Santa Catarina, não ocorrendo mais no do Rio Grande do Sul. Unidades devonianas não ocorrem na parte leste da Bacia do Chaco, na Argentina. A ausência não elimina a hipótese de uma comunicação através da Mesopotâmia Argentina, pois pode ter sido conseqüência de soerguimento e erosão durante a discordância eocarbonífera.

Nas bacias do Parnaiba e do Amazonas (Fig. 80, p. 153), sobre folhelhos transgressivos do Emsiano Superior, ocorrem também seções arenosas regressivas com típicas assinaturas de granocrescência em direção ao topo, registrando progradações em condições de nível de mar alto durante o Eifeliano (Mb. Lontra da 
Fm. Maecuru na Bacia do Amazonas; Fm. Itaim na Bacia do Parnaíba). Falta de seção do Emsiano Inferior é registrada em muitos poços da Bacia do Parnaíba, onde a Fm. Itaim (Eifeliano) sobrepõe diretamente a Fm. Jaicós (Devoniano Inferior/Siluriano Superior). Na Bacia do Amazonas não ocorrem nem mesmo unidades correlatas às formações Furnas e Jaicós, sendo o registro do Devoniano iniciado com folhelhos do Mb. Jatapu da Fm. Maecuru, de idade neo-emsiana.

A análise da figura 78 (p. 151) permite verificar que progradações no Devoniano Médio não são fenômenos isolados, constituindo padrão em várias bacias gondwânicas. Na Bacia do Cabo, na África do Sul, o Sgr. Ceres do Gr. Bokkeveld (Emsiano superior/Eifeliano) é caracterizado pela presença de quatro eventos progradacionais tectonicamente controlados (Theron and Loock 1988).

\subsection{3 - Givetiano / Frasniano: máximo da transgressão marinha no Devoniano}

Os altos sindeposionais ao tempo da sedimentação da Fm. Ponta Grossa foram recobertos somente no Givetiano, ápice da transgressão devoniana na Bacia do Paraná. O máximo da transgressão é identificado nos perfis como uma superfície de máxima inundação (Fig. 72, p. 138). O mesmo pico de máxima inundação no Givetiano é interpretado nos perfis das bacias do Parnaiba e do Amazonas (Fig. 80, p. 153).

Durante o evento, os limites da Bacia do Paraná foram ampliados e a sedimentação exorbitou as áreas de ocorrência da Formação Furnas, fazendo com que a Formação Ponta Grossa tenha recoberto diretamente o embasamento précambriano. Isto pode ser observado a leste de Iporá e nas imediações do rio Sete de Setembro, a sudeste da serra do Roncador (DNPM 1975). O sentido de progradação das cunhas deltaicas do Mb. Tibagi no Estado de Goiás e das paleocorrentes medidas em seção levantada ao sul de Amorinópolis (Fig. 68, p. 128) indicam um onlap de oeste para leste.

A interligação das bacias do Paraná e do Parnaíba durante o Devoniano, através de um sea-way, na região hoje percorrida pelos rios Tocantins e Araguaia foi sugerida por diversos autores (Weeks 1947, Lange \& Petri 1967 e Northfleet et al. 1969). A reconstrução é interessante porque a distância entre os afloramentos mais setentrionais na serra do Roncador e os mais austrais da Bacia do Parnaíba é de apenas poucas centenas de quilômetros, mas ainda não foram constatadas unidades comprovadamente devonianos entre as duas bacias. 
A presença de braquiópodos boreais dos gêneros Tropidoleptus e Pustulatia (Caster 1947a/b), no Mb. São Domingos na chapada dos Guimarães, resultou do ingresso de águas mais quentes na bacia, possivelmente vindas de norte (Bacia do Parnaíba) durante o máximo de transgressão no Givetiano. Com o ingresso de formas boreais, consolida-se a tendência de desaparecimento da fauna malvinocáfrica, cujo apogeu foi no Emsiano. Segundo Melo (1988), a endêmica fauna malvinocáfrica persistiu na Bacia do Paraná até o intervalo D4a (Eifeliano Superior / Givetiano Inferior), ou seja, até a parte inferior do Mb. São Domingos. $\mathrm{Na}$ Bolivia, o desaparecimento da fauna malvinocáfrica foi posicionado no Eifeliano (Isaacson \& Sablock 1988).

A partir do pico máximo de inundação no Givetiano, o empilhamento readquire padrão progradacional, evidenciando características regressivas no Frasniano. Este último ciclo está muito mal preservado na bacia, sendo bons exemplos os poços 2-AP1-PR (Apucarana) e 2-TL-1-MS (Três Lagoas). Novos estudos podem trazer novos dados que permitam melhor interpretar este último trato de sistemas de mar alto, inclusive com a possibilidade de identificação de seções famennianas. Como se pode ver na figura 80 , esta seção regressiva no topo da Fm. Ponta Grossa pode ser correlacionada com as formações Cabeças da Bacia do Parnaíba e Curiri da Bacia do Amazonas, unidades portadoras de depósitos glaciogênicos (Caputo \& Crowell 1985).

\section{4 - DISCORDÂNCIA NO CARBONIFERO INFERIOR}

A discordância que separa as seqüências devoniana e neocarboniferapermiana da Bacia do Paraná abrange um período de tempo muito longo, de aproximadamente 40Ma. Não existem camadas do Andar Famenniano e dos andares do Carbonífero Inferior (Mississipiano), sendo do Westphaliano os estratos basais mais antigos do Gr. Itararé (Souza 1996). Isto não significa que não houve deposição durante o intervalo de tempo Famenniano/Carbonífero Inferior, já que formas retrabalhadas deste intervalo ocorrem na seção inferior do Gr. Itararé (Souza 1996). Significa apenas que os estratos não ficaram preservados ou que ainda não foram constatados.

A discordância é de natureza inter-regional, reconhecida em todo Gondwana, representando um hiato no registro sedimentar que varia de bacia para bacia. $\mathrm{Na}$ Bacia do Parnaíba, por exemplo, as formações Longá e Poti representam o registro contínuo até pelo menos o topo do Tournaisiano (Carbonífero Inferior), faltando os 
andares Viseano e Namuriano. Hiato menor existe na Bacia do Amazonas, já que, segundo Cunha et al. (1994), a Fm. Faro do Gr. Curuá é de idade tournaisiana/viseana, faltando apenas o Andar Serpukhoviano (Namuriano Inferior). A passagem gradual do Devoniano para o Carbonifero Inferior é bastante clara no registro dos poços (Fig 80, p. 153).

Nas bacias do Parnaíba e do Amazonas o ciclo de $2^{a}$ ordem corresponde, portanto, ao intervalo Devoniano Inferior/Carbonifero Inferior, o que também é o caso do Paleozóico do Altiplano da Bolívia (Isaacson \& Diaz Martinez 1995). Nestas áreas, onde a lacuna no registro sedimentar é menor, o hiato corresponde à parte superior do Carbonífero Inferior (Namuriano Inferior ou Serpukhoviano), sendo portanto cronocorrelata à discordância que divide o Mississipiano do Pensilvaniano nas bacias da América do Norte. Esta discordância (sub-Absaroka de Sloss 1963) coincide com acentuada queda do nível do mar em escala global (Saunders \& Ramsbottom 1986) (Fig. 75), provavelmente produzida por eventos glaciais num intervalo de tempo que Veevers \& Powell (1987) consideram o período de máxima glaciação no Gondwana.

No Carbonifero Inferior ocorreu erosão acentuada nos altos delineados durante a sedimentação da Fm. Ponta Grossa. Além de altos internos, como os de Campo Grande/Dourados e de Guapiara, arcos marginais a nordeste e a noroeste tiveram comportamento ascendente, com remoção das unidades devonianas. O Arco de Assunção adquiriu expressão fisiográfica plena, funcionando como área-fonte durante a deposição dos sedimentos do Carbonífero Superior (Bigarella \& Comte 1969).

Também o Arco do Rio Grande já se apresentava como uma feição com expressão geomorfológica. Em poços situados no Estado do Rio Grande do Sul o Gr. Itararé está representado somente pela sua seção superior, que, com espessuras bastante reduzidas e em onlap de norte para sul, assenta-se diretamente sobre o embasamento pré-cambriano/eopaleozóico, não tendo sido constatadas, até o momento, unidades pré-carboníferas. A região atuou como um alto durante o Carbonífero, possivelmente recoberto por geleiras, servindo de área-fonte para as areias do Grupo Itararé depositadas ao norte. Esta interpretação encontra forte evidência nas paleocorrentes para norte medidas no Arenito Lapa (Gr. Itararé), apresentadas por França et al. (1994).

Na região leste do Estado do Paraná também foi detectada a emergência de um alto. Na figura 37 (p. 76), pode-se verificar que a Fm. Furnas se acunha para leste devido a truncamento, no topo, pelo Gr. Itararé, numa discordância de pequena angularidade. Nessa área, a Fm. Furnas é sobreposta diretamente pelo Gr. Itararé, 
com remoção total da Fm. Ponta Grossa, evidenciando a pronunciada erosão durante a discordância carbonifera. Este alto não tem relação alguma com Arco de Ponta Grossa, que é uma feição mesozóica, interpretação corroborada pelo fato de que sobre o prolongamento do arco, em subsuperfície, está preservada a seção mais completa da Formação Ponta Grossa (poço 2-AP-1-PR).

Ao lado dos eventos de tectônica modificadora no Carbonífero, processos de erosão glacial desempenharam importante papel na geração da discordância, como agentes de erosão dos sedimentos devonianos da Bacia do Paraná. Feições canalizadas na superfície da discordância, como a observada na seção sísmica da figura 36 (p. 75), poderiam ser conseqüência de erosão glacial, já que muitas tem traçado NS, coincidente com o sentido de deslocamento das geleiras no Carbonifero. 


\section{8 - EVOLUÇÃO TECTONO-SEDIMENTAR}

A Bacia do Paraná é uma bacia intracratônica, que adquiriu características tipicamente interiores a partir do Carbonifero Superior com a consolidação do levantamento do Arco de Assunção. Em tempos pré-carboniferos, a Bacia do Paraná consituía uma bacia de caracteristicas estratigráficas e tectônicas diferentes, cuja origem e evolução são ainda muito pouco comprendidas. Esta condição não é privativa da Bacia do Paraná, pois as bacias intracratônicas são, dentre os vários tipos de bacia, as menos compreendidas (Leighton \& Kolata 1990).

Pretende-se, com a argumentação apresentada a seguir, rediscutir algumas das interpretações e alguns dos modelos propostos anteriormente para a evolução précarbonífera da bacia, à luz dos novos dados apresentados neste trabalho.

Ressaltando a deficiência e discrepância de dados e interpretações sobre a evolução tectono-sedimentar das bacias e orogenias pré-andinas (Bolívia, Argentina e Chile), facilmente constatadas quando se consulta a literatura geológica sobre as mesmas, esforço foi feito no sentido de correlacionar eventos dessas regiōes pericratônicas com a evolução intraplaca da Bacia do Paraná. Esta atitude tem como premissa que o interior das placas respondem tectonicamente, evidentemente de forma atenuada, aos estados de tensão em suas bordas, as quais se deformam mais intensamente por absorverem a maior parte dos esforços derivados do movimento das placas litosféricas.

\section{1 - UM RIFTE INICIAL?}

Bacias intracratônicas podem ser geradas por subsidência termal subseqüente a processos de rifteamento continental, sendo melhor exemplo a Bacia do Mar do Norte no pós-Triássico. Este modelo foi considerado efetivo por Klein and Hsui (1987) para explicar a origem das quatro grandes bacias intracratônicas paleozóicas da América do Norte (Williston, Michigan, Illinois e Hudson). Na mesma linha de raciocínio, Fúlfaro et al. (1982) propuseram que a subsidência inicial na Bacia do Paraná, correspondente à deposição dos estratos ordovício-silurianos do Gr. Caacupé, foi condicionada por aulacógenos (riftes) de direção NW, com subseqüente fase de subsidência térmica dando origem à sinéclise intracratônica. 
A partir da caracterização da seqüência ordovício-siluriana no Brasil (Gr. Rio Ivai), novas informações têm permitido rediscutir a questão. Milani et al. (no prelo), com base na existência de estruturas de direção NE, detectadas abaixo da Fm. Furnas em seções sísmicas, aventaram a hipótese de que a seqüência ordovício-siluriana está estruturada por falhas de direção $N E$, conseqüência de um episódio distensivo não focalizado. A partir disso, Milani et al. (1994) interpretaram a Fm. Alto Garças como o registro de uma fase rifte inicial na Bacia do Paraná. Esta concepção foi adotada por França et al. (1995) e Tankard et al. (1995), que consideraram a deposição da Fm. Alto Garças condicionada por grábens de direção NE.

O volume de dados disponíveis é pequeno, de forma que não existem elementos que permitam uma opção segura em termos da disposição espacial da seção psamítica neo-ordoviciana (Fm. Alto Garças/Gr. Caacupé). Não existem, entretanto, indicações de estruturas rúpteis de direção NW condicionando a distribuição dos estratos ordovício-silurianos. Também a interpretação de estruturas NE carece ainda de melhor caracterização, porque a qualidade das seções sísmicas disponiveis não é boa e os baixos estruturais não foram testados por perfurações, podendo corresponder a bacias molássicas distensionais (ou transtracionais) cambroordovicianas (como a Bacia de Castro, por exemplo). Somente na área do poço 1-SE1-SC (Seara) pode-se afirmar que a distribuição da Fm. Alto Garças está condicionada por estruturas de direção NE, relacionadas à zona de falha Lancinha-Cubatão, que representa o limite SE de ocorrência da unidade (Fig. 21, p. 49). Na falta de informações sobre a natureza, direção e localização das estruturas, optou-se neste trabalho pela construção dos mapas de isópacas do Gr. Rio Ivaí (Fig. 9, p. 33) e da Fm. Alto Garças (Fig. 21) unicamente por interpolação linear entre os valores de espessura medidos em poços e em seções de superfície.

Além destes fatos, não existem dados que permitam concluir com segurança que a estruturação é sindeposicional, podendo, ao contrário, ser produto de preservação diferencial de blocos movimentados por tectônica modificadora, como pode se depreender das conclusões apresentadas em Milani et al. (no prelo).

Do ponto de vista faciológico, não foram constatadas na Fm. Alto Garças fácies de leques aluviais e/ou lacustres, típicas de bacias rifte. A unidade constitui extensos tratos de sistemas transgressivo e de mar alto, depositados em condições pericratônicas, num mar epicontinental conectado a oeste com um proto-Oceano Pacífico (item 7.1.1). 
Poder-se-ia pensar, então, que as bacias cambro-ordovicianas embutidas em blocos baixos, definidos por falhas de direção $N E$, constituir-se-iam o registro dos riftes que originaram a Bacia do Paraná. Tais bacias cambro-ordovicianas encontram-se associadas aos cinturões orogênicos que bordejam a bacia, não tendo sido até o momento constatadas em sua porção central, onde Brito Neves et al. (1984) interpretaram um núcleo cratônico mais antigo. Mas, como explicar que riftes tão localizados deram origem a uma bacia com as dimensões da Bacia do Paraná?

Também com relação à origem das bacias intracratônicas norte-americanas, o modelo de subsidência térmica pós-rifte tem sido questionado. Para Quinlan (1987), o tempo entre o rifteamento e o início da subsidência intracratônica (da ordem de 500 a $600 \mathrm{Ma}$ para a Bacia de Michigan) é muito longo, não podendo a subsidência intracratônica ser atribuída ao decaimento da anomalia térmica produzida pelo rifteamento. Para o mesmo autor, em nenhuma daquelas bacias os dados sísmicos existentes são consistentes com o afinamento crustal necessário para aplicação dos modelos de subsidência térmica.

Uma das principais dificuldades de aplicação do modelo (rifte inicial seguido de subsidência termal) é explicar os eventos alternados de subsidência e soerguimento, que caracterizam as bacias intracratônicas como entidades policíclicas. Seria necessário um rifte inicial para cada seqüência, já que cada seqüência representa em última análise uma nova bacia superposta à anterior. Além disso, como explicar a sincronia de seqüências e discordâncias em diferentes bacias cratônicas, demonstrada por Sloss (1963) para as bacias cratônicas norte-americanas e por Soares et al. (1978) para as bacias intracratônicas brasileiras.

Interessante linha de pesquisa alternativa é a tentativa de correlacionar fenômenos intraplaca com eventos nas bordas das placas, sobretudo com orogenias. No caso da Bacia do Paraná, os trabalhos de Zalán et al. (1987b, 1990) foram pioneiros, apresentando a correlação entre discordâncias na bacia e orogenias préandinas. Posteriormente, Zalán (1991) desenvolveu tal proposição, advogando a mesma correspondência entre orogenias pré-andinas e discordâncias nas bacias do Amazonas e do Parnaíba. Para avançar nesta questão, discutir-se-ão a seguir os eventos orogênicos pré-andinos (caracterizados por diversos autores nas regiões andinas e subandinas da Argentina, Chile e Bolívia) e as seqüências tectonosedimentares pré-carboníferas da Bacia do Paraná (discutidas neste trabalho). 


\section{2 - O CICLO OROGÊNICO FAMATINIANO E A EVOLUÇÃO PRÉ-CARBONIFERA DA BACIA DO PARANÁ}

O continente de Gondwana foi formado no Proterozóico Superior a partir da convergência de grandes placas litosféricas continentais e de uma complexa trama de vários terrenos alóctones em rotas de múltiplas colisões, no que é conhecido como Ciclo Orogênico Brasiliano (correspondente ao Ciclo Pampeano de Aceñolaza \& Toselli 1976). Este ciclo encerrou-se no Cambriano Inferior/Médio (Orogenia Tilcarica), quando colidiram os últimos blocos cratônicos, como o Cráton de Arequipa-Antofalla.

Após a cratonização dos terrenos acrescidos e amalgamados, teve início, numa paleogeografiia gondwânica, um novo ciclo de $1^{\text {a }}$ ordem na história geológica (Cambriano Superior/Triássico Superior). A primeira metade deste ciclo, transcorrido no intervalo Cambriano Superior/Devoniano Superior em condições de greenhouse, corresponde ao Ciclo Orogênico Famatiniano do Noroeste da Argentina (Aceñolaza \& Toselli 1976) O Ciclo Famatiniano, que em sentido amplo é equivalente ao Ciclo Caledoniano do Hemisfério Norte, compreende as orogenias Oclóyica e Chanica, correspondentes respectivamente às orogenias Taconiana e Acadiana da América do Norte (Fig. 83). Os várias eventos deste ciclo, reconhecidos na região atualmente entre os paralelos 20 e $35^{\circ} \mathrm{S}$, estão ilustrados tentativamente no esquema evolutivo da figura 84 .

O Ciclo Famatiniano iniciou-se com um evento regional de distensão no Cambriano Superior/Ordoviciano Inferior (Fase Iruyica). Distensão a leste do Cráton de Arequipa-Antofalla deu origem à Bacia da Puna do Noroeste da Argentina, interpretada por alguns como back-arc distensional (Ramos 1988) e por outros como aulacógeno (Sempere 1995). A este evento distensivo regional podem ser correlacionadas as bacias transtensionais pós-orogênicas (bacias molássicas) da região centro-sul do Brasil, sobretudo condicionadas pela reativação de estruturas rúpteis brasilianas de direção NE, como por exemplo a Bacia de Castro no Estado do Paraná.

O regime tectônico foi compressivo na margem sudoeste do continente de Gondwana no Ordoviciano Médio/Superior, resultando na inversão da Bacia da Puna (Llanvirniano, Evento Guandacol) e numa nova colisão do Cráton de ArequipaAntofalla com o Terreno Pampeano (Ashgilliano, Orogenia Oclóyica). No Cráton de Arequipa-Antolfalla e na porção ocidental do Terreno Pampeano desenvolveu-se um arco magmático (Ramos et al. 1986). O máximo da atividade magmática ocorreu no 
limite Ordoviciano/Siluriano, produzindo quartzo dioritos, monzonitos e granitos de margens destrutivas de placa (Rapela et al., apud Ramos 1988). O Arco da Puna deu origem à proto-Cordilheira dos Andes, separando, a partir de então, um mar epicontinental do proto-Oceano Pacífico (Fig. 85). Por sobrecarga tectônica, bacias pericratônicas foram convertidas em bacias foreland. À Orogenia Oclóyica parece também estar associada a acresção do terreno alóctone da Precordillera Argentina, pois somente a partir do Ordoviciano Superior o empilhamento sedimentar neste terreno passou a ter afinidade gondwânica, quando antes tinha afinidade apalachiana.

\begin{tabular}{|c|c|c|c|c|c|c|}
\hline \multicolumn{2}{|r|}{$\begin{array}{l}\text { CRONOESTRATIGRAFA } \\
\text { SISTEMA/SERRIE }\end{array}$} & $\begin{array}{c}\text { GEOCR. } \\
\mathrm{Ma}\end{array}$ & $\begin{array}{c}\text { FASES } \\
\text { DLASTRÓFCAS }\end{array}$ & $\begin{array}{l}\text { EVENTOS } \\
\text { PRINCIPAIS }\end{array}$ & $\begin{array}{c}\text { CICLOS } \\
\text { OROEÊNICOS }\end{array}$ & $\begin{array}{l}\text { BACIA DO } \\
\text { PARANA }\end{array}$ \\
\hline \multirow{5}{*}{ 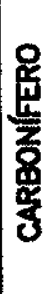 } & STEPHANIANO & \multirow{7}{*}{$\begin{array}{l}342 \\
355 \\
375\end{array}$} & \multirow[b]{4}{*}{$\begin{array}{l}\text { DISTENSAO } \\
\text { SOMUNCURA }\end{array}$} & \multirow{6}{*}{$\begin{array}{l}\text { - Colisdo do Torreno } \\
\text { Chilenio }\end{array}$} & \multirow{4}{*}{ CONDWANICO } & \multirow[t]{2}{*}{ G. Itorard } \\
\hline & WESTPHALLANO & & & & & \\
\hline & NAMURLANO & & & & & \\
\hline & VSEANO & & & & & \\
\hline & TOURNALSANO & & \multirow{6}{*}{$\begin{array}{l}\text { OROGENIA } \\
\text { CHANICA }\end{array}$} & & \multirow{11}{*}{ FAMATINIANO } & \\
\hline \multirow{5}{*}{ 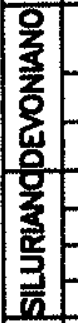 } & SUPERIOR & & & & & \\
\hline & MÉDIO & & & & & Ponto Grosso \\
\hline & INFERIOR & \multirow{6}{*}{$\begin{array}{l}390 \\
410 \\
424 \\
428 \\
438 \\
446 \\
455\end{array}$} & & & & Fm. Furnos \\
\hline & $\begin{array}{l}\text { PRIDOLIANO } \\
\text { DUDLOWLANO } \\
\text { WENLOCKIANO }\end{array}$ & & & & & \\
\hline & WANDOVERIANO & & & & & \multirow{2}{*}{$\begin{array}{c}\mathrm{Fm} \text {. Vilo Moria } \\
\mathrm{Fm} \text {. lap } \\
\mathrm{Fm}\end{array}$} \\
\hline \multirow{5}{*}{ 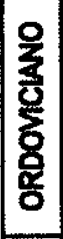 } & ASHGILUANO & & \multirow{2}{*}{$\begin{array}{l}\text { OROGENIA } \\
\text { OCLÓYCA }\end{array}$} & \multirow{3}{*}{$\begin{array}{c}\text { Nova Coliszo do } \\
\text { Craton do Arequipo- } \\
\text { Antofollla }\end{array}$} & & \\
\hline & CARADOCIANO & & & & & Fm. Nito Gareas \\
\hline & LANDEILANO- & & & & & \\
\hline & ARENIGANO & \multirow{2}{*}{$\begin{array}{l}470 \\
490 \\
510\end{array}$} & \multirow{2}{*}{ GUANDACOL } & & & \\
\hline & TREMADOCIANO & & & & & \multirow{3}{*}{ Gr. Costro } \\
\hline \multirow{3}{*}{ 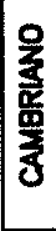 } & SUPERIOR & \multirow{2}{*}{523} & \multirow{2}{*}{$\begin{array}{l}\text { DISTENSAO } \\
\text { IRUMCA }\end{array}$} & \multirow{4}{*}{$\begin{array}{l}\text { Colisco do Cróton } \\
\text { de Arequipa-Antofolla } \\
\text { Formocdo do Conti- } \\
\text { nente de Gondwana }\end{array}$} & \multirow{4}{*}{ BRASILANO } & \\
\hline & MÉDIO & & & & & \\
\hline & INFERIOR & \multirow{2}{*}{$\begin{array}{l}530 \\
570\end{array}$} & \multirow{2}{*}{$\begin{array}{l}\text { OROGENIA } \\
\text { TILCARICA }\end{array}$} & & & \\
\hline \multicolumn{2}{|r|}{ PRÉ-CAMBRIANO } & & & & & \\
\hline
\end{tabular}

Figura 83 - Ciclos orogênicos e fases diastróficas no Paleozóico Inferior/Médio na margem sudoeste do continente de Gondwana, entre os atuais paralelos $20^{\circ}$ e $35^{\circ} \mathrm{S}$ (Argentina, Chile e Bolivia) (baseado em Aceñolaza \& Toselli 1976, Ramos et al. 1986, Ramos 1988, Rapela et al. 1992, Tankard et al. 1995, Mon \& Salfity 1995). 


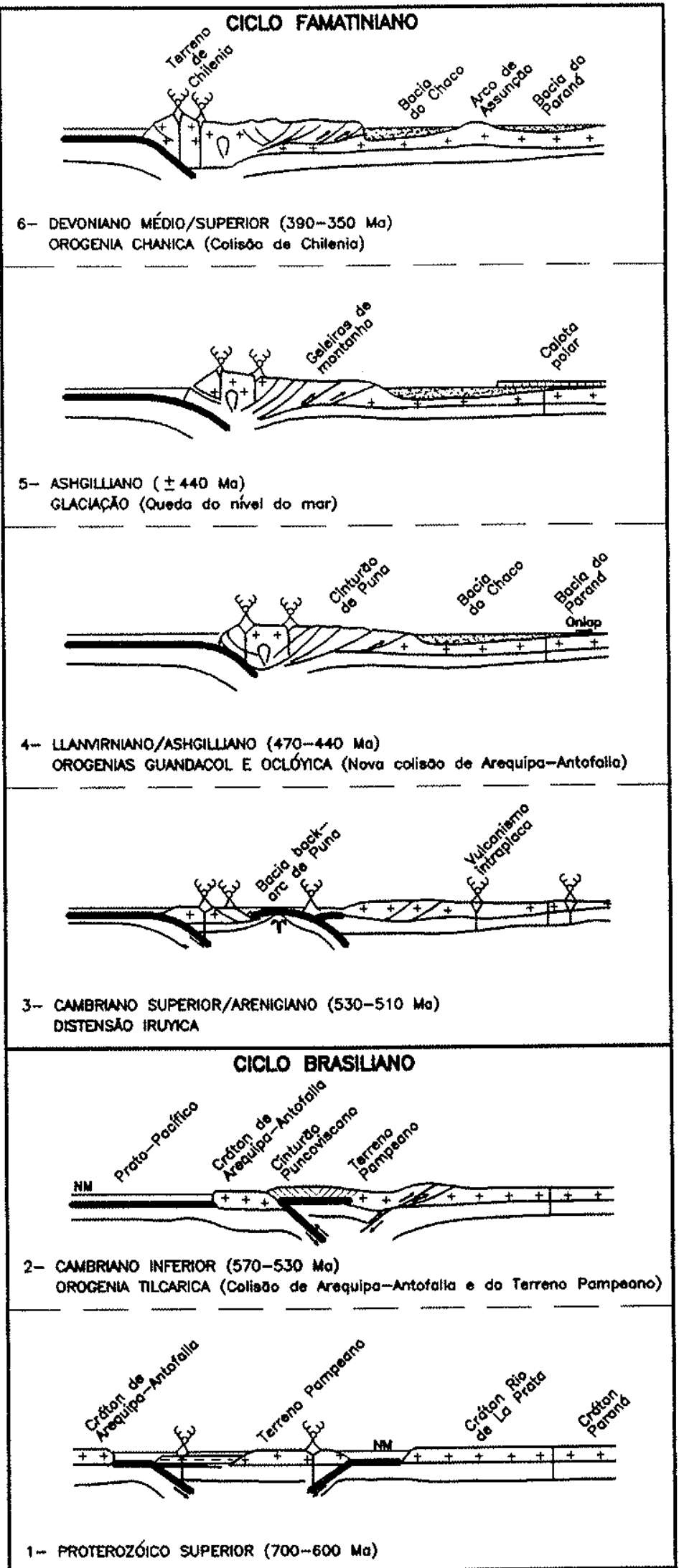

Figura 84 - Evolução geológica da região centro-sul do continente sulamericano, no Paleozóico Inferior/Médio (esquema baseado em: Ramos et al. 1986, Ramos 1988, Sempere 1995). 


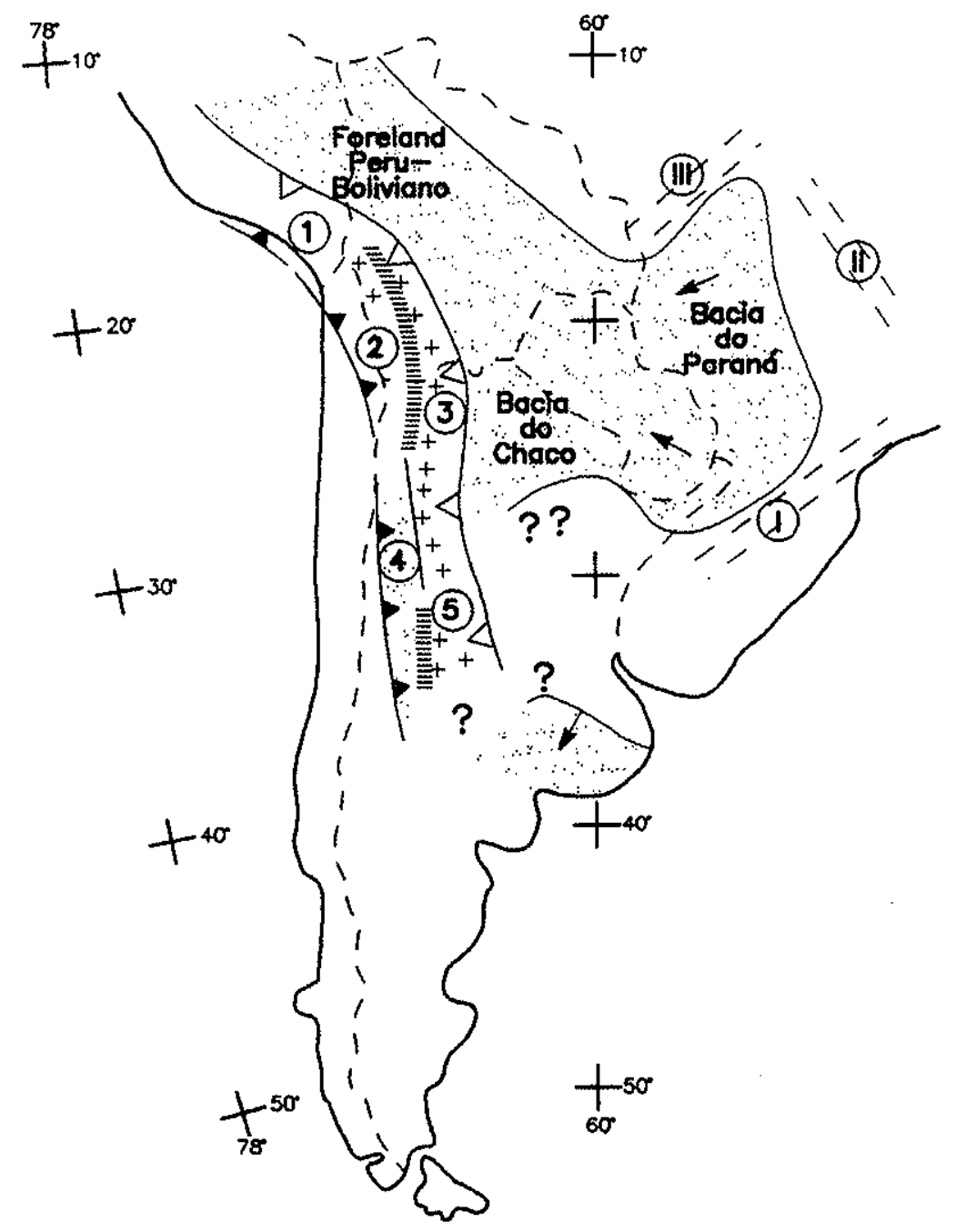

\section{OROGENOS BRASILLANOS}

I- Ribeiro

II- Araxó-Canastro

III- Paroguai-Aroguaio

TERRENOS:

1- Arequipo

2- Antofollo

3- Puna

4- Precordilhero

5- Pompeono

\section{LEGENDA:}

D. Bacios neo-ordovicianas

4 Cinturso de Covalgamento

D Zono de Subduçoo

++ Arco Nogmático

\# Suturos meso-ordovicionos

6 Paloocorrentes

$1000 \mathrm{Km}$

Figura 85 - Mapa paleogeológico da região centro-sul do continente sul-americano no Ordoviciano Superior (sintese a partir de várias fontes, entre as quais: Ramos et al. 1986; Ramos 1988; Benedetto et al. 1992; Dalla Salda et al. 1992, Gohrbandt 1992).

A este episódio de compressão, aparentemente está associada a sedimentação da Fm. Alto Garças e do Gr. Caacupé da Bacia do Paraná, que então se instalava como uma bacia intracratônica adjacente às bacias do Chaco, estas situadas em contexto foreland retroarco do orógeno oclóyico.

Um curto episódio glacial ocorreu no final do Ordoviciano (Ashgilliano Superior) causando regressão em praticamente todas as bacias gondwânicas (Fig. 78, p. 151). 
As causas de sua ocorrência em um período greenhouse ainda não estão elucidadas. Na Bacia do Paraná o evento é materializado pela Fm. lapó. Com a deglaciação e conseqüente subida do nivel do mar, a margem sudoeste do continente de Gondwana foi palco de deposição de unidades transgressivas em onlap de oeste para leste, como indicado por Sempere (1995) para a Bolívia. Na Bacia do Paraná, uma rápida transgressão ocorreu no Llandoveriano com a deposição dos pelitos das Formações Vila MariaNargas Peña.

Segundo alguns autores, como Cuerda \& Caminos (1983) e Suárez-Soruco (1995), a Orogenia Oclóyica prolongou-se até o Llandoveriano, promovendo o incremento na subsidência nas bacias bolivianas e deposição em águas profundas. Fácies de ressedimentação e evidências de deslizamentos na Fm. Cancañiri, que atinge $1500 \mathrm{~m}$ de espessura, são interpretadas como o registro sedimentar desta atividade tectônica no Llandoveriano. No evento, os estratos ordovicianos da Cordilheira Oriental, da Puna e da Zona Subandina foram metamorfoseados, dobrados e invertidos. Plútons sin e tardi-orogênicos (431 $\pm 10 \mathrm{Ma})$ e eventos termais (440Ma) foram relatados por Coira et al. (1982). Após o evento oclóyico, ○ Arco da Puna permaneceu uma área positiva e nos estratos ordovicianos alojaram-se granitóides pós-tectônicos de idade siluriana inferior (Bahlburg \& Breitkreuz 1991).

Nas bacias pericratônicas do foreland peru-boliviano ("Bacia Andina Central" de Benedetto et al. 1992) e nas bacias do Chaco, a sedimentação continuou ocorrendo durante quase todo o Siluriano. O empilhamento é nitidamente regressivo até o limite Siluriano/Devoniano, quando então passa a ser novamente transgressivo. Embora a maioria dos autores tenha considerado uma passagem contínua, é possível a existência de pequenos hiatos deposicionais ou, mesmo, descontinuidades erosivas.

$\mathrm{Na}$ Bacia do Paraná houve regressão a partir do Llandoveriano Médio, possivelmente motivada inicialmente pelo rebound glácio-isostático com o recuo das geleiras. Queda acentuada do nivel do mar no interregno Pridoliano/Lochkoviano deu origem a uma discordância entre o Siluriano Inferior e o Devoniano Inferior. Por nãodeposição e/ou erosão, não ficaram preservados estratos do Wenlockiano ao Pridoliano, fenômeno que ocorreu em menor escala nas bacias do Amazonas e do Parnaíba. Esta discordância não está relacionada a nenhuma orogenia pré-andina na região entre os atuais paralelos 20 e $35^{\circ} \mathrm{S}$. Pelo contrário, segundo Gohrbandt (1992), do início do Siluriano até o final do Devoniano Inferior, a margem sudoeste do Continente de Gondwana foi tectonicamente quiescente. Granitos eodevonianos das 
serras pampeanas orientais são em sua maioria pós-tectônicos (Ramos et al. 1986). Segundo Boucot (1990), o período Siluriano foi praticamente anorogênico.

O Devoniano caracterizou-se como um período de progressiva elevação eustática do nível do mar (Fig. 79, p. 152). O espaço gerado para acomodação dos sedimentos eodevonianos da Fm. Furnas foi proporcionado essencialmente pela elevação do nível de base com o primeiro pico de transgressão no Lochkoviano, não havendo evidências de tectonismo sinsedimentar (item 7.3.1).

No intervalo de tempo Emsiano/Eifeliano, a margem gondwânica, da África do Sul à Bolívia, foi caracterizada por uma fauna peculiar de invertebrados, especialmente braquiópodos e trilobitas, conhecida como fauna malvinocáfrica. Uma das causas de seu endemismo foi atribuída ao seu isolamento, proporcionado pela existência de uma proto-Cordilheira dos Andes (Isaacson \& Sablock 1990). Seu desaparecimento tem sido atribuido ao ingresso de águas mais quentes na bacia com a transgressão no Givetiano, o que teria favorecido a migração de formas boreais para a Bacia do Paraná, como braquiópodos do gênero Tropidoleptus encontrados no $\mathrm{Mb}$. São Domingos na Chapada dos Guimarães (item 7.3.3).

Apesar dessa tendência eustática ascendente, houve um importante episódio de progradação de sistemas deltaicos no Eifeliano (Mb. Tibagi), interpretado como resultado de atividade tectônica sin-sedimentar (item 7.3.2). Outras evidências, como a existência de altos durante a sedimentação da Fm. Ponta Grossa e hiatos no registro sedimentar, corroboram esta interpretação.

Esta reativação na bacia pode ser correlacionada com os eventos colisionais da Orogenia Chanica (Fig. 83). Segundo Ramos et al. (1986) e Breitkreuz et al. (1988), esforços de compressão tiveram início no Devoniano Médio (Fig. 86). Nessa época as bacias pericratônicas pré-andinas conheceram altas taxas de sedimentação. As bacias do Chaco passaram a ter subsidência acentuada, acumulando-se na Bacia do ChacoParaná mais de $4000 \mathrm{~m}$ de sedimentos. O Cráton de Arequipa-Antofalla e o Arco da Puna constituíram a principal fonte de clásticos para as bacias bolivianas (Isaacson \& Sablock 1988, Ramos et al. 1986), representando uma reversão de polaridade sedimentar em relação às áreas-fonte dos sedimentos silurianos (Sempere 1995). Segundo Baldis (1992), a Fm. Huamapampa da região subandina da Bolívia registra as primeiras paleocorrentes vindas de oeste, ou seja, do arco magmático na Orogenia Chanica (Arco da Puna e Cráton de Arequipa-Antofalla), onde é evidente forte atividade orogênica. 


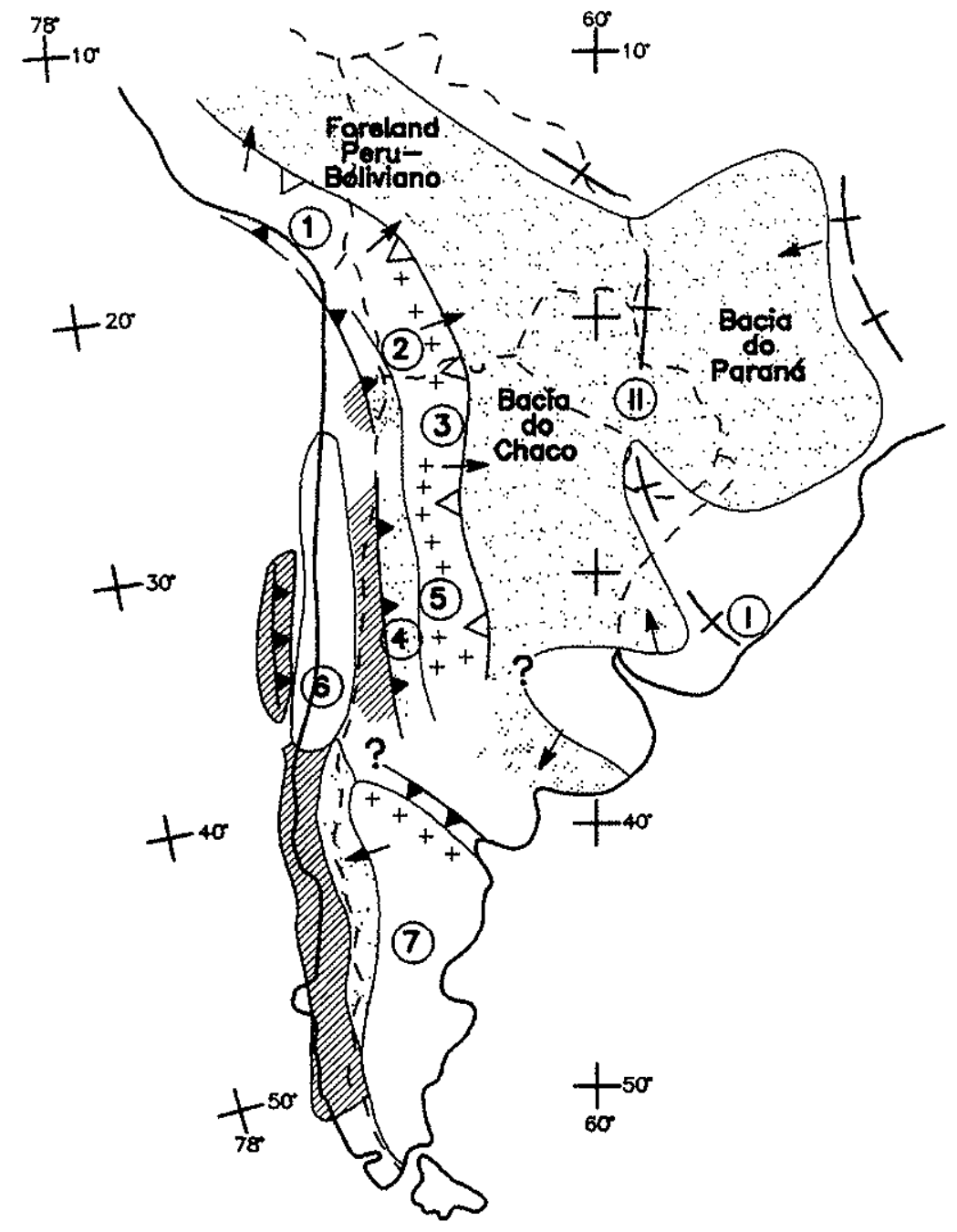

ARCOS E ALTOS

I- Rio Grondo

il- Assunço

TERRENOS:

1- Arequipe

2- Antofalla

3- Puna

4- Precordithera

5- Pompeano

6- Chilenio

7- Potogonia

LEGENDA:

Bocios devoniones

Crosto Oceonico

4 cinturdo de Cavalgamento

Z Zono de Suboucça

+ Arco Mogmático

+ Areos O Altos

- Paleocorrentes

$1000 \mathrm{~km}$

Figura 86 - Mapa paleogeológico da região centro-sul do continente sul-americano no Devoniano Médio (sintese a partir de várias fontes, entre as quais: Ramos et al. 1986; Ramos 1988; Gohrbandt 1992; Breitkreuz et al. 1988)

A Orogenia Chanica (Devoniano Médio/Carbonífero Inferior), com granitóides sincolisionais datados entre 374 e $323 \mathrm{Ma}$ (Coira et al. 1982), constitui um evento maior de deformação e plutonismo. O evento, que foi reconhecido no Peru, na Bolívia e no norte da Argentina e do Chile, foi atribuído à colisão do Terreno Chilenia (Ramos et al. 1986). Marca o fim do Ciclo Famatiniano, após o qual adveio o Ciclo Orogênico Gondwânico (Fig. 86), quando houve rearranjo geotectônico com o deslocamento do arco magmático cerca de $300 \mathrm{~km}$ para oeste (Ramos 1988, Breitkreuz et al. 1988). 
No processo, as bacias devonianas que se desenvolveram nas proximidades da região do arco magmático (bacias de Callingasta e Ariazo na Argentina, por exemplo), foram intensamente deformadas e apresentam forte discordância angular com os estratos eocarboníferos (López-Gamundi \& Rossello 1993). Inversão de menor intensidade ocorreu nas bacias foreland siluro-devonianas subandinas adjacente ao arco. Na Bacia do Chaco-Paraná houve basculamento para oeste e os estratos carboníferos jazem em discordância angular de pequena angularidasde sobre unidades devonianas, evidenciando uma tendência de redução de deformação para leste em direção ao interior do continente (Mon \& Salfity 1995).

$\mathrm{Na}$ Bacia do Paraná, esforços compressivos intraplaca derivados da convergência pré-andina promoveram movimentos diferenciais de blocos. A subsidência foi incrementada em alguns setores, paralelamente à emergência de altos internos e marginais onde ocorreu erosão e/ou não-deposição. No evento, o Arco de Assunção adquiriu expressão fisiográfica, resultando no isolamento parcial da Bacia do Paraná em relação às bacias do Chaco.

López-Gamundi \& Rosselo (1993) atribuíram à Orogenia Chanica a gênese da discordância entre o Devoniano e o Carbonífero (por eles referida como EoHerciniana), tomando como referência a Bacia de Calingasta-Uspallata, situada no flanco oeste da Precordillera Argentina. Nesta bacia, o contato dá-se em discordância angular entre estratos do Givetiano e do Tournaisiano, definindo uma fase de inversão no Famenniano. Os referidos autores concluíram que, em conseqüência deste evento, um longo período (cerca de $60 \mathrm{Ma}$ ) de soerguimento e erosão, sem deformação significativa, ocorreu nas bacias do Chaco e do Paraná no Carbonífero Inferior, uma vez que nestas bacias a lacuna no registro sedimentar compreende um hiato de tempo muito maior, do Fammeniano ao Namuriano.

A análise conjunta de várias bacias sul-americanas permite interpretar, entretanto, quadro um pouco diferente do exposto por López-Gamundi \& Rosselo (1993). Isto porque a discordância na Bacia de Calingasta-Uspallata não define a duração da Orogenia Chanica, já que os estratos do Carbonífero Inferior são, segundo aqueles autores, produto de sedimentação aluvial sintectônica, ao que parece do final do ciclo orogênico. Além disso, uma discordância angular num local apenas não representa a idade do máximo encurtamento na borda de uma placa, uma vez que a convergência não se dá à mesma taxa em todos os segmentos, nem a colisão é necessariamente síncrona. Enquanto algumas áreas sofrem inversão, outras subsidem e recebem os sedimentos derivados daquelas que se elevam e são palco de erosão. 
É importante enfatizar o fato de que as orogenias são freqüentemente diácronas em diferentes segmentos das margens colisionais, pois a convergência é normaimente obliqua. As discordâncias representam assim momentos dentro de um espectro mais amplo. Enquanto algumas bacias sofrem inversão, em outras pode ocorrer subsidência acentuada e alta taxa de sedimentação, constituindo o receptáculo dos detritos erodidos dos blocos que se elevam. Discordâncias em algumas bacias podem, mesmo, inexistir. Este é o caso do Paleozóico no Altiplano boliviano, onde há registro sedimentar contínuo do Ordoviciano Superior ao Carbonifero Inferior. Em função destas peculiaridades, a associação direta entre orogenias e discordâncias nem sempre é válida.

A discordância no Altiplano boliviano, assim como nas bacias intracratônicas do Parnaíba e do Amazonas, ocorreu no Namuriano, não associada portanto à Orogenia Chanica. Na Bacia do Paraná, a constatação de formas famennianas e eocarboníferas nos estratos westphalianos da base do Gr. Itararé (Souza 1996) sugere que o modelado da superfície de discordância é também de idade namuriana..

Regressão no Namuriano foi global e simultânea à queda acentuada do nível do mar (Ross \& Ross 1985, Saunders \& Ramsbottom 1986). O evento tem sido associado a episódio maior de glaciação (Veevers \& Powell 1987), mas outros pesquisadores buscam resposta em eventos tectônicos globais que teriam alterado o volume das bacias oceânicas. Considerando que a origem de discordância tão significativa ainda careça de explicação satisfatória, Leighton \& Kolata (1990) postularam que sua origem foi conseqüência de soerguimento generalizado das duas placas maiores (Gondwana e Laurussia), acompanhado de colisão entre a Eurasia e a margem gondwânica norteafricana.

O regime de esforços na margem sudoeste do Gondwana deixou de ser compressivo no Carbonífero Inferior com o advento da Distensão Somuncura (Mon \& Salfity 1995, Tarkard et al. 1995) (Fig. 83). No Chile, a Fm. El Toco (Devoniano Superior) foi intrudida por plútons pós-tectônicos de idade serpukhoviana (320Ma) (Breitkreus et al. 1988). Estes eventos podem ser atribuídos à cessação da compressão e da sobrecarga litosférica nas bacias de foreland, que caracterizam a fase de relaxação no modelo de Tankard (1986).

A partir do Carbonífero a bacia adquiriu estilo tipicamente interior e sua geometria foi substancialmente alterada. Paleocorrentes medidas por Bigarella \& Comte (1969), em estratos fluviais da Fm. Coronel Oviedo, revelaram sentido de fluxo para $\circ$ azimute $60^{\circ}(\mathrm{N} 60 \mathrm{E})$, indicando que no Carbonífero Superior $\circ$ Arco de 
Assunção já se impunha na geomorfologia como borda oeste da bacia, separando a Bacia do Paraná das bacias do Chaco. A estruturação do $\mathrm{Gr}$. Itararé não guarda relação com o embaciamento devoniano, havendo inversão de depocentros e altos, 0 que pode ser verificado quando se compara o mapa de isópacas da Fm. Ponta Grossa (Fig. 60, p. 117) com o do Gr. Itararé (Fig. 87).

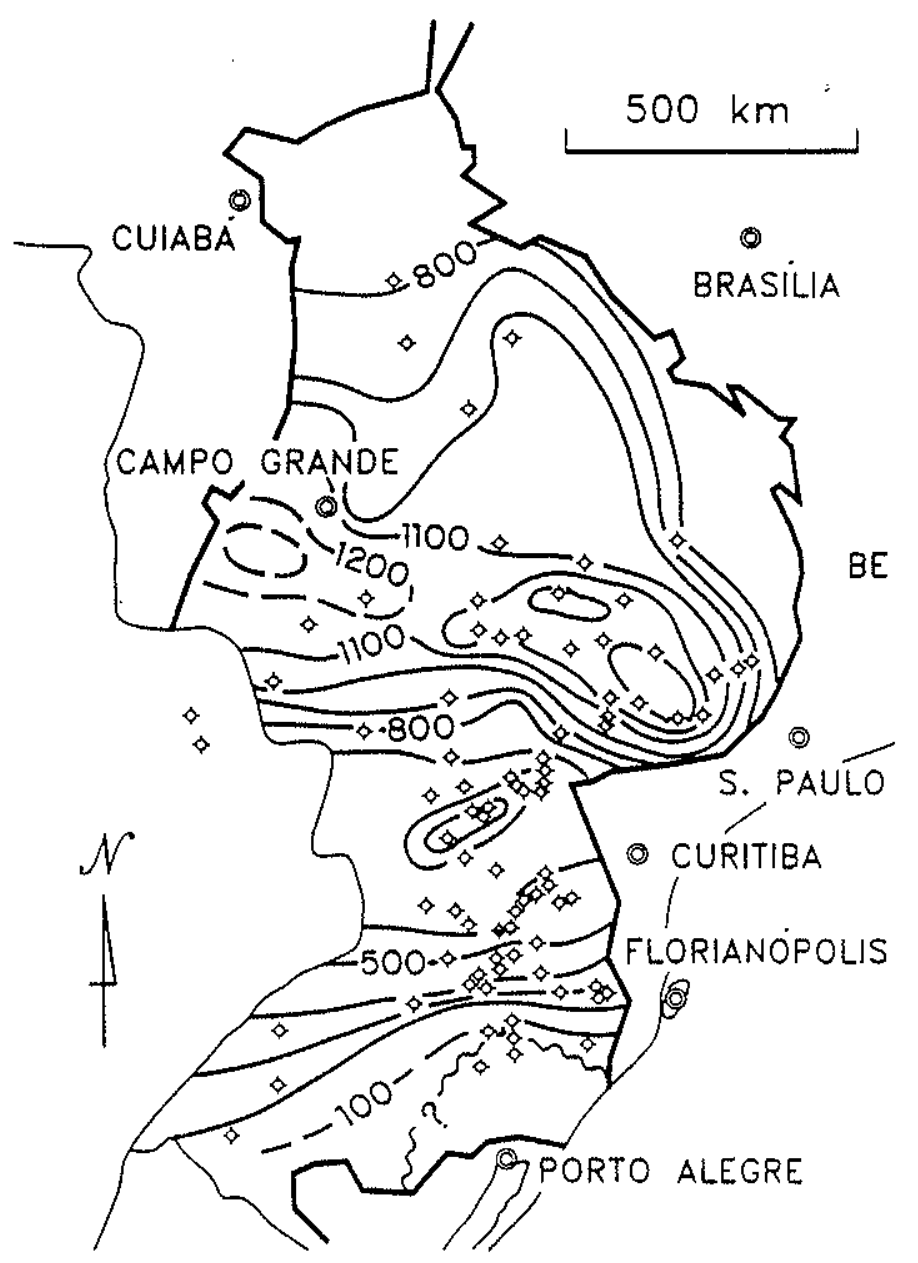

Figura 87 - Mapa de isópacas do Gr. Itararé (França 1994). Observa-se uma inversão na movimentação dos blocos: o Grupo Itararé apresenta depocentro de direção aproximada $\mathrm{EW}$, coincidente com altos internos contemporâneos à sedimentação da Fm. Ponta Grossa, que compartimentalizaram a bacia devoniana em duas subbacias (comparar com o mapa de isópacas da Fm. Ponta Grossa, figura 60) 


\section{3 - CORRELAÇÃO ENTRE AS SEQÜÊNCIAS PRÉ-CARBONÍFERAS DA BACIA DO PARANÁ E AS OROGENIAS PRÉ-ANDINAS}

Pelas informações apresentadas acima, verifica-se razoável correlação temporal das orogenias Oclóyica (Ordoviciano Superior/Siluriano Inferior) e Chanica (Devoniano Médio/Carbonífero Inferior), respectivamente com as seqüências ordovício-siluriana e devoniana da Bacia do Paraná. Isto significa que os períodos de subsidência na bacia coincidiram, ao menos na major parte do tempo, com épocas de compressão nos orógenos pré-andinos.

Esta constatação é oposta à relação direta entre discordâncias na bacia e orogenias pré-andinas, aventada por Zalán et al. (1987b, 1990) e Zalán (1991). Isto se deve ao fato de que os referidos autores utilizaram a cronologia de eventos orogênicos apresentada por Miller (1984), que, na região considerada, não corresponde aos dados e interpretações apresentados no item anterior para o Paleozóico Inferior/ Médio.

Deve-se considerar, portanto, que não há necessariamente correspondência biunivoca entre orogenias nas margens das placas com discordâncias em bacias intracratônicas. Ao contrário, tectônica convergente e orogenias nas margens das placas podem ser síncronas com movimentos epirogenéticos descendentes e grandes transgressões em bacias intracratônicas. Este tipo de correlação não é uma proposição inusitada, tendo sido já evidenciada por Johnson (1971), que verificou correlação direta entre orogenias nas margens da placa e períodos de subsidência nas bacias intracratônicas fanerozóicas da América do Norte (Fig. 88).

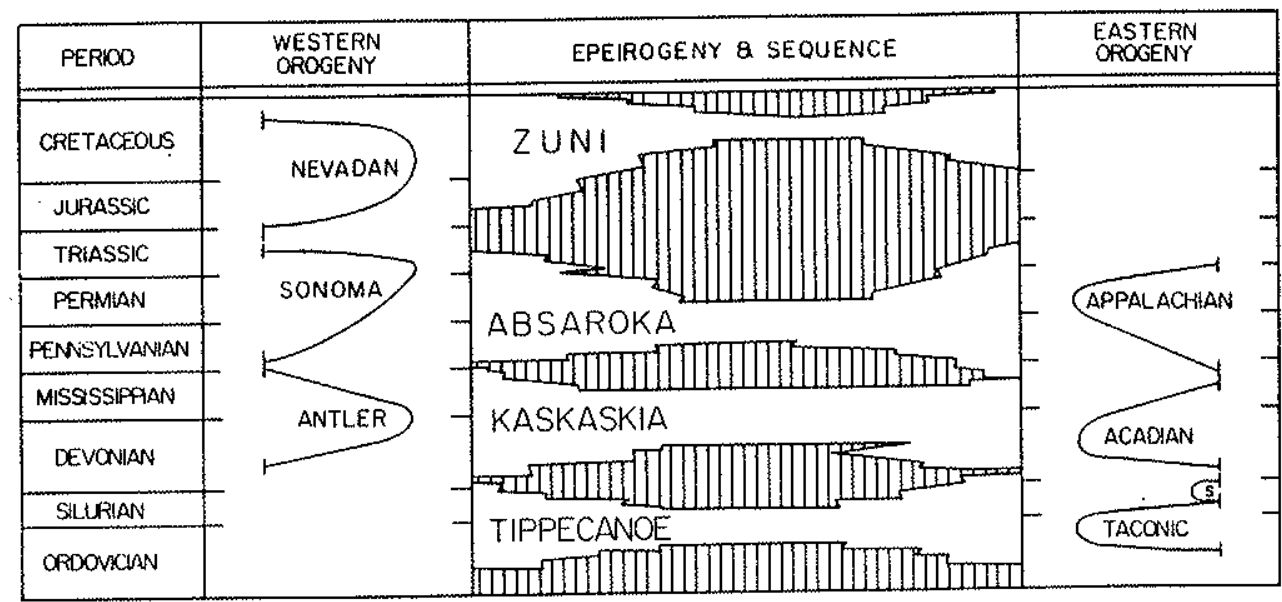

Figura 88 - Correlação entre orogenias e seqüências cratônicas norteamericanas. Linhas verticais indicam hiatos (Johnson 1971). 
O contexto geológico regional permite considerar que, durante a sedimentação das seqüências ordovício-siluriana e devoniana, a Bacia do Paraná constituiu uma bacia intracratônica adjacente às bacias do Chaco, as quais juntamente com as bacias subandinas da Bolívia e do Peru constituiam o foreland retroarco das orógenos oclóyico e chanico.

Mas, como uma tectônica compressiva na margem da placa pode ter relação com eventos de subsidência em bacias intracratônicas? Para responder a esta questão, Quinlan \& Beaumont (1984) modelaram satisfatoriamente o preenchimento das bacias de Illinois e Michigan através de um modelo flexural, concebido em conjunto com a evolução da bacia foreland dos Apalaches, gerada pela sobrecarga produzida pelo cinturão de cavalgamento do Orógeno dos Apalaches (Fig. 89). Embora o modelo não explique a origem das bacias intracratônicas, evidencia que a subsidência nas mesmas pode ser incrementada pela tectônica compressiva nos limites de placas convergentes. Quinlan \& Beaumont (1984) calcularam máximo alcance flexural devido à sobrecarga litosférica entre 500 e $600 \mathrm{~km}$, do que se conclui que $o$ arco flexural (forebulge) pode ocorrer em distâncias de até no máximo $600 \mathrm{~km}$ do ponto onde é aplicada a sobrecarga litosférica (cinturão de cavalgamento). De acordo com o modelo, a sucessão de seqüências e discordâncias no interior do cráton, verificadas por Sloss (1963), é explicada pela alternância de fases compressivas e de relaxação nos orógenos marginais.

Com relação à Bacia do Paraná, o candidato a arco flexural é o Arco de Assunção, possibilidade aventada por Zalán et al. (1990). Sua distância da frente de cavalgamento na margem leste da proto-cordilheira andina é de cerca de $700 \mathrm{Km}$. Se se considerar os cálculo de Quiinlan \& Beaumont (1984), tal distância é muito grande para que se possa atribuir sua origem a um arqueamento flexural (forebulge). Outros estudos permitem supor que a distância pode ser maior, a depender do valor da carga topográfica e da espessura elástica da placa. As modelagens realizadas por Shiraiwa (1994) para explicar a origem da Bacia do Pantanal, por flexura litosférica continental derivada da sobrecarga da cordilheira dos Andes, indicaram arqueamento flexural de 600 a $800 \mathrm{~km}$ do cinturão de cavalgamento na região subandina.

Vários autores têm relacionado estruturas intraplaca com esforços compressivos em suas bordas. Para Cloetingh (1988), esforços intraplaca horizontais podem ser transmitidos através de placas continentais por milhares de quilômetros. Para Rabinowicz et al. (1983), convecção secundária do manto pode ser responsável por movimentação tectônica no interior do cráton a $1600 \mathrm{~km}$ das trincheiras de subducção. 
A possibilidade de relacionar os períodos de subsidência na Bacia do Paraná com orogêneses pré-andinas pode contribuir significativamente para o entendimento da evolução tectono-sedimentar da bacia. A questão está, entretanto, apenas colocada. Seu equacionamento requer maior acervo de dados estratigráficos, estruturais e geofísicos, maior conhecimento das descontinuidades do embasamento da bacia, zoneamentos bioestratigráficos mais refinados e de muita criatividade para elaborar modelos adequados para a simulação do preenchimento sedimentar.

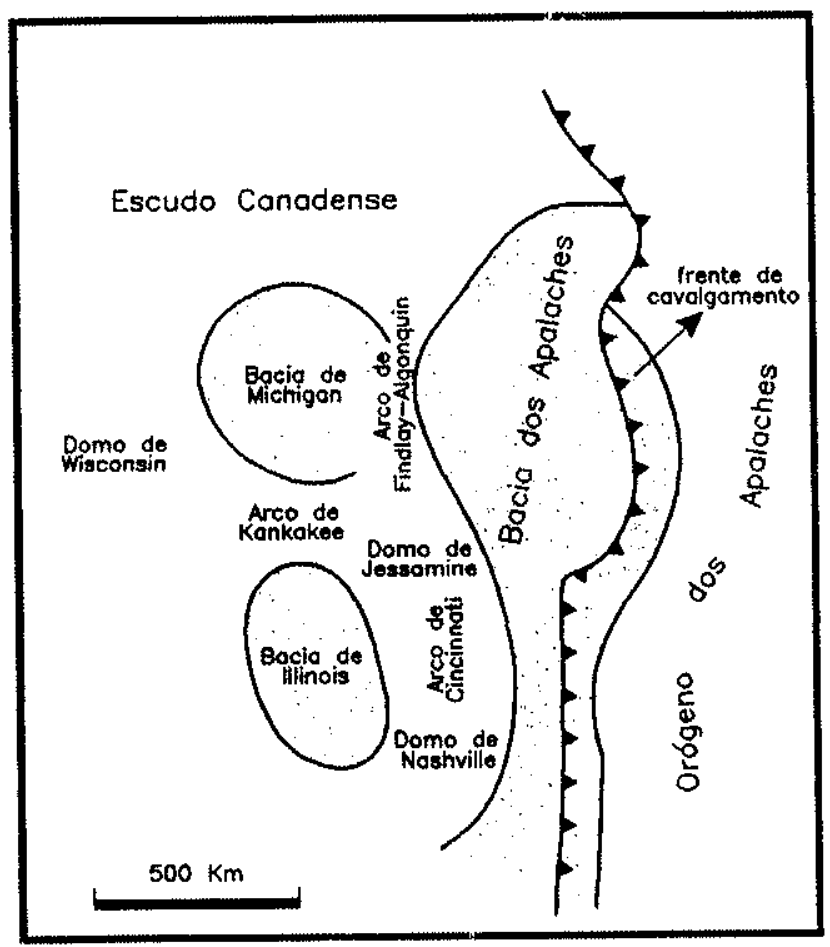

Figura 89 - Disposição geográfica das bacias intracratônicas norteamericanas de Michigan e Illinois, adjacente à bacia foreland e ao orógeno dos Apalaches. Quinlan \& Beaumont (1984) consideram os arcos de Cincinnati e de Findlay-Algonquin como o forebulge flexural, formado pela sobrecarga dos Apalaches sobre o escudo canadense.

Com relação à questão da origem, a dimensão do problema extrapola a própria Bacia do Paraná, pois a origem das bacias intracratônicas é ainda um assunto pouco compreendido. Mesmo a tectônica de placas, que revolucionou as geociências, não explica satisfatoriamente o que ocorre no interior das placas. Quinlan (1987) concluiu que nenhum dos modelos propostos na literatura até então (decaimento termal, erosão subaérea, erosão subcrustal, mundanças de fase, esforços compressivos horizontais etc) era suficientemente satisfatório para explicar a origem das quatro grandes bacias intracratônicas norte-americanas (Michigan, Illinois, Williston e Hudson). 


\section{9- CONCLUSÕES}

1. O registro pré-Carbonífero da Bacia do Paraná no Brasil compreende estratos do Ordoviciano Superior/Siluriano Inferior (Gr. Rio Ivaí) e do Devoniano (Gr. Paraná), que compõem duas seqüências limitadas por discordâncias regionais.

2. O Gr. Rio Ivaí é constituído pelas formações Alto Garças, lapó e Vila Maria. Extensa faixa de afloramentos da Fm. Alto Garças foi verificada no flanco noroeste da bacia, do norte de Rondonópolis (MT) até ao sul de Rio Verde do Mato Grosso (MS), onde, pela primeira vez, foram identificados diamictitos da $\mathrm{Fm}$. lapó. Seções representativas foram levantadas na região de Rio Verde de Mato Grosso.

3. A Fm. lapó foi constatada nas faixas de afloramento nos estados do Paraná, de São Paulo, Goiás, Mato Grosso e Mato Grosso do Sul, e em vários poços no interior da bacia. É uma unidade pouco espessa, mas de ampla distribuição geográfica. As fácies descritas apresentam empilhamento estratigráfico repetitivo na maior parte das seções: diamictitos maciços (fácies $\mathrm{Dmm}$ ), conglomerados maciços (fácies $\mathrm{Gm}$ ) e arenitos conglomeráticos (fácies $\mathrm{St}$ ). Tais fácies apresentam-se geneticamente associadas, tendo sido interpretadas como subglaciais. Para o topo são sucedidas por diamictitos levemente estratificados (fácies Dms), arenitos com ondulações de corrente (fácies $\mathrm{Sr}$ ) e lamitos com seixos pingados (fácies Fld), que em conjunto formam associação de fácies gláciomarinhas (invertebrados marinhos foram observados em duas seções).

4. Paleocorrentes na Fm. Alto Garças indicam área-fonte a leste e mergulho deposicional para oeste em direção às bacias do Chaco. Em conjunto com as paleocorrentes também para oeste no Gr. Caacupé, evidenciam que no Ordoviciano Superior o Arco de Assunção não existia. Ambientes costeiros a marinhos plataformais de grande extensão geográfica, com geometria assimétrica e espessamento para oeste, são características que não se coadunam com interpretações de fase rifte inicial para a bacia.

5. $\mathrm{Na}$ Ordoviciano Superior/Siluriano Inferior (ciclo de $2^{\mathrm{a}}$ ordem) foram caracterizadas duas seqüências deposicionais: caradociana - ashgilliana (Fm. Alto Garças) e neo-ashgilliana - llandoveriana (formações lapó e Vila Maria). O limite entre as duas seqüências é dado por descontinuidade entre as formações Alto Garças e lapó, gerada na fase inicial do evento glacial. 
6. A seção psamítica da Fm. Alto Garças constitui tratos de sistemas transgressivo na base e de mar alto na porção média/superior.Os diamictitos e conglomerados subglaciais do trato de sistemas de mar baixo da Fm. lapó marcam o início da seqüência deposicional ashgilliana - eollandoveriana. O episódio glacial é correlato à glaciação neo-ashgilliana, registrada em várias bacias gondwânicas. Fácies glácio-marinhas do topo da Fm. lapó, originadas com o recuo das geleiras, marcam o decínio da glaciação. Os folhelhos pós-glaciais da Fm. Vila Maria foram depositados em condição de transgressão regional, com superfície de máxima inundação no Llandoveriano Inferior. A seção do topo da Fm. Vila Maria registra tendência regressiva, que culminou com a geração de discordância generalizada no Siluriano Médio/Superior.

7. A seqüência devoniana é composta pelas formações Furnas e Ponta Grossa. A Fm. Furnas foi subdividida em três unidades caracterizadas por faciologia e paleocorrentes distintas. A unidade 1 (inferior) é areno-conglomerática, apresenta padrão de afinamento textural para o topo e paleocorrentes para oeste, tendo sido depositada em sistemas deltaicos construídos por rios entrelaçados, em contexto retrogradacional. A unidade II (média) é essencialmente arenosa, apresenta frequentes intercalações síltico-argilosas, paleocorrentes unimodais para sudoeste interpretadas como correntes marinhas paralelas à costa. A unidade III (superior) é caracterizada por padrões bimodais oblíquos a bipolares e pavimentos de cascalho nas superfícies planares do topo dos cosets, interpretados como depósitos residuais de processos de joeiramento (winnowing) por ondas e correntes de marés.

8. Icnofósseis são comuns na Fm. Furnas. Ocorrem até mesmo nas fácies arenoconglomeráticas da unidade I, mas é na unidade II que existem as mais expressivas ocorrências. A existência dos icnogêneros Rusophycus e Cruziana, respectivamente traços fósseis de repouso e deslocamento de trilobitas, constitui fator de grande importância paleoambiental, pois atesta origem marinha para os estratos onde ocorrem.

9. A subdivisão tripartite da Fm. Ponta Grossa (membros Jaguariaiva, Tibagi e São Domingos) tem aplicabilidade em toda a bacia. $\mathrm{Na}$ faixa de afloramentos no Estado de Goiás o Membro Jaguariaíva não ocorre e o contato com a Fm. Furnas é discordante, com presença de lags transgressivos. Na chapada dos Guimarães a parte superior do que foi considerada Fm. Furnas por autores prévios foi reclassificada como Fm. Ponta Grossa. 
10. Paleolinha de costa NS, áreas-fonte a leste e mergulho deposicional para oeste foram interpretados para a parte inferior da seqüência devoniana, tendo por base as paleocorrentes para oeste dos sistemas deltaicos da unidade I da Fm. Furnas. Medidas do eixo "a" de seixos em depósitos residuais (lags) marinhos da unidade Ill e de cristas de ondulações de onda na Fm. Ponta Grossa, bem como o sentido de progradação dos deltas Tibagi em Goiás, indicam que a paleogeografia não se alterou significativamente até o final do Eifeliano.

11. O Devoniano da bacia (ciclo de $2^{a}$ ordem) compreende três seqüências deposicionais. A seqüência basal, de presumida idade lochkoviana, resultou de rápida transgressão sobre embasamento peneplanizado, em onlap de oeste para leste, fenômeno que gerou espaço para acomodação de tratos psamíticos de sistemas transgressivo e de mar alto (partes inferior e média da Fm. Furnas).

12. O contato entre as unidades II e III da Fm. Furnas representa descontinuidade litológica no meio da Fm. Furnas. A associação faciológica da unidade III é caracterizada pela presença de níveis conglomeráticos, introduzidos na bacia pelo avanço de sistemas deltaicos costeiros e retrabalhados por ondas e marés. Este abaixamento relativo do nível do mar foi interpretado como limite inferior da seqüência praguiana-eifeliana e as fácies conglomeráticas da unidade III da Fm. Furnas como trato de mar baixo.

13. A passagem entre as formações Furnas e Ponta Grossa é concordante na maior parte da bacia. A seção do topo da Fm. Furnas e da base da Fm. Ponta Grossa constitui trato de sistemas transgressivo que atinge superfície de máxima inundação no Emsiano Superior em folhelhos do Membro Jaguariaiva. No Eifeliano o empilhamento foi regressivo progradacional, constituindo o Membro Tibagi trato de mar alto.

14. Tectonismo sinsedimentar no intervalo Emsiano/Eifeliano foi responsável pela individualização de altos internos e marginais, resultando no levantamento inicial do Arco de Assunção e na compartimentação das sub-bacias de Apucarana e Alto Garças. Também foi responsável pelo contato discordante entre as formações Furnas e Ponta Grossa no Estado de Goiás.

15. O Mb. Tibagi foi resultado de aumento no aporte sedimentar no Eifeliano, embora as curvas de variação global do nível do mar indiquem elevação eustática progressiva do Emsiano ao Frasniano. Por isso, a regressão Tibagi foi considerada produto de reativação das bordas da bacia, constituindo mais uma evidência de tectonismo sinsedimentar. 
16. Diferença marcante existe entre as seções emsiano-eifelianas das faixas de afloramento nos flancos norte e sudeste da bacia. No Estado de Goiás o empilhamento reflete condições de borda de bacia, com a presença de deltas retrabalhados por ondas. No Estado do Paraná os arenitos originaram-se em barras de costa-afora construídas por ondas, indicando contexto distal de plataforma externa dominada por tempestades.

17. A seqüência givetiana-frasniana (Membro São Domingos) é caracterizada por rápida transgressão até superfície de máxima inundação no Givetiano Superior, quando ocorreu máxima transgressão no Devoniano da Bacia do Paraná. É possivel que tenha havido interligação com a Bacia do Parnaíba. O declínio da fauna malvinocáfrica (austral) é associado a esta elevação eustática do nivel do mar, que proporcionou o ingresso de faunas de afinidade boreal. No Frasniano, que na bacia ficou preservado em apenas algumas áreas, o empilhamento foi novamente regressivo, sendo interpretadas progradações deltaicas.

18. A seqüência devoniana é recoberta em discordância ligeiramente angular por unidades westphalianas do Gr. Itararé. A discordância envolve hiato de cerca de $45 \mathrm{Ma}$, mas evidências paleontológicas indicam que, embora não tenha havido preservação, é provável que tenha ocorrido sedimentação até o início do Carbonífero Inferior. A discordância seria assim namuriana, à semelhança das bacias do Amazonas e do Parnaíba.

19. Os eventos de subsidência no pré-Carbonífero da Bacia do Paraná têm relação com as orogenias pré-andinas da Bolivia, do Chile e do noroeste da Argentina. A seqüência ordovício-siluriana coincide com a Orogenia Oclóyica (Ordoviciano Superior/Siluriano Inferior) e a seqüência devoniana é, na maior parte do tempo, cronocorrelata à Orogenia Chanica (Devoniano Médio/Carbonifero Inferior). Esta correspondência no tempo, entre as orogenias pré-andinas nas bordas da placa e os eventos de subsidência e transgressão em seu interior, sugere que os fenômenos têm causas comuns.

20. Como contribuição para a compreensão da tectônica formadora das seqüências, a coincidência de eventos de subsidência na bacia com orogenias pré-andinas foi relacionada a esforços intraplaca derivados da sobrecarga litosférica nas bacias foreland da região do Chaco (Paraguai, Argentina e Bolívia). Pelo modelo, o soerguimento do Arco de Assunção, de direção NS e localizado na borda oeste da Bacia do Paraná, teria sido resposta flexural à compressão derivada dos processos de convergência durante a Orogenia Chanica. 


\section{REFERÊNCIAS BIBLIOGRÁFICAS}

ACEÑOLAZA, F.G. \& TOSELLI, A.J. 1976. Consideraciones estratigráficas y tectónicas sobre el Paleozoico inferior del Noroeste Argentino. In: CONGR. LATINOAMER. GEOL., 2, 1973. Actas... Caracas, t.ll, p. 755-763.

ALLEN, J. R. L. 1983. Studies in fluviatile sedimentation: bars, bar-complexes and sandstone sheets (low-sinuosity braided streams) in the Brownstones (L. Devonian), Welsh borders. Sedimentary Geology, 33: 237-293

ALVARENGA, C.J.S. \& GUIMARÃES, E.M. 1994. Siluro-Devoniano no noroeste da Bacia do Paraná: região entre Diorama e Amorinópolis, GO. In: SIMP. GEOL. CENTRO-OESTE, 4, 1994. Atas... Brasília, SBG, p. 53-56.

ANDERTON, R. 1976. Tidal-shelf sedimentation: an example from the Scottish Dalradian. Sedimentology, 23: 429-458.

ANDRADE, S.M. \& CAMARÇO, P.E.N. 1980. Estratigrafia dos sedimentos devonianos do flanco nordeste da Bacia do Paraná. In: CONGR. BRAS. GEOL., 31. Camboriú, 1980. Anais... Camboriú, SBG. v. 5, p. 2828-2836.

ANDRADE, S.M. \& CAMARÇO, P.E.N. 1982. Seqüências sedimentares pré-carboníferas dos flancos nordeste da Bacia do Paraná e sudoeste da Bacia do Parnaíba e suas possibilidades uraniferas. In: CONGR. BRAS. GEOL., 32. Salvador, 1982. Anais... Salvador, SBG. v. 5, p. 2132-2144.

ANTELO, B. 1978. Las formaciones de edad Silurica en el noroeste argentino (Provincias de Jujuy y Salta). Rev. Asoc. Geol. Argenina, 33: 1-16.

ASSINE, M. L. 1992. Análise estratigráfica da Bacia do Araripe, Nordeste do Brasil. Rev. Bras. Geoc., 22(3): 289-300.

ASSINE, M.L. \& SOARES, P.C. 1989. Correlações nas seqüências mesopaleozóicas da Bacia do Paraná. Acta Geológica Leopoldensia 12(29):39-48.

ASSINE, M. L. \& SOARES, P. C. 1993. Glaciação neo-ordoviciana na Bacia do Paraná. In: SIMP. CRONOESTRAT. BACIA DO PARANÁ, 1, Rio Claro, 1993. Bol. Resumos... Rio Claro, UNESP, p. 8-9.

ASSINE, M. L.; SOARES, P. C.; MILANI, E. J. 1994. Seqüências tectono-sedimentares mesopaleozóicas da Bacia do Paraná, Sul do Brasil. Rev. Bras. Geoc., 24(2): 77-89.

BAHLBURG, H. \& BREITKREUZ, C. 1991. Paleozoic evolution of active margin basins in the southern Central Andes (northwestern Argentina and northern Chile). J. South American Earth Sci., 4(3): 171-188.

BALDIS, B. 1992. Marco estructural de las cuencas del Paleozoico Inferior sudamericano en su contesto gondwánico. In: GUTIÉRREZ-MARCO, J.C.; SAAVEDRA, J.; RÁBANO, I. (eds.) Paleozoico Inferior de Ibero-América. Espanha, Universidade de Extremadura, p. 119.

BALDIS, B. \& BLASCO, G. 1975. Primeros trilobitas ashgillianos del Ordovícico sudamericano. CONGR. ARGENT. PALEONT. BIOESTR., 1, Tucumán. Actas... Tucumán, t.1, p. 33-48.

BANKS, N.L. 1973. Tide-dominated offshore sedimentation, Lower Cambrian, north Norway. Sedimentology, 20: 213-228. 
BARRET, S.F. \& ISAACSON, P.E. 1988. Devonian paleogeography of South America. In: MCMILLAN, N. J.; EMBRY, A.F.; GLASS, D.J. (eds.) Devonian of the world. Can. Soc. Petrol. Geol., p. 655-667 (Memoir 14).

BENEDETTO, J.L. 1990. Los géneros Cliftonia y Paromalomena (Brachiopoda) en el Ashgilliano tardío de la Sierra de Villicum, Precordillera de San Juan, Argentina. Ameghiniana, 27(1-2): 151-159.

BENEDETTO, J.L; SANCHEZ, T.M.; BRUSSA, E.D. 1992. Las cuencas silúricas de América Latina. In: GUTIÉRREZ-MARCO, J.C.; SAAVEDRA, J.; RÁBANO, I. (eds.) Paleozoico Inferior de Ibero-América. Espanha, Universidade de Extremadura, p. 119-148.

BANERJEE, | \& MCDONALD, B.C. 1975. Nature of esker sedimentation. In: JOPLING, A.V. \& MCDONALD, B.C. (eds.) 1975. Glaciofluvial and glaciolacustrine sedimentation. Soc. Econ. Palaeontol. Mineral., p. 304-320 (Spec. Publ. 23).

BERGAMASCHI, S. 1992. Análise sedimentológica da Formação Furnas na faixa de afloramentos do flanco norte do anco estrutural de Ponta Grossa, Bacia do Paraná, Brasil. Rio de Janeiro, 172p. (Dissertação de Mestrado, UFRJ).

BEURLEN, K. 1959. Geologia da zona de Barra do Garças a Chavantina - Estado do Mato Grosso. Rio de Janeiro, DNPM/DGM, 61p. (Boletim 193).

BIGARELLA, J.J. 1973. Paleocorrentes e deriva continental (comparação entre África e América do Sul). Bol. Parana. Geoc. 31:141-224.

BIGARELLA, J.J. \& COMTE, D. 1969. O Grupo Caacupé e sua importância na paleogeografia do Siluriano sul-americano. Bol. Soc. Bras. Geologia, 18(1): 31-37.

BIGARELLA, J.J. \& OLIVEIRA, M.A.M. 1966. Nota preliminar sôbre as direções de transporte dos arenitos Furnas e Botucatu na parte setentrional da Bacia do Paraná. Bol. Parana. Geografia, 18/20: 247-256.

BIGARELLA, J. J. \& SALAMUNI, R. 1967. Some palaeogeographic features of the Brazilian Devonian. In: BIGARELLA, J. J. (ed.) Problems in Brazilian Devonian Geology. Bol Parana. Geoc., 21/22: 133-151.

BIGARELLA, J.J.; SALAMUNI, R.; MARQUES, P.L.,Fo 1966. Estruturas e texturas da Formação Furnas e sua significação paleogeográfica. Bol. UFPR (Geologia) 18:1-114.

BLATT, H.; BERRY, W.B.N.; BRANDE, S. 1991. Principles of stratigraphic analysis. Boston, Blackwell Scientific Publ.. 512p.

BOLZON, R.T.; ASSINE, M.L.; GUERRA-SOMMER, M. 1994. Ocorrência de Cooksonia Lang, 1937 na Formação Furnas, Estado do Paraná. In: REUNIÃO DE PALEOBOTÂNICOS E PALINÓlOGOS, 8, São Paulo, 1994. Resumo das Comunicações... São Paulo, p. 11.

BORGHI, L. 1992. Caracterização e análise faciológicas da Formação Fumas (Pridoli Devoniano inferior) em afloramentos do bordo leste da bacia sedimentar do Paraná, Estado do Paraná, Brasil. Rio de Janeiro, 227p. (Dissertação de Mestrado, UFRJ).

BOUCOT, A. J. 1971. Malvinokaffric Devonian marine distribution and implications for Gondwana. Anais Acad. Bras. Ciênc., 43(Suplemento): 23-49.

BOUCOT, A.J. 1990. Silurian biogeography. In: MCKERROW, W.S.; SCOTESE, C.R. (eds.). Palaeozoic palaeogeography and biogeography. Geol. Soc. London, p. 191-196 (Memoir 12).

BOULTON, G.S. 1990. Sedimentary and sea level changes during glacial cycles and their control on glacimarine facies architecture. In: DOWDESWELL, J.A. \& SCOURSE, J.D. 
(eds.). Glacimarine Environments: processes and sediments. Londres, Geological Society, p. 15-52 (Sp. Publication 53).

BRANISA, L.; CHAMOT, G.A.; BERRY, W.B.N.; BOUCOT, A.J. 1972. Silurian of Bolivia. In: BERRY, W.B.N. \& BOUCOT, A.J. (eds.) Correlation of the South American Silurian rocks. Geol. Soc. Amer. Spec. Paper, 133: 21-31.

BREITKREUZ, C.; BAHLBURG, H.; ZEIL, W. 1988. The Paleozoic evolution of northern Chile: geotectonic implications. In: BAHLBURG, H.; BREITKREUZ, C.; GIESE, P. (eds.) The southern Central Andes. Berlin, Springer-Verlag, p. 87-102.

BRENCHLEY, P.J.; ROMANO, M.; YOUNG, T.P.; STORCH, P. 1991. Hirnantian glaciomarine diamictites - evidence for the spread glaciation and its effect on Upper Ordovician faunas. in: BARNES, C.R. \& WILLIAMS, S.H. ed. Advances in Ordovician Geology. Geol. Surv. Can., p. 325-336 (Paper 90-9).

BRITO NEVES, B.B.; FUCK, R.A.; CORDANI, U.G.; THOMAZ Fo, A. 1984. Influence of basement structures on the evolution of the major sedimentary basins of Brazil: a case of tectonic heritage. J. Geodynamics, 1: 495-510.

BROQUET, C.A.M. 1992. The sedimentary record of the Cape Supergroup: a review. In: DE WIT, M.J. \& RANSOME, I.G.D. Inversion tectonics of the Cape Fold Belt, karoo and Cretaceous basins of Southern Africa. Rotterdam, Balkema, p. 159-183.

BURJACK, M.I.A. \& POPP, M.T.B. 1981. A ocorrência do icnogênero Arthrophycus no Paleozóico da Bacia do Paraná. Pesquisas 14:163-167.

CANT, D.J. \& HEIN, F.J. 1986. Depositional sequences in ancient shelf sediments: some contrasts in style. In: KNIGHT, R. J. \& MCLEAN, J. R. (eds.) Shelf sands and sandstone reservoirs. Canadian Society Petroleum Geologists, p.303-312 (Memoir 11).

CAPUTO, M.V. \& CROWELL, J.C. 1985. Migration of glacial centers across Gondwana during Paleozoic Era. Geol. Soc. Amer. Bull. 96:1020-1036.

CAPUTO, M.V. \& LIMA, E.C. 1984. Estratigrafia, idade e correlação do Grupo Serra Grande Bacia do Parnaíba. In: CONGR. BRAS. GEOL., 33. Rio de Janeiro, 1984. Anais... Rio de Janeiro, SBG. v. 2, p. 740-753.

CAROZZI, A.V.; PAMPLONA, H.R.P.; CASTRO, J.C.; CONTREIRAS, C.J.A. 1973. Ambientes deposicionais e evolução tecto-sedimentar da seção clástica paleozóica da Bacia do Médio Amazonas. In: CONGR. BRAS. GEOL., 27. Aracaju, 1973. Anais... Aracaju, SBG. v. 3, p. 279-314.

CASTER, K. 1947a. Expedição geológica em Goiás e Mato Grosso. Mineração e Metalurgia, 12(69): 126-127.

CASTER, K. 1947b. Devonian System in Goiás and Mato Grosso, Brazil. Bull. Geol. Soc. Amer., 58(12): 1172 (abstract).

CHANDLER, F.W. 1988. Quartz arenites: review and interpretation. Sedimentary Geology, 58: 105-126.

CHEEL, R.J. 1991. Grain fabric in hummocky cross-stratified storm beds: genetic implications. J. Sedim. Petrol., 61(1): 102-110.

CIGUEL, J. H. G.1988. Tentaculites itacurubiensis n. sp., dos depósitos regressivos do Paraguai Oriental, Siluriano inferior da Bacia do Paraná. Rev. Bras. Geoc., 18: 86-92.

CIGUEL, J. H. G. \& ACEÑOLAZA, F. G. 1986. Icnologia da Formação Furnas (Paleozóico médio), Bacia do Paraná. An. Acad. Bras. Ci., 58: 595-596. 
CIGUEL, J.H.G. \& ACEÑOLAZA, F.G. 1991. Icnologia da Formação Furnas (Paleozóico Médio), Bacia do Paraná. Rev. Tecnica de YPFB, 12(1): 145.

CINGOLANI, C.A.; CUERDA, A.J.; ACEÑOLAZA, F.G. 1992. El Paleozoico Inferior sedimentario de Argentina y Chile. In: GUTIERREZ-MARCO, J.C.; SAAVEDRA, J.; RÁBANO, I. (eds.) Paleozoico Inferior de Ibero-América. Espanha, Universidade de Extremadura, p. 255-277.

CLARKE, J. M. 1913. Fósseis devonianos no Paraná: Brasil. Rio de Janeiro, Serviço Geoiogia e Mineralogia, 353p. (Monografia 1).

CLIFTON, H. E. 1973. Pebble segregation and bed lenticularity in wave-worked versus alluvial gravel. Sedimentology, 20: 173-187.

CLOETINGH, S. 1988. intraplate stress: a new element in basin analysis. In: KLEINSPEHN, K.L. \& PAOLA, C. (eds.). New perspectives in basin analysis. Springer-Verlag, Berlin and New York, p. 205-230.

COIRA, B.; DAVIDSON, J.; MPODOZIS, C.; RAMOS, V. 1982. Tectonic and magmatic evolution of the Andes of northern Argentina and Chile. Earth-Sci. Reviews, 18: 303-332.

COOPER, M. R. 1986. Facies shifts, sea-level changes and event stratigraphy in the Devonic of South Africa. South African J. Sci, 82: 255-258.

CUERDA, A. \& CAMINOS, R. 1983. Los movimientos taconicos en la Precordillera de San Juan - Republica Argentina. Rev. Tecn. YPFB, 9(1-2): 143-152.

CUNHA, P.R.C.; GONZAGA, F.G.; COUTINHO, L.F.C.; FEIJO, F.J. 1994. Bacia do Amazonas. Bol. Geoc. PETROBRÁS, 8(1): 47-55.

DAEMON, R. F.; QUADROS, L. P.; SILVA, L. C. 1967. Devonian palynology and biostratigraphy of the Paraná Basin. in: BIGARELLA, J. J. (ed.) Problems in Brazilian Devonian Geology. Bol. Parana. Geoc., 21/22: 99-131.

DALLA SALDA, L; CINGOLANI, C.; VARELA, R. 1992. Early Paleozoic orogenic belt of the Andes in southwestern South America: result of Laurentia-Gondwana collision? Geology, 20: $617-620$.

DA SILVA, J.S. 1990. Ciclo transgresivo-regresivo del mar devonico en Uruguay verificado por palinologia. Rev. Tecn. YPFB, 11(1): 59-63.

DELLA FÁVERA, J.C. 1990. Tempestitos da Bacia do Parnaíba. Porto Alegre, v.2 (Tese de Doutoramento, UFRGS).

DERBY, O.A. 1878. A geologia da região diamantífera da Província do Paraná. Rio de Janeiro. Archivos do Museu Nacional, 3: 89-98.

DERBY, O.A. 1890. Notas sobre a geologia e paleontologia de Mato Grosso. Rio de Janeiro, Archivos do Museu Nacional, 9: 59-88.

DEYNOUX, M. 1985. Terrestrial or waterlain glacial diamictites? Three case studies from the Late Precambriam and Late Ordovician glacial drifts in West Africa. Palaeogeogr., Palaeoclimat., Palaeoecol. 51:97-141.

DEYNOUX, M. \& TROMPETE, R. 1981. Late Ordovician tillites of the Taoudeni Basin, West Africa. In: HAMBREY, M.J. \& HARLAND, W.B. (eds.). Earth's pre-Pleistocene glacial record. Cambridge, Cambridge University Press, p.89-96.

DINIZ, M. 1985. Interpretação ambiental da Formação Ponta Grossa na parte central da Bacia do Paraná - um estudo de subsuperfície. São Paulo, 148p. (Dissertação de Mestrado, IGUSP). 
DINO, R. \& RODRIGUES, M. A. C. 1995. Palinomorfos eodevonianos da Formação Furnas Bacia do Paraná. An. Acad. Bras. Ci., 67(1): 107-116.

DINO, R; BERGAMASCHI, S.; PEREIRA, E.; MELO, J.H.G.; LOBOZIAK, S.; STEEMANS, P. 1995. Biochronostratigraphic investigations of the Pragian and Ensian stages on the southeastern border of the Parana Basin. In: SIMP. CRONOESTRAT. BACIA DO PARANÁ, 2, Porto Alegre, 1995. Bol. Resumos Expandidos... Porto Alegre, ILEA-UFRGS, p. $19-25$.

DNPM , 1975. Carta geológica do Brasil ao milionésimo. Folha Goiânia (SE-22). Brasilia, DNPM/DGM, 87p.

DUKE, W.L. 1990. Geostrophic circulation or shallow marine turbidity currents? The dilemma of paleoflow patterns in storm-influenced prograding shoreline systems. J. Sedim. Petrol., 60: $870-883$.

EYLES, N. 1993. Earth's glacial record and its tectonic setting. Earth-Sci. Reviews, 35: 1-248.

EYLES, N.C., EYLES, C.H., MIALL, A.D. 1983. Lithofacies types and vertical profile models: an alternative approach to the description and environmental interpretation of glacial diamict and diamictite sequences. Sedimentology, 30: 393-410.

FARIA, A. 1982. Formação Vila Maria - nova unidade litoestratigráfica siluriana da Bacia do Paraná. Ciências da Terra 3:12-15.

FARIA, A. \& REIS NETO, J.M. 1978. Nova unidade litoestratigráfica pré-Furnas no sudoeste de Goiás. In: CONGR. BRAS. GEOL., 30. Recife, 1978. Resumo das Comunicações... Recife, SBG. p. 136-137.

FERNANDES, A.C.S. \& GUIMARÃES NETTO, R. 1985. O estado atual da paleoicnologia no Paleozóico da Bacia do Paraná. In: CONGR. BRAS. PALEONT., 9, Fortaleza, 1985. Resumos das Comunicações... Fortaleza, SBP, p. 41.

FERREIRA, F. J. F.; MORAES, R. A. V.; FERRARI, M. R.; VIANNA, R. B. 1981. Contribuição ao estudo do alinhamento estrutural de Guapiara. In: SIMP. REG. GEOL., 3, Curitiba, 1981. Atas... São Paulo, SBG, v.1, p.226-240.

FIGUEIRAS, A. 1991. Fauna eodevonica del Uruguay. Rev. Tecn. YPFB, 12(1): 57-64.

FISHER, A.F. 1984. The two Phanerozoic supercycles. In: BERGGREN, W.A. \& VAN COUVERING, J.A. (eds.). Catastrophes and Earth History. The New Uniformitarianism. Princeton, Princeton University Press, p. 129-150.

FRANÇA, A.B. 1994. Itararé Group: Gondwanan Carboniferous-Permian of the Paraná Basin, Brazil. In: DEYNOUX, M.; MILLER, J.M.G.; DOMACK, E.W.; EYLES, N.; FAIRCHILD, I.J.; YOUNG, G.M. Earth's glacial record. Cambridge, Cambridge University Press, p. 70-82.

FRANÇA, A.B.; WINTER, W.R.; ZANOTTO, O.A.; ASSINE, M.L. 1994. Arenitos Lapa-Vila Velha (Gr. Itararé - B. Paraná): um exemplo de sistema canal-lobo subaquoso com influência glacial. In: SEMINÁRIO DE INTERPRETAÇÃO EXPLORATÓRIA, 2, Rio de Janeiro, PETROBRÁS, p. 123-128.

FRANÇA, A.B.; MILANI, E.J.; SCHNEIDER, R.B.; LÓPEZ P., O; LÓPEZ M., J.; SUÁREZ S., R.; SANTA ANA, H.; WIENS, F.; FERREIRO, O.; ROSSELLO, E.A.; BIANUCCI, H.A.; FLORES, R.F.A.; VISTALLI, M.C.; FERNANDEZ-SEVESO, F.; FUENZALIDA, R.P.; MUÑOZ, N. 1995. Planerozoic correlation in southern South America. In: TANKARD, A.J.; SUÁREZ SORUCO, R.; WELSINK, H.J. Petroleum basins of South America. AAPG (Memoir 62), p. 129-161.

FREY, R. W. \& PEMBERTON, S. G. 1984. Trace fossil facies models. In: WALKER, R. G. (ed.) Facies models. 2a ed. Toronto, Geoscience Canada, p.189-207 (Reprint Series 1). 
FULFARO, V. J.; SAAD, A. R.; SANTOS, M. V.; VIANNA, R. B. 1982. Compartimentação e evolução tectônica da Bacia do Paraná. Rev. Bras. Geoc., 12(4): 590-611.

GAMA, E., Jr.; BANDEIRA, A. N., Jr.; FRANÇA, A. B. 1982. Distribuição espacial e temporal das unidades litoestratigráficas paleozóicas na parte central da Bacia do Paraná. Rev. Bras. Geoc., 12(4): 578-589.

GÓES, A.M.O. \& FEIJÓ, F.J. 1994. Bacia do Parnaiba. Bol. Geoc. PETROBRÁS, 8(1): 57-67.

GOHRBANDT, K.H.A. 1992. Paleozoic paleogeographic and depositional developments on the central proto-Pacific margin of Gondwana: their importance to hydrocarbon accumulation. J. South American Earth Sci., 6(4): 267-287.

GOLDSTEIN, B. 1994. Drumlins of the Puget Lowland, Washington State, USA. Sedim. Geol., 91: 299-311.

GRAHN, Y. 1992a. Ordovician Chitinozoa and biostratigraphy of Brazil. Geobios, 25(6): 703723.

GRAHN, Y. 1992b. Revision of Silurian and Devonian strata of Brazil. Palinology, 16:35-61.

GRAHN, Y. \& CAPUTO, M.V. 1992. Early Silurian glaciations in Brazil. Palaeogeogr., Palaeoclimat, Palaeoecol., 99: 9-15.

GRAY, J.; COLBATH, G.K.; FARIA, A.; BOUCOT, A.J.; ROHR, D.M. 1985. Silurian-age fossils from the Paleozoic Paraná Basin, Southern Brazil. Geology 13:521-525.

GRAY, J.; THERON, J.N.; BOUCOT, A.J. 1986. Age of the Cedarberg Formation, South Africa and early land plant evolution. Geol. Mag., 123(4): 445-454.

HARRINGTON, H.J. 1972. Silurian of Paraguay. In: BERRY, W.B.N. \& BOUCOT, A.J. (eds.) Correlation of the South American Silurian rocks. Geol. Soc. Amer. Spec. Paper, 133: 4150 .

HART, B.S. \& PLINT, G. 1995. Gravelly shoreface and beach deposits. In: PLINT, G. (ed.) Sedimentary facies analysis. Oxford, Blackwell Science, p. 75-99 (Sp. Publ. IAS 22).

HAYES, M.O. 1967. Relationship between coastal climate and bottom sediment type on the inner continental shelf. Marine Geology., 5: 111-132.

HUSSEINI, M.I. 1991. Tectonic and depositional model of the Arabian and adjoining plates during the Silurian-Devonian. Amer. Assoc. Petrol. Geol. Bull., 75(1): 108-120.

ISAACSON, P.E. \& SABLOCK, P.E. 1988. Devonian system in Bolivia, Perú and Northern Chile. in: MCMILLAN, N. J.; EMBRY, A.F.; GLASS, D.J. (eds.) Devonian of the world. Can. Soc. Petrol. Geol., p. 719-728 (Memoir 14).

ISAACSON, P.E. \& SABLOCK, P.E. 1990. Devonian palaeogeography and palaeobiogeography of the central Andes. In: MCKERROW, W.S.; SCOTESE, C.R. (eds.). Palaeozoic palaeogeography and biogeography. Geol. Soc. London, p. 429-433 (Memoir 12).

ISAACSON, P.E. \& DÍAZ MARTÍNEZ, E. 1995. Evidence for a middle-late Paleozoic foreland basin and significant paleolatitudinal shift, central Andes. In: TANKARD, A.J.; SUÁREZ SORUCO, R.; WELSINK, H.J. Petroleum basins of South America. AAPG, p. 231-249 (Memoir 62).

JOHNSON, H.D. \& BALDWIN, C.T. 1986. Shallow siliciclastic seas. In: READING, H.G. (ed.). Sedimentary environments and facies. Oxford, Blackwell Scientific Publ., p. 229-282.

JOHNSON, J.G. 1971. Timing and coordination of orogenic, epirogenic and eustatic events. Geol. Soc. Amer. Bull., 82: 3263-3298. 
JOHNSON, J.G.; KLAPPER, G.; SANDBERG, C.A. 1985. Devonian eustatic flutuations in Euramerica. Geol. Soc. Amer. Bull, 96: 567-587.

KLEIN, G. deV. 1967. Paleocurrent analysis in relation to modern marine dispersal patterns. Amer. Assoc. Petrol. Geol. Bull, 51: 366-382.

KLEIN, G. deV. 1982. Probable sequential arrangement of depositional systems on cratons. Geology, 10: 17-22.

KLEIN, G.deV. \& HSUI, A.T. 1987. Origin of cratonic basins. Geology, 15: 1094-1098.

KOMAR, P. D. 1976. Beach processes and sedimentation. Englewood Cliffs, New Jersey, Prentice-Hall, 426p.

LANGE, F.W. 1942. Restos vermiformes do Arenito das Furnas. Arquivos do Museu Paranaense, 2: 2-18.

LANGE, F. W. 1967. Bioestratigraphic subdivision and correlation of the Devonian in the Paraná Basin. In: BIGARELLA, J. J. (ed.) Problems in Brazilian Devonian Geology. Bol. Parana. Geoc., 21/22: 63-98.

LANGE, F.W. \& PETRI, S. 1967. The Devonian of the Parana Basin. In: BIGARELLA, J. J. (ed.) Problems in Brazilian Devonian Geology. Bol. Parana. de Geociências, 21/22:5-55.

LAUBACHER, G.; BOUCOT, A.J.; GRAY, J. 1982. Additions to Silurian stratigraphy, lithofacies, biogeography e paleontology of Bolivia and Southern Peru. J. Paleont. 56(5):1138-1170.

LECKIE, D. A. 1988. Wave-formed, coarse-grained ripples and their relationship to hummocky cross-stratification. J. Sed. Petrol., 58(4): 607-622.

LECKIE, D. A. \& KRYSTINIK, L.F. 1989. Is there evidence for geostrophic currents preserved in the sedimentary record of inner to middle shelf deposits? J. Sedim. Petrol., 59(5): 862870.

LEIGHTON, M.W. \& KOLATA, D.R. 1990. Selected interior cratonic basins and their place in the scheme of global tectonics. In: LEIGHTON, M.W.; KOLATA, D. R.; OLTZ, D. F.; EIDEL, J. J. (eds.) Interior cratonic basins. Tulsa, Amer. Assoc. Petr. Geol., p. 729797 (Memoir 51).

LEITHOLD, E.L. \& BOURGEOIS, J. 1984. Characteristics of coarse-grained sequences deposited in nearshore, wave-dominated environments - examples from the Miocene of south-west Oregon. Sedimentology, 31: 749-775.

LEVY, R. \& NULLO, F. 1974. La fauna ordovícica (Ashgilliano) de Villicum, San Juan, Argentina. Ameghiniana, 9(2): 173-194.

LONG, D.G.F. \& YOUNG, G.M. 1978. Dispersion of cross-stratification as a potential tool in the interpretation of Proterozoic arenites. J. Sedim. Petrol., 48: 857-862.

LÓPEZ-GAMUNDI, O.R. \& ROSSELLO, E.A. 1993. Devonian-Carboniferous unconformity in Argentina and its relation to the Eo-Hercynian orogeny in southern South America. Geol. Rundsch., 82: 136-147.

MAACK, R. 1946. Geologia e geografia da região de Vila Velha, Estado do Paraná, e considerações sôbre a glaciação carbonífera no Brasil. Curitiba, Arquivos do Museu Paranaense, V: 1-305.

MAACK, R. 1947. Breves noticias sobre a geologia dos estados do Paraná e Santa Catarina. Curitiba, Arquivos de Biologia e Tecnologia (IBPT), Il: 63-154. 
MAACK, R. 1950-51. Vestígios pré-devonianos de glaciação e a seqüência de camadas devonianas no Estado do Paraná. Curitiba, Arquivos de Biologia e Tecnologia (IBPT), VVl: $197-230$.

MAINO, U.M. 1965. Relatório geológico final, poço 2-AG-1-MT. Ponta Grossa. Petrobrás/Desul (Relatório Interno).

MELO, J.H.G. 1985. A Província Malvinocáfrica no Devoniano do Brasil; estado atual de conhecimentos. Rio de Janeiro, 890p. (Dissertação de mestrado, UFRJ).

MELO, J.H.G. 1988. The malvinokaffric realm in the Devonian of Brazil. In: MCMILLAN, N. J.; EMBRY, A.F.; GLASS, D.J. (eds.) Devonian of the world. Can. Soc. Petrol. Geol., p. 669703 (Memoir 14).

MIALL, A.D. 1974. Paleocurrent analysis of alluvial sediments: a discussion of directional variance and vector magnitude. J. Sedim. Petrol., 44(4): 1174-1185.

MIALL, A. D. 1978. Lithofacies types and vertical profile models in braided river deposits: a summary. In: MIALL, A. D. (ed.) Fluvial Sedimentology. Can. Soc. Petrol. Geol., p. 597-604 (Memoir 5).

MIALL, A.D. 1985. Architectural-element analysis: a new method of facies analysis applied to fluvial deposits. Earth-Sci. Reviews, 22(4): 261-308.

MIALL, A.D. 1990. Principles of sedimentary basin analysis. $2^{\mathrm{a}}$ ed. New York, Springer-Verlag. $668 p$.

MILANI, E.J.; FRANÇA, A.B.; SCHNEIDER, R.B. 1994. Bacia do Paraná. Bol. Geoc. Petrobrás, 8(1): 69-82.

MILANI, E.J.; ASSINE, M.L.; SOARES, P.C.; DAEMON, R.F. (no prelo). A seqüencia ordovício-siluriana da Bacia do Paraná. Bol. Geociênc. Petrobrás.

MILLER, H. 1984. Orogenic development of the Argentinian/Chilean Andes during the Paleozoic. J. Geol. Soc. London, 141: 885-892

MITCHUM JR., R.M.; VAIL, P.R.; THOMPSON III, S. 1977. Seismic stratigraphy and global changes of sea level, part two: the depositional sequence as a basic unit for stratigraphic analysis. In: PAYTON, C.E. (ed.) Seismic stratigraphy - applications to hydrocarbon exploration. AAPG, p..53-62 (Memoir 26).

MON, R. \& SALFITY, J.A. 1995. Tectonic evolution of the Andes of Norjthern Argentina. In: TANKARD, A.J.; SUÁREZ SORUCO, R.; WELSINK, H.J. Petroleum basins of South America. AAPG, p. 269-283 (Memoir 62).

MONALDI, C.R. \& BOSO, M.A. 1987. Dalmanitina (D.) subandina n.sp. (trilobita) en la Formación Zapla del Norte Argentino. CONGR. LATINOAMER. PALEONT., 4. Actas... t.1, p. $149-158$.

MORAES REGO, L. F. 1931. A geologia do petróleo no Estado de São Paulo. Rio de Janeiro, Serviço Geológico e Mineralógico do Brasil, 110p. (Boletim 46).

MORO, R.X.; BONACIM, E.A.; SOARES, P.C. 1994. Geologia da Bacia de Castro-PR. Bol. Parana. Geoc., 42: 43-58.

MUSSA, D.; BORGHI, L.; BERGAMASCHI, S.; SCHUBERT, G.; PEREIRA, E.; RODRIGUES, M. A. C.1996. Estudo preliminar da tafoflora da Formação Furnas, Bacia do Paraná, Brasil. An. Acad. Bras. Ci., 68(1): 65-89.

NEMEC, W. \& STEEL, R.J. 1994. Alluvial and coastal conglomerates: their significant features and some comments on gravelly mass-flow deposits. In: KOSTER, E. H. \& STEEL, R. J. 
(eds.). Sedimentology of gravels and conglomerates. Can. Soc. Petrol. Geol., p. 1-31 (Memoir 10).

NORTHFLEET, A. A.; MEDEIROS, R. A.; MUHLMANN, H. 1969. Reavaliação dos dados geológicos da Bacia do Paraná. Bol. Técn. da Petrobrás, 12(3): 291-346.

ODIN, G.S. 1982. The Phanerozoic time scale revisited. Episodes, 3: 3-9.

OLIVEIRA, E. P. 1912. O terreno devoniano do sul do Brasil. Ann. Esc. Minas de Ouro Preto, 14: $31-41$.

OLIVEIRA, E.P. 1927. Geologia e recursos minerais do Estado do Paraná. Brasil, Serviço Geológico e Mineralógico, 172p. (Monografia 6).

OLIVEIRA, M.A.M. \& MÜHLMANN, H. 1965. Geologia de semi-detalhe da região de Mutum, Jaciara, São Vicente e Chapada dos Guimarães. Ponta Grossa, Petrobrás/DEBSP, 63p. (Relatório 300).

OLIVEIRA, M.A.M. \& MÜHLMANN, H. 1967. Observations on the geology of Chapada Guimarães, Mato Grosso In: BIGARELLA, J. J. (ed.) Problems in Brazilian Devonian Geology. Bol. Parana. de Geoc., 21/22: 57-61.

OLIVEIRA, S. F. 1991. Acritarcas e Prasinófitas da Formação Ponta Grossa (Devoniano) no flanco noroeste da Bacia do Paraná. São Paulo, 157p. (Dissertação de Mestrado, USP).

PARRISH, J.T.; GAYNOR, G.C.; SWIFT, D.J.P. 1984. Circulation in the Cretaceous Western Interior seaway of North America, a review. In: SCOTT, D.F. \& GLASS, D.J. (eds.) The Mesozoic of Middle North America. Can. Soc. Petrol. Geol, p. 221-231 (Memoir 9).

PERALTA, S.H. \& BALDIS, B. A.J. 1992. Diamictitas del Ordovícico tardio sudamericano: correlaciones regionales y su relacion com un evento glacial gondwanico. In: REUNIÓN ARGENTINA DE SEDIMENTOLOGIA, 4. Actas... v.3, p.169-176.

PERALTA, S.H. \& CARTER, C.H. 1990. La glaciacion gondwanica del Ordovícico tardio: evidências en fangolitas guijarrosas de la Precordillera de San Juan, Argentina. In: CONGR. GEOL. ARG., 11. San Juan, 1990. Actas... San Juan, AGA. v. II, p. 181-185.

PEREIRA, E. 1992. Análise estratigráfica do Paleozóico médio da Sub-Bacia do Alto Garças, no sudoeste de Goiás. Bacia do Paraná, Brasil. Rio de Janeiro, 172p. (Dissertação de Mestrado, UFRJ),

PEREIRA, E.; BERGAMASCHI, S.; LARANJEIRA, N.P.F.; FERNANDES, A.C.S. 1995. Nova ocorrência de sedimentos eossilurianos (Formação Vila Maria), no bordo noroeste da Bacia do Paraná, região de Rondonópolis (MT). In: SIMP. CRONOESTRAT. BACIA DO PARANÁ, 2, Porto Alegre, 1995. Bol. Resumos Expandidos... Porto Alegre, ILEA-UFRGS, p.32-35.

PETRI, S. 1948. Contribuição ao estudo do Devoniano paranaense. Rio de Janeiro, DNPM/DGM, 125p. (Boletim 129).

PETRI, S. \& FÚLFARO, V. J. 1967. Considerações geológicas sôbre a região de Itapeva, SP. Bol. Soc. Bras. Geologia, 16(1): 25-41.

PETRI, S. \& FÚlFARO, V. J. 1976. Observação sobre o Siluriano do Brasil e sua bioestratigrafia. In: CONGR. BRAS. GEOL., 29, Ouro Preto, 1976. Anais... Ouro Preto, SBG, v.2, p. 75-79.

PETRI, S. \& FÚLFARO, V.J. 1983. Geologia do Brasil (Fanerozóico). São Paulo, T.A.Queiroz/EDUSP, 631p. 
PEZZI, E.E. \& MOZETIC, M.E. 1989. Cuencas sedimentarias de la región chacoparanense. In: CHEBLI, G.A. \& SPALLETI, L.A. Cuencas sedimentarias argentinas. Tucuman, Univ. de Tucuman, p. 65-78 ( Série Correlación Geológica 6).

PHILLIPS, R. L. 1984. Depositional features of Late Miocene, marine cross-bedded conglomerates, California. In: KOSTER, E. H. \& STEEL, R. J. (eds.). Sedimentology of gravels and conglomerates. Can. Soc. Petrol. Geol., p. 345-358 (Memoir 10).

PIRES, F.A.; OLIVEIRA, S.F.; BURJACK, M.I.; PETRI, S. 1992. A glaciação devoniana na Bacia do Paraná: dados paleontológicos. In: CONGR. BRAS. GEOL., 37, São Paulo, 1992. B. Resumos Expandidos... São Paulo, SBG, v. 1, p. 533-534.

POPP, J.H. \& BARCELLLOS-POPP, M. 1986. Análise estratigráfica da seqüência devoniana da Bacia do Paraná (Brasil). Rev. Bras. Geoc. 16(2):187-194.

POPP, M.T.B.; BURJACK, M.I.; ESTEVES, I.R. 1981. Estudo preliminar sobre o conteúdo paleontológico da Formação Vila Maria (pré-Devoniano) da Bacia do Paraná. Pesquisas 14:169-180.

POTTER, P.E. \& PETTIJOHN, F.J. 1977. Paleocurrents and basin analysis. $2^{a}$ ed., Berlin, Springer-Verlag, 425p.

QUADROS, R. 1981. Braquiópodes devonianos do afloramento Tope de Fita, Chapada dos Guimarães, Mato Grosso, Brasil. An. Acad. Bras. Ci., 53(4): 767-784.

QUINLAN, G.M. 1987. Models of subsidence mechanisms in intracratonic basins, and their applicability to North American examples. In: BEAUMONT, C. \& TANKARD, A.J. (eds.). Sedimentary basins and basin-forming mechanisms. Canadian Society of Petroleum Geologists (Memoir 12), p. 463-481.

QUINLAN, G.M. \& BEAUMONT, C. 1984. Appalachian thrusting, lithospheric flexure, and the Paleozoic stratigraphy of the eastern interior of North America. Canadian J. Earth Sci., 21: 973-996.

RABINOWICZ, M.; LAGO, B.; SOURIAU, M. 1983. Landward flow in the upper mantle: effects of heat sink and viscous coupling of the sinking slab. Earth and Planetary Sci. Letters, 63: 76-88.

RAMOS, A. N. 1970. Aspectos páleo-estruturais da Bacia do Paraná e sua influência na sedimentação. Bol. Técn. Petrobrás, 13(3/4): 85-93.

RAMOS, V. A. 1988. Late Proterozoic-Early Paleozoic of South America - a collisional history. Episodes, 11(3): 168-174.

RAMOS, V.A.; JORDAN,T.; ALLMENDINGER, R.; MPODOZIS, C.; KAY, S.; CORTÉS, J.; PALMA, M.; 1986. Paleozoic terranes of the central Argentine-Chilean Andes. Tectonics, 5(6): 855-880.

RAPELA, C.W.; COIRA, B.; TOSELLI, A.; SAAVEDRA, J. 1992. El magmatismo del Paleozoico Inferior en el sudoeste de Gondwana. In: GUTIÉRREZ-MARCO, J.C.; SAAVEDRA, J.; RÁBANO, I. (eds.) Paleozoico Inferior de Ibero-América. Espanha, Universidade de Extremadura, p. 21-68.

RICHARDS, M.T. 1986. Tidal bed form migration in shallow marine environments: evidence from the Lower Triassic, Western Alps, France. In: KNIGHT, R.J. \& MCLEAN, J.R. (eds.). Shelf sands and sandstones. Canadian Society of Petroleum Geologists, p.257-276 (Memoir 11).

ROBARDET, M.; PARIS, F.; RACHEBOEUF, P.R. 1990. Palaegeographic evolution of southwestern Europe during Early Palaeozoic times. In: McKERROW, W.S. \& SCOTESE, 
C.R. (eds.) Palaeozoic palaeogeography and biogeography. Londres, Geological Society of London, p. 411-419 (Memoir 12).

RODRIGUES, R. \& QUADROS, L.P. 1976. Mineralogia das argilas e teor de boro das formações paleozóicas da Bacia do Paraná. In: : CONGR. BRAS. GEOL., 29, Ouro Preto, 1976. Anais... Ouro Preto, SBG. v. 2, p. 351-379.

ROSS, C.A. \& ROSS, J.R.P. 1985. Late Paleozoic depositional sequences are synchronous and worldwide. Geology, 13: 194-197.

ROSS, C.A. \& ROSS, J.R.P. 1988. Late Paleozoic transgressive-regressive deposition. In: WILGUS, C.K. et al. (eds.). Sea-level changes: an integrated approach. Tulsa, Soc. Econ. Paleont. Mineral., p. 227-247 (Spec. Publ. 42).

RUSSO, A.; FERELLO, R.; CHEBLI, G. 1979. Llanura Chaco Pampeana. In: SIMP. GEOL. REG. ARGENTINA, Córdoba, 1979. Actas... Córdoba, Acad. Nac. Cienc., v.1, p. 139183.

RUST, B.R. \& ROMANELLI, R. 1975. In: JOPLING, A.V. \& MCDONALD, B.C. (eds.) 1975. Glaciofluvial and glaciolacustrine sedimentation. Soc. Econ. Palaeontol. Mineral. (Spec. Publ. 23), p.281-303.

RUST, I.C. 1981. Early Palaeozoic tillite, South Africa. In: HAMBREY, M.J. \& HARLAND, W.B. (eds.). Earth's pre-Pleistocene glacial record. Cambridge, Cambridge University Press, p. 113-117.

SAES, G.S.; OLIVEIRA, N.M.; SUNDARAM, D.; FREITAS, J. 1993. Análise ambiental e seqüência estratigráfica do Grupo Chapada na borda noroeste da Bacia do Paraná, MT e MS. In: SIMP. CRONOESTRAT. BACIA DO PARANÁ, 1, Rio Claro, 1993. B. Resumos... Rio Claro, UNESP, p.20.

SÁNCHEZ, T.M.; BENEDETTO, J.L.; BRUSSA, E. 1991a. Late Ordovician stratigraphy, paleoecology, and sea level changes in the Argentine Precordillera. In: BARNES, C.R. \& WILLIAMS, S.H. ed. Advances in Ordovician Geology. Geol. Surv. Can., p. 245-258 (Paper 90-9).

SÁNCHEZ, T.M.; WAISFELD, B.; BENEDETTO, J.L. 1991b. Lithofacies, taphonomy, and brachiopod assemblages in the Silurian of western Argentina: a review of Malvinokaffric Realm communities. J. South Amer. Earth Sci., 4(4): 307-329.

SANDFORD, R. M. \& LANGE, F. W. 1960. Basin study approach to oil evaluation of Paraná miogeosyncline, south Brazil. Amer. Assoc. Petrol. Geol. Bull., 44(8): 1316-1370.

SAUNDERS, W.B. \& RAMSBOTTOM, W.H.C. 1986. The mid-Carboniferous eustatic event. Geology, 14: 208-212.

SCHLAGINTWEIT, O. 1943. La posición estratigráfica del yacimiento ferrífero de Zapla y la difusión del horizonte glacial de Zapla en la Argentina y em Bolivia. Buentos Aires, Revista Minera, 13(4): 115-127.

SCHNEIDER, R.L.; MÜLMANN, H.; TOMMASI, E.; MEDEIROS, R.A.; DAEMON, R.F.; NOGUEIRA, A.A. 1974. Revisão estratigráfica da Bacia do Paraná. In: CONGR. BRAS. GEOL., 28. Porto Alegre, 1974. Anais... Porto Alegre, SBG. v. 1, p. 41-65.

SCHUBERT, G. 1994. Estratigrafia e sistemas deposicionais do Devoniano da Bacia do Paraná na borda NW, região da Chapada dos Guimarães - MT. In: CONGR. BRAS. GEOL., 38, Camboriú, 1994. Anais... Camboriú, SBG, v.1, p.92-94.

SEILACHER, A. 1967. Bathymetry of trace fossils. Marine Geology, 5: 413-428.

SELLEY, R. C. 1968. A classification of paleocurrents models. J. Geol., 76: 99-110. 
SELLEY, R.C. 1982. Introduction to Sedimentology. $2^{\mathrm{a}}$ ed., Londres, Academic Press, 417p.

SEMPERE, T. 1995. Phanerozoic evolution of Bolivia and adjacent regions. In: TANKARD, A.J.; SUÁREZ SORUCO, R.; WELSINK, H.J. Petroleum basins of South America. AAPG, p. 207-230 (Memoir 62).

SERRA, O. 1985. Sedimentary environments from wireline logs. Houston, Schlumberger Educational Services, 211p.

SHIRAIWA, S. 1994. Flexura da litosfera continental sob os Andes Centrais e a origem da Bacia do Pantanal. São Paulo, 86p. (Tese de Doutoramento, USP).

SLOSS, L.L. 1963. Sequences in the cratonic interior of North America. Geol. Soc. Amer. Bull., 74: $93-113$.

SMALLEY, I. \& WARBURTON, J. 1994. The shape of drumlins, their distribution in drumlin fields, and the nature of the sub-ice shaping forces. Sedimentary Geology, 91: 241-252.

SNEDDEN, J.W. \& SWIFT, D.J.P. 1991. Is there evidence for geostrophic currents preserved in the sedimentary record of inner to middle shelf deposits? - discussion. J. Sedim. Petrol., 61(1): 148-151

SOARES, P.C. 1991. Tectônica sinsedimentar cíclica na Bacia do Paraná - controles. Curitiba. 131p. (Tese de Professor Titular, UFPR).

SOARES, P.C.; LANDIM, P.M.B.; FÚLFARO, V.J. 1978. Tectonic cycles and sedimentary sequences in the Brazilian intracratonic basins. Geol. Soc. Amer. Bull. 89:181-191.

SOUZA, P.A. 1996. Palinologia e bioestratigrafia do Subgrupo Itararé em Araçoiaba da Serra (Westphaliano, Bacia do Paraná), Estado de São Paulo, Brasil. São Paulo, 192p. (Dissertação de Mestrado, IGUSP).

SPRECHMANN, P.; MONTAÑA, J.; GAUCHER, C. 1993. Devónico. In: Geologia y recursos minerales del Departamento de Durazno. Montevideo, Universidade da República (Uruguay)/Faculdade de Agronomia, p. 25-55.

SUÁREZ-SORUCO, R. 1992. El Paleozoico Inferior de Bolivia y Perú. In: GUTIÉRREZMARCO, J.C.; SAAVEDRA, J.; RÁBANO, I. (eds.) Paleozoico Inferior de lbero-América. Espanha, Universidade de Extremadura, p. 225-239.

SUÁREZ-SORUCO, R. 1995.Comentarios sobre la edade de la Formacion Cancañiri. Rev. Tecn. YPFB, 16(1-2): 51-54.

SUNDARAM, D. 1994. Dados paleontológicos adicionais sobre a Formação Vila Maria (Siluriano) na borda norte da Bacia do Paraná. Bol. Geoc. Centro-Oeste, 17: 20-24.

SWIFT, D.J.P.; HAN, G.; VINCENT, C.E. 1986. Fluid processes and sea-floor response on a modern storm-dominated shelf: middle Atlantic shelf of North America. Part I: the stormcurrent regime. In: KNIGHT, R.J. \& MCLEAN, J.R. (eds.) Shelf sands and sandstones. Can. Soc. Petrol. Geol., p. 99-119 (Memoir 11).

SWIFT, D.J.P.; THORNE, J.A.; OERTEL, G.F. 1986. Fluid processes and sea-floor response on a modern storm-dominated shelf: middle Atlantic shelf of North America. Part II: response of the shelf floor. In: KNIGHT, R.J. \& MCLEAN, J.R. (eds.) Shelf sands and sandstones. Can. Soc. Petrol. Geol., p. 191-211 (Memoir 11).

SWIFT, D. J. P.; PHILLIPS, S.; THORNE, J. A. 1991. Sedimentation on continental margins, IV: lithofacies and depositional systems. In: SWIFT, D. J. P.; OERTEL, G.F.; TILLMAN, R. W.; THORNE, J. A. (eds.). Shelf sand and sandstone bodies: geometry, facies and sequence stratigraphy. Oxford, Blackwell Sci., p. 89-152 (Sp. Publ. IAS 14). 
TANKARD, A.J. 1986. On the depositional response to thrusting and lithospheric flexure: examples from the Appalachian and Rocky Mountain basins. In: ALLEN, P.A.; HOMEWOOD, P.; WILLIAMS, G.D. (eds.) Foreland basins. Oxford, Blackwell Science, p. 369-392 (Sp. Publ. IAS 8).

TANKARD, A.J.; ULIANA, M.; WELSINK, M.; RAMOS, V.; TURIC, M.; MILANI, E.; FRANÇA, A.B.; BRITO NEVES, B.B.; EYLES, N.; SKARMETA, J.; DE SANTA ANA, H.; WIENS, F.; CIRBIÁN, M.; LOPEZ PAULSEN, G.; GERMS, G.J.B.; De WIT, M.J.; MACHACHA, T.; MILLER, R.McG. 1995. Structural and tectonic controls of basin evolution in southwestern Gondwana during the Phanerozoic. In: TANKARD, A.J.; SUÁREZ SORUCO, R.; WELSINK, H.J. Petroleum basins of South America. AAPG, p. 5-52 (Memoir 62).

TAYLOR, T.N. \& TAYLOR, E.L. 1993. The biology and evolution of fossil plants. New Jersey, Prentice Hall, 982p.

THERON, J.N. \& LOOCK, J.C. 1988. Devonian deltas of the Cape Supergroup, South Africa. In: McMiLLAN, N. J. et al. (eds.) Devonian of the world. Can. Soc. Petrol. Geol., p.729 740 (Memoir 14).

TILLMAN, R. W. 1985. A spectrum of shelf sands and sandstones. In: TILLMAN, R. W.; SWIFT, D. J. P.; WALKER, R. G. (eds.). Shelf sands and sandstone reservoirs. Soc. Econ. Pai. Min., p. 1-46 (Short Course Notes 13).

TREIN, E. \& FUCK, R.A. 1967. O Grupo Castro. Bol. Parana. Geoc., 23/25: 294-296.

VAIL, P.R.; MITCHUM, R.M. Jr.; THOMPSOM, S., III. 1977. Seismic stratigraphy and global changes of sea level, part four: global cycles of relative changes of sea level. In: PAYTON, C.E. (ed.) Seismic stratigraphy - applications to hydrocarbon exploration. AAPG, p. 83-98 (Memoir 26).

Van HOUTEN, F.B. \& PURUCKER, M.E. 1984. Glauconitic paloids and chamositic ooids favorable factors, constraints and problems. Earth-Sci. Reviews, 20: 211-243.

VASLET, D. 1990. Upper Ordovician glacial deposits in Saudi Arabia. Episodes 13(3):147-161.

VEEVERS, J.J. \& POWELL, C. MCA. 1987. Late Paleozoic glacial episodes in Gondwanaland reflected in transgressive-regressive depositional sequences in Euroamerica. Geol. Soc. Amer. Bull., 98: 475-487.

VEROSLAVSKY BARBÉ, G. 1994. Análise faciológica e estratigráfica do Devoniano da borda sul da Bacia do Paraná - Uruguai. Rio Claro, 208p. (Dissertação de Mestrado, UNESP).

VIEIRA, A.J. \& MAINGUÉ, E. 1972. Geologia de semi-detalhe do centro e nordeste do Paraná e centro-sul de São Paulo. Ponta Grossa, Petrobrás/DESUL, 49p. (Relatório 425).

VISHER, G.S. 1965. The use of the vertical profile in environmental reconstruction. Am. Assoc. Petrol. Geol. Bull, 49: 41-61.

VISSER, J. N. J. 1974. The Table Mountain Group: A study in the deposition of quartz arenites on a stable shelf. Trans. Geol. Soc. South Africa, 77: 229-237.

VISSER, J.N.J. 1989. The distinction between ancient mountain and shelf glaciations. In: INTERN. GEOL. CONGR., 28, Washington D.C., 1989. Abstracts... v.3, p.303-304.

VISSER, J. N. J. 1992. The late Ordovician Pakhuis Glaciation in the Cape Supergroup, South Africa. In: CONGR. BRAS. GEOL., 37, São Paulo, 1992. Bol. Resumos Expandidos... São Paulo, SBG, v. 1, p. 525-527.

VISTALLI, M.C. 1989. La cuenca Siluro-Devonica del Noroeste. In: CHEBLI, G.A. \& SPALLETI, L.A. Cuencas sedimentarias argentinas. Tucuman, Univ. de Tucuman, p. 1941 ( Série Correlación Geológica 6). 
WALKER, R. G. 1984. General introduction: facies, facies sequences and facies models. In: WALKER, R.G. (ed.) Facies Models. $2^{\text {a }}$ Ed., Toronto, Geoscience Canada, p.1-9 (Reprint Series 1).

WALKER, R. G. 1985. Ancient examples of tidal sand bodies formed in open, shallow seas. In: TILLMAN, R.W.; SWIFT, D. J. P.; WALKER, R.G. (eds.) Shelf sands and sandstone reservoirs. Tulsa, SEPM, p. 303-341 (Short course 13).

WEEKS, L.G. 1947. Paleogeography of South America. Amer. Assoc. Petrol. Geol. Bull., 31(7): 1194-1241.

WIENS, F. 1990. Estratigrafia fanerozoica resumida del Paraguay. Assunção, Geoconsultores, 6p. (Relatório Interno).

WIENS, F. 1995. Phanerozoic tectonics and sedimentation in the Chaco basin of Paraguay, with comments on hydrocarbon potential. In: TANKARD, A.J.; SUÁREZ SORUCO, R.; WELSINK, H.J. Petroleum basins of South America. AAPG, p.185-205 (Memoir 62).

WILLIAMS, K.E. 1995. Tectonic subsidence analysis and Paleozoic paleogeography of Gondwana. In: TANKARD, A.J.; SUÁREZ SORUCO, R.; WELSINK, H.J. Petroleum basins of South America. AAPG, p.70-100 (Memoir 62).

ZALÁN, P. V. 1991. Influence of Pre-Andean orogenies on the Paleozoic intracratonic basins of South America. In: SIMP. BOLIVARIANO, 4, Bogotá, 1991. Memorias... Bogotá, Tomo I (Exploracion petrolera en las cuencas subandinas), trabajo 7.

ZALÁN, P.V.; WOLFF, S.; CONCEIÇÃO, J.C.J.; VIEIRA, I.S.; ASTOLFI, M.A.M.; APPI, V.T.; ZANOTTO, O.A. 1987a. A divisão tripartite do Siluriano da Bacia do Paraná. Rev. Bras. Geoc. 17(3):242-252.

ZALÁN, P.V.; WOLFF, S.; CONCEIÇÃO, J.C.J.; VIEIRA, I.S.; ASTOLFI, M.A.M.; APPI, V.T.; ZANOTTO, O.A. 1987b. Tectônica e sedimentação da Bacia do Paraná. In: SIMP. SULBRAS. GEOLOGIA, 3, Curitiba, 1987. Atas... Curitiba, SBG, v. 1, p. 441-477.

ZALÁN, P.V.; WOLFF, S.; ASTOLFI, M.A.M.; VIEIRA, I.S.; CONCEIÇÃO, J.C.J.; APPI, V.T.; NETO, E. V. S.; CERQUEIRA, J. R.; MARQUES, A. 1990. The Paraná Basin, Brazil. In: LEIGHTON, M.W.; KOLATA, D. R.; OLTZ, D. F.; EIDEL, J. J. (eds.) Interior cratonic basins. Tulsa, Amer. Assoc. Petr. Geol., p. 681-708 (Memoir 51). 